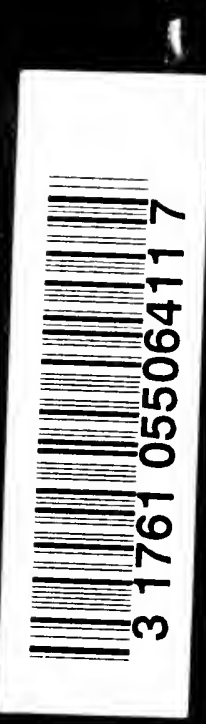




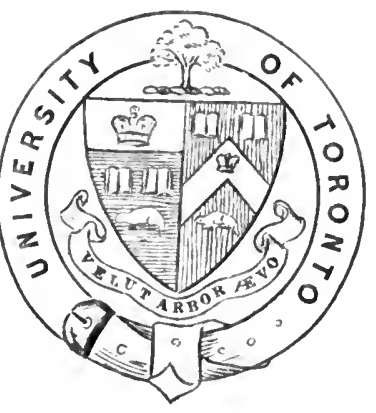

Dresenteo to

\section{The $\mathfrak{L}$ ibrate}

of the

\section{University of Toronto}

by

Professor Alexander Brady 

IRELAND IN FICTION

$+$ 



\section{LE, Bb D28788i \\ IRELAND IN FICTION}

A GUIDE TO IRISH NOVELS, TALES. ROMANCES, AND FOLK-LORE

NEW EDITION.

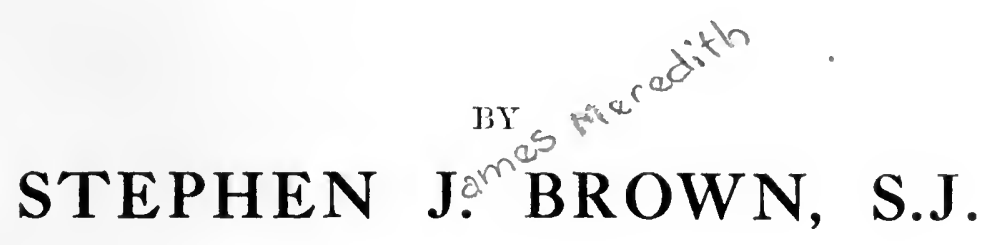
Author of "A Reader's Guide to Irish Fiction," "A Guide to Books on Ireland," etc.

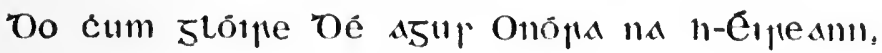

MAUNSEL AND COMPANY, LIMITED:

DUBLIN AND LONDON 1919. 


\section{9 F4B7 \\ 1919}


TO MY FATHER. 
Digitized by the Internet Archive in 2007 with funding from Microsoft Corporation 


\section{CONTENTS.}

Note to New Edition . . . . . . . . . viii

Preface . . . . . . . . . . . $\mathrm{x}$

Preface to A Reader's Guide to Irish Fiction. (1910). . . xiii ACKNOWLEDGMENTS . . . . . . . . . . . . nvi

Signs, AbBreviations, hTc. . . . . . . . xis

Irish Fiction under names of aUthors alphabeticalli ARRANGLD . . . . . . . . 1

APpENdix :

A.-Some useful Works of Refelence: . . 317

B.-Publisheris and Sermes . . . . . 320

C.-Classhined Lists:

I.-His'torical Fiction . . . . 324

II.-Gaelic Epic and Romantic Literitulie . 309

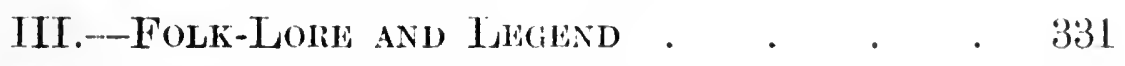

IV.-Famy 'Tales for Childile . . . 332

V.-Catholic Clerical Life . . . . 333

VI.--Humorous Books . . . . . . 333

VII.--BOOKS FOR BOYS . . . . . 334

D.-Thish Fiction in Periodicals . . . . . 335

Index of Titues and Subjects . . . . . . . 345 


\section{NOTE TO NEW EDITION}

T'He first edition of Ireland in Fiction was destroyed by fire in the course of the Rising in Dublin at Easter, 1916. A few copies survived but the book has now been for some time quite out of print. I have taken advantage of the opportunity thus afforded for a new edition by endeavouring not only to bring the work up to date but to improve it in various ways. The improvements may be summarised as follows:-(1) Information has been obtained about nearly all the books left without notes in the previous edition. (2) Notes on many books overlooked in the first edition have been added, the total number of books annotated being now over 1,700. (3) A large number of new biographical notes on the authors have been inserted. 'This edition contains, in fact, nearly five hundred and fifty entirely new notes on books and authors. (4) A great many minor additions and corrections have been made. (5) The Appendices have been revised, that dealing with Irish fiction in periodicals being much enlarged. (6) The titles of the books have been continuously numbered throughout, a more precise mode of reference being thus provided.

The aim and scope of the book have, I hope, been sufficiently dwelt upon in the preface to the former edition.

It remains for me to express my gratitude to the inany who have helped me in various ways in the preparation of this new edition. To the following in particular I wish to express my special indebtedness. For work in the British Museum Library I have to thank Mr. Frank Macdonagh and Mr. J. D. Noonan, Mrs. M. Pearde Beaufort (to whom the Index is entirely due), and Miss C. J. Hamilton. I am under a similar obligation to Miss $A$. Cuming for work in the Bodleian. For valuable suggestions, new noter, and corrections I wish to thank Dr. J. S. Crone, Editor of the Irish Book Lover, Mr. Patrick Mulhall of Castlecomer, Mr. Edmund Downey of Waterford, Mr. A. A. Campbell of Belfast, Mr. J. de L. Smyth, Dr. W. H. Grattan-Flood, Mr. J. P. Gannon of Laragh, Mr. John Sweetman of Kells, and Father Hickey of 
Leeds, who kindly placed at my disposal his remarkable collection of Irish books. Prof. Dumne of the Catholic University, Washington, and Mr. J. D. Hackett of New York kindly obtained for me notes on some Irish-American novels. Mr. R. I. Best of the National Library greatly supplemented my notes on translations from the Irish.

I cannot sufficiently express my sense of the courtesy and helpfulness of the staff of the National Library and in particular of Mr. F. W. Poulter.

The completeness of the work was greatly promoted by those Editors of periodicals who were so obliging as to insert for me in their pages lists of books about which I was seeking information. In this connection I have to thank the Editors of Notes and Queries, The Irish Book Lover, The Iris! Rosary, America, The Weekly Freeman, The Leader, New Ireland, and the Irish Monthly. The last named periodical for some two years published in the form of a supplement many of the notes that now appear in this book.

Lastly, I must express my gratitude to those publishers-the Irish publishers in particular-who generously sent me copies of newly published Irish novels. But for their generosity this work would not have been possible.

Clongowes Wood College, Co. Kildare, April, 1919. 


\section{PREFACE.}

IT may be well to state at the outset in what respects the present work differs from A Reader's Guide to Irish Fiction published in 1910, and now out of print. The differences may be reduced to four :-

(1). The number of books dealt with is almost double that of the earlier work.

(2). The arrangement is quite new. In the former work the books were classified according to subject matter : in this they are arranged under the names of Authors, these names being arranged alphabetically. Some lists are appended in which the books are classified as historical novels, Folk-lore, Gaelic Epic and Romantic Literature, \&c.

(3). A combined title and subject index has been provided, both of which were lacking in the earlier book. Some new matter is given in the Appendix, in particular some notes on fiction in Trish periodicals.

(4). In A Reader's Guide, \&c., a few notes on Authors were added at the end. In the present work biographical notes on a large proportion of the Authors are given immediately before the notes on their books.

Apart from these differences, the two works have the same scope and ain. In both, the scope includes all works of fiction published in volume form, and dealing with Ireland or with the Irish abroad, and such works only. The present book, therefore, is not, any more than was the earlier book, a guide to the works of Irish novelists-else, Goldsmith, for instance, might surely claim a place. Neither is it, properly speaking, a book of advice as to what is best to read. The aim has been to provide descriptive notes of an objective nature, to record facts, not to set forth personal views and predilections. This is a book of reference pure and simple; it neither condemns nor recommends. In this respect it differs from several other guides to fiction which at first sight it seems to resemble. The Abbé Bethléem's most valuable Romans à lire et Romans à proscrire has been mentioned in the former preface. Its title proclaims its character. Of a similar nature are some works by members of my own Order that have 
since come to my knowledge. It will be useful to record their titles :

1. P. Gerardo Decorme, s.J.--Lecturas recomendables. (Barcelona : Luis Gili). 1908.

2. P. Pablo Ladron de Guevara, s.J.-Novelistas malos y buenos. Pp. 523. (Bilbao). 1910.

3. Was soll ich lesen? Ein Ratgeber [advice giver] für Studierende (Trier), 1912.

4. Guide de Lecture. (Brussels). Second ed., 1912. A magnificent 4to volume of $1032 \mathrm{pp}$., compiled by a Belgian Jesuit, Fr. Schmidt, and constituting the catalogue of his great Bibliothèque Choisie of 200,000 volumes.

No. 1 devotes only a chapter to fiction. No. 2 contains a critical examination from a moral point of view of 413 Spanish writers, 1,220 French, 150 English, 98 German, as well as Russian Belgian, \&c. No. 3 devotes a section to Schöne Literatur giving notes and bibliographical details. Symbols are used to indicate the suitability of the books to readers of various ages. The same plan is followed in No. 4, but to a much fuller extent, and the whole work is on a larger scale.

Enough has been said, 1 think, in the former preface as to the object aimed at in the notes. I have tried to make that object clear : I am far from thinking that it has always been attained, even in this revised work. Some of the excuses for incompleteness that held good for the first steps into an almost untrodden field have no doubt ceased to lave the same force. I have had time to explore new ground, and to survey anew that already occupied. On the other hand the years that have slipped away since the former book have been filled by many duties that left little time for literary work. Yet, though I am unable to sily with confidence that this work is bibliographically exhaustive, I trust that, for practical purposes, for the purposes for which it is intended, it may be found reasonably complete. For the achievement of even this result I can by no means claim all the credit. My obligations to my numerous helpers are very great indeed, as will appear from the Acknowledgments.

One further point needs to be dwelt upon--the non-inclusion of works of fiction written in the Irish language. I cannot do better in this connection than quote from the preface to a former 
work* in which this same point came up for explanation :- "I have not included books in the Irish language. My reasons for this are threefold. In the first place my own knowledge of Irish is not yet sufficient to enable me even to edit satisfactorily notes of books in Irish . . . . In the second place I do not think that a bibliography of works in Irish should be made a mere appendage or sub-section, as it would inevitably be, of a work such as the present. Lastly, it may well be doubted whether the time be yet come for doing this work in the way that it deserves to be done." This last reason is partly based on the fact of the great mass of Irish literature still remaining in MS., a quantity probably much greater than what has been printed and published. The publication of the National Library's bibliography is mentioned in the Appendix on Gaelic literature as an additional reason for my omission of books in Irish.

Nevertheless, the omission of books in the Irish language from a Guide to Irish Fiction remains an anomaly, one of the many anomalies produced by the historic causes that have all but destroyed the Irish language as the living speech of Ireland.

Dublin, September, 1915. 


\section{PREFACE TO A READER'S GUIDE TO IRISH FICTION (1910).}

The present Guine ro Irish Fiction is intended by the Author as the first part of a work in which it is hoped to furnish notes on books of all kinds dealing with Irish subjects.

Before explaining the scope of this section of the work it may be well, in order to forestall wrong impressions, to say at once what it is not. In the furst place, then, it does not lay claim to be a bibliography. By this I do not mean that I am content to be inaccurate or haphazard, but simply that I do not aim at exhaustive completeness. In the second place, it is not a catalogue of books by Irish writers. Lastly, it does not deal exclusively with books printed or published in Ireland.

'The Author's aim has been to get together and to print in a convenient form a classified list of novels, tales, \&c. (whether by Irish or by foreign writers), bearing on Ireland--that is, depicting some phase of Irish life or some episode of Irish history-and to append to each title a short descriptive note.

Two things here call for some explanation, viz., the list of titles and the descriptive notes.

As to the former, I have, with some trifling exceptions, included everything that I have been able to discover, provided it came within the scope of the work, as indicated above. It has been thought well to do this, because a vast amount of fiction that, from an artistic or from any other point of view, is defective in itself may yet be valuable as a storehouse of suggestion, fact, and fancy for later and better writers. For was it not worthless old tales and scraps of half-mythical history that held the germs of "Hamlet" and "Macbeth," " King Lear" and "Othello "? 'There remains, indeed, a large class of novels and tales that, so far as one may judge, can serve no useful purpose. It may be thought that with such books the best course to pursue is to allow them to pass into merited oblivion. But it must be remembered that booksellers and publishers will naturally continue to push such books because it is their business to do so, and the public will continue to buy them because it has ordinarily no other means of knowing 
their contents than the publisher's announcement, the title, orthe cover. A "Guide" would, therefore, surely shirk an important portion of its task if it excluded worthless books, and thereby failed to put readers on their guard.

Next, as regards the descriptive notes: there are three points which I should wish to make clear-the source of the information contained in these notes; their scope, that is, the nature and extent of the information with which they purpose to furnish the reader; and, thirdly, the tone aimed at throughout the work.

Information about the books has been obtained in various ways. A considerable number have been read by the Author. Indeed, there are few writers of note included in the Guide about whose works he cannot speak from first-hand knowledge. Of the books that remain the great majority have been specially read for this work by friends, and a full account of the same written by them according to a formula drawn up for the purpose. In all cases, except in a very few-and these have been indicated-the wording of the final note is mine. In the few cases referred to, printed reviews or notices of the books have been drawn upon, the source of the note being mentioned in each instance.

I word about the scope of the notes. My chief object in undertaking this work was to help the student of things Irish. This object determined the character of the notes. A few years ago there appeared in France an excellent work, entitled Romans à lire et Romans à proscrire (Cambrai: Masson), by the Abbé Bethléem, which has since passed through many editions. In this work novels are classed au point de vue moral. In the rare cases in which the books included in my list contain matter objectionablo from a moral or a religious standpoint, I have not hesitated to remark the fact in the note. 'This was, however. but a small part of the task. It will be clear likewise, from what has been said that my object is not to attempt literary criticisms of Irish fiction. Such literary appreciations are to be found in other works already published, accounts of several of which will be found in the Appendix. True, a certain amount of criticism is often needed lest the account given of a book should be misleading, but it has been avoided wherever it did not seem to further the main purpose. This purpose, let me repeat, is, above all, to give information to intending readers. I have, therefore, endeavoured, as well as might be, in the small space available, simply to give a clear idea of the contents of the books. In a good many cases I have further attempted an appreciation, or rather a characterization, of the book in question, but this was not always possible nor, indeed, necessary. 
Of the tone adopted in these notes little need be siid. I did not consider that it would further my purpose to aim at that literary flavour and epigrammatic turn of phrase affected, and with reason, by reviewers in many periodicals. Moreover, to do so would have been inconsistent with brevity. Then, I must disclaim all intention of saying " clever" things at the expense of any book, however low it may deserve to be rated. I have endeavoured to avoid, too, the technicalities of criticism. Lastly, I trust the little work has not been rendered suspect to any class of Irishmen by the undue intrusion of religious or political bias.

Apology might well be made here for the defects of the work. They will, I fear, be but too evident. But it should be borne in mind that, with the exception of Mr. Baker's works, to which I cannot sufficiently acknowledge my indebtedness, I have had no guide upon the way, since no writer, so far as I am aware, has hitherto dealt in this way with Irish fiction as a whole.

It may be asked, for whom especially this book is meant? In the first place, I hope it may be useful to the general reader who wishes to study Ireland. Next, it may help in the important and not easy task of selection those who have to buy books for any purpose, such as the giving of presents, the conferring of prizes in school or out of it, the stocking of shops and libraries-in other words, booksellers, library committees, heads of schools and colleges, librarians, pastors, and many others. Again, it may be of some service to lecturers and to popular entertainers. I have some hopes, too, that coming writers of Irish fiction, from seeing what has been done and what has not yet been done, may get from it some suggestions for future work. It may even help in a small way towards the realization of a great work not yet attempted, the writing of a history of Anglo-Irish literature. 


\title{
ACKNOWLEDGMENTS.
}

\author{
(Reader's Guide, etc.)
}

MY best thanks are due, in the first place, to the authorities of Clongowes Wood College, without whose constant aid and encouragement my task would have been impossible.

Next, I wish to thank those publishers who courteously sent me copies of a number of their books, viz:, the Irish publishers, Messrs. Gill; Duffy; Sealy, Bryers and Walker; Maunsel; and Blackie : and the Iondon publishers, Nessrs. Macmillan; Nelson; Methuen; Dent; Chatto and Windus; Burns and Oates; Sands; Blackwood; Nutt; Elliot Stock; and Smith, Elder. I should like to give greater prominence to the publications of these firms. The plan of this book prevents me from doing so, but I may say that this little work, which will, I hope, help to make known their books, conld not have appeared but for their generosity.

To those who, as already mentioned, have aided in the work by reading books, and supplying information about them, my sincerest thanks are hereby tendered. I should be glad, if it were possible, to express here my obligations to each individually, but I must, for obvious reasons, limit myself to this general acknowledgment. There are, however, some whom, on account of special obligations on my part, I shall have the pleasant task of thanking by name. 'To Mr. E. A. Baker, M.A., D.LITT., I ibrarian of the Woolwich Public Library, I am indebted both for kind permission to quote from his books and for constant advice and suggestion given with the greatest cordiality. To Dr. Conor Maguire, of Claremorris, I owe most of my notes of books on Irish Folk-lore, and to Mr. Edmund Downey, the well-known author and publisher, notes on Iuever's books, together with many useful suggestions. Mr. Francis J. Bigger, M.R.I.A., of Belfast, the always ready and enthusiastic helper of every Trish enterprise, has aided me with valuable advice and no less valuable encouragement. Mr. J. P. Whelan, Librarian of the Kevin Street Public Library, Dublin, has rendered me every assistance in his power. Dr. J. S. Crone, of London, Editor of the Irish Book Lover, has on several occasions kindly opened to me the pages of his periodical. Iuastly, I must acknowledge here, with sincere thanks, much help of various kinds 
given me by many members of my own Order, and notably, Rev. M. Russell, s.J. ; Rev. M. Corbett, s.J. ; Rev. P. J. Connolly, s.J., and the Rev. J. F. X. O'Brien, s.J.- the last of whom very kindly undertook the tedious labour of revising my proofs.*

\section{[Additional (Present Work, First Edition.)]}

MY obligations to my various kind helpers in the present work are even greater than in the case of the former book, and I am at a loss for an adequate expression of them. My thanks have, of course, been privately conveyed, but there are some collaborators who have had so large a share in the making of this book that I cannot but place on record its indebtedness towards them.

For valuable work in the British Museum Library extending over a considerable length of time I have to thank Mrs. Pearde Beaufort, Miss C. J. Hamilton, and Miss G. B. Ryan. For much tedious labour in the rearrangement of the matter contained in the earlier book, I am indebted to the Misses Chenevix Trench (who also supplied many notes), and to Mrs. O'Neill, of Dundalk. To Dr. Crone, whose readiness to help when any Irish literary enterprise is afoot is inexhaustible, I owe many corrections, suggestions, and additions, and the laborious task of revising my MS. and correcting my proofs. Mr. Edmund Downey, of Waterford, has kindly read part of the proofs. Many books have been read for me and notes supplied by Lady Gilbert, Mrs. Concannon, of Galway; Mrs. L. M. Stacpoole Kenny, of Limerick; Miss J. F. Walsh, of Derry; Miss R. Young, of Galgorm Castle, Co. Antrim; Mrs. Macken, of the National University; Fr. MacDwyer, of Killybegs; and, perhaps most of all, Fr. J. Rabbitte, s.J., of St. Ignatius College, Galway. Mr. D. J. O'Donoghue, Librarian of the National University, has given me many suggestions, as well as some useful notes on fiction in Irish periodicals. Mr. Frank Macdonagh also has been very helpful with notes and corrections. I owe likewise a debt of gratitude to the authorities and the staff of the National Library for their conrtesy and helpfulness. Nor must I omit a word of thanks to the publishers (including all the

* Through an unfortunate oversight the earlier work contained no mention of much kind help rendered me by several students of St. Patrick's College, Maynooth, notably by Rev. J. Henaghan and Rev. J. Pinkman, at present priesta on the mission, I now gratefully acknowlodge this help. 
Irish publishers, and Messrs. Flynn, of Boston), who, as on a former occasion, made my task much lighter by supplying me with review copies of their books.

Lastly, to all the others, and they are many, who have in various ways given me help my very sincere thanks are hereby tendered.

For the matter contained in my notes on the Authors, I am much indebted to Mr. D. J. O'Donoghue's Poets of Ireland, and to the pages of the IrISH Book Lover. 


\section{SIGNS, ABBREVIATIONS, ETC.}
b. $\quad$ = born.
c. (before dates) = approximately.
d. $\quad=$ died.
ed. $\quad . \quad=$ edition, edited, editor, educated.
ๆ.v. $\quad=$ which may be referred to.
n.d. $\quad=$ no date printed in the book referred to.
sqq. $\quad \cdot \quad=$ and following (years or pages).
C.B.N. $\quad$ = Catholic Book Notes.
D.N.B. $\quad$. $\quad$ The Dictionary of National Biography.
D.R. $\quad$ = The Dublin Review.
I.B.L. $\quad=$ The Irish Book Lover.
I.E.R. $\quad=$ The Irish Ecclesiastical Record.
I.M. $\quad$ = The Irish Monthly.
N.I.R. $\quad$ = The New Ireland Review.
T. Lit. Suppl. $=$ The Times Literary Supplement.
C.T.S.I. $\quad \cdot \quad=$ Catholic Truth Society of Ireland.
S.P.C.K. $\quad$ = Society for the Promotion of Christian Knowledge.
R.T.S. $\quad$ = Religious Tract Society.
Allibone $\quad=$ Allibone's Dictionary of English Literature, 5 Vols.
Baker $\quad$ = Baker's Guides (see Appendix A). A 2 indicates that the new ed. has been used.
Krans $\quad \cdot=$ Krans's Irish Life in Irish Fiction. (Appendix A).
Read . = The Cabinet of Irish Literature. (Appendix A).
I. Lit. $\quad=$ Irish Literature in twelve Vols. (Appendix A)
N.Y $\quad=$ Now York 
SIGNS, ABBREVIATIONS, ETC.

The place of publication has been mentioned in the case of books not published in Dublin or in London. A list of the Irish publishers will be found in Appendix B.

The price of most new novels on first publication has been until recently $6 s$., not net. Conditions produced by the war have greatly affected this standard price. I have not thought it useful to insert the prices of books no longer to be had otherwise than from second-hand booksellers : second-hand prices are constantly varying. The publication Book-Prices Current might be usefully consulted in some reference library. The price $I$ have given is usually the price at which the book was originally published. But more recent prices have frequently been added.

Dates in square brackets, thus [1829], indicate dates of first publication. Besides these, I have also mentioned the date of the latest edition I. am aware of.

The name of an Author placed within square brackets is an indication that the name in question did not appear on the title page of the book to which it is now affixed, the book having been published anonymously, or under a pen-name.

Inverted commas are used thus "M. E. Francis" to indicate a pen-name. The writers' works are entered under the name most familiar to the public, under Katharine Tynan and Rosa Mulholland rather than under Mrs. Hinkson and Lady Gilbert. However, in the case of old books I have not thought it useful to place the book under the literary disguise. I have entered them under the real name, with a cross-reference. I fear that perfect uniformity and consistency has not been secured, but hope that the book's usefulness-utility, and not scientific precision, has been the aim-1s not thus impaired.

The publishers mentioned are, so far as I have succeeded in discovering them, the publishers not of the first, but of the latest, edition.

Books published under mere initials or under a pseudonym which obviously could not be a real name, I have entered as anonymous, except where $I$ have come to know the real name, in which case it will be found under the real name, with a cross reference from the pseudonym.

When the note depends mainly or exclusively on a single already published authority or source, this authority or source is indicated at the end of the note. 


\section{IRELAND IN FICTION}

\section{ANONYMOUS}

NoTE-Included under this heading are :-

(1) Works which of their very nature are without name of Author, such, for instance, as collections of tales by different writers.

(2) Works published anonymonsly, and whose authors I have been unable to discover.

Anonymities unveiled are entered under the Author's real name, this name being placed in square brackets.

1 - ADVENTURER, THE.

In Mitchel's Life of Hugh Q'Neill there is a note in reference to his wooing of Sir Henry Bagenal's sister, stating that a novel was published founded on this story, and entitled The Adventurer. (Query in I.B.L., vol. iv., p. 161.) This book does not seem to be in the British Museum Library, but I have found in an old catalogue a book with the title The Adventurers; or, Scenes in Ireland in the Reign of Elizabeth, 1825. This is probably the book referred to by Mitchel.

2- ADVENTURES OF FELIX AND ROSARITO, THE; or, The Triumph of Love and Friendship. Pp. 58. (Title-p. missing). 1802.

The hero is one Felix Dillon. Though the story begins and ends in Dublin, its scene is chiefly France, and afterwards Spain.

3- ALBION AND IERNE: A Political Romance; by "An Officer." Pp. 192. (Marcus Ward). 1886.

An allegory in which the personages stand for countries and institutions. Ierne is of course Ireland, Albion is England. Then there are minor characters, such as Dash, Dupe, Plan, Sacrifice. Under this form the relations between the two countries and the possible results of separation are exhibited. Ends with the happy marriage of Albion with Kathleen, Ierne's sister, and the burial of the hereditary feud.

4 - ANNIE REILLY; or, The Fortunes of an Irish Girl in New York. (N.Y.: Pustet). 1.00 .

A volume of the "Irish National Library."

5- BALLYBLUNDER : an Irish Story. Pp. 291. (London: Parker). 1860.

Scene: the N.E. coast of Ireland, with its rugged, rocks and lofty cliffs. The plot concerns the Kindly family of "Ballyblunder," on whose estate sheep are constantly being killed. A priest instigates to the crime, and encourages the perpetrators. Mr. Kindly's son goes out to track the sheep-killers; a friend of his is murdered, and Brady, the murderer, falls off a cliff and is killed. The Kindlys
eventually sell the estate. Some social scenes are interspersed. Written in a spirit of religious intolerance. 


\section{ANONYMOUS-(continued).}

6— BALLYSHAN CASTLE; a tale founded on fact, by "Sheelah." Pp. 355. (N.Y.: T'ibbals). 4 or 5 illusts. 1857.

"A tale in which the religion of the Bible is displayed in its effects, in high, low, and middle life." (Publ.) "The most essential and marvellous incidents of the story are literal facts." (Pref.) "The blessings of Protestantism are distinctly brought out." (Lion's Herald.) Scene: "One of the midland counties of Ireland, and Athlone. Ellen Martin, the heroine, makes a love match with the O'Dougherty, Catholic owner of Ballyshan Castle. The marriage turns out a failure. Ellen dies of decline, exacting a promise from her sister to abduct the child and have it brought up a Protestant. The sister has it put into the Foundling Hospital in Dublin. Then we have the life story of this child, who, growing to man's estate, makes many converts through Bible reading, marries successfully, and emigrates to Canada. Viewpoint fanatically evangelistic: not offensive to Catholics in expression: almost Irish-Ireland.

7- BEGORRA! A Collection of the Funniest Short Irish Stories ever published. (London: Felix McGlennon.) Paper, 6d. n.d. (recent).

A companion volume to Bedad! A collection of the funniest Irish jokes.

\section{8-BLACK MONDAY INSURRECTION. Pp. 135-328.}

Bound up with The Puritan, q.v. The story opens at Bandon with the rescue of two of the principal characters who had been kidnapped by Rapparees. Then follows the taking of Bandon by McCarthy More. The battles of the Boyne and Aughrim, the sieges of Athlone and Limerick are also dealt with, the two latter being described in detail. Standpoint: Williamite. The Irish are "barbarians," "bravo and savage bacchanalians;" the Rapparees are "infernal banditti," etc., but on the whole the tone is not violent. Through it all runs an interesting and curious story of the private fortunes of several persons. See The Last of the O'Mahonys.

9 - BOB NORBERRY; or, Sketches from the Note Book of an Irish Reporter; ed. by "Captain Prout." Pp. 360. 18 good illustr. by Henry MacManus, A.R.H.A., and others. Dedicated to C. Bianconi. (Duffy). 1844.

The Author (Pref.) tells us that he has written the book to vindicate the character of his countrymen, and to show Irish affairs to Englishmen in their true light. Accordingly we have, not so much a novel, as a series of crowded canvases depicting nearly every phase of life in Ireland from a period before the Union to the date of this book. It begins with the marriage of the hero's grandparents in Dublin at the end of the 18th century (1780). We have a glimpse of penal laws at work and of agrarian disturbances, but the Author is especially at pains all through the book to set forth how the law works in Ireland. There are swindling attorneys, bribed and perjured jurors, packed benches, partisan judges, endless proceedings in Chancery, and so on. Young Bob is sent finst to a private school, then to Stonyhurst (an account is given of the Jesuits). He is first intended for the priesthood and goes to Louvain, but finally becomes a reporter on a Dublin paper. Here we have a picture of low journalism. Bob shows up several frauds of selfstyle philanthropists. Describes trial at Assizes of Lord Strangeways' evicted tenants. This brings in much about the agrarian question. The book ends with his elopement to the Continent and marriage with Lady Mary Belmullet. There are innumerable minor episodes and pictures. There is no literary refinement in the style, and the colours of the picture are laid on thickly.

N.B.-According to the late D. J. O'Donoghue the author of this story was a writer named Levey.

10_ BRIDEGROOM OF BARNA, THE. Pp. 80. 1884. (N.Y.: Sadlier).

Scene: Barna, nr. Ballymore, Co. Tippenary. Lawlor, the bridegroom, ill-treats a tramp who in revenge reveals to the authorities a murder wrought by Lawlor year's before. The bride dies broken-hearted, and at length $L$. is taken at his wife's grave but shoots the informer. A sad story, not sensational, but told with a restrained pathos that is effective. Good description of rural marriage ways. 
ANONYMOUS-(continued).

11- BRIDGET SULLIVAN; or, The Cup without a Handle. A Tale. 1854.

12 - BY THE BROWN BOG; by "Owen Roe and Honor Urse." Pp. 296. (Longmans). Illustr. by silhouettes. 1913.

An imitation of the Somerville and Ross stories, but with their leading features exaggerated. For Flurry we have Fossy, for Slipper Timsy Conroy. Instead of by an R.M. the stories are told by a young D.I. There is the same background of comic and filthy peasants, the same general Irish slovenliness and happy-go-luckiness, and universal drunkenness. The brogue is made the most of. Moonlighters of a very sinister kind appear once or twice. The incidents are such as hunting, racing, the local horseshow, country petty sessions, etc. They are very well told, with a jaunty style, and in a vein of broad comedy. There is a chapter purporting to relate experiences in "The Black North," but for the most part the scene is West Cork. Some of these sketches appeared in the Badminton Magazine.

13-CAPRICE; or, Anecdotes of the Listowel Family, an Irish novel. 3 vols. 1824. (Sherwood).

14 CASTLE CHRISTMAS EVE, A; or, The Tales the Portraits Told. Pp. 72 double column. 1885. (United Ireland Offices). 6d.

Originally appeared as Christmas Number of United Ireland, 1884. Michael Kelly, reporter, goes to Dublin Castle with a deputation on the subject of the deterioration of the Irish oyster. Humorous description. He falls asleep in one of the rooms and is locked in. Dream of banquet in which the Viceregal portraits come to life and tell stories-How Castlereagh bought Bohola (Cornwallis's story). Arms and the Man (Eglinton's story), and so on for Grafton, Chesterfield, Tyrconnell, etc., etc. The authors are-T. M. Healy, M.P.; John Augustus O'Shea, Justin Huntley McCarthy, M.P.; M. T. Pender; Edmund Leamy, M.P.; Katharine Tynan; William Redmond, M.P.; E. O'Shea Dillon, James O'Connor, Hanmah Lynch, J. J. O'Shea, William O'Brien, M.P. A very clever and entertaining production.

15-CAVERN IN THE WICKLOW MOUNTAINS, THE; or, Fate of the O'Brien Family. Two Vols. 12mo. (Dublin, printed for the Author). 1821.

Told in letters between "Augustus Tranton" and "Sir Edward Elbe." Said on title-p. to be " a tale founded on facts." Seems to be a re-issue in a slightly altered form of The UNITED InIshman, $q \cdot v$. The story is related to "Aug. Tranton" by a gentleman (O'Brien) who had been a U.I., and as a result had lost all, and was then in hiding in a cave near the Dargle river.

\section{6- CHARACTERISTIC SKETCHES OF IRELAND AND THE IRISH. 16mo. Pp. 288. (Halifax). 1849.}

A reprint of an earlier publication by Philip Dixon Hardy, the fourth edition of which appeared in 1842. Contents : I. By Carleton :- "The Horse Stealers," "Owen McCarthy," "Squire Warnock," "The Abduction," "Sir Turlough." II. By, 1.over:- "A Legend of Clanmacnoise", (sic), "Ballads and Ballad Singers,", "Paddy Mullowney's Travels in France." III. By Mrs. Hall :- " The Irish Agent," "Philip Garraty."

17- CHARLES MOWBRAY; or, Duelling, a tale founded on fact. Pp. 82. (CCRK). 1847.

By the author of "The Widow O'Leary." Dr. B., whose parents live at Y. (probably Youghal), has a practice in England. He is challenged to fight a duel by Sir J. C. He is killed, and his parents both die from the shock. A dull little book, with much moralising.

18-COLONEL ORMSBY; or, the genuine history of an Irish nobleman in the French service. Two Vols. (DUBLIN). 1781.

In form of letters between the Colonel and Lady Beaumont, couched in the most amatory terms. There is no reference to Ireland and little to the history of the gallant Colonel: the correspondence is all about the private love affairs of the writers. 


\section{ANONYMOUS-(continued).}

19-DANIEL O'CONNOR, by "C. G." 32mo. Pp. 200. (Tours: Mame). 1853, 1861, 1866, 1867.

One of the "Bibliothèque des Petits Enfants" series (" appouvée par M. l'évêque de Nevers"). It is the story of an Irish family in 1691 ruined by the careless chattering of a child. C. G. was probably C. Guénot, who published an historical work, Le Comte de Tyrone, at Tours in 1863 (new ed. 1867). See infra.

20 DARK CLOUD, THE. (Ward Lock). 5s. 1862.

"Subt.: A tale of priestly influence in Ireland in the present day."

21- DAVENELS, THE; or, A Campaign of Fashion in Dublin. Two Vois. (Colburn). 1829.

22 - DOUBLE TRIAL, THE; or, The Consequences of an Irish Clearing, a tale of the present day. Three Vols. (300 pp. each.) (Smith Elder). 1834.

Two children are exchanged in infancy. When they have grown up two lawsuits (the second reversing the decision of the first) take place, as a result of which their identity is determined and their titles to estates, etc., settled. This is the main thread but with it are interwoven innumerable minor episodes (including a ghost), scarcely relevant to the main issue, long discussions, and conversations. Yet the book is valuable for its admirable statement of Irish economic conditions and its forcible denunciation of the evils of absenteeism and the abuses of landlordism. See especially Vol. 1, p 7 sqq. Vol. ii, p. 44-7. The Author is clearly a lawyer and a Protestant. The scene is laid in Ireland only for the first few chapters. The period is $1812-1825$ or so. The work of the Hibernian Bible Society is favourably noticed in Vol. ii. p. 134 sqq.

\section{3- DUNSANY: an Irish Story. Two Vols. 12mo. Pp. $278+308$.}

\section{(LONDON). 1818.}

The principal character and a few of the others, e.g., Mrs. Shady O'Blarney (!), happen to be born in Ireland, and there is talk of the usual tumbled-down castle somewhere in Ireland, but at this the Irishism of the story stops. The scene is England, the persons wholly English in sympathy and education. A sentimental and insipid story dealing chiefly with the marrying off of impecunious sons and daughters. Interesting as giving a picture, seen from an English standpoint, of the Irish society of the day. No politics.

24- EARLY GAELIC ERIN; or, Old Gaelic Stories of People and Places. (DUBLIN). $19 Q 1$.

\section{5- EDMOND OF LATERAGH: a novel founded on facts. Two Vols.} (Dublin). 1806.

Two lovers kept apaxt by cruel circumstances and villainous plots meet at last and are happy. This thread serves to connect many minor plots, which brings us from Ireland (near Killarney) to England and then the continent and back again, and introduce a great variety of personages. These latter are nearly all of the Anglo-Irish Protestant gentry - Wharton, Wandesford, Peyton, Ulverton, Blackwood, Elton-no Irish name is mentioned. Great profusion of incident, but not very interestingly told. No historical or social background. Relates rather a large number of instances of misconduct. Speaks of " paraphernalia of Popish doctrine," yet one of the best characters is Father Issidore (sic).

26- EDMUND O'HARA: an Irish Tale. Pp. 358. (Dublin: Curry). 1828.

By the author of Ellmer Castle. A controversial story of an anti-Catholic kind. The hero goes to Spain to be educated for the priesthood. Ho meets Hamilton, who indoctrinates him with Protestantism. They are wrecked off the Irish coast. A priest refuses them the money to take them home to the North of Ireland, while the Protestants generously give it. He falls in love with Miss Williams, who insists on a year's probation so that he may be sufficiently "adorned with Christian graces." But he dies, and she marries Hamilton. 
ANONYMOUS-(continued).

27- ELLMER CASTLE. Pp. 320. (Dublin: Curry). 1827.

By the author of Edmund O'Hara, q.v. Henry Ellmer travels, and comes back converted to convert his family. He causes only anger and disturbance. They turn him out, and he departs with a blessing. But after some adventures returns to his father's deathbed. Contains much controversial matter.

23- EMERALD GEMS. (Boston). 1879.

" A Chaplet of Irish Fireside Tales, Historic, Domestic, and Legendary. Compiled from approved sources."

29 FAITHFUL MIKE, the Irish Hero, by "Old Sleuth." (N.Y.: Munro).

30- FATHER BUTLER; or, Sketches of Irish Manners. 16mo (Phildadelphia). 1834.

I am not sure whether this is the American edition of a little Souper tract by Carleton ' $q . v$.$) published by Curry in 1829, in which Father Butler finally is con.$ vinced of the falsity of his religion and becomes a Protestant.

31_ FATHER JOHN ; or, Cromwell in Ireland (1649) ; by " S. E. A." Pp. 477. (Whittaker, later Gill). Still reprinted. [1842].

A well told story, with a love interest and a mystery admirably sustained to the end. The plot largely turns on the misfortunes and sufferings brought about by Father John's fidelity to the secrecy of the confessional, a fidelity which the author strongly condemns. The hero is a young Irish Protestant, who before the close of the story has converted to his faith such of the Catholic personages of the tale as do not rank as villains. The moral of the story is the iniquity and falseness of the Catholic religion, for which the author throughout displays a very genuine horror. The author's political sympathies are Ormondist, but Owen Roe O'Neill is favourably described. The massacres of Drogheda and Wexford are described. It is "by the Author of The Luddite's Sister, Richard of York, \&c.

32 - FOLK-LORE AND LEGENDS (Ireland); edited by “C. J. T." $16 \mathrm{mo.}$ P. 192. (Gibbings). 1889.

A volume of a good popular series which includes vols. on Oriental, English, German, American, and other folk-lores. Thirty-three tales chosen from published collections, chiefly Croker's. A good selection. Humorous and extravagant element not too prominent. Some in dialect. Some titles:- "Fuin (sic) MacCumhal and the Salmon of Knowledge," "Flory Cantillon's Funeral," "Saint Brandon" (sic), and "Dongaha," "Larry Hayes," and "The Enchanted Man," "The Brewery of Egg-shells," "The Field of Boliauns," \&c. 33_ FORD FAMILY IN IRELAND, THE. Three Vols. (London: Newby).

(Ford, an English merchant, comes to the west coast of Ireland to pursue a business speculation in grain, and brings his family. He is imprisoned owing to a misunderstanding, and his daughter marries an officer, Macalbert, who becomes chief of the pikemen, and eventually dies on the scaffold. Period: '98, soon after' the landing of French at Killala. Point of view : very sympathetic towards Ireland and anti-Orange. No religious bias. A pathetic and a dramatic story.

34 - FRANK O'MEARA; or, The Artist of Collingwood; by "T. M." Pp. 320. (Dublin: McGlashan of Gill). 1876.

Frank, of the tenant class, falls in love with the landlord's daughter, Fanny. Their love is discovered, and Frank finds it best to emigrate to Australia. Here he has various adventures-bush-rangers, gold-diggings, and so on. A comic element is afforded by the sayings and doings of his man, Jerry Doolin. Meanwhile F's father and his friend, another widower, contend for the favours of the widow Daly-rather broad comedy-while Fanny, without losing her place in society, is running a bookshop while waiting for Frank. All is well in the end. A very 


\section{ANONYMOUS-(continued).}

pleasant story in every respect. "Collingwood" is a village near Melbourne. Part of the story takes place at Bray.

35- GERALD AND AUGUSTA; or, The Irish Aristocracy. Pp. 320. (Cameron d Ferguson). 6d. paper.

How Gerald, orphan son of Lord Clangore, is brought up in London to be antiIrish, while his sister is brought up by a Mr. Knightly (a stay-at-home Irish squire absorbed in Ireland) to love Ireland. How chance brings Gerald to Ireland, where he is quite won over to her oause. This chance is a wreck off the W. coast of Ireland, resulting in Gerald's falling temporarily into the hands of "Captain Rock." Many amusing adventures and situations follow. The author's sympathies are all for Ireland, but they are not blind or unreasoned sympathies. Very ably written both in style and construction.

N.B.-This is a reprint under another title of Banim's Anglo-Irish of the Nineteenth C'entury. q.v.

36- HARRY O'BRIEN : a Tale for Boys. (N.Y.: Benziger. 0.25 net. Burns and Lambert). 1859.

By the author of Thomas Martin. A little pious and moral Catholic story. The scene is laid in London.

37- HERMITE EN IRLANDE, L'. Two Vols. 12mo. (Paris: Pillet Ainê). 1826.

"Ou observations sur les mours et usages des irlandais au commencement du xix siècle." Interspersed with stories, occupying a large part of the book. Titles:"Le Cunnemara," "Le naufrage," "Mogue le Boiteux," "Lre rebelle," "La sorcière de Scollough's Gap," "Les bonnes gens," "Les cluricames," " Bill le Protestant," "Turncoat Watt ou l'apostat," "Le double vengeance," "Le retour de l'absent," etc. These are obviously taken for the most part from Whitty's book, q.v.

38- HOME MISSION, THE: an Irish Story. (Dublin : Robertson). c. 1849.

By the author of The. C'urate's Grate. "A work which abounds with lucid statements of doctrinal truth, and brings before us, in minute detail, the ministerial labours of a clergyman of our church engaged for the Home Mission in the South of Ireland."-(Dublin Evening Packet.)

39- HONOR O'MORE'S THREE HOMES. (N.Y.: Christian Press Association 7'ubl. ('o.) 0.25 net.

A story for girls. Catholic.

40- HUGH BRYAN: The Autobiography of an Irish Rebel. (Belfast). P.p. 478. 1866.

Scene: Valley of Blackwater, Lismore. Time: end of eighteenth century (1798) and beginning of nineteenth century. May be described as a Souper story. Purports to the a moving picture of the last struggle of the Gael against the English Planter, ending in failure, and resulting, in the hero's case, in conversion to Protestantism. He finally marries an escaped nun whom he meets in an English town while engaged in slum-work. The author is said to be the Rev. Samuel Anderson of Dunmurry.

41- IRISH BUBBLE AND SQUEAK, THE. Pp. 160. (London: Clarke do Beeton). 1854.

"A selection [thirty-five in all] of the most popular Irish tales, anecdotes, wit, and humour, illustrative of the manners and customs of the Irish peasantry." There is many a hearty laugh in these stories, especially for ourselves, for in them the Irishman always comes out on top. Some of the titles are:- "Serving a writ in Ireland," "Anecdotes of Curran," "Irish Bulls," "Paddy Doyle's Trip to Cork," "Lending a Congregation." \&c. 
ANONYMOUS-(continued).

42_- IRISH COQUETTE, THE: a novel. Vol. I. 1844.

No more published. Scene: an old Castle in the South of Ireland.

43_- IRISH DETECTIVE, THE, by "Old Sleuth." (N.Y.: Munrc).

In the Seaside Library, publ. between 1876 and 1884.

44- IRISH FAIRY TALES. Illustr. by Geoffry Strahan. (Gibbings). 2s. 6d.

A neat little volume, prettily illustrated, suitable as a present for children.

45- IRISH FIRESIDE STORIES, TALES AND LEGENDS. Pp. $400 . \quad$ (N.Y.: Kenedy). 63 cents. net. Illustr. 1910.

"It brings out very well the true Irish wit, for which that race is famous." $-(P u b l$.$) .$

46- IRISH GIRL, THE: a Religious Tale. Pp. 102. (London: Walker). One engraving by Parris. 1814. Second ed. same year.

By the Author of Coelebs Married. The girl begins life in a mud hut in the filthiest and most disgusting conditions. She is found in a barn and taken in by kindly English people, and after a little management becomes a Protestant at the age of fourteen, and indeed quite a theologian in her way. A visit to a church in Cork and to Ardman, near Youghal, where the dust of St. Dillon is sold by the bushel for miracle purposes, completes her conversion. The book is full of the vilest slanders against the Catholic Church. The Irish are represented as murderers and savages driven on by their priests.

47-IRISH GIRL, THE; or The True Love and the False. Pp. 118. (Cameron \& Ferguson). 6d.

Alice goes to England to stay with an aunt. Alfred St. Clare falls in love with her, but leaves her for the superior attractions of Georgina, whom he marries. Marriage turns out unhappy; he is tried for poisoning his wife; is saved by Alice and marries her in the end.

\section{8- IRISH GUARDIAN, THE : a Pathetic Story; by "A Lady." Two Vols.} (DUblin). 1776.

Told in a series of letters to Miss Julia Nesbitt, Dublin, from Sophia Nesbitt, of "Brandon Castle," in Co. Antrim, and from Sabina Bruce, of "Edenvale," Co. Antrim. The two Miss Nesbitts fall in love, and the course of their love affairs forms the chief subject of the letters. These are dated 1771. There is some vague description of Irish places, but feminine matters, chiefly, absorb the writers. To be found in Marsh's Library, Dublin.

50_- IRISHMAN AT HOME, THE. Pp. 302. (McGlashan \& (irr). Five Woodcuts by Geo. Measom. 1849.

"Characteristic Sketches of the Irish Peasantry." In part reprinted from the Dublin Penny Journal. "The Whiteboy";-(1828) Cahill, a scullogue, hanged an innocent man, for which the Whiteboys cut out his tongue. "The Rockite" is a man who took the oath of the secret society when drunk and had to go through with the business. "The Wrestler," description of the Bog af Allen and of a wake. "The False Step," a pathetic story of an Irish girl's ruin, her broken heart, and her mother's death. "The Fatal Meeting" (1397);- - How a Palmer meets Raymond de Perrilleaux at St. Patrick's Purgatory in Lough Derg, and what came of the meeting. They nearly all depict wild times. There is no religious bias, an absence of humour, and much description of scenery.

51 IRISHMAN, THE; or, The Favourite of Fortune. Two Vols. (Londox). 1772 . 


\section{ANONYMOUS-(continued).}

52__ IRISHMAN, THE : a Military-Political Novel; by "A Native Officer." Two Vols. 12mo. (London: Newman). 1810.

Title-page:- “ Wherein the idiom of each character is carefully preserved and the utmost precaution constantly taken to render the ebullitionary phrases peculiar to the sons of Erin inoffensive as well as entertaining." Told in letters between Major O'Grady and Major-General O'Lara, Miss Harriet O'Grady, and Lady Arabella Fitzosborne. The letters are full of italics and of the trifling gossip of fashionable or domestic life. The personages all live in England. Letters from Patrick O'Rourke to Taddy McLenna-heavy humour. Seem to contain no politics save a passing reference to the war then (1808) in progress.

53- IRISH PEARL, THE: a Tale of the Time of Queen Anne. Pp. 98. (Dublin : Oldham). 1850.

Reprinted from the Christian Ladies' Magazine for 1847 and published for charitable purposes. A religious tale of a strongly Evangelical and anti-Roman character, in which Father Eustace, the hermit of Gougane Barra, relates to Lady Glengeary his own conversion to Protestantism and that of her mother. Lady G., in her turn, relates her conversion to Lady Ormond, who tells the story to Queen Anne.

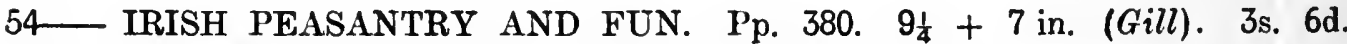
16 illustr. by J. F. O'Hea. [1892] 1910 .

Still reprinted without change, and is as popular as ever. Seventy-two stories, fourteen anonymous, the bulk of the remainder by Carleton, Lover, and Lever. Maginn, Maxwell, and M. J. Barry are represented by two each; Irwin, Lefanu, Lynam, Coyne, Sullivan by one each. Practically all the tales are of the Lover ( Handy Andy, q.v.) type, genuinely funny in their way, but broadly comic, farcical, and full of brogue. The illustrations are some of them clever, but inartistic and of the most pronouncedly Stage-Irish kind.

55_ IRISH PRIEST, THE; or, What for Ireland? Pp. 171. 16mo. (Longman, Brown, Green, \&c.). 1847.

"This sees the light with the earnest hope that it may conciliate prejudice, disarm opposition ..." The Author speaks of his "intensest sympathy for a despoiled, neglected, ill-used people." Supposed to be a MS. given to a doctor in the W. of Ireland by a priest on his deathbed. Sentimental and emotional in style. A rambling series of incidents in priest's life, with much moralising of a non-Catholic tone. Incidents of land agitation given, without explanation of their causes. Suggestions to make Ireland an ideal place, \&c.

56_- IRISH WIDOW, THE; or, A Picture from life of Erin and her Children; by author of "Poor Paddy's Cabin." Pp. 205. 12mo. (London: Wertheim and Macintosh). 1855.

Like the Author's former work, this deals with the religious question in Ireland from a Protestant (Evangelical) standpoint. But in this case the personages are drawn from the middle classes, the causes of their ensiavement to Rome being set forth. It is full of religious controversy. See ch. xvi. "The Fruits of an Irish Church Missions sermon," and ch. xviii., "Priest and Landlords."

\section{7- JIM EAGAN. (N.Y.: Pratt). \$1.0.}

58- KATHLEEN: A Tale of the Fifth Century, by E. A. Pp. vi +218. (Belfast: Mullen). Five illustr. 1880.

About an Irish slave girl carried off by Norse sea robbers. She brings about the conversion of some of them to Christianity. On her Irish harp she "sings the wild songs of her dear native land." 
ANONYMOUS-(continued).

59-KATHLEEN'S MOTTO; or, The Sea King; by T. D. B. (Barnet: St. Andrew's Press). 2s. 6d. 1898.

" A charming story of a sweet, pure Irish maiden and her devotedness to an invalided father and an unfortunate brother. The scene is laid in Ireland and England, with enough of India to lend colour and interest. The Sea King is a very kind relative whose privilege it is to set some wrongs right in a fairy godfatherly style. (Review in the Ave Maria).

60_ LAND OF THE KELT, THE: a tale of Ierne in the days of '98. From an unpublished MS. by Peter Paradox, M.D., deceased. 3 vols. (LoND.: Saunders \& Otley). 1860.

The story leads up to a lawsuit in which Stephen Bingham is declared to be really Stephen FitzStephen and heir to the Earldom of Glanmore. Sir Roderick O'Conor is arrested for high treason, but escapes, only to be killed at Castlebar. Catholic in tone.

61_ LAST DROP OF '68, THE: a Picture of Real Life with Imaginary Characters ; by "An Irish Bramwellian." Pp. 127. (Hodges Figgis). 1s. 1885.

Begins in Dublin, the teller being a Dublin lawyer, but nearly all the incidents take place out of Ireland. All the personages are more or less disreputable, including the teller, but especially the hero, Helgate, who is a thorough blackguard. The story consists chiefly of the doings of this latter, a drunken, swindling wretch, who deceives foolish people and lives on them. The writer does not seem to adopt any definite moral attitude. '68 refers to the vintage of that year.

62 - LAST OF THE O'MAHONYS, THE; and other historical tales of the English settlers in Munster. Three Vols. (Bentley). 1843.

Contents:-1. The title-story. 2. "The Physician's Daughter." 3. "The Apprentice." 4. "Emma Cavendish." 5. "The Puritan." 6. "Black Monday." Scene: Co. Cork and chiefly around Bandon. All deal with troublous times of 17th century as seen from the settlers' point of view, with which the Author is in sympathy. The Irish are painted in no flattering colours. Useful historical notes are appended. Longer notices of Nos. 5 and 6 are given elsewhere as specimens of the whole.

63- LEAVES FROM MY NOTE BOOK. By An Ex-Officer, R.I.C. Pp. 170. (LoND.: Dean). n.d. (c. 1876).

Twelve episodes or tales portraying Irish life and character. A considerable proportion are concerned with crime-murders, faction fights, religious disturbances; but various customs of the peasantry-feasts, dances, etc.-are agreeably described. So also are scenes in various parts of Ireland, notably Kilkenmy, Athlone, and Dingle. The Author, a non-Catholic, seems free from religious and political bias and anxious for harmony between various sections of Irishmen. The 17 illustrations are rather crude; some are grotesque.

64- LEGENDS AND FAIRY TAIES OF IRELAND. With 50 wood engravings. Large 12 mo. (N. Y.: Kenedy). 63 cents net.

Being a complete collection of all the Fairy Tales published by Crofton Croker and embodying the entire volume of Kenedy's Fictions of the Irish Celts.

65- LIFE IN THE IRISH MIIITIA; or, Tales of the Barrack Room. Pp. 255.

(LoNDON: Ridgway). 1847.

The dedication (to O'Connell) is dated 1834, and the first words of the book are "In the summer of $1833 . . . "$ A very eccentric book, intended by the Author (a lady) as a satire on the "fashionable depravities of the times," with intent to "exhibit folly and vice to public scorn and reproach." (Pref.). She is out against proselytism, bigotry, hypocrisy, aristocracy, race-hatred between Ireland and England, and all abuses that bear heavily on the people. This book consists of various parts:-I. "The Sojourner in Dublin"-a young Englishman who lives in 


\section{ANONYMOUS-(continued).}

lodgings and tells what he sees and hears. II. "The Modern Pharisees of the city of Shim-Sham in Ireland," in the form of a story. III. "Life in the Irish Militia"a fierce attack on the militia, especially a Northern and a Kerry regiment. IV. "A Visit to Killarney." V. An Allegorical 'Tale.

\section{6 - MARY OF THE WINDS AND OTHER TALES. By “Enedeen.” Pp. 305. (Murray). 6s. u. 1918.}

"These stories have been gathered in the S. of Ireland; most of them from old people living in the remote parts of Kerry. The writer has no pretence to knowledge of folk-lore; allusions to old customs and superstitions, and the turns of the phrases, have been written down just as they happened to be remembered." (Pref.). The stories are almost impossible to classify; some are traditional folk-lore, some local incidents, some are connected with the war. For the most part they are sad and even depressing. Some of the sketches are very slight. The style varies greatly from grandiloquent, semi-epic language to peasant talk. Often the note does not seem to ring true. Perhaps the best are the stories of simple country life, and the story entitled "A Song" in which, says a reviewer, is "all the atmosphere of Irish convents." I am informed that the Author is the Countess of Kenmare.

67- MICK TRACY, THE IRISH SCRIPTURE READER; or, The Martyred Convert and the Priest; by "W. A. C." (Partridge). 3s. 6d. Iilustr., but without reference to the story. n.d.

The hero is "a day labourer reared in the R.C. communion but through mercy enabled to see its delusions and to escape from them." He is denounced by the priest and assaulted by the parishioners. These are prosecuted, but the only result is moonlighting, murder, and the kidnapping of converts. Yet the converts multiply. The reproduction of the brogue is ludicrous. See 'Tim Doolin. •

58- MISTLETOE AND THE SHAMROCK, THE; or The Chief of the North; by An Antiquary. Pp. 286. (Glasgow: Cameron \& Ferguson). n.d.

"A national tale of the fifth century" (subt.), intended to set forth the conflict between druidisn and Christianity during the lifetime of St. Patrick, who appears in the story. The love of King Laogaire's son for the fair druidess, Ethne, provides a romantic element. Some of the persons of the story are made to speak in the broadest of brogues, and the book has many anachronisms.

69_- MY OWN STORY: a Tale of Old Times. Pp. 168. (Curry). One illustr. by Geo. Petrie, engraved by Kirkwood. 1829.

James O'Donnell is sworn in by a priest and joins the rebels, but later he is made a "Bible Christian," turns traitor, and is eventually hanged. Period: some time in reign of George III. The country about Fort ra nGall and the woods of Coolmor'o are described.

70_ NATIONAL FEELING; or, The History of Fitzsimon: a Novel, with Historical and Political Remarks; by "An Irishman." Two Vols. (Dublin). 1821.

A straggling story of the adventures in Ireland (Co. Mayo and Dublin) and abroad of Edward F. Tells of the progress of his wooing of Matilda, which is much interfered with by the machinations of a wicked lord. There are also some minor love affairs. Pp. $103 \mathrm{sqq}$. of Vol. I. contain some pictures of Dublin life at the time, introducing public personages such as the Duke of Leinster, Lady Rossmore, Mr. Justice Fletcher, Alderman M'Kenny, \&c. The hero goes to the U.S. and then to $\mathrm{S}$. America. The title of the tale seems to be due to his meeting various peoplesFreeks, Argentiners, Chilians, \&c.-fighting for their national independence. See pp. 206, 217, 222. I failed to come across Vol. II. Preface shows Author to be Nationalist in his Irish views. 
ANONYMOUS-(continued).

71- NICE DISTINCTIONS: a Tale. Pp. 330. (Hibernia Press Offices). 1820.

Scene: Co. Wicklow. The Courtneys of Glendalough Abbey have a tutor named Charles Delacour, who makes friends with the clergyman's family-Mr. Vernon and his wife, son, and daughters. Presented ultimately with a living, he marries Maria Vernon. Many subordinate characters of no importance are introduced into this invertebrate tale, the style of which is stilted and unnatural.

72- OLD COUNTRY, THE: a Christmas Annual. Pp. 200. Demy 8vo. (Sealy, Bryers). 1s. 1893.

Irish Stories (and Poems) by Katharine Tynan, F. Langbridge, Dick Donovan, Edwin Hamilton, W. B. Yeats, Edmund Downey, Nora Wynne, \&c., \&c.

73_ O'NELLL McDARRAGH, the Detective ; by “Old Sleuth." (N.Y.: Munro).

74 ON TIPTOE: A Collection of Stories and Sketches by Irishwomen. Ip. 112. (Gill). 1s. 1917.

Contents:- "At the Crib," by "Mary Prendergast"; "The Message of the Shamrock," by Nora Ni Arrachtain; "The Egg Trust," by Stephanie de Maistre; "A Railway Party," by Mary O'Sullivan; "The Romance of a Picture," by Mary Cross; "On the Bog Road," by Maire Ni Chillin; "The Bogwood Rosary," by C. M. Lynch; "Nancy Brogan's White Leghorns," by Marie J. Blake ; and other stories by the same and other authors, seventeen in all. Three deal with the humours of school life. "At the Crib" is a tender little study. Most of them bear the marks of inexperience, and are somewhat immature.

75- O'RUARC: An Irish Tale. Pp. 126. (Dublin: Milliken). 1832.

"This production is chiefly remarkable as emanating from the precincts of the 'Silent Sister,' as old Trinity has been called, and being dedicated to our clever' countrywoman, Lady Morgan. The work is written avowedly to expose the evils. of absenteeism, and is full of the foelings of nationality and indignation which the virtues and sufferings of Ireland must excite in every generous mind. It is not often we hear from the members of Trinity College such sentiments as these." (Irish Monthily Magazine, Dec., 1832).

76_ OUTCAST, THE: a Story of the Modern Reformation. Pp. 172. (Curry). 1831.

The "Outcast" was educated for the priesthood, read Voltaire and Rousseau, but did not finally awake to the error of the Roman "system " until he had read Italy, hy Lady Morgan. He ceases to believe in Catholicism; is turned out by his father, while his mother dies of a broken heart. There is a description of the Slaney. Contains much that would be extremely offensive to Catholics and some remarks about Confession and Mass that would appear to them blasphemous.

77- PASSION AND PEDANTRY: a Novel illustrative of Dublin Life. Three Vols. (London: Newby). 1853.

A somewhat ordinary tale of the fortunes of young Charles Desmond, an army officer, is made the vehicle for a careful and detailed picture of manners and customs at the period, and for a presentation of the Author's views on things Irish, though with little reference to politics or to religion. The plat, such as it is, turns chiefly on the question whether Charles will come in for his old uncle's money and will, in spite of whispering tongues, marry the lady-both of which he does. The conversation of some of the personages is full of pedantry and of quotations in various languages. Dublin life well portrayed by a keen observer.

78 - PEAS-BLOSSOM; by the Author of "Honour Bright." (II"ells, Gurdner).

3s. 6d. 30 illustr. by Helen Miles. C. 1911.

“' 'Peas-blossom' may be described as a rollicking, respectable Irish story, the. names of the juvenile pair of heroes tbeing Pat and Paddy.... An exceptionally readable volume."-(Times). 
ANONYMOUS-(continued).

79 PHILIP O'HARA'S ADVENTURES [and other tales]. Pp. 144.

(Chambers). 1885.

A young man's adventures in the American Civil War. Only the first story has the slightest connection with Ireland.

80- PICNICS FROM THE DUBLIN PENNY JOURNAL. Pp. 328. (Dublin:

P. Dixon Hardy, and LondoN). Ten engravings by B. Clayton, jnr. 1836.

"A selection from the legends, tales, and stories of Ireland which have appeared in the published volumes." Contents:- "Darby Doyle's Voyage to Quebec"; "Reminiscences of a Rockite"; "The Pooka"; "Meelan,' a legend of the South (verse); "The Dreamers"; "The Smugglers"; "Shaun Long and the Fairies"; "Ellen Duncan, Murtagh Oge the Outlaw"; "The Leprachaun"; "Paddy Doyle's First Trip to Cork"; "The Red Spirit"; "The Unforgiven"; and four others. Nearly all well told, though the adventure stories are very melodramatic. The tales are very various in character, and deal with many different-parts of the country, chiefly the South. The brogue is not caricatured, and the moral tone is high. They are but a few samples of the rich treasures buried in Dixon Hardy's magazine.

81__ POOR PADDY'S CABIN ; or, Slavery in Ireland. By "An Irishman." Pp. xii.+242. 12mo. (London: Wertheimer \& Macintosh). 2nd ed. 1854.

"A true representation of facts and characters," names of persons and places being disguised. "His [the Author's] aim has been, along with a matter-of-fact representation of the real state of things in Ireland, to exhibit in a parable . . . a just and true view of what the gracious dealings of the Almighty always are." (Pref.). A pamphlet in story form written against the Catholic Church in Ireland and in support of the "Irish Reformation Movement." Appendix, giving with entire approval a bitterly anti-Catholic article from the TrMes of November 29th, 1853 (?), and others of like nature from the Morning Advertiser (Oct. 22nd, 1853). The character's are drawn from the peasant class.

\section{2 — POPULAR TALES AND LEGENDS OF THE IRISH PEASANTRY.}

Pp. 404. (Dublin: W. F. Wakeman). Illustr. by Samuel Lover. 1834.

Fifteen stories, including two by Carleton and one by Mrs. S. C. Hall. Five are by Denis O'Donoho, three by J. L. L., and one each by J. M. L. and B. A. P. Titles:- "Charley Fraser," "The Whiteboy's Revenge," "Laying a Ghost," "The Wife of Two Husbands," "Micky Delany," "The Lost One," "The Dance," "The Fetch," "The 3 Devils," "The Rebel Chief, 1799," \&c., \&c.

\section{3- PRETTY ROSE O’DONOGHUE. By “M.D.” 12mo. Pp. $142 . \quad$ (Duffy).} n.d. 1908.

The heroine is an Irish governess from Kerry in the family of Sir William Temple at Heatherly Hall, somewhere in England. The eldest son (an officer quartered in Kerry during Fenian times) falls in love with her. As a result of a quarrel with Lady T., Rose goes as a postulant to the convent in Italy, where she had been educated. But Arthur comes to claim her, and they live happily, etc. The story is readable, but slight.

84 - PRIESTS AND PEOPLE: a No-Rent Romance; by the Author of Lotus, etc. Three vols. (London: liden Remington). 1891.

ijotus is by I. M. O. $\Lambda$ book inspired by the bitterest dislike and contempt for Ireland. The views expressed by the young English soldier ( $p$ 101) seem throughout to be those of the author. The interest turns almost entirely on the relations between landlord, tenant, and League, and no effort is spared to represent the two latter in the most odious light. It is the work of a practised writer, and the descriptions are distinctly good and the story well told. The brogue is painfully travestied. The author is ignorant of Catholic matters. 
ANONYMOUS-(continued).

85- PROTESTANT RECTOR, THE. Pp. 216 (Nesbit). 1830.

At the hospitable Protestant rectory even the priest is received. This priest "performed several Masses on Sundays"; he is frequently drunk. He goes to Rome and, at the "fearful sight" of the Pope treated as God, he recoils in disgust, and is converted. On his return he is again welcomed at the Rectory, where he converts many and dies a holy death.

86- PURITAN, THE. Pp. 134.

The interest of this story turns chiefly on the religious differences of the times. The author is for "the calm and rational service of the Church of England " as against the new fanaticism of the Parliamentarians. The characters, such as those of Obadiah Thoroughgood and Lovegrace, are well-drawn. There is but little local colour and no description of scenery. The scene is laid at Bandon, Co. Cork. Bound up in one vol. with "Black Monday Insurrection," q.v., being Vol. III. of The Last of The O'Mahonys

8i- RANELAGH, the Lightning Irish Detective; by "Old Slenth." (N.Y.: Munro).

88- RIDGEWAY; by "Scian Dubh." Pp. xx. +262 (close print). (Buffalo: $M c$ Carroll). 1868.

"An historical romance of the Fenian invasion of Canada," June, 1866. Introd. (pp. xx. close print) gives a view of Irish history and politics from a bitterly antiEnglish point of view. England has been "a traitor, a perjurer, a robber, and an assassin throughout the whole of her infamous career." Append. gives in $5 \mathrm{pp}$. an "Authentic Report" of the invasion of Canada. Fenianism is fully discussed, especially in ch. vi. Career of Gen. O'Neill, ch. vii. A love story of an ordinary kind is used as a medium for politics and historical narrative. The author's name was, I understand, O'Carroll.

89- ROBBER CHIEFTAIN, THE. Pp. 342. Post 8vo. (Duf y). 2s. 1858. Still in Print.

Scene: chiefly Dublin Castle. Cromwellian cruelties under Ludlow depicted, and early years of Restoration. The Robber Chieftain is Redmond O'Hanlon, the Rapparee. The Ven. Oliver Plunket is also one of the characters. Some incidents suggest Catholic standpoint, but in places the book reads like a non-Catholic (though not anti-Catholic) tract. The hero and heroine are Protestant. Full of sensational incidents, duels, waylayings by robber bands, law court scenes, tavern brawls. Also many repulsive scenes of drunkenness among the native Irish, and of murder, wild vengeance, and villainy of all kinds. Hardly suitable for young people.

90- ROMAN CATHOLIC PRIEST, THE. Pp. 298. (Curry). One illustr. by Kirkwood. 1827.

A Catholic boy, Doyle, risks his life and saves a Protestant boy from drowning. The boy's father, out of gratitude, offers to send Doyle to T.C.D., guaranteeing that "he will not have to make even a temporary renunciation of his religion." But the priest refuses, and soon Doyle becomes a Protestant.

91__ SAINT PATRICK: a National Tale of the Fifth Century; by "An Antiquary." Three Vols. (EDrN.: Constable). 1819.

A romance of love and vengeance and druidical mysteries into which St. Patrick enters as one of the dramatis personce. There are plenty of exciting incidents, some fine scenes, and a very good picture of druidism in the fifth century. Very well written but for the unfortunate introduction of modern Irish brogue and Scotch dialect. The religious point of view is Church of Ireland, and there is an effort to represent the Christianity of those days as essentially different from the Catholicism of these. Scene: chiefly Tara, Dunluce, the Giant's Causeway, the Bann. 
ANONYMOUS-(continued).

92_ SEPARATIST, THE; by “A New Writer." Pp. 323. (Pitman). 6s. 1902.

The love story of Stella Mertoun, who is a Royalist, and Philip Venn, who is on the Parliamentary side in the Civil War. Only a small portion of the action takes place in Ireland. The Author's sympathies are with the Puritans, but the bias is not pronounced.

93 - SHAMROCK LEAVES: Gleaned in the Fertile Field of Irish Literature. Pp. 336. (Boston: Donohoe).

"Being tales and stories of Ireland selected from the most popular authors."

94_ SIEGE OF MAYNOOTH, THE: or Romance in Ireland. Two Vols. (Chelsea: Ridgeway). 1832.

A very long novel with a rather confused plot, but containing good scenes. Purports to be a M.S. given to her descendant by the old Countess of Desmond, who has fallen on evil days, and relating stirring incidents of the Desmond wars and of the rebellion of Silken Thomas, including the attack on Desmond Castle by the Butlers, the defeat and capture of Lord Grey in Glendalough, the escape of Lord Thomas Fitzgerald from the Black Castle of Wicklow, and the siege and betrayal of the Castle of Maynooth. Written on the whole from the Irish point of view.

95_ SIR ROGER DELANEY OF MEATH; by “Hal." Pp. 228. (Simpkin, Marstiall). 6s. 1908.

The Sir Roger of the story (he is "10th baron Navan") is an elderly married man, blustering, cursing, lying, cheating, but described in such a way that one does not see whether the author means him for a hero or not. He falls in love with Lady Kitty, who is in love with somebody else. Sir Roger tries to get the latter into disreputable situations. They fight a duel, and the curtain falls on Sir Roger mortally wounded. The book is quite devoid of seriousness.

\section{6- SMITH OF THE SHAMROCK GUARDS; by "An Officer." (Stanley Paul).}

97_ STORIES OF IRISH LIFE, PAST AND PRESENT; by " Slieve Foy." Pp. 160. (Lynwood). 1s. 1912.

Ten stories, amusing and pathetic, some of which have appeared in the WeEkLY FreEman and the IrISh EMERaLd.

98 - STORY OF NELLY DILLON, THE; by the author of "Myself and my Relatives." Two Vols. (London: $\lambda^{2}$ ewby). 1866.

Nelly Dillon, daughter of a Tipperary farmer, is abducted in suspicious circumstances by a former lover, who is a Ribbonman and illicit distiller. She is disowned by her parents but befriended and sheltered by Bet Fagan, a fine character. The latter prevails upon the abductor, when under sentence of death, to clear Nelly Dillon's character in the presence of the parish priest, who afterwards tells the facts from the altar. The parents wish to receive Nelly back, but she rejects their advances and dies. A sad story, well told, and with a healthy moral.

\section{9_- TALES AND LEGENDS OF IRELAND. Two Vols. (Conk: Bolster). 1831.}

"Illustrative of society, history, antiquities, manners, and literature, with translations from the Irish, biographical notices, essays, etc."

100_THOMAS FITZGERALD THE LORD OF OFFALEY; by "Mac Erin O'Tara, the last of the Seanachies." Three Vols. (London). 1836.

"The first of a projected series illustrative of the history of I." (Title-p). See also Introd. (pp. xxx.) containing some interesting remarks about Irish historical fiction. Claims to "give the history as it really occurred." The book is a quite good attempt to relate the rebellion of Silken Thomas in a romantic vein (though 
ANONYMOUS-(continued).

with no love interest) and to picture the times. The conversations, though somewhat long-drawn-out, are in very creditable Elizabethan English, redolent of Shakespeare. Opens with a description of Christmas in Dublin in 1533. The Author is not enthusiastically Nationalist, but is quite fair to the Irish side.

101- TIM DOOLIN, THE IRISH EMIGRANT. Pp. 360 (close print).

(Partridge). 3s. 6d. Illustr. Third ed., 1869.

By the Author of "Mick Tracy" (q.v.). Tim, son of a small farmer in Co. Cork, as a result of his conversion to Protestantism, has his house burned down and his cattle killed. He emigrates to U.S.A., but soon passes to Canada, and helps to. repel the Fenian raid. He is joined by his family, and all live happily at Castle Doolin. Less offensive than "Micky Tracy" in its allusions to religious controversies.

102_ TOUR DE LOUGH-ERNE, LA : Nouvelle irlandaise, par l'auteur de Serge Batourine. Pp. 329. (Lausanne: Mignot). 1884.

Founded on the ostracism of Captain Boycott and on his Relief Expedition. Sir Robert Molvneux. M.P., and landlord. comes over with Parnell, falls in love with Kathleen Macmahon, marries her, and, under her influence, works a revolution on his estate. Gives account of Land Act of 1881 ; describes a rent day, a wake and an agrarian murder. Fair on the whole but anti-Catholic in tone.

103 UNITED IRISHMAN. THE: or, The Fatal Effects of Credulity. Two Vols. (Dublin). 1819.

A United Irishman who had escaped from Dublin Castle by the heroism of a sister. tells the tale of his woes to an Englishman, who meets him by accident. The latter in turn tells his story, equally woeful. The writer seems to be a Catholic and to sympathise more or less with the United Irishman. The book contains material for a good story, but it is told in a rambling manner, without art, and is full of sentimentality. No attempt to picture events or life of the times. See supra. "The Cavern in the Wicklow Mountains."

104-UP AND DOING; by Irish Priests. Pp. 110 . (Gill.). 1s. Frontisn., photo of authors. 1916.

Fifteen tales and sketches by Frs. Brennan, O'Keeffe. Redmond. Kitchen, Costello, Henaghan, Campbell, Murrin, MacLaughlin, J. .T. O'Kelly, O.S.F.; J. J. Kelly, D.Ph.. and two anonymous writers. All are Irish in subject but vary much in character. Four or five of them are humorous. Some of them. notably "Maureen." depict very beautifully the simple holiness of the Irish poor. The two stories about "Skylark Grove," a squalid London street, are bright and amusing. Others, on the contrary, are of a depressing, if not a morbid, nature.

105- VIRTUE REWARDED; or, The Irish Princess. A New Novel. Pp. 184. 16mo. (London: Bentley). 1693.

This is No. III. in Vol. xii. of Modern Novels, printed for R. Bentley, 1692-3. Dedicatory Epist. "To the Incomparable Marinda." (Pref.) "To the ill-natured reader." A pretty foreign prince in the train of William III. falls in love with an Irish beauty whom he sees in a window when passing through Clonmel. The story tells of the vicissitudes of his love suit. It is eked out by several minor incidents. Nothing historical except the mention of the siege of Limerick.

N.B.-This is the earliest Irish novel I have been able to discover. It is in Marsh's Library, Dublin.

106-VEUVE IRLANDAISE ET SON FILS, LA; Histoire veritable. Pp. 36. (PARIS: Delay). 1847.

A little Protestant religious tract telling how a poor Irish widow was brought round to Protestant ideas by means of Bible readings.

107_ WALTER O'NEIL: or, The Pleasure of Doing Good. (London: Darton c. Harvey). 1838. 


\section{ANONYMOUS-(continued).}

\section{8- WEIRD TALES. Irish. 256 pp. 18mo. (N.Y.: Paterson). [1890].}

Eleven tales selected from Carleton ("The Lianhan Shee"). Lover ("The Burial of O'Grady"), Lever, Croker ("The Banshee"), Mrs. Hall, and J. B. O'Meara, together with some anonymous items.

109_WILLIAM AND JAMES; or, The Revolution of 1689; by "A Lady." Pp. xiv. +354. (DUBLIN). 1857.

"An Historical Tale, in which the leading events of that . . period of our history ... are faithfully and truly narrated." Introduces William III., James II., Tyrconnell, Sarsfield, Richard Hamilton, \&c. Describes Boyne and Aughrim. Scene: chiefly Co. Fermanagh. Tone strongly Protestant (there are digressions on religious matters), but without offensiveness to the other side. It is a rather rambling, ill-connected story, the work of a prentice hand. The initials of the author seem to be J. M. M. K.

ABRAHAM, J. Johnstone, a native of Coleraine. B.A., 1898; M.D., T.C.D., 1908; a consulting Surgeon in London; now serving in R.A.M.C. Author of The Surgeon's Log.

110 - THE NIGHT NURSE. Pp. 318. (Chapman \& Hall). 6s. Fifth edition. 1913. 2s.

Life in a Dublin hospital, carefully observed. Sex problem of "the greater and the lesser love," studied in a distinctly "biological "way. As foil to the main characters, who are of the respectable Protestant classes, we have "R.C.'s" of a most undesirable type, and, in the background, the wholly disreputable Irishry of a western town. The four plagues of Ireland are Priests, Politicians, Pawnbrokers, and Publicans, according to one of the personages. The medical interest is prominent throughout.

\section{ADAMS, Joseph.}

111- UNCONVENTIONAL MOLLY. Pp. 320. (Met/uen). 6s. 1913.

The young heir of the old rackrenting absentee comes (from Cambridge) incognito among his tenantry in the West and lives their life. He meets the heroine, who gives its title to the book-with the expected result. The rest is a series of little episodes-fishing in a western mountain-stream, a day's shooting on a moor, a sail on Clew Bay, a Petty Sessions Court, a match-making, a fair, \&c., \&c., all with a splendid setting of Western scenery. Might be written by a sympathetic and kindly visitor who had enjoyed his holiday.

ADDISON, Henry Robert, Col. 2nd Dragoon Guards, author of Stories of Indian Life, The Diary of a Judge, d.c.

112 - RECOLLECTIONS OF AN IRISH POLICE MAGISTRATE and Other Reminiscences of the South of Ireland. (Ward, Lock and Tyler). 1862.

Scarcely to be reckoned as fiction but told in the form of 33 stories or episodes. The magistrate in question is a "Major Vokes," at whose exploits the writer, while stationed with his regiment at Limerick, professes to have assisted. The stories relate to a period about 30 years previous to date of publication. The Clare election is included. Other episodes relate to raids for arms, agrarian troubles, crimes, etc. The stories are stated to be all relations of fact.

“ ALEXANDER, Mrs." Annie French Hiector (1825-1902), dau. of Robert French, a Dublin solicitor. Published her best-known novel, The Wooing O't, in 1873, and over forty others since. (D.N.B.)

\section{3_ KITTY COSTELLO (Fisher Unwin). 6s.}

The last of her novels. Experiences of a beautiful and well-born Irish giri suddenly plunged, somewhere about the "forties," into commercial circles in a busy English port. The attraction of the book consists in the brightly drawn contrasts of the Irish and English temperaments, with their widely different views of life. (Publishers note.) The book contains a brief memorial introduction. 
ALEXANDER, Eleanor. Born at Strabane, daughter of the late Dr. Alexander, Archbishop of Armagh (d. 1911), and of Mrs. Cecilia Frances Alexander, both of them well-known as poets. Educated at home. Has written verse for the SPECTATOR and for other periodicals. At the outbreak of war was preparing for publication a collection of Ulster stories illustrative of the peculiar humour of the North. Her Lady Anne's Walk, a miscellany of historical reminiscences woven round a place and one who walked there long ago, contains an excellent bit of Ulster dialect-the talk of the old gardener.

114- THE RAMBLING RECTOR. Pp. 344. (Arnold). Third impression, 1904 (N.Y.: Longmans). 1.50.

A story of love, marriage, and social intercourse among various classes of Church of Ireland people in Ulster. Draws a sympathetic picture of clerical life, the hero being a clergyman. Every character, and there are very many interesting types, is drawn with sure and distinct traits. There are no mere lay figures. John Robert is a curious and amusing study of a certain type of servant. Full of shrewd observation and knowledge of human nature, at least in all its outward aspects. Very well written.

\section{ALEXANDER, Evelyn.}

115- THE HEART OF A MONK. Pp. 318. (Long). 0s. 1910.

The love story of Ivor Jermyn, who for reasons connected with an hereditary family curse is induced by his mother to become a Benedictine. During a vacation five years after his profession he meets his former love at a country house, and a liaison is formed. Taxed with this by his rival, the shock makes him see the family "ghost" - the "old man of horror." A fatal illness results, and he leaves the field to his rival. Written pleasantly and lightly. Shows little knowledge of Catholic ways and doctrines.

\section{6_ THE ESSENCE OF LIFE. Pp. 320. (Long). 6s. 1911.}

Youth is " the Essence of Life," as exemplified in the heroine's crowded momenty in the social life of Dublin and London, closing with her marriage with Lord Portstow, but shadowed by the tragedy of a beautiful actress, who turns out to be her mother. The novel does not rise above the common-place.-[TIMes Li'. SUPPL.].

ALEXANDER, L. C., Author of The Wife Sealers.

117- THE BOOK OF BALLYNOGGIN. Pp. 315. (Grant, Richards). 6s. 1902.

Stories of a miscellaneous lind, mostly humorous, told in a pleasant and readable style. Shows little knowledge of Irish life. The peasantry are treated somewhat contemptuously. The interest at times turns on the absurdities of Irish politics and of Irish legal proceedings.

ALEXANDER, Miriam (Mrs. Stokes). Born at Birkenhead. Educated at home, except for a short period at Alexandra College, Dublin. Was much interested in the Gaelic League till alienated from it by recent events.

118- THE HOUSE OF LISRONAN. Pp. 312. (Melrose). 6s. 1912.

A tale of the Williamite wars. Dermot Lisronan vows vengeance on the brutal Dutchman who has driven him from his ancestral home and been the death of his mother. The book is a story of that vengeance. Dermot by a strange fatality marries the daughter of this Dutchman, and some fine psychological and human interest is afforded by the struggle in her mind between love (the love of Dermot's once bosom friend, Fitz Ulick) and wifely duty. The book is full of exciting and dramatic incidents and situations, and never flags from the lurid beginning to the tragic close. The characters are clearly drawn and they are worth drawing:Bartley, the Hedge-schoolmaster; Taaffe, the besotted coward, sorry product of Williamite rule; Father Talbot, the devoted priest of penal days; Barry Fitz Ulick, a kind of Sir Launcelot, and the rest. William III. is painted in darkest colours, 


\section{ALEXANDER, Miriam (Mrs. Stokes)-(continued).}

and the penal days that he inaugurated are shown in their full horror, though as an offset to this we have a picture of the persecution of Huguenots in France.

N.B.- This novel gained a 250 guineas prize by the unanimous award of three competent judges. Six editions were sold in less than two months.

\section{9_ PORT OF DREAMS, THE. Pp. 351. (Melrose). 6s. 1912.}

Dedication: To Caitlin ni Houlihan. A stirring and vivid romance of Jacabite days (18th century) in Ireland, containing some intensely dramatic episodes, e.g., the escape of Prince Charles Edward. There are many threads in the narrative, but the chief interest, perhaps, centres in a Jacobite who, having served the cause well for twenty years, finds himself confronted with the spectre of physical cowardice. To save the cause from disgrace, his cousin Denis takes his place on the scaffold. The girl marries Clavering for the same reason, noit for love. The Author interrupts her narrative at times to express her views on Celticism (for which she is enthusiastic), religious per'secution, and modern degeneracy.

\section{RIPPLE, THE. Pp. 367. (Melrose). 6s. 1913.}

Opens in Mayo (Achill scenery described), but soon shifts to Poland and then to France. Adventures of Deirdre van Kaarew (daughter of a recreant Irishman who has Dutchified his name and turned Protestant), who has followed her brother to rescue him from the designs of a hated kinsman. She falls in love with Maurice de Saxe (of whom a careful and vivid portrait is drawn), and the story of this "friendship" takes up much of the book. She refuses him in the end, and rnarries the hated kinsman. A fine plot, full of dramatic incidents.

121- MISS O'CORRA, M.F.H. (Melrose). 6s. 1915.

Miss O'Corra, who has become a rich heiress, leaves her English home and comes to hunt in Ireland. She is quite ignorant of equine matters, and various amusing difficulties beset her. She meets her fate in the person of a young Irish sportsman. -(Press).

ALEXANDER, Rupert. (Author of The Vicar of St. Nicholas).

\section{2- BALLYRONAN Pp. 364. (Digby Long). [1897]. New ed. (Burleigh).} 1899.

"A wonderfully interesting story, written in an easy, raittling style, with cleverly conceived plot, abundant humour, and no lack of incident. There is an unmistakably Irish atmosphere about it, and it bespeaks an intimate personal knowledge of the people, not only in regard to their speech, but also as to many of their characteristic ways and customs."-(Press Notices).

123 MAUREEN MOORE: a Romance of '98. Pp. viii.+355. (Burleigh). 6s. 1899.

A well told story, introducing Lord Edward and the other leaders. Maureen, an American, is the niece of John Moore, who is driven into rebellion by the persecution of the "Yeos." His two sons, one a captain in the army, the other a priest, also join the rebel ranks. A love interest with cross purposes pervades the story. Larry Farrell is a great character, performing wonderful deeds of bravery and having equally wonderful escapes. The book leans entirely to the rebel side. The fight at New Ross and the atrocities of Wexford are vividly described.

ALGER (Horatio). Author of over 50 such books, with titles suoh as Making his Way, The Young Salesman, Bound to Rise, Facing the World, etc.

124 ONLY AN IRISH BOY; or, Andy Burke's Fortunes. (N. Y.: Hurst). n.d. (Burt). 1904.

Scene laid altogether in U.S.A. A book for boys, relating the adventures (which are of a somewhat stereotyped kind) of a young Irish boy. 
ANCKeTILL, W. R., of Quintin Castle, Co. Down; a J.P. D. 1889, aged 69.

125- THE ADVENTURES OF MICK CALLIGHIN, M.P.: A story of Home Rule; and THE DE BURGHOS: A Romance. Pp. 243. (Tinsley). Seven rather rough illustr. 1874. Second ed. Belfast, 1875. 1s.

1. Mick Callighin leaves Ballypooreen, near the Galtees, of which there is a fine description, for Dublin and then London. He meets his future wife in Kensington Gardens. The plot is slight, but there is a good deal of pleasant wit, many political hits, and much satire, not of Home Rule but of Home Rulers.

2. Arthur Mervyn meets Col. de Burgho and his daughter, home from Italy. An Italian count, who is also a pirate, carries off Nora, but she is rescued and married to Arthur. A pretty story, with some good descriptions of life among the better classes in the West of Ireland.

126 DOWDENHAM: A Tale of High Life in the Present Period. Pp. 491. (Marcus Ward). 1879.

The scene of the first half of the book is laid in England. Aristoclatic circles enlivened by the humour of the Rev. Hercules Mulligan, who had migrated to England after Disestablishment, the rights and wrongs of which are discussed by the personages. Geo. Fitzwalter, a young absentee landlord, has his eyes opened to the evils of landlordism by visiting his estates. His visit is the beginning of better things. Iife in country town well described. Gond dialect (with glossary at the end of book). Politics much discussed, with Protestant sympathies.

ANDERSON (Paris). This name is not a nom-de-plume. "There was a Lieutenant Paris Anderson in the Kilkenny Militia in 1815, and a Paris Anderson, presumably the same, was living in No. 13 Belvidere Place, Dublin, in 1837." (IRIsH Booklover, Vol. VII., p. 102). He published in the Kilkenny Moderator, about 1848, a series of articles, since republished (1914), under the title, Nooks and Corners of the Co. Kilkenny.

127-- THE WARDEN OF THE MARSHES; A Kilkenny Story of the Pale. Pp. 176. (Kilkenny : Printed at the Moderator Office). 1s. 6d. 1884.

Period: 1335-6. Scene: The Marshes of Ballygowran and adjoining districts of Co. Kilkenny. The plot turns on a feud between de la Fraine and de Rupe on the one side and Cantwell and le Poer, Lord Seneschal of Kilkenny, on the other. Other personages are Cantwell's Italian wife, Beatrice Donati, Richard Leddrede, Bishop of Ossory, the Abbot of Duiske Abbey, and the famous witch, Dame Alice Kyteler. The author has built up his romance with much lore from archives and from legends, and describes carefully the manners, dress, etc., of the period. This is perhaps the chief interest of the book. The story was written about 1840 .

ANDREWS, Elizabeth, F.R.I.A., dau. of late T. Andrews, M.D., F.R.S., Vice-Pres. of Queen's College, Belfast

128- ULSTER FOLKLORE Pp. 121. (Stock). 5s net. Fourteen illustr., mainly from photos. 1914.

A series of papers read before local learned societies or contributed to archæological journals. An endeavour to deal with the folk belief in fairies from an archæological point of view. The conclusion is that the "souterrains" were originally the abode of a primitive pigmy race. Imbedded in these pages (the outcome of much personal research) are many good fairy and folk stories.

\section{ANDREWS, Marion.}

129_ COUSIN ISABEL. Pp. 147. (Wells Gardner, Darton) 1s. 6d. Two illustr. 1903.

A tale, for young people, of the Siege of Londonderry, the hardships of the defenders, and their brave patience. Isabel, a veritable angel of mercy for her uncle and cousins, is a pleasant study. Another fine character is old Geoffrey Lambrick, drawn from a quiet life and his tulips into the smoke of battle. 
[ARCHDEACON, Matthew], b. Castlebar, Co. Mayo c. 1800 . Afterwards taught an academy there. D. 1853 in destitute circumstances.

130- LEGENDS OF CONNAUGHT, TALES, \&c. Pp. 406. (DUblin: John Cumming). 1829.

Seven stories:-_Fitzgerald," “The Banshee," "The Election," “Alice Thomson," "M'Mahon," "The Rebel's Grave," "The Ribbonman," "Almost every incident in each tale is founded on fact." (Pref.). The first story (165 pp.) depicts Connaught " in a wild and stormy state of society" towards the close of the eighteenth century, and records the wild deeds and memorable exit of the very widely known individual who is its hero. Told in a spirited and interesting way.

131_- CONNAUGHT: a Tale of 1798. Pp. 394. (Dublin: printed for $M$. Archdeacon). 1830.

The Author was "from infancy in the habit of hearing details of "the time of the Frinch", . . . . and has "had an opportunity of frequently hearing the insurrectionary scenes described by some of the Actors themselves." (Pref.). The Author is loyalist, but not bitterly hostile to the rebels. The rebellion is not painted in roseate colours, but it is not misrepresented. Humbert's campaign is vividly described, but history does not absorb all the interest. The love story (the lovers are on the rebel side) is told with zest, and there is abundance of exciting incident. Quite well written.

132_ EVERARD: An Irish Tale of the 19th Century. Two Vols, continuously paged. Pp. 422. (Dublin : printed for M. Archdeacon by J. Taaffe). 1835.

Publ. by subscription and anon. Machinations of the Ribbonmen in a Connaught locality during the Tithe War of the thirties. Everard is a young man of good education but down in the world and déclassé. Commor Coleman, leader of Ribbonmen, inveigles him into the conspiracy in order to make use of his superior qualities. The hero is very ineffective and the personal and romantic interest slight. Style, old-fashioned, with florid and elaborate phraseology. But there are glimpses of folk-lore and pictures of manners and contemporary conditions which give the book a certain value.

\section{3_ SHAWN NA SOGGARTH, THE PRIEST HUNTER. Pp. vii.+416.} (Duffy). Frontisp. 1844.

Scene: West Mayo during Penal Days (early 18th century). The plot is chiefly concerned with the efforts of the priest-hunter, John Mullowney, to capture Father Bernard Kilger, lately returned to his parish from Portugal, and his nephew, Friar Bourke of Clare Galway. His schemes are long baffled by Johnny McCann, the pedlar. The sequel relates the tragic fate of $\mathrm{Fr}$. Bernard and the retribution that overtakes Shawn. The worst aspects of the working of the Penal Code are brought strongly into prominence.

ARCHER, Patrick, “MacFinegall." Born at Oldtown, North County Dublin, about fifty years ago. Iives in Dublin, where he is a Customs Official.

134- THE HUMOURS OF SHANWALLA. Pp. 162. (Gill). 2s. 6d. Frontisp. photo of Author. [1906]. New edition, 1s. 6d. 1913.

A series of sketches exhibiting the humorous side of village life in the North County Dublin district, or thereabouts. Quite free from caricature; in fact tending to set the people described in a favourable light, and to make them more appreciated. There is a portrait of a priest, earnest, persevoring, and wholly taken up with his people's good. Thoroughly hearty, wholesome humour.

ARGYLE, Anna. Author of Cecilia; or, The Force of Circumstances. N.Y.: 1866; Cupid's Album; The General's Daughter.

135- OLIVE LACY. Pp. 365. (PhIladelphia: Lippincott). 1874, and earlier editions.

Scene: Wicklow during rebellion. Story told in first person by Olive Lacy, a peasant's daughter, adopted into a country gentleman's family. Castlereagh and Curran are introduced. A good specimen of the latiter's table talk is given. Olive's 
ARGYLE, Anna-(continued).

father becomes a United Irishman, is betrayed by a foreign monk (who goes about in a habit and cowl!), escapes, is re-arrested, and finally is shot. A general description of the rising is given. Tone, healthy. Story well told, but for some improbabilities.

\section{ARTHUR, Frances B.}

136 - THE DUCHESS. Yp. 302. (Nelson). Illustr. 1907.

Scene: mainly in Donegal. Standpoint: Protestant and English. Not unfair to peasantry. A pleasantly told little story. The hero implicated in Fenian movement, and arrested, escapes from prison through the cleverness of his little daughter, "the Duchess."

ASHE, Trevor Lloyd, of Castle Mary, Ash Grove, Bansha, Co. Tipperary, and formerly of St. Alban's Hall, Oxford, who describes himself (P.iv.) as "a Deacon of the Roman Catholic Church." Apparently the Author was a convert to that Church.

137- THE ATTORNEY; or, The Contrast. Pp. xii.+15- demy 8vo., closely printed. (Lond.: Ackerman). Frontisp., Castle Mary. 1844.

Subt. : "A descriptive itale illustrative of the advantages of teetotalism, both in its physiological and moral bearings" on society at large, dedicated . . . to the V. Rev. Theobald Mathew. In the Pref. the Author details his treatment at the hands of the lawyers and explains that the tale is intended to exhibit the abuses of the law as practised in Ireland. "I endeavour to point out the terrific evils of litigation" and I (show) "that teetotalism strikes at the very root of those causes that hitherto gave rise to endless litigation." (Pref.). Gives descriptions of many places in Tipperary. It is full of erudition, and is written in an extraordinary style. As a story it has no interest except as a vehicle of the Author's views.

[ASHWORTH, John H.] Author of The Saxon in Ireland. Graduated at Oxford, 1819.

138- RATHLYNN. Three Vols. (Hurst \& Blackett). 1864.

A young Englishman, son of "Admiral Wyville," takes up and works a property in a remote district in Ireland. Told in first person. The chief interest seems to lie in jealousies and consequent intrigues arising out of love affairs.

ASKEW (Alice and Claude). Claude Askew, in collaboration with his wife, wrote between 1904 and 1917 a series of novels, among which were The Shulamite (1904), The Etonian, The Baxter Family, The Plains of Silence, The Englishwoman, The Stricken Land (1916), and some twenty others. In 1918 their vessel was torpedoed in the Mediterranean and they were lost. 139- BARBARA. Pp. 319. (Unwin). 6s. 1912.

A study in contrasted temperaments, English and Irish. The English heroine, Barbara, marries Pierce Maloney out of pique, and returns with him to Connemara, where, to her horror, she discovers that he is impecunious and a widower with several children. The story tells how she came to love her irresponsible but warmhearted husband. The story goes on to relate the fortunes and marriages of Barbara and her step-children after Pierce's death. Brightly told, with careful characterization. Incidentally there is a sympathetic portrait of a kind-hearted Irish priest.

\section{“ATHENE" see HARRIS.}

AUSTIN, Stella. Author of S'tumps, Somebody, Tib and Sib, For Old Sake's Sake, \&c., \&c.

140_ PAT: A Story for Boys and Girls. Pp. 266. (Wells Gardner). 2s. 6d. Illustr. 1902.

"One of the prettiest stories of child life. Even the adult reader will take a great liking to the lively Irish Boy."- (Christian WorLd). 
"AYSCOUGH, John" [Mgr. Bickerstaffe Drew]. The Author is a Catholic priest (a convert), till recently acting as a chaplain in the British Army in France. $\mathrm{He}$ is one of the best-known writers of the day.

\section{1- DROMINA. Pp. 437. (Arrowsmith). 6s. 1909.}

The Author brings together in a queer old castle on the Western coast the M'Morrogh, descendant of a long line of Celtic princes, his children by an Italian wife, his French sister-in-law, a band of gypsies of a higher type, whose King is Louis XVII. of France, rescued from his persecutors of the Terror and half-ignorant of his origin. These are some of the personages of the tale. It is noteworthy that not one of the characters has a drop of English blood. I shall not give the plot of the story. The last portion is full of the highest moral beauty. The lad Enrique or Mudo, son of Henry M'Morrogh (whose mother was an Italian) and of a Spanish gypsy princess, is a wonderful conception. When the Author speaks, as he does constantly, of things Catholic (notably the religious life and the Blessed Sacrament), he does so not only correctly but in a reverential and understanding spirit. The one exception is the charaoter of Father O'Herlihy, which is offensive to Catholic feeling. The moral tone throughout is high. One of the episodes is the seduction of a peasant girl, but it is dealt with delicately and without suggestiveness.

BANIM, John and Michael "The O'Hara Family." John Banim (1798-1842) and Michael Banim (1796-1876) worked together, and bear a close resemblance to one another in style and in the treatment of their material; but the work of John is often gloomy and tragic. That of Michael has more humour and is brighter. They have both a tendency to be melodramatic, and can picure well savage and turbulent passion. They have little lightness of humour or literary delicacy of touch, but they often write with vigour and great realistic power. The object with which the "O'Hara" Tales were written is thus stated by Michael Banim: "To insinuate, through fiction, the causes of Irish discontent and to insinuate also that if crime were consequent on discontent, it was no great wonder; the conclusion to be arrived at by the reader, not by insisting on it on the part of the Author, but from sympathy with the criminals."

P. J. Kenedy, of New York, publishes an edition of the Banims' works in ten volumes at seven dollars the set.

BANIM, John. B. Kilkenny, 1798. Went in 1814 to Dublin to study art. But, after some years as an art teacher in Kilkenny, he gave up art and took up literature in London. About 1829 his health broke down, and he continued practically an invalid till his death in Kilkenny in 1844. Besides the "O'Hara" Tales, John Banim wrote a good deal of poetry, several plays, and much miscellaneous literature for periodicals.

142 - JOHN DOE; or, The Peep o' Day. 1825.

The story of a young man who, for revenge, joins the Shanavests, a secret society, terrible alike to landlord, tithe-proctor, and even priest. The first of the Tales by the O'Hara Family, republished separately by S'imms di M'Intyre, 1853; and Routledge, $n \cdot d$.

\section{3_ THE FETCHES. (Duffy). [1825].}

A gloomy story, turning on the influence of superstitious imaginations on two nervous and high-strung minds. The fetch is the spirit of a person about to die said to appear to friends. The story is somewhat lightened by the introduction of two farcical characters.

144 _ THE NOWLANS. Pp. 256 (close print). [1826], 1853, \&c.

The temptation and fall of a young priest, resulting in misery which leads to repentance. Contains some of Banim's most powerful scenes.

145_ PETER OF THE CASTLE. Pp. 191. (Duffy). [1826].

A sensational and romantic tale. The opening chapters (by Michael Banim) give a detailed description of country matchmaking and marriage festivities at the time, c. 1770. 


\section{BANIM, John-(continued).}

146- THE BOYNE WATER. Pp. 564. (Duffy). 2s. [1826]. Many editions since.

In this great novel, which is closely modelled on Scott, scene after scene of the great drama of the Williamite Wars passes before the reader. Every detail of scenery and costume is carefully reproduced. Great historical personages mingle in the action. The two rival kings with all their chief generals are represented with. remarkable vividness. Then there are Sarsfield and Rev. George Walker, Galloping O'Hogan the Rapparee, Carolan the bard, and many others. The politics and other burning questions of the day are thrashed out in the conversations. The intervals of the great historical events are filled by the adventures of the fictitious characters, exciting to the verge of sensationalism, finely told, though the deus ex machinc is rather frequently called in, and the dialogue is somewhat old-fashioned. The wild scenery of the Antrim coast is very fully described, also the scenes through which Sarsfield passed on his famous ride. The standpoint is Catholic and Jacobite, but great efforts are made to secure historical fairness. The book ends with the Treaty of Limerick.

147- THE ANGLO-IRISH OF THE NINETEENTH CENTURY. Three Vols. (Colburn). [1828]. Republ. in one volume by Duffy in 1865 under title Lord Clangore.

Opens in London. Several members of Anglo-Irish Society are introduced-the Minister (Castlereagh) and the Secretary (Wilson Croker). 'There are long disquisitions on Emancipation, the conversion of the peasantry, \&c. Gerald Blount, younger son of an Irish peer, has all the anti-Irish bias of this set. Flying after a duel he reaches Ireland, where he has many exciting adventures with the Rockites. Finally he succeeds to the title and settles down. The "double" (or mistaken identity) plays a part in this story, as in so many of Banim's. A meeting of the Catholic Association with O'Connell and Shiel debating is finely described, also a Dublin dinner-party, at which Scott's son appears. The early part is somewhat tedious, but the later scenes are powerful. See supra. Gerald and Augusta. (Anon.).

148- THE CONFORMISTS. Pp. 202. (Duffy). [1829].

Period: reign of George II. A very singular story, whose interest centres in the denial under the Penal Laws of the right of education to Catholics. A young man, crossed in love, resolves to become a "conformist" or pervert, and thus at onse disgrace his family, and oust his father from the property.

149_ THE DENOUNCED : or, The Last Baron of Crana. Pp. 235. (Duffy). [1826.] (Colburn). 1830. (N.Y.: Benziger). 0.75.

Deals with the fortunes of two Catholic families in the period immediately following the Treaty of Limerick. Depicts their struggles to practise their religion, and the vexations they had to undergo at the hands of hostile Protestants. The tale abounds in incident, often sensational. There is a good deal in the story about the Rapparees.

150-- THE CHANGELING. Three Vols. Pp. 315+350+414. (London). 1848.

Published anonymously. Preface tells us it was written some few years before date of publication. Scene: City of Galway and Connemara (including Aran). The main plot is concerned with the mystery surrounding the heir of Ballymagawley got out of the way in early childhood by the present owner, Mr. Whaley, but returning in disguise to claim his rights. The interest is threefold:-First, Mr. Whaley's awful secret unknown to the daughter, whom he loves with his whole soul, and who returns his love, and the desperate efforts he makes to avert the revelation; 2nd, the study of character: Clara Whaley, high-souled, intellectual, unworldly, scorning fashion and flirtation; the astute worldly intellectual Hon. Augustus Foster; the empty-headed Miss Fosters and so on; 3rd, a series of quite admirable and amusing vignettes of the petite bourgeoisie of Galway-the vulgar and showy Mrs. Heffernan with her absurd accent, the match-making Mr's. Flanagan (an inimitable 


\section{BANIM, John-(continued).}

portrait), the mischief-making Peter Harry Joe, Considine the Butler, the consequential Captain O'Connor, and the endless flirtations of the marriageable young ladies. The peasantry are well drawn, but it is quite an outside view of their life. The conversations are clever, but sometimes tediously long, as are also the Author's reflections.

BANIM, Michael. B. Kilkenny, 1796. Ed. first in his native town at the academy of a certain eccentric Mr. Buchanan; afterwards under Dr. Magrath, who conducted a school considered first-class in its day. He took up his father's business and made a success of it. He was fond of long country rambles, and in the course of them came to lnow the peasantry intimately. He helped his brother in several of the latter's novels. He tools part with O'Connell in the struggle for Emancipation. For many years before his death he suffered from ill health, brought on by reverses of fortune. In 1874 he died.

\section{1- CROHOORE OF THE BLLHOOK. (Duff $y$ ). [1825].}

Has been a very popular book. The action lies in one of the darkest periods of Irish history, when the peasantry, crushed under the tithe-proctor, middleman, and Penal laws, retorted by the savage outrages of the secret societies. One of these latter was the "Whiteboys," with the doings of which this book largely deals. The Author does not justify outrage, but explains it by a picture of the conditions of which it was the outcome. A dark and terrible story. The scene is Kilkenny and neighbourhood. It must be added that most of the characters savour strongly of what is now known as the "stage Irishman."

\section{2- THE CROPPY. Pp. 420. (Duffy). 2s. Still reprinted. [1828].}

Opens with a long and serious historical introduction. There follow many pages of a love story of the better classes which is, perhaps, not very convincing. Samples of the outrages by which the people were driven to revolt are given. Then there are many scenes from the heart of the rebellion itself, some of them acquired from conversation with eye-witnesses. The attitude is that of a mild Nationalist, or rather Liberal, contemplating with sorrow not unmixed with contempt the savage excesses of his misguided countrymen. The rebellion is shown in its vulgarest and least romantic aspect, and there are harrowing descriptions of rebel outrages on Vinegar Hill and elsewhere. The one noble or even respectable character in the book, Sir Thomas Hartley, is represented as in sympathy with constitutional agitation, but utterly abhorring rebellion. The other chief actors in the story are unattractive. They have no sympathy with the insurgents, and the parts they play are connected merely accidentally with the rebellion. There is much movement and spirit in the descriptive portions.

\section{3_ THE MAYOR OF WINDGAP. Pp. 190. (Duffy). [1834].}

Romantic and sensational-attempted murders, abductions, \&c. Not suitable for the young. Interest and mystery well sustained. Scene: Kilkenny in 1779 . There was a Paris edition, 1835.

\section{4- THE BIT O' WRITING.}

This is the title-story of a volume of stories. First published in London, 1838. It may be taken as typical of Michael Banim's humour at his best. It is a gem of story-telling, and, besides, a very close study of the ways and the talk of the peasantry. The "ould admiral," with his sailor's lingo, is most amusing. It was republished along with another story, The Ace of Clubs, by Gill, in a little volume of the O'Connell Press Series, pp. 144, cloth, 6d., 1886. The original volume, with twenty stories, is still published by Kenedy, New. York.

\section{5_ FATHER CONNELL. Pp 358. [1840].}

The scene is Kilkenny. The hero is an Irish country priest. The character, modelled strictly (see Pref.) on that of a priest well known to the Author, is one of the noblest in fiction. $\mathrm{He}$ is the ideal Irish priest, almost childlike in simplicity, pious, lavishly charitable, meek and long-suffering, but terrible when circumstances 


\section{BANIM, Michael-(continued).}

roused him to action. Interwoven with his life-story is that of Neddy Fennell, his orphan protégé, brave, honest, generous, loyal. Father Connell is his ministering angel, warding off suffering and disaster, saving him also from himself. The last scene, where, to save his protégé from an unjust judicial sentence, Father Connell goes before the Viceroy, and dies at his feet, is a piece of exquisite pathos. There is an element of the sombre and the terrible. But the greater part of the book sparkles with a humour at once so kindly, so homely, and so delicate, that the reader comes to love the Author so revealed. The episodes depict many aspects of Irish life. The character-drawing is masterly, as the best critics have acknowledged. There is Mrs. Molloy, Father Connell's redoubtable housekeeper; Costigan, the murderer and robber; Mary Cooney, the poor outcast, and her mother, the potatobeggar; and many more. The Author faithfully reproduces the talk of the peasants, and enters into their point of view. Acknowledged to be the most pleasing of the Banims' novels.

\section{6- THE GHOST-HUNTER AND HIS FAMILY. (Simms \& M'Intyre). [1833]. 1852.}

Still published by P. J. Kenedy, New York : 75 cents. An intricate plot skilfully worked out, never flagging, and with a mystery admirably sustained to the end. Gives curious glimpses of the life of the times (early nineteenth century), as seen in a provincial town (Kilkenny). But the style often offends against modern taste. The book soon turns to rather crude, if exciting, melodrama. Moreover, though the Author is always on the side of morality, there is too much about abduction, \&c., and too many references to the loose morals of the day to make it suitable reading for certain classes.

157- THE TOWN OF THE CASCADES. Two Vols. Pp. 283+283. (Chapman \& Hall). 1864.

Scene: sea-board town in West. A powerful story in which the chief interest is a tragedy brought about by drink. The town seems to be Ennistymon, Co. Clare. The characters belong to the peasant class, and of course are drawn with thorough knowledge. The work could easily go in one not very large volume.

" BAPTIST, Father" see Mgr. R. B. O'BRIEN.

BARBOUR, M. F.

158_ THE IRISH ORPHAN BOY IN A SCOTTISH HOME. Pp. 87. (LoNDoN). [1866]. 1872.

"A sequel to The Way Home, \&c." A little religious tract (Protestant) in story form.

\section{BARDAN, Patrick.}

159_ THE DEAD-WATCHERS. Pp. 83. (Mullingar: Office of Westmeath GUARDIAN). 1891.

"And other Folk-lore Tales of Westmeath." The Author is a member of the Royal Society of Antiquaries. Intended as a contribution to folk-lore. But the title-story (54 pp.) is a fantastic story told in melodramatic modern English, and has little or no connexion with folk-lore. The remainder consists of ghost stories, spirit-warnings, superstitions, chiefly of local interest. Appended are a few explanatory notes of some value.

BARLOW, Jane. B. Clontarf, 1857. Dau. of late Rev. Prof. J. W. Barlow, ViceProvost, T.C.D. She lived almost all her life in the neighbourhood of Dublin, being fond of long walks in the Dublin and Wicklow mountains. Between her. first poem in the Dublin University Magazine, 1886, and her last sketch, "Rescues" in the Saturday Review, ten days before her death in April, 1917, she did a great deal of literary work. The little tragedies and comedies of the home lives of the Western peasantry form the theme of all her best books. Of these lives she knew the minutest details as far as an outsider could know them. 
BARLOW, Jane-(continued).

The qualities of her writings are a delicate and quiet humour, a pathos produced by no elaborate appeals to feeling but by simple narrative, a power of reproducing with great fidelity the humorous quaintness and picturesqueness of peasant talk, a strong sense of the beauty of landscape and much literary power of painting it, and sympathy with the joys and sorrows of the humble people she depicts.

160- IRISH IDYLLS. Pp. 284. (Hodder Stoughton). 6s. [1892]. Ninth ed. (N.Y. : Dodd \& Mead). 2.00. 1908.

Doings at Liscomnell, a poverty-stricken little hamlet, lost amidst a waste of unlovely bogland. These sketches have been well described as "saturated with the pathos of elementary tragedy." Yet there is hunour, too, and even fun, as in the story of how the shebeeners tricked the police. The illustrated edition contains about thirty exceptionally good reproductions of photographs of Western life and scenery.

161- KERRIGAN'S QUALITY. Pp. 254. (Hodder d Stoughton). 6s. Eight Illustr. [1893]. (N.Y.: Pratt). 1.75. Second edition.

In this story the peasants only appear incidentally. The main characters are Martin Kerrigan, a returned Irish-Australian; the invalid Lady O'Connor; her son, Sir Ben; and her niece, Merle. The story is one of intense, almost hopeless, sadness, yet it is ennobling in a high degree. It is full of exquisite scraps of description.

162- STRANGERS AT LISCONNELL. Pp. 341. (Hodder \& Stoughton). 6s. [1895]. (N.Y.: Pratt). 1.75.

A second series of Irish Idylls, showing the Author's qualities in perhaps a higher degree even than the first. A more exquisite story than "A Good Turn" it would be hard to find. Throughout there is the most thorough sympathy' with the poor folk. The peasant dialect is never rendered so as to appear vulgar or absurd. It is full of an endless variety of picturesqueness and quaint turns. No problems are discussed, yet the all but i'mpossibility of life under landlordism is brought out (see p. 15). There are studies of many types familiar in Irish country life-the tinkers; Mr. Polymathers, the pedagogue (a most pathetic figure) ; Mad Bell, the crazy tramp; and Con the "Quare One." It should be noted that, though there is in Miss Barlow's stories much pathos, there is an entire absence of emotional gush.

163-MAUREEN'S FAIRING. Pp. 191. (Dent). Six Illustr., of no great value. [1895]. (N.Y.: Macmillan). 0.75.

Eight little stories reprinted from various magazines in a very dainty little volume. Like all of Jane Barlow's stories, they tell of the "tear and the smile" in lowly peasant lives, with graceful humour or simple, tender pathos. The stories are very varied in kind.

164- MRS. MARTIN'S COMPANY. (Dent). Uniform with Maureen's Fairing. [1896]. (N.Y.: Macmillan). 0.75 .

"Seven stories, chiefly of a light and humorous kind, very tender in their portrayal of the hearts of the poor. There is a touching sketch of child-life and a police-court comedy."-(Baker).

165-_ FROM THE EAST UNTO THE WEST. Pp. 342. (Methuen). 1s. 8vo. Cloth. First ed., 1898; new ed., 1905.

The first six of this collection of fifteen stories are tales of foreign lands-Arabia, Greece, and others. The remainder deal with Irish peasant life. They tell of the romance and pathos that is hidden in lives that seem most common-place. The Field of the Frightful Beasts is a pretty little story of childish fancies. An Advance sheet is weird and has a tragic ending.

166- FROM THE LAND OF THE SHAMROCK. Pp. 318. (Methuen). 5s. (N.Y.: Pratt). 1.50. 1900. (N.Y.: Dodd \& Mead). 1.50.

Fourteen stories, some humorous, some pathetic, including some of the Author's 
BARLOW, Jane-(continued).

best work. There is the usual sympathetic insight into the eccentricities and queernesses of the minds of the peasant class, but little about the higher spiritual qualities of the people, for that is not the Author's province. Among the most amusing of the sketches is that which tells the doings of a young harum-scarum, the terror of his elders.

167- THE FOUNDING OF FORTUNES. Pp. 335. (Methuen). 1s. Cloth 8vo. [1902]. New ed. 1906.

The tale of how Timothy Galvin, a ragged urchin living in a mud cabin and remarkable only for general dishonesty and shrewd selfishness, is given a start in life by an ill-gotten purse, and rises by his mother wit to wealth. The study of the despicable character of the parvenu is clever and unsparing. Other types are introduced, the landlord of the old type, and two reforming landlords, who appear also in Kerrigan's Quality. The book displays Jane Barlow's qualities to the full. 168-- BY BEACH AND BOGLAND. Pp. 301. (Fisher Unwin). 6s. One

Seventeen stories up to the level of the Author's best, the usual vein of quiet humour, the pathos that is never mawkish, the perfect accuracy of the conversations, and the faithful portrayal of characteristics. The study in "A Money-crop at Lisconnell," of the struggle between the Widow M'Gurk's deep-rooted Celtic pride and her kind heart, is most amusing. As usual, there are delightful portraits of children.

\section{9- IRISH NEIGHBOURS. Pp. 342. (Hutchinson). 1907.}

Seventeen stories of Irish life, chiefly among the peasantry. They have all Miss Barlow's wonted sympathy and insight, her quiet humour and cheerful outlook.

170_ IRISH WAYS. Pp. 262. (George Allen). 15s. Sq. demy 8vo. Sixteen Illustr. in colour. Headpieces to chapters. 1909.

Chapter I., "Ourselves and Our Island," gives the Author's thoughts about Ireland, its outward aspect, the peculiarities of its social life, its soul. It includes an exquisite pen-picture of Irish landscape beauty. The remaining fourteen sketches are "chapters from the history of some Irish country folk," whom she describes as "social, pleasure-loving, keen-witted," but " prone to melancholy and mysticism." The last sketch is a picture, almost photographic in its fidelity, of a little out-ofthe-way country town and its neighbourhood. The illustrations are pretty, and the artist, who, unlike many illustrators of Irish books, has evidently been in Ireland, has made a great effort to include in his pictures as much local colour as possible. Yet it seems to us that un-Irish traits often intrude themselves despite him.

171- FLAWS. Pp. 344. (Hutchinson). 6s. 1911.

Embroidered upon an exceptionally involved plot-four times we are introduced to a wholly new set of characters-we have the Author's usual qualities, minute observation and depiction of curious aspects of character, snatches of clever picturesque conversation, an occasional vivid glimpse of nature. But in this case the caste is made up of spiteful, petty, small-minded and generally disagreeable personages. They are nearly all drawn from the middle and upper classes in the South of Ireland, Protestant and Anglicized. The snobbishness, petty jealousies, selfishness of some of these people is set forth in a vein of satire. The incidents include an unusually tragic suicide.

172_- MAC'S ADVENTURES. (Hutchinson). Pp. 320. 6s. 1911.

Eight stories in which Mac, or rather Macartney Valentine O'Neill Barry, who is four years old in the first and six in the last, plays a leading part. Indeed he is quite a little deus ex machina, or rather a good fairy in the affairs of his elders. $\mathrm{Mac}$ is neither a paragon nor a youthful prodigy. He is just a natural child, with a child's love of mischief and "grubbiness," and full of quaint sayings. Bright and genial in tone.-(Press Notices). 
BARLOW, Jane-(continued).

173_- DOINGS AND DEALINGS. Pp. 314. (Hutchinson). 6s. 1913.

Thirteen stories, all but one (the longest) dealing with peasant life in the Author's wonted manner. Perhaps scarcely so good as some of her earlier collections.

174 A CREEL OF IRISH STORIES. (Methuen). 1s. Cloth. 8vo. (N.Y.: Dodd \& Mead). 1.25 .

The first of these, "The Keys of the Chest," is a curious and original conception, showing with what strange notions a child grew up in a lonely mansion by the sea. The story of the suicide is a gem of story-telling. "Three Pint Measures" is a comic sketch of low Dublin life.

175- ANOTHER CREEL OF IRISH STORIES. Published, I believe, in U.S.A. (On sale by Pratt: N.Y.). 1.75.

176_- IN MIO'S YOUTH. Pp. 340. (Hutchinson). 6s. 1917.

Published posthumously. A domestic story in which the personages are drawn from the county family class. The Delaney family is in reduced circumstances, the father striving to keep the woif from the door; the sons a happy-go-lucky, lazy, pleasant lot; the mother and daughters aiming at respectability and good matches. Mio, a sensitive, imaginative, refined child, is Captain D.'s adopted daughter. There are many subsidiary characters, and the plot is loose yet complicated. In element of pathos is introduced when the Captain, who has become blind, acts as tutor to his son, who does not know him, having been separated from him in early youth. Little or nothing about the peasantry.

\section{BARLOW, Madge.}

177-THE CAIRN OF THE BADGER. Pp. 343. (Cassell). 6s. 1908.

An Irish story of love and intrigue. Nan Le Poer's two lovers figure largely in the plot. An innocent man is condemned for manslaughter of which he believes Nan guilty.

\section{BARNEVAL (L. Tachet de).}

178- HISTOIRE LEGENDAIRE DE l'IRLANDE. Pp. $384 . \quad$ (Paris). 1856.

It might be supposed from the title that this book would deal with Irish epic and saga, but, in the words of the preface, "Il s'agit ici de la Vie des Saints d'Irlande." But the first two chapters deal with pre-Christian Ireland. The Author was a Professor at the Iycée of Douai.

BARR (Robert). B. Scotland; brought up in Canada, where he afterwards lived as a school-teacher. Then worked in U.S.A. on the staff of the DETRoIT Free Press. In later years he went to live in England.

179 THE PALACE OF LOGS. Pp. 320. (Mills \& Boon). 6s. 1912.

Scene: Dublin during Buckingham's second term of office, 1789, shifting later to London and then to U.S.A. and Canada. The hero is a younger son of the Talbots of Malahide. Going in company with his friend, ensign Arthur Wesley (or Wellesley) (afterwards Duke of Wellington) to a fancy dress ball at Malahide Castle he enters upon an undignified scuffle with a former poa her, returned from Canada. This, in spite of all attempts to make good, loses him the affections of the heroine, who marries a parson and goes to Canada. Talbot becomes a drunken sot in London. But a message from his former fiancée recalls him to himself and he goes to Canada to carve out a new kingdom and rule it from a palace of logs. Shows little knowledge of Ireland. The historical background is faintly drawn.

[BARRETT, J. G.], “ Erigena."

180 EVELYYN CLARE; or, The Wrecked Homesteads. Pp. viii.+274. (Derby : Richardson). 1870.

"An Irish story of love and landlordism." Crude melodrama with all the usual 
[BARRETT, J. G.] " Erigena."-(continued).

accessories-a landlord, "Lord Ironhoof," and an agent, "Gore," eviction, agrarian murders, a disguised priest, and secret Mass, a poteen still, an elopement, a changeling brought up in wealth, a lover supposed drowned, and an innocent man unjustly convicted. No sense of reality. Scene: West of Ireland, c. 1850. Several anachronisms.

\section{BARRINGTON, F. Clinton.}

181- FITZ-HERN; or, The Irish Patriot Chief. Pp. 122. (Glasgow: Cameron \& Ferguson). n.d.

Scene: Galway Bay. Crude melodrama, without historical significance. Wicked married bishops, scheming foreign monks, and coarse fat friars are the villains of the piece. But the hero, a smuggler of noble birth, always escapes from their clutches, and finally marries the heroine. Specimen of dialect:- "Arrah, gorrah, avis, father John, it's the Pope o' Rome ye bate, out and out." (p. 13).

\section{BARRON, Percy.}

182- THE HATE FLAME. Pp. 382. (Hodder \& S'toughton). 6s. 1908.

The story of a noble life wrecked by racial hatred. The hero, a young English man, Jack Bullen, fights a duel, in Heidelberg, with an Irish student, and kills him. This deed comes in after years between him and the Irish girl (cousin of the slain student, and pledged against her will to vengeance by his father) whom he was to marry - and this through the plotting of her rejected lover and a priest. Bullen had, for the upraising of the Irish people, started a great peat factory in Ireland, and it had prospered. This work is wrecked by the same agency that ruins his private. happiness. Throughout the book the Author attacks all the cherished ideas of Irish. Nationalism and of the present Irish revival, and sets over against them the ideals of England and his personal views. Much bitterness is shown against the priests of Ireland. The scene-painting and the handling of situation and of narrative are very clever. There is nothing objectionable from a moral point of view.

BARRY, Canon William, D.D. Born in London, 1849. Educated at Oscott and Rome. $\mathrm{He}$ is a man of very wide learning, a theologian and a man-of-letters, known in litenature both by his novels (The New Antigone, \&c.) and by important historical and religious works. Is now Rector of St. Peter's. Leamington.

183__ THE WIZARD'S KNOT. Pp. 376. (Unwin). 6s. Second ed. (N.Y.; P'ratt). 3.00. 1900 .

Dedicated to Douglas Hyde and Standish Hayes O'Grady. Scene: coast of Southwest Cork during famine times, of which some glimpses are shown. There is a slight embroidery of Irish legend and a good deal about superstition, but the incidents, characters, and conversations have little, if any, relation to real life in Ireland. It is mainly a study of primitive passions. It might be described as a dream of a peculiarly "creepy" and morbid kind. It is wholly unlike the Author's New Antigone.

BAX, Arnold. See "Dermot O'Byrne."

\section{BARTRAM (George).}

184_ THE WHITE HEADED BOY. (Fisher Unwin). 1898.

Scene: Kerry in Fenian times, viz., the "sixties" of last century. The Author seems divided between a conviction of the absurdity of the Fenians as rebels, the grotesque inadequacy (in his view) of their means, on the one hand, and on the other their heroic spirit as men. He does not definitely take sides for or against. There is no sentimental interest. 


\section{BAYNE, Marie.}

185- FAIRY STORIES FROM ERIN'S ISLE. Pp. 131. (Sands). 2s. 6d. net. Illustr. by Mabel Dawson and John Petts. 1908.

Pretty and attractive picture-cover. Six little stories told in pretty, poetic style, one about a fairy changeling, another about the mermaids. The "Luck of the Griddle Darner" is in pleasant swinging verse. So is the "Sleep of Earl Garrett." Though intended for small children, none of the stories are silly.

186 - TALES OF IRELAND FOR IRISH CHILDREN. (Fallon). Four full-p. illustr. in each part, mostly by Geo. Monks. 1916.

They form one of the "Ideal" Series, ed. by Rev. T. A. Finlay, S.J., and published in four parts, paper. Tales from Irish mythology and history, for the most part very short-there are 33 in the first 83 pages; but they grow longer in the succeeding parts. Told in very simple language. Some in verse. Thoroughly Irish and Catholic in spirit and outlook, though the Author is a non-Catholic and resides in Scotland. The history is taken in chronological order.

BELL, J. J.

187- JESS \& CO. (N.Y.: HARPER). \$1.25. 1904.

Jess, an energetic peasant woman, marries a happy-go-lucky, idle character, with a taste for roses but little for his business of carpenter. But Jess gradually takes over the management, makes it a success, and makes the family prosperous. (Publ.).

BENNETT, Loule. Born in Dublin, educated there by private tuition and in London. Has done some joumalistic work, but is chiefly interested in social questions, in particular the woman's movement and pacifism. Resides near Bray, Co. Wicklow.

\section{8- THE PROVING OF PRISCILLA. Pp. 303. (Harper). 190\%.}

Scene: varies between Mayo and Dublin. Story of an ill-assorted marriage. The wife, daughter of a I'rotestant rector, is a Puritan of the best type, simple, religious, and sincere. The husband is a fast man of fashion, who cannot understand her "prejudices." After much bickering they part. Troubles fall on both. In the end his illness brings them together again-each grown more tolerant. Quiet and simply but well written, with nothing abjectionable in the treatment.

189_- PRISONER OF HIS WORD, A. Pp. 240. (Maunsel). 6s Handsome cover. [1908]. New ed. 1s. 1914.

"A tale of real happenings" (sub-title). Opens at Ballynahinch, Co. Down, in June, 1797. A pleasant, exciting romance, written in vigorous and nervous style. A young Eanglishman joins the Northern rebellion. He pledges himself to avenge his friend taken after a fight at Ballynahinch, and hanged as a rebel. The story tells how he carries out the pledge. The only historical character introduced is Thomas Russell. His pitiful failure in 1803 to raise another rebellion in Ulster is related. The little heroine, Kate Maxwell, is finely drawn.

\section{BERENS, Mrs. E. M.}

190_- STEADFAST UNTO DEATH. Pp. 275. (Remington). Frontisp. by Fairfield. 1880.

" A tale of the Irish famine of to-day." Period: 1879-80. Place: Ballinaveen, not far from Cork. Black Hugh, a kind of outlaw of the mountains is the hero. $\mathrm{He}$ had loved Mrs. Sullivan before she married the drunken, worthless Pat. He promises her when she is on her deathbed to care for the children she is leaving, and the worthless husband. Hugh takes the blame of the latter's crime, and is hanged in Dublin. The family is rescued by benevolent English poople. A welltold, but very sad story. The people's miseries are feelingly depicted. Standpoint of a kind-hearted Englishwoman who pities, but does not in the least understand Ireland. 


\section{BERTHET, Elle.}

\section{1- LE DERNIER IRLANDAIS. Three Vols. 16mo. (Bruxelles:}

Meline). 1851.

Ireland in the eighteen forties. Abortive rising under one of the O'Byrnes of Wicklow (Le dernier Irlandais). O'Connell looms in the background as the opponent of all this. The rebellion, which at once fizzles out, is the result of an insult to O'Byrne's sister by a rouê named Clinton. O'B. flies to Cunnemara (sic) with Nelly Avondale, daughter of the landlord of Glendalough, is besieged there in a fortress. Nelly returns to marry the above-mentioned roue and O'B. flies. The Author is evidently not consciously hostile to Ireland, but he is totally ignorant of it. The peasants are travestied. They are all drunkards, slovenly, sly, mean, lawless. Some descriptions of scenery in Wicklow and Connemara.

BESTE, Henry Digby, 1768-1836. Son of the prebendary of Lincoln. Became a Catholic 1798. An interesting biographical sketch of him (largely autobiographical) is prefixed to the novel here noticed. It includes a full account of his conversion.

192 - POVERTY AND THE BARONET'S FAMILY : An Irish Catholic Novel.

Pp. xxxii.+415. (London: Jones). 1845.

Bryan O'Meara, son of a poor Irish migratory labourer, is educated as a gentleman by Sir Cecil Foxglove, of Denham, near Grantham, in gratitude for the rescue of his child by Bryan's father. Coming to man's estiate, and being refused by the Baronet's daughter he retiurns to his father's people at Athlone, where for some time he plays at being a farmer's lad-and at rebellion. But a fortunate chance puts great wealth into his hands, and he returns to marry the Baronet's daughter. Interesting glimpses of Catholic life in penial days (the story opens in 1805) when Catholicism was at the lowest ebb in England. The Dublin Review says (1848, Vol. xxiv., p. 239): "The hero is a pious pedant, a truculent fellow, and a self-conceited proser. The story itself is purposeless; bitter in sentiment, and swamped in never-ending small-talls." The "small-talk," however, is, if anything, over-serious and moral.

" BIRMINGHAM, George A." Rev. James Owen Hannay, M.A., Canon of St. Patrick's Cathedral (1912). Born 1865, son of Rev. Robert Hannay, vicar of Belfast. Educated at Temple Grove, East Sheen; Haileybury; T.C.D. Rector of Westport, 1892-1913. Resigned this cure in order to devote himself to literature, and is now incumbent of a small parish near Carlow. Is a member of the General synod of the Church of Ireland. He has shown himself equally at home in political satire, humorous fiction and historical fiction. $\mathrm{He}$ is in sympathy with the ideals of the Gaelic League, and has actively shown this sympathy. He seems on the whole Nationalist in his views, but has nothing in common with the Parliamentary Party. His earlier books showed strong aversion for the Catholic Church, but, except perhaps in Hyacinth, he has never striven to represent it in an odious light, and he is an enemy of all intolerance.

193_ THE SEETHING POT. Pp. 299. (Arnold). 6s. [1904]. New ed. 2s. 1917.

Main theme: the apparently hopeless embroilment of politics and ideas in Ireland. Many aspects of Irish questions and conditions of life are dealt with. Many of the characters are types of contemporary Irish life, some are thinly disguised portraits of contemporary Irishmen, e.g., Dennis Browne, poet, asthete, egoist; Desmond O'Hara, journalistic freelance (said to be modelled on Standish O'Grady); Sir Gerald Geoghegan, Nationalist landlord; John O'Neill, the Irish leader, who is deserted by his party and ruined by clerical influence; and many others. All this is woven into a romance with a love interest and a good deal of incident.

194- HYACINTH. (Arnold). 6s. 1906.

An account, conveyed by means of a slight plot, of contemporary movements and personages in Ireland. Most of these are satirized and even caricatured, especially

"Robeen" Convent, by which seemed to be meant Foxford Mills, directed by the Sisters of Charity (see New Ireland Review, March, 1906, and Pref to Benedict Kavanagh). A grasping, unscrupulous selfishness is represented to be one of the chief characteristics of the Catholic Church in Ireland. 
" BIRMINGHAM, George A."--(continued).

195_- THE BAD TIMES. Pp. 312. (Methuen). 6s. [1907]. New ed, 1s. 1914.

Period : chiefly Isaac Butt's Home Rule movement. Stephen Butler, representiative of a landlord family of strong Nationalist sympathies, determines to work for Ireland. He joins the Home Rule Party, but he hates agrarian outrage, and so, through the Land League, becomes unpopular in his district in spite of all he has done. The Author introduces types of nearly every class of men then influential in Ireland: a priest who favours and a priest who opposes the new agrarian movement, an incurably narrow-minded English R.M., an old Fenian, and so on. The impression one draws from the whole is much the same as that of the Seething Pot. The Author's views are strongly National, and there is no bitter word against any class of Irishmen, except the Irish Parliamentary Party.

\section{6- BENEDICT KAVANAGH. Pp. 324. (Arnold). 6s. 1907.}

Dedication in Irish. Foreword in which the Author states that by "Robeen" Convent he did not intend Foxford (cf. Hyacinth). A criticism of Irish political life, free from rancour, and from injustice to any particular class of Irishmen, showing strong sympathy for the Gaelic League, and all it stands for. The hero is left at the parting of the ways, with the choice before him of "respectability" and ease, or work for Ireland. The book should set people asking why it is that Irishmen-no matter what their creed or politics-cannot work together for their common country?

197- THE NORTHERN IRON. Pp. 320. (Maunsel). Bound in Irish linen. [1907]. New ed. at 1s., 1909. Cheap ed. (Everett), 7d., 1912. New ed. (Maunsel), 1s. 6d., 1918.

Scene: Antrim. A few incidents of the rising woven into a thrilling and powerful romance. Splendid portraits-the United Irishmen James Hope, Felix Maties, and Micah Ward, the loyal Lord Dunseverick, chivalrous and fearless, Finlay the Informer, and others. Vivid presentment of the feelings and ideas of the time, without undue bias, yet cnlisting all the reader's sympathies on the side of Ireland.

I93- SPANISH GOLD. (Methuen). 6s. [1908]. Cheap ed. 1s. (N.Y.:
Doran.). 1.20. Many eds. since.

A comedy of Irish life, full of the most amusing situations. Scene : a lonely island off the coast of Connaught, in which treasure is hidden. The action consists of the adventures of various people who come to the island-an Irish chief secretary, ia retired colonel, a baronet, a librarian, a Catholic priest, and a Protestant curate. This last, the Rev. J. J. Meldon, is a most original creation. There are touches of social satire throughout, but without bitterness or offensiveness.
199
THE SEARCH PARTY. Pp. 316.
(Methuen). 6s. [1909].
(N.Y. : Doran.). 1.20. 12th ed., 1s., 1913.

How a mad Anarchist made bombs in a lonely house on the west coast of Ireland, and imprisoned the local doctor for fear least he should reveal the secret. How the latter's English fiancée sets in motion in search of him all the machinery of law and order. Mr. Birmingham's irresponsible gaiety carries the farce along at a fine pace. Patsy Devlin, and Jimmy O'Loughlin and Dr. O'Grady (the last especially) provide endless humour. Wholesale lying on every side is, as usual, a feature of the story. "May the Lord forgive us," says Jimmy, "for the lies we're after telling, fresh ones every hour of the day."

\section{0_LALAGE'S LOVERS. Pp. 312. (Methuen). 6s. (N.Y.: Doran). 1.20.} [1911]. 3rd ed., 1915.

The main idea-in so far as the book is serious-may be stated thus:-How much can one young person (aetat 14 sqq.) of perfect candour and fearlessness do to upset the peace of comfortable people, who are jogging along in the ruts of convention and compromise. Lalage begins with her governess, then tries the bench of bishops, but causes most consternation by disturbing an election with her Association for the Suppression of Public Lying. The whole is full of fun and laughter. L. has been well described as " an especially enterprising and slangy schoolboy in skirts." 
"BIRMINGHAM, George A."-(continued).

201- THE MAJOR'S NIECE. Pp. 302. (Smith, Elder). 6s. 1911.

Rev. J. J. Meldon in new situations. Major Kent expects from Australia a grown-up niece, who turns out to be a naughty little girl of ten. Mr. Meldon had made innumerable plans for the reception and treatment of the young lady. How does he face the new situation? There are capital minor characters-Doyle the hotel keeper, and Fiather MacCormack, and the house-keeper, Mrs. O'Halloran.

\section{2_ THE SIMPKINS PLOT. Pp. 384. (Nelson). 2s. net. (N.Y.: Doran).} 1.20. 1911.

Scene: "Ballymoy." Problem: how to get rid of Simpkins, a meddlesome busybody. The interest of the plot mainly turns on the amusing mancuvres of Rev. J. J. Meldon (the hero of s'panish Gold) to marry Simpkins to a mysterious "Miss King," a lady supposed to be identical with a Mrs. Lorimer, recently acquitted, agtainst the opinion of the Judge, of the murder of her husband. Full throughout of fun, clever talk, and deftly sketched character study. Sabina Gallagher, Sir Gilbert Hawksby, and Major Kent are all well done, and there is no mistaking the nationalities.

203

THE LIGHTER SIDE OF IRISH IIFE. Pp. 271. (Foulis). 16 illustr.

in colour by H. W. Kerr, R.S.A. 1911.

Chapters:-As others see us, As we see ourselves, The Irish clergy, The Irish official, the Government, The Irish peasant, The brogue, Old Customs and superstitions, The "Yank," The Irish servant, Wit and humour, Spoil Five. Not so much fiction as the material for fiction or the setting for the Author's stories. The illustrations are artistic and are not caricatures. The view point is that of the Author's novels.

\section{4-THE INVIOLABLE SANCTUARY. Pp. 370. (Nelson). 2s. 1912.}

How Frank Mannix comes for vacation to Rosnacree (in the wildest west of Ireland) in all the glory and dignity of a Haileybury prefect. How, owing to a sprained ankle, he is obliged to spend the time sailing in the bay with Priscilla, his fifteen-year-old madcap cousin. How various exciting adventures follow, including the finding, in most unexpected and comical circumstances, by a Cabinet Minister of his daughter, who had eloped with a clergyman, and how Frank and Priscilla were responsible for the reconoiliation. Told with all the Author's sense of fun and fair for comic situations. But why must all Irish peasants appear as liars?

\section{5- THE RED HAND OF ULSTER. Pp. 318. (S'mith Elder). 6s. Cheap ed., 6d. [1912] and 1s. 11. 1917.}

How an Irish-American millionaire runs a revolution in Ireland, sweeping into his plans the rabid Orangemen, who are in deadly earnest, the Tory M.P. who only meant to bluff, and members of the Irish Tory aristocracy who meant nothing in particular. Of this class is poor Lord Kilmore, who tells the story, and was an unwilling actor in the whole business. The book is a mixture of shrewd satire (e.g., Babberley, M.P., the Dean, and McConkey) in which all parties receive their share, and of Gilbertian extravaganza. The denoucment is both amusing and unexpected.

206- THE ADVENTURES OF DOCTOR WHITTY. Pp. 320. (Methuen). 6s, [1913]. 4th ed., 1915.

Types and humours of a west Connaught village--the P.P., the Protestant Rector, Colonel Beresford, Thady Glymn, proprietor of "The Imperial Hotel," chairman of the League, and popular demagogue, J.P., general philosopher, and "ipse dixit" of the village, and then the Doctor himself, genial, sociable, "all things to all men" to an extent that gets him into fixes, and that is not easily reconcilable with the moral order. There are broadly comical situations from which the Doctor extricates himself, and emerges radiant as ever. The seamy side of Irish life is depicted in the Author's usual vein of satire. 
“BIRMINGHAM, George A."-(continued).
207
GENERAL JOHN REGAN.
Pp. 324.
(Hodder \& Stoughton). $6 \mathrm{~s}$.
Second ed., 1913.

A very slight plot, centring in the erection of a statue to an imaginary native of Ballymoy. 'The real interest lies in the Author's satirical pictures of Irish life, and in his humorous delineations of such types as Dr. O'Grady, Doyle the dishonest hotel-keeper, Major Kent, whom we have met in Spanish Gold, Thady Gallagher, the editor of the local paper, and a rather undignified and not wholly honest P.P. The thesis, if there be any, would seem to be that the Irishman is so clever and humorous that he will allow himself to be gulled, and will even gull himself for the pleasure of gulling others.

\section{8- THE LOST TRIBES. Pp. 331. (Smith Elder). 3s. 6d. [1914].}

Mrs. Dann, a hustling American lady, owing to a clause in her husband's will, comes to look up a relative of his who has married the clergyman of a remote village in Co. Galway. Mrs. D. immediately sets to work to "boost" Druminawona and to liven things up generally. To the great embarrassment of Mr. Mervyn and Fr. Roche, and of their respective bishops, she wants, among other things, to run a miracle play on commercial lines. The clash of her transatlantic notions with oldworld traditions in Druminawona provides much excellent comedy. The effect is heightened by the amusing American talk of Mrs. Dann and her nephew, Bobby Sebright. The title is due to Mrs. D's. pursuance of her husband's idea that the lost tribes of Israel might be located in Ireland.

209_ MINNIE'S BISHOP, and Other Stories of Ireland. Pp. 320. (Hodder \& Stoughton). 6s. 1915.

Not all of these stories deal with Ireland. Those that do are very varied in character. Some are in the Author's most humorous vein, others are more serious in tone. In several he pokes fun at Government methods in the West, and some show the comic side of gun-running, despatch-riding, and other Volunteer activities. In the background, at times, is a vision of the hopeless poverty of the Western peasant's lot.

\section{0_ GOSSAMER. (Methuen). 6s. 1915.}

An Irish landlord of the "bought-out" type and an Irish Nationalist politician, who is also journalist and playwright, find themselves in company on a trip to U.S.A. They make the acquaintance of an atheistical German banker and his artist wife. The latter becomes strongly interested in the politician's handsome brother, a checktaker in an American circus who devotes his real energies to invention. These inventions furnish the main interest. Towards the end the various parties return to Europe, and there are glimpses of Sir Edward Carson's movement in Ulster, the Curragh Mutiny, and finally the European War. The theme of the book would seem to be a defence of the modern capitalist system. There are occasional disparagements of the Catholic clergy.

BLACAM, Aodh de.

211_ THE SHIP THAT SAILED TOO SOON, and Other Stories. (Maunsel). 1919.

BLACK, William. Born in Glasgow, 1841. One of the foremost of English nineteenth century novelists. Published his first novel 1864; thirty-three others appeared before his death in 1898, at Brighton, where he had long resided.

212- SHANDON BELLS. Pp. 428. (Sampson, Low). 2s. 6d. [1883]. (N.Y.: Harper). 0.80. New and revised ed. 1893. (Nelson), 9d. n., 1917.

Scene: partly in London, partly in city and county of Cork. A young Irishman goes to London to make his fortune. Disappointed in his first love, he turns to love of nature. The book has all the fine qualities of W. Black's work. Sympathetic 
BLACK, William-(continued).

references to Irish life and beautiful dezcriptions of Irish scenery in Cork. Willy Fitzgerald, the hero, had for prototype William Barry, a brilliant young Corkman and a London journalist.

" BLACKBURNE, E. Owens." Elizabeth O. B. Casey, 1948-1894. Born at Slane, near the Boyne. Lived the first twenty-five years of her life in Ireland; then went to London to take up journalistic work. In 1869 her first story was accepted, and in the early seventies her In at the Death (afterwards published as $A$ Woman Scorned) appeared in The Nation. To the end sho used the pen-name "E. Owens Blackburne." Other works of hers were A Modern Parrhasius, The Quest of the Heir, Philosopher Push, Dean Swift's C'hest, The Love that Loves alway. "Her stories are mostly occupied with descriptions of Irish peasant life, in which she was so thoroughly at home that she has been ccmpared to Carleton. They are for the most part dramatic and picturesque; and she understood well the art of weaving a plot which should hold the reader' interest."-(Irish Lit.).

213- A WOMAN SCORNED. Three Vols. (Tinsley). [1876]. Also one Vol. (Moxon), 1878.

Out-at-elbows Irish household-upper class-brother, sister, and young stepsister (the heroine) Katherine. Captain Fitzgerald falls in love with Katherine. The elder sister (the woman scorned) filled with jealousy plots to marry $K$. to a rich elderly suitor. The plot miscarries, and she dies a miserable death. Scene: near the Boyne. Some good descriptions of river scenery.

214- THE WAY WOMEN LOVE. Three Vols. ('Tinsley). 1877.

Hugh O'Neill, a Donegal man, after an unsuccessful career as an artist in London, settles near Weirford (Waterford). He has two daughters-Moira, handsome. proud of her ancient lineage and a poet, and Honor, plain and domestic. The story is concerned with the loves of these two. Local society cleverly hit off. Local newspapers and their editors come in for a good deal of banter; several real characters, thinly disguised, being introduced. Brogue very well done.

215- A BUNCH OF SHAMROCKS. Pp. 306. (N.Y.: Munro: "Seaside Library"). [1879]. 1883.

A collection of tales and sketches, illustrating for the most part the gloomier side of the national character, viewed, apparently, from a Protestant standpoint. In one, "The Priest's Boy," there is much pathos.

216- MOLLY CAREW. Three Vols. (Tinsley). n.d. (1879).

A tale of the unrequited love of an Irish girl of talent, but of humble origin, for a selfish and ruffianly English author named Eugene Wolfe. She falls in love with him as a child and then, in young womanhood, falls still more deeply in love with the ideal of him which she forms from his books. Nothing can kill or even daunt this love, and for its sake she undergoes the supremest sacrifices, but all in vain. The two chief characters are carefully and consistently drawn, and there are some dramatic scenes. The action passes chiefly in London, whither Molly Carew had followed her ideal.

217- THE GLEN OF SILVER BIRCHES. Two Vols. (Remington). 1880. (N.Y.; Harper). 1881.

Nuala O'Donnell's extravagant father has mortgaged his estate in the Donegal Highlands, near Glenvich (The Glen of Silver Birches). A scheming attorney tries to get the family into his toils, and to marry N. The scheme is defeated, and N. marries Thorburn, an English landlord, who has bought the neighbouring estate. Some good characters, e.g., kindly old Aunt Nancy and N.'s nationalist poet cousin.

218- THE HEART OF ERIN : An Irish Story of To-day. Three Vols. (N.Y.: Munro: "Seaside Library"). [1882]. 1883.

Standish Clinton, a clever speechmalier, raises himself to a foremost position 
"BlaCKBURNe, E. Owens "-(continued).

in Parliament. Getiting into higher social circles he breaks with his faithful Mary Shields. The mystery of his birth is cleared up in the end, and he succeeds as lawful heir to the family mansion of the Hardinges. The campaign of the Land League, with which the Author is in sympathy, forms the background. The famous letter of Dr. Nulty, of Meath, is cited as an argument for land reform. Interesting picture of the peasantry.

BLAKE-FORSTER, Charles Ffrench. B. Forster street Ho., Co. Galway, in 1851. Was High Sheriff of Galway in 1874, and died in that year, unmarried. Had been expelled from the County Clubs of Galway and Clare for his Nationalist opinion,; and especially for publishing the following book with a crownless harp on the cover.

\section{9 - A COLLECTION OF THE OLDEST AND MOST POPULAR LEGENDS OF THE PEASANTRY OF CLARE AND GALWAY.}

220 - THE IRISH CHIEFTAINS; or, A Struggle for the Crown. Pp. 728, demy 8vo. (M'Glashan \& G'ill). 1872.

An account, in the form of a tale, of the Williamite Wars, from the landing of James II. at Kinsale to the surrender of Galway, with all the battles and sieges (except Derry). Into this is woven large sections of the family history of the O'Shaughnessy and Blake-Forster clans of Co. Galway. This latter story is carried past the Treaty of Limerick down to the final dispossession of the O'Shaughnessys in 1770. It includes many episodes in the history of the Irish Brigade in France and of the history of the period at home (including the Penal Laws and the doings of the Rapparees). A surprising amount of erudition drawn from public and private documents is included in the volume. The notes occupy from p. 479 to 523. An Appendix, pp. 574 to end, contains many valuable documents, relating largely to family history, but also to political history. The standpoint is Jacobite and national.

\section{" BLAYNeY, OWEN," Robert White.}

221 - THE MACMAHON; or, The Story of the Seven Jolnns. Pp. $x+351$. (Constable). 6s. 1898.

Founded on a County Monaghan tradition. Colonel MacMahon escaping from the defeat at the Boyne entrusts his infant son to John M'Kinley, a settler. The boy grows up, falls in love with M'Kinley's daughter, and after unsuccessfully pleading his cause with the father, abducts her. M'Kinley calls to his aid six other setitlers of the name of John, pursues the fugutives, seizes them, and hangs MacMahon on the windmill at Carrickmacross. A powerful story giving a faithful picture of the times. Ulster dialect good.

\section{[BLENKENSOP, A.]}

222 - PADDIANA; or, Scraps and Sketches of Irish Life, Past and Present. Two Vols. (Bentley). [1847]. Second od. 1848

By the Author (an Englishman, see p. 2) of A Hot Hater Cure. Contents:1. "Mr. Smith's Irish Love." 2. "Mlick Doolan's Head." 3. "Still-Hunting.", 4. "A Mystery Among the Mountains." 5. "The Adventure of Tim Daley.", 6. “Mrs. Fogarty's Tea Party." 7. "A Quiet Day at Farrellstown." 8. "A Duel." 9. "Mr. H- " " 10. "The Old Head of Kinsale." 11. "Barney O'Hay." 12. "Headbreaking." 13. "Cads, Fools, and Beggars." 14. "The Mendicity Association." 15. "The Dog-Fandier." 16. "Dublin Carmen." 17. "Horses." 18. "Priests : Catholic and Others." 19. "An Irish Stew." Vol. II.-1. " Executions." 2. "Ronayne's Ghost." 3. "The Last Pigtail." 4. " The Green Traveller." 5. "Larry Lynch." 6. Potatoes." Then (pp. 142-275) follows "Irish History"scraps from various Irish annals and histories, told in a facetious and anti-Irish 
[BLENHENSOP, A.]-(continued).

spirit. All the old calumnies are raked up and set down here. The Author concludes that the Irish are an uncivilised people, and that their national character bs " a jumble of contradictions." The stories are told with considerable verve.

N.B.-A new ed. (n.d.) pp. 363 was publ. by Ch. II. Clarke of London, under title Larry Lynch, or Paddiana. It contains the same stories, but in a different order.

BLESSINGTON, Countess of. Marguerite Power, born near Clonmel, 1789, daughter of Edmund Power and Ellen Sheehy. In 1818 she married the Earl of Blessington, and became a leader of society in London, afterwards in Paris, and then again in London. Wrote upwards of thirty books-novels, travel, reminiscences, \&c. Died 1849.

223- - THE REPEALERS; or, Grace Cassidy. (London). [1833].

"Contains scarcely any plot and few delineations of character, the greater part being filled with dialogues, criticisms, and reflections. Her ladyship is sometimes sarcastic, sometimes moral, and more frequently personal. One female sketch, that of Grace Cassidy, a young Irish wife, shows that the Author was most at home among the scenes of her early days."-(Chambers' Cyclopsedia of ENGLish Literature).

224-COUNTRY QUARTERS. Three Vols. (London: Shoberl).

[1850].

Port. Second ed. 1852.

In Vol. I., pp. iii.-xxiiil., memoir of Author by M. A. P. (Marguerite A. Power, her niece). Scene: South of Ireland (description of Glanmire and references to Waterford and to the Blackwater), among county and garrison people. There is a great deal about their courtships and marriages, much small talk and pages of reflections. Grace, the heroine, is loved by two officers, friendly rivals. Mordaunt makes Vernon propose. V. is refused, but M. is too poor to marry. However, after many vicissitudes, Grace is united to M. Full of sentimentality.

\section{BLOOD SMITH, MisS see " DOROTHEA CONYERS."}

BLUNDELL, Mrs., see "M. E. FRANCIS."

BODKIN, M. M'DonneII, K.C.; County Court Judge of Clare since 1907. Born 1850. Son of Dr. Bodkin, of Tuam, Co. Galway. Educated at Tullabeg Jesuit College and Catholic University. Was for some years Nationalist M.P. for North Roscommon. Besides many works of fiction, has published an historical work on Grattan's Parliament. Resides in Dublin.-(Wно's Wно). See his Recollections of an Irish Judge, 1915.

225- POTEEN PUNCH. (Gill). 1s. 1890.

"Afiter-dinner stories of love-making, fun, and fighting," supposed to be told in presence of Lord Carlisle, one of the Viceroys, in a house at Cong, whither he has been obliged to go, having been refused a lodging at Maam by order of Lord Leitrim. The stories are of a very strong nationalist flavour, some humorous, some pathetic.

\section{6- PAT O' NINE TALES. (Gill). 1894. (N.Y.: Benziger). 0.90.}

Stories of various kinds, all pleasantly told. The first and longest is a pathetic tale, introducing an evictıon scene vividly described. Among other stories there is "The Leprachaun," humorous, and told in dialect; a "ghost" story; a story of unleoked for evidence at a trial; a tale of Fontenoy, Sc. The last, "The Prodigal Daughter," is, from its subject, hardly suitable for certain classes of readers.

227— IORD EDWARD FITZGERALD. Pp. 415 (Chapman \& Hall). 1896.

The story of the early years of Lord Edward is woven into the love-story of one Maurice Blake. Pictures Irish social life at the time in a lively, nivid way. 


\section{BODKIN, M. M'DonnelI, K.C.-(continued).}

Hepenstal, the "walking gallows," Beresford and his riding school, the infamous yeomanry and their doings, these are prominent in the book. The standpoint is strongly national. "History supplies the most romantic part of this historical romance. The main incidents of Lord Edward's marvellous career, even his adoption into the Indian tribe of the Great Bear, are absolutely true. Some liberties have, however, been taken with dates."-(Pref.).

\section{8- THE REBELS. Pp. 358. (Duffy). 2s. [1899]. (N.Y.: Benziger). 0.60.}

Sequel to Lord Edward. Later years of Lord Edward's life. Shows Castlereagh and Clare planning the rebellion. Shows us Government bribery and dealings with informers. Some glimpses of the fighting under Father John Murphy, also of Humbert's invasion and the Races of Castlebar. A stirring and vigorous tale, strongly nationalist.

\section{9 - SHILLELAGH AND SHAMROCK (Chatto). 3s. 6d. 1902.}

Short stories dealing mainly with the wild scenes of old election days. Pictures of evictions and the old-time fox-hunting, whiskey-drinking landlord. Always on the peasants' side. Tales full of voluble humour and "go." The peasants' talk is faithfully and vividly reproduced.

\section{0. - IN THE DAYS OF GOLDSMITH. Pp. 309. (Long). 6s. 1903.}

A panegyric of Goldsmith, dealing with the part of his life spent in England. Conversations introducing Reynolds, Beauclerk, Johnson, etc.; the latter's talk recorded with Boswellian fidelity. A picture, too, of the life and manners of the day drawn with such frankness as to render the book unfit for the perusal of certain classes of readers.

\section{1_ PATSY THE OMADHAUN. Pp. 260. (Chatto). 3s. 6d. . (N.Y.:} Benziger). 0.60. 1904.

A' dozen short stories, in which the village tailor recounts the exploits of Patsy, who proves to be by no means the fool he seems, and extricates himself and his friends from all kinds of comical situations. All told in broadest brogue. Somewhat farcical comicality.

\section{2- TRUE MAN AND TRAITOR. (Duffy). 1910.}

The career of Robert Emmet from his Trinity days to his tragic end, told in the Author's usual spirited fashion. Emmet is represented as an able and practical organiser, but the story of his love for Sarah Curran is not neglected. The historical facts are thoroughly leavened with romance-Emmet's perilous voyage to France in a fishing-hooker, the detailed accounts of his interviews with Napoleon, the character of Malachi Neelin, the traitor; these and many other things are blended with the narrative of real events.

233_ OLD ROWLEY. Pp. 303. (Holden d. Hardingham). 5s. n. n.d. (1916).

From Cromwell's siege of Drogheda Hugh O'Donnell escapes and lurks in hiding. His son, Hugh, the hero of the tale, refuses under torture to betray him. Young Hugh is a courtier at Versailles; then after the Restoration he comes to the Court of Charles II. under an assumed name. His early love is one of the ladies of the Court but does not recognise him. Then follow a series of intrigues and exciting incidents, during which the heroine masquerades as a man. The lovers remain true to each others' memory and are united in the end. 'The shameless amours and intrigues of Charles's Court are set forth undisguisedly, apparently as a foil to the virtue of the Irish hero and heroine. "Old Rowley" was a contemporary nickname for Charles II.

\section{BOINVILLe, Mrs. N. M. Chastel de}

233A- O'REILLY OF THE GLEN. (Hutchinson). 6s. 9d. net. November, 1918. A story of the 1916 Rising. 'See Addenda. 
[BOLES, Agnes], "J. A. P."

\section{THE BELFAST BOY. Pp. 464. (Nutt). 5s. 1912.}

Opens in Belfast during the great riots of twenty-five years ago. The hero, falsely accused of murder, flees to South Africa, where he becomes a millionaire, and is known as "The Belfast Boy." The heroine, when she is going out to marry him, omits to mention that she is leaving a son and his father (the villain) in Belfast. These are conveniently got rid of, one by lightning, the other by lightninglike small-pox. Several real persons are introduced as personages in the story. Many of the incidents are sensational, there is much dialect, and the style in places is far from refined. An intense love for Belfast and its surroundings pervades the book. - (Press Notices).

BOWLES, Emily. Published more than a dozen books, between 1861 and 1888 . These were largely translations from French Catholic literature, e.g., Joan of Arc, Fleurange, In the Camergue, etc., etc.

235- IRISH DIAMONDS : A Chronicle of Peterstown. Pp. 219. (Richardson). 1864.

A story of landlord and tenant, of illicit distilling, and of proselytising. A Bible reader, an agent, and the sister of a landlord are the villains of the piece. Tone strongiy Catholic and anti-Protestant. There is a love interest and a certain amount of adventure, which are not made subordinate to the pictures of Souperism. In 1878 a writer in the Dublin Review said of it: "It has not been surpassed since it was written. . . . The characters are so well drawn that even those in barest outline are interesting and individual. .... Told in the brightest, most natural, and most quietly humorous way."

BOYCE, Rev. John, D.D. [From Inishowen and Tirconnell, by W. J. Doherty]. Born in Donegal, 1810. Ordained Maynooth, 1837. Emigrated to U.S.A., 1845. Died 1864. Besides the three novels mentioned in the body of this work, he published lectures on the Influence of Catholicity on the Ants and Sciences, Mary Queen of Scots, Queen Elizabeth, Charles Dickens, Henry Grattan, \&c.

236- SHANDY MAGUIRE: or, Tricks upon Travellers. (N.Y.: Pratt). 1.75. [1848]. Also (Richardson) 1855, and Warren, Kilmainham, n.d.

"First appeared in a Boston periodioal, with the pen-name of Paul Peppergrass. It attracted at once the attention of Bishop Fenwick of Boston. Dr. Brownson, in his QUARTERLY Review, pronounced upon the book the highest eulogium, and assigned to the writer a place equal if not superior to any writer of Irish romance. Shandy Maguire was recognised by the London Press and the Dublin Review as a work of great merit. It has been successfully dramatised and translated into German" (from Inishowen and Tirconncll, by W. J. Doherty).

237_- THE SPAEWIFE: or, The Queen's Secret. [1853]. Still in print.

(Boston: Marlier). 1.50.

Begins at Hampton Court. The faoility with which Father Boyce makes Nell Gower, the Scotch Spaewife (a woman gifted with second sight), discourse in broad Scotch dialect, in contrast with the stately and imperious language of Elizabeth, displays an unusual power of transition. No finer character could be depicted than Alice Wentworth, daughter of Sir Geoffrey Wentworth, the representative of an old English Catholic baronetage, who suffered persecution under Elizabeth; whilst Roger O'Brien, attached to the Court of Mary Queen of Scots, affords an opportunity of presenting the high-spirited and brave qualities that ought to belong to an Irsh gentleman. Elizabeth appears in anything but a favourable light.

238- MARY LEE; or, The Yankee in Ireland. Pp. 391. (N.Y.: Pratt). 1.75. (Baltimore: Kelly \& Piet). Frontisp. by J. Harley. 1864.

The last story written by this Author, for whom see General Note. It is considered to display an intimate knowledge of Irish character, and to contain an excellent description of the typical Yankee. The scene is Donegal. Time 185-. 
BOYLE, Robert Whelan, son of 'Thomas Boyle. B. in N. of Ireland, 1822. D. 1889. Was from 1877 Ed. of London DaILY Chronicle.

\section{9- LOVE UNTIL DEATH. Pp. 152. (Spencer Blackett). n.d.}

The love story of a young Protestan' doctor. The scene is laid in Heathborongh (=Maryborough) about 1820, and there is a good deal of description of the town and its surroundings. Religious matters are frequently touched upon, but with a singular absence of any trace of bias. Miss Desmond in the end rejects Dr. Parnell and enters a convent. The umpretertious little tale ends pathetically.

BOYLE, William. Born in Dromiskin, Co. Louth, 1853; ed. St. Mary's College, Dundalk. Has written many poems, songs and plays, including some of the best modern Irish comedies. The atmosphere of his stories is thoroughly Irish and their humour and pathos are genuine.

240_ A KISH OF BRoGUES. (O'Donoghue). Pp. 252. 2s. 6d. 1899.

The humour and pathos of country life, Co. Louth. The author knows the people thoroughly, and understands them. There is much very finthful character-drawing of many Irish peasant types, and a few good poems.

\section{BOYSE, E.C.}

\section{1- THAT MOST DISTRESSFUL COUNTRY. Three Vols. (F. V. White).} 1886.

A tale of love and marriage. Scene: first in Wexford, opening with pleasant pictures of country-house life and merry-making. Then there is an account of some minor incidents of the rebellion of 1798, viewed from loyalist standpoint, with insistence on savage cruelty of rebels. Then the scene shifts to London, and thence to Dublin, where we have piatures of life in military society. Finally, the scene is transferred to Tuam, where word is brought of Humbert's campaign in the West. Pleasant style, but the conversations, full of chaff and nonsense, are long drawn out. Author says in preface that the incidents are taken from private letters or accounts of eye-witnesses.

\section{BRAY, Lady.}

242- - EVE'S PARADISE. (Wells, Gardner). 6*. Etched frontispiece and titlepage. [1893].

Lady B.'s descriptions of child life are admirable, well-observed, and cleverly done."-(Pall Mall Gazette).

243_ A TROUBLESOME TRIO; or, Grandfather's Wife. (Wells, Gardner). 2s. 6d. Second ed. 1892.

BRERETON, Capt. F. S. Author of between 30 and 40 popular books for boys, including several that deal with the Great War.

244- IN THE KING'S SERVICE. Pp. 352. (Blackie). Attractive cover. Eight Illustr. by Stanley L. Wood. (N.Y. : Scribncr). 1.50. n.d. (1901).

Exciting adventures, abounding in dramatic climaxes, of an English cavalier during Cromwell's Irish campaign. Chief scenes of latter described from English cavalier standpont. Burlesque brogue. Juvenile.

\section{BRESLIN, J. W.}

245— THADY HALLORAN OF THE IRISH BRIGADE. Pp. 252. (Unwin). 1899.

Adventures of T. H., a gallant, reckless swordsman in the French service. Opens with description of conditions in Ireland towards the end of the reign of Queen Anne-recruiting for the "Wild Geese," etc. The hero takes part in the '15. The 
BRESLIN, J. W.-(continued).

escape of Wogan and other Jacobites from Newgate Prison is well told. Also Wogan's rescue of the Princess Clementina (of Mason's Clementina), in which T. H. is made to share. At the close Halloran, disgusted with his treatment by King Louis, dramatically lays down the sword and quits the French service.

BREW, Margaret W. A Co. Clare lady, who wrote much for the Irish Monthiy and other Irish periodicals. Brew and Burton are well-known Clare names.

246- THE BURTONS OF DUNROE. Three Vols. Pp. 934. ('T'insley). 1880. Scene: Munster c. 1810, also Dublin and (in third vol.) Spain, when the hero, William Burton, takes part in the Peninsula War. Robert marries beneath him, and is disinherited by disappointed father, who has meant him for his cousin Isabella. Rose, Robert's wife, dies. Robert goes to the wars, and returns covered with glory to marry Isabel and settle down in respectable prosperity. Conventional and a little dull. Much brogue as comic relief to the prevailing appeal to the tender feelings. Catholic in tone.

247- CHRONICLES OF CASTLE CLOYNE. Three Vols. (Chapman of Hall). 1886.

Highly praised by the Times, the Standard, the Morning Post, the Scotsman, \&c., \&c. The IRISH Monthly says: "It is an excellent Irish tale, full of truth and sympathy, without any harsh caricaturing on the one hand, or any patronising sentimentality on the other. The heroine, Oonagh M'Dermott, the Dillons, Pat Flanagan, and Father Rafferty are the principal personages, all excellent portraits in their way; and some of the minor characters are very happily drawn. The conversation of the humbler people is full of wit and common sense; and the changes of the story give room for pathos sometimes as a contrast to the humour which predominates. Miss Brew understands well the Irish heart and language; and altogether her "Pictures of Munster Life" (for this is the second title of the tale) is one of the most satisfactory additions to the store of Irish fiction from Castlc Rackrent to Marcella Grace." Pictures of the Famine, a country wedding, a wake, etc.

[BRITTAINE, Rev. George]. Was Rector of Kilcormack, Diocese of Ardagh. Died in Dublin, 1847. The AthenaEvm of December 14, 1839, said of the first three works mentioned below: "The sad trash which is here put forward as a portraiture of the social condition of the Irish peasantry needs no refutation; in his ardour to calumniate, the Author has forgotten that there are limits to possibility, and that when they are overstepped the intended effect of the libel is lost in its absurdity." All this writer's books seem to have appeared anonymously.

248-CONFESSIONS OF HONOR DELANY. Pp. 86. (Dublin: Tims). 1s. 6d. [1830]. Third ed., 1839. She admits getting a pension as a reward for "turning."

249- IRISH PRIESTS AND ENGLISH IAANDLORDS. P'). 249. (Dublin:

Tims). [1830]. Second ed., 1839; others 1871, 1879.

"By the author of Hyacinth O'Gara." A priest has anthority from a bishop to marry a girl to a man against her will. She refuses, aud subsequently dies-a martyr to the Protestant faith.

250- IRISHMEN AND IRISHWOMEN. Pp. 292. (Dublin: Tims). 3rd. ed. 1831.

Scene: "Derrynaslieve," in a North Western County of Ireland. Principal incidents:-two agrarian outrages in which the peasantry are represented as coldblooded and remorseless murderers, and the conversion of a Mrs. Costigan to Protestantism. Various charges (superstition chiefly) against the peasantry and the Irish priests are suggested passim. One priest, "Mr. Duff," is represented as 


\section{[BRITTAINE, Rev. George]-(continued).}

kindly and good-natured but half a Protestant at heart. The other, "Mr O'Floggin," is very objectionable. There are long discussions (one of $20 \mathrm{pp}$.) on religion. The Author has the knack of reproducing peasant talk naturally and humorously.

\section{1- RECOLLECTIONS OF HYACINTH O'GARA. Pp. 64. (Dublin: Tims). 6d. Fifth ed., 1839.}

Nos. 248, 249, and 251 were originally written by Rev. Geo. Brittaine. They were "re-written and completely revised" by Rev. H. Seddall, Vicar of Dunany, Co. Louth, and published by Hunt, London, 1871. They are frankly proselytising tales designed "to give a true picture of the Irish peasantry, and how priestcraft has wound itself into all their concerns." (Pref.) The peasantry are represented as exceedingly debased, the priesthood as conscienceless and selfish tyrants. Religion is practically the sole theme throughout. There is practically no reference to contemporary questions. One reviewer says: "There is nothing more graphic in all the pages of The Absentee, or Castle Rackrent than the account of Kit M'Royster's disclosures to his brother, the Popish Bishop, about the heretical purity of their niece; or the description of Priest Moloney's oratory about the offerings at the funeral of old Mrs. O'Brien." - Christian Examinen.

252_- JOHNNY DERRIVAN'S TRAVELS. Pp. 36. (Dublin: Tims). 6d. [1833]. Second ed., 1839.

Not religious in subject. Deals with Irish amusements, drinking \&c.

\section{3 - MOTHERS AND SONS. Pp. 297. (Dublin: Tims). 1833.}

A lady turns Methodist at the age of 44. The Author thereby takes occasion to condemn dyed hair and wigs, and many other things. The story includes a murder, of which a Curate is the victim. The murderer dies howling for the priest.

254_ NURSE M'Vourneen. Pp. 33. (Dublin: Tims). Second ed., c. 1839.

255- THE ELECTION. Pp. 331. (Dublin: Tims). [1840]. 1848.

Election manœuvres described. There is a murder in the story. Tone very antiCatholic.

[RRONTE, Rev. Patrick, B.A.]. 1777-1861. A county Down man, father of the famous novelists. His name was originally Prunty.

256- THE MAID OF KILLARNEY; or, Albion and Flora. Pp. 166 (Baldwin). [1818]. 1898.

Albion, an Englishman, visits Killarney, and falls in love with Flora Loughlean, The tale exhibits the anti-Catholic bias of the time.

BROOKE, Richard Sincluir, D.D. (1802-1882). Incumbent of Mariners' Church, Kingstown, afterwards Rector of Eyton. Published several volumes of verse and prose. Father of Stopford Brooke.

257- THE STORY OF PARSON ANNALY. Pp. 429. (Drought). 1870.

A long, rather involved story, in part reprinted from Dublin UnIvensity Magazine. It contains some excellent descriptions of Donegal scenery-Glenveagh and Barnesmore.

BROPHY, Michael, ex-Sergeant, R.I.C.

258_ TALES OF THE ROYAL IRISH CONSTABULARY. Pp. xx.+192. (Dublin: Bernard Doyle). 2s. [1888]. 1896.

Intended as the first volume of a series. Introduction gives a condensed history of the Force. This is followed by a long story founded on facts-" The Lord of Kilrush, Fate of Marion, and Last Vicissitudes of Lord Edward Fitzgerald's 
BROPHY, Michael-(continued).

Estate." 'This tells how Sub-Constable Butler, a real "character," bought in the Encumbered Estates Court the property of Lord Edward near the Curragh of Kildare, but was subsequently dispossessed-a curious tale, containing much out-of-the-way information, including an inquiry into the Parentage of Pamela. Then follow "Episodes of '48" (Ballingarry, \&c.), and "The Story of a Sword," (8 pp.) Sub-Constable Butler and Sub-Inspector Tom Trant are amusing person. ages.

BROWN, Rev. J. Irwin. Minister of the Scottish Church in Rotterdam, and son of Rev. Dr. Brown of Drumachose, Derry, in his time a well-known public speaker, and a defender of the Irish tenant farmers.

259_- IRELAND : Its Humour and Pathos. (Rotterdan: J. M. Bredee). 1910. The book contains some racy stories; and is bright and readable throughout. -I.B.L.

BRUYERE, Loys. Born in Paris, 1835. A French foll-lorist, Vice-President of the Société des Traditions Populaires. A frequent contributor to French folk-lore periodicals.

\section{CONTES POPULAIRES DE LA GRANDE BRETAGNE. Pp. 382.}

(Paris: Hachette). 1875.

Contains 100 tales. A very few are English (chiefly Cornish), none are Welsh. The majority are Scotch (largely from Campbell's collection), but there are a good many Irish, taken from Croker and Kennedy. The book is entirely in French.

\section{BRUNTON (F. Carmichael).}

261- THE ENCHANTED LOCHAN. Pp. 208. Sq. 8vo. (Harrap). 3s. 6d. n. 4 illustr. in colour by Noel L. Nisbet. 1917.

"Stories of Celtic Mythology" (Substitute). A young Scotch boy is taken to. the bottom of an enchanted lake, and there hears from the lips of each of the Celtic deities in turn the story of their mighty doings We have thus the stories of Angus Og, Nuad'a of the Silver. Hand, Midir, Manannan of the Sea, the Sons of Turenn (sic) and so on. The tales are meant for children, but lack a simple directness and narrative charm. On p. 90 St. Brigid seems to be identified with the Celtic goddess Bride. The whole has a neo-Pagan atmosphere. The coloured illustrations have a tendency to the grotesque.

BUCHANAN, Robert, 1841-1901. Born in Staffordshire, son of Robert B., "Socialist, Missionary, and Journalist." Educated at Glasgow. Published many volumes of poetry and several plays, among others a dramatised version of Harriett Jay's Queen of Connaught $\left(q . v^{\circ}\right)$. In 1876 published his first novelThe Shadow of the Sword. Many ethers followed. In 1874 he settled at Rosspoint, Co. Mayo, but left Ireland in 1877. Father Anthony was written during this period, but not published till later. See the notice in D.N.B., and the LIFE, published in 1903, by Harriet Jay, his adopted daughter.

262- FATHER ANTHONY. (tomg). 6s. 16 illustr. Many editions. 1903. New ed., 7d. 1916.

Scene: a country village in the West of Ireland. Father Anthony is a young priest, who for his brother's sake has sacrificed a career in the world to devote himself to God's poor. He finds lrimself called upon in virtue of his sacred office to keep the secret of the confessional when by a word he could save his brother from the hangman's hands. The pathos of the young priest's agony of mind is depicted with great power and symp'athy. The other priest, Father John, is drawn as the true parish priest of the old type, blood and bone of the people, jovial, homely, lovable and beloved. The Author, though alien in faith and race, tells us that he knew intimately and loved both priests and people during his stay in Ireland. 


\section{BUCHANAN, Robert-(continued).}

\section{3 - THE PEEP-O'-DAY BOY: A Romance of '98. (Dicks). 6d. 'n.d.}

A conventional sensational tale, little above the "shilling shocker," with oathbound societies meeting in under-ground caverns, abductions, informers, an absentee landlord, the Earl of Dromore, whose daughter loves the expatriated owner, The O'Connormore, and sofonth. The three chapters on the insurrection are from Cassell's History of Ireland. The story is scarcely worthy of this Author.

BUCKLEY, William. Born in Cork, and ed. there at St. Vincent's Seminary and the Queen's College. His first literary work appeared in MacmiLLan's Magazine. Resides in Dublin.

\section{4- CROPPIES LIE DOWN. Pp. 511. (Duckworth). 6s. 1903.}

Scene: Wexford, the year of the rising. The Author banishes all romance and artistic glamour, and deals with the horrors of the time in a spirit of relentless realism. Quite apart from historical interest, the book is thrilling as a story of adventure. The tone is impartial, but the writer clearly means the events and scenes described to tell for the Irish side. The NEw IRELAND REview says that "it sketches the origin and course of the Wexford insurrection with a conscientious accuracy which would do credit to a professed historian" ; and it praises the Author's " exceptional liter"ary ability" and the "intense reality of his characters." "Rather more than justice is done to the English authorities (e.q., Castlereagh), to the Irish Protestants, and even to the Government spies."-(Baker, 2).

\section{5- CAMBIA CARTY AND OTHER STORIES. Pp. 230. (Maunsel). 1s.} 1907.

Close descriptions of lower and middle classes in modem Youghal. In places will be unpleasant reading for the people of Yonghal. Picture of Cork snobbery decidedly unfavourable to Cork people, and on the whole disagreeable and sordid.

BUGGE, Alexander, Professor of University of Christiania, ed.

266- CATHREIM CELLACHAIN CAISIL: The Victorions Career of Cellachain of Cashel. Pp. xix.+171. (Christiania). 1905.

The original Irish text, from the Book of lismore, edited in a scholarly way and accompanied with an English translation, notes, and index. There is an interesting itroduction. It is a story of the struggles of Cellachan and the Danes in the tenth century.

BULlOCK, Shan F. Born Co. Fermanagh, 1865. Son of a Protestant landowner on Lough Erne. Depicts with vigour and truth the country where the Protestant North meets the Catholic and almost Irish-speaking West. There is at times a curious dreariness in his outlook which mars his popularity. But his work is "extraordinarily sincere, and at times touched with a singular pathos and beauty. ... He writes always with evident passion for the beauty of his country, and an almost pathetic desire to assimilate, as it were, national ideals, of which one yet perceives hinı a little incredulous."-(Stephen Gwynn).

\section{7- THE AWKWARD SQUADS. (Cassell). 5s. 1893.}

The Author's first book. Has all the qualities for which his subsequent books are remarkable. It is a study of the people of his native country-the borders of Cavan and Fermanagh - their political ideas, general outlook, humours and failings, their peculiar dialect and turns of thought. Four stories in all:-The title story, "The White Terror," "A State Official," "One of the Unfortunates."

\section{8- BY THRASNA RIVER. Pp. 403. (Ward, Lock). 6s. Illustr. 1895.}

The experiences of two lads on an Ulster farm in the district where the Author lays nearly all his scenes. There are many pleasant studies of peasant types. The hero is an Englishman, an amusing character. The story of his unsuccessful love 
BULLOCK, Shan F.-(continued).

affair with the "Poppy Charmer" is told by one of the lads familiar to us as Jan Farmer. There is no approach to anything objectionable in the book. Chapter" XXI., "Our Distressful Country," is good reading.

\section{9-_ RING O' RUSHES. Pp. 195. (Ward, Lock). 1s. 6d. (Chicago: S'tone).} 1.00. 1896.

A cycle of eleven stories dealing with various aspects of Ulster life in the neighbourhood of Lough Erne. In "His Magnificence" an emriched peasant returns to his native village and tries to show off his grandeur. "Her Soger Boy" recounts. a mother's innocent fraud, and her soldier lad's savage retaliation.-(Baker.2).

270- THE BARRYS. Pp. 422. (Methuen). 1.. Full-sized cloth. 1899. (N.Y. : Doubleday). 1.25.

Book I. has its scene at Innishrath, an island in Lough Erne. Frank Barry, on a visit from London to his uncle, betrays a peasant girl named Nan. In Book II. we find Nan in London. She discovers Frank's treachery. So does Frank's wife, and the Nemesis of his deeds overtakes him. But Nan finds consolation with her still faithful lover, Ted. A study in temperaments.

271_-IRISH PASTORALS. Pp. 308. (Grant Richards). 6.. (N.Y.: Mc(lure). 1.50. 1901.

A series of pictures-The Planters, the Turf-cutters, the Mowers, the Haymakers, the Reapers, the Diggers, \&c.--forming an almost complete view of life among the rural classes in Co. Cavan. These pictures are the setting for comntry idylls, humorous, pathetic or tragic. In all there is the actuality, the minute fidelity that can be attained only by one who has lived the life he describes and has the closest personal sympathy with the people. The descriptions of natural scenes, the weather, \&c., are admirable. McClure). 1.50 .1903$.

A study of Ulster marriage customs. Jane Fallon is practically sold to the Squireen by her family, and after long resistance, yields, and marries him. Tragic consequences follow. Most of the characters are Ulster Protestant peasants. "The Squireen" is a study of the old type of fox-hunting gentleman farmer, but it is a soul-study mather than a study of by-gone ways.

\section{3- THE RED LEAGUERS. Pp. 315. (Methuen). 6s. (N.Y.: Pratt). 0.75. 1904}

Scenes from an imaginary rebellion in Ireland, purporting to we related by a Protestant who has sided with the rebels and captains the men of Armoy, a barony a little to the north of the Woodford River (the Thrasna of the story), which enters Lough Erne about two miles to the west of where the River Erne flows into the same. England, having left Ireland almost without a garrison, the Protestants are all (except in a few places) killed or taken, the Irish Republic triumphs. Then the country gives itself up to an orgy of thoughtless rejoicing and more or less drunken revelling. In "a handful of weeks" the "land is hungry, wasted, lawless, disorganised, an Ireland gone to wrack." The story closes with the news of English troops landing in Cork and Derry and Dublin. The author does not write simply from the standpoint of the dominant class. Much less is he merely anti-Catholic and anti-Irish. He merely lacks faith in the wisdom and staying-power of Irish character. He tries to show the actualities of the rebellion in their naked realism, eschewing all romance. He succeeds in being strangely vivid and realistic, without apparent effort. Of the leaders on the Irish side one is a coward and a swaggerer, another 1s bloodthirsty, all are selfish and vulgar. The heroes are in the opposite camp.

N.B.-The scene of this story is also the scene of the Author's other North of Ireland studies and sketches. 
BULLOEK, Shan F.-(continued).

274_ THE CUBS. Pp. 349. (Werner Laurie). 6s. 1906.

A story of life in an Irish school, recognised by old schoolfellows of the Author as beraring a strong resemblance to the Author's old school at Farra, near Mullingar. It is naturally thought to be partly autobiographical. It is the history of a great friendship. It includes also some scenes of home life.

275__ DAN THE DOLLAR. (Maunsel). 3s. 6d. [1906]. New edition. 1908.

A study of national character and of human nature in which tine touch is delicate, sure and true. The whole study is concentrated on five persons. First there is the picture of the neglected farm of the happy, easy-going Felix. His wife is a contrast with him in all, yet they agree perfectly. Then there is Mary Troy, a Catholic girl living with them, a beautifully drawn character, and Felim, the dreamer of dreams. Into their life suddenly comes Dan, who, after years of hard sordid striving in the States, has made his pile. He brings his hard, practical American materialism to bear on the improvement of "this God-forsalien country," with what result the readers will see. There is a love-story of an exceptional kind, handled with much subtlety and knowledge of human nature. There is much pathos and noral beauty in the story.

\section{6- A LAUGHING MATTER. (Murray). 1908.}

The scene is laid in London, and the chief characters are not Irish, but a very Irish flavour is given to the book by the story and the character of Paudeen, gardener to the teller of the tale. $\mathrm{He}$ is an old Irish peasant who has come to London in quest of his daughter who had left him, married a Protestant, and disappeared from his ken. The exile's heart-sickness for home is well brought out, and $P$ 's character is a sympathetic study.

277- MASTER JOHN. Pp. 281. (Werner Laurie). 6s. 1909.

Master John is a strong man, who makes his way in the world and returns wealthy to settle in Fermanagh. The place he buys has a curse upon it, and strange things happen. The story is told by an old retainer-now a car-driver-whose verbosity and ramblingness are very quaint and amusing.

278- HETTY: The Story of an Ulster Family. Pp. 322. (Laurie): 6s. 1911.

Essentially what the suk-title suggests, a domestic story, with careful delineation of character for its chief interest. Old Dell is perhaps the central figure, an old Northern farmer, reserved, silent, conservative, with his love of the land and his unwillingness to part with his authority, even to the end. Then there is the contrast between Hetty, quiet, retiring, peace-loving, and her wilful, wayward, younger sister Rhona, lively, quick of tongue, and beautilul. The coming of Rholla makes shipwreck of poor Hetty's happiness, and well-nigh brings tragedy into the family life. A quiet, slow-moving sitory, intensely faithful to reality. "Problems" are in the background but are not wearisomely worked out. There is an occasional gleam of humour, but there is much true pathos.

BUNBURY, Selina.-B. at Kilsaran Ho., Co. Louth, in 1802, daughter of Rev. Henry Bunbury, and one of a family of fifteen. She was descended on the one hand from a family of Bunburys that settled in Carlow in Elizabethan times, and on the other from the Shirleys, the family of Earl Ferrers. Her first work, A Visit to my Birthplace, 1821, passed through twelve editions during her lifetime. For fifty years she. was a prolific author, her last work appearing in 1870. After the death of her parents she began to travel, and visited every country in Europe, except Greece and Portugal, recording her experiences in many volumes. Her most successful work was Coombe Abbey: an historical tale of the days of James I. (Dublin : Curry), 1844. She died at Cheltenham, 1882. "Her early books supply contemporary pictures of the Ireland of the early nineteeth century, as seen by a sympathetic observer, of a higher social environment than the other authors who have dealt with that period, and thus 
BUNBURY, Selina-(continued).

they possess a value of their own." Unfortunately her earlier books are written in a spirit of extreme bigotry, which, however, is almost absent from her later writings. She contributed much to the Leisure Hour, the Sunday at Home, Fraser's Magazine, and the Dublin University Magazine.

279- CABIN CONVERSATIONS AND CASTLE SCENES. Pp. 173. 12 s. (Nisbet). 1827.

Period: 1815. Theme: the evils of Popery. A story of proselytising efforts in the W. of Ireland. 280- MY FOSTER BROTHER. Pp. 134. (T'ims). [1827]. Second edition,

Alick, foster-brother to Mr. Redmond's boy, converts the latter, Bible in hand. The boy dies a pious death.

281- THE ABBEY OF INNISMOYLE: A Tale of another Century. I'p. 336. (Curry). [1828]. Second edition, 1829. Engraved frontisp.

Consists largely of the history of the Abbey from its foundation in the twelfth century. The story is very rambling and obscure. Introduces, incidentally, a "cold, ambitious, plotting Jesuit," and inveighs against the "monstrous creed of Jesuitism.", The Abbey is in "an unfrequented part of the north-western coast of Ireland." We take leave of it in Protestant hands.

282_ TALES OF MY COUNTRY. Pp. 301. (Curry). 1833.

Viz., 1. "A visit to Clairville Park, and the Story of Rose Mulroon." 2. "An Arrival at Moneyhaigue, and the Doctor's Story of Eveleen O'Connor." 3. "A Tale of Monan-a-gleena." 4. "Six Weeks at the Rectory." In 3 the Irish are represented as cherishing a diabolical thirst for vengeance. 4 is a long lecture. 1 is a '98 story.

\section{3 _ SIR GUY D'ESTERRE. Two Vols. (Routledge). 1858.}

Sir Guy is a young soldier in the train first of Sir Philip Sidney, then of Essex. Before the latter he comes to Ireland-" the cursedest of all lands," in his opinionwhere he is captured, and taken to the Castle of the O'Conmors. Here he falls in love, and here begins his troubles. Enemies plot his ruin. He is thrown into the Tower, but is released by Essex, and goes with him to Ireland on his fatal campaign. Careful and vivid portraits of Elizabeth, Essex, Hugh O'Neill, and other historical characters. A vigorously-written and interesting historical novel, not Natjonalist, but fair and even sympathetic to Ireland. No religious bias. Essex meeting with O'Neill, V. II., p. 151.

\section{BURKE, Edmund.}

284 A CLUSTER OF SHAMROCKS. Pp. 312. (Lynwood). 6s. 1912.

"Very pleasing and human tales of humble life, Swiss, Breton, Norwegian, English, \&c.; some of them rather in the school of Hans Andersen."-(T. LIT. SUPPL.). "Pleasantly-written short stories drawn from many sources, home and Continental. There is a purity of feeling about them which renders them exceptionally suitable for young people."-I.B.L. The Author shows himself a lover of flowers and of nature generally. Press notices speak of him as Mr. E. Burke, of Liverpool, an M.A. of T.C.D.

\section{BURKE, John.} 285 - CARRIGAHOLT: a Tale of Eighty Years ago. Pp. 77. (Hodges Figgis).
1s. 1885 .

A story of Ireland (S.W.) in early days of 19th century. Shows us the goodnatured spendthrift landlord, the gombeenman, the nice young ladies whose education has been "finished" in Belgium, the young men of property whose objects in life are sport and attention to the young ladies; and the scapegrace youth, who narrowly escapes being hanged for forgery. 
BURKE (U. R.). Author of Beating the Air, 1879, Couleur de Rose, 1884. 286- LOYAL AND LAWLESS. Two Vols. (Chapman d: Hall). 1880.

A society novel of a bitterly anti-Catholic and anti-Irish tone. The leading personages are all titled. Their matrimonial affairs are not edifying. But Lord Chippendale's daughter, Cecil, gets happily married in the end. Politics, viewed from a strongly Tory standpoint, are frequently introduced. "Ireland is lawless, India is loyal." Landlords are eulogised, priests represented as money grabbing and punch loving. England's failure in Ireland is due to not having eradicated Popery. There is a fierce denunciation of Fenianism.

BURROW, C. Kennett. B. in 1868 at Rio Grande do Sul, of English parents. Ed. Ackworth School (Yorks) and King's Coll., London. Sometime Assistant Ed. of THE ACADEMy and of T. P.'s WEEKLY. Has published many short stories of Irish life, with which he is familiar from residence in the S. of Ireland. Au. of The Way of the Wind, The Fire of Life, T'ony Heron (Oct., 1918), and of several vols. of poems.

287- PATRICIA OF THE HILLS. Pp. 330. (Lawrence \&. Bullen). 6s. 1502.

A love story of which the incidents take place during the Famine years and the Young Ireland movement. With the latter the hero, who tells the story, is clearly in sympathy, though no controversial matter is introduced. The characters (exceptionally well drawn) are types, but also very live personalities. Locality not indicated. An interesting and uncommon tale.

BURTON, J. Bloundelle. Author of some 30 novels.

288- _ THE I.AND OF BONDAGE. (F. V. White). 6s. 1904.

Ireland and England in 1727 ; then the colony of Virginia, adventures with Indians. \&c. The last pages bring us to 1748.-( Nield).

\section{BUTLER, A.}

289-_ SHAMROCK LEAVES. (S'ealy Bryers). Pp. 84. 1s. 1886.

"The (five) stories are founded-not upon unreliable, secondhand informationbut bona fide facts."-(Preface). " A kindly Irish spirit runs through these Tales."-Nation.

BUTLER, Mary E. Mrs. O'Nowlan. Daughter of Peter Lambert Butler, and granddaughter of William Butler, of Bunnahow, Co. Clare. Educated privately, and at Alexandra College, Dublin. Married (1907) the late Thomas O'Nowlan, Professor of Classics and Irish in University College, and at Maynooth. Lives in Dublin.-(Catr. Who's Who).

290 - A BUNDLE OF RUSHES. Pp. 150. (Sealy, Bryers). 1s. 1899.

A little volume of short stories, pleasantly written; Irish in tone and poetic. Well received by the Press and by the public. Fifteen stories in all. Six are prose idylls of ancient Celtio inspiration, nine are lively little modern sketches in which he and she get happily married in the end.-(I.MI.).

\section{1- THE RING OF DAY. Pp. 360. (Hutchinson). 6s. 1906.}

A romance the interest of which centres in the aspirations of the Irish Ireland movement. Highly idealized, but full of intense earnestness and conviction. The characters are types and talk as such. Eoin, however, is a strong personality.

BUTLER, Gen. Sir William. B. 1838 in Tipperary and died there 1910. From 1858 to 1905 he served in the British Army in various parts of the world. Was Commander of the British forces in S. Africa when the Boer War broke out. $\mathrm{He}_{\mathrm{e}}$ has related his experiences in his Autobiography (Constable), 1911. His last years were spent in work for Ireland. Many of his Irish ideas will be found in his book, The light of the West. 


\section{BUTLER, Gen. Sir William-(continued).}

292_ RED CLOUD. Pp. 327. (Burns \& Oates). 8 good illustr. [1882]. new ed. 1907. Another new ed. with Pref. by Sir R. Baden Powell and memoir of Author by Sebastian Meynell. 1911.

In this story of the Canadian prairies the Author has embodied some of the experiences which he related in his books, The Great Lone Land and The "Wild North Land. It opens with a beautiful chapter that reads like autobiography but is not. It tells the hero's childhood in a Kerry valley, and in particular a breathlessly exciting adventure in an eagle's nest overlooking the lake of Cooma-sa-harn. The rest is the adventures of the narrator and his friend Donogh in the wilds of N. W. Canada. Unlike most Indian stories, it has an Indian for its chief hero and a white man for its villain. 'A splendid boys' story.

BUTT, Isaac. Born in Glenfin, Co. Donegal, 1813. Son of Rev. Robert Butt, Rector of Stranorlar. Educated Royal School, Raphoe, and T.C.D. Helped to found the Dublin UNiversity Magazine, 1833, and was editor from 1834-38. Was called to the Bar and distinguished himself there. Opposed O'Connell and Repeal. Defended Smith O'Brien, 1848, and the Fenian prisoners in 1865-9. Became a Home Ruler, practically founded the party in 1870, and worked strenuously for it. Died 1879. Wrote important works on many subjects, Irish and other.

293 — IRISH LIFE IN THE CASTLE, THE COURTS, AND THE COUNTRY. Three Vols. (LoNDoN). 1840.

Story of a young barrister named Tarleton, who while studying in London forms a firm friendship with Gerald MacCullagh (really O'Donnell), who becomes a nationalist leader. The latter, in spite of himself, sees the national movement drift into one of incendiarism and robbery, resulting, among other things, in a night attack (fully described) on Merton Castle, somewhere in Co. Clare. Tarleton refusing to give up his friend is disowned by his father, and comes to live in a Dublin boarding house. There are good pictures of Dublin life, the amusing foibles of a peculiar section of the upper classes being well hit off. The Author gives his views on the various questions of the day. Shows how the Bar was injured by the prevalent jobbery. There are a good many incidents, but perhaps they scarcely rescue the book from being dull. By some this book is attributed to a W. $J$. McMaholl.

\section{4 - THE GAP OF BARNESMORE. Three Vols, each about 335 pp.} (LONDON). 1848.

" A tale of the Irish Highlands and the Revolution of 1688." Appeared without the Author's name. An attempt to portray without partisan bias the events of the time and the heroism of both sides in the Williamite Wars. The whole question at issue between the colonists and the native Irish is well discussed in a conversation between Father Meehan, representing the latter, and Captain Spencer, representing the former. Every word of it applies, as it was meant to apply, to modern times.

\section{5- CHAPTERS OF COLLEGE ROMANCE. Pp. 344. (LoNdon). 1863.}

A reprint of stories that first appeared in the Dublin UnIversiry MAGazine, some of them as far back as 1834. The purpose and character of these stories is well described in Preface:- "When I say that these pages are the romance of truth, I mean that they are true. .... I am very sure that if I succeed in simply bringing before the reader's eyes the life and the death of many whom I myself remember, gay and light-hearted .... I shall have done something towards impressing on his mind the lesson, "remember thy Creator." He itells us also, "I was much, very much, longer an inmate of Alma Miater than falls to the average of her sons." Five Stories, tragic for the most part, viz. I. "The Billiard Table" (ruinous results of gambling.) II. "Reading for Honours" (a harrowing story of the fatal results of jealousy). III. "The Mariner's Son." IV. "The Murdered Fellow; an incident of 1734." V. "The Sizar," "a story of a young heart broken in the struggle for distinction." 
BUTT, Isaac-(continued).

296- CHILDREN OF SORROW.

An obituary notice in, I think the IRISH Tmies, describes this as Butt's first essay in fiction, but the book is not in the British Museum Library, and I have been unable to trace it.

\section{BUXTON, E. M. Wilmot-, see WILMOT-BUXTON.}

[BYRNE, E. J.]. Author of Without a God.

297- AN IRISH LOVER. Pp. 271. (Kegan Paul). 6s. 1914.

A melodrama full of plot and murder and hair-breadth escape, in which the hero wins his way to the heroine through unheard of perils from swindlers, assassins, jealous rivals, and all the other dramatis personce of melodrama. Yet the hero and heroine start with a peaceful youth in Tipperary as members of the small farmer class. Parents oppose the match, and the hero goes to Dublin, where he falls into the hands of a gang of desperadoes. Then the scene shifts to America, to return to Ireland only for the wedding bells of the close. The Irish peasant at home is appreciatively described, his intense spirit of faith being dwelt on.

\section{BYRNE (Frank).}

298- AN IRISH STEW. Pp. 63. (London: The St. Catherine Press). $1 s$. 1916.

Six short stories about Irish people, unpretentious and amusingly told. The Author makes as much as possible of the Irish brogue and Irish peculiarities, even to the point of exaggeration. But the tales are wholesome reading. The character of the priest in "Father McNulty's Temptation" is sympathetically drawn.

CADDELL, Cecilia Mary. Of an old Catholic family that through times of persecution clung to the faith and at the same time retained the family estates. Her father was Richard O'Farrel Caddell, of Harbourstown, Co. Meath; her mother, Pauline, was sister of Viscount Soutnwell. Though. Miss Caddell suffered much from bad health she contributed to many Catholic periodicals. As a rule her writings were devoted to the illustration of Irish history and the Catholic faith. She died in 1877, at the age of 64. She wrote also: Wild Times, Marie; or, the Workwoman of Liège; Lost Geneviève; The Miner's Daughter; Flowers \& Fruit; most of which are still in print. (Duffy).

299 NELLIE NETTERVILLE; or, One of the Transplanted. (N.Y.: Catholic Publication Co.). 1878. Burns \& Oates. [1867].

" A tale of Ireland in the time of Cromwell.".

300-BLIND AGNES; or, Little Spouse of the B. Sacrament. (Duffy). 2nd ed. 1856. 5th edition, 1873. Translated into French and Italian. Still in print. 1s. 6 d.

A church in Niaples: a blind beggar girl rapt in prayer before the B. Sacrament: Lady Oranmore, a Protestant from Ireland, enters, and is interested in the sight. Discovers that Blind Agnes is her grand-daughter. Agnes brought to Ireland; meets Squire Netterville while out priest-hunting. $\mathrm{He}$, the youngest of threo brothers, became a Protestant and got the estates of the eldest, Agnes' father. The second ibrother, Father Netterville, is surprised by the priest-hunters. He saves the pervert from the fury of the Catholios, but is himself murdered by the Cromwellians. The Squire returns to the true faith, restores the ill-gotten estates, enters a monastery; Lady Oranmore becomes a Catholic; Agnes dies young on the Feast of the S. Heart. The little tale has been translated into Flemish by a Premonstratensian monk of the Abbey of Tongerloo.

There was, as a fact, a Father Robert Netterville, S.J., who was beaten to death by the Puritans. 
CALLWELL, J. M. Mrs. Callwell, a member of the famous family, the Martins of Ross, Galway, is a frequent contributor to BLACKwocd's Magazine, and Author of Old Irish Life, 1912.

301- A LITTLE IRISH GIRL. Pp. 240. (Blackie). 2s. 6d. Four good pictures by Harold Copping. (N.Y.: Pratt). 1.25. 1908.

Scene: West of Ireland. The doings and adventures of a lot of very natural and "human" children, particularly the bright, wild little heroine, and Manus, a typical English-reared schoolboy. Peasants seen in relation to better class, but treated with sympathy and understanding. No moralising.

\section{CAMERON, Rev. Alexander.}

302 RELIQUIAE CELTICAE. 2 vols. (Inverness). 1894.

"Texts, papens, and studies in Gaelic literature and philology left by the late Rev. Alex. Cameron, ed. by Alex. MacBain and Rev. John Kennedy." Vol. I. is a complete corpus of Ossianic poetry in Gaelic. Vol. II. contains "Deirdre and the Sons of Usnach" (Pp. 420-474) in Gaelic and English. Text. of Edinb. MSS. 56 and 53.

CAMPBELL, Frances. A county Antrim woman, Author of For Three Moons, Dearlove, $A$ Shepherd of the Stars, etc.

303 LOVE, THE ATONEMENT. Pp. 345. (Digby, Long). 6s. Second edition. 1902.

A very pretty and highly idealized little romance of marriage, with a serious lesson of life somewhere in the background all the while. It opens-and closes-in an old baronial mansion somewhere in the West of Ireland, but the chief part of the action passes amid vice-regal society in Australia. Two quaint Australian children furnish delightful interludes.

CAMPBELL, J. [Iain] F., of islay.

304 POPULAR TALES OF THE WEST HIGHLANDS. Four Vols., containing in all cxxxi+1743 pp. (PAISLEY : Gardner). [1861]. New edition, an exact reprint of first, 1890 . Handsome binding.

Ranks among the world's greatest collection of folk-lore. Of great scientific value to the folk-lorist, for each tale is "given as it was gathered in the rough." (Preface). Moreover, the table of contents gives, besides title of story, name of teller and of collector, date and place of telling. Most, if not all of the stories are in origin Irish. The Gaelic text is given along with translation. Exceptionally interesting Introduction-untechnical, pleasantly written, and full of curious information. See fine review in Dufry's Hibernian Magazine, 1862, pp. 317-328.

CAMPBELL; J. F.

305- THE CELTIC DRAGON MYTH. Pp. li. + 172. (EDINBurgh: Grant). 6s. net. Good illustr. in colour by Miss R. A. Grant-Duff. 1911.

The Author sets down the whole Celtic Dragon legend-perhaps the most important and widespread of myths, and the basis of the state-myth of England, Russia, and Japan-in English, on the authority of many oral sources accessible between 1862 and 1884. To this is here added "The Geste of Fraoch and the Dragon " in Gaelic, with translation by G. Henderson, I ecturer in Ceitic at Glasgow University. Also Gaelic text of "The Three Ways," and "The Fisherman." Introduction, 40 pp., and Notes. Full of Irish names, references, and incidents. The English of the translation is simple and pleasant. The whole book is very well turned out. 


\section{CAMPBELL, John Gregorson, of Tiree.}

306- THE FIANS. Pp. xxxviii. + 292. (Nutt). 7s. 6d. net. One illustr., by E. Griset. 1891.

Introduction by A. Nutt treats of nature and antiquity of Gaelic folk-tales, theories about the Fenian cycle, and the classification of texts composing it, and makes some interesting remarks about its value and import. His notes at the end chiefly consist of references to D'Arbois de Jubainville's List of Irish Sources, and to Campbell of Islay's Leabhar ne Feinne. The book collects a mass of floating and fragmentary tradition about the Fians. Sources entirely oral, many of the narrators knowing no word of English. Through the greater part of the book the collector gives the substance of what he heard, but he gives also verbatim in Gaelic, with an English translation, many tales, poems, ballads. Nature-myth, God-nyth, folk-fancy and hero tales, prose and poetry, are mingled. Naturally the quality varies a good deal. Some of the tales are extravagant and even silly. Many are so corrupted in oral transmission as no longer to be intelligible. Some are very archaic, some modern. A few are noble heroic legends in verse, but the literal prose translation makes them somewhat obscure. Index.

CAMPION, Dr. J. T., "The Kilkenny Man." Born in Kilkenny, 1814, where he afterwards practised as a doctor. Contributed much verse and some prose stories to National papers, such as The Nation, United Irishyan, The Irish Felon, Irish People, Shamrock, \&c. Publ. also Traces of the C'rusaders in Ireland.

307- ALICE. Pp. 126. 12mo. (KILkenNy: Coyle Bros.). 1862. "A historical romance of the Crusaders in Ireland" (sub-title).

A simple little love-story, pleasantly told, but slight. Scene: Kilkenny city in the early fourteenth century. There are descriptions of the dress, manners and customs of the period, but these are not tedious and do not overload the tale. Describes a horse-race run by the Knights of St. John of Jerusalem, the preaching of the Crusaders at the market cross, and the plague. Introduces Friar Clynn, the annalist, who died in 1328. The Author's sympathies are Irish-Gaelic and Catholic.

308- THE LAST STRUGGLES OF THE IRISH SEA SMUGGLERS. Pp. 119. (GLaSGOW: C'ameron di F'erguson). 1869.

Scene: Wicklow coast, around Bray head, "about 50 years ago." Struggles between smugglers and Government officials, with a love interest, and a moral. Has the elements of a very good story, but is long drawn ont, and is told in a turgid style repugnant to modem taste.

309_- MICHAEL DWYER, THE INSURGENT CAPTAIN. Pp. 128 (Gill).

1s. $6 d$. Very cheap paper and print. n.d.

A reprint of a book first published many years ago. An account of the life, exploits, and death of a Wicklow outlaw, 1798-1805. The anecdotes are for the most part given as handed down among the Wicklow peasantry. They are not arranged in any special order. Many of them are so wonderful as to be scarcely credible, yet most of them are, in the main, well authenticated. The style is turgid and highflown to the verge of absurdity.

CANNING, Hon. Albert Stratford George. B. 1832, Second son of the First Baron Garvagh. Resided for the most part in Rostrevor, Co. Down, where he died in April, 1916. Wrote a long series of some thirty critical, philosophical and historical works, including two Irish historical sketches, written from a thoroughly Unionist and Protestant standpoint, viz.: T'be Divided Irish and Revolted Ireland (1886). He owned about 4,000 acres, and was D.L. for Counties Down and Derry.

310- KILSORRELL CASTLE; an Irish story. 2 vols. (Chapman \& Hall). 1863.

Scene: neighbourhood of Carlingford Lough. Plot turns on murder of two men. 
CANNING, Hon. Albert Stratford George-(continued).

including Lord K.'s illegitimate son by a villain, to whom the people show sympathy. Many of the personages of the tale are drunkards. There seems to be no moral purpose in the book. No politics. Plot rambling and hard to follow.

\section{1 -KINKORA; an Irish story. 2 vols. (Chapman d IIall). 1864.}

Many of the incidents, says the Author, are perfectly true. One of the main incidents is an attack on a gentleman, Vincent Lorton, bastard son of Lord Delamont, on a public road, all present approving, and the assassins having no need to use any concealment. Period: towards the close of 1798 , the opening scene being the execution of two rebels at Mullahone. Both Lorton and Lady Delamont appear after their deaths.

312- BALDEARG O'DONNELL: a Tale of 1690. Two Vols. (Marcus Ward). 1881.

This O'Donnell was for a short time an independent, half-guerilla, leader on the Irish side. Afterwards, on the promise of a pension, he deserted to the English. "He had the shallowness, the arrogance, the presumption, the want of sincerity and patriotism of too many Irish chiefs"--(D'Alton: History of Ireland).

313- HEIR AND NO HEIR. Pp. 271. (Eden Remington). 5s. 1890.

The scene opens in Dalragh (Garvagh, Co. Derry), shifts to London and back again. Time: the eve of the outbreak of '98. The people, with their sharply divided religious and political opinions are well described, and the Northern accent and idiom ring true. Two priests, Father O'Connor and his curate, O'Mahony, the one imbued with loyalist principles, the other leaning towards the United Irishmen, are naturally and sympathetically drawn. The plot is founded on the well-known story of the disinheritance of George Canning, the father of the Prime Minister, here called Randolph Stratford, a good-hearted and popular scapegrace, easily led astray. It is a pleasant, healthy, and well told tale.

\section{CANNON, Frances E.}

314- IERNE O'NEAL. Pp. 446. (Whitcomb o Tombs). 3s. 6r. net. 1911.

A long, gentle, and pleasing tale of an Irish girl of good family, from her childhood with her grandfather in Ireland to her life in London society (including a little turn as factory girl) and her marriage.-(Times Lit. Scrpl.).

"CARBERY, Ethna"; Anna MacManus. Mrs. MacManus, wife of Seumas MacManus, was a Miss Johnston. She was born in Ballymena, Co. Antrim, in 1866. Her early death in 1902 robbed her triends of a most lovable personality, and Ireland of one of the most promising of her poets. Her poems in The Four Winds of Erinn are full of passionate love of Ireland. A short notice of her life will be found prefixed to the volume just mentioned.

\section{5- THE PASSIONATE HEARTS. Pp. 128. (Gill). 2s. 1903.}

Studies of the heart, tender, passionate, and sincere, told in language of refined beauty. No one else has written, or perhaps ever will write, like this, of pure love in the heart of a pure peasant girl. These are prose poems, as perfect in artistic construction as a sonnet. They are full too of the love of nature, as seen in the glens and coasts of Donegal. They are all intensely sad, but without morbidness and pessimism.

316- IN THE CELTIC PAST. Pp. 120. (Gill). 1904.

Contents: "The Sorrowing of Conal Cearuach"; "The Travelling Scholars"; "Pursuit of Diarmuid and Grainne"; "The Death of Diarmuid O Duibhne", ; "The Shearing of the Fairy Fleeces"; "How Oisin Convinced Patric the Cleric,", \&c. Told in refined and poetic language. Appeared originally in the SHAN VAN Vochr. 
CARLetON, William, Born in Prillisk, Clogher, Co. Tyrone, 1794. His father, a tenant farmer, who supported fourteen children on as many acres, was remarkable for his extraordinary memory, and had a thorough acquaintance with Irish folk-lore. The family was bilingual. Carleton was chiefly educated at hedgeschools, and at a small classical school at Donagh (Co. Monaghan). Somewhere about 1814 Carleton made the Lough Derg Pilgrimage, afterwards described in a story with that title, written for the CHRistian Examiner. About the same period he seems to have gradually abandoned the profession of Catholicism, and subsequently he became a Protestant, but for the most part of his life he was indifferent to all forms of religion. After many vicissitudes he came to Dublin, where he had very varied and painful experiences in the effort to make a living. He wrote for the Christian Examiner, the Family Magazine, the Dublin University Magazine, \&c. He also wrote for the Nation, though, as Mr. O'Donoghue says, "Carleton never was a Nationalist, and was quite incapable of adopting the principles of the Young Irelanders." What he wrote from the Nationalist standpoint was written through the need of earning his bread. For, though famous long before his death, he never freed himself from money troubles. Died 1869. See D. J. O'Donoghue's Life of Carleton, two vols., which includes Carleton's Autobiography.

317- FATHER BUTLER AND THE LOUGH DERG PILGRIM: Sketches of Irish Manners. Pp. 302. (Curry) 1829.

Published anonymously. Two of Carleton's most virulent anti-Catholic writings. The second, in particular, cnntains passages which, for Catholics, are blasphemous.

318_ THE POOR SCHOLAR; and other Tales. Pp. 252. (Duffy). 1s. Still in print. [1830].

Selections, comprising some of Carleton's best work, and quite free from religious and political rancour. The Poor Scholar is full of human interest. Carleton works powerfully upon all our best feelings in turn. Particularly touching is his picture of the depth and tenderness of family affections (he was himself a doting father). The pictures of the hedge-schoolmaster's brutalities, and of the days of the pestilence are vivid. $\mathrm{He}$ is in this story altogether on the side of the perasant. This little volume contains also eight other stories, humorous for the most part, all excellent.

319_ TALES OF IRELAND. (DUBL.). Illustr. by Brooke. [1834].

Contains " The Death of a Devotee"; “The Priest's Funeral" "Lachlin Murray and the Blessed Candle"; "Neal Malone"; "The Illicit Distiller"; "The Brothers"; "The Dream of a Broken Heart." This last has been described as one of the purest and noblest stories in our literature; but the remainder are among Carleton's feeblest efforts, and are full of rank bigotry. - They appeared originally in the pages of the Christian Examiner.

320_ FARDOROUGHA THE MISER. Pp. 280. (Downey). [1839]. n.d. (N.Y.: Haverty). 0.50 .

Prefaces by the Author and by D. J. O'Donoghue. A powerful novel, full of strong character study, and of deep and tragic pathos, relieved by humorous scenes. Carleton tells us that all the characters save one are drawn from originals well known to himself. The original of the miser's wife, a perfect type of the Catholic Irish mother, was his own mother. Una O'Brien is one of the loveliest of Carleton's heroines. Honor O'Donovan is scarcely less admirable. The mental struggles of the miser, torn between the love of his son and the love of his money, are finely depicted.

321- THE FAWN OF SPRINGVALE; or, Jane Sinclair; THE CLARIONET, AND OTHER TALES. Two vols. 1841. See infra. No. 330.

Includes "Lha Dhu" and "The Dead Boxer." " Jane Sinclair" and "The Dark Day" ("Lha Dhu") were publ. in separate vol. from 1849, the remaining two, with "Barney Branagan," in 1850. The last contains some splendid comic scenes, but ends tamely. 
CARLETON, William-(continued).

\section{2 - PADDY GO EASY AND HIS WIFE NANCY. (Duffy). 1s. [1845].}

Still reprinted.

Racy sketch of humorous and good-natured but lazy, thriftless, good-for-nothing Irishman, drawn with much humour, and with the faithfulness of a keen observer. But the book leaves on the reader the absurd impression that this character is typical of the average peasant. The story is a prototype of the famous Adventurcs of Mick M'Quaid. The main title of this book was originally Parra Sastha.

323 - VALENTINE M'CLUTCHY, or, Chronicles of the Castlecumber Property. $(D u f f y) .2 s . \quad[1845]$. Numerous editions since. Still reprinted. (N.Y.: Sadleir). 1.50.

A detailed study of the character and career of an Irish land agent of the worst type. It puts the reader on intimate terms with the prejudices, feelings, aims and manners of the Orangemen of the day, and bitterly satirizes them. It gives vivid pictures of both Anglican and Dissenting proselytising efforts. Written from a strongly n'ational and even Catholic stadpoint. Contains several remarkable character studies. There is Solomon M'Slime, "the religious attorney," sanctimonious, canting, hypocritical; Darby O'Drive, M'Clutchy's ruffianly bailiff, a converted Papist; the Rev. Mr. Lucre, a very superior absentee clergyman of the Establishment, and an ardent proselytiser; the old priest, Father Roche, very sympathetically drawn. The bias throughout is very strong and undisguised. There are some grotesquely and irresistibly comic scenes, but there are also fine scenes of tragic interest. "Nothing in literature," says Mr. O'Donoghue, "could be more terrible than some of the scenes in this book." $\mathrm{He}$ calls it "one of Carleton's most amazing efforts." Of the book as a whole Mr. Krans says : "It is one of the most daring pictures of Irish country life ever executed." And Mr. G. Barnett Smith speaks of the eviction scelle as "unexampled for its sadness and pathos."

N.B.-A French version, under the title Chroniques de Château Cumber, appeared in L'UNIVERS in 1845.

324 RODY THE ROVER. (Duffy). 1s. [1845]. Still in print.

Study of the origin of Ribbonism, and of its effects upon a countryside. The hero is an emissary of the Society. The latter is represented as organised and worked by a set of self-interested rascals who deluded the peasantry with hopes of removing grievances, whilst they themselves pursued their personal ends, and were often at the same time in the pay of the Castle. The Government spy system is denounced.

324A- TALES AND STORIES OF THE IRISH PEASANTRY. See infra. No. 332.

325— DENIS O'SHAUGHNESSY GOING TO MAYNOOTH. 12mo. Pp. 200. (Routledge). Illustr. by W. H. Brooke. [1845].

The career of Denis from the moment when, in tender years, he is marked out for the priesthood to the moment when he sets out for Maynooth. The Author, as often, is divided between a desire to be true to the life and a desire to be humorous and satirical, and to poke fun at the priests. At times the latter desire gets the upper hand. But there is no bitter hostility, and there is plenty of genuine fun. In fact the whole is a strange 'blend of fun and pathos. Examples of the latter are Denis's parting with Susan Connor and his farewell to his family. "There is no people," says C., "bound up so strongly in each other by the ties of domestic life as the Irish."

326- ART MAGUIRE. (Duffy). 1s. [1845, mo. Pp. 252]. Still reprinted. (N.Y.: Sadleir). 0.15.

The story of a man ruined by drink. Conventional and obviously written for a 


\section{CARLETON, William-(continued).}

purpose, yet enlivened by scenes of humour and pathos, written in Carleton's best vein. Dedicated in very flattering terms to Father Theobald Mathew, and irreproachable from a Catholic point of view. Indidentally there is an interesting picture of one of Father Mathew's meetings. Father Mathew himself thought highly of the book.

\section{7- THE BLACK PROPHET. Pp. 408. (Laurence \& Bullen). [1847].} Introd. by D. J. O'Donoghue, and Illustr. by J. B. Yeats. 1899. (N.Y..: Sadleir). 1.50.

The plot centres in a rural murder mystery, but there are many threads in the narrative. As a back-ground there is the Famine and typhus-plague of 1817, described with appalling power and realism. Of this the Author himself was a witness, and he assures us that he has in no wise exaggerated the horrors. All through there are passages of true and heart-rending pathos, lit up by the humorous passages of arms between Jemmy Branigan and his master, the middleman, Dick o' the Grange. Many peculiar types of that day appear: Skinadre the rural miser, Donnell Dhu the Prophecyman. There is not a word in the book that could hurt Catholic or national feeling. One of the most powerful Irish novels ever written.

328- THE EMIGRANTS OF AHADARRA. [1847]. (Routledge). 1s. (N.Y.: Sadleir). 1.50.

A story of rural life, depicting with much beauty and pathos the sadness of emigration. The book is first and foremost a love story, and has no didactic object. It contains one of Carleton's most exquisite portraits of an Irish peasant girl. The struggle between her love and her stern and uncompromising zeal for the faith is finely drawn. O'Finigan, with his half-tipsy grandiloquence, is also cleverly done. A kindly spirit pervades the book, and it is almost entirely free from the bad taste, coarseness, and rancour which show themselves at times in Carleton.

\section{9 _ THE TTTHE-PROCTOR. (Belfast : Simms \& M'Intyre). [1849].}

Founded on real events, the murder of the Bolands, a terrible agrarian crime. Written in a mood of savage resentment against his countrymen. D. J. O'Donoghue says of this book: "It is a vicious picture of the worst passions of the people, a rancorous description of the just war of the peasantry against tithes, and some of the vilest types of the race are there held up to odium, not as rare instances of villainy, but as specimens of humanity quite commonly to be met with." Yet there are good portraits and good scenes. Among the former are Mogue Moylan, the cannie Soogah, Dare-devil O'Driscoll, Buck English, and the Proctor himself. The latter, hated of the people, is painted in dark colours. "As a study of villainy," says Mr. O'Donoghue. "the book is convincing. There is one touching and fine scene-that in which the priest stealthily carries a sack of oats to the starving Protestant Minister and his family." "As a study of Irish life," says Mr. O'Donoghue again, "even in the anti-tithe war time it is a perversion of facts, and a grotesque accumulation of melodramatic horrors."

330 JANE SINCLAIR; or, The Fawn of Springvale. [1849].

A melancholy story of middle-class life, with many truthful touches, but overcharged with a sentiment that to modern taste appears somewhat strained and somewhat insipid. Contains a highly eulogistic portrait of a dissenting minister, John Sinclair-Calvinistic, didactic, ibut warm-hearted and truly charitable.

331- TALES AND SKETCHES OF IRISH LIFE AND CHARACTER. (DUBLIN). Plates by Phiz. 1845. This is the original 1s. edition of the following and Amusing Irish Tales, infra.

332_ TALES AND STORIES OF THE IRISH PEASANTRY. 1851.

Is as good as the Traits, and has, moreover, little that is objectionable. Contains, besidies the stories in the Irish Penny Journal: "The Fate of Frank 
CARLETON, William-(continued).

McKenna"; "A Legend of Knockmany"; "Talbot and Gaynor, the Irish Pipers"; Moll Roe's Marriage"; "The Three Wishes "; "Condy Cullen; or, The Irish Rake"; "A Record of the Heart"; "Stories of Second Sight"; "Buckram Back."' Favourably reviewed by Davis in the Nation.

333 - THE SQUANDERS OF CASTLE SQUANDER. [1852]. 'Two Vols. Pp. $326+311$. Illustr.

An attempt to present the life of the gentry, a task for which Carleton was imperfectly qualified. "It reminds one," says Mr. O'Donoghue, " at a superficial examination, of Lever, but is far inferior to any of that writer's works. It is full of rancour and rage, and makes painful and exasperating reading: the best that can be said for it is that there are pages here and there not unworthy of the Author's better self. The latter part of the book is an acrid political argument." There is an amusing story of a trick played upon a gauger.

333A — RED HALL; or, The Baronet's Daughter. 3 vols. (LoND.) [1852]. See No. 335.

\section{4- WILLY REILLY AND HIS DEAR COLLEEN BAWN. (Duffy). 2s.} [1855]. 1908.

Introduction by E. A. Baker, M.A., LL.D., who included this in his series, "Half-Forgotten Books." (Routledge). 2s. 1904. A glimpse of the Penal Days. The most popular of Carleton's works, having passed through more than fifty large editions. A pleasant, readable, romantic melodrama, founded on the famous ballad, "Now rise up, Willy Reilly," which refers to an episode of the Penal days, c. 1745-52. It is practically free from political and religrous bias, but is greatly inferior to his earlier works.

335_ THE BLACK BARONET; or, The Chronicles of Ballytrain. Pp. 476, close print. (Duffy). 2s. [1856]. Still reprinted.

A tragedy of upper-class society life, written with a high moral purpose. The interest lies chiefly in the intricate plot, which, however, is distinctly melodramatic. There is little attempt to portray the manners of the Society about which the book treats, and there is little character drawing. The tragedy is relieved by humorous scenes from peasant life. In the Preface the Author tells us that the circumstances related in the story really happened. Contains a touching picture of an evicted tenant, who leaves the hut in which his wife lies dead and his children feverstricken to seek subsistence by a life of crime. "There is nothing," says G. Barnett Smith in The XIXTH Century (Author of notice of C. in D.N.B.), "more dramatic in the whole of Carleton's works than the closing scene of this novel." And he rates it very high.

N.B.-This is Red Hall (No. 333A) under another name, and somewhat revised.

335A- ALLEY SHERIDAN; or, the Runaway Marriage, and other Stories (Dublin). 1857.

Reprinted from the National Magazine of 1830.

336 - THE EVIL EYE; or, the Black Spiectre. (Duffy). reprinted. Illustr. by Edmund Fitzpatrick, A.R.H.A.

2.s. [1860]. Still

"Probably the weakest of his works." "Perilousiy near the ridiculous in style and plot." (O'Donoghue). It appeared in Paris in 1865, under the title $L^{\prime}($ Eil Mauvais, ou Le Spectre Noir.

337 REDMOND O'HANLON. reprinted.

The exploits of a daring Rapparee. A fine subject feebly treated. From National point of view the book is not inspiring. Very slight plot, consisting mainly in 


\section{CARLETON, William-(continued).}

the rescue by O'Hanlon of a girl who has been abducted. Moral tone good. An appendix (32 pages) by T. C. Luby gives the historical facts connected with the hero.

337 - THE DOUBLE PROPHECY; or, Trials of the Heart. 2 vols. (DUBLIN). 1862.

Appeared first in the Irish American, of N.Y., then in Duffy's Hibernian MAG. Contains an episode of seduction, delicately dealt with.

338 THE SLLVER ACRE, and Other Tales. Pp. 238. (Ward, Lock). 18. 1362.

Three tales in all. (1) "The Silver Acre" is the story of John Hogan, clever, but given to drink, who goes to the bad in Dublin. He returns just as his fiancée, Ellen Connor, is at the last gasp. She recovers, he reforms, and they are married. (2) "The Fair of Emyvale"; (3) "Master and Scholar." Not up to level of C.'s best work. Nothing anti-Catholic.

\section{A- THE FAIR OF EMYVALE-MASTER AND SCHOLAR. (LDND.)} 1870.

339 - AMUSING IRISH TALES. Two Series in One. 4th ed. $256 \mathrm{pp}$. (Hamilton Adams). 1st Series, 1889. 2nd Series, 1890.

Not to be confounded with Traits and Stories of the Irish Peasantry, by the same Author. This is an entirely different work. Contains: "Buckram Back, the Country Dancing Master"; "Mary Murray, the Irish Match-maker"; "Bob Pentland, the Irish Smuggler"; "Tom Gressley, the Irish Sennachie"; "Barney M'Haigney, the Irish Prophecy Man," and ten others.

\section{THE RED-HAIRED MAN'S WIFE. Pp. viii. + 274. (Sealy, Bryers).} 1889.

Exploits of one Leeam O'Connor, a notorious "lady-killer." One of the chief characters, Hugh O'Donnell, is implicated in the Fenian movement. Father Moran and Rev. Mr. Bayley, the priest and the rector, bosom friends, are finely portrayed. There are flashes here and there of Carleton's old powers. Mr. O'Donoghue (Life of Carleton, ii., p. 321) states that part of the original MS. was destroyed in a fire, and that the missing portions were supplied after Carleton's death by a Mr. MacDermott, and published, first in the Carlow College Magazine (1870), then in book form as above.

341 - TRAITS AND STORIES OF THE IRISH PEASANTRY. Many editions, e.g. (Routledge). One Vol. 3s. 6d. N.Y.: (Dutton). 1.50. (Ward Lock). 2 handsome vols. demy 8vo., " with the Author's last corrections, an introd., explanatory notes." Illustr. by Harvey, Gilbert, Phiz, Franklin, Macmanus, etc. Pp. $424+432$. Same contents as in Dent's ed.

Perhaps the best ed. is that edited in four volumes, $3 s .6 d$ net each, by D. J. O'Donoghue, and published in 1896 by Dent. Its special features are: handsome binding, print, and general get-up; reproduction of original illustrations by Phiz; portraits of Carleton; inclusion of Carleton's Introduction; biography and critical introduction by Editor. The original edition first appeared in 1830-33. Contents : (1) "Ned M“Keown"; (2) "Three Tasks"; (3) "Shane Fadh's Wedding "; (4) "Larry M'Farland's Wake"; (5) "The Station"; (6) "An Essay on Irish Swearing"; (7) "The Battle of the Factions"; (8) "The Midnight Mass"; (9) "The Party Fight and Funeral"; (10) "The Hedge School"; (11) "The Lough Derg Pilgrim"; (12) "The Donagh, or the Horse Stealers"; (13) "Phil Purcel, the Pig Driver"; (14) "The Leanhan Shee"; (15) "The Geography of an Irish Oath"; (16) "The Poor Scholar"; (17) "Wildgoose Lodge"; (18) "Tubber Derg "; (19) "Denis O'Shaughnessy going to Maynooth"; (20) "Phelim O'Toole's Courtship"; (21) "Neal Malone." 


\section{CARLETON, William:-(continued).}

This work constitutes the completest and most authentic picture ever given to us of the life of the peasantry in the first quarter of the last century. It is the more interesting in that it depicts an Ireland wholly different from the Ireland of our days, a state of things that has quite passed away. Speaking of the Traits, Mr. D. J. O'Donoghue says that, "taken as a whole, there is nothing in Irish literature within reasonable distance of them for completeness, variety, characterdrawing, humour, pathos, and dramatic power." And most Irishmen would be at one with him. About the absolute life-like reality of his peasants there can be no doubt. But reserves must be made as to his faimess and impartiality. To the edition of 1854 he prefixed an introduction, in which he states his intention "to aid in removing many absurd prejudices ... against his countrymen," and in particular the conception of the "stage Irishman." He then enters into a vindication and a eulogy of the national character which is fully in accord with national sentiment. But many of the stories were originally written for a violently antinational and anti-Catholic periodical. Some of the Traits were consequently marred by offensive passages, some of which the Author himself afterwards regretted. $\mathrm{He}$ frequently betrays the rancour he felt against the religion which he had abandoned. The Catholic clergy in particular he never treated fairly, and in some of the Traits ridicule is showered upon them, e.g., in "The Station." Yiet in others, e.g., "The Poor Scholar," things are treated with perfect propriety. In 1846 Thomas Davis wrote for the NATION a very appreciative article on Carleton. The illustrations by Phiz are very clever, but many of them are simply caricatures of the Irish peasantry.

A German translation was publ. at Leipzig, 3 vols., 1837, under title: IV. Carleton's Skizzen und Erzahlungen aus dem Leben des ireschen Landvolks, aus dem Englischen von H. Roberts.

342- STORIES FROM CARLETON, with an Introduction by W. B. Yeats. Pp. xvii. + 302. (Walter Scott). 1s. n.d.

Contains: "The Poor Scholar"; "Tubber Derg"; "Wildgoose Lodge"; "Shane Fadh's Wedding"; "The Hedge School." Mr. Yeats says of Carleton: " $\mathrm{He}$ is the greatest novelist of Ireland, by right of the most Celtic eyes that ever. gazed from under the brows of estoryteller."

343_ CARLETON'S STORIES OF IRISH LIFE, with Introd. by Darrell Figgis, in Every Irishman's Library. (Talbot Press). 3.s. 6d. 1918.

344-ANNE COSGRAVE; or, the Chronicles of Silver Burn.

"A vigorous attempt to exhibit the manners and customs, and especially the religious feelings, of the Ulster people. Some of the chapters are very graphic, and there is no lack of Carleton's peculiar humour." (O'Donoghue). Carleton said of it himself: "Above all the characters in the book, that of Sam Coote, en old Presbyterian bachelor, who is a . . reasoner upon theology and the differerst creeds, is, for humour and benevolence, the best." A powerful, and even terrible, picture of the Northern Irish religious revivals is given.

N.B.-The novel has not yet been published.

\section{CARMICHAEL, Alexander.}

345 — DEIRDRE AND THE LAY OF THE CHILDREN OF UISNE. Pp. 146. (Gill, \&c.). 1905.

Orally collected in 1867 from the recital of John MacNeill (aged 83), of the Island of Barra. Scotch-Graelic and English on opposite pages. Differs from the average Irish version in numerous details. 


\section{CARNOT (Dom Maurus), O.S.B.}

346_- A PILGRIM FROM IRELAND. Pp. 132 . (Benziger). 45c. 1 illustr.

Translated by Mary E. Mannix. The story, told chiefly for children, of the adventures of an early Irish missionary in Rhaetia, near the source of the Rhine. Charmingly told, with a certain quaintness and a direct simplicity and realism.

\section{CARROLL, Rev. P. J.}

347- ROUND ABOUT HOME: Irish Scenes and Memories. Pp. 234. (U.S.A.: Notre Dame, Ind.). 1.00. 1915.

Idylls of Irish country life (West Limerick), told with simplicity and genuine sympathy, in language charged with feeling, and often of much beauty. Memory has no doubt cast a golden haze over the scenes and persons, idealizing them somewhat, yet they are very real for all that. They are nearly all in the form of stories, and are told with zest. Some are sad enough, but with a sadness that is softened by the kindly genial spirit of the teller. The writer is, of course, in complete sympathy wilh tle people. Many queer types (Micky the Fenian, the bell-man, Mad Matt the tramp, the polite beggar, the believer in ghosts, \&c.) are studied in these sketches. There is not one of the twenty-six sketches that is not in its way a masterpiece."-(C.B.N.).

CASEY, W. F., Author of Haphazard.

348_ ZOE : a Portrait. Pp. 376. (Herbert \& Daniel). 6s. 1911.

A study from life of an exceedingly unpleasant Dublin girl, an inveterate society flirt. The plot is chiefly concerned with her treatment of her various suitors, including a loveless marriage, contracted with one of them in order to spite another. Incidentally there are other clever character studies-Major Delaney, Barry Conway, Manrice Daly. Some are doubtless studies from life. Incidentally there is a clever and accurate picture of the Dublin middle-class, with its golf, its bridge and its theatres. The Author has written successful plays for the Abibey Theatre.-(Press Notices).

CASSIDY, Patrick Sarsfield. Born at Dunkineely, Co. Donegal, 1852. In 1869 or so he emigrated to America, where he became a journalist. He wrote also The Borrowed Bride: a Fairy Love Legend of Donegal. Pp. 255. (N.Y.: Holt). 1892. A long story in verse.

349 - GLENVEAGH; or, The Victims of Vengeance. (Boston). 1870.

First appeared in the Boston PILOT; afterwards in book form. Deals with the celebrated Glenveagh trials, arising from difficulties between landlord and tenant, at which the Author had been present in boyhood.

CAWLEY, Rev. Thomas, a priest of the diocese of Galway.

350— AN IRISH PARISH, ITS SUNSHINE AND SHADOWS. Pp. 189. (Boston: Angel Guardian Press). 1911.

Stories collected from magazines in which they first appeared (IRIsH RosakY, C.Y.M., IRISH PACKET). Giving pictures drawn with knowledge ${ }^{\circ}$ and skill, and considerable humour of local celelbrities and their political careers. Satirises the shady side of local politics, and depicts the ruin wrought by drink. But the moral is not too much obtruded.

351— LEADING LIGHTS ALL: a Contentious Volume. Pp. 129. (Galway: The Connaught Tribune). 6d. 1913.

Reprinted from An Irish Parish, q.v. 
[CHAIGNEAU, William], 1709-1781. Served in Flanders. Was afterwards an army agent in Dublin.

352- THE HISTORY OF JACK CONNOR. Two Vols. 12mo. (Dublin).

Plates. [1751]. 4th ed. 1766.

Dedicated to Lord Holland (then Henry Fox). A series of adventures of Jack Connor alias Conyers. Born 1720, son of a Williamite soldier. Though affecting to be on the side of morality, the writer describes minutely a long series of scandalous adventures in Dublin, Lo'ndon, Paris, \&c., of the hero. The intervals between these are filled up by disquisitions of various kinds, e.g., the schemes of benevolent landlords, \&c. Facetious tone affected throughout. No real description of contemporary manners or of politics. The foreword to this edition gives us to understand that the previous edition contained still more objectionable matter. Gives fairly accurately the average Protestant's views of priests and "popery" at the time.

CHARLES, Mrs. Rundle. Author of some sixteen stories, many of them, such as Joan the Maid, The Martyrs of Spain, etc., based on religious history.

353- ATTILA AND HIS CONQUERORS. Pp. 327. (S.P.C.K.). 2s. 1894.

Episodes of the imroad of the Huns and their contact with Christianity, chiefly in the person of St. Leo, from whose writings much of the matter is borrowed. Two young Irish converts of St. Patrick are carried off by British pirates. The story tells of their adventures on the Continent. St Patrick's historical Epistle to Coroticus is introduced. The story is somewhat in the conventional Sunday School manner, being obviously intended solely for the conveyance of moral instruction. Has no denominational bias.

\section{CHARLeVille (Christian).}

354-IN SPITE OF JEMTMA. Pp. 282. (G'ill). 3s. 6d. 1916.

Jemima is the step-sister of Col. Moorhead, the chief personage of the story. She is a sour, cantankerous, meddlesome person, well-intentioned enough and unconscious of her wrongheadedness. She has designs on the Colonel's property, and makes it her business to thwart his intended marriage and his other projects. But, in spite of her he succeeds in becoming a colonel, in adopting his niece Selma, in marrying the lady of his choice, and in doing many other good things. "The Blue Lily," whom the colonel marries in the end, Muriel Grange, his charming ward, Jemima's much-suffering husband Dick, and Pat Bracken are noteworthy characters in their way. There is a good deal of humour. The book is not without its faults, but it is full of kindly feeling, and is elevated in tone without being in any sense goodygoody. Several of the dramatis personae become converts to the Catholic Church. Ireland and things Irish are viewed in a favourable light.

\section{CHISHOLM, LOUEY.}

355- CELTTC TALES. Pp. 113. 12mo. (Jack). 1s. 6d. (N.Y.: Dutton). Eight coloured pictures by K. Cameron. [1905]. 1911, \&c.

In "Told to the Children" series. Three tales: "The Star-eyed Deirdre," "The Four White Swans," "Dermat and Grauna." Moderately well told.

"CHRistinA, S. M.," "Caple Yland," sister M. Christine Ronayne, a native of Youghal, long a member of the Community of Loreto Convent, Fermoy, Co. Cork. Her only published volume is the book noted below, but she wrote serials both in French and English for various periodicals, "Kilvara," "The Forbidden Flame," "A Modern Cinderella," "Sir Rupert's Wife," "A Steel 
"Christina, S. M."-(continued).

King " (all Irish in subject), "Yolanda," "A Royal Exile," “ Une gerbe de lis," "Mis à l'épreuve," are some of the titles. She was an enthusiast in the cause of a literature which, while genuinely Irish, should be also Catholic in spirit. D. at Fermoy Convent, Jan., 1917.

\section{L LORD CLANDONNELL. Pp. 166. (Washbourne). 2s. 1914.}

An ingenious and pious little story, pleasantly written, with abundance of incident (secret marriage, lost papers, rightful heir restored to his own in wonderful manner), and many characters. The scene shifts between Donegal, Italy, America, and Rostrevor. The Clandonnell family, in spite of the bigoted old Lord, is brought back into the Catholic Church.-(I.B.L. and C.B.N.).

\section{CHURCH, Samuel Harden.}

357- JOHN MARMADUKE. (Putnam). 6s. 0.50. [1889]. Fifth edition. 1898.

Opens 1649 at Arklow. Captain M., who tells the story, is an officer under the Cromwellian General Ireton. Closes shortly after massacre of Drogheda. The Author says in his Oliver Cromwell, a History (p. 487): "He (Cromwell) had overthrown a bloody rebellion in Ireland, and transformed the environment of that mad people into industry and peace." Elsewhere he speaks of Cromwell's " pure patriotism, his sacrifice to duty, his public wisdom, his endeavour for the right course in every difficulty." The novel is written in the spirit of the history, a panegyric of Cromwell. It is full of battles, sieges, and exciting adventures. The Author tells us that he "went to Ireland, traced again the line of the Cromwell Invasion, and gave some studious attention to the language and literature of the country." (Pref.). Anti-Catholic in tone.

\section{CLARK, Jackson C.}

358- KNOCKINSCREEN DAYS. Pp. 308. (Methuen). 6s. Illustr. 1913.

Episodes in a Lough Neagh-side village, conceived in a vein of broad comedy, in which Mr. Peter Carmichael, a young squire on the look-out for amusement and his irresponsible - and resourceful-friend Billy Devine are the chief characters. How the two of them defeated the Nationalist candidate for the dispensary, and how two members of the Force arrested the County Inspector on a charge of Sunday drinking. The local colour and the dialect are perfect, and the local types well sketchod.

\section{CLARKE, Mrs. Charles M.; "Miriam Drake," née Marion Doak.}

\section{9 - STRONG AS DEATH. Pp. 538. (ABerdeen: Moran). 6s.}

The scene is laid in Ulster: the personages are Irish Presbyterians. The Author's sympathies are with the rebels, but she does justice to the men on the loyalist side. The book contains many stirring adventures, but is far removed from mere sentationalism (Publ.).

CLERY, Arthur E.; "A. Synan." Born in Dublin, 1879. Educated at Clongowes Wood College and Catholic University School. Professor of Law in University College, N.U.I., since 1910. Author of The Idea of a Nation, and of some books on law. Usual pen-name "Chanel."

360_ THE COMING OF THE KING: a Jacobite Romance. Pp. $143 . \quad$ (C.T.S. of Ireland). 1s. Pretty binding. 1909.

Deals with an imaginary landing of James II. to head a rising in Ireland. Scene: first on shores of Bantry Bay, then in Celbridge. A plot to seize Dublin Castle, in which the King is aided by Swift, fails through divisions caused by sectarian hatred. A rapidly moving story, with many exciting situations. Though no elaborate picture of the time is attempted, innumerable small touches show the Author's thorough acquaintance with their history and literature. The style is pleasant, and the conversations seldom jar by being too modern in tone. 
COATES, H. J.

361_ THE WEIRD WOMAN OF THE WRAAGH; or, Burton and Le Moore. Four Vols. Pp. 1224. (London: Newman). 1830.

Wild adventures in 1783, sqq. The Wraagh is a cave near Baltinglass. The scene frequently shifts from one part of Ireland to another-Cork, Wicklow, Kilkenny, Cashel (historical sketch given), \&c. Kidnappings, hairbreadth escapes from robbers, a duel, love story of Walter (whose identity is long a mystery) with Lena Fitzgerald, and their final marriage. Several long stories are sandwiched in here and there. Tone quite patriotic. Well-written on the whole.

362_ LUCIUS CAREY; or, The Mysterious Female of Mora's Dell. Four Vols. Pp. 1007. (London: Newman). 1831.

Dedicated to O'Connell. Lucius goes over to England with his followers, fights in the Royalist cause, and finally returns to Ireland. Sympathies: Royalist and Irish. But the noble characters are for the most part English, some of the Irish characters being little better than buffoons. The book is full of Astrology. There are some interesting allusions to Irish heroic legend.

363 THE WATER QUEEN; or, The Mermaid of Loch Lene, and other Tales. Three Vols. (London: Newman). 1832.

A very romantic story of Killarney in the days of Elizabeth's wars with Hugh O'Neill. Sir Bertram Fitzroy, a gallant young Englishman, comes over with Essex, and is sent down to Killarney. He becomes friendly with the Irish, and falls in love with the "Mermaid" Eva, a young lady who chose this disguise for greater safety. She wins him to love Ireland. They are kept apart by the schemes of the villain O'Fergus, standard bearer to $O^{\prime} N$ Neill. But, after a scene of considerable dramatio power, in which O'Fergus is slain, they are united again. There are many adventures and much fighting. Killarney is well described. In sympathy with Ireland. No religious bias.

\section{COBRIM (JOe).}

364 THE KIDNAPPING OF SALLY LUNHAM. Pp. 178. (Duffy). $3 s 6 d$. 1916.

An adventure and three love affairs, involving, among others, Sally and three young men, Dick Park, Jack O'Rourke, and Matthew Maxwell, Sally and the two latter being from the North of Ireland. All takes place in Barcelona, where Sally is carried off (with a view to ransom) by a gang of high-class thieves. The story is quite a slight thing, but it is brightly told, the irresponsible, lively, and often slangy, talk of the dramatis personae being well reproduced. Matthew the sententious philosopher with the Armagh brogue is the only approach to a character study. There is much harmless sentimentality. No religious or political topic is touched upon.

COGAN, V. Rev. James Joseph, O.C.C.-B. Englishtown, Co. Wicklow. Ed. at Terenure Coll., University Coll., Dublin, and Rome. From 1900 to 1909 he worked in Australia as a Bush missioner, and there in 1901 he founded with Father Magennis the Stella Maris. Since 1909 he has lived in Ireland, and is at present Provincial of the Irish Province of his Order. Resides at the Carmelite Priory, Aungier St., Dublin. Old Irish Hearts and Homes was a great success in Australia, and has appeared in three continental languages.

365- OLD IRISH HEARTS AND HOMES : A Romance of Real Life. Pp. 271. (Mrlbourne: Linehan). 3s. [n.d.]. New edition, 1908.

A series of episodes, somewhat idealised by memory, from the annals of an Irish Catholic family of the well-to-do farmer class. The style is plain and unpretentious, but this is made up for by the evident faithfulness and the intrinsic interest of the 


\section{COGAN, V. Rev. James Joseph, O.C.C.-(continued).}

pictures. Old de Prendergast is admirably drawn. Brings out well how thoroughly penetrated with religious spirit many such families in. Ireland are. A sad little boyand-girl love story runs through the book. Scene: Dublin (election of Alderman well described) and west Wicklow.

COLLINS, Wilkie, the celebrated English novelist. B. in London 1824. D. 1889. Lived for a time in Italy, but does not seem to have had any first-hand knowledge of Ireland. Author of 'The Dead Secret, The Woman in White, The Moonstone, The New Magdalen, Legacy of Cain, etc. Blind Love, as we are told in the Pref. by Walter Besant, was Wilkie Collins's last novel. It was left by him unfinished, and was completed from the Author's notes by the editor.

365A-BLIND LOVE. 3 Vols. (Chatto of Windus). Pref. by Walter Besant, and illustr. by A. Forestier. 1890.

The central theme is the blind love of Iris Hadley for the worthless scapegrace Lord Harry Norland. Iris is a London girl who takes refuge from her father with her god-father, Sir C. Mordaunt, a banker, living at "Ardoon," in Kerry. She will not marry his son the devoted Hugh Mordaunt. Twice she saves Norland's life from murder by the Invincibles. A third time she saves him when he is on the point of suicide, and then marries him. He feigns death, and disappears, so as to get the insurance money with which to pay his debts. But soon he comes out of hiding and goes back to Ireland, to meet his death at the hands of the Invincibles, with whom he had been all along connected. The Irish background is faint.

COLLINS, William, 1838-1890, A Tyrone man who emigrated to Canada, and thence to U.S.A. Authnr of The IV ild Geese; Desmond; or, The Two Flags; Songs, Poems \& Ballads, etc.

\section{6- DALARADIA. (N.Y.: Kenedy). 36 cents. 1890.}

Opens summer A.D. 432 at Court of Milcho, chief of Dalaradia (Antrim), whose sons and daughters are the chief personages of the tale. Tells of Druidic plots against Mahon, Chief of 'Tirowen, to thwart his love, of Mahon's conversion, of the conversion by Patrick of Milcho's household, but not of Milcho himself, of Milcho's fate, of the coming of Patrick to Tara, ending with the nuptials of Mahon and Sybilla. Incidents largely founded on history and tradition. Dramatically told, with good descriptions of scenery and spirited dialogue.

\section{COLPOYS, Mrs.}

367- IRISH EXCURSION, THE; or, I Fear to Tell You. Four Vols. Pp. 1205.

(Dublin : Lane). 1801.

How Mrs. M'Gralahan and family came to London, and what they heard and saw and did there. The Irish are represented as dishonest, extravagant, and many other things, lbut all this and more is to be remedied by the great panacea-the Union-and the last of the four volumes closes with, "Bless the Beloved Monarch of the Union." "Full of political discussions and of lectures delivered to Ireland. What the Author "fears to tell" us is not clear.

COLTHURST, Miss E. "A Cork lady of marked poetical ability. She wrote also some prose works, such as The Irish Scripture Reader, The Little Ones of Innisfail, \&c. Most of her works were publ. anon. She was associated with the Rev. E. Nangle's mission to Achill " (D. J. O'Donoghue, Poets of Ireland).

368- TALES OF ERIN. Pp. 102. 2in. x 3in. (LoND.: Wright). n.d.

Contents: "Converts' Song," "Dennis Dunleavy," "The Kerry Cows," "The May Feast," "The Contented Irishman," “The Great Blasket," etc. Proselytising in purpose. 


\section{COLTHURST, Miss E.-(continued).}

369 IRRELAGH; or, The Last of the Chiefs. Pp. 448. (London: Houlston \& Stoneman). 1849.

Dedication dated from Danesfort, Killarney. Scene: Killanney. Time: towards the close of the 17th century, but there is no reference to historical events, and the tone and the atmosphere are quite modern. A Waldensian pastor comes to live in the family of the O'Donoghue, and converts that family and some of the neighbouring chieftains' families. A great deal of Protestant doctrine is introduced; Catholic doctrines (e.g., the Rosary, p. 49) are referred to with strong disapproval. There is a slight love interest and some vague descriptions of scenery. The style is somewhat turgid.

COLUM, Padralc. Born in Longford, 1881. Has published several plays, which have been acted with success in the Abbey Theatre and elsewhere; a volume of verse; and a very interesting social study of Ireland. My Irish Year.

370 - A BOY IN FIRINN. Pp. 255. (N.Y.: Dutton). Frontisp. in colour and four Illustr. by Jack B. Yeats. 1913. Now ed. (Dent), 1915.

Third volume in "Little Schoolmate Series." Adventures of peasant lad, Finn O'Donnell at home in the Midlands and on his way to Dublin by Tara in the time of the Land War. Charming pictures of the world as seen with the wondering eyes of a child. Finn learns Irish legend and history from stories told by his grandfather, by a priest, and others. The pictures of things seen and lived in Ireland are what one might expect from the Author of My Irish Year-Literal reality vividly but very simply presented. This boy is not idealised; he is very life-like and natural. The Author does not "write down" to children.

N.B. - In this case at least the reader would do well to take the book before the Preface, which latter is by the general editor of the series.

\section{COMYN, David.}

371— THE YOUTHFUL EXPLOITS OF FIONN. Pp. $122.16 \mathrm{mo}$. (Gill). [1881]. 1896.

Re-issued for the use of schools, with transl., under the auspices of the Gaelic Union. It is the text first publ. by O'Donovan (q.v.) for the Ossianic Soc., but with the addition of matter amounting to about one-third of the original, which D.C. transcribed from the Bodleian MS.

CONCANNON, Mrs. née Helena Walsh. Born in Maghera, Co. Derry, 1878. Educated there, and at Loreto College, St. Stephen's Green, Dublin; also at Berlin, Rome, and Paris. M.A. (R.U.I.) with Honours in Mod. Lit. Besides the story mentioned below, she has published $A$ Garden of Girls (Educational Co. of Ireland), and a Life of St. Columbanus which won against noteworthy competitors a prize offered by Dr. Shahan of the Catholic University of America. Has contributed to Catholic magazines. Resides in Galway. Her husband is prominently connected with the Gaelic League, and she herself reads and speaks Irish.

372- THE SORROW OF LYCADOON. 12mo. Pp. 150. (C.T.S.I.: Iona Series). 1s. 1912.

Story of the life and martiyrdom (1584) of Dermot O'Hurley and of the first mission of the Jesuits to Ireland. The Author has an "historic imagination" of exceptional vividness. The incidents and the colouring are both solidly based on historic fact. But erudition is mever allowed to obtrude itself on the reader. The characters are flesh and blood, and the story has a pathetic human interest of its own. It is told with much charm of style. 
CONDON, John A., O.S.A. Born in Dungarvan, Co. Waterford, in 1867. Educated locally at the Augustinian Seminary, and at Castleknock College. Became an Augustinian in 1883. Has studied in Rome and travelled in U.S.A. and Canada. He has resided in various parts of Treland-New Ross, Cork, Dublin. Has held positions of special trust in his Order.

373 - THE CRACKLING OF THORNS. Pp. 175. (Gill). 3s. 6d. Six Illustr. by M. Power O'Malley. 1915.

Ten stories of various types. The majority are of the high-class magazine type and very up-to-date in subject and treatment, but here and there one comes upon bits of real life observed at first hand, and pictured with genuine feeling. Severa. are Irish-American, and their interest turns on the sorrow and hardship of emigra. tion. The last, "By the Way," in which Sergeant Maguire, R.I.C., spins yarns is full of the most genuine Irish humour (dialect perfect), and is a fine piece of story-telling.

\section{CONRAYVILLE (Marie).}

374 THE ADVENTURES OF MAEVE. Pp. 196. (Browne \& Nolan). Illustr. by P. Hughes. n.d. (recent).

Maeve, a spoilt only child, comes from India into a large Irish family living nea Lough Foyle. She meets with every kindness, but owing to a childish quarrel sh sets out for India again. Geoff Brennan brings her back, and from thenceforth $i$ her fast friend. She goes to school in Derry. Then on her 17th birthday her fathe comes, as promised, to take her home. For children. Wuitten in very pleasan tone, with much appreciation of Ireland.

CONWAY, Katherine E. A well-known American Catholic writer. B. Rochester Ed. Academies of the S. Heart, Rochester and N.Y., and at St. Mary's Acad. Buffalo. Was first assistant ed. then managing ed. of the PILOT for man: years. Taught in St. Mary's College, Notre Dame, Ind. Awarded the Laetar medal by the University of Notre Dame and decorated by Pope Pius X., 1912.

375_L LALOR'S MAPLES. (U.S.A. : 'T'he Pilot Publishing Co.). 1.25. 1901

An American story, with many Irish-American characters-the Lalors themselves Raymond Fitzgerald, Father Byrne and others. Favourably reviewed in THE Av: Maria.

CONYERS, Dorothea. Born 1871. Daughter of Colonel J. Blood Smyth, Fedamore Co. Limerick. Has published, besides the works here mentioned, Recollection of Sport in Ireland, and Further Strayings of Sandy. Resides near Limerick It may be said of her books in general that they are humorous, lively storie of Irish sport, full of incident, with quick perception of the surfaces and broal outlines of character. Her dramatis personae are hunting people, garriso officers, horse dealers, and the peasantry seen more or less from their poin of view.

376- THE THORN BIT. Pp. 332. (Hutchinson). 6s. [1900]. New ed. 6d 1909.

An earlier effort, with the Author's qualities not yet developed. Society in small country town, days with the hounds, clever situations.

377__ PETER'S PEDIGREE. Pp. 326. (Arnold). 6s. [1904]. New ed. 28 1917.

One of the best of .her stories. Hunting, horse-dealing, and love-making in Co Cork.

378- AUNT JANE AND UNCLE JAMES. Pp. 342. (Hutchinson). [1908]. New ed. 7d. 1917.

A sequel to the last, with the same vivid descriptions of "runs" and "deals. A murder trial enters into the plot. 
CONYERS, Dorothea-(continued).

$379^{\circ}$ THE BOY, SOME HORSES AND A GIRL. Pp. 307 . (Arnold). 6s. [1908]. New ed. 2s. 1917.

Of the same type as the last, and scarcely inferior. Irish peasants and servants are described with much truth as well as humour. Full of glorious hunts and pleasant hunting people.

380- THREE GIRLS AND A HERMIT. Pp. 328. (Hutchinson). 6s. $1 \leqslant 08$. Life in small garrison town. Many droll situations.

381- THE CONVERSION OF CON CREGAN. Pp. 327. (Hutchinson). 6s. 1909.

Thirteen stories, dealing mostly with horses and hunting. Full of ihrewd wit and kindly humour. Shows a good knowledge of Irish life and character, and an understanding of the relationg between the classes. One of the stories is a novel in itself.

THE STRAYINGS OF SANDY. Pp. 362. (Hutchinson). 6s. and 1 s.

[1909]. Now in its 15th edition.

The externals of Irish country life as seen by a London business man on a holiday. Study of Irish character as seen chiefly in sporting types-needy, good-natured, spendthrift-as contrasted with the Englishman, wealthy, businesslike, and miserly. Contact with Irish life softens the Englishman's asperities. Full of genuinely humorous and amusing adventures of Sandy with race-horses and hounds, and other things. The brogue is not overdone, and we are not, on the whole, caricatured. Scene: West coast.

383_ TWO IMPOSTORS AND TINKER. Pp. 344. (Hutchinson). 6s. 1910.

One impostor is Derrick Bourke Herring who, under his namesake cousin's name, took up the Mullinboden hounds, and the other was his sister Jo who, in man's clothes, acted as whip. Tinker is a yellow mongrel who does many wonderful things in the course of the story. The main interest centres in the doings of these three, chiefly in the hunting field. A melodramatic element is introduced by the attempt of the father of the wealthy heiress Grania Hume to steal her jewels. Of course there are love affuirs also. A breezy story, with much lively interest and pleasant humour.

384- SOME HAPPENINGS OF GLENDALYNE. (Hutchinson). 6.8. 1911. Now ed. 7d. 1917.

Eve O'Neill is under the guardianship of The O'Neill, an eccentric, rapidly growing into a maniac. His mania is religious, he has a passion for horse-racing, and keeps the heir, Hugh $\mathrm{O}^{\prime}$ Neill (supposed to be dead) shut up in a deserted wing of the old mansion. Here the latter is accidentally discovered by Eve, and then there are thrilling adventures. Atmosphere throughout weird and terrifying in the manner of Lefanu. Peasantry little understood, and almost caricatured.(Press Notice).

385- THE ARRIVAL OF ANTONY. Pp. 348. (IIutchinson). 6s. 1912.

Anthony Doyle, brought up from childhood in Germany, and with the breeding of a gentleman, comes home to help his old uncle, a horse-dealer, living in an oldfashioned thatched farmhouse in a remote country district in Ireland. Tells of the wholly inexperienced Antony's adventures among horse-sharpers, of his devotion to his old uncle, and of the social barriers that for long keep him aloof from his own class and from his future wife. The backwardness and slovenliness of Irish life are a good deal exaggerated, but the story is very cleverly told, with a good deal of dry humour. The Author's satire is not hostile. 


\section{CONYERS, Dorothea-(continued).}

\section{6- SALLY. Pp. 307. (Methuen). 6s. 1912.}

How Sally Stannard charms the hero from his melancholia more efficaciously than the hunting in Connemara, on which he was relying for his cure. Has all the appearances of a story dashed off carelessly and in haste for the publishers. Nothing in it is studied or finished.

\section{7- SANDY MARRIED. Pp. 365. (Methuen). 2s. [1913]. 4th ed.}

The plot hinges on the Grand National, on the result of which hang the fortunes of the chief personages in the story, according to the eccentric will of a deceased relative. Two of these personages, an unamiable pair of cousins, are bound by the terms of the will to maintain a stud of race-horses, which they consider "ungodly." Much comedy is afforded by their bickerings and their attempts at hunting. As usual, the book is full of horses, dealers, and hunting, and depicts life in the South of Ireland among the sporting gentry, the horse-dealing middle-classes, and the retainers of both.

388- OLD ANDY. Pp. 309. (Methuen). 6s. 1914.

Peasant life in Co. Limerick.

389- A MIXED PACK. Pp. 296. (Methuen). 6s. 1915.

A collection of stories of very various type-hunting sketches, the strange experience of an engine-driver, the adventures of a traveller for a firm of jewellers.

390_ MEAVE. Pp. 336. (Hutchinson). 6s. 1915.

Here the scene is laid in England, and the characters are English, all but a wild little Irish girl, Meave, who plays one of the ehief parts. The story is full of hunting scenes.

391— THE FINANCING OF FIONA. Pp. 316. (Allcn \& Unwin). 6s. 1916.

How Fiona, owing to the mutilation of a will, comes in for a fine house without money to keep it up. How she tries to make up for this lack of finances by taking in paying guests, among them a young English baronet. A pathetic interest is afforded by Fiona's pride and bravery in bearing up against her poverty and against domestic troubles caused by the importunity of well-meaning relatives. Her Irish servants and some English servants who come over with the visitors provide much amusing by-play. This by-play and the spirited hunting scenes give the book its chief interest. The picture of this side of Irish life is realistic and sympathetic.

\section{2— THE SCRATCH PACK. Pp. 320. (Hutchinson). 1916.}

The scene is Castle Freyne, somewhere on the Atlantic coast, where dwell Gecrge and Matilda Freyne and their step-daughter Gheena. If Gheena marries, the castle and estate fall to her. Her detested step-father plots and plans to keep the estate by marrying her to a creature of his own. Eventually she marries a member of the English Secret Service whom she had suspected of being a German spy, but who proves his loyalty by rescuing her from a German submarine. The unselfishness of her old friend who is ready to marry her in order to save her hunters and the estate but retires in favour of her genuine choice, is well brought out. Some hunting scenes are described in great detail.

393- THE EXPERIMENTS OF GANYMEDE BUNN. (Hutchinson). 6s. 1917.

The hero of this story, Ganymede Bunn, was formerly a clerk in a London store, when he receives an unexpected bequest from an aunt. He has always longed to ride and live in the country, and he resolves to speculate his capital in horses, with a view to increasing his inheritance. He goes over to Ireland, where he makes plenty of good friends, notwithstanding his odd language and other peculiarities: and he falls in love. His relatives try, but are not successful, in their endeavours to prove him mad.-(Publ.). 
CONYERS, Dorothea-(continued).

394-THE BLIGHTING OF BARTRAM. Pp. 314. (Methuen). 6s. ๓. 1918.

" Another of this fertile novelist's cheerful novels about hunting and horsedealing, hard riding and hard drinking, in Ireland; with a rich variety of Irish characters, human and equine-the villains mostly equine." (T.L.S.).

CONYNGHAM, Major David Power, LL.D.; "Allen H. Clington." Born in Killenaule, Co. Tipperary. Took part, along with his kinsman, Charles Kickham, in the rising of 1848 . Fought in the American Civil War in the 'Sixties, after which he engaged in journalism until his death in 1883 . Wrote many works on Irish and American subjects.

395__ FRANK O'DONNELL : a Tale of Irish Life; edited by " Allen H. Clington." Pp. 370. (Duffy). 5s. 1861.

Tipperary in the years before (and during) the Famine of 1846. Glimpses of Tipperary homes, both clerical and lay. Almost every aspect of Irish life at the time is pictured-the Famine, Souperism, an Irish agent and his victims (ch. xii.), how St. Patrick's Day is kept, Irish horse races (ch. ii.), \&c. "I have shown how the people are made the catspaw of aspiring politicians [elections are described] and needy landlords." Author says the characters are taken from real life. They are for the most part very well drawn, e.g., Mr. Baker, "a regular Jack Falstaff," full of boast about wonderful but wholly imaginary exploits; and Father O'Donnell. A pleasant little love-story runs through the book. The whole is racy of the soil. The dialect is good, but the conversations of the upper class are artificial and scarcely true to life. Introduces the episode of the execution of the Bros. $\mathrm{C}$ - in N-. Souperism is depicted in the person of Rev. Mr. Sly.

N.B.-This book was originally published by Messrs. Duffy in the fifties, under the title The Old House at Home; or, The Surprising Adventures of Frank O'Donnell. By a Tipperary Boy.

396- SARSFIELD; or, The Last Great Struggle for Ireland. Donahue). Port. of Sarsfield. [1871].

The Author calls this a historical romance, but the element of romance is very small. Ch. I. gives a backward glance over Ireland's national struggle in the past. The nominal hero is Hugh O'Donnell and the heroine Eveleen, granddaughter of Florence McCarthy, killed on the Rhine. But Sarsfield is the central figure, and the Author contrives to give us his whole career. There is plenty of exciting incident, partly fictitious-forays of the Rapparees, captures, escapes. In spite of the schemes of the villain rival, Saunders, hero and heroine are united. The historical standpoint seems fair if not quite impartial.

397- THE O'DONNELIS OF GLEN COTTAGE. Pp. 498. (N.Y.: Kenedy). n.d. (1874). Still in print.

This is an American edition of Frank O'Donnell. Supra.

398- THE O'MAHONY, CHIEF OF THE COMERAGHS. Pp. 268. (N.Y.: Sadlier). 1879 .

A tale of Co. Waterford in 1798, written from a strongly Irish and Catholic standpoint. Depicts the tyranny of the Protestant gentry, the savagery of the yeomanry. Typical scenes are introduced, e.g., a flogging at the cart's tail through the streets of Clonmel, seizures for tithes, the execution of Father Sheehy (an avowed anachronism), \&c. Chief historical personages: Sir Judkin Fitzgerald, the "flogging" Sheriff, and Earl Kingston. A vivid picture, though obviously partisan, and marred by some inartistic melodrama. 399 ROSE PARNELL; or, The Flower of Avondale. Pp. 429 . (N.Y.: Sadlier).
1.25. [1883]. 2nd ed. 1905.

Ireland 1790-1800, giving, from a strongly national and Catholic standpoint, a 


\section{CONYNGHAM, Major David Power-(continued)}

view of the working of the Irish Parliament in its last years, and of the rebellion, together with a full account of the Society of United Irishmen. Many historic personages figure in the tale, including Sir John Parnell. The scene is largely in Avondale, near Avoca, Co. Wicklow. Love story of Garret Byrnes (sic) and Rose Parnell, who is " the embodiment of all the noble and patriotic qualities which have characterised the Parnell family," and, as the Author says in his Pref., is modelled on Miss Fanny Parnell. Plenty of exciting incidents.

CORKERY, Daniel. B. in Cork city, 1878. Ed. by the Presentation Brothers, Cork. Resides in Cork. Has publ. besides his works of fiction three one-act plays, "The Yellow Bittern," "King and Hermit," and "Clan Falvey."

400- A MUNSTER Twilight. Pp. 150. (Dublin: The Talbot Press). $1 s$. net. [1916]. New ed. with Illustr. in colour by Michael Willmore, 2s. $6 d \mathrm{n}$. 1917.

Sixteen short stories, the scenes of which are Cork County and City, and Kerry. They have a peculiar flavour which is both literary, Irish, and personal to the writer. They vary from that weird fancy, "The Ploughing of Leaca-na-Naomh," which is uncanny, to the absolute realism of the pictures of low life in Cork, and from a sort of violence and harshness to the simple tenderness of "The Child Saint." There is humour, gruesomeness, pathos, grotesqueness by turus. The dialect is reproduced with fidelity. The stories, both as to manner and theme, are something quite new in Irish fiction.

\section{1- THE THRESHOLD OF QUIET. Pp. 310. (Dublin: The Talbot Press).} 6s. n. 1917.

This remarkable book does not deal in incident nor in sentiment, nor in descriptions, nor in pictures of Irish ways. Its interest is centred in the inner lives of a few persons whose paths are in "the cool sequestered vale of life." The writer does not work by detailed character analysis, but by quiet suggestion and delicate touches. $\mathrm{He}$ makes us know his personages as intimate friends and take a corresponding interest in their fortunes. He shows us pathos, poetry, heroism, deep religious feeling hidden in these commonplace lives. Finbarr Bresnan, after a momentary belief in his vocation to the priesthood, sets out for America, and Lily Bresnan, after a conflict between love and duty and the call of God, enters the peace of Kilvina Convent. The scene is laid in the suburbs of Cork city. The book leaves an impression of simple sincerity.

COSTELlO, Mary. B. at Kilkenny. Has done much literary work both for magazines, such as the CoRNHILL, and for the stage. She has written several nove!s, among them Addie's Husband.

\section{2_ PEGGY THE MILLIONAIRE. (C.T.S. of Ireland: Iona Series). 1s. 1910.}

The story of an Irish girl living in "Loughros," in the West of Ireland, some fifty years ago. She is the third and plain daughter of a disappointed " fine lady," who has married a country doctor out of pique, and rues her fate for the rest of her life, as she cannot appreciate her husband's good heart, and he cannot give her luxuries and grandeur. To this home Peggy comes from school. And the book tells us, with plenty of good fun in the telling, how she made her fortune, and how she scattered happiness and blessings around her.-(Press Notices).

COTTON, Rev. S. G.

403- THE THREE WHISPERS, AND OTHER TALES. Pp. 256. (DUbLIN: Robertson). c. 1850.

In the title story we have two attempted suicides of parents distraught with grief, the return of a former convict, and an inheritance for the people who were dying with hunger. Dublin is the scene. The next story, "Grace Kennedy," 
COTTON, Rev. S. G.-(continued).

takes place in the Queen's Co.: a mother murders her boy, the sister holds the corpse to the fire and " nestles beside him." In "The Foundling" the mother drowns herself, but some charitable Protestants rescue her child and bring him up in their religion. "Ellen Seaton" tells how Ellen's father goes off to be a priest and her mother to be a nun, and deals with the efforts made by priests and nuns to get hold of her. Finally she converts her nun jailer, and both escape. In some of these stories the Author introduces very vulgar brogue, with coarse expressions.

[CoX, S. A.], a Dublin man, residing at Sandymount.

404-JACK WESTROPP: An Autoibiography. 2 vols. (Downey). 1895.

The life story of a political adventurer. Jack is a clever, cynical, unscrupulous young man of good family in Co. Clare. He plays the free-lance in Dublin journalism, but finally sides with O'Connell and Repeal. It is merely, however, with a view to his owin advancement, which he eventually achieves, marrying the lady of his choice. O'Connell makes a speech at the wedding breakfast. Jack's brazen audacity and his high spirits divert the reader's attention from his unscrupulousness and wholly selfish aims. Law court scenes well described. A lively picture of the society of the time in Dublin and London.

CRAIG, Rev. J. Duncan. B. 1831. Graduated T.C.D., 1851, and took Orders.

Was long Vicar of Kinsale. Afterwards he was incumbent of Trinity Church, Lower Gardiner St., Dublin. D. 1909. He was an authority on the language and literature of Provence. He wrote Real Pictures of Clerical Life in Ireland, and a volume of Reminiscences, also Ballads of the Irish Reign of Terror, 1880, and other volumes of verse.

405- BRUCE REYNALL, M.A. Pp. 271. (Elliot Stock). 3s. 6d. 1898.

A story of an Oxford man who came to Ireland as locum tenens in the most disturbed time, and found life a good deal more exciting than at his English curacy. The Orangemen are very favourably represented. In the preface to the following work the Author says of this, "The Reign of Terror which prevailed in Ireland while the horrors of the Land League were brooding over the land, and a picture of which I have endeavoured to delineate in Bruce Reynall."

\section{6- REAL PICTURES OF CLERICAL LIFE IN IRELAND. Pp. 351. (Elliot Stock). [1875]. 1900.}

The first six chapters are autobiographical, the remaining sixty-five are a series of anecdotes and stories in which the Catholic clergy and the doctrines of the Church appear to great disadvantage. The lawlessness and brutality of the peasantry are also much insisted on, and the conversion of Ireland to Protestantism seems to obsess the writer. Some of the incidents related are improbable in the extreme, and it is not clear from the Preface to what extent the Author intended them as narratives of actual fact. At all events they are told in the form of fiction. There are also gruesome reminiscences of agrarian disturbances and of the F'enian outbreak, and a chapter against Home Rule.

CRAIG, 'Richard Manifold, 1845-1913. Born in Dublin, and educated there. $\mathrm{He}$ entered the army as surgeon, and retired with the rank of Lieut.-Colonel. His other works of fiction-A Widow Well Left, All Trumps, A Sacrifice of Fools, \&c.-do not deal with Irish subjects.

\section{7- THE WEIRD OF "THE SILKEN THOMAS." Pp. 230. (ABERdeEN :} Moran). 1900.

The story of how Lord Thomas Fitzgerald was drawn into revolt by the treachery of a private eneny. Purports to be a narrative written at the time by Martyn Baruch Fallon, "scrivener and cripple," a loyal inhabitant of Maynooth, with 
CRAIG, Richard Manifold-(continued.

some account of the latter's private affairs. Written in quaint, antique language difficult to follow, especially at the outset of the book. It seems of little value from an historical point of view.

CRANE, Stephen, and BARR, Robert (See under Barr).

408- THE O'RUDDY. (Methuen). 6s. 1904.

Has been well described as a fairy story for grown-nps, with plenty of humorous incident-love affairs, duels, \&c. The O'Ruddy is a reckless, rollicking, lovable character. There is little or no connection with real life.-(THe ACADEMY).

\section{CRAWFORD, Mrs. A.}

409_ LISMORE. Three Vols. (London: Newby). 1853.

A rambling and sentimental tale, the scene of which is Southern Ireland (Lismore and Ardmore) and Italy in 1659-60. It is in no sense historical, nor does the Author seem to have any knowledge of the period dealt with. The personages live in "suburbs" and ring the "breakfast-bell." An amusing ignorance of Catholic matters is evidenced. The plot is confused and without unity.

\section{CRAWFORD, Mary 8.; "Coragh Travers," Author of Rolf the Imprudent.}

410 - HAZEL GRAFTON. Pp. 350. (Long). 6s. 1911.

Hazel leaves Bournemouth and her school days and two rejected suitors-both curates-to live with her adoring parents in the W. of Ireland. She and Denis Martin fall in love, but the course of love does not run smooth. The two are kept apart by their parents, who are intent on other matches. A quarrel completes the breach, but all comes right in the end by help of a divorce and a death. Trips to Dublin and to Bundoran and the performances of a genuine stage-Irishman art introduced to enliven the tale.

\section{CRAWFORD, Michael George}

411- LEGENDARY STORIES OF THE CARLINGFORD LOUGH DISTRICT. Pp. 201, close print. (NEwRY: Offices of "The Frontier Sentinel"). 1s. 1914.

Thirty-four stories, embodying the legends of a district exceptionally rich in memories of old Gaelic Ireland-Cuchulain and the Red Branch-and also with great Irish-Norman families like the De Courcys and De Burgos. By a writer thoroughly acquainted with the district.

CRICHTON, Mrs. F. E. Born in Belfast, 1877 ; educated at a private school near Richmond. Travelled much in Italy, Switzerland, and Germany. Besides the three novels noted below she publ. some short stories, a little book, The Precepts of Andy Saul, based on the character of an old gardener, and some books for children.

412_ THE SOUNDLESS TIDE. Pp. 328. (Arnold). 6s. 1911.

Life of country gentry and peasantry in County Down. With the latter the Author is particularly effective, bringing out their characteristics with quite "pawky" humour. Especially there is Mrs. M'Killop and her wise saws. But the Colonel and his wife are also very well drawn. There is pathos as well as humour. Noteworthy also are the descriptions of sea-coast scenery, and the story of the fight on the "twalth"-(I.B.L.) It is a simple tale of lovers' misunderstandings. Religious strife is pictured with perhaps undue insistence.

\section{3- TINKER'S HOLLOW. Pp. 336. (Arnold). 6s. 1912.}

A charming and delicately-told love story, with a background of life among the Presbyterians (both the better class and the peasantry and servants) near a 
CRICHTON, Mrs. F. E.-(continued.

small town in Co. Antrim. Shows an intimate and sympathetic knowledge of the people that furnishes the characters of the story. The dialect is perfectly reproduced. There is a pleasant picture of the bright and sunny Sally Bruce growing from girlhood into womanhood amid the dull austerity of Coole House, in the society of her two maiden aunts and her bachelor uncle. There are pleasant gleams of Northern humour, not a few gems of rustic philosophy, and vignettes of Antrim scenery. The human interest is, however, strongest of all.

\section{THE BLIND SIDE OF THE HEART. Pp. 299. (Maunsel). 6s. 1915.}

The story of Dick Sandford's choice between his cousin Betty-English like himself-bright, charming, wholly of this world, and Ethne Blake, whom he meets while on a visit to Ireland. The book is really a study, or rather an imaginative presentment of this strange, almost unearthly, figure as typifying the mystic, faery side of the Celtic temperament, and of the back-ground of haunted Irish landscape and peasant fairy-lore, against which she moves. The vital difference in the two temperaments, Celtic and Saxon, is suggested throughout. The peasantry of the remete mountain glens are pictured with sympathy and insight.

CROKER, Mrs. B. M., wife of Lieut.-Col. Croker, late Royal Munster Fusiliers; daughter of Rev. W. Sheppard, Rector of Kilgefin, Co. Roscommon; educated at Rockferry, Cheshire. She spent fourteen years in the East, whence the Eastern subjects of some of her novels. These number nearly forty. She resides for the most part in London and Folkestone.

415- A BIRD OF PASSAGE. Pp. 366. (chatto \& Windus). [1886]. New edition. 1903.

A love story, beginning in the Andamans. There is a lively picture of garrison life, including the clever portrait of the "leading lady" (and tyrant), Mrs. Creery. The lovers are separated by the scheming of an unsuccessful rival. The girl first lives a Cinderella life with disagreeable relations in London, then is a governess, and finally ( $p .256)$ goes to a relation in Ireland. Then there are amusing studies of Irish types-carmen (Larry Flood, with his famous " Finnigan's mare"), and servants, and a family of broken-down gentry. Things come right in the end.

416- IN THE KINGDOM OF KERRY. (Chatto \& Windus). 3s. 6d. 1896.

"Seven sketchy little stories of poor folk, written in light and merry style." $-($ Baker $)$.

417- BEYOND THE PALE. (Chatto \& Windus). 3s. $6 d$ and $6 d$. (N.Y.: Fenno). 0.50. 1897.

Story of an Irish girl of good family, who is obliged to train horses for a living, but ends successfully. Scene: a hunting county three hours' journey from Dublin. Much stress is laid on the feudal spirit of the peasantry, who are viewed from the point of view of the upper classes but sympathetically.

418- TERENCE. Pp. 342. (Chatto \& Windus). 6s. Six illustr. by Sidney Paget. (N.Y.: Buckles). 1.25. 1899.

Scene: an anglers' hotel in Waterville, Co. Kerry, and the neighbourhood, which the Author knows and describes well. A tale of love and foolish jealousy. The personages belong to the Protestant upper classes. The chief interest is in the working out of the plot, which is well sustained all through. "Contains comedy of a broad and sometimes vulgar kind, turning on jealousy and scandal."(Baker 2).

419- JOHANNA. Pp. 315. (Methuen). [1903]. 3rd ed., 1s. n. 1917.

The story of a beautiful but very unsophisticated and stupid peasant girl who, forced by a tyrannical stepmother to fly from her home in Kerry, sets off for Dublin. On the way she loses the address of the house she is going to, is snapped 
CROKER, Mrs. B. M.-(continued).

up by the keeper of a lodging-house, and there lives as a slavey a life of dreadfuI drudgery and of suffering from unpleasant boarders. But her lover comes home from the wars, and all is well

420 - A NINE DAYS' WONDER. Pp. 310. (Methuen). 6s. 1805.

How Mary Foley, brought up for twenty-one years in an Irish cabin, is suddenly claimed as his daughter by an English peer, and becomes Lady Joseline Dene. How she gives Society a sensation by her countrified speech and manners, and by her too truthful and pointed remarks, but carries it by storm in the end, and marries her early love. The writer has a good knowledge of the talk of the lower middle classes. There is no bias in the story, which is a thoroughly pleasant one.

421- LISMOYLE: an Experiment in Ireland. Pp. 384. (Hutchinson). 6s. 1914.

The six months' visit of a young English heiress to the stately, dilapidated mansion of Lismoyle, in the Co. Tipperary, involving a comedy of courtship, many amusing situations, and some description of the small social affairs of the county. No Irish "problenı" is touched upon.

421A- BRIDGET. Pp. 288. (Hutchinson). 6s. n. 1918.

Bridget was very beautiful and very lovable, and (till near the end of the story) very poor; and it's all about her and her far corner of Ireland, and her deplorable parents and her soldier suitors, and Dublin dances and garden parties. All very far from what we are thinking and doing nowadays-and none the worse for that.(T. Lit. SUPPL.)

The scenes of some others of her novels are laid partly in Ireland, e.g., TWO MASTERS (Chatto), 1890; and INTERFERENCE (Chatto), 1894.

CROKER, T. Crofton. Born in Cork, 1788; died in London, 1854. Was one of the most celebrated of Irish antiquaries, folk-lorists, and collectors of ancient airs. He helped to found the Camden Society (1839), the Percy Society (1840), and the British Archæological Association (1843). Was a Fellow of the Society of Antiquaries, and of many Continental Societies. Wrote or edited a great number of works. His leisure hours were spent in rambles in company with a Quaker gentleman of tastes similar to his own. In these excursions he gained that intimate knowledge of the people, their ideas, traditions, and tales, which he afterwards turned to good account.

422- LEGENDS OF THE LAKES. [1828]. Illustr. by. Maclise.

Killarney. A series of stories, similar to those in the Fairy Legends, of fairies, ghosts, banshees, \&c.

423- KILIARNEY Legends. Pp. 294. 16mo. (London: Fisher). Some steel engravings (quite fanciful). [1831]. 1879.

An abbreviated ed. of Legends of the Lakes. Ed. of 1879 was edited by Author's son, T. F. D. Croker. Topographical Index. An ed. arranged as a guide to the Lakes was publ. 1853.

424 FAIRY LEGENDS AND TRADITIONS OF THE SOUTH OF IRELAND. New and complete edition. Illustr by Maclise and Green. 1882.

First appeared in 1825; often republished since, e.g. (LoND.: Tegg), 1862, with memoir of the Author by T. F. Dillon Croker. Pp. 366. Classified under the headings:-The Shefro; the Cluricaune; the Banshee; the Phooka; Thierna na oge (sic); the Merrow; the Dullahan, \&c. "I make no pretension to originality, and avow at once that there is no story in my book which has not been told by nalf the old women of the district in which the scene is laid. I give them as I found them" (Pref.). This is the first collection of Irish folk-lore apart from the peddler's chap-books. Dr. Douglas Hyde (Pref. to Beside the Fire) calls this a delightful book, and speaks of Croker's "light style, his pleasant parallels from 
CROKER, T. Crofton-(continued).

classics and foreign literature, and his delightful annotations," but says that he manipulated for the English market, not only the form, but often the substance, of his stories. Scott praised the book very highly in the notes to the $1830 \mathrm{ed}$. of the Waverley Novels, as well as in his Demonology and Witchcraft. The original ed. was trans. into German by the Bros. Grimm, 1826, and into French by P. A. Dufour, 1828.

\section{5- THE ADVENTURES OF BARNEY MAHONEY. Pp. $299.12 \mathrm{mo}$.}

(LoND. : Fisher, Son \& Jackson). 1832.

Blunders, scrapes, and escapades of a comic Irish servant in the employment of various families. Barney's one idea was to make his way-honestly, if he could, but at all events to make it. Of his character the Author says (p. 41), "The conscience of our young Irishman was of a most conveniently elastic nature. $\mathrm{He}$ had a superabundant share of that low cunning so frequently found in his rank of life, with a remarkably open countenance and simplicity of manner." The book opens with an overdrawn picture of Irish poverty and slovenliness. The writer, who is believed to be Mrs. Crofton Croker, shows but a superficial knowledge of Irish life and character. But her general view seems to be expressed in lines prefixed to the book and ending-

I do believe, with fault and folly teeming,

The Irish heart, when tried, will shine with bright redeeming.

[CROLLY, Rev. Geo.]. A former distinguished Professor at Maynooth, Author of important theological works.

426- THE FAVOURITE CHILD; or, Mary Anne O'Halloran. Sq. 16mo. Pp. 79. (Duffy). [1851]. 5th ed. n.d.

The story of a spoiled child who turns out badly, but, taught by suffering and sorrow, ends as a Sister of Charity. Charmingly told. The villain is, perhaps, impossibly wicked. The moral is very well brought out.

CROMARTIE, Countess of; Sibell Lillan Mackenzie, Viscountess of Tarbat, Baroness of Castlehaven and Macleod. Born 1878. Lives at Castle Leod, Strathpeffer, N.B. Publ. The End of the Song, 1904; The lleb of the Past; The Decoy, \&c.

427_- SONS OF THE MILESIANS. Pp. 306. (Eveleigh, Nash). 1906.

Short stories, some Irish, some Highland Scotch, somewhat in the manner of Fiona MacLeod's beautifu! Barbaric Tales. The stories deal with various periods from the time of the Emperor Julian to the present day, and they are vivid pictures of life and manners of these different epochs. The stand-point is thoroughly Gaelic, and there is much pathos and much beauty in the tales.

428 - THE DAYS OF FIRE. Pp. 114. (Wellby). Artistic cover in white and gold. 1908 .

The scene is laid in Ireland in the days of the first Milesians, but does not deai with historical events. Tells of the love of Heremon the King for a beautiful slave. Full of sensuous description, in a smooth, dreamy style. Frankly pagan in spirit.

429 - THE GOLDEN GUARD. Pp. 407. (Allen). 6s. 1912.

" A tale of 'far off things and battles long ago,' when King Heremon the Beautiful, who reigned at Tara over Milesian and Phœnician ..... fought with his Golden Guard against, the Northern Barbarians. Lady Cromartie gives fire and passion to the shadowy figures, filling her imaginative pages with crowded hours of love and fighting, toil, pleasure, and vigorous life."-(T. Lit. Surpl.). 
CROMIE, Robert. Born at Clough, Co. Down, the son of Dr. Cromie. Was on the staff of Belfast NorTHERN WHIG, and died some years ago. Author of The Crack of Doom, The King's Oak, For England's Sake, \&c

\section{0 _ KITTY'S VICTORIA CROSS. Pp. 306. (W'arne). 6s. 1901.}

The scene is mainly Woodbine Cottage, "Innisboffin," where dwells Kitty O'Neill, Enter two English officers, Peterson and Linton. Kitty loses her heart to the former. There is an eviction, and P. orders his men to fire on the people. He then goes away and $K$. is broken-hearted. $K$. soon learns from a newspaper that $P$. is dead, and consoles herself with L., who has meanwhile won a V.C. There is a minor plot with Kendrick, an American, and Nannie, a clergyman's daughter, friend to Kitty, as hero and heroine.

431 - THE SHADOW OF THE CRaSS. Pp. 326. (Ward \& Lock). 6s. 1902.

A sympathetic study of Ulster Presbyterian life is the background for the romance, ending in tragedy, of a young minister. Apart from the occasional dialect (well handled) there is little of Ireland in the book, but the story is told with much skill, and never flags. Bromley, an unbeliever, almost a cynic, but a true man, and unselfish to the point of heroism, is a remarkable study.

CROMMELIN, May de la Cherois. Born in Ireland. Daughter of late S. de la Cherois Crommelin, of Carrowdore Castle, Co. Down, a descendant of Louis Crommelin, a Huguenot refugee, who founded the linen trade in Ulster. Educated at home. Early life spent in Ireland; has resided since tin London; has travelled much. Publ. more than thirty novels.-(Who's Who). Queenie was the Author's first novel. A Jewel of a Girl deals with Ireland and Holland.

432 ORANGE LILY. Two Vols., afterwards One Vol. (IIurst \& Blackett). 1879.

The story of Lily Keag, daughter of a Co. Down Orangeman, who, to the disgust of her social circle, falls in love with her father's servant boy. The latter goes to America, and thence returns, a wealthy man, to claim Lily. The scenery is well described, and the dialect well rendered. A healthy and high-toned novel.

\section{3- BLACK ABBEY. Pp. 447. (Sampson Low). [1880]. 1882.}

We are first introduced to a delightful circle, the three children of Black Abbey (somewhere in Co. Down) and those about them, their German Governess and Irish nurse, and their playmate Bella, born in America, granddaughter of the old Presbyterian minister. The picture of their home-life is pleasant and life-like, with a, vein of quiet humour. Then they grow up, and things no longer run smoothly. Bella, by her marriage, well-nigh wrecks four lives, including her own, but things seem to be righting themselves as the story closes. The dialect of the Northern servants is very well done. The tone of the book is most wholesome, though by no means "goody-goody."

434 - DIVIL-MAY-CARE; alias Richard Burke, sometime Adjutant of the Black Northerns. Pp. x. +306. (F. V. White). 6s. 1899.

A series of humorous and exciting episodes, forming the adventures of an officer home from India on sick leave. Most of them are located in Antrim. No religious or political bias, but a tinge of the stage Irishman.

\section{5- THE GOLDEN BOW. (Holden \& Hardingham). 6s. c. 1912.}

Story of the sorrows and suitors, from an: unhappy childhood to a happy engagement, of an Irish girl, who is poor, proud, and pretty. A loviable character is Judith's crippled sister Melissa. Scene : N. of Ireland. There is a good deal of dialect, and the ways of the peasantry are faithfully depicted

CRONIN, T.B., a native of Co. Kerry. Ed. at Irish College, Paris, and at Maynooth. Contested South Kerry against Mr. Boland, M.P. Died in Feb., 1917 , at the age of 33. Wrote some excellent stories that were published by the C.T.S. of Ireland. See Append. B.9. 
[CRONIN, William] " Liam."

436- A HAMPER OF HUMOUR. Pp. 176. (Gill). 2s. 1913.

A series of character and genre studies-the shy man, the drunken driver who wakes to find himself in a hearse and thinks it is his own funeral, the returned American, the magistrates who do a good turn for their friends. In this last and and in several other sketches (notably in the two concerned with Cork railways) there is a note of satire. There is plenty of genuine humour to justify the title. The Cork accent is cleverly hit off; practically all the sketches are more or less Corkonian.

Crosbie, Mary. B. in England. Ed. privately and at various English schools. Has frequently visited and stayed in Ireland. Her first novel, Disciples, was publ. in 1907; but it was the second that was most successful, three editions being called for within a short time. Wrote also Escapade.

437- KINSMEN'S CLAY. Pp. 389. (Close print). (Methuen). 68. 1st and 2nd eds. 1910.

Main theme: wife and lover waiting for invalid and impossible husband to die. The treatment of this theme and that of a minor plot makes the book unsuited for certain classes of readens. Moreover, the tone is alien to religion. God is "perhaps the flowering of men's ideals under the rain of their tears." But the tone is not frankly anti-moral. The personages are all of the country Anglo-Irish gentry, except one peasant family, and this shows up badly. The types are drawn with much skill, and there is constant clever analysis of moods and emotions. The story brings out in a vague way the transmission through a family of ancestral peculiarities.

438- BRIDGET CONSIDINE. Pp. 347. (Bell). 6s. 1914.

Bridget's father is the son of a broken-down shopkeeper somewhere beyond the Shannon, but clings to aristocratic notions. She grows up in London along with "Lennie-next-door," but her mind outgrows his. She goes to stay W. of the Shannon as secretary to a rich lady. There she becomes engaged to Hugh Delmege, a young landowner. All her yearnings seem fulfilled, yet somehow it is not what she had expected; a short separation from Hugh still further opens her eyes, and she returns disillusioned. This is the bare skeleton: it does not do justice to the philosophy and the style of the book, both of which are remarkable.

\section{CROSBIE, W. J.}

439 DAVID MAXWELL. (Jarrold). 6s. 1902.

'98 from the loyalist standpoint, and adventures in Mexico and South Texas, \&c. "David" is "Scotich-Irish."-(Baker, 2).

\section{CROSFIELD, H. C.}

440_ FOR THREE KINGDOMS. Pp. 241. (Elliott Stock). 1909.

"Recollections of Robert Warden, a servant of King James." By a series of accidents the teller finds himself on board one of the ships that raises the blockade of Derry; he escapes and goes to Dublin, where he has exciting adventures. Tyrconnell is introduced-a very unfavourable portrait; and the hero goes through the Boyne campaign. Told in lively style, with plenty of incident.

CROTTIE, Julia M. Born in Lismore, Co. Waterford, 1853. Ed. privately and at Presentation Convent, Lismore. Contributed to the Catholic WorLd, N.Y., and to other American Catholic periodicals, also to the MontH, the Rosary, \&c. She long resided in Ramsay, Isle of Man.

441— NEIGHBOURS. Pp. 307. (Unwin). 6s. 1900.

Pictures of very unlovely aspects of life in a small stagnant town. Twenty 


\section{CROTTIE, Julia M.-(continued).}

separate sketches. Wonderfully true to reality, and to the petty unpleasant sides of human nature. The gossip of the back lane is faithfully reproduced, though without vulgarity. The stories are told with great skill.

442_ _ THE LOST LAND. Pp. 266. (Fisher Unwin). 6s. [1901]. 1907.

"A tale of a Cromwellian Irish town [in Munster]. Being the autobiography of Miss Annita Lombard." A picture of the pitiful failure of the United Irishmen to raise and inspirit a people turned to mean, timid and crawling slaves by ages of oppression. Thad Lombard, sacrificing fortune, home, happiness, and at last bis life, for the Lost Land, is a noble figure. The book is a biting and powerful satire upon various types of Anglicized or vulgar or pharisaical Catholicism (the Author is a Catholic). The whole is a picture of unrelieved gloom. The style, beautiful, and often poetic, but deepens the sadness. Thad Lombard, a hundred years before the time, pursues the ideals of the Gaelic League. Period: c. 1780-1797.

CROW (Mrs. Louisa). Wrote also, By Order of Queen Maude (1887), Mollie's Maidens (1894), etc.

443 ROSE AND SHAMROCK, a Domestic Story. Pp. 102. (London: Dicks). 6d. 10 Illustr. by L. Huard. c. 1882.

Co. Galway in the fifties. A story of people of the upper class living on a small estate. Ireland as viewed by Anglicized country family and army people.

CROWE, Eyre Evans, 1799-1868. Though born in England, this distinguished historian and journalist was of Irish origin, and was educated at 'i'rinity. In BLACKWOOD he first published several of his Irish novels. Though imperfectly acquainted with the art of a novelist, this writer is often correct and happy in his descriptions and historical summaries. Like Banim, he has ventured on the stormy period of 1798 , and has been more minute than his great rival in sketching the circumstances of the rebellion.-(Chambers's C'yclopaedia of English Literature).

444 TO-DAY IN IRELAND. Three Vols. (Iondon: Knight). 1825.

Four stories :-1. "The Carders." 2. "Connemara." 3. " Old and New Light." 4. "The O'Toole's Warning." The scene of 1 is "Rathfinnan," on Lough Ree, not far from Athlone. It is a very dark picture of the secret societies and of the peasants in general, but an equally merciless picture of certain types of the Ascendancy class, notably a Protestant curate and Papist-hunter named Crosthwaite. The hero, Arthur Dillon (a true hero of romance), is a young Catholic student of T.C.D., who narrowly escapes being implicated in the secret societies. He dreams of rebellion, and is nearly caught in the meshes of a villainous, plotting Jesuit. There is a love story with a happy ending. 2. Is a burlesque story telling how M'Langhlin, a sort of King of Connemara, escaped his debtors in a coffin. Some smuggling episodes. Description of the fair of Ballinasloe, p. 196. Much about wild feudal hospitality and lawlessness. 3. Is a satirical study of Protestant religious life at " Ardennore," Co. Louth. "Sir Starcourt Gibbs " seems obviously intended as a portrait of Sir Harcourt Lees, an Evangelical Orange leader in Dublin in the twenties and thirties.

445- CONNEMARA OU UMA ELEICAO NA IRLANDA: Romance Irlandez tradusido por C[amillo] A[ureliano] da S[ilva] e S[ousa] (Porro). 1843.

446_ YESTERDAY IN IRELAND. Three Vols., containing two long stories, viz. : 1. "Corramahon." Pp. 600. Large loose print.

O'Mahon, an Irish Jacobite soldier of fortune, is the hero. The plot consists mainly of the intertwined love stories of men and women separated by barriers of class, creed, and nationality. Good picture of politics at the time. Hardships of Penal days illustrated (good description of Midnight Mass). Ulick O'More, the 
CROWE, Eyre Evans-(continued).

Rapparee, is a fine figure. Interest sustained by exciting incidents. Scene laid near town of Carlow.

2. "The Northerns of '98." Pp. 367.

Scene: Mid-Antrim. Adventures of various persons in '98 (Winter and Orde are the chief names). Feelings and sentiments of the times portrayed, especially those of United Irishmen. Battle of Antrim described. Author leans somewhat to National side."

[CRUMPE, Miss]. Daughter of Dr. Crumpe (1766-1796), a famous physician in Limerick. According to the Madden MSS., she wrote several other novels.

447 - GERALDINE OF DESMOND; or, Ireland in the Reign of Queen Elizabeth. Three Vols. (London: Colburn). [1829]. 2 Vols., 1841, "by E.C.A."

Dedicated to Thomas Moore. A story of the Desmond Rebellion, 1580-2, (battle of Monaster-ni-via, the massacre of Smerwick, \&c.) with, as personages in the story, the chief historical figures of the time:- the Desmonds and Ormonds, Fr. Allen, s.J., Sanders, Sil Henry Sidney, Sir Willıam Drury, Dr. Dee, the Astrologer, Queen Elizabeth herself. The Author has worked into the slight framework of her story an elaborate and careful picture of the times, the fruit, she tells us, of years of study and research. As a result the romance is overlaid and well-nigh smothered with erudition, apart even from the learned notes appended to each volume. The Author is obviously inspired by a great love and enthusiasm for Ireland, and takes the national side thoroughly. The book is ably written, but resembles rather a treatise than novel.

448_ THE DEATH FLAG; or, The Irish Buccaneers. 3 vols. (LoND. : William Shoberl). 1852.

Period: 1748-88, ending with the funeral of the young Pretender. The scene varies between Ireland, France, England and Italy. The story deals with the adventures and intrigues of the O'Sullivans of Berehaven, the Irish Buccaneers, and their ship, the Death Flag. But the hero is Lord Ogilvy, a devoted Jacobite, whose love for Eva O'Sullivan forms one of the threads of the narrative. Jacobite intrigues form one of the main sources of interest. The object, says the Preface, is " to point a moral and adorn a tale" by showing the retribution that follows upon crime. This is not made unduly prominent. Standpoint: Irish and nationalist.

CUNINGHAME, Richard. Author of In Bonds But Fetterless, 1875.

449_ THE BROKEN SWORD OF ULSTER: A brief relation of the Events of one of the most stirring and momentous eras in the Annals of Ireland. Crown 8vo. (Hodges \& Figgis). 3s. 6d. (1904).

Account of chief events. Not in form of fiction. Tone somewhat anti-national ( $c f$. authorities chiefly relied on). Moral: Ireland's crowning need is to accept the teaching of St. Paul on charity. This is "the God-provided cure for all her woes."

CURTIN, Jeremiah. One of the greatest linguists of modern times. B. 1838, at Milwaukee, of Irish parents, just come to the States from Thomond. Ed. at Harvard. Learned to write and speak every living tongue from the Balkans to Ireland; also Turkish, Arabic, Persian, Chinese, Japanese, Buriat, Tungu, etc., and several N. American Indian dialects. Translated Sienkiewicz and other Polish Authors. Collected Slav and Indian folk-lore. Publ. many important works on the history of languages, and on folk-lore. . In 1887 came to Ireland and collected folk-lore from the peop.e of the Gaedhelaltacht. Again in 1894. Much of his fugitive work in periodicats remains to be collected. D. in 1910.

450 - MYTHS AND FOLK-LORE OF IRELAND. (S'ampson, Low). 9s. Etched frontispiece. 1890.

"Twenty tales," says Douglas Hyde (Preî. to Beside the Fire), "told very well, 


\section{CURTIN, Jeremiah-(continued).}

and with much less cooking and flavouring than his predecessors employed." The tales were got from Gaelic speakers through an interpreter (Mr. Curtin knowing not a word of Gaelic). Beyond this fact he does not tell us where, from whom, or how he collected the stories. Dr. Hyde says again, "From my own knowledge of folk-lore, such as it is, I can easily recognise that Mr. Curtin has approached the fountain-head more nearly than any other." The statement as to Mr. Curtin's knowledge of Gaelic is not quite correct.

\section{1- HERO TALES OF IRELAND, collected by. Pp. Lii. $\div 558$. (Macmillan).}

\section{7s. $6 d .1894$.}

Learned introduction speculates on origin of myths of primitive races. Compares Graelic myths with those of other races, especially North American Indians. Contends that the characters in the tales are personifications of natural forces and the elements. And that the tales themselves in their earliest form give man's primitive ideas of the creation, \&c. The volume consists of twenty-four folk-lore stories dealing chiefly with heroes of the Gaelic cycles. Not interesting in themselves, and with much sameness in style, matter and incident. There is some naturalistic coarseness here and there, and the tone in some places is vulgar. The stories were told to the Author by Kerry, Connemara, and Donegal peasants, whose names are given in a note on p. 549.

\section{2_ TALES OF THE FAIRIES AND OF THE GHOST WORLD. Pp. ix. +198.} (Nutt). 1895.

Preface by Alfred Nutt. This collection supplements the two previous collections. It is collected from oral tradition chiefly in S.-W. Munster. Illustrates the presentday belief of the peasantry in ghosts, fairies, \&c. There are thirty tales, many of them new. A good mumber of them are, of course, grotesque and extravagant. They contain nothing objectionable, but obviously are hardly suitable for shildren.

CURTIS, Robert. Was an Inspector of Police, and published (1869) The History of the R.I.C. and The 'Trial of Captain Alcohol. Pp. 48. (McGlashan \&: Gill). 1871.

453_ THE IRISH POLICE OFFICER. Pp vii+216. (Ward, Lock). 1861.

Six short stories, reprinted from Dublin University Magazine, entitled "The Identification," "The Banker of Ballyfree," "The Reprieve," "The Two Mullanys," "M'Cormack's Grudge," "How "The Chief' was Robbed." They deal chiefly with remarkable trials in Ireland. "They are all founded upon facts which occurred within my own personal kinowledge; land for the accuracy of which not only I, but others, can vouch."-(Pref).

454 RORY OF THE HILLS. Pp. 356. Post 8vo. (Duffy). 2s. [1870]. Still in print.

A faithful and sympathetic picture of the peasant life and manmers at the time (early nineteenth century). The Author, a police officer, has drawn on his professional experiences. The tale, founded on fact, is an edifying one despite the unrelieved villainy of Tom Murdock. The influence of religion is felt throughout, especially in the heroic charity of the heroine even towards the murderer of her lover. Peastant speech reproduced to the life.

CURRAN, H. G. (1800-1876). Natural son of John Philpot Curran. A barrister. 455- CONFESSIONS OF A WHITEFOOT. Pp. 306. (Bentley). (Edited by G. C. H., Esq., B.L.). 1844.

The supposed teller beglan as a supporter of "law and order," but the conviction of the abuses of landlordism is forced upon him by experience and observation, and he ends by joining the secret society of the Whitefeet. He makes no secret of the crimes of this body, and many of them are described in the course of the narrative. 
CUSACK, Mary Frances, known as “The Nun of Kenmare." Originally a Protestant, she became a Catholic and a Poor Clare. From her convent in Kenmare she issued quite a library of books on many subjects-Irish history, general and local, Irish biography, stories, poems, works of piety and of instruction. Subsequently she left her convent, went to America, ano reverted to Protestantisn. Died Leamington, 1899, aged 70 . She has pubiished her autobiography.

456 NED RUSHEEN; or, Who Fired the First Shot? Pp. 373. (Burns d Oates. Boston: Donahoe). Four rather mediocre Illus. [1871]. New ed. (Gill). 1880.

A murder mystery. The hero is wrongly accused, but is acquitted in the end. The real culprit (scapegrace son of the victim, Lord Elmsdale) confesses when dying. The mystery is well kept up to the end. Indeed, the explanation of it is by no means clear, even at the close. The moral purpose is kept prominently before the reader throughout. Tone strongly religious and Catholic, the Protestant religion being more than once compiared, to its disadvantage, with the Catholic.

457__ TIM O'HAILORAN'S CHOICE; or, from Killarney to New York. Ip. 262. (LoNDoN : Burns). [1877]. 1878.

"This little story gives a strong picture of the heroic faith, sufferings, and rative humour of the Irish poor."-(Press Notice). When Tim is dying a priest and a "Souper" contend for possession of his boy Thade. Tim is faithful to his Church, but after his death the boy is kidnapped by the proselytisers. He escapes, and is sheltered by a good Catholic named O'Grady. Subsequently he finds favour with a rich American, who takes him off to New York.

N.B.-Publ. in U.S.A. (N.Y.: Pustet) under title From Killarney to New York; or, How Thade Became a Banker. (1877).

“DANBY, Frank," Mrs. Julia Frankan. B. 1864, in Dublin. D. in 1916. Author of several careful biographies and of a number of successful novels, e.g., Pigs in Clover, 1902; Baccarat, Concert Pitch, Full Swing, 1914. Her first novel was published in 1885 . A posthumous work by her, We Mothers and Our Children, appeared in Nov. 1918.

458- LET THE ROOF FALL IN. 1910.

An Irish peer, Lord Rathmore, is killed at Sandown. His cousin succeeds to the title. The dowager Lady $R$. has as companion an Irish girl, who has been seduced by the late Lord $R$. The new Lord $R$. marries her and takes her to India, where her son is born. Lord R. adopts him as his own. The Dowager has a prejudice against the boy, and tries to injure him, but takes to him when she sees him. Clever society scenes. Irish dialect very bad.

\section{D'ANJOU (Germaine).}

459__ LA PETITE-NIECE D'O'CONNELL. Pp. 286. in-12. (PARIS : Lecoff re) $2 f r .1888$.

Opens at a village near Kenmare in 1874. On the death of her mother Ellen MacGaway is taken away to Scotland by her uncle and guardian, Sir Robert Glengarry. The closing scenes are in Kenmare. Ellen, after twice well-nigh ruining her life by doing heroically what she believed to be her duty, is made heiress of Lord G., who dies a Catholic, and eventually she marries a young French officer. A simple tale, of pronouncedly moral and religious tone. The background of natural scenery is nicely, if a little vaguely, painted. No reference to politics nor to social and other conditions in Ireland. 
D'ARBoIS DE JUBAINVILLE, Henri. Born in Nancy, 1827. Died 1910. Educated in Ecole des Chartes. A biographical notice of him, followed by a bibliography of his works, will be found in the Revue Celtique (Vol 32, p. 456, 1911), which he edited from 1886 till his death. The list of his works contains 238 items, the greater number of which concern Celts. Perhaps rather more than half deal with Ireland. They include a Cours de Litterature Celtique in 12 vols., a history of the Celts, a work on the Irish mythological cycle, ind a catalogue of the epic literature of Ireland. That on the Irish mythological cycle has been well translated by R. I. Best (Hodges \& Figgis). 1903. Pp. xv. +240.

460_ TAIN BO CUALNGE. ENLEVEMENT DU TAUREAU DIVIN ET DES VACHES DE COOLEY. Pp. 190. (PARIS: Champion). En livraisons. 1907-9.

“ La plus ancienne épopée de l'Europe occidentale traduite par Ir. d'A. de J., Membre de l'Institut, Prof. au College de France, avec la collaboration de MM. Alexandre Smirnoff et Eugène Bibart."

\section{D'ARCY, HaI.}

461— A HANDFUL OF DAYS. Pp. 319. (Long). 6s. 1914.

" How John O'Grady left his initlating wife and selfish children to revisit the home of his fathers in $I$. for a short time; how he met .... Mary O'Connor .... ; how he fell in love, and told her so-forgetting to mention the irritating wife, \&c. . . . The picture of the old Irish priest, Mary's uncle, is the one redeeming feature of a mawkish, unsatisfactory tale."-(T. LITT. SUPPL.) This fairly describes the story. Non-Catholic, but not prejudiced. Scene: Glendalough.

DAMANT, Mary. The Author is a daughter of General Chesney, the Asiatic explorer.

462- PEGGY. Pp. 405. (Allen). 1887.

Domestic life in North Antrim previous to and during, the Rebellion of 1798. "Many of the facts of my little tale were told me in childhood by those whose recollection of the rising was rendered vivid by desolate homes, loss of relations, \&c."-(Pref.) Eschews historical or political questions. Favourable to " poor deluded peasants." Thinks little of United Irishmen, who are "imbued with the poison of revolutionary principles." Well and pleasantly written in autobiographical form.

DAUNT, Alice O'Neill, 1848-1915. Was the only daughter of W. J. O'Neill Daunt. Contributed to The Lamp, Ireland's OWN, and other magazines. She wrote many little stories, as serials or in book form, for the most part religious (Catholic) and didactic.

463-EVA; or, as the Child, so the Woman. Pp. 107. 16mo. (Richardson). 1s. 1882 .

One of a little series of Catholic Tales for the young. A sad little story, full of piety. Scene in Ireland, but the story is not specially Irish in any way.

DAUNT, W. J. O'Neill. "Denis Ignatius Moriarty," "John O'Brien Grant." Born in Tullamore, 1807. Son of Joseph Daunt, of Ballyneen, Cork. Became a Catholic about 1827. Was in Repeal Association from the first, and remlained to the end one of O'Connell's most loyal co-operators. Lived at Kilsascan Castle, Ballyneen. Died 1894. His biography has been published under the title, A Life Spent for Irtand, 1896.

464- THE WIFE HUNTER AND FLORA DOUGLAS. Three Vols.* (Bentley). 1838.

Prefatory notice signed by "John O'Brien Grant," of Kilnaflesk, the teller of the story. K. is " situated in a remote corner of the kingdom," near Bandon (vol.

* The first two (pp. $342+332$ ) are taken up by The Wife Hunter. 
DAUNT, W. J. O'Neill-(continued).

II., p. 186); it is an old rambling family mansion, dating from 1713 . We are introduced to a set of hard-drinking, Orange squireens. The hero, refused by his nurse's daughter Mary, has a "go "at a rich heiress, merely to better himself. $\mathrm{He}$ also, in company with Morrough O'Driscoll, a "restless, blustering, dexterous, successful, ambitious, amusing and farcical genius," throws himself into politics. Then there are a number of burlesque electioneering scenes. Duly elected, the hero goes to Dublin, meets Charlemont, \&c., in high society. Hero marries Mary after all; then, on her death, rescues an heiress and marries her.

A third matrimonial venture is unsuccessful. There is no seriousness in the book.

\section{5- THE HUSBAND HUNTER. Three Vols. 1839}

A society novel. Scene: Kerry, c. 1830. There is very little plot, and the matrimonial complications (a Russian prince and a German baron are involved) of the lady who gives to the story its title form by no means the central episode. The conversations are rather artificial and the humour a little insipid. Pleasant portrait of a priest of the old sporting type. Nothing objectionable.

\section{A- INNISFOYLE ABBEY. Three Vols. (London). 1840.}

A story dealing with the religious question in Ireland, as seen from a Catholic standpoint. It is full of able controversy, and shows keen observation. The hero Howard's Protestant and anti-Irish prejudices are made to give way as the real situation of things is forced in on him. The restoration of Innisfoyle Abbey is one of the main incidents. Some of the incidents are taken from facts, e.g., the Rathcormac tithe massacre. These incidents are related with energy and pathos. But in general the story is of a lighter character, full of broad Irish humour, and placing the sayings and doings of our Orange fellow-countrymen in a point of view as ludicrous as it is horrible. "A rambling, spirited, and racy tale, eccentric and even absurd sometimes, but very original and entertaining." "This writer is known as the author of several amusing and clever novels." - (D.R.).

466 SAINTS AND SINNERS. Two Vols. aftds. One Vol. (Duffy).

(N.Y.: Pratt). 0.50. 1843, \&c.

"The reader who expects in this narrative what is commonly called the plot, or story, of a novel will, we fairly warn him, be disappointed. Our object in becoming the historian of Howrard is merely to trace the impressions produced on his mind by the very varied principles and notions with which he came in contact" (beginning of chap. xiii.). The book is, besides, a very satirical study of various types of Ulster Protestantism, and a controversial novel, reference to scripture and to various Catholic authorities being frequently given in footnotes. The story, a slight one, moves slowly, but the situations have a good deal of humour.

N.B.-Originally published under title of Innisfoyle Abbey (q.v.), of which Saints and Sinners is a condensed and altered version, with footnotes and Appendix added.

\section{7- HUGH TALBOT. Pp. 473. (Duffy). 1846.}

"A Tale of the Irish confiscations of the 17th century," i.e., the reign of James I. Scene varies between. England, Ireland and Scotland. Opens in 1609. Portrait of James I. No other historical personage. Persecution, arrest, and adventures of Father Hugh Talbot. Chief interest lies in the picture of the times, which is carefully drawn. The story, however, is well told, the conversations clever and fairly natural, the character-drawing good. The Author is strongly opposed to religious persecution. The Irish localities are not specified.

468- THE GENTLEMAN IN DEBT. Pp. 339. (Cameron \& Ferguson). 1s. (N.Y.: Pratt). 1.50. [1848]. 1851, \&c.

Adventures of a penniless young gentleman trying to get a position. Depicts (after Lever), first life in Galway, among impecunious, fox-hunting, hard-drinking 
DAUNT, W. J. O'Neill-(continued).

duelling squires (Blakes, Bodkins, and O'Carrolls); then the vapid life of Castle aristocracy in the Dublin of the time, with its place-hunting and ignoble timeserving. Incidentally (for the Author does not moralise) we have glimpses of the working of the Penal laws. The story is an unexciting one of rather matter-of-fact courtship and of domestic intrigue. There are not a few amusing scenes, mothing objectionable, and little bias. A striking character study is that of the Rev. Julius Blake, who is of the tribe of Pecksniff, but with quite distinctive features. A note in the Author's Autobiography informs us that this was intended as a portrait of O'Connell.

[DEACON, Wm. Frederick,] 1799-1845. Journalist and Author. B. in London; ed. at Cambridge. Ed. of The De Jeune, 1820. Publ. The Innkeeper's Album, Warreniana (1824) ; also Annette, a tale, posthumously, 1853, to which is prefixed a memoir of the Author by Hon. Sir T. N. Talfourd. A biography of him will be found in D.N.B.

469- THE EXILE OF ERIN; or, The Sorrows of a Bashful Irishman. Two Vols. (Whittaker). 1835.

Farly 19th century. Adventures of a villain of the worst type in Ireland, England, and on the Continent. Commits almost every conceivable crime, including bigamy and embezzlement. Acts every part from strolling player to journalist and political partisan. Tells all this in first person. Incidentally the book is a bitter satire on Ireland, Irish priests, Irish politicians. Represents the "O'Connellite rabble" as oapable of any outrage, and O'Connell himself (under the name of O'Cromwell) as a political adventurer. The story attained considerable popularity in England and America.

\section{0- ADVENTURES OF A BASHFUL IRISHMAN. (LoNDON). 1862.}

This is a new ed. of The Exile of Erin; or, the Sorrows of a Bashful Irishman.

DEASE, Alice, Mrs. Chichester. Daughter of J. A. Dease, of Turbotstown, Co. Westmeath. Lives in England. Wrote also Mother Erin, A Priest and His Boys, ifc.

471— THE BECKONING OF THE WAND. Pp. 164. (Sands). 3s. 6d. Very tastefully bound. 1908. (N.Y.: Benziger). 1.00. Cheap edition, 1s. 6d. 1915.

We are used to having depicted with painful realism all our faults, all the defects of Irish life on the material side. This little book denies none of these, but it shows another side of the Irish character, the deep-rooted intense Catholic iaith, the union with the supernatural, that brightens even the most squalid lives. The anecdotes, which are true, are related with delicate insight by one who knows and loves the people. There is a vivid sketch of a Lough Derg pilgrimage. .

\section{2— OLD-TIME STORIES OF ERIN. Pp. 215. (Browne \& Nolan). 2s.} Illustr. by C. A. Mills. 1908.

Sixteen old Gaelic hero legends retold in simple, lucid style for children. Most of them are well-known: "The Wise Judgment of Cormac Mac Art"; "The Neck Pin of Queen Macha" "; "The Chivalry of Goll Mac Morna," \&c.

473- GOOD MEN OF ERIN. (Browne \& Nolan). 2s. Six Illustr. 910.

Stories of a quaint legendary kind connected with nine Irish Saints. Prettily told.

474-THE MARRYING OF BRYAN; and Other Stories. Pp. 83. (Sands). 7d. Coloured frontisp. (N.Y.: Benziger). 0.50. Second edition. 1911.

Six little tales, slight in theme, but delicately wrought. They are the poetry of real life, mostly Irish peasant life. A moral may be gleaned from each, but there is no irritating insistence on it. One tells how, through his love for birds and his 
DEASE, Alice, Mrs. Chichester-(routinued).

fear of frightening them, a good old P.P. loses his chance of a canonry. Another tells of the beautiful neighbourly charity of the Irish peasant. Four are love stories. They are perfect of their kind.

474A- GOOD WOMEN OF ERIN : The story of their Heroic Lives and Deeds. (Washbourne). 2s. Illustr. n.d.

Fourteen stories founded upon Irish history and old tradition.

475_ SOME IRISH STORIES. Pp. 96. (C.T.S.). 6d. Stiff wrapper, 1912.

Eight little stories similar in character and qualities to Down West, q.v.

476_ - THE LADY OF MYSTERY. Pp. 159. (Duffy). 2s. 1913.

Better class Catholic family life somewhere in the West-O'Malleys, Dillons, Burkes. Two interwoven love-stories, a mystery of identity, and the story of a philanthropic enterprise, the Drinagh Mills. Thoroughly Catholic atmosphere and moral purpose.

477- DOWN WEST, and Other Sketches of Irish Life. Pp. 119. (Roemanipton: The Catholic Library). 1.. Preface by Sir H. Bellingham. 1914.

Glimpses of real life in Connemara and Aran (described p. 48 sq.), dealing less with outward incidents than wlith the beauty of the people's faith, the hardness of their lot, the joys and sorrows of their lives. Told with a very delicate suggestiveness, full of touches of humour and of feeling, without preaching or moralising, by one in thorough sympathy with the people, and alive, too, to all the influences of nature. The dialect is reproduced with great fidelity.

DEASE, ChARLOTTE. B. at Rath House, Queen's Co. Educated in the Convent at Saint Germain en Laye of the "Dames de Saint Thomas de Villeneuve," originally founded for the children of Irish Jacobite exiles, and at the Sacré Cœur. Has written many short stories and sketches of Irish peasant life for Irish and English periodicals, and also articles on various subjects. Besides this book of stories she has published a book of Irish. (Gaelic) prayers, collected in large part direct from Irish speakers, and a Rhymed Alphabet of Irish Saints.

478- CHILDREN OF THE GAEL. Pp. 196. (Washbourne). 2s. 6d. (N.Y.: Benziger). 0.75. 1911.

Eight little studies-vignettes-of Irish peasant types, evidently drawn direct from real life. They are in narrative form, but in most the incident is slight. They give curiously vivid glinpses of the life of the poor, of which the Author has intimate knowledge. The tone is Catholic and "Gaelic." The Author avoids phonetic renderings of peasant dialect.

DEBENHAM, Mary H. Author of The Captain of Five, Sowing and Harvesting, A Flood Tide, and some twenty other stories, historical for the most part. Also two miracle plays: "The Coming of the Dawn" (St. Columba) and "The Light Bearer's" (St. Patrick).

479_ CONAN THE WONDER WORKER. Pp. 302. (National Society). 3.s. 6d. Four or five illustr. (N.Y.: Whittaker). 1902.

Norway, c. 912-3. Conan is a Christian Scot (i.e., Irtshman) who is captured by a Viking, and brought to Norway. In time he converts the Viking and his family. A good story for children, and even for grown-ups. 
DEBENHAM, Mary H.-(continued).

480 _ THE SHEPHERD PRIOR; and other Stories for Sunday Evenings. Pp. 252. (National Society). 2s. 6d. Four illustr. by Violet M. Smith. (N.Y.: Whittaker). 1907.

Written for children in a religious vein, with a moral attached. Only one story deals with Ireland, "The Great Handwriting." In it the conversion of the King's daughters by St. Patrick is prettily told. Protestant, but not unsuited to Catholic childreu.

DEENEY, Daniel, a National School Teacher, and a native speaker of Irish.

481- PEASANT LORE FROM GAELIC IRELAND. Second edition. Pp. xv. +80 . (Nutt). 1s. Stiff wrapper. 1901.

Relates to the Donegal Highlands and Connemara, in the latter of which (at Spiddal, I believe) the writer taught Irish. Consists of illustrations of the peasants' belief in the preternatural world of spirits and fairies and influences, with examples of common superstitious practices. The writer, if he does not share these beliefs, at least is very far from despising them. "The majority of them [the items included] were related to me in the broken English of a Western peasant "(introd.). The book is chiefly interesting to folk-lorists.

The same Author's Tales and Superstitions of the Connaught Peasants. (Nutt), 1s., 1901, is a collection similar to the preceding.

\section{DENANCÉ, L. V.}

482 _ O'SUTLIVAN, DERNIERE INSURRECTION DE L'IRLANDE. Pp. 130. (LiMOGES: Ardant et T'hibant). 1874?

Historical introd. very favourable to Ireland. Scene of story: Cork. Relates incidents of '98, including French expedition. Told by O'S. himself, part of whose adventures take place in Africa. The last page brings him back to Ireland.

\section{DENNY, Madge E.}

483- IRISH TOWN AND COUNTRY TALES. Pp. 232. (Sealy, Bryers). $1 s$. An ugly cover. n.d.

Pleasant little tales, some of them humorous, written in a light, breezy style. Many of them deal with love and courtship, and are sentimental enough, but not in the least objectionable.

DENVIR, John. Born 1834, at Bushmills, Co. Antrim. Lived nearly all his life in England (Liverpool, London, and Birmingham). Throughout his long career he never ceased to work for Ireland. Conducted for some years the Catholic Times. Publ. The Irish in England and his own autobiography. The Lite Story of an Old Rebel (1910), new ed., 1914. He has publ. a considerable number of popular books in London about Ireland, including " Denvir's Irish Library," booklets at a penny each. The first series was in 1870, the second 1902. One of his pen-names was "Slieve Donard." D. at Wimbledon, 1916.

484 THE BRANDONS : a Story of Irish Life in England. Pp. 153. (Denvir's Irish Library). 2s. 6d. Paper 1s. 1903.

An Italian carbonaro tragedy that by a strange combination of circumstances comes into a peaceful backwater of Liverpool, Homer's Gardens, and mingles with the lives of its Irish inhabitants. A romantic interest is added by the love of Hugh and Jack Brandon for Rose Aylmer. Jack's self-sacrifice is rewarded in the end. There are several pleasant Irish characters besides Hugh and JackFather MacMahon, genial, generous, and fatherly; Mick Muldowney and his wife, rough customers enough, but always cheery, and willing to share their last crust with anyone in need. 
DENVIR, John-(continued).

484A- OLAF THE DANE. Pp. 103. (Sealy, Bryers). 6d. H'aper.

Scene: Donegal. Extraordinary story, full of sensational incidents. It turns chiefly on a prophecy made in the ninth century about men then living, which is fulfilled in their descendants of the nineteenth century. One of these latter is endowed with supernatural powers. There are some pretty faithful pictures of the peasantry.

[DERENZY, M. G.]

485- THE OLD IRISH KNIGHT : a Milesian Tale of the Fifth Century. Pp. 186. (London: Poole \& Edwards). 1828.

By the Author of A Whisper to a Newly-married Pair, Parnassian Geography, \&c. In spite of an apparent effort to be archæologically correct the book is full of rather absurd anachronisms. There are already in Ireland abbeys with long lines of arches, there is talk of the finest organ in Europe being purchased for one of them, and so on. The story does not hang together. It is merely a string of disjointed incidents, most of them wholly improbable.

DESART, Earl of, William O'Connor Cuffe, 4th Earl, B. 1845, ed. at Eton and in Germany. Wrote several successful novels, e.g., The Honourable Ella, Kelverdale, Lord \& Lady Piccadilly, and many others.

486- MERVYN O'CONNOR and other Tales. 3 Vols. (Hurst \& Blackett). 1880.

The title story (which appeared originally in VANITY FAIR) is an unwholesome tale, turning upon conjugal infidelity, and upon a family curse according to which the heirs of the O'Connor family are doomed to die for some woman. Mervyn accidentally kills his father in a discreditable scuffle. The story takes leave of Mervyn and his mother living miserably in Ireland and longing for death. In the 3rd Vol. is a sporting tale, "The Pride of Kilclare," told in humorous vein. Several of the stories are not Irish in subject.

D'ESPARBES, Georges. The Author is a distinguished writer, and very prolific, having produced a long series of novels, volumes of verse, \&c. Born in 1863 in the department of Tarn-et-Garonne.

487- LE BRISEUR DE FERS. Pp. 316. (PARIS: Louis-Michaud). 3f.10. [1908]. New edition, 1911.

Dedication (to Colonel Arthur Lynch), and Preface (telling about the erection of the Humbert Memorial at Ballina). Humbert's invasion told in impassioned and somewhat high-flown language. Describes some of the episodes with extraordinary vividness. Based mainly on reliable works, but not strictly historical.

DEVINE, D. C. Is a native of Tubbercurry, Co. Sligo, where at present he is a National School Teacher. Is a man of about 50 .

488- FAITHFUL EVER, and Other Tales. Pp. 280. (Duffy). 2s. 1910.

Eleven stories of Sligo peasant life. The Author has thorough sympathy with the aspects of life about which he writes. Three of the tales are love stories, one is a story of '67, others are humorous, e.g., "Meehaul M'Cann's Wooing." We have a glimpse of the dance, the pattern, rustic courtship, lake and mountain scenery. The Author avoids politics, but the Catholic atmosphere is pronounced throughout. The literary standard is, perhaps, not of a high order.

489 BEFORE THE DAWN IN ERIN. Pp. 308. (Duffy). 2s. [1913]. Second edition. 1914.

A story of landlord, agent, and tenant in the County Sligo, about the eighteen thirties or forties, bringing out what a hostile agent can do to make the lot of the peasants a very hard one, and showing how in the end his machinations are brought 
DEVINE, D. C.-(continued).

to nought thanks to Father Pat. This latter and Father Tom are fine types of Irish priests. The Author has a good eye for characters and a keen sense of humour.

DILLON Patricia. Born in Dublin. Educated chiefly in France. Has lived most of her life in London. Has written for periodicals on historical subjects for the most part.

490- EARL OR CHIEFTAIN. Pp. 140. (C.T.S. of Ireland). 1s. 1910.

The opening career of Hugh O'Neill looked at on its romantic side, including his marriage with Mabel Bagenal. Other historic characters appear in the tale, notably Feagh MacHugh O'Byrne.

DODGE, W. P.

491- THE CRESCENT MOON. Pp. 125. (Long). 1s 6d. 1911.

A little love story, told skilfully enough in letters from Sir Desmond Fitzgerald to his brother in S. Africa.-[T. Lir. SUPPL.].

DOLLARD, Rev. J. B. B. 1872 at Mooncoin, Co. Kilkenny. Ed. there and at College School, Kilmacow. Ordained in Toronto, 1896, where he has since worked. Is now Pastor of St. Monica's, Toronto. Has written much for American periodicals. Publ. vols. of verse, Irish Mist and Sunshine. and Irish Lyrics and Ballads. (Kenedy, 1917).

492- THE GAELS OF MOONDHARRIG. Pp. 124. (Sealy, Bryers). 6d.

A collection of pleasant, breezy tales of the exploits, especially in hurling, of the young men of Moondharrig (South Kilkenny), showing an intimate knowledge and love of the people of the Author's native place. An unobtrusive spirit of piety runs through it.

DONELAN (Miss A. M.). Author of What 'tis to Love (1873) and Flora Adair (1867).

493 _ THE VALUE OF FOSTERSTOWN. A tale oî Irish life. 2 vols. (Chripman \& Hall). 1871.

Plot turns on two brothers, Fosters, one of whom in the Penal times became a Protestant to save the property. A curse seems to weigh on his descendants, all of whom meet with misfortune. Margaret Foster wishes to make amends and restore the property to her cousin Reginald. After many contretemps arising from an intercepted letter $M$. and $R$. are happily united. Scene: Bray, also Dublin, Brussels and Rome. Strongly Catholic in standpoint.

DORSEY, Anna Hanson.* Born Georgetown, D.C., 1815. Received into the Catholic Church, 1840. She is a pioneer of Catholic light literature in the States. Nearly all her stories-there are more than thirty of them-have a religious purpose, but as a rule this is not too much forced on the reader. She was a Laetare medallist, described as the highest honour the Church in America can bestow. Some titles of her books are-Tears on the Diadem, Dummy, Tangled Paths, Warp and Woof, and her last, P'alms, which was by many considered her best.

494-THE HEIRESS OF CARRIGMONA. Pp. 381. (Boston: Murphy). Third thousand. (Washbourne). 4s. 1910.

Scene: Co. Wicklow and Western U.S.A. Chiefly concerned with the fortunes of an Irish peasant family named Travers, especially the son, who goes to America,

* Her daughter, Ella Loraine Dorsey, has written even more than Mrs. A. H. Dorsey, and is one of the most prominent figures in American Catholic literature. 
DORSEY, Anna Hanson-(continued).

gets into trouble, is rescued, and then-. A strong warning against emigration is conveyed in this latter part of the story. Mrs. Dorsey's peasants here, as usual, are life-like and interesting. Their best cualities-trust in Providence, resignation under trial, piety, self-sacrifice-are well brought out. The brogue is not overdone. Anti-Irish characters represented as mean and hypocritical.

495- MONA THE VESTAL. Pp. 163-324. $\quad$ (N.Y.: Christian P'ress
Association Publishing Co.). n.d.

Bound in same vol. as "Norah Brady's Vow" and under latter title. An endeavour to place the heroic virtues of new Christians in contrast with the decaying Druidic paganism. The writer claims the Abbé McGeoghegan's authority (also that of Mooney and Carey) for her descriptions of the Ireland of the time. But, with the exception of the incident of Patrick's arrival at Tara, the story and its setting are purely imaginary and ideal. The Druids worship in vast temples with long corridors and fine carvings. Tara is a great city of marble palaces.

495__ NORA BRADY'S VOW. Pp. 160. (N.Y. : Christian P'ress Association Publishing Co.). 0.50. n.d.

Nora is only a servant girl, but is, without suspecting it, a true heroine. But she is no saint, and has a sharp tongue in her head. Her witty sallies are cleverly reproduced. The Author tells us that Nora was a " real and living person." John Halloran takes part in the rising of '48, and is obliged to fiy to America. Nora vows not to settle down in life until the fortunes of the Hallorans are restored. She goes to America, works to support the family, which has been ruined by an informer, and at length finds Halloran, and reunites the family once more. Scene: near Holy Cross Abibey on the Suir, afterwards Boston. On the whole the tone and style are very enotional, but with an emotion that rings true. This is relieved by not a few gleams of pleasant humour. Irish dialect well done. Sympithy strongly national.

DOTTIN, Henry Georges. Born 1863 in France. Prof. of Greek Lit. (1905) at the University of Rennes. Has contributed to learned reviews and has published several learned works, La religion des C'eltes, 1903; La Bretagne et le Culte du Passé, 1900.

497- CONTES IRLANDAIS TRADUITS DU G.IEIIQUE. Pp. 274 (RENNes). 1901.

Tales, thirty-five in number, collected in Conuaught and republished from the “Annales de Bretagne," tome $x$.

N.B.-A book with the title of "Contes Irlandais" was published by Messrs. Gill, of Dublin, $70 \mathrm{pp}$., 4to. 7s. 6d. It consists of extracts from the untranslated port:on of Douglas Hyde's "Leabhar Sgenluigheachta " translated into French by M. Georges Dottin, with the original Irish text in Roman letters on the opposite page.

498- CONTES ET LEGENDES D'IRLANDE. P!. 218. (Te Havre) 3 fr. 50. 1901.

See previous item. Thirty-eight tales translated from Irish texts, published without translation in the Gaelic Joumal since 1882 . Collected in all parts of Ireland, e.g., Les exploits de Fion MacCumhail et de son géant Seachrin. Fion MacCumhail et son pouce de science. Le Gobán Saor et Saint Moling. Ia belle fille rusée du Gobán Saor. Le trèfle à quatre fenilles, \&c.

DOUGLAS, James. Born in Belfast of a Tyrone family. Is assistant editor and literary critic of the London Star. Author of The Man in the Pulpit, Adventures in London, \&c. Contributes to Anthendum, Bookman, \&c.

499- THE UNPARDONABLE SIN. Pp. $\mathrm{x}+418$. 6s. (Grant Richards). 1907.

Falls into two parts. Part I. describes upbringing of a boy in Belfast (Bigots- 


\section{DOUGLAS, James-(continued).}

borough). Pictures sectarian hatred leading to riots, in one of which, vividly described, the hero loses a little brother. Other characters finely portrayed are "Jane the Nailor" and the then Head Master of the Model School ("the Castle"). In Part. II. the boy has become a great preacher. All London flocks to hear him, but he is beset with doubts and difficulties. W. B. Yeats and Miss Maud Gonne are introduced under thinly disguised names. The first part has been called by editor of I.B.L. " the finest delineation of Belfast boyhood ever penned." The second part has been not inaptly described as "the dream of an opium-eater."

DOWLING, Richard. B. in Clonmel, Co. Tipperary in 1846. Ed. at Crescent College, Limerick, where he gained the friendship of Father Matithew Russell, S.J. Lived some years at a shipping office in Waterford, where he acquired a great love for things nautical. He did much journalistic work here and afterwards in Dublin, where he edited the comic papers, Zozimus and Ireuand's Exe. In 1874 he went to London, and lived there till his death, in $1898 . \mathrm{He}$ wrote much for Tinsley's MAGAziNE and many other London periodicals. His best work, perhaps, is contained in his volumes of essays-On Babies and Ladders, Ignorant Essays, Indolent Essays. Other novels (he published nearly 20) are The S'port of Fate, Under St. Paul's, The Weird Sisters. (See I.B.L., vol. ix., page 1 ).

500 THE MYSTERY OF KILLARD. Pp. 357. (Tinsley Bros.) [1879]. New edition, 1884.

A tale of the Clare coast and its fishing population (drawn with much skill and fidelity) half a century back. The story centres in a mysterious and romantic rock unapproachable by sea, and connected with the land by a single rope only. There is a mysterious owner, or rather a series of them, and mysterious gold. But the central idea of the book (one of the most original in literature, it has been justly called) is the study of a deaf-mute who, by brooding on his own misfortune, grows to envy and then to hate his own child, because the child can hear and speak.

501- SWEET INNISFAIL. Three Vols. (Tinsley). 1882.

Scene: chiefly the neighbourhood of Clonmel. The interest is mainly in the plot, which is full of dramatic adventure and of movement, without any very serious study of Irish character.

502 — OLD CORCORAN'S MONEY. Pp. 310. (Chatto \& Windus). Crown 8vo. Cloth. 3s. 6d. 1897.

Money is stolen from an old miser. The interest of the complicated plot centres in the detection of the thief. Clever sketches of life in a southern town. Characters carefully and faithfully drawn, especially Head-Constable Cassidy, R.I.C.

503_ ZOZIMUS PAPERS. (N.Y. : Kenedy). 0.38 net. 1909.

" A series of comic and sentimental tales and legends of Ireland." The title is most misleading. There are six pages of an introduction dealing with Michael Moran, a famous Dublin "character," nicknamed Zozimus. The rest of the book consists of a series of stories of Carleton, Lover, Lever, Barrington, \&c. The contents have nothing to do with Dowling, nor with the famous periodical Zozrmus.

DOWNE, Walmer, Author of The Bloom of Faded Years. (Greenock, 1896). A Scottish story.

504- BY SHAMROCK AND HEATHER. Pp. 325. (Digby, Long). 1898.

Scene: mainly in Ards of Down, near Strangford Lough, but shifts to Edinburgh, London, and Capetown. Theme: an American girl visiting her father's native place in Ireland. Consists largely of gossip about the characters introduced, not rising above this level. The writer likes Ireland and the Irish, but knows little of them. There is an air of unreality and improbability about the whole book. Some prejudice against Church of Ireland clergymen is displayed. 
DOWNEY, Edmund; “F. M. Allen." Born (1856) and educated in Waterford. Being the son of a shipbroker, he came to know well the various sea types that frequent a port. Went to London at 22, and became partner in the firm of Ward and Downey. Retired in 1890, and in 1894 founded Downey and Co. Both of these firms, especially the latter, did a great deal for the publishing of Irish books. His writings are many and varied. They include humorous sketches, extravaganzas, sea stories, fairy tales, sensational stories, a biography of Lever, a volume of reminiscences, and a history of Waterford, and the two novels, Clashmore and the Merchant of Killogue. $\mathrm{He}$ at present carries on a publishing business in Waterford, and owns and edits The Waterford News.

505- IN ONE TOWN. (Ward \& Downey). 2s. [1884].

A seafarer's life ashore. Scene: a port not unlike Waterford. Many portraits of old salts, \&c., drawn from life. Some descriptions of scenery. "By turns romantic, pathetic, and humorous "-(Review).

506- ANCHOR WATCH YARNS. Pp. 315. (Downey). [1884]. 7th ed. n.d.

Yarns told in quaint nautical lingo by old salts around the inn fire in a seaport town. The characters of the teliers are very cleverly brought out in the telling. Full of humour without mere farce.

507- THROUGH GREEN GLASSES. ( I ard \& Downey). Various prices from 6s. to $6 d$. [1887]. Many editions since. (N.Y.: Appleton). New ed. (WATERFord News). 6d. 1918.

This now famous book belongs to the same class as the Comic History of England, but its humour is much superior in quality. It consists of a series of historical or pseudo-historical episodes, purporting to be related by a humorous Waterford countryman, Dan Banim, as seen from his point of view. Kings and princes, saints and ancient heroes, all play their part in the delightful comedy, and talk in the broadest brogue. "From Portlaw to Paradise," one of the best known, may be taken as a type. King James's escape after the Boyne is also admirably done.

508_ THE VOYAGE OF THE ARK. (Ward \& Downey). 1s. [1888]. Several editions since.

The scriptural narrative of Noah and the Ark is made the basis for a $s$ ries of farcical episodes related in brogue.

509_ FROM THE GREEN BAG. (Ward \& Downey). 2s. 6d. and 1s. 1889.

More stories by "Dan Banim," like those in Through Green Glasses. The Pope and St. Patrick, Horatius and Julius Cæsar figure in the stories. We cannot see that these stories are "irreverent" in any serious sense, though they have sometimes been taxed with irreverence.

510 BRAYHARD: the Strange Adventures of One Ass and Seven Champions. Pp. 308. (Ward \& Downey). 2s. 6d. 37 Illustr. by Harry Furniss.

Extravaganza founded on legends of the Seven Champions of Christendom. Full of jokes, repartees, and comic situations.

\section{1- CAPTAIN LANIGAN'S LOG. (Ward \& Downey). 2s. (N.Y.: Pratt).}

1.75. 1891, and since.

Story of an Irish-Canadian lad who runs away to sea, and goes through all sorts of adventures full of excitement and fun.

512- GREEN AS GRASS. (Chatto o Windus). 3. 6d. (N.Y.: Pratt). 1.75. 1892.

More "Dan Banim" stories. The first, running to 160 pages, is a humorous account of Dermot MacMurrough's love affair with Dervorgilla, and his ietrityal of Ireland. Another tells how the Earl of Kildare found out that Lambert Simnel was an imposter by the latter's skill in cooking griddle cakes. 
DOWNEY, Edmund-(continued).

513 - THE ROUND TOWER OF BABEL. (Ward \& Downey). 1s. Several editions; first, 1892.

Further adventures in foreign parts of descendants of the Co. Waterford voyagers in the Ark.

514- THE LAND-SMELLER. (Fard i Downey). [1892], and severa]
editions since.

Yarms of sea-captains.

515 - THE MERCHANT OF KILLOGUE: $a^{\star}$ Munster Tale. 3 vols. (Heinemann). [1894]. Single vol. eds. since.

A story of shopkeeping life in an inland Munster town (there are indications of Clonmel) in days preceding the introduction of the ballot system at elections. This is perhaps the Author's ablest piece of sustained and serious fiction.

516- BALLYBEG JUNCTION. Pp. 276. (Downey). Very well illustr. by John F. O'Hea. (N.Y.: Pratt). 1.75. 1895.

A comedy of southern Irish life, full of fun, without farcical exaggeration, and true to reality.

517- PINCHES OF SAIT. Pp. 246. (Downey). 3.s. 6d. 1895.

Nine Irish tales, mostly humorous, not told in dialect; full of keen observation of Irish life.-(Review). "The Eviction at Ballyhack," and "The Viceroy's Visit" are among the best.

518- GLIMPSES OF ENGLISH HISTORY. (Doneney). 3.s. 6d. Illustr. by J. F. Sullivan. 1901.

Versions of episodes in English History told by "Dan Banim" in his usual dialect.

519- THE LITTLE GREEN MAN. Pp. 152. (Downey). Illustr. very tastefully by Brinsley Lefanu.

The pranks of the Leprechaun and his dealings with his human friend Denis. $A$ delightful fairy-tale, told with a purpose, which does not take anything from its interest.

E20- CLASHMORE. Pp. 406. (Waterford: Downey). 1s [1903]. New edition. 1909.

A tale of a mystery centring in the strange disappearance of Lord Clashmore and his agent. The story is healthy in tone, and never flags. There is a pleasant love interest. The dénouement is of an original and unexpected kind. The scene is the neighbourhood of Tramore and Dunnore, Co. Waterford. There is little or no study of national problems or national life, but some shrewd remarks about things Irish are scattered here and there in the book. The characters are not elaborately studied, but are well drawn.

521 - DUNLEARY: Humours of a Munster Town. Pp. 323 (Sampson, Low). 6s. 1911.

Fourteen capital yarns told with great verve and go just for the sake of the story. They are all humorous, just avoiding upioarious farce. The personages of the stories are the various queer types to be met with in a small southern port:the convivial spirits in the local semi-genteel club, those of lower degree who foregather in the bar parlour of the "Dragon," the rival editors of the local papers, the candidates for the harbour mastership, the skippers of the Dunleary steampacket company, the professional jail-bird-Mickey Malowney, and the "general play boy" Jeremiah Maguire. There is no stage Irishism and no politics. Dunleary might be New Ross, or some other similar river port. 
DOYLE, J. J., a well-known Gaelic League Author.

522- CATHAIR CONROI, and other Tales. Pp. 45. (Scaly, Bryers). 6d.

Written for the Oireachtas, 1902, and now translated by the Author from his own Irish original. I. A folk-tale. II. A trick played on the Board of Works Inspector. III. Mitching from School and so on.

"DOYLE, Lynn"; Leslie A. Montgomery. Born Downpatrick, Co. Down. Educated at Educational Institution, Dundalk. Has written a successful play,

"Love and Land." Is a bank-manager, residing at Skerries, Co. Dublin.

523- BALLYGULLION. Pp. 249. (Maunsel). 6s. Handsome cover. [1908]. Cheap edition, 1s. 1915. New ed. illustr. by William Conor. 5s. 1917.

A dozen stories supposed to be told by one Pat Murphy, in the humorous brogne affected by country story-tellers. Comic character and incident in neighbourhood of Northern town. Considerably above the usual books of comic sketches. A good example of the humour is "The Creamery Society "- the visit of the Department's expert, and his failure to make butter from whitewash, and the difficulties that arise incidentally between Nationalists and Orangemen, followed by Father Comnolly's famous speech. Perhaps "Father Con's Card-table" ought to have been omitted.

524- MR. WILDRIDGE UF THE BANK. (7)uckworth). 6s. [1916]. repr. 1917.

The intimate life of a North of Ireland town portnayed from close acquaintance and keen observation. The view point is humorous, without being merely comic or over satirical. It is a study in character and manners, but the interest of the plot never flags. The hero schemes to benefit the town in spite of itself. $\mathrm{He}$ weaves Sinn Feiners, Hibernians, and Orangemen into his plot by humouring them severally. Nora, the Rector's lively daughter, provides the sentimental element, while the rivalry of the local banks and the interplay of character (amusing local types are cleverly sketched) provide much genuine humour.

[DOYLE, M.]; "M. E. T."

525- EXILED FROM ERIN. Pp. 266. (I)uffy). n.d. (N.Y.: Benziger). 0.45.

A homely, pleasant tale, relating the pathetic life-story of two brothers of the peasant class. The scene of the first part of the tale is laid in Shankill. Vale of Shanganagh, Co. Dublin, afterwards it changes to Wales, and then to America. The Author tells us that his story is a true one, and that his endeavour throughout has been to draw a faithful and sympathetic picture of the life of the humbler classes. The sorrow and misfortune of emigration is feelingly rendered.

" DRAKE, Miriam." See Clarke.

DREISER, Theodore. Author of Sister Carrie, The Financier, the Titan, The Genius.

526- JEN NIE GERHART. (Harper). 6s. 1.35. 1911.

"A piece of industrial realism, inirtistic and undramatic, but thoroughly honest and full of serious thought. The fortunes of two immigrant families, German and Irish, are contrasted. Jennie is the daughter of the unsuccessful Germant, and falls a viotim to the pleasure-loving son of the enterprising Irishman, who illustrates the dangers of our .... social organisation."-(Baker 2).

\section{DROHOJOWSKA, Mme. la Comtesse.}

527- RECITS DU FOYER, LEGENDES IRLANDAISES, SCENES DE MAEURS. Pp. 208. (PARIS : Josse). 1861.

Introd. very favourable to Ireland, but based on insufficient and not first-hand information. It dwells chiefly on Irish religious faith; also on superstition in Ireland. Then come the legends-King Laura Lyngsky, Glendalough (King O'Toole's Goose), Donaghoo (a learned schoolmaster, who found a gold mine); King O'Donoghue (Killarney)', Gnace O'Malley and Queen Elizabeth, The King of Claddagh, John O'Glyn (a fisherman who marries a mermaid, and joins her in the sea), Jiames Lynch, \&c. 


\section{DUFF, GORDON, Lady.} 528 STELLA AND VANESSA. Trans. (Ward, Lock). [1850: Bentley]:

Days of Swift, c. 1730. From the French of Léon de Wailly. The scene is laid entirely in Ireland. The story opens at Laracor. Swift is, of course, one of the central figures.

DUFFIN, Helen. A Belfast lady, great-granddanghter of William Drennan.

529 OVER HERE. Pp. viii.+309. (Methuen). 6s. n. 1918.

A tale of the Irish middle classes (Protestant) in happy pre-war days, of untroubled country house life with its tennis and afternoon teas and picnics. Patricia Benson goes to Derrymore, Co. Down, as companion to Honor Shannon, a girl of weak mind and melancholy disposition, who is at the mercy of wicked, scheming servants. The plot consists of the progress of several mild love affairs, broken in upon for a time by a ghost mystery. No problems nor politics of any kind. A fresh, pleasant story. A first novel.

DUFFY, Bernard. B. Carruckmacross, 1882. Ed. (but for a stay in Clongowes Wood College which was very brief, owing to ill health) at Grammar School, Carrickmacross and T.C.D. (B.A., 1905). Called to the Bar, 1907. Has engaged much in journalism. Has had five plays produced since 1915.

530_ ORIEL. Pp. 383. (T'albot Press). 7s. net. 1918.

Scene: "Farney" (Carrickmacross), the way from there to Dublin, and Dublin itself. Life story of a foundling. Rather a loosely-strung series of episodes than an elaborate plot. Glimpses of life in country town, with pleasantly-drawn sketches of lucal types, including the delightful old Dean. Also glimpses of life among the queer folk of the roads and the fairs, a quack doctor, itinerent players, etc. Throughout there is a genuine sense of reality without affectation or strain. There is some quiet humour. In the recorded talks the brogue is not overdone. Thoroughly Irish and Catholic, without any controversy.

\section{DUGGAN, Ruby M.}

531_ ONLY A LASS. Pp. 169. (Sealy Bryers). 6d. Paper.

A sensational story, with nothing specially Irish about it. The only Irish character is almost a carioature.

\section{DUNBAR, Aldis.}

532_ THE SONS O' CORMAC; an' Tales of other Men's Sons. Pp. x. +240. (Longmans). 6s. Eight illustr. by Myra Luxmoore. 1904.

" Some of the old heroic legends retold by a humorous Irishman for children." (Baker). The stories (there are twelve) are very clever, picturesque, and, like all good tales of faërie, full of unconscious poetry. - I.E.R.

DUNN, Joseph. (Professor in the Catholic University of Washington, D.C., U.S.A.).

533-THE ANCIENT IRISH EPIC TALE: TAIN BO CUALGNE, THE CUALGNE CATTLE RAID. Now for the first time done entire into English out of the Irish of the Book of Leinster and allied Manuscripts. Pp. xxxvi. +382. Demy 8vo. (Nutt). 25s. 1914.

Pref., on Irish Epic in general, and on the Táin in particular. The Editor calls it " the wildest and most fascinating saga tale, not only of the entire Celtic world, but even of all Western Europe." The work is a scholarly one, the various MSS. being carefully collated by means of marginal and foot-notes. The Irish text is not given. Index of place and personal names. A somewhat archaic style is adopted, but this is not overdone. "The Táin," says the Ed. truly, " is one of the most precious monuments of the world's literature.". 
[DUNN, N. J.].

534-VULTURES OF ERIN : a Tale of the Penal Laws. Pp. 530. (N.Y.: Kenedy). 1.50. One woodcut. 1884.

Edward Fitzgerald is robbed of his property by his enemy, Templeton, who accuses him falsely of a murder instigated by himself. Shemus M'Andrew plots and plans to save Fitzg., but the latter is nevertheless condemned to death, and his wife loses her reasor $\mathrm{He}$ escapes, however, and after many years returns with proof of T.'s guilt. The wife recovers, and all ends happily. Scene : between Slieve Bouchta and Lough Derg. Religion not formally introduced, but Catholic bias very strong. Penal laws denounced, and scripture-readers appear in unfavourable light.

DUNNE, Finley Peter. B. 1867 in Chioago; ed, common schools in his native city and by the Jesuits; has been in journalism since 1885, and has edited several important Chicago newspapers. Resides in N.Y. (American CATHolic Who's WHo).

535 - THE DOOLEY BOOKS:-

1. MR. D. IN PEACE AND WAR. (Routledge). 7th ed. 1906.

2. MR. D.'S PHILOSOPHY. (Heinemann). 3s. 6d. Illustr. 1901.

3. MR. D.'S OPINIONS. (Heinemann). 3s. 6d. 1905.

4. MR. D. IN THE HEARTS OF HIS COUNTRYMEN. 1909.

5. OBSERVATIONS BY MR. D. (Heinemann). 3s. 6d.

6. DISSERTATIONS BY MR. D. (Harper). $6 s$.

7. MR. DOOLEY SAYS. (Heinemann). 3s. 6d. 1910.

A series of fictitious conversations purporting to take place over the counter of his bar in Archey road, a seedy Irish quarter of Chicago, between Mr. Dooley, "traveller, historian, social observer, saloon-keeper, economist, and philosopher," who has not been out of his ward for twenty-five years " but twict," and his friend Hennessy. From the cool heights of life in the Archey road Mr. Dooley muses, philosophizes, moralises on the events and ideas of the day. He talks in broad brogue (perhaps overdone), but his sayings are full of dry humour; and the laugh is always with him. Many of these sayings have the point and brevity of epigrams. No ridicule is cast on Irish chanacter, with which the Author, himself an Irishman, obviously sympathises. The view of politics, \&c., is wholly at variance with that which comes to us from the English Press.

\section{DUNNE, F, W.}

536 - THE PIRATE OF BOFINE; an historical romance. Three Vols. 12mo. (LONDON). 1832.

A strange medley of melodramatic episodes. The story jumps from place to place in the most bewildering way, and wholly without warning to the reader. Scene laid in various parts of the W. of I. (Broffin, Galway, Bantry, \&c.) in reign of Henry VIII. Historioal characters are introduced, but without historical background. Style: "Know you aught of my maternal parent." (Vol. III., p. 15). " Fire flashed from bis eyes, and death sat upon his gleaming blade," and so forth.

"EBLANA," see ROONEY.

ECCLES, Charlotte O'Conor; " Hal Godfrey." Was a daughter of A. O'C. Eccles, of Ballingard Ho., Co. Roscommon. She wrote first for Irish periodicals. Later she went to London, and became a prominent lady journalist there. Her The Rejuvenation of Miss Semaphore is a very clever and witty novel. D. in 1911.

537— ALIENS OF THE WEST. Pp. 351 (Cassell). 6s. 1904.

Six stories reprinted from the American Ecclesiastical Review (Catholic) and the Pall Mall Magazine. Scene: "Toomevara," an Irish country town of about 


\section{ECCLES, Charlotte O'Conor-(continued).}

2,000 inhabitants, near Shannon estuary. Life in this town is depicted in a realistic and objective way, without moralizing, and without obtrusive religious or political bias. Yet there are lessons-the miseries of class distinctions and of social and religious cleavage; the disasters of education above one's sphere (even in a convent). There is much pathos in the death of the peasant iboy-poet, and in the faithfulness of the servant girl to the fallen fortunes of the family. A serious and earnest book.

\section{EDELSTEIN, Joseph.}

538- THE MONEYLENDER. Pp. 110. (Dublin: Mollard). Illustr. by Phil Blake. 1908.

A strangely realistic story of Jewish life in Dublin, told with rude power. Written by a Jew, it gives a dreadful picture of the life of the poor in Dublin slums, and of the misery wrought by the Jewish moneylender, who grows rich on their misery. The Jew, Levenstein, who is driven on in his evil course by destre to avenge the sufferings of his persecuted race, is a revolting, yet a pathetic figure.

EDGE, Jchn Henry, M.A., K.C. Born 1841. Son of late John Dallas Edge, B.x. Ed. T.C.D. Was a legal land commissioner. Died Sept., 1916.

539-AN IRISH UTOPIA. Pp. 296. (Hodges \& Figgis). 3s. 6d. Frontnsp., View of Glendalough. 1906 and 1910. Fourth ed. (Cassell), with fine portraits and interesting autobiographical introduction, 1915.

"A Story of a Phase of the Land Problem." Scene: Wicklow County and Shropshire, England. A slender plot, telling of the abortive attempt of a younger twin to oust the rightful heir from title and property, ending with a lawsuit in which some well known lawyers are introduced under slightly disguised names. Father O'Toole is a very pleasant character study. The famous "J.K.L.," Dr. Doyle, Bishop of Kildare and Leighlin, figures in the story. The standpoint is that of an Irish Conservative, without religions bias, and sympathising with certain Irish grievances. Humour, pathos, and brogue are absent.

\section{0_- THE QUICKSANDS OF LIFE. Pp. 392. (Milne). 6s. 1908.}

Scene: first half in England, portion of second half on an estate somewhere in the South of Ireland. The interest centres chiefly in the plot, which is complicated, a great many of the personages passing through quite an extraordinary number of vicissitudes. Though the Author is never prurient, a considerable number of dishonest "love" intrigues are introduced, treated in a matter-of-fact way as every. day occurrences. Of Ireland there is not very much. The land troubles furnish incidents for the story, but are not discussed. The Irish aristocracy shows up somewhat badly in the book. Some tributes are paid to the virtues of the Irish peasantry.

EDGEWORTH, Maria. Scott, in his Preface to Waverley (1829), speaks of "the extended and well-merited fame of Miss Edgeworth, whose Irish chlaracters have gone so far to make the English familiar with the character of their gay and kind-hearted neighbours of Ireland." And he continues: "Without being so presumptuous as to hope to emulate the rich humour, tho pathetic tenderness, and admirable tact, which pervade the works of my accomplished friend, I felt that something might be attempted for my own country, of the same kind as that which Miss Edgeworh has so fortunately achieved for Ireland." She came of an old County Longford family, but was born in England in 1767; her father was a landed proprietor at Edgeworthstown, Co. Longford. She afterwards wrote a biography of him. Most of her long life was spent in Ireland. She came to know the Irish peasantry very well, though from outside, and also the country life of the nobility and gentry. She had much sympathy for Ireland, but was unable to understand that radical changes were needful if the grievances that weighed upon the country were to be removed. She 


\section{EDGEWORTH, Maria-(continued).}

died in 1849. The circulation of her books has been enormous, and they are still frequently reprinted both in these countries and in America. An able and certainly not over-enthusiastic estimate of Miss Edgeworth will be found "in the Dublin Review, April, 1838, p. 495, sq.

Uniform editions of her works: (1) Macmillan, with excellent illustrations, $2 s .6 d$. and $3 s .6 d$. each ; Pocket edition 2s. and leather $3 s . \quad(2)$ Dent, in twelve vols.; $2 s .6 d$. each, very tasteful binding, etched frontisp., ed. by W. Harvey. Messrs. Routledge also publish Stories of Ireland; introduction by Professor Henry Morley; $1 \dot{s}$.

\section{1- TALES AND MISCELLANEOUS PIECES. Nine Vols. (LondoN).}

These were receivedı with a chorus of praise by critics such as Lord Jeffrey, Lord Dudley and Sir James Mackintosh. Scott called them " a sort of essence of common sense."

542- CASTLE RACKRENT. (Macmillan \&.c.). (N.Y.: Pratt). 0.75. [1800].

A picture of the feudal gentry in the latter half of the seventeenth century, in the form of reminiscences by an old retainer of the glories of the family he had served. One after another, he tells the careers of his various masters, the wild waste and endless prodigality of one, the skinflint exactingness of another. There is no religious bias nor discussion of problems, the chief interest being the ingenuous and unquestioned devotion of the old servant and his quaint observations. The literary merits of the books are usually rated very high.

\section{3 - THE ABSENTEE. (Macmillan, \&c.) (N.Y.: Pratt). 0.75. [1809].}

A vivid impression of the Irish nobility trying to dazzle London saciety, and to prove itself more English than the English themselves, while the English great ladies mock at their parvenu extravagance and outlandish ways. The fine lady spends her days in social emulation, while her lord sinks to the complany of toadies and hangers-on, until the conscience of the young heir is aroused by a tour in Ireland, and he brings the thamily back to their estates. The peasants are drawn purely in their relation of grateful and patient dependents.

\section{4- ENNUI. [1809].}

The Earl of Glenthorn, an English-bred absentee landlord, is afflicted with ennui. He determines to attempt a cure by a visit to Ireland, and the cure is effected in a very unlooked for way. The Author draws in an amusing and vivid way the contrast as felt by Lord Glenthorn between English tasites, prejudices, and decorum and the strange Irish ways, which surprise him at every turn.-(Krans).

545—_ ORMOND. P. 379. (Macmillan, Dent, \&c.). [1817].

Pictures of the scheming, political, extravagant gentry, especially of a type of the Catholic country gentleman, the good-natured, happy-go-lucky Cornelius O'Shane, known to his "worshipping tenantry as King Corny. There is also a sketch of Paris society, to which Ormond, the attractive, impulsive young hero, is introduced by an officer of the Irish Brigade. Generally thought the most interesting, gayest, and most humorous of Miss Edgeworth's books.

546- TALES FROM MARIA EDGEWORTH. (Wells, Gardner, Darton). 10s $6 d$. Illustr. "by High" Thomson. 1912.

Introd. by Austin Dobson.

547- MISS EDGEWORTH'S IRISH STORIES (A Selection).

Ed. by Malcolm Cotter Seton, M.A., in Every Irishman's Library. (The Talbot Press). "3s." 6d. 1918. 


\section{EDGEWORTH, Theodore.}

548_THE SHIPWRECK; or, Memoirs of an Irish Officer and his Family. 3 vols. 12mo. (London: Tregg). 1811.

The Irish officer (in the French service), Capt. O'Neill, is wrecked on the coast of Wicklow, and befriended by a Major O'Hiara. The story consists of the fortunes of these two families, ending with the marriages of the young persons of both families. Incidentally many phases of eighteenth century Irish life are depictedthe life of the squireens, the penal laws, life in T.C.D., difficulties of travelling, etc. All is seen from an ultra-English and Protestant standpoint. A parish priest, Father Blarney, is the villain of the pioce. He is represented in a most odious light, every vice being attributed to him.

"EDWARDES, Martin"; Edward Martin Murphy. Son of Mr. W. M. Murphy, of Dartry. Ed. at Clongowes Wood College. He was for many years Managing Director of the Independent Newspapers Co. Died in 1917.

549 THE LITTLE BLACK DEVIL. Pp. 190. (Everett). 3s. 6d., and $1 s$.

A first novel. By a new Irish writer. Scene: Bantry and London. The story of a young Irishman who, badly treated at home by his guardian, goes to London to make his fortune. His heart is broken by an adventuress, but in the end he marries a true woman. A little immature, but pleasant, and suitable for any class of readers.

EDWARDS, R. W. K., Lecturer in Mathematics at King's College, University of London, an M.A. of Cambridge, and author of several works on mathematics. B. 1862, in Isle of Wight. Lived for a year in Ireland in 1884, as a master in Foyle College, Derry, and has been a frequent visitor to Donegal for 25 consecutive years. Spent two summers on Tory Island, the scene of one of his novels.

\section{0- UNCHRONICLED HEROES. Pp. 119. (Dennx: Gailey). 1s. 1888.}

A story of the Siege of Derry. Walker and Mackenzie are introduced, the former highly lauded, the latter disparaged. Appendix (fillng nearly half the book) gives extracts from scarce documents relating to the siege.

551— THE MERMAID OF INISH-UIG. Pp. 248. (Arnold). 3s. 6d. 1898.

To Inish-Uig (Tory Island) with its primitive people, comes a new lighthouse keeper, a scoundrel and a hypocrite, who leads "Black Kate" astray. He tries to turn to account the illicit stilling propensities of the people, but is foiled in an amusing way. Father Tim and a Presbyterian minister on the mainland are two finely drawn characters. The islanders are well described, and their dialect well rendered.

EGAN, Maurice Francjs, M.A., LL.D. Born Philadelphia, 1852. Educated at La Salle Coll., Philadelphia, and Georgetown Coll., Washington. Was Prof. of English Literature in Catholic University of Washington till his appointment as American Ambassador at Copenhagen. Has edited several periodicals, and has contributed to most of the noteworthy periodicals in the States. Has published many books on a great variety of subjects. His father was from Tipperary.

\section{2 - THE SUCCESS OF PATRICK DESMOND. Pp. 400. (Notre Dame,}

INDIANA: Office of Ave Maria). 1893.

A novel with a purpose. "The Author does not waste much space on descriptions or impersonal reflections, nor does he trust to sensational incidents. The development of feeling and character, very often as revealed in natural conversation, seems to be his strong point. He knows his own people best, but we are sorry that he considers Miles and Nellie to be typical of the manners and dispositions of that class of the Irish race in the United States. The book is so cleverly written that one might cull from its pages a very respectable collection of epigrams." --(I.M.). 
EGAN, Maurico Francis-(continued).

553 THE WILES OF SEXTON MAGINNIS. Pp. 380. (N.Y.: The Century Co.). 1.50. 21 clever illustr. by Arthur I. Keller. [1902]. 7th ed. 1910.

Scene: "Bracton," a parvenu Maryland town. The personages are nearly all American-Irish of the lower classes, aspiring to respectability. A series of episodes, given a centain unity by the persontality of Maginnis, a delightfully humorous character. $\mathrm{He}$ is full of guileless trickery, the success of which is promoted by an entire freedom in dealing with matters of fact. But $M$. is not an ordinary liar. As he says himself, "I've taken liberties with the truth myself; but a real liar" like Carmody is too much for me." The whole book is full of delicate social satire, pointed, yet not unkind. There are intimate little glimpses of Catholic clerical life. Practically all the personages are Catholics, but there is no propagandism even of a covert kind. Other humorous characters are Mrs. Magee (Herself) and Mary Ann and Mrs. Gilooly.

[EGAN, Pierce] was of Irish origin, and perhaps b. in Ireland about 1772 . Was a sport reporter, founded a paper, BELL's LIFE, and publ. a large number of works.

554- REAL LIFE IN IRELAND.; or, the Day and Night Scenes, Rovings, Rambles, and Sprees, Bulls, Blunders, Bodderation and Blarney, of Brian Boru, Esq., and his elegant friend Sir Shawn O'Dogherty, exhibiting a real Picture of Characters, Manners, \&c., in High and Low Life, in Dublin and various parts of Ireland, embellished with humorous coloured engravings from original designs by the most eminent Artists, "by a real Paddy." [1821].

Messrs. Methuen in 1904 reprinted the book from the fourth ed. which was publ. by Evans \& Co. The title-p. well describes the book. Brian and his friend were what were then called bucks and bloods. There is much absurdity and extreme exaggeration. The follies and vagaries of the two heroes are told in a facetious and roistering style. There is coarseness not a little. But the book is interesting for its side-lights on the period, 1820-1830. Geo. IV.'s visit is described in a vein of burlesque. The illustrations are even more vulgar than the text, but have a similar interest. Egan.

N.B.-The late Mr. D. J. O'Donoghue held that this book was not written by

EGAN, P. M. Author of A History and Guide to Waterford,

555- SCULLIYDOM : an Anglo-Irish Story of To-day. Pp. 360 . (Maxwell). 2s. Picture boards. 1886.

Scene: Kilkenny. Time: 1880-84. Lucifer Scully, moneylender, by degrees becomes possessed of much land, and grinds down the tenants. They revolt, and this gives opportunity for good descriptions of evictions and reprisals. Fred O'Brien, a fine character, whose sweetheart is spirited away by the villainy of Scully, goes in pursuit of her, and has many adventures and disappointments before all ends happily. Mickey Crowe with his love episodes supplies the comic relief. The tone is strongly National, and the dialect well done.

“ELIzABETH, Charlotte," Mrs. Tonna. B. Norwich, 1790, dau. of Rev. Michael Browne. Her second husband was Lewis H. Tonna. Lived in Kilkenny and other parts of Ireland for many years. D. 1846. Wrote many tracts and missionary works for the Dublin Tract Society. Also several vols. of verse, including two vigorous Orange songs.

556- THE ROCKITE. [1832].

The Tithe War (c. 1820) from Protestant standpoint. Captain Rock was a famous leader of Whiteboys during the anti-tithe war. The Memoirs of Captain Rock were published anonymously, 1824; in Paris, by Thomas Moore. 


\section{"ElIzABETH, Charlotte," Mrs. Tonna-(continued).}

557 _DERRY : A Tale of the Revolution. Pp. xxiv. +317. (Nisbet). [1839]. Sixth ed. 1886, and others since.

Story of the Siege of Derry, written from ultra-Protestant standpoint. The proceeds of the sale of the book are to be devoted to teaching the Protestant religion " in their own tongue to the Irish-speaking aborigines of the land."-(Pref.). The Author says elsewhere that "Popery is the curse of God upon a land." And the expression of similar views is very frequent in the book.

ELRINGTON, Miss $H$. Author of many stories for young people, such as The Nursery Rebels, In the Days of Prince Hal, Ralph and Percy (S.P.C.K.), and The Burleighs, 1911.

RALPH WYNWARD.
Good illustr. n.d. (1903).

(Nelson). 2s. Attractive binding.

Youghal in the days of Queen Elizabeth. A tale of adventure in wild times, ending in the sack of Youghal during the Desmond Wars. Without bias. Told by Ralph himself, a descendant of the 8th Earl of Desmond, who runs away from his home in England. The 16th Earl and Sir Richard Boyle (afterwards the Great Earl of Cork) appear in the story. Juvenile.

\section{9_- THE SCHOOL-BOY OUTLAWS. Pp. 266. (simpkin). 2s. 6d. Six illustr. 1905.}

Life at a school in the South of Ireland "for the sons of the gentry." Incidents of resistance to masters attempting a reform. Two of the boys, Jerry and Fitzgerald (who tells the story, and is "the son of a well-known Dublin clergyman"), run away, and live as outlaws. The accession of Queen Victoria (1837) is the means of obtaining their pardon. A pleasant tale for boys, free from religious or political bias.

[ENNIS, Allcia Margaret.]

560 IRELAND; or, Memoirs of the Montague Family. 3 voss.

\section{ENSELL, MrS.}

561— THE PEARL OF LISNADOON. Pp. 126. (Elliot Stock). 1886.

Scene: Killarney in the time following O'Connell's imprisonment. Aims to prove that the landlords were extremely ill-treated, and that the Irish are uncivilised, and more or less savage. Strong Protestant bias. Usual pictures of agrarian crime.

ERVINE, St. John G. B. 1883, in Belfast. Has publ. several plays for the Abbey Theatre, e.g., "Mixed Marriage," a political study, Sir Edward Carson and the Ulster Movement, 1916, and, besides the following novels, another, Alice and a Family. Hopes to publ. in the near future a new novel, The Foolish Lovers. Resides in London.

562— EIGHT O'CLOCK, and Other Stories. P. 128. (Maunsel). 2s. 6d. 1913.

Reprinted from various periodicals. Six out of the seventeen are Irish in subject. There is the sketch of Clutie John, a queer old North of Irelander, whose profession is " fin'in' things." "The Well of Youth," a fantastic and humorous story about the Well of St. Brigid in the Vale of Avoca-told in North of Ireland dialect!' In "The Fool," John O'Moyle, a little " astray in his mind," gives an English tourist some eye-opening facts about the condition of peasant farms (Catholic and Protestant) in Donegal. "The Match" is a satire on match-making. In "Discontent" a young Antrim boy on Lurigedan tells of the hunger of the country-bred for the excitements of town life. "The Burial" is concerned with life in Ballyshannon. Clever and finished. The remainder deal with English life. 


\section{ERVINE, St. John G.-(continued).}

\section{3_ MRS. MARTIN'S MAN. Pp. 312. (Maunsel). 6s. 1915.}

Theme: the triumph of an injured wife over a situation that would have finally wrecked the lives of most women-her desertion by an unfaithful husband, and, still harder to face, his return after sixteen years, a worthless, drunken lout, to live with her again. Mrs. Martin is the book, which is both a careful character study and a page of life-philosophy. But the minor characters are good-the Presbyterian clergyman, verbose and self-sufficient (a very unfavourable portrait), the canting and narrow-minded Henry Mahaffy, and Mrs. Martin's Man himself. There is a somewhat drab back-ground of lower middle-class life in Ulster (Ballyreagh $=$ Donaghadee and Belfast). A very remarkable book that has had a deservedly great success. As for its moral aspect, the Author is against cant, hypocrisy and intolerance; he is somewhat contemptuous towards religion; he is never salacious, but there is an occasional sensuousness in his treatment of a painful subject.

\section{4- CHANGING WINDS. Pp. 571. (Maunsel). 6.s. n. 1917.}

A novel on a large scale, well described as being of the H. G. Wells type. As a story it deals with the fortunes of four school chums who, after school, settle down together in London. One of these is Irish, Henry Quinn, who may be regarded as the hero. $\mathrm{He}$ is represented as a thorough physical and moral coward. Moreover he makes love (and this episode is dwelt on at great length) to a married woman whom, as he know, his intimate friend had asked to elope with hin. There is some romance and some character study. Some types are cleverly sketched, notably the hero's Ulster Protestant father who, though a Unionist, is thuroughly fond of Ireland. Real personages are introduced, but only one, John Marsh (?MacDonagh), is portrayed. On the whole the story is a thread to string together discussions, reflections, criticisms on politics (English and Irish), religion, social questions and other questions of the day. The scene for more than half the book is laid in England, varying between Devonshire and London. Ireland on the whole is a rather dim background. Irish affairs are viewed with attempted sympathy, but quite from the outside. In the last quarter of the book the war is the main interest. Quite at the close the Easter Week Insurrection in Ireland is an episode. The Author intrudes himself little, leaving his personages to vent their views. The conversations are thoroughly natural, Fnglish school-boy and student slang being very well reproduced.

ESLER, Mrs. Erminda Rentoul. Daughter of Rev. Alexander Rentoul, M.D., D.D., of Manor Cunningham, Co. Donegal. Lives in London, and contributes to Cornhill, Chambers's, Quiver, Sunday at Home, and many other periodicals. Author of The Way of Transgressors (1890), Youth at the Prow, The Awakening of Helena T'horpe.

\section{$565-$ THE WAY THEY LOVED AT GRIMPAT: Village Idylls. (Sampson
Low). 1893.}

Little love stories told with unaffected pathos or quiet humour, and here and there a note of satire.

\section{6- A MAID OF THE MANSE. Pp. 315. (Sampson, Low). 1895.}

A story of Presbyterian clerical life in Co. Donegal forty years ago. A pleasant, readable story, with a well wrought plot. There is both pathos and humour in the book, and as a picture of manners it is true to life, if somewhat idyllic. "The whole tone of the book," says a Scottish reviewer, "is essentially Scotch." Rosie Wedderburn's love story forms part of the plot.

567- THE WARDLAWS. (Smith). 3s. 6D. 1890.

"A grave domestic story worked out on a basis of character, laid in an Irish rural district."-(Baker). 


\section{ESLER, Mrs. Erminda Rentoul-(continued).}

568- THE TRACKLESS WAY. Pp. 465. (Brimley Johnson). 6s. 1904.

"The story of a man's quest for God." (Sub.-t). Scene: chiefly "Garvaghy, Co. Innismore," in Ulster. The book is a searching study of the inward religious and outward social life of a Presbyterian minister, Gideon Horville, his difficulties, aspirations, friendships, disappointment in marriage. $\mathrm{H}_{\Theta}$ is dismissed by his Church for teaching erroneous doctrines, begins to write, and subsequently helps his great friend Lord Tomnitoul in his religious and socialistic schemes. The Author's religious attitude is equally opposed to Catholicism, to Calvinism, and, indeed, to all existing forms of Christianity. The background, Horville's social circle, with its meannesses, spites and petty jealousies, is not a pleasant one. The Author writes with thorough knowledge. There are no politics.

\section{'ESMOND, HENRY."}

569_ A LIFE'S HAZARD: or, The Outlaw of Wentworth Waste. Three Vols. (Sampson, Low). 1878.

Scene: N. Co. Dublin. A sensational tale-abducted heir, forged will, usurped title, jealousy, revenge, attempted murder's, perjury, \&c. The outlaw, O'Grady, a T.C.D. man and a barrister, heads a popular rising, twice escapes execution, and performs wonderful deeds always appearing in the nick of time to rescue beauty in distress, or upset the schemes of the false lord. There is much brogue-of a sort. The supernatural is frequently introduced.

\section{“ESSE (James)"' [ ? James Stephens].}

570- HUNGer: A Dublin Story. Pp. 29. (Dublin: The Candle Press). 1s., wrappers. 1918.

A little glimpse of Dublin life that is only too real, the starving slowly to death of a house painter's family. A picture of poignant, unrelieved gloom, drawn with a literary restraint that makes it all the more poignant.

FABER, Christine. An American Catholic writer. Other novels-An Original Girl (1901), Ambition's Contest, A Fatal Resemblance, Reaping the Whirlwind (1905), A Chivalrous Deed, The Guardian's Mystery, A Mother's Sacrifice. All of these are published by P. J. Kenedy of New York.

571- CARROLL O'DONOGHUE; a Tale of the Irish Struggles of 1866 and of recent times. Pp. 501. Pretty cover (Duffy). 3s. 6d. [N.Y.: 1881]. 1903.

Scene laid chiefly in Kerry at the time of the Fenian movement, though it is not a narrative of the latter. A very dramatic story finely wrought out. Full of local colour, humour, and pathos.

\section{FALLOON, Mrs. Garnett.}

\section{2 - WILD FLOWERS FROM THE GLENS. Pp. viii. +322. [1840]. 4th ed. 1866.}

(LoND.)

Contents :-(1) Short description of Glens of Antrim. (2) "The Dooming Rose," the love story of one Maurice Fitzgerald and the daughter of Sir Raymond O'Neill of Cushendun. A ghost in Layde churchyard, Cushendall, figures in the tale. (3) The Fairy of Tivora, a Cushendall love story with a deus ex machina in the shape of a friendly fairy. (4) The Wishing Arch, a tale of Portrush. (5) The Flower of Glenarriff, a love story with a sad ending. The whole is sentimental and gushing, with many poetical pieces interspersed. Good descriptions of local scenery.

N.B. - The first ed. was publ. (Lond., Dubl., and Belfast) without the Author's name. In the 4 th ed. the name appears with the intimation that copies are to be had of the Author, Rosbercon, New Ross, Co. Wexford. 
" FALY, Patrick C."; John Hill, of the Ulster family of Hills. Contr. to TinsLey's in the eighties. Publ. A Wild Rose, 1886.

573 NINETY-EIGHT: being the Recollections of Cormac Cahir O'Connor Faly (late Col. in the French Service) of that awful period. Collected and edited by his grandson, Patrick C. Faly, Attorney-at-Law, Buffalo, N.Y. (Downey). Illustr. A. D. M'Cormick. 1897.

Cormac is heart and soul with the rebels. Life in Dublin, 1798, described. Then we are brought all through the scenes of the rising.

FARADAY, Winifred, M.A.

574- THE CATTLE RAID OF CUALNGE. (Táin bó Cuailnge). An ancient Irish prose epic [Grimm Library, No. 16). Pp. xxi.+141. (Nutt). 4s. (N.Y.: Scribner). 1.25. 1904.

A close student's translation from the Leabhar na h-Uidhri and the Yellow Book of Lecan. No notes, but interesting and scholarly introduction.

\section{FENNELL, Chariotte and J. P. O'CALLAGHAN.}

575_ A PRINCE OF TYRONE. Pp. 363. (Blackwood). 1897.

The amours of Seaghan O'Neill. Seems worthless from an historical point of view. O'Neill appears as little better than a villain of melodrama.

FERGUSON, Sir Samuel. Born Belfast, 1810. Son of John Ferguson, of Collen House, Co. Antrim. Educated Academical Institution, Belfast, and T.C.D. Was first deputy keeper of the public records in Ireland. Was a noted antiquarian, but is better known as one of the best of our Irish poets. Most of his poetry deals with the heroic period of early Ireland. Died 1886. See Sir Samuel Ferguson in the Ireland of his Day, by Lady Ferguson. Besides the Hibernian Nights, Sir Samuel wrote also a very amusing if not very reverent sketch, "Father Tom and the Pope," which had the unique distinction of being reprinted in BLACKWood's MAGAZINE, 1910. It was publ. separately in U.S.A., but without the Author's name.

576- HIBERNIAN NIGHTS ENTERTAINMENTS. Three Vols. Pp. $146+$ 184+278. (Sealy, Bryers). 1s. each, paper; 2s. cloth. [1887]. Still in print.

Written by the Author in early youth. Supposed to be told in 1592 by Turlough O'Hagan, O'Neill's bard, to Hugh Roe O'Donnell and his companions imprisoned in Dublin Castle. They are almost entirely fictitious, but give many details of locality and of contemporary manners, customs, and modes of fighting. There is an historical introduction. "Contents: "Children of Usnach," "The Captive of Killeshin," "Corby MacGillmore," "An Adventure of Seaghan O'Neill's," and the "Rebellion of Silken Thomas." Popular in style and treatment.

N.B.-There was an American ed. which contains stories not included in the Irish ed.

577- THE "RETURN OF CLANEBOY." Pp. 43-98.

Relates how Aoŕ buróe O'nélll regained (c. 1333) his territory of Claneboy in Antrim on the death of William de Burgh, Earl of Ulster. The story is rather an ordinary one-fighting and intrigues. There is some description of men and manners and of County Antrim scenery.

578- THE "CAPTIVE OF KILLESHIN." Pp. 98-146.

A tale of the struggle of the Leinster Clans-chiefly the O'Nolans-with the English settlers. Full of stirring incidents, including a battle most vividly described.

Period: end of 14th century. 
FERGUSON, Sir Samuel-(continued).

579 _CORBY MACGILLMORE." Pp. 140.

Scene: North Antrim at the beginning of the fifteenth century. A Franciscan preaches Christianity to the MacGillmores, who had relapsed into barbarism and paganism. There is a very warlike and un-Christian abbot in the story. The chief interest is the enmity between the Clan Gillmore and the Clan Savage of North Down, and the events, dark and tragic for the most part, that result from it.

580.-THE "REBELLION OF SILKEN THOMAS." Pp. 278.

The main features of the rebellion are told in form of romance. The real hero is Sir John Talbot, who first joins Iord Thonias but afterwards leaves him. The story of Sir John's private fortunes occupies a large part of the narrative. The Author is, of course, perfectly acquainted with the history of the time.

581- THE DEATH OF THE CHILDREN OF USNACH. Pp. 14-92.

The beautiful Saga of Deirdre briefly but worthily told.

582- AN ADVENTURE OF SHANE O'NEILL'S. Pp. 143-184.

Exciting adventures in which $O^{\prime} N$. (and the Irish in general) appears in a very unfavourable light.

FERGUSSON, Rev. R. Menzies, D.D. Author of Rambles in the Far North, 1883; Scottish Social Sketches, Silver Shoebuckle: a Tale of the '15, etc. He is Minister of Logic, Bridge of Allan, Scotland.

583 - THE OCHIL FAIRY TALES. Pp. 157. (Nutt). 3s. 6d. 1lustr. 1913.

Most of the tales related in this book are founded on local tradition: they are the echoes of that Celtic folk-lore which is fast dying out. The western spurs of the Ochill hills and the country lying between the Allan Water and the River Forth form the scenes of the curious cantrips of the Wee Folk, once so firmly believed in by the people of a former generation. The purpose of the Author is to preserve some of those curious tales which are still floating in the popular mind. In another generation it will be too late.-(Publ.).

FIELD, Mrs. E. M. This Author (born 1856) is daughter of J. Story, J.P., D.L., of Bingfield, Co. Cavan. Besides Ethne, she has published several other novels, e.g., At the King's Right Hand.

584- DENIS. Pp. viii.+414. (Macmillan). 2s. [1896]. Still in print.

A story of the famine. Interesting portrait of Young Ireland leader. Standpoint rather anti-national. Dedicated "to my kinsfolk and friends among the landowners of Ireland."

585- ETHNE. P户. 312. (Wells, Gardner). 3s. 6d. Three or four good Illustr. [1902]. Third edition. 1911.

A tale of Cromwell's transplantation of the Irish to Connaught. Purports to be taken partly from the diary of Ethne O'Connor, daughter of one of the transplanted, and partly from the "record" of Roger Standfast-on-the-Rock. The former is converted to the religion of the latter by a single reading of the Bible. The interest of the book is mainly religious.

FIGGIS, Darrell. Born Gleann-na-Smol, Co. Dublin, 1882. Was taken to India in infancy and remained there till he was ten years old. Was put into a London business house, and did not abandon this walk of life, in which his fortunes were sometimes low enough, till about 1909, the date of his first volume of poems, $A$ Vision of Life. Since then he has been engaged in journalism and literature. He has taken an active part in the national movement in Ireland. 
FIGGIS, Darrell--(continued).

For the past five years he has spent every winter in Achill, where he now lives permanently. Has written two other novels, Broken Arcs and Jacob Elthorne. Has been more than once in prison for his advanced national views. 586-CHILDREN OF EARTH. Pp. 303. Closely printed. (Maunsel). 1918.

A story of primitive passion among the primitive people in the wilds of Achill Island (here called Maolan). A combination of almost brutal and sordid realism, with ideas of mysterious influences exercised by earth or nature over men. The nature descriptions and the psychology are both worked out with painstaking thoroughness. So also is the idiom of peasant speech. The personages of the story are represented as swayed by elemental and primitive passions, and the darker forms of these are chiefly dwelt upon. The rôle of their religion as a motive force is ignored. The plot turns upon a girl being rushed into marriage without her real consent, her love remaining with another. The result is tragedy. There ar several passionate scenes. Unsuited to younger people.

FILDES, H. G.

587-_ “TRLM" AND ANTRLM'S SHORES. Pp. 312. (Greening). 6s. 1904.

Account of holiday trip, supposed to be taken by the writer (an Englishman) and his friend, "Trim," to the coast of Antrim, alio Loagh Neagh and a few other places. Consists mainly of humorous incidents treated more or less in the T'hree Men in a Boat, or rather the 'l'hree Men on the Bümmel style, but much inferinr. Little or no description of Antrim.

\section{FINLAY (JOhn H.).}

588- THE ORANGEMAN. Pp. 328. (Cincinnati : Montford)* ${ }^{*}$ 1.25. 1915.

Scene: Cos. Monaghan and Cavan in 1821, the days of the Ribbonmen. The burden of the book is the sufferings endured and the dangers incurred by the Orangemen, a God-fearing, law-abiding, enlightened, progressive, honourable population, at the hands of their ignorant, fanatical, and lawless neighbours, the Catholics, who are sunk in the grossest superstition, and given over to the tyranny of the priests, a class tainted, but in an enhanced degree, with all the formers' worst qualities. One of the main episodes is the abduction, with a view to immuring her in Cavan Convent, of a beautiful Protestant girl, Anne Yalnif, who is finally rescued by a handsome and chivalrous young Orangeman. The hero of the story is one William Yalnif. The following is a specimen of the brogue as represented in this book:- "Oi have been told," said Fildy [a Ribbonman who is on the verge of conversion, thanks to a chance-found bible] "that the first thing taught in the Boible is that God made mon in his own image. Now, a well-informed mon loike yersilf wil undershtand at wance that it is not prastes he made in His imageGod f'bid! Mon's the wurrud that is used, and it ambraces the howl human race, which Oi suppose wud take in the prastes at a pinch." There is a plentiful sprinkling of pig stories, shillelahs, and "dhraps iv th' mountain dew," to give Irish flavour and colouring.

FINLAY, T. A., S.J., M.A.; " A. Whitelock." Born 1848. Educated at Cavan College, at Amiens, and at the Gregorian University, Rome. Entered Irish Province S.J., 1866. Commissioner of Intermediate Education, 1900; VicePresident of Irish Agrisultural Organisation Society; Ex-Fellow of Royal Univ. of I. ; Editor, THe Lyceum and then The New Ireland Review (18941910) ; President of Univ. Hall, Dublin, since 1913.-(CAтн. Who's Who). 589- THE CHANCES OF .WAR. (Gill). [1877]. New edition, 1908, and (Fallon); 2s. 6d. 1911.

Aims (cf. Preface) to indicate the causes that led to failure of Confederation of Kilkeniny. Represents in the characters introduced the aims and motives of the

* But a circular directs us to order the book from the Westminster Press, 509 So. Wabash Ave., Chicago,.Ill., which is likewise the nddress of the Preshyterian Bard of Publication and Sabbath School Work. 
FINLAY, T. A., S.J.-(continued).

chief actors in the events of the period, such as Owen Roe O'Neill, Rinuccini, Sir Charles Coote, \&c. There is a spirited description of the first relief of Derry, the Battle of Benburb, Ireton's siege of Limerick. The hero is an exile returned from a continental army. Between him and the heroine the villain Plunkett interposes his schemes. Scene: Chiefly an island in Lough Derg. Though the main aim is historical, this fact in no way detracts from the interest and excitement of the romance. Written in a style above that of the majority of Irish historical novels. Standpoint: Catholic and national, but free from violent partisanship.

FINN, L. A.

590_- BARNEY THE BOYO.* Pp. 180. (Ireland's Own Library). 6d. n.d.

How B. is, with many sighs of relief, sent forth by his native village to found his fortune on a subscribed capital of $£ 42 \mathrm{~s}$. 10d. How he is involved in the Castle Jewels mystery, wins the "Ardilveagh Cup" at the Horse Show, swims the Channel, and has many topical adventures, succeeding always by his native wit. Plenty of broad, popular humour, somewhat in the vein of Mick McQuaid.

FINN, Mary Agnes. Author of A Broken Rosary and other Stories.

591— NORA'S MISSION. Pp. 268. (Washbourne). 2s. 6d. (N.Y.: Benziger). 1.75. [1911]. Second edition. 1914.

The mission was to bring back her uncle, who had settled in Australia, both to his Church and to his country, and she successfully carried it out: his wife and daughters, too, " adapted themselves speedily to Irish manners and customs." And her visit to Australia unravelled some mysteries which we shall not reveal. Scene laid in I. and most of characters Irish. The "brogue" is avoided, but the conversation is somewhat stilted ard unnatural. The book is nicely printed and prettily bound.-(C.B.N.).

\section{FINNEY, Violet $G$.}

592 - THE REVOLT OF THE YOUNG MACCORMACKS. Pp. 227. (Ward \& Downey). Illustr. by Edith Scannell. (N.Y.: Pratt). 1.50. 1896.

A story written for children and much appreciated by them. The four young MacCormacks are very live and real children. Their delightfully novel pranks are told in a breezy, natural style. Many a "grown-up" will find interest in the book. Scene: partly in Dublin, partly in West of Ireland.

592A- A DAUGHTER OF ERIN. Pp. 224. (Blackie). 2s. 6d. Well illustr. by G. Demain Hammond.

A bright little story, free from " problems," "morals," morbidnass, and prejudice. It tells how Norah's hostility and dislike to her cousin, John Herrick, gradually changes to love, in spite of herself. Her old lover accepts the inevitable like a brave man, and loses his life in trying to do a service, for her sake, to the favouned suitor. The Irish characters are capitally sketched-Mrs. Ryan and Judy, the Rector's housekeeper. Bertie, the spoilt little invalid, is drawn to the life. So, too, is the somewhat sententious old Rector.

FITZGERALD, John Godwin.

593 - RUTH WERDRESS, FATHER O'HARALAN, AND SOME NEW CHRISTIANS. Pp. 340. (Blackwood). 6s.

An argument in narrative form against the celibacy of the Catholic priesthood. Ruth W., flying from a home made unhappy by evangelicalism, takes refuge with Father O'H., P.P., of Blossomvale, who receives her into the Catholic Church. Father $\mathrm{O}^{\prime} \mathrm{H}$. falls madly in love with her, and there ane a series of situations; compromising and equivocal in appearance. Under extraordinary circumstances

* A Midland word for the Western "playboy" or general wag and practical joker. 
FITZGERALD, John Godwin-(continued).

the two are forced into a merely formal marriage. We need not reveal the sequel. There is a great deal about Catholic usages, priests, nuns, \&c., with which the Author shows considerable superficial acquaintance. The Author is cautiously fair in detail, but the general impression produced is sometimes distinctly unfavourable to Catholicism. The new Christians are a sect of latter-day evangelicals whom the Author satirises severely. One scene we consider particularly offensive to Catholic feeling, and highly improbable into the bargain.

[FITZGERALD, M. J.].

594 THE MAKING OF JIM O'NEILL. Pp. 140. 16mo. (C.T.S.I.: Ione Series). 1910.

The story of the course of a young man's vocation to the priesthood, of his life at a typical Irish provincial seminary, and of his vacations at home. The doings of the seminarists are described frankly, not being at all idealised. The tale is pleasantly and plainly told, without much analysis of motive or of emotion. It is a vivid glimpse of the making of a priest.

FitzGerAld, Rev. T. A., O.F.M. Born Callan, Co. Kilkenny, 1862. Brought up in Thurles; ed. at Christian Bros. Schools and St. Patrick's College. Became a Franciscan in 1879. Spent five years in Rome, and twenty in Australia. Since his return to Ireland has learned the Irish language, and has taken part in the revival movement. Witness his Stepping Stones to Gaeldom. Resided in Galway for some time, but is now in Dublin.

595 — HOMESPUN YARNS: WHILE THE KETTLE AND THE CRICKET SING. Pp. 222. (Gill). 3s. 6d. Illustr. 1914.

Eighteen tales and sketches of Irish life-at home and in exile. For the most part humorous, with genuine and spontaneous humour. But pathos is often not far off, and edification is to be got, though it is not thrust upon the reader. The sketches of life in the slums and back streets of Dublin show the Author at his best, for his errands of mercy have made him know them thoroughly.

596_ FITS AND STARTS. (Gill). 1915.

Another series of sketches similar to the previous, but here, besides making the acquaintance of Cook Street, Great Britain Street, and Chancery Lane, we have glimpses of Dalkey, Kingstown, Rathmines, and even Lower Leeson Street. "The Adventures of Black Pudden" is an exceptionally comic story.

\section{7- A GOOD THIRD. Pp. 254. (Gill). 3s. 6d. Illustr. 1916.}

Contains four Australian stories, four sketches connected with the Irish language (the Wexford Feis, Storytellers of Connaught, etc.) and nine stories of Dublin life. The stories are best described as capital yarns told in a vein of broad comedy tending. to the farcical (or to "funniosity," to use a word of the Author's coining) and free from "moral" of any kind or any purpose beyond the tale. There is much Dublin slang, and the manner throughout is that of the oral storyteller with his refrain of "what did me brave boyo do next" or the like. Suburbia is dealt with in a facetious and satirical strain. The illustrations are of unequal quality.

598_ FOUR IN HAND. Pp. 256. (Gill). Ilustr. by pen and ink sketches. 1917.

Twenty-five stories and sketches. The former resemble those of the Author's three previous collections, but are not all Dublin stories, Belmullet, Skibbereen and Carrick-on-Suir being the respective scenes of three of then. They are for the most part broad comedy. Several of the sketches deal with Irish-Australia-Peter Lawlor, the founder of Australian democracy; Burke, the explorer, and Cardinal Moran being among the subjects. Other sketches deal with Irish Canals, the Children's Hospital, Temple Street; the hostel for working women in Meatl Street. 
FITZGERALD, Rev. T. A.-(continued).

598A- THE FIVE OF TRUMPS. Pp. 256. (Gill). 1918.

Twenty-three stories of a miscellaneous character. There is an Australian story and a story translated from the French. Some are comedies or farces, others more serious. The sceres are laid in many parts of Ireland-the Dublin slums, Blackrock, Connemara, Clonakilty, Kerry, Ballyhaunis, Ballyragget (the Curser's Glen), Abbeyfeale, and so on. All are told in the Author's faniliar, breezy style.

FITZPATRICK, Kathieen. B. in Belfast 1872, and ed, there. Has contributed to the Westminster Gazette short articles on Irish peasant life. Resides in England.

599- THE WEANS AT ROWALLAN. Pp. 234. (Methuen). 6s. Illustr. Second edition. 1905.

"We think it is one of the best books about children published since the days of Mrs. Ewing."-(Spealer). "Amusing and pleasant. Some of the fun is tinged with the unconscious pathos of child-life, and the mixed mirth and melancholy of the Irish peasantry."-(Athenaeum).

FITZPATRICK, Mary; Mrs. W. C. Sullivan. Born in Barony of Farney, Co. Monaghan, but belongs to the Fitzpatricks of Ossory. Educated in Dublin and Paris. In 1894 married Dr. W. C. Sullivan, son of the late Dr. W. K. Sullivan, President of the Queen's College, Cork. Has contributed a good deal to periodicals in Ireland and in America. Her writings are marlsed by love for Ireland, and faith in her future.

600_ THE ONE OUTSIDE. Pp. 245. (Maunsel). 3s. 6d. 1914.

Eight stories, six of which are Irish in subject. Seven of the stories are tragedies. "The Doctor's Joke" is the only comedy. The title story tells how the father, after sixteen years of absence, bread-winning in England, comes home to find that the wife and children of the reality are far other than what his dreams had pictured, and his wife has a similar disillusionment. $\mathrm{He}$ is an outsider, and he realises it bitterly. Painful tragedy is the outcome. The 2nd is a tragedy of blighted hopes. The 3rd a lighter story, laid in Fenian times. 4. W. of Ireland. Love's young dream destroyed by the plotting of an ambitious and masterful old woman. Atmosphere of loneliness and terror given to the whole. 5. A London slum tragedy, with Irish characters. 6. A study in character, and a peasant lovetale. All are told in beautiful and refined language, often charged with pathos. The situations are dramatic. The whole manner, the atmosphere, and the sentiment are Irish.

FITzPATRICK, T., LL.D. Born 1845, in Co. Down. Became a teacher in early life. He was attached successively to Blackrock Coll., Dublin; St. Malachy's, Belfast; Athenry, Galway, and Birr schools. Of the last he was headmaster in 1876. Was author of a serious historical work-T'he Bloody Bridge and Other Studies of 1641. Died 1912 in Dublin.

601- JABEZ MURDOCK, by "Banna Borka." Two Vols. Pp. $300+335$.

(Duffy). 1s. 6d. (Two vols. in one). [1887]. 1888 still in print.

Scene: South Co. Down. The central figure is a rascally Scotch settler who dabbles in poetry, and attains to wealth as "a jint" by unscrupulous means. Between the episodes of his life are interlarded scenes illustrating nearly every aspect of peasant life at the time, all minutely and vividly described, and conversations in which the problems of the times are discussed. A good deal of humorous incident and character. The Author evidently writes from first-hand knowledge. $\mathrm{He}$ is on the Catholic and popular side. Period : first quarter of nineteenth century.

602- THE KING OF CLADDAGH. Pp. 249. (Sands). Frontisp. ancient map of Galway in 1651. 1899.

Galway City and County during Cromwellian period. Atrocities of the eight years' rule of the Roundheads. Forcible and vivid. Point of view: National and Catholic. 
FITzsıMon, Miss E. A. Married Dr. Walsh, of Providence R.I., U.S.A. Now living in Boston.

603- THE JOINT VENTURE: A Tale in Two Lands. Pp. 327. (N.Y. : Shechy). [1878]. New ed. 1887.

Scene opens in a valley of the Knockmealdowns, passes to U.S.A. in ch. 7 (p. 109). Was a first novel, and so somewhat immature. High moral and Catholic tone (perhaps somewhat aggressive at times). Attacks Protestant divorce laws. One of the best incidents, perhaps, is Mrs. Ned O'Ieary's conversion to Catholicism. - (Press Notices). This was republ. in 1881 under title Gerald Barry; or, The Joint Venture.

FLEMING, Mary Agnes, an Irish-American Catholic writer very popular in her day. After her death, in 1880, many of her stories appeared in various periodicals in these countries, notably in Young Irecand. She is fond of introducing Irish characters into her stories, e.g., Terry Dennison in $A$ Mal Marriage, 1875, but they are not very characteristic, and there is little else in the tales that is of Irish interest. Wrote also:Lady Evelyn, Pride and Passion, A Terrible Secret ("a tale of Ireland, England, and America"), The Midnight Queen, 1890; The Actress's Daughter, 1903, etc. She was for some years a school teacher in the North of Ireland.

604 A WONDERFUL WOMAN. (N.Y.: Street). 1906.

Various illustrations of the adage, "The course of true love never did run smoothe." e.g., Redmond O'Donnell, an impoverished Irish gentleman, meets an English lady who is with her titled father on a shooting tour in Ireland. Many obstacles having been overcome they are united, but it then transpires that the lady is only the daughter of a servant who had exchanged babies with her mistress.

\section{5- MAUD PERCY'S SECRET. '(N.Y.: Dillingham).}

This story is practically English, but in the middle a number of the principal personages are shifted to Ireland. This episode has little to do with the plot.

FLOOD, Joseph M., B.L., Professor of Law in Univ. Coll., Galway. B. Longford 1882

Ed. at St. Mel's Coll. Longford, Ecole Albert le Grand, Arcueil, Paris, and

Univ. Coll., Dublin. Very distinguished career at the King's Inns. Besides

the following works has publ. Memoir of Abbe Edgeworth, Poets of the Faith

(C.T.S.I.), Ireland: its Saints and Scholars, In Five Provinces (DubuIN:

Kiersey) and many articles in Irish periodicals.

606- IRELAND: ITS MYTHS AND LEGENDS. Pp. 136. 12mo. (Dublin:

The Talbot Press). 1s. 20 line-drawings by C. MacDowell. 1916.

Irish heroic legend, told in simple yet picturesque and forceful language. Demigods, Red Branch Knights and Fianna pass in vivid procession through the pages. The illustrations are of ancient Irish forts and monuments.

\section{"FLOREDice, W. H.," WIIliam Hart.}

607-- MEMORIES OF A MONTH AMONG THE " MERE IRISH." Pp.xxix. +321. (Kegan, Paul). [1881]. Second edition, 1886.

A record of conversations held and things seen, but especially of legends, stories, and anecdotes heard from the peasantry during a stay made by the Author when a youth at Doe Castle, near the head of Sheephaven, Co. Donegal. Owen Gregallah (Gallagher?), an old water-bailiff, with whom the Author used to go fishing, tells many of these latter, in the local dialect, which is faithfully reproduced. The stories are interesting in themselves, and very well told. Dr. Mahaffy referred in the Academy to one of them as the funniest Irish story in print. There is no condescension in the Author's tone. He likes and respects, as well as enjoys, his peasant companions. He seems to be an American. The Preface to the second ed. gives a humorous account of the difficulties of travel in Donegal in those days.

N.B.-The title on the cover is " "Mere Irish' Stories." 


\section{"FLOREDICE, W. H.," William Hart-(continued).}

607A- DERRYREEL. Pp. vi.+184. (London: Hamilton, Adams). 1886.

"A collection of stories from N.W. Donegal." This writer published also a volume entitled Flloredice S'tories.

FLYNN, T. M. Was living at Carrick-on-Shanmon at the time of writing these sketches.

608- A CELTIC FIRESIDE: Tales of Irish Rural Life. (Sealy Bryers). 1s. 1907.

Nine little tales-tragedies and comedies-of Irish life in country and city. Many little touches show how well the Author knows Irish life. He has a power, too, of making the truth of his pictures go home to our hearts.-(N.I.R.).

FOREMAN, Stephen. Other novels of this writer, a Corkman, living in Cork, are The Errors of the Comedy, The Fen Dogs, The Terrible Choice.

609- THE OVERFJOWING SCOURGE. Pp. 335. (Alston Rivers). 6. 1911.

Career of an unprincipled lawyer, who gains judgeship by a series of crimes and keeps it by crimes even more heinous. A greatly overdrawn picture of a dark and unpleasant side of life. Such incidents as a packed jury condemning unjustly the presiding judge's son (with the judge's own approbation) to penal servitude seem wholly improbable. The parson and his wife afford a gleam of humour. Alihough some of the worst of the characters are Protestants, there are several apparent sneers at things Catholic. "It is not written virginibus puerisque."-$(I . B . L$.$) . The career of Blanco Hamilton seems to be founded on that of Judge$ Keogh, and the incidental references are to the latter's times.

FORSTER, C. F. Blake-, see BLAKE-FORSTER.

FRANCILLON, Robert E.

610_UNDER SLIEVE BÁN : a Yarn in Seven Knots. Pp. 275. (N.Y. : Holt). 1881. It originally appeared as a Christmas Annual with Coloured Illustrations. Pp. 128 . (Grant). 1 s.

A story of faithful love, laid (at least its opening and closing scenes) in Wexford ("Dunmoyle"). Period about 1798. Michael and Phil both love Kate Callan. Kate loves P. best and $M$. goes away. Returning after three years he finds Kate mourning P., said to be lost at sea. M. and Kate are married, but on the evening of the marriage M. meets P. M. " disappears," but in foreign parts meets P.'s French wife. The two couples are united again. Kate is shot in the rebellion, but survives to discover that M. was the best man after all. Dialect natural but refined.

"FRANCIS, M.E."; Mirs. Blundell. Born at Killiney Park, near Dublin. Is the daughter of Mr. Sweetman, of Lamberton Park, Queen's County; and was educated there and in Belgium. In 1879 she married the late Francis Blundell, of Liverpool. This home of her married life is the background of many of her stories-(Ir. Lit.). Among her books are: Whither (1892), In a North Country Village, A Daughter of the Soil, Among Untrodden Ways, Maimie. o' the Corner, Pastorals of Dorset, The Manor Farm, The Tender Passion (1910), and several others, besides those noticed in this book-about thirty in all. All Mrs. Blundell's writings are noted for their delicacy of sentiment, deftness of touch, pleasantness of atmosphere. They are saved from excessive idealism by close observation of character and manners. Her Irish stories show sympathy, and even admiration for the peasantry. Her book The Things of a Child (1918) tells of her childhood in Ireland.

611- THE STORY OF DAN. (LoNDON: Osgood, M'Ilvaine). Boston: Houghton). 0.50. 1894.

"A brief tale, told with directness and tragic simplicity of a magnanimous peasant, who adores with infatuation a worthless girl, and sacrifices himself 
FRANCIS, M. E."; Mrs. Blundell-(continued).

uselessly and blindly. Friendly portraits of Irish country people are among the minor characters."-(Baker).

612- FRIEZE AND FUSTIAN. (Osgood). 3s. 6d. 1896.

The book is in two parts-the first a reflection or picture of the mind and soul of the Irish peasant, the second of that of the English peasant. The comparison or contrast is not elaborated or insisted upon. The pictures are there, the reader judges. A series of short stories or studies form the traits of the pictures, bringing out such points as the kindness of the poor to one another, a mother's love, a mother's pride in her son become priest, a servant's fidelity, and various stories of love. All told with delicate feeling and insight. The Author has lived among both pooples. There is a good deal of dialect.

613-MISS ERIN. Pp. 357. (Methuen). 6s. [1898]. Included in Benziger's (N.Y.) series of Standard Catholic Novels at 2s.; also 1.00.

The story of a girl who, brought up as a peasant, afterwards becomes a landowner. She tries to do her best for her tenants, and her difficulties in the task are well depicted, the Author fully sympathising with Irish grievances. There are some sensational scenes-among them an eviction. The love interest is well sustained, and the character-drawing very clever.

614 NORTH, SOUTH, AND OVER THE SEA. Pp. 347. (Country Life, and Newnes). Charming Illustr. by H. M. Brock. 1902.

Somewhat on the plan of Frieze and Fustian by the same Author, q.v. Three parts, each containing five stories or sketches. The first part deals with North of England life, the second with South of England, the third with Ireland. Humble life depicted in all. In last part the subject of the first sketch (an amusing one) is a rustic courtship of a curious kind; 2 , an old woman dying in the workhouse; 4 and 5, a rural love-story. Studies rather of the minds and hearts of poor Irish folk than of their outward ways. The Author has reproduced almost perfectly that brogue which is not merely English mispronounced, but practically a different idiom expressing a wholly different type of mind.

\section{5-CHILDREN OF LIGHT AND OTHER STORIES. (C.T.S.). 1908.}

The best is the title story. Bride Kinsella is true to life, as is also Father Kearney. Only through sorrow do the "Children of Light" learn life's lessons. The glimpses of Father $K$. and of his curate are a story in themselves, and a very touching story, too. Other titles are "Little Jack and his Christmas Pudding" and "The Home Coming of Godfrey Davis." (Press).

\section{6- THE STORY OF MARY DUNNE. Pp. 312. (Murray). 6s. 1913.}

The love story of Mat, "the priest's boy:" for Mary, beginning as a sweet and tender idyll in the home in Glenmalure, ending in the tragedy of a law-court scene, where the hero is on trial for murder and Mary faces worse than death in telling the story of her wrongs-she has been an innocent victim of the white slave traffic. Full of exquisite scenes, with touches of humour as well as pathos. But in the main the book is a tragedy. Its purpose seems clearly to be a warning and an appeal. The poignant consequences of Mary's undoing are not suitable for every class of reader, but there is nothing approaching to prurient description.

\section{7- DARK ROSALEEN. Pp. 392. (Cassell). 6s. 1915.}

The story of a "mixed marriage" between Norah, a Connemara peasant girl, and Hector, a young engineer of Belfast origin. They go to live at Derry. Bitterness and misunderstanding come to blight their love, and the end is tragedy. 'The two points of view, Protestant and Catholic, are well put (T. Lrr. SuppL.), but all the Author's sympathies are clearly with the people of the West. Good description of Galway. 
FREDERIC, Harold: an American journalist. B. near Utica, N.Y. State. Lived a long time in London as correspondent to the NEw YoRK TIMEs. Wrote many articles on Ireland showing much sympathy and not a little understanding of the Irish point of view. In his novel The Illumination of Theron Ware he contrasts the Catholic Irish in America with the descendants of the Puritan, to the advantage of the former. Though not himself a believer, he held that the future was with the Catholic Church in America. D. 1898, aged 42.

618_-THE RETURN OF THE O'MAHONEY : a Romantic Fantasy. Pp. 279.

(Heinemann). 3s. 6d. Three Illustr. 1893.

Scene: South-west Cork in Fenian times. The O'M., who comes to Muirisc is not the real $\mathrm{O}^{\prime} \mathrm{M}$. at all, but a $\mathrm{Mr}$. Tisdale, who has managed to secure the papers of the real O'M., who is not aware of his own origin and real name. 'T. becomes a model landlord, and is beloved of all. Tries his hand at Fenianisin, but soon abandons it, and goes abroad to foreign wars. O'Daly, left as manager, thrusts himself into his master's place. But a young American engineer (the real O'M. of course) turns up and spoils his plans, but does not reveal his own identity till after Tisdale's death. Besides this there are numerous exciting incidents and several mysteries. The characters are well drawn. The Author is distinctly favourable to Ireland, and seems to have a good knowledge of the country.

\section{FRENCH (James).}

619_ CLONGIBBON ; or, The White Knight of the Forest. Pp. 416. demy rvo. (Duffy). 1845.

A story of a stereotyped kind with abductions of "sylph-like" heroines by impossibly wicked villains, of whom the worst is Clongibbon, and rescues of the former by gallant heroes. Told in a style artificial and turgid to the point of absurdity. The personages talk in long periods with stilted phrases and poetic quotations. But behind the story is an interesting, and detailed, if somewhat biased account of the wars of the Confederation of Kilkenny from 1641 to about 1646. The Author's point of view is Catholic, and, on the whole, national, but very hostile to Rinuccini, and little in favour of Owen Roe O'Neill. The references in footnotes indicate wide historical reading.

" FREMDLING, A." see LIPSETT, E. R.

FROST, William Henry, author of The Knights of the Round Table, The Cour of King Arthur, The Wagner Story Book.

620 FAIRIES AND FOLK OF IRELAND. Pp. xvi. +290. (N.Y.: Scribner's). 1.50. 19 illustr. (including vignettes) by S. R. Burleigh. 1900.

A rather ordinary love-story blended with a great deal about fairy influence, and interspersed with folk-lore stories and legends. The O'Briens and Sullivans finding life too hard in Ireland go to America against superstitious old Mrs. O'Brien's advice concerning the fairies. But the fairies who have migrated to Central Park, N.Y., substitute a changeling for the Sullivan baby. Nineteen years after all comes well. The O'Brien girl marries the refound Sullivan boy.

FROUDE, James Anthony. 1818-1894. This celebrated writer had already published his History of England when, in 1869, he came to live (for the summer) at Derreen, Kenmare, Co. Kerry, where ho began his The English in Ireland in the Eighteenth Century (first vol. appeared 1872). Like most of F.'s books, it provoked numerous answers, among others that of Father Thomas Burke, O.P., Froude on Ireland. The novel mentioned below embodies his chief ideas on Ireland.

621- THE TWO CHIEFS OF DUNBOY. Pp. 456. (Tongmans). 38. $6 d$.

[1889]. Several editions since.

Scene: the O'Sullivan's country in south-west Cork. Period: 1750-98. The ideas expressed in the Author's The English in Ireland put into the form of fiction. Thesis: if England had from the first striven to replace the hopeless Celt by Anglo-Saxon and Protestant Colonists she would have avoided her subsequent troubles in Ireland, and all would have been well. The English character (Colonel Goring) is throughout contrasted with the Irish (Morty Sullivan), the whole forming a powerful indictment of Ireland and the Irish as seen by Froude. 
FULLER, J. Franklin; "Ignotus." Born 1835. Is a native of Derryquin, near Sneem, Co. Kerry. In his young days he was a close friend of the priest (Fr. Walsh) who was the original of A. P. Graves's "Father O'Flynn." As Architect to the Ecclesiastical Commissioners and to the Church Representative Body he has travelled extensively through Ireland, and has lived in various parts of it-North, South, East and West-always on friendly terms with his Catholic neighbours. He resides in Dublin. In 1916 appeared his Omnianc: The Autobiography of an Irish Octogenarian.

622- CULMSHIRE FOLK. Pp. 384. (Cassell). [1873]. Third edition. n.d.

The plot is concerned with Sidney Bateman, heir of a family that has come down in the world, his struggles against misfortune, and his eventual attainment of fortune and happiness. But the chief interest is the kindly, thoughtful study of character and motive, of human nature in fact, also in the picture of the ways of the little society (largely clerical, e.g., the egregious Mr. M'Gosh) of Culmshire. Lady Culmshire, woman of the world, but with a warm and true heart within, is the central figure, and is a very pleasant, happily drawn portrait. The Irish interest is (1) the excellent description of the homecoming of Sidney Bateman to the ancestral castle of Rathvarney, in the wilds of Kerry, which are well described; (2) the doings of Tim Conroy, a sort of Mickey Free, and the Leveresque stories told of him by Capt. Howley; (3) the portrait of the old P.P. of Rathvarney, Fr. Walsh (the original of Graves's "Father O'Flynn").

623- JOHN ORLEBAR, CLERK. Pp. 293. (Cassell). [1878]. Second edition. n.d.

The plot of a villainous attorney, Joe Twinch, and his clerk, an absconding Fenian, to cheat the rightful heiress out of the Arderne estates. Dr. Packenham, a personal friend of Orlebar, who had married the heiress, suspects foul play, and comes to Kerry, where the first Lady Arderne had for some time resided, to make enquiries. He puts up at Rathvarney (see Culmshire Folk), meets Tim and Fr. Walsh (who helps to unravel the mystery), and sees something of Ireland in the sixties (Pp. 240-274). This something, it must be confessed, is chiefly squalor, described, however, in a humorous and not unsympathetic way.

FULTON, M. A.

624 ARTHUR'S REST; A Story of Trial and Conquest. Pp. 208. (Stockuell). 3s. net. n.d. (1903).

A novel written to advocate the provision of seats for shop assistants. Sceno: Ballycastle, Giant's Causeway, and Belfast. The Authoress is from Ballykelly, Co. Derry.

FURLONG, Alice. Better known as a poetess of much merit. She began to publ. poems in 1892. Many appeared in the IRISH MonthLy. Her volume Roses and Rue appeared in 1894.

625- TALES OF FAIRY FOLKS, QUEENS, AND HEROES. Pp. $212 . \quad$ (Browne \& Nolan). 2s. Four or five Illustr. by F. Rigney. Pretty cover. 1909.

Stories from ancient Gaelic Literature simply and pleasantly told. Contents :"Illan Bwee and the Mouse"; "Country Under Wave"; "The Step Mother" ; "The Fortunes of the Shepherd's Son "; "The Golden Necklet"; "The Harp of the Dagda Mor "; "The Child that went into the Earth," and several others.

GALlAHER, Miss Fannie; "Sydney Starr." Dau. of John Blake Gallaher, who was for 26 years Editor of the Freeman's Journal. She has been for the past 31 years secretary to the Duchess of Bedford, Bedford Park, London.

626- KATTY THE FLASH. (Gill). 1880.

The Flashes, mother and daughter, were specimens of the lowest type of Dublin fisherwomen. The story is founded on actual happenings, in particular the death of "Katty" in Grangegorman Prison, where she and her mother had often found themselves before. Their lives are set forth in all their ugliness amid the filth and squalor of their environment. 


\section{GALL,AHER, Miss Fannie; "Sydney Starr"-(continued).}

\section{7- THY NAME IS TRUTH. Three Vols. (Maxwell). 1884.}

Incidentally describes the Hospice for the Dying, Harold's Cross, and the inner working of a daily newspaper office. Cleverly written. The conversations are natural, and the human interest strong. The politics of the time (1881) are discussed, but they are not the main interest.

GAMBLE, Dr. John. I take the following account of this writer from a note on him contributed by Mr. A. A. Camplbell, of Belfast, to the IrIsH Book Lover (September, 1909) ; Dr. Gamble was born in Strabane, Co. Tyrone, in the early seventies of the eighteenth century. $\mathrm{He}$ was educated in Edinburgh. He devoted most of his life to a study of the people and characteristics of U.lster. He used to make frequent journeys on foot, or by coach, through the country, chatting with everyone he met, picking up story and legend and jest, and noting incidents. All his writings were imbued with a deep sympathy for his fellow-countrymen. As a vivid picture of the Ulster of his day his books are invaluable. They did much to produce in England a kindly feeling for his countrymen. He died in 1831.

\section{8- SARSFIELD. Three Vols. 12mo. (London). 1814.}

The hero is a young Irishman who, under the name of Glisson, is a French prisoner of war at Strabane. Aided by the daughter of the postmaster he escapes, and wanders all over Ulster, where (c. 1760) the wildest excitement about the threatened French invasion prevailed. Thence he goes to Scotland, England, and abroad. He fights with Thurot at the Siege of Carrickfergus, and eventually returns to Strabane, where he meets with a tragic ending. The Author embodies in the story many local traditions and much of his own observation and experience. Well worthy of republication.

\section{9 - HOWARD. Two Vols. 12mo. (London). 1815.}

"The subject of the following tale was born in a remote part of Ireland . . . my principal character is not altogether an imaginary one." The hero of this autobiography is Irish. The scene is London. The central incident is his seduction of a young lady who after attempting suicide dies of remorse and chagrin.

\section{0 - NORTHERN IRISH TALES. Two Vols. 8vo. (London). 1818.}

"Stanley," the first tale tells the adventures of a young profligate, son of a Derry Alderman, chiefly in Dublin. After a life of debauch he gets married, but goes bankrupt. His wife dies, he attempts suicide, but is rescued, and plunges once more into vice. The rest of the story tells of his determined pursuit of a young lady, ending in a murder for which he is tried and hanged. It is founded on a romantic episode well known in Ulster, the courtship and murder of Miss Knox, of Prehen, near Derry, by Macnaughton, and his subsequent execution for the crime. "Nelson" is a story of the American Revolutionary War. Vol. II. contains only one tale, "Lesley." The hero is a North of Ireland man, whose travels and love adventures on the Continent and at home are described. The Author indulges in a good deal of moralising.

631- CHARLTON; or, Scenes in the North of Ireland. Three Vols. 12 mo. (LoNDON). [1823]. New edition, 1827.

Depicts with sympathy for the views of the United Irishmen, the state of Ireland during the years that immediately preceded the rebellion. The hero is a young surgeon in a $\mathbf{N}$. of Ireland town who is tricked into becoming a United Irishman, and leads the rebels at Ballynahinch. Under the name of Diamond the Rev. James Porter is introduced, and many quotations are made from his satire "Billy Bluff." Northern dialect very well done. 
GANNON, Nicholas J. B. Ballyboy, Co. Meath, 1829. Brought up at Benada Abbey, Co. Sligo, residence of Mr. Daniel Jones. Ed. at Clongowes Wood College and Stonyhurst. For most of his days he lived a retired and literary life at his residence of Laragh, near Maynooth, with intervals of foreign travel. Besides his novels he publ. two vols. of poetry and several articles in the IRISH QUARTERLY ReVIEW. D. 1875.

632- ABOVE AND BELOW. 2 vols. (London: Newby). 1864.

The family of Sir Redmond O'Leary is "Above"; the McCarthys of the neighbouring town are "Below." The tale pursues through many vicissitudes the love of Sir Redmond's son for Mary McCarthy, and that of his daughter for John MoCarthy. But in the end the "Below" proves to be "Above" ako and the situation is saved without a mésalliance. There are some sensational scenes (attempted abductions, murders), but the book is by no means mere melodrama. Scenery (Sligo) is well described. Incidentally there are pictures of an archery meeting, a foxhunt, a wake, a fair and faction fight; and there is some fairy lore. The style is good, but old-fashioned in manner.

633- ROSE WALDRON; or, A Drag on the Wheel. Pp. 253. (Glasgow: C'ameron \& Ferguson). 6d. and 1s. n.d.

Subt.:-A Novel of Fashionable Life. Period: about 1848; Scene: partly in Ireland, partly in various parts of Europe. Rose and Robert McCloran are kept apart by unscrupulous plotting of a wicked aunt, the machinations of a rival suitor, and complications caused by mistaken identity. But all comes well.

GAUGHAN, Jessie. Born in Shropshire; one parent Irish, the other Scotch. Educated in Paisley and in Ursuline Convent, Sligo. Besides the book here mentioned she has publ. serially in I.M. The Brooch of Lindisfarne, and has in preparation a story dealing with Ireton's days in Limerick.

634- THE PLUCKING OF THE LILY. Pp. 220. (Washbourne). 1912.

Reprint from I.M. 1911-12. A charming little story of Elizabethan times in Ireland (c. 1589-94), telling the love-story of Eileen daughter of Earl Clancarthy and Florence M'Carthy. Their love is crossed by the policy of Elizabeth, who, for State purposes, wants an English husband for Eileen, and not till the end are the two lovers united again. The historical setting and colouring are accurate, but never interfere with the story. The tone is Catholic, but not obtrusively so. Good portrait of Elizabeth. Burleigh (in a favourable light), Sir Warham St. Leger, and other historical personages appear.

GAY, Mrs. Florence, née Smith. Born in Molong, N.S.W., Australia. Is an ardent imperialist, but proud of the strain of Celtic blood in her family, and sympathetic towards Ireland. Resides in Surrey.

635- THE DRUIDESS. Pp. 195. (Ouseley). 2s. 6d. 1908.

Cormac, a youth of Pictish royal blood has a mission from his dying father to rescue from the Saxons the mother of his intended bride. His adventures in carrying out this mission bring him from Damnonia (between the Yeo and the Axe) to Ireland (Glendalough, Tailltenn, Donegal). $\mathrm{He}$ is present at the halfpagan-festival of Beltaine, and at the Convention of Drumceat. At the latter he meets St. Columba, who is sympathetically described. The story deals largely with the lingerings of Paganism in Ireland. Several battles between Saxons and Britons are described. The savage manners of the time are pictured with realistic vividness. The wild scenes of adventure follow one another without a pause. Intended for "boys and others."

[GETTY, Edmund]. 1799-1857. Sometime Secr. of the Belfast Harbour Board and contributor to Ulster Journal of ARCheology.

636- THE LAST KING OF ULSTER. Three Vols. (London: Madden). 1841.

Ostensibly a tale, in reality a kind of historical niscellany of Elizabethan times, containing memoirs, anecdotes, family history, \&c., of the O'Neills, O'Donnells, and other Irish chiefs. The Author was one of the best of our Northern antiquaries. 
GIBBON, Charles. B. Scotland. D. 1890, at age of 42 . Wrote some 30 other novels.

637-_ IN CUPID'S WARS. Three Vols. (F.V. White). 1884.

The scene is laid in Kilkenny in 1798 or thereabouts, but both the topographical and historical settings are of the vaguest-there is very little local colour, and practically no depiction of historical events, though there is much about rebellion and secret societies. The story is thoroughly melodramatic: it has no serious purpose, but the tone is wholesome. The characters of the story are all represented as Catholics.

[GIBSON, Rev. Charles Bernard]. (1808-1885). Was chaplain at Spike Island, and sometime minister of the Independent congregation at Mallow, Co. Cork, but afterwards joined the Church of England. He was made M.R.I.A. in 1854. He wrote a History of Cork City and County (1861), and five or six other works, including Historical Portraits of Irish Chieftains and Anglo-Norman Knights, 1871.

638- THE LAST EARL OF DESMOND. Two Vols. (Hodges \& Smith). 1854.

Extensive pref., introd. (summarising history of Earls of Desmond), and notes. Scene: Mallow, various parts of Munster, and the Tower of London. All the great personages of the time, English and Irish, figure in the story, but several fictitious characters are introduced, and many fictitious episodes are throughout the story mingled with the facts of history. The main plot turns on the Sugán Earl's love for, and marriage with, Ellen Spenser (an imaginary daughter of the poet). The bias is strongly anti-Catholic. Fr. Archer, s.J., is the villain of the piece, stopping at no crime to gain his ends. It is also, though not to the same extent, intiIrish. He relies for his facts entirely on Pacata Hibernia (point of view wholly English). The Irish chiefs are made to speak in vulgar modern-Irish dialect ("iligant," " crattur," "yr sowls to blazes," \&c., \&c.). The humour is distinctly vulgar, as in the case of the Author's other novel. Raleigh is one of the personages.

639_ DEARFORGIL, THE PRINCESS OF BREFFNY. Pp. 287. (London: Hope). [1857]. 2nd ed. (Longmans). 1884. Pp. xxiv.+284.

Story of Diarmuid MacMurrough's abduction of the wife of O'Ruairc of Breffni, and subsequent events, including an account of the Norman Invasion. The tone throughout is anti-National, and most offensive to Catholic feeling. The frequent humorous passages are nearly always vulgar, and in some instances coarse. There are many absurdities in the course of the narrative.

\section{GIBSON, Jennie Browne.}

\section{0- AILEEN ALANNAH. Pp. 86. (Stockwell). 1s. net. One good illustr.} 1911.

Desmond Fitzgerald and Aileen have been sweethearts from childhood. D. has to go to America. Percy Gerrard intercepts their letters, and tries to marry Aileen. She is broken-hearted, and goes as nurse to a London hospital. Percy at the point of death confesses his wickedness, and No. 27 in one of the wards turns out to be - Scene : at first Donegal. A very pleasant story, full of kindly Irish people, entirely free from bigotry, and with an excellent though unobtruded moral purpose.

"GILBERT, George" ; Miss Arthur. Has written also In the Shadow of the Purple (1902), The Baton Sinister (1903), and To My King Ever Faithful.

641— THE ISLAND OF SORROW. Pp. 384. (Long). 6s. 1903.

Deals, in considerable detail, with political and social life in the Ireland of the time. The circles of Lord Edward and Pamela Fitzgerald (centring in Leinster House), of the Emmet family (at the Casino, Milltown), and of the Curran family (at the Priory, Rathfarnham) are fully portrayed and neatly interlinked in private life. The whole romance of Emmet and Sarah Curran is related. There are many 


\section{"GILBERT, George"; Miss Arthur-(continued).}

portraits-Charles James Fox, Curran (depicted as a domestic monster), many men of the Government party, above all, Emmet. This portrait is not lacking in sympathy, though the theatrical and inconsiderate character of his aims is insisted on. The whole work shows considerable power of dramatizing history, and is made distinctly interesting. "The author," says Mr. Baker, "tries to be impartial, but cannot divest himself of an Englishman's lack of sympathy with Ireland. The book is preceded by a valuable list of authorities and sources.

\section{GILL, E. A. Wharton.}

642_- AN IRISHMAN'S LUCK. (Hodder \& Stoughton). 6s. 1914.

"A domestic tale of young folk in a British settlement in Manitoba, and of the Canadian contingent in the Boer War."-(T. Lir. SUPpl.).

\section{" GODFREY, Hal," see CHARLotTe O'C. ECCLES.}

GOLDRING, Douglas. B. Greenwich, 1887. After some time at Oxford took up journalism. Was on the staff of Country Life and of The Engirsh Review, as sub-editor. Since 1911 has publ. upwards of a dozen books-travel, verse, and fiction-including (under the pien-name "An Englishman?") Dublin: Explorations \& Reflections, and A Stranger in Ireland, 1918. His other novels are: It's an Ill Wind, Margot's Progress, and Polly. Is a grandnephew of Rev. James Carlile, a former Moderator of the Presbyterian Synod. His home is now in Dublin.

643_- THE FORTUNE. A Romance of Friendship. Pp. 332. (Maunsel). 5s.

Several strands of interest are interwoven in this novel. There is (1) the psychological study of the peculiar and rather one-sided friendship between English Harold Fairbank, an "intellectual," and James Murdock, a young Irishman of the landlord class. (2) It is a study in pacifism. The Author describes the process of disillusionment in Harold, whose first enthusiasm for the war is extinguished by his experiences at the front, by war scandals at home, and by the influence of his friend. There is a somewhat cynical picture of the English war fever. (3) There is the more directly Irish interest. The scene near the outset is laid at "Mount Dori," somewhere beyond Rathfarnham, and there are fine descriptions of Dublin and surroundings. Towards the close the hero's duties bring him to Ireland. $\mathrm{He}$ is in command of English troops during the Easter Week Rising of 1916, but is half in sympathy with the rebels. The moral tone of the male characters in the story is distinctly low, and passes without reproof. There is a vivid narrative of a couple walking out at night, and some needless sneers at Belgian religion.

GOODRICH, Samuel Griswold; "Peter Parley." Born 1793 in Connecticut. Author of 170 volumes, the list of them, with notes, occupying $7 \frac{1}{2}$ columns of Allibone, of which 116 appeared under pseud, "Peter Parley." Seven millions had, according to the Author, been sold at date of Allibone.

\section{TALES ABOUT IRELAND AND THE IRISH. 16mo. Pp. 300.}

(LoNDON: Berger). [1834]. 1836, 1852, 1855. n.d. c. 1865.

In $\mathrm{Ch}$. I. there is a short account of the physical features, climate, etc., of $\mathrm{I}$. Pages 20-140 give a popular account of Irish history from the English point of view, but on the whole not unfair to Ireland. At p. 150 commences a pleasant little description of a tour round I., with some little account of antiquities seen on the way; also occasional legends and stories connected with places. Mlustrated by a number of small nondescript woodcuts of no valne. The above work seems to be a portion of the Author's Tales About Great Britain. First publ. Baltimore. 1834. 


\section{"GRANT, John O'Brien"; “Denis Ignatius Moriarty." See DAUNT, W. J. O'NEILL.}

GRAVES, Alfred Perceval. Born in Dublin, 1846, but his family resided in Kerry. Son of late Dr. Graves, Bp. of Limerick. Educated at Windermere Coll. and T.C.D. Was Inspector of Schools from 1875-1910. For eight years Hon. Sec. of Irish Literary Society. Publ. upwards of 20 books, nearly all on Irish subjects-poems, songs (including the famous "Father O'Flynn"), translations from the Irish, essays. Resides in Wimbledon.

\section{5- THE IRISH FAIRY BOOK. (Fisher Unwin). Illustr. by George}

Denham. [1909]. new. ed. 6s. n. 1918.

A collection of fairy, folk, and hero-tales, nearly all selected from books already published, together with poems by Mangan, Tennyson, Nora Hopper, \&c. Also tales from Standish H. O'Grady, Brian O'Looney, Thomas Boyd, Mrs. M‘Clintock, Mrs. Ewing, Douglas Hyde, O'Kearney, \&c. All are inspired by Gaelic originals. "The book is one to delight children for its simple, direct narratives of wonder and mystery," while the fairy mythology will interest the student of the early life of man. The illustrations are as fanciful and elusive as the beings whose doings are told in the tales. Mr. Graves's Preface is a popular review of the origin and character of fairly lore.-(Press Notice).

GRAVES, Arnold, brother of the preceding.

646_ PRINCE PATRICK. Pp. 108. (Downey). V. well illustr. by Arthur McCormick. 1898.

An Irish fairy tale laid in old Gaelic times. Scene: Co. Kerry, round Cahirciveen and Staigue Fort. Prince $P$. is spirited away when a baby by a witch and a changeling substituted. When Prince P. grows up he succeeds in finding a linen garment which proves his identity. He saves the Princess Nora, is acknowledged as Tanist, and lives happily ever after.

\section{GRAVES (Charles L.) ed.}

647- HUMOURS OF IRISH LIFE. Pp. xxxvi.+349. (DUBLIN: The Talbot, Press). 2s. 6d. Frontisp. by Geo. Morrow. 1915. [Every Irishmax's LIBRARY].

Introd. (36 pp.) by Ed. deals with the humorous writers represented in this collection with casual mention of a few others. It is largely taken up with a very eulogistic appraisement of the writers known as Somerville and Ross. The book consists of selections from Maginn, Lever, Lover, Le Fanu, Patrick Kennedy, P. J. McCall, E. Alexander, Jane Barlow, G. A. Birmingham, Shan Bullock, Padraic Colum, Lynn Doyle, Somerville and Ross, K. F. Purdon, Frank Mathew, Percy French, Sir Samuel Ferguson, C. O'Conor Eccles, John Stevenson, H. de Vere Stacpoole, Thomas Ettingsall. The selection is a wide one, but there is surely room for another volume, which should include Edmund Downey, Seamus MacManus, Archibald McIlroy, Father T. A. Fitzgerald, Canon Sheehan, Judge Bodkin. The pieces given are thoroughly amusing, but, as is perhaps natural in such a volume of selections, they are all in a vein of very broad comedy. Not a few are of the tare an' ouns type verging on the "stage Irishman." The first seven are folk-tales.

GREER, James. Died in Derry in 1913 at an advanced age. He edited a Guide to Londonderry and the Highlands of Donegal, 1885, which went through several editions.

648 - THREE WEE ULSTER LASSIES; or, News from our Irish Cousins. (Cassell). 1s. 6d. Illustr. by old blocks. 1883

The three lassies are Bessie Strong, the Ulster-Saxon, a landlord's daughter; Jennie Scott, the Ulster-Scot, a farmer's daughter; and Nellie Nolan, the UlsterKelt, a peasant girl. The Author insists throughout on the vast superiority of the English and Scotch elements of the population- "the grave, grim, hardy sturdy race." Interlarded with texts and hymns. In the end Nelly, after an encounter with the priest and stormy interviews with the neighbours, is converted and goes to America. 
GREER, Tom. Was born at Anahilt, Co. Down, a member of a well-known Ulster family. Ed. at Queen's College, Belfast. M.A. and M.D., Queen's University, and practised in Cambridge. Unsuccessfully contested North Derry as a Liberal Home Ruler, 1892. Died a few years afterwards. The central idea of this tale was suggested by the old Co. Derry folk tale of Hudy McGuiggen. Seo HARKIN, Hugh.

\section{9- A MODERN DEDALUS. Pp. 261. (London: Griffith, Farran, \&c.).} 1885.

The introd. is signed John O'Halloran, Dublin, 30th Feb., 1887! A curious story, told in first person, of a Donegal lad who learned the secret of aerial flight by watching the sea-birds. He flies over to London. Is in the House of Commons for a debate. Parnell is well described. The way Parliament and the Government and the Press dealt with the new invention is cleverly and amusingly told. Jack, the hero, is imprisoned but escapes, and on his return there is a successful rising in Ireland, who establishes her independence by her air fleet. The book is full of politics (Nationalist point of view). An eviction scene in Donegal- "The Battle of Killynure"-is described. Shrewd strokes of satire are aimed at the Tories throughout.

GREGoRY, Lady. Dau. of Dudley Persse, D.L., of Roxborough, Co. Galway. Has identified herself with the modern Irish literary movement. Besides the books here noted she has written a great many plays for the Abbey Theatre. Her home is Coole Park, Gort, Co. Galway, in the barony of Kiltartan.

The Cuchulain legends woven into an ordered narrative. The translation for the most part is taken from texts already published. Lady Gregory has made her own translation from them, comparing it with translations already published. "I have fused different versions together and condensed many passages, and I have left out many." The narrative is not told in dialect but in the idiom of the peasant who speaks in English and thinks in Gaelic. "I have thought it more natural to tell the stories in the manner of thatched houses, where I have heard so many legends of Finn, \&c. . . . than in the manner of the slated houses where I have not heard them." The matter also is often such as the peasant Seanciure might choose; the clear epic flow being clogged with garbage of the Jack-the-Giantkiller type. Fiona MacLeod says very well of the style that it is "over cold in its strange sameness of emotion, a little chill with the chill of studious handicraft,", and speaks elsewhere of its "monotonous passionlessness" and its "lack of virility." Yet to the book as a whole he gives high, if qualified, praise. W. B. Yeats, in his enthusiastic Preface, speaks of it as perhaps the best book that has ever come out of Ireland. These remarks apply also to the following work.

651- GODS AND FIGHTING MEN. Pp. 476. (Murray). 6s. Pref. by W. B. Yeats. (N.Y.: S'cribner). 2.00. 1906.

Treats of : Part I. "The Gods" (Tuatha De Danaan, Lugh, The Coming of the Gael, Angus Og, the Dagda, Fate of Children of Lir, \&c.); II. "The Fianna" (Finn, Oisin, Diarmuid, and Grania). The Finn Cycle is treated as being wholly legendary.

\section{2_ A BOOK OF SAINTS AND WONDERS. (Murray). 5s. 1907.}

A series of very short (half page or so) and disconnected stories or fragmentary anecdotes. Told in language which is a literal translation from the Irish, and in the manner of illiterate peasants. First, there are stories of the saints, all quite fanciful, of course, and usually devoid of definite meaning. Then there is the voyage of Maeldune, a strange piece of fantastic imagination often degenerating into extravagance and silliness. The book is not suitable for certain readers owing to naturalistic expressions. 
GREGORY, Lady-(continued.

653- THE KILTARTAN WONDER-BOOK. Pp. 103. 9 in+7. (Maunsel).

3s. 6d. net. Illustr. by Margaret Gregory. Linen cover. 1910.

Sixteen typical folk-tales collected in Kiltartan, a barony in Galway, on the borders of Clare, from the lips of old peasants. "I have not changed a word in these stories as they were told to me."-(Note at end). But some transpositions of parts have been made. It does not appear whether the stories were told to Lady Gregory in Irish or in English. Nothing unsuited to children. All the tales are distinctly modern in tone if not in origin. The illustrations are quaine and original, with their crude figures vividly coloured in flat tints.

\section{GRIERSON, Elizabeth.}

654- THE CHILDREN'S BOOK OF CELTIC STORIES. Pp. 324. (Black). 6s. Twelve very good illustrations in colour from drawings by Allan Stewart. 1908.

Sixteen fairy, folk, and hero-tales, partly Irish, partly Scotch, dealing, among other things, with wonderful talking animals that prove to be human beings transformed, adventures of king's sons amid all kinds of wonders, \&c. One is "The Fate of the Children of Lir," and there are five or six about Fin. There is little or no comicality. The style is simple and refined, free from the usual defeots of folk-lore. The book is beautifully and attractively produced.

655-THE SCOTTISH FAIRY BOOK. Pp. 384. (Fisher Unwin). 6s. $100 \mathrm{Ill}$. by M. M. Williams. 1910.

Same series as Mr. A. P. Graves's Irish Fairy Book, q.v. Illustr. in a similar way. Not all of these tales will be new to Irish children.

GRIERSON, Rev. Robert. B. in Dublin, 1843. Ed. privately and at T.C.D. The family is of Scotch origin but long settled in Ireland. $\mathrm{He}$ resides in Rathmines. Among his stories are: "The New Weekly: a Satire"; "How the Laundry Class was Broken Up"; "A Secret Crime"; "The Story of a New Woman"; "Her Boy: a Nurse's Story"; "The Mystery of Hamilton Grange." The MSS. of his many stories were sent to his relative Gen. B. H. Grierson for publication in the U.S.A. On the death of the General shortly after, the MSS. were lost.

656- THE INVASION OF CROMLEIGH: a Story of the Times. Pp. 226. (Operative Jewish Converts' Institution), 2s. 1900.

657-_ BALLYGoWNA. Pp. 142. (Aberdeen: Moran). 1s. 1898.

A story of Irish plots and disturbances.

GRIFFIN (Amy), a Co. Clare lady.

658- HIS SHARE OF THE WORLD. Pp. 199. (Greening). 1904.

Scene, Co. Cork, shifting during part of the story to New York. Mrs. Donovan's twin boys and her adopted daughter, Moira, grow up together. Connor is adopted by rich American relatives. He returns after seven years. Both brothers love Moira, but she chooses Connor and John makes the noble sacrifice of his love and happiness. An interesting character is Poppie the lively daughter of the American relatives: There are incidental pictures of Irish country life. The moral tone is high, and the Irish people are represented in the most favourable light. 
GRIFFIN, Gerald. Is one of our foremost novelists of the old school. Born in Limerick 1803, died 1840. Brought up on the banks of the Shannon, twentyeight miles from Limerick. At twenty he went to London, where most of his writing was done. But he paid many long visits to Ireland (Pallas Kenry). Two years before his death he became a Christian Brother. "He was the first," says Dr. Sigerson " to present several of our folk customs, tales, and ancient legends in English prose. Griffin wrote with a high moral purpose. P. J. Kenedy, of New York, publishes an edition of his works in seven volumes, and Messrs. Duffy have an edition in ten vols. at $2 s$. each, including his Life by his brother, publ. in 1842.

659-HOLLAND TIDE. Pp. 378. (Simpkin \& Marshall). [1827].

First series of Tales of the Munster Festivals, q.v. Often published separately.

660 - THE COLLEGIANS; or, The Colleen Bawn. (Duffy). 2s. [1828]. Still reprinted. (N.Y.: Benziger). 0.75. New eds. (Duffy). 3s. 6d. 1918. (Talbot Press). 3s. 6d. 1918. With introd. by Padraic Colum.

Pronounced the best Irish novel by Aubrey de Vere, Gavan Duffy, and Justin $\mathrm{M}^{\prime}$ Carthy. Its main interest lies in its being a tragedy of human passion. The character of Hardress Cregan, the chief actor, is powerfully and pitilessly analysed. Eily O'Connor is one of the most lovable characters in fiction. Danny Man, with his dog-like fidelity; Myles, the mountainy man, simple yet shrewd; Fighting Poll of the Reeks; Hardress Cregan's mother, are characters that live in the mind, like the memories of real persons. There are pictures, too, of the life of the day, the drunken, duelling squireen, the respectable middle-class Dalys, the manners and ways of the peasantry, whose quaint, humorous, anecdotal talk is perfectly reproduced, but who are shown merely from without. The scene is laid partly in Limerick and partly in Killarney. Dion Boucicault's drama, "The Colleen Bawn," is founded on this story, which itself is founded on a real murder trial in which O'Connell defended the prisoner and which Griffin reported for the Press.

N.B. - I have since come across a little book (111 pp.) publ. Dublin, 1910, but bearing no name of publisher or printer. It is entitled Ellen Hanly; or, The True History of the Colleen Bawn, by one who knew her in life and saw her in death. The account opens with 1819. Real names not given: only initials and dashes.

661 CARD-DRAWING, \&c. 1829.

Second series of Tales of the Munster Festivals, q.v.

662 THE CHRISTIAN PHYSIOLOGIST. Tales illustrative of the Five Senses. Pp. xxvi.+376. (Bull). 1830.

The itales are:-1. "The Kelp Gatherers"; 2. "The Day of Trial"; 3. "The Voluptuary Cured"; 4. "The Self Consumed"; and 5. "The Selfish Crotarie." Clever little stories of ancient and modern Ireland, intended to describe the mechanism and use of each sense. Several of them have been reprinted separately by Messrs. Duffy.

663-THE INVASION. Very long. (Duffy). 2s. [1832]. Still reprinted.

[N.Y.: Benziger). 0.75.

Scene: chiefly the territory of the O'Haedha sept on Bantry Bay. The story deals with the fortunes of the O'Haedhas, but there are many digressions. The innumerable ancient Irish names give the book a forbidding aspect to one unacquainted with the language. The narrative interest is almost wanting, the chief interest being the laborious and careful picture of the life and civilization of the time, the eve of the Danish Invasions. The archæology occasionally lacks accuracy and authority, but these qualities are partly supplied in the notes, which are by Eugene O'Curry. The invasion referred to is an early incursion on the coasts of West Munster by a Danish chief named Gurmund. Some of the characters are finely drawn, e.g., the hero, Elim, and his mother and Duach, the faithful kerne.

664 - THE RIVAIS. 1832.

Third series of T'ales of the Munster F'estivals, q.v. 
GRIFFIN, Gerald-(continued).

664A- TALES OF THE MUNSTER FESTIVALS. (IN.Y.: Pratt). 0.50.

Scene: the wild cliffs and crags of Kerry and West Clare. Theme: the play of passions as wild and terrible as the scenes; yet there are glimpses of peasant home-life and hospitality, and many touches of humour. The tales appeared in three series, 1827, 1829, and 1832. The first (Holland Tide) contained the "Aylmers of Ballyaylmer," a story about a family of small gentry on the Kerry coast, with many details of smuggling; "The Hand and Word," "The Barber of Bantry," with its picture of the Moynihans, a typical middle-class fanily, like the Dalys in The Collegians, and several shorter tales. The second series contains "Card-drawing," "The Half-Sir," and "Suil Dhuv the Coiner," which deals with the "Palatines" of Limerick. The third series contains The Rivals and Tracy's Ambition. These are sensational stories. The first has an interesting picture of a hedge-school, the second brings out the people's sufferings at the hands of "loyalists" and government officials. They contain several instances of seduction and of elopement. Perhaps the best of these is "Suil Dhuv the Coiner." The characters of the robbers who compose the coiner's gang are admirably discriminated, and the passion of remorse in "Suil Dhuv" is pictured with a power almost equal to that of The C'ollegians. The Author's aim, as he tells us, was "never to travel out of perfect and easy probability." In several of the tales there is a magnificent background of wild coast scenery.

\section{5_ TALES OF MY NFIGHBOURHOOD. Three Vols. (S'aunders \& Otley). 1835.}

Vol. 1 contains "The Barber of Bantry," a story of a somnambulist, with a supernatural element. Vol. 2. Three sketches and the dramatic ballad "The Nightwalker." Vol. 3. Eight short sketches and the poems "Shanid Castle" and "Orange and Green."

\section{6- THE DUKE OF MONMOUTH. Pp. 423. (Maxwell). 1842.}

A clever historical novel, dealing with this unfortunate nobleman and the battle of Sedgmoor. Two Irish soldiers, Morty and Shemus Delany, supply the comic relief. "The fine ballad, "The Bridal of Malahide," first appears here, and the song, "A Soldier, A Soldier."

667- TALES OF THE JURY ROOM. Pp. 463. (Duffy). 2s. [1842]. Still reprinted. Original title Talis Qualis.

The scenes of three of these tales are in foreign lands-Poland, the East, France in the days of Bayard. The remaining ten are Irish. Among them are fairy tales, tales of humble life, an episode of Clontarf, a story of the days of Hugh O'Neill, and several, including the Swans of Lir, that deal with pre-Christian times. All are well worth reading, especially "Antrim Jack"-Macalister, who died to save Michael Dwyer.

668- THE OFFERING OF FRIENDSHIP. (LoND.). 1854. Is the Christian Physiologist with a new title.

669 _ JUVENILE TALES.

These are to be had in separate volumes at about a shilling each, pub. by Duffy, or in penny numbers, publ. by C.T.S.I. Their titles are "The Kelp Gatherer," "The Day of Trial," "The Voluptuary Cured," "The Young Milesian," "The Beautiful Queen of Leix," "The Song of Psyche," "The Knight Without Reproach."

GRIFFITH, George, Author of some 40 novels.

670 - THE KNIGHTS OF THE WHITE ROSE. Pp. 311. (J. F. Shaw). 3s. 6d. Several good illustr. by Hal. Hurst. 1908.

The adventures of three young soldiers, an Englishman (the hero), an Irishman, and a Scotchman, in a Jacobite crack regiment. Lively descriptions of fighting before Derry and at the Boyne. Good outline of the campaign, but little historical detail or description. Told in pleasant style, with plenty of go. For boys. 


\section{GRIFFITHS (Gertrude).}

671_ IN THE LAND OF PAT. P. 5. 51. (A. L. Humphreys). 2s. 1917.

"A slight, good-natured account of a pleasant holiday enjoyed by a small party of English visitors amid the wilds of Mayo. The writer, a keen observer, delightfully hits off the foibles of her servants and neighbours, and notwithstanding her inability to transfer the brogue into print, she has succeeded in producing an excellent volume, of which three impressions have been called for in a month." I.B.I.

GRImSHAW, Beatrice. An Irish Authoress, born in Cloona, Co. Antrim. Most of her novels do not deal directly with Ireland, but some of her chief characters are Irish. Thus Hugh Lynch, a Co. Clare man, is the hero of her When the Red Gods Call (Mills \& Boon), 1910, and Geo. Scott, a typical Belfastman plays a prominent part in Guinea Gold (Mills \& Boon), 1912. These novels deal with New Guinea life.

672- BROKEN AWAY. (Tane). 6ะ 1897.

The first novel of this Author, who began her career in Belfast. Scene : Dublin and Belfast. Stuart Rivington's great success as a novelist arouses the jealousy of Alfred Moore, an author who has written himself out. Rivington retires to the Wicklow mountains to finish the book that is to be his masterpiece. Moore follows with intent to steal the MS., loses his reason, attempts murder, but loses his life in the attempt. "The people," said the New IRLEand Review, in a critique, " act and speak, gossip and criticize one another, as people in what is called Dublin Society are supposed to do."

\section{GRINDON, Maurice.}

673-KATHLEEN O'LEOVAN : a Fantasy. Pp. 107. Two illustr. (Simpkin, Marshall). 1896.

Levan, grandson of an O'Leovan who had settled in England, visits the home of his ancestors, Castle Columba, Kilronan, and meets the heroine.

\section{GUENOT (C.).}

674- LE COMTE DE TYRONE; or, L' Irlande et le Protestantisme au XVI. siècle. Pp. 350. Demy 8vo. (Tours: Marne). 1867.

Something between history and an historical novel, e.g., all the historical events are related, but the conversations are given in full. Covers period 1542 to 1603. Written with enthusiasm for the Irish cause. See supra No. 19.

GUINAN, Rev. Joseph. Father Guinan is P.P. of Dromod, in Co. Longford. Before his appointment to an Irish parish he passed five years in Liverpool. This gave him "the fresh eye," the power to see things which, had he remained in Ireland, he might never have observed. His books deal with two things - the life of the poorest class in the Midlands and the life of the priests. Of both he has intimate personal knowledge, and for both unbounded admiration. He writes simply and earnestly. To the critic used only to English literature, his work may seem wanting in artistic restraint, for he gives free rein toemotion. But this is more than atoned for by its obvious sincerity.

675- SCENES AND SKETCHES IN AN IRISH PARISH; or, Priests and People in Doon. (Gill). 2s. Fourth edition. 1906.

A faithful picture of typical things in Irish life: the Station, the Sunday Mass, the grinding of landlordism, the agrarian crime, the eviction, the emigration-wake. See especially the chapter "Sunday in Doon." This is the Author's first novel, and is somewhat immature. 


\section{GUINAN, Rev, Joseph-(continued).}

\section{6- THE SOGGARTH AROON. (Gill d Duffy). 2s. 6d. (N.Y.: Benziger).} 1.00. 2nd ed. 1907. 3rd, 1908.

Pathetic experiences of a country curate in an out-of-the-way parish, where the people's faith is strong and their lives supernaturally beautiful. The Soggarth shares the few joys and the many sorrows of their lives.

\section{7- THE MOORES OF GLYNN. Pp. 354. (Washbourne). 3s. 6d. (N.Y.:} Pratt). 2.00. [1907]. 3rd ed. 1915.

The fortunes of a family of four children whose mother is a beautiful and lovable character. The book is full of pictures of many phases of Irish life, the relations between landlord and tenant, priests and people, evictions, emigration, a "spoiled priest." A typical description is the realistic picture of the pig fair. Full of true pathos, with an occasional touch of kindly humour.

678— THE ISLAND PARISH. Y'p. 331. (Gill). 1908.

The work of an ideal young priest in Ballyvora, a kind of Sleepy Hollow whero all is stagnation, poverty and decay. The picture of these squalid conditiony of life is one of photographic and unsparing exactness. Yet with loving insight the Author shows the peasant's quiet happiness, beauty of soul, and downright holiness of life in the midst of all this. There is no plot, the book is a series of pictures loosely strung together. There is a chapter on Lisdoonvarna.

\section{9- DONAL KENNY. (W'ashbourne). 1910. (N.Y.: Benziger). 1.10.}

Donal tells his own story-his mother's early death, followed by his father's rapid fall into habits of drink; his own early struggles; his love for Norah Kenny; his search for traces of her real identity; and the happy ending of it all. Displays all the Autlior's knowledge of Irish life in sketches of priests and people. Especially good is the character study of the faithful old nurse, Nancy, with her quaint sayings.-(Press Notice).

\section{0_THE CURATE OF KIICLOON. Pp. 282. (Gill). 3.s. 6d. 1913.}

Labours, sorrows, and consolations of a young priest in a very out of the way country parish. He had been very distinguished at Maynooth and seemed thrown away on such a place as Kilcloon, but he finds that there is work there worth his doing-temperance to be promoted, the Gaelic League to be established, industries to be fostered. The story has the same qualities as the Author's former books, and in fact differs little from them.

GWYNN, Stephen. Born in Donegal, 1864. Eldest son of Rev. John Gwynn, T.C.D. Is a grandson of William Smith O'Brien. Educated St. Columba's College, Rathfarnham, and Oxford, where he read a very distinguished course. Since 1890 he has published a great deal-literary criticism, translations, Irish topography, journalism, novels, politics. Was Nationalist M.P. for Galway City 1906-1918, and was one of the most active members of the Irish Parliamentary Party. Joined the British Army in the present war, and holds the rank of Captain.

\section{1- THE OLD. KNOWLEDGE. (Macmillan). 6. 1901.}

A book quite unique in conception. Into the romance are woven fishing episodes and cycling episodes and adventures among flowers. There are exquisite glimpses, too, of Irish home life, and the very spirit of the mists and loughs and mountains of Donegal is called up before the reader. But above all there is the mystic conception of Conroy, the Donegal schoolmaster, whose soul lives with visions, and communes with the spirits of eld, the nature gods of pagan Ireland.

\section{2- JOHN MAXWELL'S MARRIAGE. (Macmillan). 6s. 1903.}

Scene: chiefly Donegal, c. 1761-1779. A strong and intense story. Interesting not only for its powerful plot, but for the admirably painted background of scenery 
GWYNN, Stephen-(continued).

and manners, and for its studies of character. It depicts in strong colours the tyranny of Protestant colonists and the hate which it produces in the outcast Catholics. One of the main motives of the story is a forced marriage of a peculiarly odious kind. In connection with this marriage there is one scene in the book that is drawn with a realism which, we think, makes the book unsuitable for certain classes of readers. The hero fights on the American side in the war of Independence, and takes a share in Nationalist schemes at home.

683- THE GLADE IN THE FOREST . Pp. 224. (Maunsel). 1s. Cloth. 1907. New eds. since.

Seven short stories, chiefly about Donegal, five of them dealing with peasant life, of which the Author writes with intimate and kindly knowledge. "The Grip of the Land" describes the struggles of a small farmer and the love of his bleak fields that found no counterpart in his eldest boy, who has his heart set on omigration. Compare Bazin's La Terre qui Meurt. All the stories had previously appeared in such magazines as the CoRnHILL and BLACKwood's.

\section{4- ROBERT EMMET. (Macmillan). 6s. Map of Dublin in 1803. 1909.}

An account of the Emmet rising related with scrupulous fidelity to fact and in minute detail. The Author introduces no reflections of his own, leaving the facts to speak. His narrative is graphic and vivid, the style of high literary value. The minor actors in the drama-Quigley, Russell, Hamilton, Dwyer-are carefully drawn. Though he gives a prominent place in the story to Emmet's romantic love for Sarah Curran, Mr. Gwynn has sought rather to draw a vivid picture of the event by which the young patriot is known to history than to reconstruct his personality.

\section{HALL, E.}

685- MUNNTER FIRESIDES; or, The Barrys of Beigh. Pp. 394. (M'Glashan d Gill). [1875].

Scene: banks of Shannon twenty miles below Limerick. Story opens about 1775.

HALL, Mrs. S. C. Born in Dublin, 1800. Brought by her mother (who was of French Huguenot descent) to Wexford in 1806. Here she lived, mixing a good deal with the peasantry, until the age of fifteen, when she was taken away to London, and did not again return to Wexford. Wrote nine novels, and many short stories and sketches. Besides the works noticed here, she and her husband produced between them a very large number of volumes. See his Reminiscences of a Long Life. Two vols. London. 1883. A reviewer in BLACKwood's describes her work as "bright with an animated and warm nationality, apologetic and defensive." She died" in 1881.

686- SKETCHES OF IRISH CHARACTER. Pp. 443. (Chatto \& Windus). 7s. 6d. 61 illustr. by Maclise, Gilbert, Harvey, George Cruikshank, \&c. [1829]. 1854 (5th), 1892, \&c., \&c.

Mrs. Hall intends in these sketches to do for her village of Bannow, in Wexford, what Miss Mitford did for her English village. This district, she says, "possesses to a very remarkable extent all the moral, social, and natural advantages, which are to be found throughout the country." The author proclaims (cf. Introduction) her intention "so to picture the Irish character as to make it more justly appreciated “ i and more respected in England." She applies to the peasantry the saying "their virtues are their own; but their vices have been forced upon them." Again she says, "the characters here are all portraits." Yet it must be confessed that the standpoint is, after all, alien, and something strangely like the traditional stage Irishman appears occasionaliy in these pages. There is, however, not a shadow of religious bias. The "Rambling Introduction" makes very pleasant reading. 
HALL, Mrs. S. C.-(continued).

687- LIGHTS AND SHADOWS OF IRISH LIFE. Three vols. (long). (Colburn). 1838.

In five parts:-1. "The Groves of Blarney" (whole of Vol. I.). 2. "Sketches on Irish Highways during the Autumn of 1834" (whole of Vol. II.). 3. "Illustrations of Irish Pride" (two stories). 4. "The Dispensation." 5. "Old Granny." No. 1 " derives its title from an occurrence . . . in . . Blarney . . . about the year 1812." -(Pref.). It is a thoroughly good story, telling how Connor in order to win the fair widow Margaret, his early love, takes an oath against drinking, flirting, and faction-fighting for a year, and how a vengeful old tramp woman makes him break it on the very last day. Amusingly satirical portrait of the little Cockney, Peter Swan. Author's sympathies thoroughly Irish. Contents of Vol II. :- "The Jaunting Car," "Beggars," "Naturals," "Servants," "Ruins" [or stories told à propos of them], \&c. The dialect is very well done, full of humour and flavour. Characters all drawn from peasant class.

\section{8- STORIES OF THE IRISH PEASANTRY. Pp. 302 (close print).}

(Chambers). [1840]. 1851, \&c.

Aims to reconcile landlords and peasantry. To this end tries to show each to what their enmity is due and how they may remedy the :evil. The stories' are to show the peasantry that their present condition is due to defects in the national character and in the prevailing national habits-chiefly drink, early marriages, laziness, conservatism, superstition. The Authoress has a good grasp of the ways of the people, but her reasoning is peculiar. When a peasant, driven to desperation by a cruel eviction, swears vengeance, this is put down to innate lawlessness, sinfulness, and a murderous disposition. Twenty stories in all, some melodramatic, some pastoral.

\section{9_ THE WHITEBOY. (Ward, Lock, Routledge). 2s., and 6d. [1845].} Several eds. since. (N.Y.: P'ratt). 0.50.

In the height of the Whiteboy disturbances, which are luridly described, a young Englishman comes to Ireland with the intention of uplifting the peasantry and bettering their lot. After some terrible expericnces he at length succeeds to a wonderful extent in his benevolent purposes. The book is of a didactic type.(Krans). Deals with period 1761-4.

690_ THE FIGHT OF FAITH : a Story of Ireland. Twn Vols.. (Chapman \& Hall). [1862]. 1869.

Opens at Havre in 1680 with a Huguenot family about to fly from persecution. The ship is wrecked off the Isle of Wight, where the little girl Pauline is rescued and adopted by an old sea-captain. The scene then changes to Carrickfergus, then held by Schomberg. Geo. Walker is introduced, and the story ends with the battle of the Boyne (the fight of faith). View-point strongly Protestant.

691- NELLY NOWLAN, and Other Stories. Popular Tales of Irish Life and character. 7th ed., with numerous Illustr. Demy 8vo. (London). 1865.

Contains 25 delightful tales of Irish life, with numerous illustrations by Maclise, Franklin, Brooke, Herbert, Harvey, Nichol and Weigall; "Sweet Lily O'Brien," "Mary Ryan's Daughter," “The Bannow Postman," “Father Mike," and twentyone other tales. As a graphic delineator of Irish life and character, few writers have dealt with the subject so delightfully and truly as Mrs. Hall. This is perhaps her best book.

692 — TALES OF IRISH LIFE AND CHARACTER. Pp. 323. (T. N. Foulis) 5s. With Sixteen Illustr. in colour from the famous Irish paintings of Erskine Nichol, R.IS.A. 1909.

Contents:- "The Jaunting Car," "The Bannow Postman," "We'll See About it," "Beggars," " Naturals," "Kelly the Piper," "Illustrations of Irish pride," “Lilly O'Brien," "Take it Easy," "Master Ben," "Moyna Brady," etc. 
HALPINE, Charles Graham; "Private Myles O'Reilly." Born in Oldcastle, Co. Meath, 1829. Son of Rev. N. J. Halpin (sic). Ed. T.C.D. Took up journalism and went first to London, where he came to know some of the Young Irelanders, and thence to America. Became a well-known journalist. Fought through the Civil War. His songs became very well-known throughout the Union. D. 1868. Pub. also a series of prose sketches, Baked Meats of the Funeral, and a vol. of reminiscences.

693-MOUNTCASHEL'S BRIGADE; or, The Rescue of Cremona. Pp. 151 (close print). (Dublin : T. D. Sullivan). Fifth ed., 1882.

Episodes in the story of the Irish Brigade in the service of France. The narrative is enlivened with love affairs, duels, and exciting adventures very well told.

694- THE PATRIOT BROTHERS; or, The Willows of the Golden Vale. (Dublin). Sixth ed. 1884. One ed., pp. 173 (small print), n.d., was publ. by A. M. Sullivan.

Sub-title: A page from Ireland's Martyrology. A finely-written romance dealing with the fate of the brothers Sheares, executed in 1798. Their story is followed with practically historical exactitude, a thread of romance being woven in. A good account of the politics of the time, especially of the elaborate spy-system then flourishing, is given, but not so as to interfere with the interest of the tale. There are fine descriptions of the scenery of Wicklow, in which the action chiefly takes place, and especialiy of the Golden Vale between Bray and Delgany.

HAMILTON (Mrs, Ann). Author of Adrentures of a Seven Shilling Piece. 695- THE IRISHWOMAN IN LONDON. A modern novel. 3 vols. (LoND.: Hughes). 1810.

Ellen O'Hara tells her own story. She lived with her parents in Dublin. Her mother dies, then her father, after which she lives with an aunt near Monaghan. She marries a drunken squireen, but deserts him and goes to London as companion under an assumed name. Her husband tracks her and carries her off to Somersetshire. He dies and she marries a man who had been her suitor in London. Full of digressions and stories about people unconnected with the plot.

HAMILTON, Catherine J. Born in Somerset of Irish parents, her father being from Strabane and her mother from Queen's Co. Ed. chiefly by her father, a vicar of the $\mathrm{Ch}$. of England. At his death, in 1859, removed to Ireland, and lived there more than thirty years. Publ. at twenty-five her first story, Hedged with Thorns. Wrote verse for the ARGOsY and Irish stories for the GraPhic; contributed regularly to WeEkly Irish Times and Ireland's Own, including several serials. At present resides in London. Author of Notable Irishwomen (1904), Women Writers, their Works and Ways (1892), \&c.

696-MARRIAGE BONDS; or, Christian Hazell's Married Life. Pp. 439. (Ward, Lock). n.d. (1878).

First appeared in The Englishwoman's Domestic Magazine. An unhappy marriage of a sweet, loving, sensitive nature to a man of a hard, selfish character, who treats his wife with studied neglect and discourtesy. Christian comes from hel' native English manor house to live with Alick Hazell in an ugly, ill-managed Irish country house, among disagreeable neighbours somewhere on the S.E. coast of Ireland. He hates the people, and is a bad landlord. She has no friend until the arrival of his cousin Eustace, whose mother was Irish and who loves Ireland. Almost unawares they fall in love, but E. is a man of honour, and C. is faithful to her husband to the very end. The author is on Ireland's side, though somewhat. apologetically and vaguely. Good picture of bitterly anti-Irish narrow-minded typo of minor country gentry.

697— The FLYNNS OF FLYNNVIILE. Pp. 250. (Ward, Lock). 1879.

A story of the sensational kind, founded on the murder of a bank-manager by a constabulary officer called Montgomery, and the subsequent trial, which many years ago excited considerable interest. Scene: $\mathbf{S}$. of Ireland. 


\section{HAMILTON, Catherine J.-(continued).}

\section{8_ TRUE TO THE CORE: a Romance of '98. Two Vols. (F. V. White).} 1884.

The story of the lovie of a Kerry peasant girl for the ill-fated John Sheares. The interest is that of plot, history being quite of minor importance, and centres in the scheming of his various enemies to compass the destruction of John Sheares in spite of all the efforts of his guardian angel, Norah Nagle. There is not one really sympathetic character. Sheares is a mere dreamer; Norah is generous and faithful, but lies and "barges" on occasion, almost all the rest, except Norah's peasant lover are fools or villains of the blackest sort. Disagreeable picture of the Dublin of the day. The story is told with considerable verve and carries one along. The Author is not at all hostile, but seems unstirred to any feeling of enthusiasm for the cause of Ireland.

699 _ DR. BELTON'S DAUGHTERS. Pp. 169. (Ward, Lock). 1890.

Alice, the second, marries a curate in the W. of Ireland and struggles to keep up on small means a good appearance. Her husband is an incurablo optimist.

700— THE LUCK OF THE KAVANAGHS. (Sealy, Bryers). 6d. 1910.

Strange adventures of an emigrant Irish boy.

HAMILTON, Edwin, M.A., B.L., M.R.I.A. Born 1849. E.d. Durham Grammar School and T.C.D. Resides at Donaghadee, Co. Down Author of Dublin Doggerels (1880), The Moderate Man (1888, Downey). Has edited many comic jourrals. and annuals, and produced many libretti.

701- BALLYMUCKBEG. (Griffith \& Farran). 1892.

Political satire.

702_-WAGGISH TALES. Pp. 164. (Sealy, Bryers). 1897.

Short humorous stories. Three of them are Irish in subject.

HAMILTON, Lord Frederick. B. 1856, son of the Duke of Abercorn. Ed. at Harrow. Formerly in the Diplomatic Service, serving successiveiy at Berlin, Petrograd, Lisbon, and Buenos Aires. M.P. (Unionist) for South Tyrone, 1892-5. Ed. Pall Mall Magazine to 1900. Wrote his first work of fiction The Holiday Adventures of Mr. P. J. Davenant in his sixtieth year. Publ. six novels in two years, viz., three other Davenant books, Lady Eleanor, etc., and The Assembly.

703_ LADY ELEANOR, Private Simmonds, and Others. Pp. 320. (Hurst d Blackett). 1918.

A story of N.E. Ulster. Scene: chiefly in neighbourhood af Derry. Two penniless young persons who wish to marry; a worthless father who sells the girl's hand to a rich vulgarian who turns out to be a German spy; a Lady Bountiful or Fairy Godmother who causes everything to turn out happily; and Private S. who acts as a sort of Good Fairy for Lady E. Private S., half-gipsy, unconscious mystic, light-weight champion, and incorrigible poacher, is an original creation. Plenty of wholesome humour, especially in the clever talk of S. and others. The standpoint as regards Ireland is that of a convinced but good-natured Ulster Unionist. Some good-humoured fun is poked at Ulster Presbyterianism. Nothing offensive to Catholics. Vulgar and slovenly Mrs. Mooney is perhaps overdone.

HAMILTON, John, of St. Ernan's. "An Irishman" [N.M.]. Has told his lifestory in Sixty Years' Experience as an Irish Landlord, and given his views in Thoughts on Ireland by an Irish Landlord (1886).

704-THE THREE FENIAN BROTHERS. (Macmillan). 18mo. $1866.1 s$.

Paul, Mark, and Ned Ryan, sons of a well-to-do farmer, were enticed into joining the Brotherhood, the two former by Patrick Mahoney, the village schoolmaster. Ned had served in the Federal Army (U.S.A.), and was sent back to Ireland as a captain. "The characters and careers of the brothers are vividly depicted in an interesting tale, the dialogue is pointed, often witty ... In the unfolding of the story much light is incidentally thrown on the state of feeling in Ireland in 1865-6. 
" HAMILTON, M.”; Mrs. Churchill-Luck, née Spottiswoode-Ashe. Is a native of Co. Derry. Publ. also The Freedom of Harry Meredith, M'Leod of the Camerons, A Self-denying Ordinance, Mrs. Brett, The Woman who Looked Back, 1914, etc. She resides in London.

\section{5___ ACROSS AN IRISH BOG. (Heinemann). 1896.}

An ugly, but very powerful, tale of seduction in Irish peasant life. The study of the ignominious aspirations of the seducer, a Protestant clergyman, after social elevation forms the pith of the book. The difficulty of his position, technically on a level with the gentry, though ho 1 s wholly unequal to them in breeding, is brought out.

\section{6 — BEYOND THE BOUNDARY. Pp. 306. (Hurst \& Blackett). 1902.}

Scene: first in London, afterwards among Ulster peasantry (dialect cleverly reproduced). Theme: a curiously ill-assorted marriage. Brian Lindsay, son of Presbyterian Ulster peasants, had during a panic deserted his men in action. Afterwards he had been decorated mistakenly, instead of the man who had died to save him. In London he meets this man's sister, a solitary working girl, but a lady. They are married, and he takes her home. Disillusionment on the wife's part follows, and Brian is threatened with the discovery of his secret. What came of it all is told in a beautiful and convincing story. Not gloomy nor morbid. Running through the main plot is the story of poor little French Pipette, deserted by the foolish, selfish, mother, whom she adores. Old Lindsay, dour and godly, is very well done. An element of humour is found in the characters of Miss Arnold of the venomous tongue; fat little Mr. Leslie, who loves his dinners; and Maggie, the Lindsays' maid-of-all-work.

\section{7— ON AN ULSTER FARM. Pp. 143. (Everett). 1s. 1904.}

A realistic sketch of the life of a workhouse child sent out to service to a particularly unlovable set of hard Scotch Ulster folk. Interesting as a study of character and as an exposure of the misery attendant on the working of certain parts of the workhouse system. This subject is also treated in Rosa Mulholland's Nanno, q.v.

\section{HANNAY, Rev. James Owen, see " GEORGE A. BIRMINGHAM."}

" HAMISH (Maureen)," Mary Loughran. The Author, a native of Cookstown, Co. Tyrone, was a teacher there for some time. She then become a domestic servant, among other places, in the Viceregal Lodge. This story was written in order to earn the means of bringing her sick father to Lourdes.

707A- ADVENTURES OF AN IRISH GIRL AT HOME AND ABROAD. Pp. 239. (Publ. at 14 Temple street, Dublin). $1 s$ 6d. 1914.

The story, told by herself, of an Ulster Catholic servant, beginning about 1886 . Her rise from maid of all work in a Scotch farmhouse to the position of head cook. The plain tale is told with some literary ability. The life of the servant class is minutely described. She dwells upon her difficulties in the practice of her religion. She is very fair towards her employers.

N.B.-An earlier edition (1906) was published by J. K. Mitchell, of Grafton street, Dublin.

HANNIGAN, Denis F. Was born at Dungarvan, 1855 . Ed. at St. John's, Waterford, and Queen's College, Cork. Called to Irish bar, and formerly a journalist in Dublin; is now in America. Contributed a long serial, The Moores of Moore's Court, to the Moniton, 1879, and other stories to the Dublin press.

708- LUTTRELL'S DOOM. Pp. 76. (AberdeEN: Moran). 18. 1896.

Purports to be extracts from an Irish gentlewoman's diary kept between 1690 and 1726. 
HANNON, John. Born at Isleworth, 1870. Son of John Hannon, of Kildorrery, Co. Cork. Ed. at St. Edmunds, England. For long engaged in educational work, he afterwards took up journalism. He resides in Isleworth.-(CATH. WHO's WHO).

709__ THE KINGS AND THE CATS: Munster Fairy Tales. Pp. 78. Size $6 \frac{3}{4}+9 \frac{3}{4}$. (Burns \& Oates). 2s. 6d. Thirteen illustr. by Louis Wain. 1908.

Handsomely produced. Preface by Father M. Russell, S.J. Introductory verse by Katharine Tynan. Stories gleaned from old Irish peasants in England. Full of quaint, amusing turns of expression.

HANNON, Father W. B. Borm in Limerick, 1870. Ordained priest in U.S.A. Publ. Leaves from the Note Books of a Missionary, giving his own experiences on the mission. Also The Lady Margaret and several novels. Contributes to Catholic missionary literature in U.S.A.

710 - QUAINT IRISH BYGONES. Pp. $95\left(7+4 \frac{3}{4}\right)$. (Drane). 1s. 1916.

A collection of short sketches of the interesting characters to be found in many a country town half a century ago, enlivened with many a humorous touch, by a writer recalling his earlier days. Internal evidence points to Limerick as the scene. I.B.L.

HANRAHAN, P. R., of Farnogue, Co. Wexford. For some time director of: an academy. D. in Wexford, 1893, aged 78.

711 EVA; or, The Buried City of Bannow. Pp. 242. (Virtue). 1866.

A story of the Norman invasion, opening in 1169, and chiefly the episode of the marriage of Eva MacMurrough to Strongbow. The remainder of the volume (pp. 243-374) is occupied by a story-" Frank Farrell, the Irish National Teacher." What is historical in the first story is founded on Giraldus Cambrensis.

[HARDING, Mrs. A. R.]. Author of Correction, Decision, etc.

712_- THE REFUGEES; an Irish Tale. 3 vols. Pp. 287, 301, 354. (Longmans, etc). 1822.

Sir Phelim O'Brien, an absentee Irish landlord, driven from France by the Revolution (which hás guillotined his son), returns to Ireland with his foolish fashionable wife, his daughter Calista, his surviving son St. Louis, and an Italian follower. Everything in Ireland is rude and barbarous as they journey to Clairfoyne Castle, in the Galtees, their dilapidated mansion. The O'Brien estate, with its rackrenting agent, is contrasted with that of the neighbouring Lord Dungarron. Love story between Calista and heir of Lord D. St. Louis, who has become a United Irishman, is killed in a rising. Religion little spoken of.

[HARDY, Elizabeth]. 1794-1854. B. in Ireland. Author of Owen Glendower, a romance, 1849. She died in Queen's Bench prison.

713 MICHAEL CASSIDY; or, The Cottage Gardener: a tale for small beginners. (Seeley). [1840]. 1845.

By the Author of The Confessor, "a Jesuit tale of the times founded on fact" [viz., Miss Hardy]. The 1845 ed. has a Pref. by C. B. Tayler. It is an attempt to urge people to small allotments, green crops, rotation, economy, and hard work.

HARDY, Philip Dixon. c. 1794-1875. Was a bookseller and editor of various Dublin periodicals. Publ. several volumes of verse, some books on Irish topography, and some religious works of a strongly anti-Catholic character.

714__ LEGENDS, TALES, AND STORIES OF IRELAND. Pp. 328. (DUBLIN : John Cumming). 1837.

Dedicated to Sir W. Betham. Hardy was the first editor of the DUBLIN PENNY Journal. His tales of Irish life deal with fairies, faction-fights, smugglers, and 


\section{HARDY, Philip Dixon-(continued).}

burlesque or tragic adventures in a manner by no means without vivacity and cleverness, though the trail of the "stage-Irishman" is over most of his work. This edition was illustrated in a somewhat coarse and stage-Irish fashion. Other works of this Author were:-Essays and Sketches of Irish Life and Character; Ircland in 1846-7, considered in reference to the rapid growth of Popery, and soveral works on Irish topography.

HARKIN, Hugh (1791-1854). B. Co. Derry; became a teacher and a journalist; was first ed. of The LAMP, a Catholic periodical. Was a strong supporter of O'Connell. Died in Belfast, 1854.

715_ THE QUARTERCLIFT: or, the Adventures of Hudy McGuiggen.

(BELfAST). c. 1841. In shilling monthly parts. Illustrated.

An amusing story founded on the old Co. Derry folk tale of a "gommeral " named Hudy McGuiggen, who didn't see why he couldn't fly. So he made himself wings out of the feathers of a goose. Arrayed in these, he jumped off a high mountain (still shown by the peasantry), and of course came to grief. Strange to say, he recovered and lived to be an old man. This and other incidents are related with great verve and truth. and many well pourtrayed characters are introduced. See GREER, Tom.

\section{[HARPUR, Rev. W. G.]}

716- THE GLEN FARM; or, Jim McGuire's dream and what came of it. (Henderson: Young Fouks Office).

Jim, a small Ulster farmer, dreams three times of a crock of gold hidden at a certain spot of the Glen Farm. He finds-not a crock of gold, but an infant in a basket. Jim rears the boy, but they do not get on. So the boy goes his way, makes his fortune, and discovers his parentage.

[HARRIS, Miss S. M.]; "Athene." Fourth daughter of a Co. Down farmer, the late William Harris, of Ballynafern, Banbridge. The family has been long resident in Belfast.

717- IN THE VALLEYS OF SOUTH DOWN. Pp. viii.+155. (Belfast: $M^{\prime}$ Caw, Stevenson (c Orr). 1898.

Rupert Stanwell is kept apart from Mabel Mervyn, for his parents want him to marry a rich American heiress; but the two are joined in the end, and all is well. Conventional and unobjectionable, without any special local colour.

718- GRACE WARDWOOD. Pp. 269. (Duffy). 2s. 6d. Tasteful binding. 1900.

A domestic tale of middle-class folk in Co. Down. Several love stories intertwined. Gracefully written but "feminine," and not very mature in style. Contains littlo that is characteristically Irish, except some legends introduced incidentally.

719 DUST OF THE WORLD. Ip. vi.+293. (Allen). 6s. 1913.

Sub-t. ; "An historical romance of Belfast in the 17th century." Introduces the Earl of Donegall, the lord of the soil; Lady Donegall who, to the annoyance of Bp. Jeremy Taylor, has hankerings after Presbyterianism; George Macartney, the Sovereign or Mayor; and other Belfast townsfolk of the day. Swift is an anachronism in this story, and there are no grounds in history for the portrait given of Patrick Adair, an early Presbyterian Minister. Lord Donegall is made to talk with a brogue, while a butcher's wife talks in the best of English. 
" HART, Elizabeth." B. Dublin, 1883. Ed. by the Ursulines in Ireland and in France. Resides in Co. Dublin. Has publ. only the following novel. 720-IRRECONCILABLES. Pp. 480. (Melrose). n.d. [1916].

The main interest of this novel is not the double love story that runs through it, but its exposition of Irish politics and its picture of Irish social life. The Duke of Galwayshire and Dr. Ryan of Merrion Square are the representatives and exponents of the Unionist and the Nationalist points of view respectively. The Western peasantry, the Gaelic League, the Nationalist middle classes, the Catholic Church (in the person of "Cardinal Byrne"-a very sympathetic study) are pictures from a viewpoint which seems nationalist and Catholic but is, says the ILLUSTRATED LoNDoN NEws, "without a trace of exaggeration." Some objection might fairly be made to the naturalism of some of the love-making.

HARTLEY, Mrs., née May Laffan. Born in Dublin. Widow of the late W. N. Hartley, F.R.s. Hex brother Wiliam Laffan was at the head of Laffan's Agency. For some considerable time past she has done no literary work.

721- - HOGAN, M.P. Pp. 491. (Macmillan). 3s. 6d. [1876]. New ed. 1882.

Picture of Dublin society, showing how Catholics are handicapped by their want of education and good breeding, due, in the Author's view, to wholly wrong system of Catholic education. Discursive and garrulous. Full of social manœurres, petty intrigues, gossip, and soandal. Convent education from within.

722-THE HON. MISS FERRARD. [1877]. (Macmillan). 1882. 3s. 6d.

The Hon. Miss $F$. is the only daughter of the ancient and broken-down louse of Darraghmores. The father squanders his income faster than he gets it, and has to keep moving from place to place, living chiefly on credit. Miss F. is brought up in this inconsequent, semi-gipsy family, with wild harum-scarum brothers. The Author does not blink the consequent shortcomings of the heroine. Amusing things happen when she goes to live with her maiden aunts at Bath-an unsuccessful experiment. Her choice between her Irish farmer lover and the admirable English Mr. Satterthwaite-we shall not reveal. Good minor characters - Cawth, the old servant of the family; Mr. Perry, the family lawyer. "The Author represents the interiors of all Irish households of the middle classes as repulsive in the extreme .... There is in them an innate vulgarity of thought, with an atmosphere of transparent pretension."-(SATURDAY REV., xliv., 403).

\section{3 - FLITTERS, TATTERS, AND THE COUNSELLOR. (Macmillan).}

3s. 6d. [1879]. New ed. 1883.

Four stories: (1) Three little Dublin street arabs, nicknamed as in the title. Lively and realistic portraits. Poignant and sympathetic picture of slum misery and degradation. (2) Deals with the same subject. (3) Glasgow slum life. (4) Lurid and revolting story of conspiracy and murder in a country district. There are those who consider No.1 quite the most perfect thing that has been written about Dublin life.

\section{4- THE GAME HEN. (DUblin). 1880.}

A charming little story.

725-CHRISTY CAREW. Pp. 429. (Macmillan). 2. [1880]. New ed. 1883; still in print.

Written in spirit of revolt against Catholic discouragement of mixed marriages, showing the social disabilities which it draws upon Catholics. Several portraits of priests, e.g., a collector of old books and a model priest. Studies of various aspects of Catholic life.

\section{6- ISMAY'S CHILDREN. (Macmillan). 2s. [1887].}

Tale of Fenian times, little concerned with political aims, but rather with personal fortunes of the lads who are drawn into the midnight drillings. Little political bias, but sympathies are with "the quality." Close studies of Irish middle-class domestic life. Scene: Co. Cork. The. Arhen wum pronounced this novel to be the most valuable and dispassionate contribution towards the solution of that problem [the Irish character] which has been put forth in this generation in the domain of fiction." 
HARTSTONGE (Mathew Weld), M.R.I.A. This author's real name was Mathew Weld. He graduated in T.C.D., 1799. He had already published an antiUnion pamphlet. He published several volumes of verse dealing with Irish themes; corresponded with Sir Walter Scott, was hiving in 1834.

727- THE EVE OF ALL-HALLOWS; or, Adelaide of Tyrcomell. 3 vols. 1825.

HARVEY, William. B. 1874. Story editor for Messr's. Leng and Co.'s Publications, Dundee. Publ. among other works, Complete Manual of Freemasonry (DUNDEE), 1910.

728- IRISH LIFE AND HUMOUR. Pp. 221. (Stirling: Eneas Mackey). 2s. 6d. 1906.

A collection of short, witty anecdotes and jokes, four or five to a page. Source not indicated, but they are obviously culled from periodicals, or from previous collections of the kind. A few seem to be taken from serious biographies. They are given without comment, exactly as he found them, says the Author (Pref.). They exhibit no religious or racial bias (witness the last chapter on Priest and People), but throughout you have the "Paddy" of the comic paper, and in many places the traditional Stage-Irishman whirls his shillelagh and "hurroos for ould Oireland" in a wholly impossible brogue. The stories are classified under various heads, but for convenience only. They do not illustrate national traits nor phases of national life. The above is an abridgment of a larger work [1st ed., 1904, without illustr.] with the same title, of which a new edition, pp. 488, twelve illustrations in colour, 5s. net, has been issued (August, 1909) by Simpkin, Marshall, \& Co. More recently a cheap ed. has been issued at 1s., pp. 206, paper covers, with some poor jllustr.

"HASLETTE, John." The Author's real name is Vahev. He resides at Bournemouth. He is of Huguenot descent, but was b. (1881) and ed. in Ireland. Wrote also The Mesh, The Shadow of Salvador, Johnnie Maddison, 1914. DESMOND ROURKE: Irishman. (Sampson, Low). 6s. 1911.

Scene: South America. The hero is intended to be typically Irish. The story is described as racy and dashing, and has received high praise from the Press.

HATTON, Joseph, 1841-1907. B. at Andover, Derbyshire. Novelist and journalist. Ed. the Buistol Mirron 1863, and the Gentleman's Magazine 1868. sq. See D.N.B.

730 - JOHN NEEDHAM'S DOUBLE. Pp. 208. 16mo. (Maxwell). 1s. Paper. n.d. (1885).

"A story founded on fact," viz., John Sadleir's career, his fraud on the Tipperary Bank, Sc. An excihing and melodramatic story. Needham poisons his "double," Joseph Norbury, and deposits his body on Hampstead Heath, then escapes to America, is tracked and arrested, but dramatically takes poison when under arrest. Told with considerable verve. Thirty of this Author's books are enumerated by Allibone.

HAYENS, Herbert. Chief Ed. Collins \& Co. B. 1861 . Author of some 30 books for boys and various educational works. Resides in Glasgow.

731- - AN AMAZING CONSPIRACY. Pp. 247. (S.P.C.K.). 2s. 6d. Illustr. by Adolf Thiede. n.d. (1914).

An exciting boys' adventure story, opening in an island of the W. coast of Ireland, where mysterious events take place, but passing chiefly in Guatemala, where the bero goes through thrilling adventures in various revolutions. 
HEALY, Cahir. Resides in Enniskillen, where he holds a position in the Civil Service.

732 - A SOWER OF THE WIND. Pp. 168. (Sealy, Bryers). 6d. Paper. c. 1910

Scene: the Donegal coast. A sensational and romantic story. Local Land League doings described. The Author writes of the people with knowledge and sympathy.

733- - THE ESCAPADES OF CONDY CORRIGAN. Pp. 172. (Society of the Divine Word: Techny, Ill., U.S.A.). 0.50 .13 illustr. by H. Horina. 1910.

Scene: Donegal at some indefinite period "a 'ong time ago." A series oí comic episodes in which Condy Corrigan is the central figure, retold, the Author tells us, from memories of the Shanachies' yarns heard in youth, by a Donegal fireside. They are folk-lorish and picaresque, bubbling with wholesome but extravagant humour. Out of every adventure and scrape and tight corner Condy, the rogue, comes triumphant. The dialect is not overdone.

[HEMPHILL, Barbara]. Daughter of Rev. Patrick Hare, Rector of Golden, Co. Tipperary, a descendant of the Clare sept O'Hehir. Published her first story "The Royal Confession" in Dublin University Magazine, 1838. Wrote also Lionel Jeerhurst, London, 1846, which was edited by Lady Blessington, and F'reida the Jongleur, London, 1857. Died 1858. Her son became Liberal M.P. for North Tyrone and first Baron Hemphill. (D.N.B.).

734 - THE PRIEST'S NIECE. Three Vols. (Hurst d Blackett). 1855.

In the first two volumes there is nothing about Ireland. In the third the scene shifts to Cashel, and there are some attempts to picture Irish life. The Anthor is not anti-Catholic nor anti-Irish: she is amusingly ignorant of Catholic matters and is not interested in Ireland. I. 37-a scene of Irish lawlessness (capture of a private still). P. 40-unpleasant description of a wake. The plot hinges mainly on the strife in the hero's mind between his love for Ellen, the penniless peasant girl, to whom he owes several rescues from the Shanavests, and the heiress to marry whom would be to save his father from ruin.

HENDERSON, George. Was a lecturer in Celtic languages and literature in the University of Glasgow. He died some years agn.

735- THE FEAST OF BRICRIU: an Early Gaelic Saga. (Irish Texts Society). 6s. 1899.

Belongs to Cuchullin cycle. C. contends in a series of competitive feats with Conall and Loigare for the championship of Ulster . . . the origin of the contest being the desire of $\mathbf{B}$. to stir up strife among his guests. Introd. and notes.

736- SURVIVALS IN BELIEF AMONG THE CELTS. Pp. 340. Demy 8vo.

(EDINBURGH: MacLehose). 10s. net. 1911.

The substance of a series of lectures on Folk Psychology. It is a study in Celtic "psychical anthropology"-practically a study of magic, superstitions, and other survivals of primitive paganism. Deals chiefly with the Scottish Highlands, but there are frequent allusions to Irish folklore and legend. Highly technical in conception and language.

[HENDERSON, Rev. Henry]; “ UIster Scot." Was for many years a Presbyterian minister in Holywood, Co. Down, and wrote for BelFast WeEkLY News Woodleigh Hall, a Tale of the Fenians, and The Moutrays of Clonkeen.

737- THE TRUE HEIR OF BALIYMMORE. Pp. 80. Demy 8vo. (Belfast).

1s. Wrappers. 1859.

Sub-t.:- "Passages from the history of a Belfast Ribbon Lodge." Frontisp.the insignia of Ribbonism. An anti-Ribbon pamphlet in the form of a story. 


\section{[HENDERSON, Rev. Henry]; “UIster Scot"-(continued).}

Relates the machinations of a certain Ribbon lodge for the destruction of Protestant. ism, and, in particular, the scheme whereby a Catholic widow is made to inveigle Col. Obrey into marriage. The latter drives out his sister and nephew, and Ballymore is invaded by a low-class drinking set of Catholics, who finally bring the poor Colonel to his grave. Subsequently it transpires that Mrs. Connor's husband was alive all the time, and the Colonel's nephew comes into his own. The book is full of the awful crimes of Ribbonism, and closes thus:-“"No statesmanship, no good government will ever deliver our land from Ribbon disloyalty, outrages, and savage assassinations until Romanism is extirpated from the country. Ribbonism is the offspring of Romanism."

THE DARK MONK OF FEOLA: Adventures of a Ribbon Pedlar. Pp. 80. (Office of Belfast News LetTer). c. 1859.

"The first part contains a very affecting episode illustrative of the evils which are certain to follow the uninn of Protestant women with men who belong to the Roman Catholic faith. To all Protestants the story cannot fail to be interesting; and Orangemen, especially, will peruse it with peculiar pleasure."--(Dowsshre Protestant).

739_- THE SANDY ROW CONVERT: a Tale of the Belfast Revival. Pp. 128. (Belfast: Phillips). n.d. (c. 1860).

Scene: a Belfast street called Sandy Row. The plot concerns the conversion of certain Catholies during the "Revival" of 1859.

\section{HENNESSY, William M.}

740_- MESCA ULAD; or, the Intoxication of the Ultonians. Pp. xvi.+58. Demy 8vo. (Hodges, Figgis). 4s. 1889.

Todd Lecture Series, R.I.A. No. I. With transl. and introductory notes. After a carouse the Ultonians issue forth and make a furious raid into Munster, where they burn the palace of Tara Luachra in Kerry. It is full of interesting information about places, habits, and manners. Irish text with trans. opposite.

HENRY-RUFFIN, Mrs. M. E. The only daughter of the late Thomas Henry, of Mobile, Alabama.

741- THE NORTH STAR. Pp. 356. (Boston : Little, Brown). 1.50 net. Six good Ill. by Wilbur D. Hamilton. [1904]. 1908.

Scene: Norway and Ireland. The story of how Olaf Trygvesson, the exiled king of Norway,returned as a Christian champion, and overthrew his pagan rival. The wild brutal paganism of the time is depicted with realism. There is an interesting account of a great gathering in Dublin, and a sketch of Olaf's life in exile amid his Irish hosts. There is also a love interest.

HENTY, G. A. Born 1832, in Cambridgeshire. He spent some time in Belfast in his capacity of Purveyor to the Forces. D. 1902. One of the greatest, perhaps quite the greatest, of writers for boys. His 86 or more published stories deal with almost all countries and every period of history. All his stories are sane and healthy, and told in the manner that boys love. Their historical side is carefully worked out.

742-FRIENDS THOUGH DIVIDED. (Frowde and Hodder \& Stoughton.). 3s. 6d. Excellent coloured Illustr. Attractive binding and general get-up. (N.Y.: Burt). 1.00. [1883]. New eds.

A fine boys' adventure story of the English Civil War. Scene : mainly Great Britain, but at end shifts to Ireland for the Siege of Drogheda, which is well described. Good account of Cromwell, the two Charleses, Argyll. Sympathies of writer clearly royalist. Ireland represented to be in a state of semi-barbarism. Juvenile. 
HENTY, G. A.-(continued).

743 ORANGE AND GREEN. (Blackie). 5s. Handsome binding; eight Illustr. by Gordon Browne. (N.Y.: Burt). 1.00. [1887]. 1907.

Adventures of two boys (one a Protestant, the other a Catholic) in the Williamite Wars. Battles of Boyne, Aughrim, sieges of Athlone, Cork, and Limerick, described. Impartial. Williamite excesses condemned. Sarsfield's action after Limerick severely dealt with. There is no bigotry, but the Protestant tone is rather pronounced.

744- IN THE IRISH BRIGADE. Pp. 384. (Blackie). 6s. Twelve excellent illustr. by Chas. M. Sheldon. (N.Y.: Scribner). 1.50. 1901.

Adventures of Desmond Kennedy, officer of the Irish Brigade, in the service of France, during the War of the Spanish succession-chiefly in Flanders and Spain. The facts are based on O'Callaghan's History of the Irish Brigade and Boyer's Annals of the Reign of Queen Anne. No Irish Nationalist could quarrel with the views expressed in the Author's Preface.

HEYGATE, W. E. Author of a dozen other historical stories.

745- WILD SCENES AMONG THE CELTS. Pp. 114. (Parker). 6d. 1859. One of a series "Tales for Young Men and Women" (Church of England). This volume contains the two following tales:-

The Penitent.-How Shossag, a prince of S. Leinster, was accessory to his brother's murder. How punishment overtook him, and how he ended his life as a penitent at the feet of St. Piran of Cornwall. Period c. 410 A.D.

The Fugrtive. - A story of crime, and its punishment in the person of a Pictish chief. St. Columba has a prominent place in the story. Of him a sympathetic and appreciative picture is drawn. Scene: Scottish mainland, Iona, and N. Connaught, c. 590-597. The two stories above noted are quite suitable for Catholic children.

HICKEY, Emily. B. Macmine Castle, Co. Wexford, dau. of Rev. Canon Hickey. Read a very distinguished course at Cambridge. Co-founder with Dr. Furnivall of the Browning Society, 1881. Is at present lecturer in English language and literature at University College and Cambridge Corrrespondence Classes. Received in 1912 the Cross Pro Ecclesia et Pontifice from H.H. Pius X. Author of many volumes of verse, of other literary works, and of some works of Catholic piety.

\section{6_ LOIS. Pp. 304. (Washbourne). 1908.}

Lois's career is traced from her childhood in the quiet refined rectory in Wexford to her death. But the writer's concern is not so much with the outward events of Lois's life, though these are fully dealt with, as with two main matters, first her literary aspirations and their outcome; secondly the story of her soul, which passes from a vague Protestantism through phases of unbelief, to an intense and fervent Catholicism. This latter vibrates through the book, but it is without a shadow of bigotry. At ch. xii. the heroine leaves I. for London, and she does not return till near the close. Told with delicate feeling, in a style refined and expressive.

HICKEY, Rov. P. Ed. Carlow College. This book was written in Cowara, N.S.W., Australia.

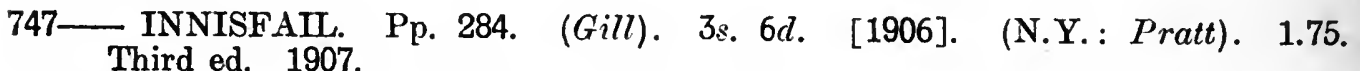

Life-story of a young priest from early youth to departure for Australia, largely told in letters from college, with verse interspersed. Sketches of life in Tipperary (fox-hunt, school scenes, etc.). 
HILLARY (Joseph). Was the son of a silversmith in Cork. Left a fortune by his father he soon ran through it, and then supported himself by journalism. Publ. in Cork in 1794 a volume of his poems. Died shortly after 1814.

(Conk: Mathews). c. 1814.

HINKSON, H. A. Born in Dublin, 1865. Married Katharine Tynan, 1893 (q.v.). Ed. Dublin High School, T.C.D., and in Germany. Called to the English Bar 1902. Until the last few years he resided in England. He lived in Claremorris, Co. Mayo, for which county he was R.M. D. 1919.

749_ GOLDEN LADS AND GIRLS. Pp. 312. (Downey). 1895.

A love story of the upper middle classes. Pictures of western (Galway) county family life, and of student life in Trinity, both strongly reminiscent of Lever. Good portraits of Irish types, the country doctor, the unpopular agent, the reforming landlord (English and a convert to Catholicism) ; the Protestant country clergyman, \&c. This latter portrait is rather satirical. The tone on the whole is nationalist and Catholic.

750_ FATHER ALPHONSUS. Pp. 282. (Unwin). 1898.

The life-story of two young seminarians. One of these, finding he has no vocation, leaves before ordination, and has no reason to repent the step. The other, ignoring uneasy feelings that trouble may come of it later, becomes a priest. Afterwards he meets with a certain lady, a recent convert from Protestantism. A mutual attachment springs up, and eventually they are married. The circumstances, as arranged by the novelist, are so strange as almost to seem to palliate this sin, were it not for his omission of one factor, viz., that particular form of divine help towards the doing of duty which Catholics call the gratia status. The erring priest ends his life in a Carthusian monastery. The tone throughout is almost faultless from a Catholic standpoint. Indeed, though there are several passionate scenes, rendering the book unfitted for certain readers, the moral tone is high. Some of the characteristics of Irish social life are admirably portrayed.

751_ UP FOR THE GREEN. Pp. 327. (Lawrence d Bullen). 6s. 1898.

"For several of the incidents related in this story, the Author is indebted to the narrative of Samuel Riley, a yeoman [Quaker] of Cork, who was captured by the rebels, while on his way to Dublin, in September, 1798." This worthy man discovers the rebels to be very different from what he had taken them to be. A healthy, breezy tale with more adventure than history. Standpoint thoroughly national. There is quiet humour in the quaintly told narrative of the Quaker. Castlereagh, Major Sirr, Grattan, Lord Enniskillen figure in the story.

752- WHEN LOVE IS KIND. Pp. 320. (Long). 1898.

A wholesome Irish love-story of the present day. The hero, Rupert Standish, is a soldier and a soldier's son. The story brings out the comradeship which may exist between father and son. The page-boy, Peter, with his gruesome tales, is a curious study. There are many passages descriptive of scenes and incidents in Ireland.

753 - THE KING'S DEPUTY. Pp. 236. (Lawrence d Bullen). 6s. (CHICAgo: $M^{\prime}$ Clurg). 1.25. 1899.

Period: the days of Grattan's Parliament, of which a vivid picture is drawn, and of the viceroyalty of the Duke of Rutland. The interest is divided between a love story and the story of a plot of the Protestant aristocracy to establish an independent Irish Republic on the Venetian model. Grattan, Curran, Napper Tandy, Sir John Parnell, Sir Boyle Roche, Father Arthur O'Leary, \&c., are introduced. Descriptions (historically accurate) of the Hell-Fire Club and the Funny Club.

754 SIR PHELIM'S TREASURE. Pp. 255. (S.P.C.K.) 1s. 6d. Illustr.

W. S. Stacey. n.d. (1901).

A boy's adventure-story of search for treasure. No "moral" or lesson. Good description of Crusoe-life on a little island off the Irish coast. Pleasant style; no tediousness nor dullness. 
HINKSON, H. A.-(continued).

755- THE POINT OF HONOUR. (Lawrence \& Bullen). 6s. (Chrcago: $M^{\prime}$ Clurg). 1.50. 1901 .

"Stories about the quarrelsome, bottle-loving, duelling gentry of the eighteenth century."-(Baker).

756_ SILK AND STEEL. Pp. 336. (Chatto \& Windus). 6s. Picture cover. 1902.

Adventures of an Irish soldier of fortune at the Court of Charles $I$., in the Netherlands, and in Ireland. Brisk and picturesque in style. Sketch of Owen Roe and description of Benburb. The hero is Daniel O'Neill, a nephew of Owen Roe. Full of historical incidents and personages, e.g., the Earl of Essex, Father Boethius Egan, Lord Antrim. Point of view national.

757- FAN FITZGERAID. Pp. 340. (Chatto \& Windus). 6s. 1902.

Young Dick Burke, brought up in England, feels the call of the Celt, and returns to his inherited estates with intent to be a model landlord. We are told in a lively and amusing style how he succeeds or fails. The Author is nationahist, but by no means a bitter partisan.

758- THE WINE OF LOVE. Pp. 320. (Nash). 1904.

Deals mainly with the upper classes in the West of Ireland. Abuses of landlordism not spared. Picture of horse-dealing, fox-hunting, and card-playing lives. Also picture of typically good landlords. Standpoint on the whole national and even Catholic. Style breezy and vigorous. Good knowledge shown of inner lives and feelings of all classes.

759_- THE SPLENDID KNIGHT. Pp. 262. (Sealy, Bryers). Illustr. by Lawson Wood. 1905.

Adventures of an Irish boy in Sir Walter Raleigh's expedition up the Orinoco. A bright and entertaining narrative.

760_ GOLDEN MORN. Pp. 303. (C'cessell). Frontisp. 1907.

Tells the strange adventures in Ireland, London, and France of Captain O'Grady. At Leopardstown Races his mare breaks her neck, just at the finish; the Captain loses a fortune, and is fain to depart on his travels-but "all is well that ends well," and so it is with Captain O'Grady.

761- O'GRADY OF TRINITY. (Lawrence if Bullen). 6s. Re-issued by C. H. White at $6 d .1909$.

Fun, frolic, and love in a student's career. A gay and wholesome novel. Sympathetic picture of Trinity College life. Highly praised by Lionel Johnston.

762_ THE CONSIDINE LUCK. Pp. 300. (Swift). 6s. 1912.

It was popularly believed that the estate could not pass from Considine hands. Sir Hugh C. dies, and lo! the estate is found to be mortgaged to Mr. Smith, of London. Mr. Smith arrives, and brings with him his English notions which he proceeds to carry out to the disgust of the locality. He refuses all attempts to buy him out, but the Considine luck comes to the rescue, and the estate falls once more into the hands of a Considine. Pleasant, light style.

\section{HOARE, Mrs.}

763- SHAMROCK LEAVES; or, Tales and Sketches of Ireland. Pp. 237. (M'Glashan). 1851.

If one could abstract from the bits of gossipy anecdote intended as links to the principal stories, this book consists of several studies, touching and true to the reality, of the lives of the poor, and in particular of their sufferings during and after the Famine years. Written with much sympathy for the lowly, and a vivid sense of actuality. Most of the tales have a moral, but it does not spoil the story. 
HOBHOUSE, Violet. Born 1864. Eldest daughter of Edmund McNeill, D.L., of Craigdunn, Co. Antrim. Married Rev. Walter Hobhouse, second son of Bishop Hobhouse. She was devoted to Irish traditions, folk-lore, \&c., and could speak Irish, but was a keen Unionist, and in 1887 and the following years spoke much against Home Rule on English platforms. After her death in 1902 a small volume of poems, serious and deeply religious, Speculum Animae, was printed for private circulation.

764- AN UNKNOWN QUANTITY. Pp. 382. (Downey). 6s. 1898.

Little concerned with Ireland. Scene: chiefly London and abroad. Miss Kilmeny, the heroine, and the faithful nurse Maria are Irish. A love story.

765-WARP AND WEFT. A story of the North of Ireland. Pp. 255. (Skeffington). 3s. 6d. 1899.

Scene: a linen-weaving district in the North. The personages are plain, middle class folk. Esther MacVeagh is inveigled into marriage with Samuel Martin, a selfish, unscrupulous, worldly-minded man. Esther, a beautifully drawn character, discovering the deception, is on the point of leaving him when she realises that he is ruined. She abides by her vows and ultimately reforms his character by her example of self-sacrifice and nobleness of mind. The elements of tragedy, suffering, and patient resignation give the book a strong human interest. The life and mentality of the Presbyterian North is well portrayed. There is no sectarian bitterness. "Tis no the warp nor the weft that maks the guid strengthy cloth, but just the weavin'."

HOCKING, Rev. Joseph. Author of Follow the Gleam, The Wilderness, The Jesuit, The Scarlet Woman, and some thirty other novels.

766- ROSAIEEN O'HARA. Pp. 352. (Hodder \& Stoughton). 3s.6d. and 1s.

Two illustr. 1913.

A product of the Home Rule controversy. The Author is a noted anti-Catholic writer, but he is also a Liberal, and desirous of defending Liberalism from the charge of seeking to establish Rome Rule in Ireland. Home Rule, so reads the story, would mean Rome Rule for some years, but would untimately lead to the emancipation of the Irish from the thraldom of priest-craft and dogma. The story tells of Denis who unexpectedly discovers that he is heir to an Irish estate, and neighbour of Elenore Tyrone, whom he had seen and loved. A quarrel and the attractions of the beautiful "Fenian," Rosaleen, separate the two for a time. The Author clearly knows little or nothing of Ireland, but he would like to be benevolent in tone to " dear old beautiful Erin."

HOEY, Mrs. Cashel, nee Sarah Jehnston. Born at Bushy Park, Co. Dublin, 1830. Wife of the well-known Irish journalist, John Cashel Hoey (d. 1892). Has published more than 27 volumes, e.g., The Question of C'ain (1882), The Lover's Creed, The Queen's T'oken, A Stèrn Chase, \&c., \&c. One of her novels was founded on the case of Kirwan, who was tried for murdering his wife on Ireland's Eye, 1852. See Judge Bodkin's Famous Irish 'Trials. She became a Catholic in $1858 . \quad$ D. 1908.

767- NO SIGN. (Hard \& Lock). [1876]. 1880.

Founded on the case of Richard Burke, hanged in Clommel for wife-murder.

HOGAN, Revd. Edmund, S.J., M.R.I.A., a distinguished Irish scholar and writer; b. 1831, near Queenstown; d. 1917. A sketch of his career written by Dr. Douglas Hyde appeared in Studies, Dec., 1917. In the same number appeared a bibliography comprising nearly 40 items, ending with his greatest work, the Onomasticon Godeticum. The following was published in his capacity as

"Todd Professor of Celtic Langnages" to the Royal Irish Academy.

768- THE BATTLE OF ROSSNAREE (Cath Ruis na Ríg for Bóinn). Pp. xxxii+281. Demy 8vo. (Royal Irish Academy). 1892.

Text and transl. of an ancient saga of the Cuchulain cycle telling of a great battle in which Conor and Cuchulain defeat the King of Leinster. The vol. includes a learned introduction and a treatise on Irish Neuter Substantives. It is vol. iv. of the Todd Lecture Series. 
HOLlAND, Denis. A well-known Irish journalist. Born in Cork about 1826 , He founded Trie Inishman, 1858. In 1867 he went to America, and died in Brooklyn, 1872. See Pigot's Recollections of an Irish Journalist.

769 DONAL DUN O'BYRNE: A Tale of the Rising in Wexford in 1798. Pp. 224. (Gill). 1s. n.d.

The story of the rising (including Oulart, Tubberneering, Gorey, and Ross, and the guerilla warfare after Vinegar Hill) from an insurgent's point of view. The book is full of scenes of blood, and breathes a spirit of vengeance. The narrative is not remarkable. Some of the scenes border on indelicacy.

770_ ULICK O'DONNELT: an Irish Peasant's Progress. 1860.

A romantic and pleasant story. Adventures in Liverpool and elsewhere in England of a clever peasant lad from Newry. He wins his way by his sterling qualities, and returns prosperous to his native Co. Down. Author tries to bring out contrasting characteristics of Fnglish and Irish.

HOLT, Emily S. B. 1836 at Stubbylee, Lancashire. Author of some 30 novels, many of them historical.

771- UNDER ONE SCEPTRE; or, Mortimer's Mission. (Shaw). 3̋. 6dı 1884.

Career of Roger Mortimer, Earl of March and Ulster (1374-98) in Monmouthshire, Ireland, and London. He was lieutenant of Ulster, Connaught, and Meath. Richard II. declared him lieir to the throne, but later grew jealous of his popularity. $\mathrm{He}$ was slain at Kells in battle with Art McMurrough Kavanagh. Juvenile.

HOPKINS, Tighe. Born 1856. Son of Rev. W. R. Hopkins, Vicar of Moulton, Cheshire. Besides the work mentioned here this Author ed. Carleton's Traits and Stories in the RED Letrer Library, and wrote Kilmainham Memories, several novels, and various other works. Resides at Herne Bay. Has written many other novels:-F'or F'reedom, 'The Silent Gate, Tozer's, 'Twixt Lovè and Duty, \&c.

772- THE NUGENTS OF CARRICONNA. Three Vols., afterwards one Vol. (Ward \& Downey). 1890.

Main theme: an old impoverished family suddenly enriched by Australian legacy. Interwoven there is an interesting love-story. Anthony Nugent, eccentric, of astronomical tastes, has on his housetop a telescope which plays a prominent part in the story. Brogue well done. The dramatic interest centres in an Inspector of Police, a type probably very rare in Irish fiction.

HOPPER, Norah, Mrs. Chesson. B. Exeter, 1871, dau. of an Irish officer in the British Army. Her first poem appeared in 1887, since when she published several volumes of verse. Several stories by her have been published. A Northern Juliet ran serially in Atalanta. D. 1906.

773_- BALLADS IN PROSE. Pp. 186. (Lane). 5s. Beautifully bound and printed. 1894.

Strange, wayward tales of far-off pagan days in which one moves as in a mist of dreams. Soaked with Gaelic fairy and legendary lore. The prose pieces, all very short, are interspersed with little poems, that are slight and frail as wreaths of vapour. Some of the stories are symbolical. They are told in simple and graceful prose.

HOUSTON, Frances Craig. Dau. of Rev. James D. Craig Houston, Presbyterian Minister of Hydepark, Belfast. Has also written Rhoda Lethbridge; or School Life in the Fatherland.

774 THE WOMAN OF THE WELL. Pp. 308 (R.T.S.): Illustr. n.d. (1903).

A Co. Antrim tale. The story of Betty O'Rorke's bad treatment by her stepmother, Lady O'Rorke. A good plot, well worked out. 
HOUstoN, Maggie J. B. Moneymore, Co. Derry. Dau. of Rev. Robert Sinclair, Married Rev. John Honston, Presbyterian Minister, Portglenone, Co. Antrin. D. 1895.

775 — A BUNCH OF SHAMROCKS. Pp. 205. (LoNd.: Hamilton Adams. Belfast: Olley). Frontisp. the old Abbey, Rathmullen. 1888.

Period: the sixties. The forlunes of the family and friends of Robert Dunbar, a Presbyterian farmer on the banks of Lough Swilly, Donegal. Good descriptions and correct dialect. Standpoint: Liberal Unionist. A pleasant and instructive story.

776- KATHLEEN CARMICHAEL'S RECOLLECTIONS. Pp. $310 . \quad$ (Dublín \& Belfast : Eason). 1894.

A visit to Palestine by an Irish Presbyterian Minister's family. Evidently intended as a reply to the agnostic teaching of Mrs. Humphrey Ward's Robert Elsmere. Scene: partly in Ireland, partly in the East.

HUDSON, Frank. This Author, after many years' work for Dublin periodicals, went to London early in the 'eighties. He wrote a few Irish sporting novels of a light and humorous kind.

777- THE ORIGIN OF PLUM PUDDING, and other Irish Fairy Tales. Illustr. by Gordon Browne. 1888.

Only one of these five stories is genuinely Irish-“"Shaun Murray's Challenge," the scene of which is Dalkey. The title-story tells how a drunken man one evening threw his sack of groceries into a pot on the fire, and in the morning found a plum-pudding.

778- THE LAST HURDLE: a Story of Sporting and Courting. Pp. 304. (Ward \& Downey). 1888.

Life in an Irish county family of the old stock, with sympathy for the poor around them. Good idea of refined Irish country life and its easy-going ways. A story full of sport, gaiety, and dramatic incidents, turning mainly on the winning of the heroine by the hero in spite of the plots of the rival. Good and bad landlords are contrasted. An eviction scene is described, with full sympathy for the victims. Shamus-the-Trout, a poacher, is a very piciuresque figuro.

779 RUNNING DOUBLE: a Story of Stage and Stable. Two Vols. (If ard d. Downey). 1890.

Scene: varies between England, Dublin, and " Ennisbeg." There are remarks on Irish life, scenery, and customs, but the chief interest is sporting-fishing, racing, betting. The stage part is in England. There is very little plot. All ends in a double wedding.

HUGHES, Mrs. Kate Elizabeth (Duval).

780_ THE FAIR MAID OF CONNAUGHT. Pp. 178. (N.Y.: Kenedy.

Philadelphia : Kilner). 1889.

"And other tales for Catholic youth." Contents:- "The fair maid of Connaught"; "The lame foot"; "Eulalie, or the little miser"; "The good old priest and the snuff box"; "Lies in action and omission"; "Vanity," etc. Only the title. story is Irish. It is a story of two sisters living on a farm near Ballinasloe. One dies and the other becomes a Sister of Mercy. Nice descriptions of scenery and character.

\section{HUGHES, Rupert.}

781— LONG EVER AGO. (N.Y.: Harpers). 1918.

Ten stories of the Irish in America, humorous for the most part. Michael Morahan, the hero of the title-story, is described by a reviewer as "a full-blooded, choleric, good-hearted, sentimental Irishman, whose wife, Delia, is still his sweetheart and whose sons have walked into their natural calling of the priesthood, the fire and the police departments." (Press Review). 
HULL, Eleanor. Born in Ireland of a Co. Down family. Daughter of Prof. Edward Hull, the eminent geologist, long Director of the Geological Survey of Ireland. Ed. at Alexandra Coll., Dublin, and in Brussels. Has written much-chiefly on Irish literature, folk-lore, and history-for various periodicals. Is the Author of several important books on Irish subjects:-Pagan Ireland, Early Christian Ireland, Ireland Under the Norsemen, A Text-Book of Irish [Gaelic] Literature, The Poem-Book of the Gael. Has for many years studied Old Irish under the best professors, and it is her chief pleasure and interest. Founded in 1899 the Irish Texts Society, and has been its Hon. Secretary evei since. Is President of the Irish Literary Society in London.

\section{2_ THE CUCHULIIN SAGA IN IRISH LITERATURE. Pp. 1xxx.+316.} (Nutt). 1898.

A collection of fourteen stories relating to Cuchullin, translated from the Irish by various scholars (Meyer, O'Curry, Stokes, Windisch, O'Grady, Duvan, \&c.). A more valuable work, says Fiona MacLeod (in substance), for students of Gaelic legend and literature than the more recent works by Lady Gregory. The book is not cast in an artistic mould. It merely contains the rude materials from which epic and lyric inspiration may be drawn. Important and valuable introduction deals with literary qualities of the Saga, its historical aspects and its mythology. Map of Ireland to illustrate Cuchullin Saga. Appendix contains chart of Cuchullin Saga. Notes pl. 289-297.

783 - CUCHUI $A I N$, THE HOUND OF ULSTFR. Pp. 279. (Harrap). 5s. net. Illustr. in colour by Stephen Reid. [1909].

Intended for young, but not very young readers. Told in modern language, free from Gaelicisms, archaisms, and difficult names. The story is continuous, not told in detached episodes. The style, though without the strange wild grandeur: of Standish O'Grady, is on the whole beautiful. The story itself is full of the spirit of heroism and chivalry. It is selected and adapted from many sources (indicated in Appendix), and the epic narrative is not mixed with puerile or absurd opisodes. Some of the illustrations are excellent. Others tend, perhaps, too much to quaintness.

HUME, Martin, a well-known historical writer who died a few years ago.

784-TRUE STORIES OF THE PAST. Pp. xi+226. (Eveleigh Nash). 5s. net. 1911.

Ed. with introd. by R. B. Cunningham Grahame. Eight stories from History. i. "How Rizzio was Avenged"; ii. "A Rebellious Love-match"; iii. "Prince and Pastry Book"; iv. "The Revenge of John Hawkins"; v. "The Scapegoat"; vi. "Sir Walter [Raleigh]'s Home-coming"; vii. "Cloth of Gold and Frieze." Some of these treat of the amours of great personages. Their standpoint is, of course, English and Protestant. viii. "The Last Stand of the O'Sullivans" is told with much spirit, and with sympathy for the Irish cause. It does not include the famous retreat of the O'Sullivans.

HUNGERFORD, Mrs. Born 1855. Dau. of Canon Hamilton, Rector of Ross, Co. Cork. Ed. in Ireland. Her early home was St. Brenda's, Co. Cork. Wrote upwards of 46 novels dealing with the more frivolous aspects of modern society. They had a great vogue in their day. The most popular of all was, perhaps, Molly Bawn. Most of her books appeared Anon. Her plots are poor and conventional, but she possessed the faculty of reproducing faithfully the tone of contemporary society. She died at Bandon 1897.-(D.N.B.). Besides those here noted some others of her stories might be classed as Irish, e.g., Rossmoyne, and Jerry (including "Irish love and marriage"). Munro of N.Y. published many of her books in the U.S. Lady Valworth's Diamonds (Ward \& Downey) is also of some Irish interest.

785- MOLLY BAWN. (Smith, Elder). 6s. and 2s. (Boston: Caldwell).

0.75 . [1878].

"A love tale of a tender, but frivolous and petulant Irish girl, who flirts and arouses her lover's jealousy, and who offends against the conventions in all innocence. A gay and witty story spiced with slang, and touched with pathos."(Baker). 
HUNGERFORD, Mrs.-(continued).

786- HER WEEK'S AMUSEMENT. Pp. 300. (Ward \& Downey). 1885.

Appeared first as a serial under titie "A Week at Killarney." A light holiday novel. How pretty Muriel Kingsley carried on a week's flirtation at Killarney with two young men until her chosen lover appears. Quite harmless sentiment. Killarney prettily described.

\section{7 - A LITTLE IRISH GIRL. Pp. 208. (Whitefriars Library). 1891.}

The first and longest (pp. 100) of six stories, the remaining five not dealing with Ireland. Dulcinea McDermott, only child of The McDermott, head of a broken. down county family in Co. Cork, is engaged to Sir Ralph Anketell, a rich neighbour. She falls in love, as she thinks, with a young Englishman, but later discovers that she does not really love him and turns again to Sir Ralph.

788- THE O'CONNORS OF BALLYNAHINCH. Pp. 261. (Heinemann). 18. $6 d$. 1896.

A domestic story of love and marriage in the Author's lightest vein. The characters belong chiefly to the landlord class, a local carman being the only peasant introduced. There is no expression of political views. The scene is laid in Cork.

789__ NORA CREINA. Pp. 328. (Chatto \& Windus). 1903.

A love-story from start to finish, without pretence of the study of character. The story of how Nora is won from dislike to love is pleasantly told. No politics. Peasants hardly mentioned. Srene not specified.

\section{HUNT, B.}

790 FOLK TALES OF BREFFNY. Pp. viii.+197. (Macmillan). 3s. $6 d$. 1913.

Breffny, i.e., Cavan and Leitrim. Many of these stories-there are twenty-six of them, all very short- "were told by an old man, who said he had more and better learning than the scholars," and are a curious mixture of literary language with a very peculiar and picturesque dialect. They are somewhat off the ordinary lines of folk-lore stories, ind are told in quaint drly-humorous vein.

HYDE, Dr. Douglas, LL.D., D.Litt.; "An Craoibhin Aoibhinn." Son of late Rev. Arthur Hyde, Frenchpark, Co. Roscommon. Ed. T.C.D. Was President of the Gaelic League from its foundation in 1893 till 1915. Is Professor of Modern Irish in the National University of Ireland. Has published more than one book (including poems) in Irish.

791- BESIDE THE FIRE. Gaelic Folk-stories. Collected, ed. (Irish text facing English), and trans. by D. H. With Introd., Notes on Irish text, and Notes on tales, by Ed. and Alfred Nutt. Pp. lviii. +204. (Nutt). 7s. 6d. 1891.

Extremely interesting and valuable Preface (50 pages) by the Author, in which he reviews what has been hitherto done for Irish folk-lore, remarks on the genesis of the folk-tale, its affinities with the Scotch folk-tale, and tells us where and from whom and in what circumstances he got his stories, ending by some explanations of the style of his translations. The preface is followed by some critical remarks on it by Alfred Nutt. The English of the translations is that of the peasants. This is the first really scientific treatment of Irish folk-lore.

\section{2 — THE ADVENTURES OF THE LAD OF THE FERULE.}

793 - THE ADVENTURES OF THE CHILDREN OF THE KING OF NORWAY. (Irish Texts Society). 1899.

Two Irish romantic tales of the 16th and 17 th centuries, ed. and transl. for the first time with introd., notes, and glossary. The "Iad" is a mysterious being who 


\section{HYDE, Dr. Douglas, LL.D., D.Litt.-(continued).}

appears to Murough, son of Brian Roru, and carrying home for him the spoils of a miraculous hunting, demands as reward a certain ferule that lies at the bottom of a lake. Murough slays a serpent, and delivers the land of the Ever Young, which lies at the bottom of the lake. The second is a long story of enchantment and marvellous adventures. - (Baker, 2).

794 _ an ssealaioe saedealac Connaught Folk Tales. Three parts. P.p. 554. Demy 8vo. With French Trans. by George Dottin. (Rennes, Oberthür). Parts 1 and 2, 10s.; Part 3, 2s. 1901.

795_ LEGENDS OF SAINTS AND SINNERS. Pp. xiv.+295. (Talbot Press: Every Irishman's Library). 2s. 6d. 1915.

Forty-six stories described by the Author as Christian folk-lore, all translated for the first time from the Irish, and for the most part gathered from the lips of the people by the Author himself, who has been gathering folk-lore for twenty-five years. Each tale is preceded by a preface giving all the details of its collection, origin, character, \&c., that are of interest to the folk-lorist as well as to the general reader. The tales are compared with similar tales occurring in foreign countries.

INGELOW, Jean. 1820-1897, novelist. Au. of Don John, Fated to be Free, etc.

796-OFF THE SKEILIGS. Three Vols. (Kegan Paul. Bos'on: Robert.3). [1872.] Second ed., c. 1881.

Has no other comection with Ireland than the episode of the picking up near the Skellig Islands, off Waterville, Co. Kerry, of a boat's crew that had escaped from a burning ship.

IRVINE, Alexander. B. in town of Antrim of very poor parents. Was a newsboy in Antrim, a coal-mmer in Glasgow, a Marine. Began again at the bottom in N.Y. 1888, and went through extraordinary experiences. Is a Socialist. Lives in Peekskill, N.Y. See his autobiography, From the Bottom Up. (Heinemann). 1910. Has recently (Autumn 1918) publ. a vol. of addresses entitled God and Tommy Atkins.

797- MY LADY OF THE CHIMNEY CORNER. Pp. 224. (Nash). 3s 6d net. Eight eds. in three or four months. 1914.

Sub-t. :- "A story of love and poverty in Irish peasant life." The central figurealmost the only figure in the book-is Anna Gilmore, a poor woman living in Pogue's Entry, in the town of Antrim. Brought up as a pious Catholic by Catholic parents, she marries a Protestant against her wish. Henceforth she has renounced Catholicism, having chosen, as she says, love instead of religion. To show that her choice was of the better part seems to be the purpose of the Author. The book is a lovingly-drawn portrait, with slight incidents, and many wise sayings of Anna as traits. There is a strong evangelical religious atmosphere throughout. The story is largely in dialect. It is laid in Famine times. Yet there are several mentions of Fenians, which seems to mean Catholic. The book would be better understood by a reading of the Author's autobiography, From the Bottom Up.

IRVINE, G. Marshall. B. 1865 in South Armagh. Ed. Royal Academical Institution, Coleraine, and at the Queen's Colleges of Cork and Belfast. After some practice as doctor in Manchester he obtained a medical position at Mountnorris, Co. Armagh, where he now resides.

798_ THE LION'S WHELP. Pp. 406. (S'impkin). 6s. 1910.

Introd. (by J. Campbell, M.A., M.D., F.R.C.S., Lx.D. (Hon Causa)) says, "In writing The Lion's Whelp Dr. Irvine has set before himself two main objects. He desires to inculcate on the medical profession the necessity which exists for the education of the public in all that pertains to the maintenance of health .... and he wishes to impress upon the public all that is summed up in the time-worn adage 
IRVINE, G. MarshalI-(continued).

- Prevention is better than cure.'" Incidentally, the book is also a satire against professional make-believe. Scene varies between Belfast, the North of England, and Denver City, U.S.A. The hero, Dan Nevin, starts his career as a doctor, witb high ideals-too high, as he discovers, for real life. The story is concerned with his love-affairs and various other adventures. A fine plot, well worked out, with several striking characters. Moral tone high. Religion scarcely touched upon. There are interesting descriptions of Co. Armagh scenery, and of life in Queen's College, Belfast.

IRWIN, Madge, see NOBLE.

IRWIN (M. E. F.).

799_ OUT OF THE HOUSE. Pp. 313. (C'onstable). 5s. n. 1916.

A rather unusual book, with a bygone flavour about it which is not unpleasant. It tells of the captivity and at last the enfranchisement of Carolin Pomfret, who comes as an orphan from Ireland to live with female relatives in London, particularly her great aunt, Catherine, the grande dame of a brilliant past. In this household one idea only dominated the life-that you were a Pomfret; and poor little Carolin became a perfectly drilled automaton in the great Pomfret tradition, until after certain matrimonial manueuvres within the sacred Pomfret circle, a young Irish violinist from the outer world breaks her fetters.-(T. Lit. S'uppl.).

IRWIN, Thomas Caulfield. 1823-1892. Is better known as a poet than as a prosewriter. Yet he wrote 130 tales of various length, essays on many subjects, and an historical romance From Caesar to Christ. He was of unsound mind for a number of years before his death.

800 WINTER AND SUMMER STORIES AND SLIDES OF FANCY'S LANTERN. P. 252. Close print. (Gill). 1879.

Contents : 1. "Old Christmas Hall"; 2. "The First Ring"; 3. "An Irish Fairy Sketch"; 4. "The Miser's Cottage" ; 5. "By Moonlight"; 6. "By Gaslight"; 7. "A Visit to a Great Artist" ; 8. "Falstaff's Wake"; 9. "A Scene in Macbeth's Castle"; 10. "Julio"; 11. "A Death"; 12. "Visions of an Old Voyage from Rome to Asia"; 13. "The Shores of Greece"; 14. "Theocritus"; 15. "A Glimpse of Arcadia"; 16. "A Ballad of Old Dublin" (verse); 17. "Corney M'Clusky" (verse) ; 18. "Ethel Maccara"; 19. "Pausias and Glycera"; 20. "Manon and her: Spirit Lover"; 21. "An Ancient Aryan Legend"; 22. "A Florentine Fortune"; 23. "Insielle's Dimple and Fan."

Miscellaneous sketches and stories. Several are literary jeux-d'esprit (e.g., 8, 9, 10). Others slight studies of curious little aspects of life, rather imaginary than real. For the most part, however, they are peculiar, weird tales, several touching the preternatural, but not morbid. The prose is poetic, imaginative, and of high literary qualities - at times comparable with those of de Quincey, e.g., in No. 4, p. 72 , sq. Here and there are exquisite pen-pictures. Several of the tales have Irish settings. No. 4 has curious pictures of old Dublin, $c .1770$.

JACOBS, Joseph. Ed. Literary Fear Book, 1898-9; Literary Ed. of Jewish Encyclopaedia. Author of Titerary Studies, Jewish Ideals, Geographical Discovery, etc. B. 1854. Died 1916.

801- CELTIC FAIRY TALES. Pp. xvi.+274. (Nutt). 6s. Complete edition. [1891]. Third, 1902.

Eight full-page plates and numerous illustrations in the text by J. D. Batten. The pictures are exquisite, and could scarcely be more appropriate. Interesting and valuable Notes and References at end, about 30 pages, giving the source of each tale and parallels. The tales are idrawn mainly from previous printed collections. The 26 tales include some Scotch and Welsh. Some are hero-tales, as "Deirdre," and "The Children of Lir" ; some folk-tales; some drolls, i.e., comic anecdotes of feats of stupidity or cunning. There are practically no fairy-tales properly so called. The tales are admirably selected, and are told in simple, straightforward language. 
JACOBS, Joseph-(continued).

802_ MORE CELTIC FAIRY TALES. Pp. xvi.+234. (Nutt). 6s. Complete edition.

All that has been said of the first series can be applied to the second, which is in every way worthy of its predecessor. Twenty stories. The two volumes may fairly be said to constitute the most representative and attractive collection of Celtic tales ever issued.

803_ CELTIC FAIRY TALES. By Joseph Jacobs and J. D. Batten. (Nutt). 3s. $6 d$.

804 MORE CELTIC FAIRY TALES. By the same Authors. (Nutt). 3s. 6d.

The above are children's editions of these well-known books. The text is practically the same as in the complete edition, but there are two or three illustrations omitted, as well as the Introduction and Notes. The tales are well known to be admirably suited to children.

N.B.-The same writers have edited English Fairy Tales, More English Fairy Tales, Indian Fairy Tales, and The Book of Wonder Voyages, which includes the voyage of Maelduin.

"JAMES, Andrew"'; James Andrew Strahan, LL.D., a Belfast man, Prof. of Jurisprudence in the Queen's Univ. there.

805- NINETY-EIGHT AND SIXTY YEARS AFTER. (Blackwood). 3s. 6d. 1911.

In two parts. Part I. (four short stories) is told in dialect (correctly rendered) by an old schoolmaster, and relates incidents of the rebellion in Presbyterian Ulster, in which the narrator's father had played a part on the loyalist side. Shows thorough understanding of the political and social conditions of the time, and is written in evident sympathy with the rebels, though with no blind partisanship. Part II. (four chapters of a longer story) introduces the supernatural, ghosts of '98 returning to influence events sixty years after. A book of much power and truth.

\section{JAMES (Humphrey).}

806_ PADDY'S WOMAN, AND OTHER STORIES. Pp. 380. (Unwin). ‘ 1896.

Little sketches or stories with but little plot, picturing sympathetically Catholic peasant life in Ulster in the 'sixties or 'seventies. Written as from within the class depicted. There is a vein of humour-Northern humour-running through these sketches. The conversations, which are in well-reproduced dialect, are at times long-drawn out, and somewhat pointless.

\section{JARROLD, Ernest.}

807- MICKEY FINN IDYLLS. P. 281. (N.Y.: Harper). 1899. Introd. by Charles A. Dana (N.Y. SuN).

Reprinted from the Sunday Sun, Lesure's WeEkuv, \&c. Mickey is a youngster of 9 or 10, born of Irish parents, settled at Coney Island, where the scene of the idylls is laid. A good deal of humour and some pathos. A goat figures largely in the sketches. 
JAY, Harriett. A sister-in-law and adopted daughter of the late Robert Buchanan, Scottish poet and novelist. She lived for some years in Mayo, and the result of her observations was two good novels. She wrote also Madge Dunraven, and some other novels, not of Irish interest.

808- THE QUEEN OF CONNAUGHT. (Chatto \& Windus). Picture boards. 2s. n.d. (1875).

How an Englishman, John Bermingham, fell in love with and man'ied the descendant of an old western family. How he tried, but failed, to reform with English ideas the Connaught peasantry. Told with considerable power and insight. Note especially the description of a police hunt over the mountains in the snow. Has been dramatised.

809 _ THE DARK COLLEEN. Three Vols. (Bentley). 1876.

Scene: an island off the W. coast. Morna Dunroon finds a French sailor, survivor of a shipwreck. She afterwards marries him, but he abandons her and goes back to France. She follows him, and passes through strange adventures, but he is still false to her. Nemesis follows in the end. Father Moy is a fine portrait of a priest. The dialect and the scenery are both true to the reality, the description of the storm at the close is particularly well done.

810 _ THE PRIEST'S BLESSING; or, Poor Patrick's progress from this world to a better. Pp. 308. (F. V. White). Two eds. 1881.

A most objectionable book from a Catholic point of view. Viery hostile picture of the priesthood of Ireland, who keep the people in "bovine ignorance," The two specimens that appear in the story are villains of the worst type. One is 25, and has been seven years a priest! He drinks heavily, and works miracles. By another a respectable peasant is incited to murder. The views of politics can only be described as "Orange."

811__ MY CONNAUGHT COUSINS. Three Vols. (F. V. White). 1883.

Jack Kenmare goes to his uncle's place in Connaught, and has a pleasant time in company with his cousins. He becomes engaged to one of them, who writes stories. Several of these are given. An excellent moral tale, and a glimpse of happy Irish life in a country house. The political point of view is not Nationalist: neither is it hostile to Ireland.

\section{JEBB, HORSLEY.}

812_ SPORT ON IRISH BOGS. Pp. 192. (Everett). 1s. Paper. 1910.

Farcical Irish stories by a Londoner who occasionally shoots and fishes in Ireland. Peasants made grotesque, but Author has no hostile intentions. Nondescript dialect. " A Home in Calery" is quite different, and makes very pleasant reading. "Sister Eugenia" is an agreeable, melodramatic story.

JESSOP, George H. Born in Ireland; ed. at Trinity. Went to U.S.A., 1873. Edited JUDGE (1884), and contributed to other humorous papers. Wrote some very successful plays. He died in 1915 at Hampstead. He was received into the Catholic Church on his death-bed.

813 GERALD FRENCH'S FRIENDS. Pp. 240. (Longmans). Well illustr. 1889.

Six stories reprinted from the Century Magazine, 1888. Gerald, a spendthrift son of good family, takes to journalism and goes to San Francisco. There he meets various types of his fellow-countrymen, and the stories are about these. "All the incidents related in this book are based on fact, and several of them are mere transcripts from actual life ... The purpose is to depict a few of the most characteristic types of the native Celt of the original stock, as yet unnixed in blood, but modified by new surroundings and a different civilisation." An excellent work, and perhaps the Author's best. 
JESSOP, George H.-(continued).

\section{4-WHERE THE SHAMROCK GROWS. (Murray \& Evenden). 3s. 6d. 1911.}

A rather commonplace story. The characters are mostly of the squireen class, notably the drunken Mat O'Hara. There are two love stories, both having happy conclusions, to which the racehorse Liscarrick largely contributes. "The paper is poor and the binding tawdry." - (I.B.L.) "The writer has only put on record that part of his experience which can be reconciled with conceptions derived from Lever." -(Irish Times).

815- DESMOND O'CONNOR. Pp. 320. (Long). 6s. 1914.

The "Wild Geese" in Flanders. Desmond is the "Lion of the Irish Brigade." A love story that moves through camps and courts, siege, battle, adventure, misunderstanding, to a happy ending, under the aegis of the Grand Monarque. Told with spirit and verve.

\section{JOHNSTON, Miss.}

816- ELLEN : A Tale of Ireland. Pp. 139. 16mo. (London). 1843.

A curious and rather meaningless little story. Ellen O'Rorick, daughter of a drunken tavern keeper of Leixlip, goes to England, and mixes in high society. Forgotten and looked down upon iby her childhood's friend, whom she loves, she marries in succession two elderly, rich men, and then settles in Ireland to a life of philanthropy, having meanwhile become a Protestant. A good deal of moralising.

\section{JOHNSTON, M. L.}

817- MAVOURNEEN; or, The Children of the Storm. Pp. 233. (Walter Scott). 1904.

Kitty O'Neill, on her way to her aunt at Lostwin, in England, is saved from a wreck by Ralph Whitteridge, of that place. Kitty grows up, and has several suitors, but meets Ralph again, and marries him in spite of the aunt, who wishes her to marry Edward, the Squire. Some of the action takes place at Malhay, in the S. of Ireland, Kitty's native place. Kitty dies, and Ralph takes to drink, but is rescued by a former rival, and on the voyage out to $S$. Africa proves his sterling worth, but is drowned in a storm along with his little boy, Curly. Author's knowledge of Ireland very slight. Brogue poor. No anti-Catholic bias.

JOHNSTON, William, of Ballykilbeg, 1829-1902. Was in his day one of the most strenuous opponents of Home Rule, a leader of Orangemen, and Unionist M.P. for Belfast during many years. His novels reflect his political opinions.

\section{8- NIGHTSHADE. (Belfast: Aicken). 2s. Portrait. [c. 1870]. Many} editions; the last $c .1902$.

The hero, Charles Annandale, a young Ulster landlord and an Oxfordman, returns to Ireland in the thick of the agrarian agitation. His agent is shot by Ribbonmen, who had been previously absolved by the priest. He is an unsuccessful candidate for Parliament. The election is well described, the Author probably drawing on his experiences at Downpatrick in 1857. Among the characters is Rev. Mr. Werd (Dr. Drew, of Belfast). The sister of Charles's betrothed is entrapped by a Jesuit, who poses as her guardian, and immured in a Paris convent, but is released after a lawsuit. "There is much denunciation of "prowling Jesuits," "Liberal Protestants," and "Puseyite Traitors."

819-UNDER WHICH KING. Pp. 308. (Tinsley). 1873.

A plain historical narrative, with little plot, and no character drawing of the various events of 1688-91-Derry, the Boyne, \&c. Very strong Williamite bias. 
JOHNSTONE, Mrs. Christina Jane. A Scotch lady who in 1834 conducted Johnstone's Edinburgh Magazine.

820_ TRUE TALES OF THE IRISH, PEASANTRY. Pp. 40. (EDINB. :

Tait, etc.). 2nd ed. 1836.

"As related by themselves. Selected from the report of the Poor Law Commissioners." The Author lets the poor tell their own story, and a pitiful and heart. rending tale it is. She is in thorough sympathy with the woes of Ireland, and here makes various suggestions and comments it propos of this report. Incidentally she deals with the Terry Alts, a secret society.

\section{JOHNSTONE (Mrs. D.).}

\section{1- THE BROTHERS IN HIGH LIFE, OR THE NORTH OF IRELAND.} 3 vols. 1837.

JONES, T. Mason. This Author ran The Tribune in Dublin in the fifties, and was afterwards well-known in England as a lecturer of the Reform League.

\section{OLD TRINITY : a Tale of real life. Three Vols. 1867.}

Period: c. 1850. . Scene: T.C.D., Ossory, and Co. Limerick. Career, told by himself of a brilliant young Trinity man, including a love story. A fine piece of narrative. But the chief source of interest, perhaps, is the account of the land troubles of the day, and the very sympathetic picture of the sufferings of the peasantry duing and after the Famine years. It includes portraits, drawn with feeling and admiration, of an Ossory P.P., and of a dissenting minister. There are pointed criticisms of educational methods and a study, none too favourable, of life in T.C.D.

JOYCE, James A. B. 1882 of a Co. Cork family. Ed. at Clongowes Wood College, Belvedere College, and University College, Dublin. He held for a long time a position in the consular service at Trieste. Besides the following he has published another work of fiction, Ulysses, and a volume of verse, Chamber Music. In 1916 he published a work entitled A Portrait of the Artist as a Young Man. It is autobiographical and resembles the reminiscences of Geo. Moore $(q \cdot v$.$) in its entire absence of reticence and of regard for the$ ordinary amenities of publicity.

\section{3- DUBLINERS. Pp. 278. (Grant, Richards). 3s. 6d. 1914.}

Seventeen genre studies in the form of stories picturing life among the Dublin lower-middle and lower classes, but from one aspect only, viz., the dark and squalid aspect. This is depicted with almost brutal realism, and though there is an occasional gleam of humour, on the whole we move, as we read, in the midst of painful scenes of vice and poverty. His characters seem to interest the Author in so far as they are wrecks or failures in one way or another. He writes as one who knows his subject well.

\section{JOYCE, Patrick Weston, M.A., LL.D. 1827-1914. B. at Ballyorgan, Co.} Limerick. Ed. at private schools; graduated at T.C.D. In 1845 he entered the service of the Commissioners of National Education. He rose to be principal of the Marlborough Street Training Schools, Dublin. Elected M.R.I.A., 1863; President of Royal Society of Antiquaries. Wrote several histories of Ireland, of one of which 86,000 copies were sold. Publ. works on Irish place-names, Irish music, a grammar of the Irish language, a social history of Ancient Ireland, \&c., \&c. D. Jan., 1914. He was writing practically up to the day of his death.

824 - OLD CELTIC ROMANCES. Pp. xx.+474. (Tongmanis). [1879].

Third ed., revised and enlarged. 1907.

Thirteen tales, selected and translated from the manuscripts of Trinity College and of the Royal Irish Academy. Some have been already published, but in a form inaccessible to the public, and in literal translations made chiefly for 


\section{JOYCE, Patrick Weston, M.A., LL.D.-(continued).}

linguistic purposes. The Author justly claims that this is "the first collection of the old Gaelic prose romances that has ever been published in fair English translation."-(Pref.). The translations are, as the Author says, in "simple, plain, homely English." $\mathrm{He}$ has made little or no attempt to invest them with the glamour of poetry. The text is preceded by some particulars concerning these tales and their origin, and followed by notes and a list of proper names. The tales are: "The Fates of the Children of Lir, Tuireann and Usnach"; "The Voyages of Mailduin and of the Sons of O'Corra"; "The Pursuit of the Gilla Dacker and of Dermat and Grania"; "Connla of the Golden Hair"; "Oisin in Tir-na-nOge," \&c. "I would bring out," said Dr. Richard Garnett, Librarian of the British Museum, "Joyce's Irish Romances in the cheapest possible form and place them in the hands of every boy and girl in the country."

JOYCE, Robert Dwyer. Brother of the preceding. B. Glenosheen, Co. Limerick, 1830. Graduated in Queen's Coll., Cork. Went to U.S.A. in 1866, where he was very successful as a doctor. Returned to Ireland, 1883, and died the same year. He is perhaps better known as a poet than as a prose writer.

825- LEGENDS OF THE WARS IN IRELAND. Pp. 352. Camplell). 1868.

(Bosron :

Thirteen historical and semi-historical legends, told by a thoroughly good storyteller, with plenty of colour and exciting incident and without clogging erudition. "A Batch of Legends" includes the story of the monks of Kilmacluth and.the wonderful bird, a story of love in the ' 45 (Culloden, \&c.), a legend about Murrough of the Burnings, c. 1663, how Patrick saved the life of his servant Duan, Black Hugh Condon's vengeance on the English, c. 1601; and another, "The Master of Lisfinry," the takings and retakings of Youghal during the Desmond rebellion, story of a lost child found. "The Fair Maid of Killarney"-the taking of Ross Castle by Ludlow during Cromwellian wars. "An Eye for an Eye"-knightly combats during the Bruce invasion, 1315. "The Rose of Drimnagh"-abduction of Eleanora de Barneval of Drimnagh (near Inchicore) by the O'Byrnes. "The House of Lisbloom," a legend of Sarsfield and the Rapparees, an exciting story. "The Whitethorn Tree," a strange tale of Rapparees and Puritans, abductions and rescues and fights. "The first and Last Lords of Fermoy," 1216 and 1660 (the faithless Charles II.). "The Iittle Battle of Bottle Hill " is another Rapparee story. "The Bridal Ring," a story of Cahir Castle. "Rosaleen ; or, the White Lady of Barna" -end of 18th century.

P.S.-Some of these legends were publ. without the name of the Author in cheap paper ed. by Cameron \& Ferguson, of Glasgow, under title, Galloping O'Hogan, and other Tales, n.d.

\section{6- IRISH FIRESIDE TALES. Pp. 376. (Boston) 1871.}

Sixteen stories, some historical (or pseudo-historical), some legendary, some serious, some comic. The scenes are laid in various parts of Ireland, and at various periods. Told in very pleasant if somewhat old-fashioned style. Contents : "The Geraldine and his Bride Fair Ellen"; "The Pearl Necklace" (a love story of Kilmallock); "The Building of Mourne" (Cork-Legend); "A Little Bit of Sport" (four comic stories); "Madeline's Vow" (modern); "The Golden Butterfly" (Co. Clare); "Creevan, the Brown Haired"; "Mun Carberry and the Phooka"; "A Story of Dublin Life in the Days of Queen Ann," \&c. Very little dialect.

JUBAINVILLE, H. d'Arbois de. See D'ARBOIS supra. KAVANAGH, REv. M.

827_ SHEMUS DHU; the Black Pedlar of Galway. (Duffy). 2s. [London: 1867]. Very many editions. Still in print. (N.Y.; Benziger). 0.60

Life in and about Galway during Penal times. The peasantry are portrayed as well as the citizens and the upper classes. The plot is somewhat rambling, yet the book is interesting. In Allibone this is said to be by Maurice Dennis Kavanagh, LL.D., called to the Bar at the Middle Temple, 1866. 
KEARY, Miss Annie. B. at Bilton Rectory, nr. Wetherby, Yorkshire, 1825. Her father, a Galway man, was rector of the parish. She wrote many novels, Early Egyptian History, The Nations Around, Heroes of Asgard, \&c. She had very little personal knowledge of Ireland. D. 1879.-(D.N.B.) See

Memoir of Annie Keary, by her sister, 1882

828_ CASTLE DALY: The Story of an Irish House thirty years ago. Pp. 576. (Macmillan). 3s. 6d. [1875]; often reprinted. Fourth ed., 1889.

(Philadelphia: Porter). 1.00.

Period: the Famine years and Smith O'Brien rising. The sufferings of the people sympathetically described. The Young Ireland movement dwelt on both from an English and an Irish standpoint. All through the book constant contrast between English and Irish characters, showing their incompatibility, and on the whole the superiority of the English; yet the book shows sympathies with Home Rule, to which one of the chief characters is converted. There are some descriptions of scenery in Connemara.

\section{KEEGAN, John.}

829 - LEGENDS AND POEMS. Pp. 552. (Sealy, Bryers). 3s. 6d. 1907.

Memoir of Author by D. J. O'Donoghue, pp. v.-xxxiii. He was a self-educated Midlands peasant, who lived in the first half of the last century. This miscellany consists of $(a)$ Six tales of the Rockites, the brutal doings of a secret society that flourished about 1830; (b) Legends and tales of the peasantry of Queen's County and North Munster; (c) Pp. 289-446, "Gleanings in the Green Isle," a series of letters written in 1846 to Dolman's, a London Catholic magazine, which deal with Irish country life, and are interspersed with stories; $(d)$ Pp. 493-552, Poems.

\section{KEENAN, Henry F.}

830 THE ALIENS. 2 vols. (Ward \& Downey). (N.Y.: Appleton). 1886-7.

KEIGHTLEY, Sir Samuel R. B. Belfast, 1859. Son of S. Keightley, of Bangor, Co. Down. Ed. Queen's Coll., Belfast. Contested Antrim as indep. Unionist (1903), and S. Derry as Liberal (1910). Member of Senate of Queen's Univ. Resides in Lisburn, Co. Antrim. Other works:-A King's Daughtcr, The Cavaliers, Heronford, \&c.

831- THE CRIMSON SIGN. Pp. 189. (Hutchinson). 6s. and 6d. (N.Y.: Harper). 1.50. [1894].

Adventures of a Mr. Gervase Orme, "sometime Lieutenant in Mountjoy's (Williamite) regiment of foot," previous to and during the siege of Derry. The story is told with great verve, and is full of romantic and exciting adventure. There is little or no discussion of politics, and no bitter partisan feeling.

832 - THE LAST RECRUIT OF CLARE'S. Pp. 333. (Hutchinson). (N.Y.: Harper). [1897]. n.d. (1908).

"Being passages from the memoirs of Anthony Dillon, Chevalier of St. Louis, and late Colonel of Clare's Regiment in the Service of France." Six detached episodes. The title story is a sentimental story of a child who was the pet of the regiment. "The King's Favour" is the story of the narrator's revenge upon the man who enticed away his fiancée to make her a mistress of Louis XV. "The Last Sacrament" is the diabolical vengeance of a minister on the seducer of his wife. "The Case of M. de Lussac" is a suicide to avoid the disgrace of cowardice. The hero is ever ready to use his sword on slight provocation. There is very little about the Brigade.

833 THE PIKEMEN. Pp. viii.+311. Well illustrated. (Hutchinson). $6 s$. 1903.

The supposed "narrative of Rev. Patrick Stirling, M. .., of Drenton, Sangamon Co., Ill., U.S.A., formerly of Ardkeen, Co. Down," telling his experiences in the Ards 
KEIGHTLEY, Sir Samuel R.-(continued).

of Down (district between Strangford Lough and the sea) during the rising. Presbyterian-Nationalist bias. Strong character study. Faithful descriptions of scenery. The study of the Government spy is especially noteworthy.

834- A BEGgaR ON HORSEBACK. Pp. 319. (Long). 1906.

A swaggering young bravo-a faint imitation of Barry Lyndon-tells his adventures in Dublin and on the Continent in the days of the drinking, gambling, out-atelbows squireens (end of eighteenth century). The hero is thus described:- "I should like to have seen the man who at cards, drinking punch, riding or selling a horse, deludhering a woman, or winging his man had any advantage of Rody Blake" (p. 12). A facetious, swashbuckler tone is adopted throughout.

\section{[KELLY (MrS.)].}

835- THE MATRON OF ERIN: a national tale. 3 vols. (Dublin: Coyne. LoNDON: Simpkin Marshall). 1816.

Scene: Connaught in ''98, Humbert's invasion providing some of the main incidents. The Author's view-point is Catholic, much stress being laid on the plight of the Church in pre-Emancipation days. She sympathises with the persecuted peasantry, but abhors rebellion and war in general. In tracing the fortunes of the heroine (a wife and mother), the Author tries to show her to us made gold in the fire of misfortune and sorrow. But she is almost " unco guid." The stilted style contrasts with the impossible brogue spoken by the peasant characters.

KELLY, Eleanor F. Resides in Dublin. She is a constant contributor to Catholic periodicals here and in the States.

836- BLIND MAUREEN; and other Stories. Pp. 160. (Washbourne). 2s. n.d. (1913).

Ten short stories reprinted from The Catholic Fireside, and other Catholic magazines. High moral tone, characterisation good, dialogue (often in dialect) natural. St. Anthony plays a prominent part. "The Fate of the Priest Hunter" is a tale of 18th century persecution in Ireland.

837- OUR LADY INTERCEDES. Pp. 210. (Washboume). 2s. 6d. 1913.

Twelve stories, several of which are Irish, devoted to showing the care of the Blessed Virgin for those who invoke her. One relates to Cromwellian times, but for the most part the stories relate to the present time.

838_ THE THREE REQUESTS; and other Stories. Pp. 192 . (Duffy). 3s. 6d. 1914.

Twelve little stories, Irish in subject. The interest of the story is always quite subordinate to the religious and moral interest. The tales deal with answers to prayer (two of them are about prayers to St. Antony), the evils of emigration, and of proselytism, the reward of charity, \&c., one is a ghost-story. They are told with great simplicity.

KELLY, MYRA. An American writer, Author of Little Citizens, Little Aliens, Her Little Young Ladyship, etc. Died a few years ago.

839 _ ROSNAH. (Daily Mail). 6d.

An Irish story, well-told, sympathetic and as faithful as could be expected from one who seems not to have had first-hand knowledge of Ireland.

[KELLY, Peter Burrowes]. 1811-1883. B. Stradbally, Queen's Co. Took an active part in politics, and was a noted speaker. Died in Dublin.

840 THE MANOR OF GLENMORE; or, The Irish Peasant. Three Vols. (LoNDon: Ed. Bull). 1839.

Scene: Stradbally, in the Queen's County. Most of the personages of the tale 
[KELLY, Peter Burrowes]-(continued).

and many of its incidents are real. The country is very well described; the book has many interesting incidents; peasant life is pictured with knowledge and sympathy. The last year of the agitation for Catholic Emancipation is the period dealt with. The famous Clare election is described, and there is a character sketch of Dr. Doyle ("J.K.L."). It criticises strongly the Protestant ascendancy and landlord party, dwells upon the doings of Orangemen and of Whiteboys, and the attempts to reconcile the two factions.

KELLY, William Patrick. B. 1848. Son of P. J. Kelly, of Mount Brandon, Graigue-na-Managh, Co. Kilkenny. Ed. Clongowes Wood College and R.M.A. Woolwich. Late R. Artillery, retired 1878. Lived in Harrogate for 19 years. Wrote seven or eight other stories, chiefly semi-historical adventure stories, e.g., The Stonecutter of Memplis. D. 1916.

841- SCHOOLBOYS THREE. Pp. 320. (Routledge). 3s. 6d. Eight illustr. (good). [1895]. Several new eds.

A story of school-boy life at Clongowes Wood College in the early 'sixties, told in a pleasant and picturesque style, and, almost all through, with frank fidelity to reality. It is full of lively incident. Was highly praised by the leading literary reviews.

[KEMBLE, Ann]; "Ann of Swansea." Author of Uncle Peregrine's Heiress, Conviction, Guilty or Not liuilty, and many other storfes.

842_ GERALD FITZGERALD; an Irish Tale. Five Vols. (!) (London: Newman). 1831.

Gerald, whose Catholic wife has deserted him, lives in an old half-ruined family castle, near Armagh. The book is an interminable (1698 pp.) series of petty scandals and flirtations, gossip, and matchmaking among the titled persons living in "Doneraile Castle," and "Lisburn Abbey." The insipid affairs of an out-ofdate beau monde.

KENNEDY, Rev. J. J. B. Dingle Park, Co. Kerry Ordained All Hallows College, Dublin, 1904. Worked in Australia at Yarrawonga, Victoria. Served as a chaplain in the great war and received the D.S.O.

843-CARRIGMORE; or, Light and Shade in West Kerry. I'p. 128.

(Wangaratta: Office of Chronicle). 1909.

KENNEDY, Patrick; “ Harry Whitney." Born in Co. Wexford, 1801. In 1823 lee removed to Dublin, and for the greater part of his life he kept a bookshop in Anglesen street. His sketches of Irish rural life as he had known it are told with spirit, and with a kind of photographic hteralness and exactness. They are very free from anything objectionable. Dr. Donglas Hyde, speaking of his folk-lore, says that "many of his stories appear to be the detritus of genuine Gaelic folk-stories filtered through an English idion and much impaired and stunted in the process. He appears, however, not to have adulterated them very much." In the Pref. to Evenings in the Duff rey he says fand the remarks apply to his other books), "On all other points [viz., than the matrimonial fortunes of his hero and heroine] there is not a fictitious character, nor incident in the mere narrative, nor legend related, nor ballad sung, which was not current in the country half a century since. The fireside discussions were really held, and the extraordinary fishing and hunting adventures detailed, as here set down." He died in 1873.

844 _ LEGENDS OF MOUNT LEINSTER. Pp. 283. 16mo. (Dublin). 1855.

Title of a miscellany published under the psendonym of "Harry Whitney." Contains: "Three Months in Kildare Place," "Bantry and Duffrey Traditions,"

"The Library in Patrick Street"; in all nine sketches, four of which are stories supposed to be told at fireside of Wexford farm-house. Careful picture of manners and customs. No. 1 is a story of the time of Brian, e. 1001 A.D. 3. A love-tale of the days of Sarsfield. 6. Penal days, a hunted priest. 


\section{KENNEDY, Patrick; "Harry Whitney"-(continued).}

845- LEGENDARY FICTIONS OF THE IRISH CELTS. (Macmillan).

[1866]. Several eds. since, e.g., 1831.

Over 100 stories, given, for the most part, "as they were received from the story-tellers with whom our youth was familiar." They are derived from the English-speaking peasantry of County Wexford. They include " Household Stories" (wild and wonderful adventures), "Legends of the Good People" or fairies, witchcraft, sorcery, ghosts and fetches, Ossianic, \&c., legends, and "Legends of the Celtic Saints." All these are in this book published for the first time. All through there is an interesting rumning comment, introductory and connective. The book is hardly suitable for children.

(M'Glashan d Gill). '2s.

\section{[1867]. New ed. 1875, \&c.}

Into the tissue of a pleasant and touching story of quiet country life in North-west Wexford the Author has woven a collection of tales, ballads, and legends, some of which are of high merit. They contain a wealth of information on local customs and traditions. Incidentally, Irish peasant character is truthfully painted in all its phases-grave, gay, humorous, and grotesque. The moral standard is very high throughout. There are many vivid descriptions of scenery. The whole is told in a simple, pleasant, genial style. The Author tells us that the chief incidents, circumstances, and fireside conferences mentioned in the book really occurred.

\section{7_ EVENINGS IN THE DUFFREY. Pp. 396. (M'Glashan \& Gill). $2 \varepsilon$.}

[1869]. 1875.

A kind of sequel to the Banks of the Boro. The adventures of the hero, Edward 0 'Brien, are continued, the story being, as before, interspersed with legends and ballads. It has the same good qualities as the earlier book, the tone being again thoroughly healthy.

\section{8- THE FIRESIDE STORIES OF IRELAND. Pp. 162. 32mo. (M'Glashan} \& Gill). 1s. 6d. 1870.

"A good book" (Douglas Hyde in Beside the Fire). Fifty tales, chiefly fairy and folk-lore, but of very varied types, full of local colour and interest. Many of them are of the kind found in the folk-tales of all nations, but have an unmistakably Irish (not stage-Irish) savour. Moreover, they are told with vivacity, quaintness, and sly humour. A good selection, suitable for readers of any age or class.

\section{9_ THE BARDIC STORIES OF IRELAND. Pp. 227. 12mo. (M'Glashan d. Gill). 2s. [1871].}

Fifty-eight stories, founded, some on pagan myth, others on historical traditions of great families. All were originally found in poetic form, and many of them retain much of their poetic qualities. Many are told with a singular humorous naïveté. In all the language is simple but very adequate and dignified. They are free from anything that would make them unsuitable for the young.

850 - THE BOOK OF MODERN IRISH ANECDOTES. Pp. 192. 12mo. New ed. (Gill). 6d: Has passed through several editions and is still in print. 1913.

"Has no higher ambition than that of agreeably occupying a leisure hour."(Pref.). "It has entered into the present writer's purpose to draw the attention of his readers to the principal events in the history of his country since the Revolution of 1691."-(Pref.). Anecdotes of Swift, Sheridan, Curran, Moore, O'Connell, \&c. Stories of duelling, gaming, hunting, shooting, acting, electioneering, drinking. Taken from such Authors as R. R. Madden, W. J. Fitzpatrick, Sir John Gilbert, Sir Jonah Barrington, Hon. Edward Walsh, \&c., \&c. Free from coarseness, and practically free from the Stage-Irıshman. In the new ed. there are about 200 proverbs transl. from the Irish and an Index. 
KENNY, Mrs. Stacpooie. B. in Dublin, dau. of Dr. J. R. Dunne, M.A., of Moymore, Co. Clare. Wife of Mr. T. H. Kenny, of Limerick, near which city she resides.

\section{1— JACQUETTA. Pp. 227. (Washbourne). 2s.6d. (N.Y.: Benziger). \\ 0.75. 1910.}

Scene: Kilrush, Co. Clare, and London. The story of an Irish-Australian girl who comes to live in Ireland with her uncle, Dr. Desmond. She had contracted an unhappy marriage, but believed her husband dead. The story tells how she finds him, and the fate that overtakes him. There is also the love-story of Dr. Desmond. In the end all is well with uncle and niece.

\section{2_ LOVE IS LIFE. Pp. 317. (Greening). 6s. 1910.}

The heroine, Iseult Dymphna Macnamara, whose mother was French, lives at the Court of Louis XIV. at the time when James II. held his exiled Court at St. Germain. She loves the son of Sarsfield, but is forced by circumstances into a loveless marriage with a noble and chivalrous Frenchman, St. Amand, whom the King had chosen for her. St. Amand goes off to the wars (Steenkirk and Landen), and meantime the king pursues Iseult with amorous attentions. To avoid them she flies $t_{0}$ Ireland. Here we get a glimpse of the Penal days in Co. Clare. All comes right when Iseult comes to love her husband. Brightly and entertainingly told.

\section{CARROW OF CARROWDUFF. Pp. 331. (Greening). 6s. 1911.}

Scene: West County (obviously Clare). The hero, son of an unpopular landlord, whose cattle have been houghed and otherwise maimed, goes, in spite of warnings, to a wake among the tenantry. This wake is described as a scene of savagery. On his return he is "shot at" and wounded, and there comes to nurse him a young nun with whom, before her entrance into religious life, he had fallen in love. It turns out that she had entered the convent in a moment of pique. The hero accordingly proposes, and they are married by the death-bed of his father, who has fallen a victim to the League.

\section{THE KING'S KISS. Pp. 288. (Digby, Long). 6e. 1912.}

A kind of sequel to Love is Life. How Iseult, who tells the story, buys the life of her cousin Harry Macnamara by a kiss given to Louis XIV. 'This, though innocent on her part, was the beginning of her troubles. Her enraged husband rides post-haste to Versailles to tell Louis what he thinks of him. St. Amand disappears, and Iseult almost dies of fever; but through a whole series of plots and court intrigues and exciting adventures things right themselves at last. James II., the Duchess of Tyrconnell, and many other historical persons play a part in the romance.

\section{5- OUR OWN COUNTRY. Pp. 142. (Duffy). 2s. 1913.}

Sequel to Carrow of Carrowduff, with the same personages. Several interworen love stories-in particular that of an English Protestant gentleman (converted in the course of the tale) with Mrs. Monsel, a widow, mother-in-law to Cesare Carrow, who tells part of the story. The denouement has a deep religious interest, which indeed is the chief interest of the whole book.

\section{6- DAFFODIL'S LOVE AFFAIRS. Pp. 320. (Holden \& Hardingham).} 6s. 1913.

A story of life among gentlefolk. Scene: near Carlingford and in London. D.'s mother, of a good but impoverished family, has five daughters on her hands, and the way in which these are married off, partly owing to her match-making exertions, forms the burden of the story. For the most part it is a light and vivacious story of social life and flirtations. But an element of tragedy is introduced in one of the subsidiary love stories, that of D.'s sister Kit, who was thus punished for a flirtation carried on with Sir Dermot de Courcy while his wife was still alive. 
KENNY, Mrs. Stacpoolo-(continued).

857- MARY: A Romance of West County. Pp. 273. (Washbourne). 2s. 6d. 1915.

On leaving her convent school in Dublin, Mary goes home to realise for the first time that her father not only cares little for her ibut dislikes her (her birth had cost her mother's life). But in the long run she wins his love. There is a double love story-her own and that of her madcap, slangy, tomboy cousin Benigna. The Author is persistently vivacious and sprightly. There is no repose or quiet beauty about the style.

KENNY, Louise. Dau. of Michael Kenny, late of Freagh Castle, Miltown Malbay, Co. Clare, where her brother, M. J. Kenny, K.C., now resides. Besides this novel she has written many short stories and articles for periodicals; also much propagandist literature in connection with Irish industrial development.

Resides in Dublin.

858- THE RED-HAIRED WOMAN : Her Autobiography. Pp. 400. (Murray). 6s. 1905.

The interest centres in an old connty family of Thomond (Co. Clare), the O'Currys. Characters typical of various conditions of life in Ireland: an unpopular, police-protected landlord, a landowner with an encumbered estate, an upstart, usurer, faithful retainers, evicted tenants, etc. (N.I.R., Dec., 1905).

KENNY, M. L., a Dublin lady.

\section{THE FORTUNES OF MAURICE CRONIN. Three Vols. (Tinsley). 1875.}

A very long novel with a very complicated plot and without a trace of brightness or of humour. The plot turns chiefly on a case of mistaken identity. Maurice returns from soldiering in India to find that he is really heir to the estates of the Grace family, and can marry Mary Grace, his cousin, whom his putative mother had thought to be his sister. No national interest. Date 184- Places such as Deverell's Chase, Desmond's Tower, Rathcroghan, are mentioned.

\section{KERR, Eliza.}

860-SLIEVE BLOOM. Pp. 153. (Wesleyan Conference Office). Three illustr. 1881.

A little non-controversial Methodist story for young people. Tells (in the present tense throughout) how Mary and Willie lived a very poor life with their maternal grandmother, but by the coming of their father's mother were raised to better circumstances. Nice descriptions of Mountmellick, the Bog of Allen, and Slieve Bloom.

861- KILKEE. Pp. 193. (Wesleyan Methodist School Union). Third ed. 1885.

A moral and religious (but not controversial) tale. Adventures of two boys near the Pollock Hole Rocks, Kilkee, the scenery around which is well described. On all occasions the boys quote Scripture texts, and the piety of the personages concerned is constantly insisted on.

862- KEENA KARMODY, \&c.: A Ta!e. Pp. 192. (Wesleyan Methodist Sunday School Union). 1887.

Also The Golden City, Hazel Haldene, and four or five others. 
KETTLE, Rosa Mackenzie, i.e., Miss Mary Rosa Stuart Kettle. B. at Overseale, Leicestershire.

863 ROSE, SHAMROCK, AND THISTLE. Pp. 286. (lisher, Unwin). 6s. 1893.

"A Story of two Border Towers." Rhoda Carysfort, an Irish girl, comes to live with her English cousins, and eventually marries a Scotch laird. Except for the heroine's nationality there is nothing Irish about the story, though the Author's sympathies are with Ireland. The tone is very "respectable" and somewhat prim. It seems intended as a book of instruction for girls.

KICKHAM, Charles J. B. Mullinahone, Co. Tipperary, 1828. Began early to write for nationalist papers-The Nation, The Celt, The Irishman, The Irish People. Most of his contributions were verse, but to The Shamrock he contributed his chief novels. He threw himself into the Fenian movement, was arrested along with John O'Leary, and sentenced to fourteen years' penal servitude. His health never recovered from this period of prison. He died in 1882 at Blackrock, near Dublin. See the short Life by J. J. Healy, publ. 1915 by Messrs. Duffy. Besides the novels mentioned below, Kickham wrote the following short stories:- "Poor Mary Maher" (a sad tale of '98) ; "Never Give Up," "Annie O'Brien," "Joe Lonergan's Trip to the Lower Regions " (Irish life in the fifties, dealing largely with land troubles); "White Humphrey of the Grange: A Glimpse of Tipperary fifty years ago"; "Elsie Dhuv" (a story of '98, full of incident, much of it humorous). These tales have been collected for publication by Mr. William Murphy, of Blackrock. K. knew thoroughly and loved intensely his own place and people. He had wonderful powers of observation, and a great fund of quet humour.

864-SALLY CAVANAGH. (Duffy). 2s.6d. [1869]. (N.Y.: Benziger).

0.75. New ed. 1902.

Kickham's first story. Contains in germ all the great qualities of Krocknagow. We feel all through that it is the work of a man of warm, tender, homely hearta man born and bred one of the people about whom he writes. It is a simple and natural tale of love among the small farmer class. Sally Cavanagh's tragedy is due to the combined evils of landlordism and emigration. Some of the saddest aspects of the latter are dwelt upon. The book is quite free from declamation and moralising, the events being left to tell their own sad tale. Perhaps the noblest characters in the book are the Protestant Mr. and Mrs. Hazlitt. There is no trace of religious bigotry. There are touches of thumour, too-for example, the love affairs of Mr. Mooney and the inimitable scene between shawn Gow and his wife.

865- KNOCKNAGOW. Pp. 628. (Duffy). 4s. [1879]. Upwards of 14 eds. since. (N.Y.: Benziger). 1.25.

One of the greatest, if not the greatest, of all Irish novels. Yet it is not so much a novel as a series of pictures of life in a 'Tipperary village. We are introduced to every one of its inhabitants and learn to love them nearly all before the end. Everything in the book has been not merely seen from without but lived by the Author. It is full of exquisite little humorous and pathetic traits. The description of the details of peasant life is quite photographic in fidelity, yet not wearisome. There is the closest observation of human nature and of individual peculiarities. It is realism of the best kind. The incidents related and some of the discussions throw much light on the Land Question. The Author does not, however, lecture or rant on the subject. Occasionally there are tracts of middle-class conversation that would, I believe, be dull for most readers.

866- FOR THE OLD LAND. Pp. 384. (Gill). 2s. [1886]. New ed. 1914. (N.Y.: Benziger). 0.75. Reprint 1916.

Main theme: the fortunes and the sufferings of an Irish family of small farmers 


\section{KICKHAM, Charles J.-(continued).}

under the old land system. The peasant's love of home and the bitter sadness of emigration are brought out in the unfolding of the tale. All through there runs a love-tale told with the Author's usual restraint, simplicity, and delicate analysis of motive. There is a humorous element, too, amusing bailiffs and policemen furnishing much of it. Constable Sproule driving home the pigs is capitally done. Rody Flynn is a grand old character, evidently sketched from life.

\section{7- THE PIG-DRIVING PEELERS.}

Appears in one of the "Knickerbocker Nuggets," entitled "Representative Irish Tales." Compiled with Introd. and notes by W. B. Yeats. (N.Y.: Putnam). Two Vols. n.d.

KING, Richard Ashe; "Basil," "Desmond O'Brien." The Author is (1917) Staff Extension Lecturer of Oxford and London Universities. Has contributed a good deal to the Connhill and to the Pall Mall Gazetre, and is reviewer for Truth. Has written, besides the books noticed here, A Leal liass (Irish in setting), Love the Debt, A Drawn Game, A Coquette's Conquest, and many others. Also a life of Swift. B. Co. Clare. Ed. at Ennis Coll. and T.C.D. $\mathrm{He}$ gave up in the eighties his living in the Church of England and began contributing to Freeman's Journal, Truth, \&c. "He is," says W. P. Ryan in nis The Inish Literary Revival, "intensely Celtic, but too candid to overlook the Celt's failings." For some time in the eighties he lived in. Blackrock, Co. Dublin. See Mrs. Hinkson's Reminiscences of Twenty-five Years. Pp. 282-3.

\section{8_ THE WEARING OF THE GREEN. Pp. 299. (Chatto \& Windus). 2s. $6 d .1886$.}

A story of the course of true love, in which the lovers are long kept apart by many untoward happenings. The writer's sympathies and the characters of his story are Protestant, yet there is no hostility to Catholics, and one of the pleasantest characters in the book is Father Mac. One of the minor incidents of the story is connected with the Fenian conspiracy. The chief interest of the book lies, perhaps, in the drawing of the lesser characters. In his delineation of all the English personages the Author is unsparingly caustic. The book is brightly written; the conversation particularly good; there is a vein of sarcasm throughout, and plenty of incident. The Author evidently sympathises with Irish grievances, and is proud of his country.

869_ BELL BARRY. Pp. 332. (Chatto \& Windus). [1891]. New ed. 1892.

Robert Barry is a man of " insufferable goodness," with a mania for reform movements. His daughter Edith is a prig of an even more insufferable type, and of a proselytising, ostentatiously philanthropic bent. His other daughter, Bell, is an extreme contrast-wayward, goodhearted, human. The story, which takes place partly in America, centres round the rehabilitation of Bell's fiancé by her rejected suitor. Only two of the personages can be called typically Irish-Tim Daly, man of all work to Robert Barry, and Mary, Bell's maid. But these are rather stock characters in comedy than portraits of real life.

870_ A GERALDINE. Two Vols. 1893. (Ward \& Downey).

A story of almost contemporary life, largely concerned with land troubles in Ireland. The heroine, a very attractive character and a woman of great resource. fulness, is the daughter of a rack-renting squireen, and is a contrast to the remainder of the family, which is weak, idle, and selfish. Other unpleasant characters are a villainous attorney and a bigoted and pedantic clergyman. Some of the duties which the R.I.C. have to perform are severely commented upon. The Author takes the popular side. The incidents are related with spirit and humour. 
"KING, Toler," Mrs. Emily Fox, Au. of Gemini (Boston, 1878), Off the Rocks, etc.

871- ROSE O'CONNOR: a Story of the Day. Pp. 173. (Chicago: Sumner). [1880]. Second ed. 1881.

Rose O'C. and Tim Brady love each other. Tim has to go to America. Mean. while the famine years come in Ireland. Rose's family is reduced to extremities, and she is compelled to promise marriage to Tim's rival in order to save it. But Tim returns in the nick of time. Locality not indicated. Purpose, to contrast the tyranny of landlordism with the refinement and gentleness of the Irish peasantry. The tone is Catholic, but not aggressively so.

KINGSTON, W. H. G. A great writer for boys. Allibone enumerates 161 of his works.

872- PETER THE WHALER. Pp. 252. (Blackie: Library of Famous Books). 1s. Full size. Cloth. One Illustr. At present in print.

Peter associates with low company in his Irish home and gets into such scrapes that he has to be sent to sea. The rest is a fine series of adventures such as boys love. Here and there a good moral lesson is slipped in, not too obtrusively.

KNOWLES (R. B. Sheridan). Son of R. B. Knowles, barrister and journalist, and grandson of James Sheridan Knowles the dramatist. Educated by the Rosminian Fathers at Ratcliffe. Has contributed many essays, sketches, and reviews to various periodicals. Glencoonoge first appeared serially in THE MoNTH, then in three volume novel form, afterwards in one vol. in U.S.A.The CATHoLIC Who's Who gives his present place of residence as Hammersmith, London, W.

873- GLENCOONOGE. Three Vols. (Blackwood). 1891.

Three threads of romance skilfully intertwined, the chief of which is the love story, of an English girl of gentle birth and a splendid young Irish peasant. The scene is an inn in a valley somewhere on the South-west coast. The valley as described bears a strong resemblance to Glengariff. The story is eminently sane and natural, reading like a record of real events. It is full of human interest, and is written in a style unaffected yet charmingly literary. There are some good portraitsthe Protestant Rector, the lovable Father John, Conn Houlahan, the hero, Old Mr. Jardine, the O'Doherty. The description of an Irish Sunday is one of the most beautiful in fiction. The book shows understanding sympathy for Irish characteristios and ideals.

[KNOX, Rev. J. Spencer], "An Irish Clergyman." He was Rector of Maghera and son of a former bishop of Derry, of which he afterwards became VicarGeneral. $\mathrm{He}$ was a friend of Charles Lever. He gives some autobiographical items in the introd. to the following book.

875- PASTORAL ANNALS. Pp. 397. (London: Seeley). [1840]. Second ed., 1841.

Contents:- "The Sick Parish," "The First Death," "The Sermon," "The Warning," "The Private Still," "The Pluralist," "The Inn," "The School," "Ribbonism" (a very unfavourable picture of bailiffs, process-servers. Very fair towards Catholics) ; "The Night," "The Starving Family," "The Birth," "The Soup Shop" (Famine of 1817), "Death by Starvation," "The Confessional" (a plea for private confession), "Family Wonship," "Tithe Setting," "Tough Derg" (facetious in tone. Lough D. pilgrimage = "a scene of mockery and dissoluteness"). A series of studies-for the most part careful and sympathetic-of peasant life as seen by a liberal-minded and kindly Protestant Rector. The part of Ireland dealt with would appear to be Donegal.

\section{KUEHNE (Fred. G.).}

\section{6 - DIE REBELLEN IN IRLAND.}

In an American classified list of novels the above is entered under Irish fiction.

$I$ have been unable to obtain information about the book. 
“ LAFFAN, May," see HARTLEY.

\section{LALOR, Desmond.}

877-_ LOUGHBAR. Pp. 252. (Stockwell). 6s. 1914.

Adventures, not of a very remarkable kind, of a young doctor in the W: of Ireland, locality indefinite. He is presented with a practice, and a furnished house. There is a ghost, but he is not a real one, and rather commonplace. The whole thing is very couleur de rose, everybody being nicely married off, and the descriptions do not give the impression of things seen.

LANE, Elinor Macartney, Mrs. Francis Ransom, 1864-1909. Au. of Nancy Stair, The Apple Tree Cottage, \&c.

878- KATRINE. (Harper). 6.s. 1909.

"An Irish-American love-story with scenes of planters' life in South Carolina. The Authoress has a keen appreciation of the psychology of the Irish character, and in her portrayal of Dermott MacDermott and Katrine Dulany, she successfully indicates the lights and shades of that puzzling combination of mysticism and practicality." - (IRISH 'Trmes).

LANGBRIDGE, Rev. Frederick. Rector of St. John's, Limerick. Chaplain district asylum. B. Birmingham, 1849. Ed. there, and at Oxford. D.Litt., T.C.D., 1907. Has publ. many volumes of poetry, and some plays.-(WHo's Who). Au. of The Dreams of Dania, Love has no P'ity, \&c., \&c.

879_ MISS HONORIA. Pp. 216. (WARne: Tavistock Library). 1894.

Sub-t.: "A tale of a remote corner of Ireland," viz., "Carrowkeel," a seaside village. Miss Honoria, a woman of 32 , full of piety and zeal, the prop of the parish, has never known love till she meets Sebert, to whom she becomes engaged. Sebert writes beautiful letters from London. Miss $\mathrm{H}$. goes there to find S. making love to her niece "Daisy." H. stands aside, and S. marries Daisy. They return to Ireland, where S. makes love to a poor girl. She is drowned. H. dies, and S. becomes an East End missionary. There is much sentiment. Some pretty descriptions of scenery, and some good minor" characters-" Kevin Kennedy " and "Corney the Post."

\section{0} THE CALLING OF THE WEIR. Pp. 304. (Large print).

(Digby, Long). 1902.

A love story of Protestant middle classes. Scene: near the Shannon Weir and Falls of Donass, Co. Limerick. Two girls become engaged to two men rather through force of circumstances than for love. Problem: are the circumstances such as to justify Mary in marrying the man she does not love? In a strange way it comes about that each girl marries the other's fiancé, and finds happiness. Not without improbabilities, but lively and piquant in style. Irish flavour and humour provided by Mrs. Mack, the housekeeper, and Constable Keogh.

881— MACK THE MISER. l'p. 125. (Elliott Stock). 1907.

A tale of middle-class Protestant life in Limerick, turning on the vindication of the supposed miser's character by a young girl. The tendency of the book is moral and religious.

LANG BRIDGE, Rosamond. Dau. of preceding. B. Glenalla, Donegal, 1880. Brought up and ed. privately in Limerick. Has contributed short stories and articles to the Manchester Guardian and to other periodicals. Her attitude towards Ireland has been expressed in a fine passage worthy to be quoted. "Nationalist by sympathy and inclination, but not by contact or association, and belonging to no particular party or clique she [the Author] believes in Ireland as the Land of Spiritual Happiness; as the Land which has kept itself innocent, religious, and vividly individualistic, in face of the wave of undis- 


\section{LANGBRIDGE, Rosamond-(continued).}

tinguishable sameness which is engulfing all national idiosyncrasy, and tends towards becoming the Esperanto of the soul. Ireland she believes in as the Child-Soul amongst nations, not to be deceived or bought, but perceiving and desiring with incorruptible ingenuousness those things which alone make individual, as well as national, life worth while: Faith and Freedom before Subordination and Sophistication, and the Traffic of the Heart to the Traffic of the Mart."

882- THE FLAME AND FLOOD. Pp. xii.+339. (Fisher, Unwin; First Novel Library). 1903.

A love-story. The lovers marry other people not for love. It is only the presence of a child that prevents the heroine from leaving her husband for her "lover." There are accordingly curious situations, but nothing positively immoral in the tone. The story is well constructed. Scene: partly in Ireland, partly in England.

883_ THE THIRD EXPERIMENT. Pp. 300. (Fisher, Uuwin). 1904.

The scene is laid amid very low class society in an Irish town. The interest centres in a young girl who is reared on charity, but finally marries a fairly respectable tradesman. The personages of the story seem to be Protestants, but religion is scarcely touched on. The brogue is very thick, but the stage Irishman humour is absent. There is a persistent attempt to study types and characters.

884 - AMBUSH OF YOUNG DAYS. Pp. vii.+344. (Duckworth). 1906.

The scene is laid in a temperance hotel. The central character is a young girl, daughter of proprietor, who is given to telling out the truth in a most unnecessary and inconvenient manner. The lodgers come prominently into the story, and the heroine ends by marrying one of them.

885_ THE STARS BEYOND. Pp. vii.+375. (Nash). 1907.

A problem novel dealing with an ill-assorted marriage-the wife's name (symbolic) is "Vérité," the husband's "Virtue"; hence the clash. Religion enters largely into the book. Types of Irish Protestant clergy. The writer's sympathy seems to waver between Catholicism and Protestantism, but the heroine rejects both. The servants' talk is in conventional brogue.

\section{6- IMPERIAL RICHENDA. Pp. 313. (Alston Rivers). 6s. 1908.}

Scene: a small watering-place near Dublin. A fantastic comedy, somewhat vulgar in places, but on the whole amusing, abounding as it does in bright dialogue, and in absurdly comical situations. Some shrewd strokes of satire are aimed at Dublin Society, and there are piquant sayings on other subjects. The central figure is a young lady who takes a situation as waitress in a small hotel. Her character is so equivocal that the book cantut be recommended for general reading.

LARMINIE, William. B. 1849 , in Co. Mayo. D. at Bray, 1900 . Was many years in the Civil Service. $\mathrm{He}$ is better known as a poet, Author of Glanlua and Fand, than as a folk-lorist.

\section{7- WEST IRISH FOLK-TALES AND ROMANCES. Pp. xxvi.+258.}

(Elliot Stock). 3s. 6d. 1898.

Taken down by the editor, between 1884 and 1898, word for word in Irish from peasants in Galway (Renvyle), Mayo (Achill), and Donegal (Glencolumbkille and Malinmore), and translated literally. Interesting introduction on the origin and sources of folk lore. At the end are some remarks on phonetics, which do not show a deep knowledge of the Irish system of orthography, and specimens of the tales in Irish written phonetically. The book is primarily for folk-lorists and some naturalistic expressions render it unsuitable reading for the young. There are eighteen stories in all.

N.B.-The Author tells us (introduction) that besides the tales in this book, he has in his possession many others not yet published. This collection, a large one, is preserved in safety, but still awaits publication. 
" LAUderdale, E. M."'; Mrs. Moore, wife of Mr. G. M. Moore of Messrs. Guy \& Co. She died at Cork, Jan., 1916.

888- TIVOLI. Pp. 278. (CoRk: Guy). 1886.

A family story (landlord class) laid first at Deer Park, near Coik, afterwards in England, whither the family retires to be out of the Land League agitation. This last is referred to with evident aversion. The interest turns largely on a mystery of identity. The Author knows the Cork district well, and describes localities accurately. Her sympathies are clearly not nationalist. The religious attitude is one of tolerance.

LAWLESS, Hon. Emily. B. in Ireland, 1845. Eldest d. of Lord Cloncurry. Came to know the W. of Ireland through her associations with the home of her mother's family. Her mother was a Miss Kirwan, of Castle Hackett, Co. Galway. See Miss Lawless's Traits and Confidences for some memories of her childhood. Sho went a good deal among the people in her natural history excursions. She had wide knowledge of Irish history, as her volume on Ireland in the History of THE Nations Series bears witness. She wrote several books besides these here noted. D. 1913. For a good article on her see Nineteenth Century, July, 1914.

889- HURRISH. Pp. 342. (Methuen). [1886]. 1902.

Scene: a wild and poverty-stricken district in Clare. A view of the bad days of the 'eighties by one to whom the Land League stands for "lawlessness and criz.e." The people are depicted as half-savage. The story is a glo omy one, full of ossassinations and the other dark doings of the Land League. The picture it givos of an Irish mother will jar harshly on the feelings of most Irisinmeu The Irish dialect is all but a caricature. Yet the story met with an immeuiate nnd extraordinary success. In a vol. published by Mr. Gladstone in iug2, sp pecial Aspects of the Irish Question, he says of Hurrish, "She has made present to her readers, not as an abstract proposition, but as a living reality, the estrangement of the people of Ireland from the law ....A to the why of this alienation, also, she has her answer (p. 309 of first ed.), "The old long-repented sin of the stronger country was the culprit.' She thinks there was a sin, a deep sin, and (so 1 construe her) an inveterate sin, but a sin now purged by repentance."

890 WITH ESSEX IN IRELAND. Pp. 298. (Methuen). 6s. [1890]. New
ed.,

A narrative of Essex's Irish expedition, 1599, purporting to be related by his private secretary. Pictures Elizabethan barbarity in warfare. It has a strange element of the uncanny and supernatural. Hints at the spell that Ireland casts over her conquerors. Written in quaint Elizabethan English which never lapses into modernness.

891_ GRANIA : the story of an Island. (Smith, Elder). 3s. 6d., and 2s. 6d. [1892].

A sympathetic picture of life in the Aran Islands, where existence is a struggle against the elements. There are typical characters, such as Honor, the slaintly and patient, with her eyes on the life beyond, and Grania, young and impetuous, and longing for joy as she biattles with the endless privations of her stern lot, and the lover, Irish alike in his goodness and in his vices. The success of this book exceeded even that of Hurrish. Swineburne thought it "just one of the most exquisite and perfect works of genius in the language." (in a letter). 892-2 MAELCHO. Pp. 418. (Methuen). 1s. (N.Y.: Appleton). 1.50.

Gloomy picture of misery and devastation during the Desmond rebellion. An English boy escaping from a night attack finds refuge in a Connemara glen among the native Irish (O'Flaherties), hideous wretches of savage appearance and uncouth tongue. Then comes a confused account of the melodramatic struggles of Fitzmaurice and his wild followers against the English, noble, steady, and civilised: 
LAWLESS, Hon. Emily-(continued).

There is a vague impression throughout of an Irish race without ideals or religion, inevitably losing ground, moved by no impulse but love of strife and cringing superstition. But the cruelties of the English at the time are not in any way slurred over.

893_- TRAITS AND CONFIDENCES. Pp. 272. (Methuen). 6s. 1897.

A volume of stories and sketches, founded for the most part on fact. Some are autobiographical episodes of childhood. There is an incident of ' 98 , an incident of the Land War, and two episodes of Irish history, the story of Geroit Mor, Earl of Kildare, and that of Art Macmurrough, told in vivid, romantic style without political bias. Again, there are extremely interesting " memories" of the Famine of 1846-7. On pages 142-150 is a remarkable description of Connemara. The storytelling is full of vivacity and picturesqueness, reminding one of French storytellers, such as Daudet. The book is filled from first to last with Ireland.

8946 - THE BOOK OF GLLY. Pp. 285. (Smith, Elder). Four illustr. by Leslie Brooke. 1906.

Scene: a small island in Kenmare Bay. Gilly is an eight-year-old boy sent to Inishbeg for a few months by his father, Lord Magillicuddy, who is in India. The book makes a marvellous pen-picture of life and scenery in this remote corner of Ireland.

\section{LAWLESS, Emily, and Shan F. BULLOCK.}

895- THE RACE OF CASTLEBAR. Pp. 364. (Murray). 6s. 1914.

The story of Humbert's invasion of Ireland in 1798, as seen by the narrator, an Englishman named Bunbury, fresh come to Ireland. B. is represented as an honest, unprejudiced, if somewhat phlegmatic personage. The historic events are presented with great vividness and vigour. The Authors aim at painstaking objectivity. On the one side the sufferings of the Catholics and the harsh treatment of the rebels are painted in strong colours. The portraits both of the rebel leaders and of the Orangemen are far from flattering. The narrative is largely based on that written at the time by Dr. Stock, the excellent Protestant Bishop of Killala. Bunbury is made to spend some weeks at his palace.

LEAHY, A. H. B. in Kerry in 1857. Is a Fellow of Pembroke Coll., Cambridge.

896- THE COURTSHIP OF FERB. Square 16mo. Pp. xxix.+100. (Nutt). 2s. Two illustr. by Caroline Watts. 1902.

Vol. 1. of Irish Saga Library. Elegantly produced in every way. An English version of Professor Windisch's German translation of an old Irish romance from the Book of Leinster (twelfth century). The verse of the original is translated here into English verse, the prose into prose. "In the verse-translations endeavour has been made to add nothing to a literal rendering except scansion and rhyme." (Pref.) The tale itself is a kind of preface to the great Tàin. It is not of very striking merit, but is told in simple, dignified language. The translation reads very well. A literal translation of all the poetry is given at the end.

897- ANCIENT HEROIC ROMANCES OF IRELAND. Two Vols. Small 4to. Vol. I., pp. xxv.+197. Vol. II., pp. ix.+161. (Nutt). 8s. net. 1905, Contents: Vol. I. "The Courtship of Etain"; "MacDatho's Boar "; "The Deatl of the Sons of Usnach" (Leinster Version); "The Sick Bed of Cuchulainn"; "The Combat at the Ford" (Leinster Version). Vol. II. "The Courtship of Fraech"; "The Cattle Spoil of Flidias"; "The Cattle Spoil of Dartaid" ; "The Cattle Spoil of Regamon." The Preface deals with Irish Saga literature in general and in particular with the sagas here translated. - Each piece is preceded by a special Introduction dealing with its sources and character. At the end of Vol $\mathbf{I}$. (pp. 163-197) are copious notes explaining difficulties and giving literal translations. 
LEAHY, A. H.-(continued).

At the end of Vol. II. is a portion of the Text of "The Courtship of Etain," with interlinear translation. Elsewhere the Text is not inserted. The book is "an attempt to give to English readers some of the oldest romances, in English literary. forms, that seem to correspond to the literary forms which were used in Irish to produce the same effect." - (Pref.). The translation is partly in prose, partly in verse. The former is dignified and fully worthy of the subject, literal and yet in literary English. The verse does not seem to us to reach as high a level. It is very varied as to metre, yet the poetic spirit seems to be wanting.

N.B.-The theme of "The Courtship of Etain," though not coarse or prurient, is such as to render it unfit for the young.

LEAHY, Rev. Walter T.

898- COLUMBaNUS THE CELT. Pp. 455. (Philadeldhia: Kilner). 1.50. 1913.

The eventful career of the great St. Columbanus (D. 615) in the form of fiction. Father Leahy bases his story on the narrative of Jonas, a monk of Bobbio, who wrote the founder's life about the middle of the seventh century. But some of the incidents (notably the incipient love story) are unhistorical. The Author does little t') reproduce the colour and " atmosphere" of these distant times. He even falls into somewhat glaring anachronisms. Yet much is done to make the story interesting.

LEAMY, Edmund. B. Waterford, 1848, and educated there and at Tullabeg (Jesuit) College, 1861-3. Was for many years in Parliament as M.P. for Waterford and afterwards for Kildare. Was a kindly man and a delightful story-teller, beloved of children. He died in 1904.

899- IRISH FAIRY TALES. Pp. xix+155. [1889]. New ed. (Gill). 2s. 6d. With Introd. by Mr. John E. Redmond, M.P., and Note by T. P. G. Delightful Illustr. by George Fagan. Cr. 8vo. Handsome art linen binding. 1906. (N.Y.: Benziger). 0.90 .

Sources of inspiration: O'Curry and Joyce. Child audience aimed at throughout. Hence naïveté in style. At times there is a simple, sweet beauty of language, and some passages, especially in the last tale, of true prose poetry. Some useful notes at end.

900 - THE FAIRY MINSTREL OF GIENMALURE. Pp. 48. 4to. (Duffy).

1s. Cover design and many pretty illustrations by C. A. Mills.

Adventures of Irish children in an Irish fairyland of giants and little old men and little old women. Told in refined and graceful style, quite free from brogue, for very little children, with here and there an unobtrusive moral.

901- BY THE BARROW RIVER, and Other Stories. Pp. 281. (Sealy, Bryers). 3s. 6d. Portrait. 1907.

Twenty dramatic, exciting stories, including several good ghost stories, tales of the exploits of the Irish Brigade, of early Ireland, of tragedy, and of comedy. By. a capital story-teller. The book would make an excellent present or prize.

902_ GOLDEN SPEARS, and other Fairy Tales. (N.Y.: Fitzgerald). Cover design in colours by Corinne Turner. 1911.

This is a new American ed. of Irish Fairy Tales.

LEE, Aubrey. Au. of John Darker.

903_ A GENTLEMAN'S WIFE. Pp. 328. (Edinburgh : Morton). 6s. 1904.

Part I. tells how a peasant girl is, after a week's acquaintance, enticed from her home by a man who, it transpires, is already married. In Part II. their daughter, adopted by a saintly English clergyman, learns her parentage on the morrow of her engagement. She releases her betrothed; but a year afterwards marries a charming The lbook is witty, the plot well worked out, some of the characters most amusing;
the end unexpected. 
LEFANU, J. Sheridan. B. in Dublin, 1814. Ed. T.C.D. Was a grand-nephew of Richard Brinsley Sheridan. Contributed largely to Dubl. Univ. Magazine, of which he became ed. and owner, as well as of the Dublin Evening Packet and Evennng Marl. D. 1873. His chief power was in describing scenes of a mysterious or grotesque character, and in the manipulation of the weird and the supernaturial. Among his pen-names are "Charles de Cresseron" and "Hyacinth Con. Carolan." A full bibliography of his writings will be found in I.B.L., vol. 8, p. 30. This Author also wrote Uncle Silas, In a Glass Darkly, The Tenants of Malory, Willing to Die, The Rose and Key, The Evil Guest, The Room in the Dragon Volant, A Lost Name, Checkmate, The Watcher, Wylder's Hand, All in the Dark, Guy Deverel, Wyvern Mystery, \&c. Nearly all published by Downey \& Co. Messrs. Duffy publ. a set of eight of his novels at $3 s .6 d$. each.

904 THE COCK AND ANCHOR: A Tale of Old Dublin. Pp. $358 . \quad$ (Duff $y)$. 3s. 6d. [1845]. 1909. (Downey). 5s. c. 1896.

A dreadful story of the conspiracy of a number of preternaturally wicked and inhuman villains to ruin a young spendthrift baronet, and to compel his sister to marry one of themselves. The threads of the story are woven with considerable skill. The tale, a gloomy one throughout, reaches its climax in a scene of intense and concentrated excitement. The time is the Viceroyalty of the Earl of Wharton, the story ending in 1710, but, except for the incidental introduction in one scene of Addison, Swift, and the Viceroy himself, the events or personages of the time are not touched upon. There are some slight pictures of the life of the people of the period, but of Ireland there is nothing unless it be the talk of some comic Irish servants.

N.B.-The first ed. of The Cock and Anchor was anon. Republ., with alterations, under title Morley Court, 1873. Another ed., with original title and illustr. by Author's son, Brinsley Le Fanu, was publ. by Downey, 1895.

905- THE FORTUNES OF COL. TORLOGH O'BRIEN. Pp. 342. (Routledge). 3s. 6d. Twenty-two Plates by Phiz. [Anon.: 1847]. Several other eds. 1896, 1904, etc. (Downey). 7s. 6d. c. 1896.

Reckoned among the three or four best Irish historical novels. Main theme: the efforts of the hero, an officer in the Jacobite army, to regain possession of his estates in Tipperary, which are held by the Williamite, Sir Hugh Willoughby, whose daughter O'Brien loves. There are many minor plots and subordinate issues, among them the unscrupulous and nearly successful conspiracy against Sir Hugh. The history is not the main interest, but there is an account of the causes of Jacobite downfall, descriptions of James's Court at Dublin, and a fine description of Anghrim. There are excellent pictures of scenery, and some skilful though roughly drawn character sketches. The action closes shortly after the Treaty of Limerick.

\section{6 - THE HOUSE BY THE CHURCHYARD. (Duffy). 3s. 6d. [1863]. In print.}

"A sensational story with a mystery plot based on a murder. Black Dillon, a sinister and ingenious ruffian, is a grim figure of melodramatic stamp. The setting gives scenes of social life in a colony of officers and their families near Dublin." (Baker, 2). Chapelizod is the scene.

\section{7— THE PURCELL PAPERS. Three Vols. (Bentley). 1880.}

Short stories collected and ed. by Mr. A. P. Graves, with short memoir of the Author prefixed. For the most part they are either rollicking comic stories, told in broad brogue, or tales of mystery and terror in the vein of this Author's longer novels. Examples of the former are:- "Billy Malowney's taste of love and glory" and "The Quare Gander." These are not meant as "stage-Irish" ridicule, but as pure fun. Examples of the latter type:- "Plassages in the Secret History of an Irish Countess" and "A Chapter in the history of a Tyrone family." There are also pure adventure stories, such as:- "An Adventure of Hardress Fitzgerald, a Royalist Captain." All are admirably told. All but one are of Irish interest. They were originally contributed to the Dublin Univ. Magazine. 
LEFANU, J. Sheridan-(continued).

908_ A CHRONICLE OF GOLDEN FRIARS, and Other Stories. Pp. 329.

(Downey). 26 illustr. by Brinsley Le Fanu and John F. O'Hea. 1896.

The Chronicle, etc., is not Irish in subject. The "Other Stories" are: "Jim Sullivan's adventures in the great snow," "The last heir of Castle Connor," "Billy Malowney's taste of love and glory," "The ghost land the bone-setter," "The quare gander. See note to The Purcell Papers.

LENIHAN, D. M. B. 1858, near Newmarket, Co. Cork. Ed. locally. From early years has travelled in the drapery business for a Cork firm, but has done a great deal of literary work. Began as contributor to the CoRK Herald, a fighting Land League paper of the eighties. Has since contributed hundreds of short stories, nearly all Irish in subject, to various periodicals. Also special articles on a great variety of subjects, ballads, and serials. Among the latter are "The Great Experiment," "The Green Neck-tie," and "Ben the Rover". (humorous adventures of a commercial traveller).

909_ THE RED SPY: A Story of Land League Days. Pp. 236. (Duffy).

3s. 6d. n.d. (in print).

Appears to be largely autobiographical. A story of Land League days, full of incident. The interest chiefly turns on the interplay of plut and counterplot, in which the various parties - the moonlighters, the Castle, and Parnell's followersfigure. 'The centre of all the plots is McGowan, the "Red Spy," a secret service agent of the Castle. The scene shifts from America to Ireland-Dublin, Kildare, the Kerry border (good description), Lisdoonvarna. Types well studied-the genial landlord Col. O'Hara; the sporting squire Sir Thady Monroe; the weak-rninded oppressor Sir Richard A-; the American journalist, \&c. The "Red Spy" in real life was "Red Jim" McDermott.

LEPPER, John Heron. B. Belfast, 1878, son of A. J. Lepper, of Carrickfergus, and grandnephew of Samuel Neilson. Ed. in Scotland and at T.C.D., where he had a very distinguished career. Is a barrister on the N.E. Circuit, but has been living in London since 1914. His sympathies and views have for some years past been constantly tending in the direction of nationalism.

910_ CAPTAIN HARRY. (Sealy, Bryers). 6d. 1908.

"Tale of Parliamentary Wars, introducing the principal characters who took part on the Royalist and the Parliamentary sides."

\section{1— FRANK MAXWELL. (Sealy, Bryers). 6d. Paper.}

Adventures of an Irish Puritan planter's son, who by an unlucky series of accidents finds himself on the roylalist and Irish side just before the rebellion of 1641 . The central incident of the story is the journey of one Hugh O'Donnell to Glasgow, where he meets Charles secretly, and is returning as Viceroy when he is wrecked, and Frank Maxwell along with him, on the coast of Antrim. The Irish are, on the whole, represented as rather bloodthirsty and barbaric, especially "Hugh O'Donnell." A good "adventure" book.

912_ A TORY IN ARMS. Pp. 296. (Grant Richards). 1916.

A story of the North of Ireland in 1715 told in the first person by one Robert Brown of Carnmoney, a Williamite settler who tiakes to smuggling as a consequence of Walpole's excise laws. A double love story furnishes the plat, together with the adventures of Colonel O'Neill, a Jacobite agent, and those of the famous "Tory" (i.è., autlaw) Aeneas O'Haughan, locally known as Neeshy Hockon, traditions of whose wild exploits still linger in the district north of Belfast. There is abundance of stirring incident. Behind all this is a carefully historic and fair picture of the Ireland of the day-the pasition of the Catholics under the Penal Laws, their relations with their Protestant neighbours and so on. The characterization is particularly well done. 
LEPPER, John Heron-(continued).

913- THE NORTH-EAST CORNER. Pp. 496. (Grant Richards). 6s. n. 1917.

Belfast and neighbourhood in the early part of the 19th century. A more ambitious book than the preceding, and very different in its "manner" and scope. The fortunes of three families of planters who have turned merchants with the mercantile uprise of Belfast are followed out with deep and accurate knowledge of Ulster social and political history. The politioal atmosphere of the times is well rendered. There are careful character studies-the hero, an estimable personage, if somewhat dull, his "implacable old scoundrel of a father" who buys himself a peerage and his son a seat in Parliament, the Jacobin John Rolfe, James Rolfe the roué, and Sarah Owens.

914-THOSE WHO WENT WEST, and Other Stories. (Dublin: Kiersey). (In the Press).

A series of stories based on Irish history, from the days of St. Patrick to our own.

LESTER, Edward. Is credited in British Museum Catalogue with books entitled Comforting Words to a Repenting Sinner (1860), and Oneness With Christ.

915_ THE SIEGE OF BODIKE: A Prophecy of Ireland's Future. Pp. 140.

(LoNDON : Heywood). 1886.

A political skit written from a strongly Tory standpoint, in which the Author tells us how he would deal with the Irish question. The time is 188-, yet an imaginary Fenian rebellion is described. Kilkenny falls into the hands of the enemy, and a bomb is dropped from a balloon on Bodike, a village in Co. Kilkenny. The whole is wildly improbable, but it is probably meant to be so.

LETTS, Winifrid M. A granddaughter of Alexander Ferrier, Esq., of Knockmaroon Park, Co. Dublin, where she spent many summers. She resided in Blackrock, Co. Dublin. Ed. at St. Anne's, Abbots Bromley, and Alexandra College, Dublin. Has written Diana Dethroned, Christina's Son, The Rough Way (Wells, Gardner), short Irish stories for children in the MoNTH and other periodicals. She is coming to be very well known as a poet, and has written some plays for the Abbey Theatre.

916— THE MIGHTY ARMY. Pp. 128. (Wells, Gardner). 5s. net. Ill. by Stephen Reid. 1912.

Stories from the lives of the saints, including St. Columba.

LEVER, Charles. Born (1806) in Dublin, of English parentage; graduated at T.C.D. Wrote much for the National Magazine, the D.U. Magazine, Blackwood's, the Cornhill, \&c. Consul at Spezzia, 1858, and at Trieste, 1867. Here he died in 1872. Is by far the greatest of that group of writers who, by education and sympathies, are identified with the English element in Ireland. He was untouched by the Gaelic spirit, was a Tory in politics, and a Protestant. "His imagination," says Mr. Krans, " did not enable him to see with the eyes of the Catholic gentry or the peasantry. He knew only one class of peasants well-servants and retainers, and he only knew them on the side they turned out to their masters. Most of his peasants are more than half stage-Irishmen." $\mathrm{He}$ had no sympathy with the religious aspirations of Catholics, and his pictures of their religious life are sometimes offensive. These are his limitations. On the other hand, his books are invariably clean and fresh, free from vulgarity, morbidness, and mere sensationalism. His first four books overflow with animal spirits, reckless gaiety, and fun. It has been well remarked by his biographer, W. J. Fitzpatrick, that his genius was much more French than English. After Hinton he is more serious, more attentive to plot-weaving, and to careful character-drawing. His books give a wonderful 
LEVER, Charles-(continued).

series of pictures of Irish life from the days of Grattan's Parliament to the Famine of 1846. Many of these pictures, though true to certain aspects of Irish life, create a false impression by directing the eye almost exclusively to what is grotesque and whimsical. Lever's portrait gallery is one of the finest in fiction. It includes the dashing young soldiers of the earlier books; the comic characters, an endless series; diplomatists, doctors, lawyers, politicians, usurers, valetudinarians, aristocrats, typical Irish squires, adventurers, braggarts, spendthrifts, nearly all definite and convincing. See Art, in Blackwood, Apr., 1862, and in Dubl. Rev., 1872, Vol. 70, p. 379. Also Edmund Downey's book, Charles Lever : his Life and Letters. Many of Lever's novels were originally published in shilling monthly parts, with two illustrations by "Phiz" (Hablot K. Browne), and had as great a vogue as those of Dickens. There have been many editions since by Routledge (3s. 6d.) and Chapman \& Hall (2s.), with and without illustrations, but the finest ever issued is:-

917- COMPLETE NOVELS. Edited by the Novelist's Daughter. Thirty-seven

Vols. (Downey). Publ. $£ 19$ 18s. Cloth. 1897-9.

The only complete and uniform ed. of Lever. Contains all the original steel engravings and etchings by "Phiz" and Cruikshank, and many ill. by Luke Fildes and other artists. Ed. and annotated by means of unpublished memoranda found among Author's papers. Lever's prefaces are printed, and bibliographical notes appended to each story.

\section{8- HARRY LORREQUER. Pp. 380. (N.Y.: Dutton). 1.00. [1839].}

The first of Lever's rollicking military novels. The hero is a dashing young English officer, who comes to Cork with his regiment, and there passes through what the Author calls " a mass of incongruous adventures. Such was our life in Cork, dining, drinking, riding steeplechases, pigeon-shooting, and tandem-driving." The book abounds in humorous incidents, and is packed with good stories and anecdotes. All sorts of Irish characters are introduced. There are sketches of Catholic clerical life in a vein of burlesque. The latter part of the story takes the reader to the Continent (various parts of France and Germany), where we meet Arthur O'Leary, afterwards made the hero of another story. Mr. Baker describes the book well as "very Irish in the stagey sense, very unreal."

\section{9_ CHARLES O’MALLEY. Pp. 632, close print. (N.Y.: Putnam). 1.00.} [1841].

From electioneering, hunting, and duelling with the Galway country gentry, the scene changes to Trinity, where the hero goes in for roistering, larking, and general fast living with the wildest scamps in town. Then he gets a commission in the dragoons, and goes to the Peninsula (p. 147). There he goes through the whole campaign, and ends by viewing Waterloo from the French camp. Throughout, the narrative is enlivened by the raciest and spiciest stories. The native Irish, where they appear, are drawn in broad caricature. "Major Monsoon" was the portrait of a real personage, and so was the tomboy Miss "Baby Blake." "Mickey Free" is the best known of Lever's farcical Irish characters.

920_- JACK HINTON. Pp. 402. (Boston : Little, Brown). 5.00. [1843].

Adventures of a young English officer who arrives in Ireland during the Viceroyalty of the Duke of Grafton. The hero's Irish experiences include steeplechasing, fox-hunting, "high life" in Dublin, a glimpse of society life in the Castle, love, duelling, and murder. But Lever wrote the book to show how Irish character and Irish ways differed wholly from English, and he represents Hinton as constantly having his prejudiced English eyes opened with a vengeance. Contains some of Lever's most famous characters: Corny Delaney, Hinton's body servant; Mr. and Mrs. Paul Rooney, parvenu leaders of Dublin society; Father Tom Loftus, Lever's 
LEVER, Charles-(continued).

idea of the jolly Irish priest; Bob Mahon, the devil-may-care impecunious Irish gentleman; most of all Tipperiry Joe. "For these," says the Author (Pref.), "I had not to call upon imagination." For the last 100 pages the scene shifts to Spain, France, and Italy. Throughout, event succeeds event at reckless speed. There are some scenes of Connaught life, and a description of a meeting of "The Monks of the Screw."

921- TOM BURKE OF “OURS." Pp. 660. (N.Y.: Duttcn). [1844].

The early scenes (150 pp.) of Tom's life (told throughout in the first person) take place in Ireland. Lever tells us (Pref.) that he tried to make Tom intensely Irish before launching him into French lifo. Tom enlists, but in consequence of a quarrel with a fatal ending has to fly the country. He goes to France, then under the First Consul, and joins the army. Military, civil, and political life in Paris is described with great vividness and knowledge. These form a background to the exciting and dramatic adventures and love affairs of the hero. Then there is the Austerlitz campaign fully described; then life at Paris in 1806. Then the campaign of Jena. Finally, we have a description of the last campaign that ended with the abdication at Fontainebieau. The portrait of Napoleon is lifelike and convincing. A pathetic episode is the love of Minette, the Vivandière, for Tom, and her heroic death at the Bridge of Montereau. Darby the Blast is a character of the class of Mickey Free and Tipperary Joe, yet quite distinct and original. The scene near the close where Darby is in the witness-box is a companion picture to Sam Weller in court, and is one of the best things of its kind in fiction.

922-ARTHUR O'LEARY. Pp. 435. (N.Y.: Dutton). 1.00. [1844].

Rather a string of adventure stories than a novel. Lever has worked into it many of his own experiences in Canada, and also at Göttingen. There is a good deal about Student life in Germany. Many stories (of the Napoleonic wars chiefly) are told by the various characters all through the book. Some contemporary critics thought this the best of Lever's books.

923_ ST. PATRICK'S EVE. Pp. 203. (Chapman \& Hall). Illustr. by "Phiz." (N.Y.: Harper). [1845].

A short and somewhat gloomy tale of a period that Lever knew well-the pestilence of 1832. Scene: borders of Lough Corrib. The life described is that of the small farmer and the peasant struggling to make ends meet. Faction-fighting is dealt with in the opening of the tale, and the relations between landlord and agent and tenantry, at the period, are described with insight. "When I wrote it, I desired to inculcate the truth that prosperity has as many duties as adversity has sorrows." It is far the most national of Lever's stories, and there is a depth of feeling and of sympathy in it that would surprise those acquainted only with Charles O'Malley and Harry Lorrequer.

824 THE O'DONOGHUE. Pp. 369. (Routledge). [1845]. In print. (Duffy).

Scene: Glenflesk (between Mlacroom and Bantry) and Killarney. Period: from just before to just after the French expedition to Bantry. The O'Donoghue, poor and proud, is intended as a type of the decaying Catholic gentry of ancient lineage, living in a feudal, half-barbaric splendour, beset by creditors and bailiffs whom fear of the retainer's blunderbuss alone kept at a distance. Mark O'Donoghue, proud, gloomy, passionate, filled with hatred of the English invader, wears a frieze coat like the peasants, sells horses, hunts, and fishes for a livelihood. He joins the United Irishmen, who are represented as making an ignoble traffic of conspiracy, and takes part in Hoche's attempted invasion. Other characters are: Kate O'Donoghue, educated abroad; Lanty Lawler, horse-dealer, who supplies plenty of humour; in particular Sir Marmaduke Travers, a well-meaning but self-sufficient Englishman, who, knowing nothing of Ireland, makes ludicrous attempts to better his tenants' condition. "I was not sorry to show," says Lever (Pref.) , "that any real and effective good to Ireland must have its base in the confidence of the people." For this book Lever was bitterly accused of Repeal tendencies. 
LEVER, Charles-(continued).

925_ THE MARTINS OF CRO' MARTIN. Pp. 625. (N.Y.: Harper). 1856. [1847].

Scene chiefly Connemara, the novel opening with a fine picture of the old-time splendours of Ballynahinch Castle, the seat of the "Mantins." For awhile the. scene shifts to Paris during the Revolution of 1830 . Illustrates the practical working of the Emancipation Act. Mantin is a type of the ease-loving Irish land. lord, "shirking the cares of his estate, with an immense self-esteem, narrow, obstinate, weak, without ideas, and with a boundless faith in his own dignity, elegance, and divine right to rule his tenants" (Krans). Rejected by his tenantry at an election he quits the country in disgust, leaving them to the mercies of a Scotch agent. Lever pictures vividly the sufferings of the people both from this evil and from the cholera, drawing for the latter upon his own experience when ministering to cholera patients in Clare. He says of the people that " no words of his could do justice to the splendid heroism they showed each other in misfortune." Mary Martin is one of Lever's most admirable heroines. There is a fine study, also, of a young man of the people, son of a small shopkeeper in Oughterard, who, by his sterling worth, raises himself to the highest positions.

\section{6- The KNIGHT OF GWYNNE. (Philadelphia : Peterson). [1847].}

A close study, based on considerable knowledge, of the ways and means adopted by the English Government to destroy the Irish Parliament. Castlereagh figures in no flattering fashion. Con Heffernan is a type of his unscrupulous tools. The Knight himself is an engaging pontrait of a lovable old Irish gentleman, frank, high-spirited, courteous, chivalrous. At first placed in ideal circumstances for the the display of all his best qualities, he shows himself no less noble in meeting adversity. Other notable characters are Bagenal Daly (a portrait of Beauchamp Bagenal), the villainous attorney Hickman, and Mr. Dempsey, the story-telling innkeeper. In describing the coasts of Antrim and Derry and the country about Castlebar and Westport, Lever draws upon his own experiences.

\section{7- ROLAND CASHEL. Pp. 612. [1850]. (N.Y.: Harper). [1849].}

Opens with vivid and picturesque description of life in the Republic of Colombia. A harum-scarum young Irish soldier of fortune almost promises marriage to the daughter of a Colombian adventurer. Then he learns he is heir to a large property in Ireland, and he immediately returns there. In Dublin the diaughters of his lawyer, Mr. Kennyfeck, and others try to capture the young heir, but instead he falls in love with a penniless girl. Then there are exciting and romantic adventures. The villain, Tom Linton, with the intention of ruining Roland, introduces him to fast society, nearly implicates him with the young wife of Lord Kilgoff; the Colombian adventurer turns up to claim him; he is charged with murder; but eventually all is well. Lady Kilgoff is an admirably drawn character, as also is the Dean of Drumcondra, a portrait of Archbishop Whately. In the last chapter there is a plassage which seems to show how Lever realised that the anglicized society of the Pale is far from being the true Ireland. Incidentally, too, the evils of landlordism are touched upon.

928- THE DALTONS; or, Three Roads in Life. Pp. 700. (N.Y.: Pratt). 1.50. [1852].

The longest and most elaborate of Lever's novels. Subject: the careers of Peter Dalton, an iabsenteo Irish landlord-needy, feckless, selfish, Micawberish--and his children, on the Continent in Germany, Austria, and Italy. Some of the leading characters are involved in the Austro-Italian campaign of 1848, land in the Tuscan Revolution. There is a study - a flattering one-of Austrian military life, and lively, amusing pictures of Anglo-Italian life in Florence. A noteworthy character is the Irish Abbe d'Esmonde, who towards the close of the book takes part in some dramatic incidents during a visit to Ireland, undertaken in the cause of the Church. There is in the book a good deal about "priest-craft." 
LEVER, Charles-(continued).

929_- MAURICE TIERNAY. . (N.Y.: Harper). 1.00. [1852].

Adventures of a young Jacobite exile in many lands, 1793-1809. Opens with vivid description of "The Terror." Later Maurice joins the Army of the Rhine, anid then Humbert's expedition to Ireland. The latter is fully related, and also the capture and death of Wolfe Tone. After some adventures in America the hero returns to Europe, and is in Genoa during its siege by the Austrians. Taken prisoner by the latter, he escapes and joins Napoleon, of whose Austrian campaign a brilliant description is given. Napoleon and some of his great marshals loom large in the story, and the military life of the period on the Continent is described. But perhaps the best part of the book is the account of Humbert's invasion of Ireland.

\section{0- CON CREgaN. Pp. 496. (Philadelphra: Peterson). [1854].}

Lever describes his hero as the "Irish Gil Blas." Born on the borders of Meath, Cregan goes to Dublin, where he has some exciting experiences, ending in his being carried off in the yacht of an eccentric baronet. $\mathrm{He}$ is wrecked on an island off the coast of North America. Here he meets a runaway negro slave, Menelaus Crick, one of the most striking characters in the book. There follow experiences (tragic and comic) in Quebec, and afterwards in Texas and Mexico, life in which is described with remarkable vividness and wealth of colour. At last Cregan returns to Ireland, and marries a Spanish lady whom he had met in Mexico.

\section{1— SIR JASPER CAREW. Pp. 490. (N.Y.: Harper). [1855].}

The early part (152 pages) deals with the career of the hero's father, a wealthy Irish gentleman of Cromwellian stock, who his estates and copper and lead mines in Wicklow. He goes to Paris, allies himself by a secret marriage with the party of the Duke of Orleans, then returns to Ireland, where he kills a Castle official in a duel, receiving himself a mortal wound. His widow is deprived of the property, and left in poverty. She retires to Mayo with her son Jasper. In this part there are elaborate pictures of politics in the early days of the Irish Parliament, and of the wild, extravagant social life of the period. Jasper goes to France, is involved in revolutionary plots, is sent to London as secret agent, and there has interviews with Pitt and Fox. Finally he returns to Ireland to claim his birthright. The story is told in the first person, and Lever intended the narrative to reveal the intimate character of the teller. The book is crammed with adventure. It was a favourite with the Author.

\section{2_- THE FORTUNES OF GLENCORE. Pp. $395 . \quad$ (N.Y.: Pratt). 1.50 [1857].}

Intended (see Pref.) as an experiment to bear out (or the contrary) his conviction, that "any skill I possess lies in the delineation of character and the unravelment of that tangled skein that miakes up human motives." The scene at first is in a castle on the shores of the Killaries, between Mayo and Galway; afterwards it is on the Continent. Lord Glencore is a passionate, proud, soured man, misanthropical and suffering from disease. A scandal connected with his wife has filled him with hatred and bitterness. He determines to disown his son, who, after a terrible scene, runs away from home. The book is largely taken up with the adventures in Italy and elsewhere of Sir Horace Upton, a distinguished diplomatist and a valetudinarian, together with the doings and sayings of his follower, Billy Traynor, formerly poor scholar, hedge-schoolmaster, fiddler, journalist, now unqualified medical practitioner-a strange character driawn from a real personage. Many of the characters are cosmopolitan political intriguers. In the end Lady Glencore's innocence is established.

\section{3 - DAVEnPort DUNN. (Philadelphia : Peterson). 1859.}

The astonishing histories of two adventurers. Dunn is an ambitious, clever man who by shady means lifts himself into a high position as a financier and launches into immense financial schemes. This character was drawn from John Sadlier, Junior 


\section{LEVER, Charles-(continued).}

Lord of the Treasury, who was the associate of Judge Keogh in "The Pope's Brass Band," (so-called) and closed an extraordiniary career by committing suicide on Hampstead Heath. Grog Davis, a blackleg, rivals Dunn in another sphere, his sporting cheats being as vast las the other's financial swindles. Davis' highhearted daughter, Lizzie, is a finely-drawn character.

\section{4— ONE OF THEM. Pp. 420. (N.Y.: Harper). 0.50. (1861).}

Scene varies between Florence and the North of Ireland, many of the incidents described being real experiences of his own gone through in each of these places. Lever having been asked which of his novels he deemed best suited for the stage, replied that if a sensation drama were required, hei thought One of Them a good subject. Deals largely with the adventures on the Continent of a queer type of Irish M.P.; but its outstanding character is Quackinboss, a droll specimen of Yankee.

\section{5- BARRINGTON. (N.Y.: Pratt). 0.50. [1862].}

A novel of social and domestic life in the middle classes. Scene: a queer little inn, "the Fisherman's Home," on the banks of the Nore, Co. Kilkenny. Here the Barringtons live. Among the striking characters are the fire-eating Major $\mathrm{M}^{\prime}$ Cormack; Dr. Dill, an excellent study of a country medical man, and his lively daughter, Polly. The interest largely turns on the disgrace and subsequent vindication of Barrington's son, George. In this Lever portrays his own son and his career.

\section{6- A DAY'S RIDE. Pp. 396. (N.Y.: Pratt). 1.50. [1863].}

The whimsical adventures of Algernon Sydney Patts, only son of a Dublin apotheciary. An extravaganza in the vein of Don Quixote, and quite unlike Lever's other works. Potts's experiences begin in Ireland, but most of them take place on Continent.

\section{7- THE DODD FAMILY ABROAD. Pp. 565. (N.Y.: Pratt). 0.50. [1863-65].}

Humorous adventures on the Continent of an Anglo-Irish family filled with preposterously false ideas about the manners and customs of the countries they visit. Told in a series of letters in which the chief personages are made the unconscious exponents of their own characters, follies, and foibles, each character being so contrived as to evoke in the most humorous form the peculiarities of all the others. There are many acute reflections on Irish life, especially in the letters of Kenny Dodd to his friend in Bruff (Co. Limerick). Kenny Dodd is a careful and thoughtful character-study. The Author considered Kate Dodd to be the true type of Irishwoman. Biddy Cobb, servant of the Dodds, is one of Lever's most humorous women characters. Lever held that he had never written anything equal to "The Dodds."

\section{8- LUTTRELL of ARRAN. (N.Y. : Pratt). 1.50. [1865].}

Opens in Innishmore, Aran Islands, off the coast of Galway. Luttrell, a proud, morbid man of broken fortunes arrives there with his wife, the daughter of an Arran peasant. The latter dies, lelaving an only son, Harry. Shortly afterwards Sir Gervais Vyner, a wealthy Englishman, calls at the island in his yacht, and renews acquaintance with Luttrell. Vyner then goes to Donegal, where he meets with and adopts a beautiful peasant girl. The interest turns largely on the success of Vyner's experiment in making a fine lady out of the girl. She is one of Lever's most charming heroines. After many vicissitudes she comes to Innishmore. Here she meets Harry, who had returned from an adventurous career at sea, and they are married. Tom O'Rorke, who keeps an inn in a wild part of Donegal, provides a good deal of the humour. His inveterate hatred of everything. English, his wit and his audacity (not always commendable), mark him out for special mention. There is also an amusing American skipper. 


\section{LEVER, Charles-(continued).}

939— TONY BUTLER. (N.Y.: Pratt). 1.50. [1865].

Scene: partly in North of Ireland, partly on the Continent. Tony gets a post in the diplomatic service, and has many adventures, strange, humorous, or stirring. Diplomatic life (Lever was a British Consul abroad for many of his days) is described with a cunning hand. Some of Tony's experiences take place during the Garibaldian war. The most striking figure in the book is Major M'Caskey, the noisy, swaggering, impudent soldier of fortune. Skeff Damer, the young diplomat, is also interesting, and Dolly Stewart is a most pleasing study.

\section{0_- SIR BROOKE FOSBROOKE. [1866]. (Routledge, \&c.). 3.. 6d. (N.Y.:} Harper). 0.50 .

Reproduces much of the humour and frolic of his earlier tales, the mess-room scene in the officers' quarters in Duiblin, with which the drama opens, recalling the sprightly comedy of Harry Lorrequer. "The vigorous story that follows contains much more serious characterization and portraiture of real life than the earlier books."-(Baker).

\section{1— THE BRAMLEIGHS OF BISHOP'S FOILY. (N.Y.: Harper). 0.50. [1868].}

Scene of first portion: North of Ireland, near Coleraine, Co. Londonderry; afterwards Italy. Deals with the experiences of a rich English banker and his family, who come to Ireland, but the central figure is the selfish old peer, Viscount Culduff, a neighbouring landowner, on whose estate coal is found. Much of the novel deals with the exploiting of the Culduff mine. Tom Cutbill, a bluff, vulgar, humorous engineer, who comes to work this mine, provides most of the fun, which is scattered through the story. All the characters are vividly drawn, among others that of a young Irish Pratestant clergyman, the only one that appears prominently in Lever's pages. The mystery that runs through the book is kept veiled with great cleverness to the very end. Finally, the book is packed with witty epigram. matic talk.

\section{2— LORD KILGOBBIN * (N.Y.: Harper). 1.00. [1872].}

Lever's last novel. It pictures social and political conditions in Ireland about 1865 , the days of the Fenians. The book is marked by almost nationalist sympathies, one of the finest characters being Daniel Donogan, Fenian Head-Centre and Trinity College student, who while "on his keeping" is elected M.P. for King's County. Matthew Kearney, styled locally Lord Kilgobbin, is a shrewd, good-natured, oldfashioned type of broken-down Catholic gentility, living in an old castle in King's County. His daughter Kate is a high-spirited, clever, and amiable girl, but the real heroine is the brilliant Nina Kostalergi, of mixed parentage (the mother Irish, the father a Greek prince and adventurer), who bewitches in turn Fenians, soldiers, politicians, and Viceregal officials. A remarkable creation is Joe Atlee, a kind of Bohemian student of Trinity, cynical, indolent, but miraculously clever and versatile. It teems with witty talk and dramatic situations. Throughout there is food for thought about the affairs of Ireland. Has been illustr. by Luke Fildes (Macmillan) 3s. $6 d$.

\section{3_ GERALD FITZGERALD. (N.Y.: Harper). 0.40. [First ed. in book form, 1899].}

The hero is a legitimate son of the Young Pretender, offspring of a secret marriage with an Irish lady. Recounts his surprising adventures and his relations with Mirabeau (whose death is powerfully described), the poet Alfieri, Madame Roland, the Pretender himself, whose court at Rome is described, \&c., \&c. There is little humour, the book being a sober historical or quasi-historical romance. There are some passages offensive to Catholic feeling.

Lever also wrote:-A Rent in a Cloud; That Boy of Norcott's; Paul Goslett's Confessions; Nuts and Nutcrackers, 1845; Tales of the Trains, 1845; Horace Templeton, 1848; Cornelius O'Dowd, 1873. 


\section{LEVER, Charles-(continued).}

944-CON O'KELLY; the Smuggler's Story. Pp. 208. Large print. (Duffy). 1s. $6 d$. In print. n.d.

A reprint from Arthur O'Leary (q.v.). Supposed to be the hero's story told by himself to Arthur O'Leary in an inn near Antwerp. A series of adventures, comic for the most part. Childhood at Aunt Judy's in Tralee. Runs away to sea on a smuggling vessel. Is wrecked and becomes a strolling player, then a horse dealer, then a dragoon, goes to Canada, returns to Tralee. Finally enters French service. There is little but the bare narrative.

\section{LEWIS (Harriet).}

945_ LADY KILDARE. (N.Y.: Dillingham), 25 cents.

The author was a popular writer of serials and feuilletons some thirty or forty years ago. The hero is one Sir Patrick O'Rian.

\section{LINDSAY, S.}

946- SONS OF ULSTER. Pp. 112. (Stockwell). 1918.

"Tales of a religious type of an Ulster clergyman's experiences among Ulstermen going to the war." (T. LIT. SUPPL.).

\section{LIPSETT, Caldwell. Au. of A Frontier Officer.}

947- WHERE THE ATLANTIC MEETS THE LAND. Pp. 268 (Lane). 3s. $6 d$. net. 1896.

Sixteen stories, many of them artistically constructed, and told with literary grace and finish. The Irish character is viewed from an unsympathetic and, at times, hostile standpoint. Only a few of the stories deal with the peasants or have any special bearing on Irish life. Two or three deal with seduction in rather a light manner.

\section{LIPSETT, E. R., "A. Fremdling."}

948- FATHER CLANCY. Pp. 358. (Duckworth). 1904.

Father Clancy is an unselfish devoted country parish priest, beloved of his people; unworldly and simple to a fault. His virtue serves to throw into deeper shadow the character of his curate, Father O'Keeffe, who is an abandoned and vicious ruffian. The purpose of the book is not at all clear to the average reader.

949 DIDY. Pp. 301. (Duckworth). 6s. 1.30. Eight full-page Illustr. by Joseph Damon. 1912.

Published in U.S.A. by the John Lane Co., N.Y., under the title of The House of a Thousand Welcomes (price 1.50), this being the name of a boarding house in New York opened by Mr. and Mrs. Dunleary and their daughter Didy, who have emigrated from Cork. The story is chiefly concerned with the lodgers in this house - the eccentric Dr. O'Dowd, a journalist, and the son of a big landlord in Irelandall of whom fall in love with Didy. The last named, is successful, and he makes the journalist, a Protestant named Healy (the remainder of the personages are Catholics), editor of the principal Irish Unionist paper, which he owns, in order "to make it a message of peace to all Ireland." The author avoids religious or political bias, and tells a merry, good-humoured story.

\section{" LISTADO, J. T."}

950_ MAURICE RHYNHART. Two Vols. (Chapman \& Hall). 1871.

"Or, A few passages in the life of an Irish rebel." The hero, descended from a Williamite soldier, " in every respect the very model of a respectable young Protestant," is a clerk in Selskar (Wexford) and in love with Miss Rowan, socially much above him. An ardent young Irelander, he joins the local branch and works might and main for the movement. Soon he is " on his keeping," but escapes to London. There he marries Miss Rowan. After many hardships they go to 
"LISTADO, J. T."-(continued).

Australia, where he rises to be Premier and is knighted. Returns, and is made M.P. for Selskar. Reminds one of the career of Sir C. Gavan Duffy. Splendidly told, the interest never flagging. Protestant dissenting tea-parties hit off cleverly. The whole atmosphere of the critical summer of ' 48 is reproduced with vividness and fidelity. Dialogue good and characterisation life-like.

951_ CIVIL SERVICE. Two vols. (H. S. King). 1874.

The fortunes of the Haughton family, county magnates. Scene: Selskar (Wexford) and London. Central incidents are a three-cornered election struggle and the great trial for the Haughton estates which ends all happily. The condition of things in the Civil Service before the days of competitive examination is described in a satirical vein. Several carefully studied types of character are introduced, and the whole story is cleverly worked out.

LlOYD (J. A. F.). Author of The Three Destinies, Thè Lady of Kensington Gardens, \&c.

952__ "QUIS?” Pp. 327. (Stanley Paul). 6s. 1916.

The story of the careers of three men (former school-fellows) and of how, in the end, the great war came into their lives. One of the three is an Irishman, and for a time the scene is laid in Ireland-Cork. Apart from this there is little of Irish interest. The work of a cultured and clever writer, with a gift of psychological analysis. His view of Ireland is that of an unprejudiced Englishman.

952A- THE UPROOTERS. (Stanley Paul). 6s. n. 1918.

Period: 1913-6. Scene: partly in an Irish country house, the home of Major Elton, his wife, and his elderly maiden sisters, also in Paris and in Dublin. The main interest is provided by the various attractions or repulsions between the men and women of the story and the consequent working out of character. Two of the personages, the German-American millionaire capitalist and the artist Ormsby, $\operatorname{ar}_{\theta}$ involved in the Dublin Rebellion of 1916.-(T. LIT. SUPPL.).

\section{LOCHHEAD, A.}

953_- SPRIGS OF SHILlELAGH. Pp. 158. (Dundee: Leng). 1907. $6 d$.

Sixteen humorous sketches, "founded on fact-more or less," reprinted from the People's Friend, e.g., "A Pig in a Poke," "The Jolly O'Briens," "The Scaring of Scanlan," "An Irishman's Duel," and soforth.

LOGAN, J.

954- THE McCLUSKEY TWINS. Pp. 112. (Drane). 1s. 1912.

"These short chapters in the life of the inmates of a typical Ulster farmhouse - $\therefore . .2$ are founded on fact and personal observation." (Foreword). The trivial incidents that vary the monotony of a northern countryside-the procession on the Twelfth, Hallowe'en merrymaking, a visit to Belfast in which the troublesome twins figure largely-are well depicted. The dialect is well handled, but is so "strong" that the reader is grateful for the glossary provided.

\section{LOUGH, Desmond.}

955_ THE BLACK WING. ("Ireland's Own" Library). 6d. n.d. (1914). A story of secret societies and of revenge. Scene: Kerry and Corsica. Unconvincing, but unobjectionable.

956- RED RAPPAREE. Pp. 179. ("Ireland's Own" Library). 6d. n.d.

Thrilling adventures and hairbreadth escapes of Cahir Ronayne, who has taken to the road in revenge for his father's execution. A fair lady is involved, also a dissolute lord, and there are plenty of plots and counter plots, duels and combats. 


\section{LOUGHNAN, Edmond Brenan.}

\section{7_ THE FOSTER SISTERS. Three Vols. (Tinsley). 1871.}

Opens in Sligo, near Lough Arrow. Largely concerned with an intricate family history and mysteries of identity. Scene soon shifts to Paris, where many of the personages have gone and where most of the action takes place. The chief interest is a very melodramatic murder in the secret room of the Chat Noir, and the subsequent tracing of the crime to the murderer, a typical stage villain. The story is pretty well told, but the conversations are most artificial.

LOVER, Samuel. B. in Dublin, 1797. Was not only a novelist but a musician, a painter, and a song-writer (he wrote some 300 songs, and composed the music for many of them). He ed. the Dublin National Magazine and Saturday Magazine. D. 1868. See "Lives" by J. A. Symington and Bayle Bernard. "Lover," says Mr. D. J. O'Donoghue, " is first and last an Irish humourist." Readers should bear this fact in mind. His humour is of the gay, careless, rollicking type. He is sometimes coarse, but never merely dull. He does not caricature the Irish character, for his sympathies were strongly Irish; but wrote to amuse his readers, not to depict Irish life. He was often accused by his friends of exaggerating the virtues of his countrymen, and it may be admitted that he sometimes did so. "The chief defect of his novels," says Maurice Francis Egan, q.v., " is that they were written with an eye. on what the English reader would expect the Irish characters to do."

\section{8- RORY O'MORE. Pp. 452. (Constable). 3s. 6d. [1837. Bentley, 3 vols.] (N.Y.: Dutton). 1.C0. 1897.}

Introduction and notes by D. J. O'Donoghue, who considers this to be Lover's best long story. A tale of adventure in 179̆8, with a slight historical background. National in sentiment, without being unfairly biased. Contains some of Lover's best humour, especially the endless drollery and whimsicalities of the hero, Rory. Some of the types are very true to life. There are passages of genuine pathos. Tries to prove that the more heinous atrocities in ' 98 were due to a few desperadoes.

\section{9- HANDY ANDY. Pp. 460. (Constable). 3s. 6d. Portrait of Lover.} [1842]. 1898. Critical Introd. and Notes by D. J. O'Donoghue. (N.Y.: Dutton). 1.00 .

A series of side-splitting misadventures of a comic, blundering Irishman. Does not pretend to be a picture of real Irish life, yet, though exaggerated, it is not without truth. Besides Andy's adventures there are scenes from the life of the harum scarum gentry, uproarions dinners, a contested election, practical jokes. The characters, include peasants, duellists, hedge-priests, hedge-schoolmasters, beggars, and poteen distillers. There is a good deal of vulgarity.

960_ TREASURE TROVE; or, He Would be a Gentleman. Pp. 469. (Constable). 3s. 6d. [1844]. Many since. (Boston: Little, Brown). 1.00. 1899.

Critical introduction by D. J. O'Donoghue. Adventures of a somewhat stagey hero, Ned Corkery, with the Irish Brigade in the service of France and of the Young Pretender. Fontenoy, and the ' 45 in Scotland, are introduced. The novel, says the editor, can only be called pseudo-historical. The writer had but imperfectly mastered the history, and treats it unconvincingly. The humour is below the author's usual standard, but the interest is well sustained. It is coarseand vulgar in parts.

961 _ LEGENDS AND STORIES OF IRELAND. Two Vols. Pp. xix. +240, and xvi. +274 . (Constable). 3s. 6d. each. [1832 and 1834; many editions since]. 1899. (N.Y.: Sadlier). 1.50.

Introd. by the Author and by the ed., D. J. O'Donoghue. A miscellany consisting chiefly of humorous stories with regular plots. It contains also some old legends told in comic vein, yarns told by guides and boatmen, and several serious stories. There is nothing to offend Catholic feeling. There is a most sympathetic 
LOVER, Samuel-(continued).

sketch of a priest and a story about the secret of the confessional that any Catholic might have written. The peasantry are seen only from outside, though the Author mixed much among them. They are not caricatured, though chiefly comic types are selected. There is plenty of brogue, faithfully rendered on the whole. The first volume contains a humorous essay on Street Ballads, with specimens. Lover is at his best in uproariously laughable stories such as "The Gridirnn" and "Paddy the Sport."

962- FURTHER STORIES OF IRELAND. Pp. 220. (Constable). 3s. 6d. 1899. Critical and biographical introd. (pp. xxviii.) by D. J. O'Donoghue.

Chiefly very short, humorous sketches. Some are stories written around various national proverbs.

963 IRISH HEIRS: A Novel. Pp. 173. (N.Y.: Dick \& Fitzgerald). Illustr. 187-.

Mentioned in catal. of N. Y. Library. Treasure Trove bore on original titlepage the announcement that it was "the first of a series of accounts of Irish Heirs."

\section{LOVER and CROKER.}

964- LEGENDS AND TALES OF IRELAND. Pp. 436. (Simpkin, Marshall, \&c.). n.d. Now in print.

Contains:-Lover's Legends and Tales of Ireland (twenty-four in all), and Croker's Fairy Legends of the South of Ireland. "Croker and Lover," says W. B. Yeats, "full of the ideas of harum-scarum Irish gentility, saw everything humorised. The impulse of the Irish literature of their time came from a class that did not-mainly for political reasons-take the people seriously, and imagined the country as a humorist's Arcadia; its passion, its gloom, its tragedy they knew nothing of. What they did was not wholly false; they merely magnified an irresponsible type, found oftenest among boatmen, carmen, and gentlemen's servants, into the type of a whole nation, and created the Stage-Irishman.-(Introd. to Fairy and Folk-tales of the Irish Peasantry).

\section{LOWRY (Frank M.).}

965- THE DUBLIN STATUES "AT HOME": A Now Year's Tale. Pp. 32. 4to. (Sealy, Bryers). 1s. Six full-page illustr. by "Taman." [1900]. New ed. 1912.

A slight facetious sketch in which the principal statues in Dublin (Goldsmith, Burke, Grattan, O'Connell) are supposed to come to life on New Year's Day. The Author entertains them at his home. Speeches are made and so on. Some miscellaneous remarks on Irish politios, etc., are worked in.

LOWRY, Mary. Has also written The Clans of Ireland, Old Irish Laws and Customs, and The Story of Belfast.

966- THE ENCHANTED PORTAL. Pp. 142. (Sealy, Bryers). 6d. Paper. c. 1910.

Scene: Antrim coast, whose scenery is vividly pictured. A novel of romance, intrigue, and adventure, pleasant and healthy in tone, but fanciful and somewhat unreal.

LYALL, David.

967- AN ENGLISH ROSE. (Cassell). 1918.

A tale of the Great War. Cicely at the front meets Kane and Steering,two officers. The latter she marries on his deathbed. The former she afterwards meets and finds him a confirmed Sinn Feiner. She fails to convert him, and follows him to Dublin, where she arrives in the thick of the Rebellion of Easter, 1916. She saves his life, but both are wounded. On recovery they are married. $\mathrm{He}$ is converted and "joins up." It is " pleasantly written and with just the touch which will make it appeal to women."-(Press Notice). 
" LYALL, Edna"; Ada Ellen Bayley. Was born and educated at Brighton, and resided there and at Eastbourne. Her first story, Won by Waiting, appeared in 1879. Titles of 18 of her books are to be found in Mudie's Lrst.

968- DOREEN. Pp. 490. (Longmans). Various prices from 6d. to 68. [1894]. 1902. New ed. 1s. 6d. (Herbert Jenkins). 1917.

Doreen, daughter of an old ' 48 man and Fenian, and herself an ardent Nationalist, is a professtional singer, but helps the Home Rule cause by her singing. The chief interest is a love story, but in the background there is the national struggle, and a vivid picture is drawn of the feelings of those engaged on both sides. The Author is on the nationalist side, and the most striking figure in the book is Donal Moore, a Nationalist member. The first ed. was dedicated to Gladstone.

LYNAM, Col. William F. Belonged to the 5th Royal Lancashire Militia. Lived at Churchtown Ho., Dundrum, 1863-87, and then at Clontarf till his death in 1894. He was a Catholic and a man of much piety. He lived a very retired life.

\section{9-_MICK McQUAID.}

The serial or series of serials centring in the character of Mick McQuaid has made a record in literature. It began in the pages of the SHAmRock on Jan.19th, 1867. With short interruptions it has been running ever since in the pages of that periodical, and is running still, though the Author died in 1894. The following are some of the series that appeared:-1. "M. McQ.'s Conversion," 1867; 2. "M. McQ. the Evangeliser," 1868-9; 3. "M. McQ. Under Agent," 52 chapters, 1869-70; 4. "M. McQ., M.D.," 28 ch., 1872; 5. "M. McQ., M.P.," 51 ch., 1872-3; 6. "M. McQ., Solicitor," 43 ch., 1873-4; 7. "M. McQ.'s Spa," 91 ch., 1876-8; 8. “M. McQ., Alderman," 61 ch., 1879-80; 9. "M. McQ., Moneylendex," 47ch., 1880-1; 10. "M. McQ., Gombeen Man," 48 ch., 1881-2; 11. "M. McQ.'s Story," 1884; 12. "M. McQ., Workhouse Master," 1885; 13. "M. McQ., Sub-Sheriff," pt. 1, 47 ch., 1888-9; 14. “M. McQ., Sub-Sheriff," pt. 2, 1889; 15. "M. McQ., Stockbroker," 61 ch., 1889-90; 16 “M. McQ., Removable," 1890.

N.B.-Series 1, 2, and 3 were reprinted in a 4 to vol. of $568 \mathrm{pp}$. with illustr.

The Author himself tired of Mick McQuaid, and tried to put other creations in the field:-" Dan Donovan," " Corney Cluskey," "Japhet Screw," " Sir Timothy Mulligan," and so on. But after a few chapters the readers invariably demanded "Mick" again, and, if the Author had not new adventures ready, he had to reproduce the already published adventures. More than once editors tried to drop the series, but the circulation which was 60,000 fell at once, and "Mick" had to appear again. Apart from their issue in the SHAMrock many of "Mick's " adventures were reproduced in penny numbers, and sold far and wide. After the Author's death the editors simply reproduced the series over again. Harry Furniss began his artistic career by illustrating Mick McQuaid. Besides Mick McQ. another humorous series, Darby Durken, P.L.G., ran in the IrIsh Emerald.

\section{LYNCH, E. M.}

970-KILBOYLAN BANK; or, Every Man his own Banker. Pp. 240. (Kegan Paul). 3s. 6d. 1896.

Father O'Callaghan returning from Italy greatly impressed by what he has seen of the Raffeisen Banking System at work, tries to start a similar system in Kilboylan. The book is the story of his efforts, difficulties, and final success. The local typeslandlord, strong farmer, miller, publican, schoolmaster, "pote," and "chaney merchant" are cleverly hit off, and their conversation rings true. The book is primarily a lesson in economics, but the characters are well brought out, and a little love-story runs through the whole. Miss Lynch also wrote for Sir Charles Gavan Duffy's NEw IrISH Library a story adapted from the French-A Parish Providence. It was intended to teach certain economic lessons to Irishmen. 
LYNCH, Hannah. B. in Dublin. Lived much in Spain, in Greece, and in France, publishing various articles and books about them, notably a book on Toledo and French Life in Town and Country. Among her novels are Prince of the Glades (a story of Fenianism), Dr. Vermont's Fantasy, Daughters of Men, Jimmy Blake, Clare Monroe. She was associated with Miss Anna Parnell in the Ladies' Land League in the eighties. When UNITED Ireland was suppressed she carried the type to Paris, and the paper was issued there. Mrs. Hinkson says of her," "She was one of the few people I have known who eat, drink, and dream books, and not many can have given to literature a more passionate delight and devotion."

971— THROUGH TROUBLED WATERS. Pp. 460. (Ward, Lock). 1885.

Scene: chiefly Carantrila House, Dunmore ("Cardene"), near Tuam, Co. Galway. Opens with an impending lawsuit about the inheritance of "Cardene." It is settled by Mrs. St. Leger giving it up to her brother-in-law for a large sum. Henceforth she plots to get it back for her son. In later years he comes on a visit to the place. He falls in love with Nora Dillon, but carries on an innocent flirtation with a peasant girl. He is accused of seduction, the real culprit being Nora's brother, and denounced from the altar. This latter scene is well done. But the truth comes out, and all is well with Hartley and Nora. The portrait drawn of one of the two priests introduced is rather satirical, but the tone is Catholic throughout.

AUTOBIOGRAPHY OF A CHILD. Publ. Anon. Pp. 306. (Blackwood).

6s. 1899.

Clearly genuine autobiography. Begins in little village in Kildare, but at five or six the child is taken to Dublin. Story of an unhappy childhood, for she was treated with great harshness by sisters and mother. Had some friends, however, among them an old gentleman, who believed himself to be Hamlet, and O'Donovan Rossa, then a young lad. (See p. 75). Her unhappiness was continued at the convent school, near Birmingham, where she was educated. Everything is set down, including a flogging she received and an account of her first confession. A very curious book, very ably written. Appeared in BLACKwood's Magazine, vol. 164.

LYON, Capt. E. D. Late 68th Durham Light Infantry.

973-IRELAND'S DREAM : a Romance of the Future. Two Vols. (Sonnenschein). 1888.

A forecast of Ireland under Home Rule. Contains much about relations of Orangemen and Catholics, the National League, secret societies, emigration, and so on. Represents an Ireland hopelessly "gone to the dogs" - no security for life or property, murder rife, prosperity gone, \&c. Written in flippant style, betraying bitter contempt for Irish nationalism.

\section{LYSAGHT (MrS.)}

974 REX SINGLETON ; or, The Pathway of Life. Pp. 183. (Wells, Gardner, Darton). 2s. Six illustr. 2nd ed. 1894. 3rd, 1911.

The model Rex comes over to stay with his wild Irish cousins and sets them a good example. The writer loses. no opportunity of developing moral lessons. A book intended for boys. It is of the Sunday. School (Protestant) type. It ends happily with the return of Rex's parents, previously supposed drowned.

LYSAGHT, Sidney Royse. Eldest son of T. R. Lysaght, of Mintinna, Co. Cork. Has published three volumes of verse between 1886 and 1911 . Is an ironmaster in Bristol and very wealthy. Wrote also A Modern Ideal (1886), The Marplot, Horizons and Landmarks (1911), etc. The family mansion where his son the Poet, E. E. Lysaght, resides in Raheen Manor, Scariff, Co. Clare. 975
- HER MAJESTY'S REBELS.
Chsap ed., 1914.
Pp. 488. (Macmillan). 6s.
[1907].

In a prefatory note the Author tells us that though the career of his hero resembles that of Charles Stewart Parnell, Connor Desmond is not intended as a portrait of

* Reminiscences, p. 76-7. 


\section{LYSAGHT, Sidney Royse-(continued).}

Parnell. "There is an historical basis for the structure of the story-not for the persons." A political novel, written. mainly about the course of national life in Ireland, 1875-1891. The central figure most obviously reproduces the career and even the personal characteristics of Parnell, who is well and even sympathetically portrayed. The writer's view-point is free, on the whole, from party bias. He is convinced that a Royal residence in Ireland would be a sure antidote to seditious tendencies. There is a strong love interest. The Author depicts many scenes of Irish life among various classes. The hero is "involved in flagitious relations with several women." (Báker, 2).

LYTTLE, Wesley Guard; “ Robin.” B. 1844, at Newtownards, Co. Down. Was successively a junior reporter, a school teacher, a lecturer on Dr. Corry's Irish Diorama, a teacher of shorthand, an accountant, an editor. Started, in 1880, The North Down and Bangor Gazette, a strong Liberal and Home Rule paper. Afterwards owned and edited The North Down Herald. Died 1896.

\section{6- ROBIN'S READINGS. Eight Vols.}

Series of humorous stories, poems, and sketches in the dialect of a Co. Down farmer, of which he had a thorough mastery. Some verse as well as prose. The Author gave several thousand recitals in various parts of the three kingdoms. The success of the above books was immediate and remarkable. They have enjoyed great popularity ever since. The character of these readings may be seen frorn the following titles:-V. I. "Adventures of Paddy McQuillan, a simple country fellow" -" his trip tae Glesco "- " his courtships"- "his wee Paddy"- "his twins"" his tay perty." V. II. "The adventures of Robin Gordon "- "Peggy and how I courted her"- "Wee Wully" - "the fechtin' dugs" - "Robin on the ice "" dipplemassy." V. III. "Life in Ballycuddy, Co. Down "- " my brither Wully" -" kirk music" - "the General Assembly of 1879" (exciting scenes, Robin's oration) - " the royal visit to Ireland "- "the Ballycuddy Meinister" "-wee Paddy's bumps," \&c., \&c.

977 SONS OF THE SOD : a Tale of County Down. 1886.

(BANGor). 1s. Paper.

A racy story dealing with the peasantry of North Down which the Author knew well, and could depict admirably. The tale gives a picture of their merry-makings, courtships, humours, joys, and sorrows, wakes, weddings, evictions, \&c., \&c.

\section{8- BETSY GRAY. Pp. 116. (Bangor). 1s. 3d. [1888]. New ed.}

(Belfast : Carswell). Revised by F. J. Bigger. 1913.

Betsy Gray, the heroine (founded on a real personage) takes part in the rebellion, and fights at Ballynahinch. A story of thrilling interest. Relates events that preceded rebellion, dwelling much on the atrocities of the yeomanry, then describes in full the chief incidents of the rebellion. Introduces Wm. Steele Dickson, William Orr, H. Joy M'Cracken, Henry Munro, and Mick Maginn-the informer. "The Author has gone over every inch of the ground, and has hunted up old documents and old traditions indefatigably." In entire sympathy with rebels. There is a good deal of local dialect, and much local colour.

\section{9— THE SMUGGLERS OF STRANGFORD LOUGH.}

"A melodramatic romance of an old-fashioned type, founded on facts. What with murder, robbery, abduction, smuggling, secret societies, and underground caverns, the reader is carried breathlessly along from start to finish. The local dialect is well conveyed."-(I.B.L.). The headquarters of the smugglers was Killinchy, and the period of the story the end of the eighteenth century.

980 — DAFT EDDIE. Pp. 162. (BfLFast: Carswell). 6d. 1914.

A re-issue of The Smugglers of Strangford Lough. 
NOTE.-The following is the arrangement adopted for names beginning with $M$. All those commencing with Mac, Mc, or $\boldsymbol{M}^{\prime}$ are placed first, arranged alphabetically according to the first letter following Mac, $M c$, or $M$ '. Then begin other names commencing with $M$.

MACALISTER, R. A. Stewart, M.A., F.S.A. B. Dublin, 1870. At present Professor of Irish Archæology in the National University. Author of a series of learned works on Palestine exploration, the Philistines, Ecclesiastical Vestments, Irish Epigraphy and Archæology, \&c.

981- TWO IRISH ARTHURIAN ROMANCES. Pp. ix.+207. (Nutt, for Irish Texts Society). 10s. 6d. net. 1908.

Text and transl. on opposite pages. Contains two stories:-The Story of the Crop-eared Dog and The Story of Eagle-Boy. They are of the Wonder-voyage type. Arthur plays a secondary part. "The dreamland of gruagachs and monstrous nightmare shapes is here as typically a creation of Irish fancy as in any of the stories of the Finn cycle." . . "Eagle-Boy is a striking story, displaying .... no small constructive ingenuity and literary feeling."-(Introd.).

M'ANALLY, D. R., Jr.

982- IRISH WONDERS. Pp. 218. (Ward, Lock). Illustr. (pen and ink), H. R. Heaton. 1888.

"The ghosts, giants, pookas, demons, leprechawns, banshees, fairies, witches, widows, old maids, and other marvels of the Emerald Isle. Popular tales as told by the people. Collected during a recent lengthy visit, in the course of which every county in the island was traversed from end to end." - (Title-page and Pref.). Very broad brogue. Somewhat "Stage-Irish" in tone.

"MacARTHUR, Alexander"; Mrs. Nicchia, née Lily MacArthur. At present residing in New York.

983_- IRISH REBELS. Pp. 219. (Digby, Long). 3s. 6d. n.d. (1893).

"O'Donoghue," the hero, a young Catholic T.C.D. student, is deputed by the secret societies to shoot a landlord. He escapes at the time, and has a successful career at the bar, in Parliament, and also in love, for he marries the girl of his choice, a daughter of "Judge Kavanagh," a bitter Orangeman. But years afterwards his crime becomes known to some of his friends, and the discovery kills his wife. The Anthor is entirely favourable to the national cause. Parnell is mentioned several times. The central figure is not O'D., but "Lowry," a remarkable portrait, probably drawn from life.

M'AULIFFE, E. F. A Cork lady who died a few years ago at a rather advanced age.

984-GRACE O'DONNELL: A Tale of the 18th Cent. Pp. 220. (Cork: Guy \& Co.). 1891.

Ireland in Penal times, middle of 18th century (Fontenoy, 1745, is introduced). Period fairly well illustrated-sufferings of Catholics, tithe-proctors, hedge-schools, et.c. Scene varies between Gralway, Madrid, London, Dublin, and Paris. The characters all belong to the better class, and the tone of the story may be described as "genteel"; there is nothing specially national about it. Author wishes to show "how many claims each [Catholic and Protestant] has on the other for love and admiration." Some poems are included.

MacCA BE, William Bernard. B. in Dublin, 1801. Was a journalist for the greater part of his life, first in Dublin, then for fifteen years in London, and again in Dublin from 1852-57. Wrote many Catholic works. Died at Donnybrook, 1891.

985- AGNES ARNOLD. Three Vols. (Lond. : Nèwby). 1861.

A well constructed plot, with many fine dramatic scenes and much truthful character drawing. Shows the courses by which the people were driven into rebellion in 1798. The Author tells us that much of the materials were gleaned from his conversations in his boyhood with Wm. Putnam MacCabe, one of the insurgent leaders. Scene: Wexford. 
M'CALL, Patrick J. B. in Dublin, 1861, and ed. at Catholic University School, Leeson Street. Much better known as a poet by his Irish Noinins, Songs of Erin, Irish Fireside Songs, and Pulse of the Bards than as a prose writer. Resides in Patrick Street, Dublin.

\section{6- FENIAN NIGHTS' ENTERTAINMENTS. Pp. 132 . (Dublin: $T$. G.}

O'Donoghue). [1895].

Twe. e evenings of story-telling at a Wexford fireside. The stories are mostly Ossianic legends, but there are a few fairy tales. They purport to be told by a farmer with all the arts of the shanachie-the quaintness, the directness, the pithy sayings, the delightful digressions, and the gay humour. They are, of course, in dialect.

MacCARTAN, Hugh A. B. 1885, near Castlewellan, Co. Down, where he lived for eight years. Then removed to Belfast. Ed. there. Entered the Civil Service. Has been living in Dublin since 1905. Has been contributing for several years to various Irish periodicals verse and fiction, including some stories of Co. Down life publ. in the IRISH WeEkLy, Belfast (Christmas numbers). Publ. also Little White Roads and other poems. (Heath, Cranton:.

986A — SILHOUETTES; some character studies from North and South. Pp. 131.

(Dublin: Kiersey). Nov. 1918.

Twelve studies of personalities and places written in a vein of reverie. Several have a thread of narrative. All seem to be choses vues et vécues-transcripts from the Author's experience. The style is highly wrought and of rich literary flavour. Among the places are a village in Co. Down, a suburb of Belfast (since disappeared), and various Dublin localities. The characters studied correspond to these places.

M'CARTHY, Justin. B. in Cork, 1830, and ed. there. Began there his literary career of over sixty years. In 1853 he went to Liverpool, and thence to London in 1860. From that time till his death in 1912 he lived almost exclusively in England. But he never lost touch with Ireland. For many years he was a Nationalist M.P., and from 1890-96 was Chairman of the Party. His works number over forty, many of them dealing with Ireland-novels, history, biography, reminiscences, \&c.

987— A FAIR SAXON. Pp. 386. (Chatto \& Windus). 3s. 6d. [1873]; several since. New ed. about 1907.

Main theme: the love of an English girl for Maurice FitzHugh Tyrone, an Irish M.P., famous in the House as a clever and insuppressible opponent of the Government. Much of the story (a complicated one) is concerned with the efforts of another lover of the Fair Saxon to supplant Tyrone, and also to get him to violate the conditions of a legacy. The latter are (1) that Tyrone shall not marry beforo forty; (2) that he shall not join the Fenians; (3) that he shall not fight a duel. His efforts meet with a wonderful succession of alternate success and failure. Incidentally we have glimpses of Fenian plotting, the Fenian movement being portrayed with little sympathy. The characters are nearly all insipid or vicious worldlings, drawn in a satirical and sometimes cynical vein. Such is Mrs. Lorn, the rich American widow, of fast life. The heroine, and to a certain extent the hero, are exceptions. The precocious young American, Theodore, is one of the best. things in the book.

988- MAURICE TYRONE. (Benziger). 0.75. The American ed. of A Fair Saxon.

989--MONONIA. Pp. 383. (Chatto \& Windus). 6s. [1901]. New ed. (1902).

Scene: a large Munster town, presumably Cork. Time: the attempted rising in 1848. The chief interest is the unfolding in action of the various characters. Some of these are strikingly and distinctively portrayed. The treatment of the love element is original, the course of true love being smooth from the start. Here and there are pleasant bits of description. The standpoint is Catholic and nationalist, but without anti-English feeling, several of the principal and most admirable characters being English. A happy love story runs through the book. 
M'CARTHY, Justin Huntley. S. of preceding. B. 1860. Ed. University College School, London. Began writing 1881. Nationalist M.P. 1884-1892, during which period he was an ardent politician. Publ. England under Gladstone (1884), and in the same year a successful play, "The Candidate." Then followed Hours with Great Irishmen, Ireland since the Union, The Case for Home Rule, \&c., and a number of books, poems, tales, \&c., on Oriental subjects. His knowledge of our myth and legend has been described as comprehensive and exhaustive. He has publ. many other novels and plays and volumes of verse. But of late years the theatrical world has claimed him wholly.

990_ LILY LASS. Pp. 150. (Chatto \& Windus). 1s. 6d. 1889.

Picture from nationalist point of view of Young Ireland movement, especially in Cork. Full of sensational incidents, told with much verve.

991- THE ILLUSTRIOUS O'HAGAN. (Hurst \& Blackett). $1905 . \quad$ (N.Y.:
Harper). 1.50, \&c.

Melodramatic adventures of two cosmopolitan adventurers of Irish origin, in various parts of Europe and, in particular, among the courts of the petty German princes, where very fast living prevails. The picture we are given of these latter is frank enough. The colouring is brilliant, the style bright and swift. Copyrighted for the stage.

992_— THE O'FLYNN. Pp. 352. (Hurst \& Blackett). 1s. (N.Y.: Harper). 1.50. 1910.

O'Flynn is a swashbuckling, swaggering soldier of fortune, who has seen service in the Austrian army. The story tells of the varying fortunes of O'F. and of Lord Sedgemouth in their rivalry for the hand of the Lady Benedetta Mountmichael. Both suitors are in the service of King James, and the scene varies between Dublin Castle and Knockmore, a castle "in the heart of the Wicklow hills." Full of more or less burlesque plots and stratagems and surprises. Written in a pleasant but reckless and rattling style. Smacks strongly of the stage throughout, indeed it was originally a successful play before appearing in book form. Incidents not historical. Not for young people.

993- THE FAIR IRISH MAID. Pp. 344. (Hurst d Blackett). 6s. (N.Y.: Harper). 1.30. 1911.

Ireland a few years after the Union; but not political. $\mathrm{Mr} . \mathrm{M}^{\prime} \mathrm{C}$., in his usual vein of gay romanticism, takes his beautiful maiden from Kerry to London, where in the modish days of the Dandies she is for a time the reigning toast. But she is true to her Kerry lover, whom she finds in London lost and ruined, and whom she rescues and enables to produce his Irish play. Other characters are Lord Cloyne, the Irish ascendancy landlord, Mr. Rubie, the English M.P. who has come to visit and improve Ireland, and an antiquary who wants to buy a round tower and provides many amusing situations.-(Press Notices).

M'CARTHY, Michael J. F. B. Midleton, Co. Cork. Ed. Midleton College, Cork; T.C.D. After the appearance of Five Years in Ireland in 1901, "has written and spoken against the power exercised by the Roman Catholic Church in politics and in education. Started and conducted Christian Defence Effort in opposition to Home Rule, 1911-14." Author of Priests and People in Ireland, Rome in Ireland, \&c.-(Wно's Wно).

994_ GALLOWGLASS; or, Life in the Land of the Priests. Pp. 540. (Simplin, Marshall). 6s. 1904.

Purports to portray the social and political life of various classes in a typical South of Ireland town ("Gallowglass"). Written in a vein of bitter satire. Peasant, shopkeeper, politician, and especially priest, are held up to unmeasured scorn. Aspersions are cast upon Catholic teachings and practices. Eviction scenes, the workings of a secret society, political meetings, a scene in Parliament, serve the writer for his purpose in various ways. 
M'CHESNEY, Dora Greenwell. 1871-1912. An American writer. Au. of Miriam Cromwell, Royalist, Cornet Strong of Ireton's Horse. Yesterday's To-morrow, etc., etc.

995- KATHLEEN CLARE. Pp. 286. (Blackwood). Six illustr. by J. A. Shearman. 1895.

Story of Wentworth, Earl of Strafford's Viceroyalty in Ireland, told in form of diary purporting to be written by a kinswoman of Strafford's, who sees him in his home life and acquires extraordinary love and reverence for him. The tale of his execution is pathetically told. Quaint Elizabethan English. Pretty Elizabethan love songs interspersed.

\section{M'CLINTOCK, Lelitia.}

996 - A BOYCOTTED HOUSEHOLD. Pp. 319. (Smith, Elder). 1881.

Period, c. 1880. Mr. Hamilton is a model as a man and landlord. His family is in very reduced circumstances owing to " No Rent Campaign." Then we have various incidents of the land war-threatening letters, burning of hay, and finally the eldest son is brutally murdered by tenants on whom favours had been heaped. The beautiful home-life, sympathetic love affairs, \&c., of the Hamiltons are dwelt upon as pointing the contrast with the wickedness of the League, and the meaningless ingratitude of the peasantry. Sympathies of Author wholly with landlords. The Hamilton boys were all educated at Rugby, and the general outlook of the family is English. Scene: King's Co. and Donegal alternately.

\section{M'CLINTOCK, Major H. S.}

997_ RANDOM STORIES; chiefly Irish. Pp. 147. (Belfast: Marcus Ward). Illustr. n.d. c. 1885.

A collection of unobjectionable smoke-room yarns, more or less original, and more or less humorous. Illustr. somewhat crude.

\section{MCCORMACK, Rev. P. J.}

998- DENNIS HORGAN GENTLEMAN, and Other Sketches. (U.S.A.: De Wolfe \& Fishe Co.).

M'CRAITH, L.M. Mrs. L. M. M'Craith Blakeney, of Loughloher, Cahir, Co. Tipperary. B. 1870 . Ed. in Ireland and at Cheltenham. Has written also The Suir from its Source to the Sea, The Romance of Irish Heroines, The Romance of Irish Heroes, \&c. In these and other writings her aim has been to popularise Irish local history and antiquities in the hope of fostering a love of country, especially in the young.

999_ A GREEN TREE. Pp. 221. (Sealy, Bryers). 3s. 6d. 1908.

A pleasant family story with a sympathetically, though somewhat dimly-sketched, Irish background. All through there is the contrast between English and Irish ideals. One or two peculiar Irish types are well drawn.

\section{MäcDERMOTT, S.}

1000_ LEIGH OF LARA; a Novel of Co. Wicklow. (Gill?). 1s. 6d.

A slight but pleasant tale, told in straightforward manner, without characterstudy, scene-painting, problems, or politics. Deals with the false and-misunderstood position of a man who has been entrusted with the charge of his sister-in-law, while his brother is abroad " on his keeping," and the complications that arise from. this position. 
MacDERMOTT, W. R., "A. P. A. O'Gara." Son of a doctor in Co. Monaghan. Ed. at T.C.D. Was for long dispensary doctor at Poyntz Pass, Co. Armagh. Here he died in Aug., 1918, aged 80 years.

1001- THE GREEN REPUBLIC. A Visit to South Tyrone. Pp. 252. (Unwin). 6s. 1902.

The scene is "Jigglestreet." We are introduced to the various characters to be found in an Irish country village-the dispensary doctor, the Rev. Cinnamon, the "Count McQhan," all, no doubt, founded on real characters. The conversation relates largely to uplifiting of poor. Introd. and epilogue, two fine essays on the then condition of Ulster and the necessity for State purchase.

1002_ FOUGHULTRA: A Forbye Story. 1'p. 326. (Sealy, Bryers). c. 1906.

Sub-t.:-A memorial of the Ulster handloom weavers. A sociological study, in form of novel, of the history and development of a family. Scene: shore of Lough Neagh. Time: present day, though the family history goes back two hundred years. The forceful and pungent dialect in which it is writien is quite natural and true to life. An unusual and noteworthy book-interesting alike for its plot, its clever character-study and the thoughtfulness that pervades it. Has considerable humour, and nothing in the least objectionable.

MACDONAGH, Michael. B. Limerick, 1862. Ed. Christian Bros.' Schools. At twenty-two joined the staff of Freeman's Journal. From 1894 to the present has been on the staff of the Times. Lives in London. His father, Michael O'Doherty MacDonagh, was a Donegal man, a printer and poet. Has been writing about Ireland all his life in an immense variety of periodicals, and has published about a dozen books, many of them relating to Parliament.

1003— IRISH LIFE AND CHARACTER. Pp. 382. (Hodder \& Stoughton). 6s. Many editions, the 5th being in 1905.

Object: "To give a clear, full, and faithful picture of Irish life and character, illustrated by anecdotes and by my own experience during a twelve years connection with Irish journalism." "I have admitted into my collection only anecdotes that are truly genuine, really humorous, and certainly characteristic of the Irish people." "The face of Ireland as seen in these pages is always puckered with a smile." (Pref.). May be described as anecdotes, chiefly comic, classified and accompanied by a running commentary. Chapters: The Old Irish Squire; Duelling; Faction Fighting; Some Delusions about Ireland (e.g., "Stage-Irishman") ; Bulls; In the Law Courts; "Agin the Government" ; Irish Repartee and Sarcasm; Love-making in Ireland (its matter-of-factness, \&c.) ; Humours of Politics In and Out of Parliament; The Ulster Irishman; the Jarvey; The Beggar; Sunniness of Irish Life, \&c. It is to be observed that the laugh is often against the Irish throughout, and perhaps our national failings are rather more prominent here than our national virtues, the serious side of Irish life being scarcely touched on at all.

ModONNelL, Aneas. B. 1783, at Westport, Co. Mayo. Ed. Tuam and Maynooth (then a lay as well as an ecclesiastical college). He took a prominent part in the struggles of the Irish Catholics for emancipation at the outset of the 19th century, being a prominent supporter of O'Connell. Later on, after the date of this book, he became agent in London for the Irish Catholics. After emancipation he parted company with O'Connell and became strongly Conservative. D. 1858, at Laragh, near Maynooth, the residence of his sonin-law, N. J. Gannon, q.v.

1004 THE HERMIT OF GLENCONEILA. (LoND.). 1820.

"Written ... to illustrate the habits and character of the peasantry of Ireland, and the peculiarities of a remote portion of that interesting country." (Pref., dated Oct. 26, 1819. Rosbeg, near Westport). O'Mahony, who had been involved in the Desmond insurrection under Elizabeth, retires to a cottage near the Killaries, and opens a school. Subsequently he is restored to his family and to his 


\section{MODONNELL, Aneas-(continued).}

estates. The plot is very slight, and moves slowly through minor episodes and many reflections on the Irish peasantry (favourably viewed) and other matters. Grace O'Malley (Granuaile) makes a brief appearance in the story. Her visit to Elizabeth is described. Some descriptions of Galway and Mayo coast scenery. Style somewhat stiff anjd formal- "The virtuous matron proceeded to her pious mission." The story was reprinted in the Mayo News, 1913.

M'DONNELL, Randal William. B. in Dublin, 1870. Son of Randal M'Donnell, Q.C. Ed. Armagh Royal School. B.A., T.C.D. Was for a time assistant librarian in. Marsh's library. Is now a L.G.B. Inspector. Has published also three volumes of verse, and some books on engineering, a profession with which he was long connected.

1005- KATHLEEN MAVOURNEEN. Pp. 270. (Sealy, Bryers). 2s. Frontisp. [1898]. 3rd ed. (Gill). 1905.

Pictures first the cause and events that led to the rebellion, Tone's visit to America, his schemes, the French invasion. Then vivid description, of the outbreak in Wicklow, the fight at Tubberneering, the battle of new Ross, the capture and. death of Lord Edward Fitzgerald.

1006_ WHEN CROMWELL CAME TO DROGHEDA. Pp. 147. (Gill). 2s. 6d. Map of Drogheda and map of Ireland in time of Cromwell. (N.Y.: Benziger). 0.90 .1906$.

"Edited from the record of Clarence Stranger," an officer in the army of Owen Roe O'Neill. Covers principal events from Cromwell's landing to the Plantation, including defence of Clonmel.

1007- MY SWORD FOR PATRICK SARSFIELD. Pp. 201. (Gill). 3s. 6d. 1907.

Adventures of Phelim O'Hara (character well drawn), a colonel in Sarsfield's: horse, who witnesses siege of Derry, battle of the Boyne, two sieges of Limerick. Much history, varied by startling adventures.

1008- ARDNAREE. Pp. 227. (Gill). 1911.

"The story of an English girl in Connaught, told by herself." Mainly a record of social life (tea-parties, military balls, \&c.), with a good deal of fairly mild lovemaking. The '98 insurrection (landing of French at Killala, \&c.) forms a kind of background but is little spoken of. The Author hits off cleverly enough the outlook and language of a narrator such as the heroine.

\section{MacDOUGALL, Rev. J.}

1009 CRAIGNISH TALES, collected by. Notes on the War Dress of the Celts by Lorid A. Campbell. Pp. xvi.+98. (Nutt). 5s. 20 plates. 1889.

\section{0_ FOLK AND HERO TALES. Pp. xxx.+311. Demy 8vo. (Nutt).}

7s. 6d. net. Three Illustr. by E. Griset. 1891.

Introduction by A. Nutt deals with aims of study of folk-lore, and various theories of the origin of this latter, and the value of Celtic folk-lore.

Ten tales collected in district of Duror (Argyllshire) between Summer of 1889 and Spring of 1890, obtained from a labouring man named Cameron, who had them in his boyhood from Donald MacPhie and others. As folk-lore they are thoroughly reliable and genuine, the Gaelic text given after each story being written at the narrator's dictation with painstaking accuracy. The stories are typical folk-tales-a string of marvellous adventures of some hero with giants and enchanted castles and witches, \&c., \&c.-often grotesque and extravagant and devoid of moral or other significance beyond the mere narrative. . . . Free from coarseness. Finn is the hero in several of these tales. Good Index. $50 \mathrm{pp}$. of Notes, devoted chiefly to variant versions of the tales, explanations of terms and comparisons with other tales. 
MacDOUGALL, Rev. J.-(continued).

1010A — FOLK TALES AND FAIRY LORE, in Gaelic and English. (Glasgow : MacLaren). 68. $n$.

Collected from oral tradition by Rev. J. MacD., ed. with Introd. and Notes by Rev. Geo. Calder. Comprises 8 folk-tales and 57 fairy tales, classified under such headings as the Social Fairies, Solitaries, and the Water Sprites. Gaelic and English on opposite pages.

\section{M'DOWELL, Lalla.}

1011— THE EARL OF EFFINGHAM. Pp. 280. (Tinsley). 187\%.

Time: the forties, in Ballyquin, Co. Galway. It is a kind of appeal in story form to the Irish landlords to stay at home and "right Ireland's wrongs." The good points in the Irish character are well brought out, the brogue is well reproduced, and there is much humour. There are some glimpses of Dublin society. The bias is somewhat Protestant.

\section{MCDOWELL, Vincent Valentine.}

1012 _ THE KEEPSAKE. c. 1853.

\section{" MACEIRE, Fergus."}

1013 _ THE SONS OF EIRE. Three vols. (Lond.: Newby). 1872.

Author styles himself "The last of the Sons of Eire," an old broken-down Irish family living in Hampshire (Vol. II. brings them back to Ireland). A long autobiography, with a multitude of rather trifling incidents, much conversation, and a good deal of moralising. The portrait of the writer's mother is interesting and curious. The Author seems Catholic and Irish in sympathies. In the end the teller marries the betrothed of his brother Brian, the real hero, who has been killed in a skating accident.

MGGEE (T. D'Arcy), the '48 man, poet, and (later) Canadian statesman.

1014 EVA McDONALD; a tale of the United Irishmen and their times. 1844.

This is given as a separate work in O'Donoghue's Poets of Ireland. It was probably one of McGee's contributions to the Boston PiLOT, but does not seem to have appeared in vol. form.

MACGILL, Patrick. "The Navvy Poet." B. Glenties, Co. Donegal, 1891. Ed. at National school until he was twelve. At fourteen began to write verse for the Derry Journal. Soon after set out for Greenock with 10s. in his pocket. " Since then I have done all sorts of things, digging, draining, farming, and navvying." In 1912 was a plate-layer on the Caledonian Railway.-(I.B.L., III., p. 71). His poems are Songs of a Navvy, Gleanings from $a$ Navvy's Scrap Book, Songs of the Dead End and Soldier Songs. Is now a soldier in the London Irish Rifles, and has written a good account of military life in The Amateur Army, also several series of sketches from the firing line: The Red Horizon, The Brown Brethren, The Great Push. Of the last of these 25,000 copies were printed as a first ed., and all his books have had enormous sales. Some two years ago he married a niece of Cardinal Gibbons.

1015- CHILDREN OF THE DEAD END. Pp. 305. (Herbert Jenkins). 6s. 1914. Five or six eds. since.

"Most of my story is autobiographical."-(Foreword). It opens in the Glenties with a faithful picture of the people and their hard life. The scene then shifts to Scotland and depicts the toils and temptations that beset the men, and especially the girls, in their sordid and insanitary surroundings. The hero goes on tramp with "Moleskin Joe," a philosophic vagabond, finely described; and the shifts they are put to and the scenes they come through all bear the mark of truth, as does the wild life led by the navvies at Kinlochleven. The description of these scenes in a London newspaper led to his employment on the press. The hero's love for Norah Ryan is purely and touchingly delineated, and, save for one unhappy gibe at the P.P., thebook is unobjectionable. Within 15 days 10,000 copies were called for 
MACGILL, Patrick-(continued).

1016- THE RAT PIT. Pp. 308. (Jenkins). 1915. Four or five eds. since. The story of Norah Ryan, the heroine of The Children of the Dead End, from her childhood in Western Donegal to her death, a woman of the streets, in a Glasgow slum. A heartrending story from start to finish, with scarcely a gleam of cheer. The Author has exceptional powers of observation and gifts of description, and the book is extraordinarily realistic. But the realism and the sombreness being exclusive, the effect is exaggerated even to falseness. Father McKeown is impossibly villainous, the picture of the wake revolting because undiscerning, Norah's innocence overdrawn. Yet on the whole the Author's claim that it is a transcript from life, life seen and lived by him, is doubtless well sustained. There are several needless sneers at the priests, e.g., p. 286, which is wantonly unpleasant. The Author is not prurient, but he describes plainly and vividly scenes in Glasgow brothels. Good picture of the conditions of life of the Irish migratory labourers.

1017- GLENMORNAN; A Story of Donegal. Pp. 318. (Jenkins). 6s. n. 1918.

A "realistic" novel of life in a Donegal glen. Doalty Gallagher, after some years of absence as a journalist in London, comes back to his native glen to settle down. His attitude towards the P.P. causes him to bo denounced from the altar. $\mathrm{He}$ has to leave and joins the army. The local colour is laid on thickly. People represented in very unattractive light-superstitious, coarse, often sensual. Religion is treated contemptuously throughout. Moral tone low and highly suggestive in places. Description of a wake.

[M'GOVERN, Rev. J. B.] “J. B. S.” Of St. Stephen's Rectory, Chorlton-onMedlock, Manchester. An enthusiast for Irish archæology and a frequent contributor on his favourite subject to N. \& Q., Cork ARChaeol. Journal, the Antiquary, \&c.

1018- IMELDA, or Retribution: a Romance of Kilkee. (Tinsley). 7s. 6d 1883.

Scene: varies between Kilkee and Meenahela on the one hand and Italy on the other. The story is concerned with the faithlessness of Imelda Lestrange, an Irish girl, to her affianced Florentine lover, Gaspar Bicchieri, whom she had met at Kilkee, and the Nemesis that befalls her in the faithlessness of her now lover-and. husband-Monckton, who deserts her for his cousin, Teresa Dempsey. Most of this happens at Kilkee. The end is tragedy. Forty years later Gaspar returns to Kilkee to brood in the scene of the catastrophe of his life. There is little or no characterisation or study of motive. The story opens in 1829.

M'HENRY, James, M.D. B. Larne, Co. Antrim, 1785. Ed. Dublin and Glasgow. Iived 1817-1842 in U.S.A. From 1842 till his death in 1845 he was U.S. consul at Derry. Publ. several volumes of verse (Mr. O'Donoghue enumerates nine) and several novels besides those mentioned below.

1019_- THE INSURGENT CHIEF. Pp. 128, very close print. (Gill). Bound up with HEARTS OF STEEL. n.d.

Adventures of a young loyalist during the rebellion in the North, pleasantly told, but with improbabilities and a good deal of deus ex machina. Gives the very best description of the scenes in Belfast and Larne leading up to the Battle of Antrim and the consequent defeat of the "United men," many of whom were personally. known to the Author. The leaders are referred to by name, and the heroic death of Willy Neilson pathetically described. The famous rebel ballad of "Blaris Moor". is put into the mouth of a ballad singer in Belfast, and the northern dialect is excellently rendered.

The original title of this was O'Halloran; or, The Insurgent Chief, [1824], Philadelphia, three vols., and in same year London, one vol. Republ. frequently in Glasgow (Cameron \& Ferguson) and Belfast (Henderson). 


\section{M'HENRY, James, M.D.-(continued).}

1020_- THE HEARTS OF STEEL. (Gill). 6d. [1825]. Still in print.

A story full of sensational adventure. There is a good deal about the Oak Boys and Steel Boys, Ulster Protestant secret societies which indulged in agrarian outrages as a protest against various abuses. The writer praises the Presbyterian religion somewhat at the expense of the Catholic. Some of the incidents related are rather coarse. Includes legends of Carrickfergus, also a good deal of verse.

M'IlROY, Archibald. B. Ballyclare, Co. Antrim, 1860. Entered first the banking and then the insurance business. Took part in public life in his native county and in Co. Down. For the last three years of his life, which was ended in the Lusitania disaster, 1915, he lived in Canada.

1021 — THE AULD MEeTTN' HOOSE GReEN. Pp. 260. (Belfast: $M^{\prime}$ 'Caw, Stevenson \& Orr). 1898.

Stories of the Co. Antrim Peasantry. Time: thirty or forty years ago. Imitative of the "Kailyard" school in England. An intimate picture of Ulster Presbyterianism and its ways of thought. Has both humour and pathos. Is offensive to no creed or class. Ulster-Scot dialect true to life. Titles of some of the stories:- "Two Little Green Graves," "At Jesus' Feet," "The Old Precenter Crosses the Bar."

1022- WHEN LINT WAS IN THE BELL. (Unwin). 1898.

1023 - BY LONE CRAIG LINNIE BURN. Pp. 153. (Unwinj. 1900.

"Two series of local stories of the Scoto-Irish folk of Ulster, the chat of village gossips, character-sketches of doctor, minister, agent, and inn-keeper: quaint blends of Scottish and Irish traits. Most of the tales of idyllic kind." - (Baker). The reviewer in the IRISH Monthly says of the second of the above: "It is a wonderfully realistic picture of various grades of social life in a little country town in the North . . . giving amusing glimpses of the working of practical Presbyterian theology in the rustic middle class. . . Leaves on the reader a very remarkable impression of truthfulness and reality." In this second novel there is some humour and a good deal of pathos. The same remarks apply here as to The Auld Meetin' Hoose Green. Craiglinnie= Ballyclare.

\section{4-A BANKER'S LOVE STORY. Pp. 247. (Fisher Unwin). 1901.}

The story opens in "the Union Bank, Spindleton" (the Ulster Bank, Belfast), the various types of bank directors and clerks being cleverly described-the mischiefmaking Blake, the jolly Harry Burke, \&c. The scene shifts to "Craig Linnie" (Ballyclare), where George Dixon's love story begins. He is transferred to Ballinasloe (good description of the big fair). Through no fault of his own he comes under a cloud, but eventually matters clear up, and all ends happily. The Author knows his Ulster types thoroughly.

1025_ THE HUMOUR OF DRUID'S ISLAND. Pp. 127. (Hodges, Figgis; and Mullan, BeLfAST). 2s. 6d. 1902.

Scene: "Druid's Island" is Islandmagee, Co. Antrim. A series of very short anecdotes told to one another by the Presbyterian country people, in their peculiar Scoto-Irish dialect, and full of the dry, "pawky" humour of the North. Gives glimpses of the manners and life of the place.

1026- BURNSIDE. Pp. 104. (Belfast: McCaw, Stevenson, \& Orr). 1908. An old clergyman's stories of country life in Ulster in the fifties. 


\section{MACINNES, Rev. D.}

1027- FOLK AND HERO TALES. Collected, ed. (in Gaelic), and trans. by; with a Study on the Development of the Ossianic or Finn Saga, and copious Notes by Alfred Nutt. Pp. xxiv. +497. (Nutt). 15s. net. Portrait of Campbell of Islay and two Illustr. by E. Griset. 1890.

Gaelic and English throughout on opposite pages. The tales were taken down at intervals during 1881-2, chiefly from the dictation of A. MacTavish, a shoemaker of seventy-four, a native of Mull. The tales are typical folk-tales, full of giants, monsters, and other mythic and in ıgic loings. They are often quaint, imaginative, and picturesque, but abound in extravagance and absurdity. In Mr. Nutt's notes (pp. 443 to end) he studies chiefly-(1) What relation, if any, obtains between the folk-tales current in Scotland and the older Gaelic literature; (2) what traces of early Celtic belief and customs do these tales reveal. They are very elaborate and scholarly. Good Index.

M'INTOSH, Sophie. Born at Kinsale, where she resided for many years, until her marriage with H. S. M'Intosh, President of Methodist College, Belfast. In her sketches she describes faithfully and vividly the poople of her native town.(IRISH LIT.).

1028 THE LAST FORWARD, and Other Stories. Pp. 152. (Brimley Johnson). Five Illustr. by Jack B. Yeats. 1902.

Ten Irish school and football stories, with plenty of schoolboy language and slang, told in lively,stirring style, never dull.

\section{MCKAY, J. G.}

1029 THE WIZARD'S GILLIE; or, Gille A'Bhuidseir and Other Tales. Fd. and transl. by J. G. McKay. (St. Catherine's Press). 3s. 6d. 1915.

A selection from the MS. collection of the tales gathered by the late J. F. Campbell, of Islay (q.v.), and preserved in the Advocates' Library, Edinburgh. The Gaelic and the translation are given on opposite pages. Some of the titles are "Donald Caol Cameron," "The Carpenter MacPheigh," "The Sept of the Three Score Fools."

MACKAY, William. One of three brothers, all well-known London journalists. He was born in Belfast in 1846. Wrote also $A$ Mender of Nets (his last novel publ. about ten years ago), Beside Still Waters, and Unvarnished Tales. Was a son of the Rev. J. W. McKay (sic), D.D., President of the Methodist College, Belfast.

1029A- THE SIX LTTTLE BANNOCKS and other Short Gaelic Fairy Tales. (GLASGOW: MacLaren). Gaelic section 4d., English transl. $2 d$.

From the MS. collections of the late J. F. Campibell of Islay (q.v.). "Some of the actual legends that used to be told around Highland firesides on winter evenings long ago. Quaint, weird, wild, and racy of the hills."-(Publ.).

1030 - THE POP.ULAR IDOL. 2 vols. (Bentley). 21s. 1876.

Frank Edgehill, a young English artist, travelling to Ballymareen, Co. Cork, on a visit to his uncle Archibald McTlavish, "a Scotch settler," and a bigot, comes across Michael Eugene Murphy, the "Popular Idol," proprietor of the local "Eagle," which has its talons in McTavish and also in a neighbouring landlord, Fitzgerald. Frank falls in love with Kate Fitzgerald, but the real heroine is Murphy's handsome, impetuous daughter Norrah,, an original creation. McTavish is shot. M. is suspected, and on the advice of Fr. O'Brien, P.P. (and poet), goes in disguise to Dublin, where he mixes in Bohemian literary circles. His arrest, trial, and defence by Jacob Butler (Isaac Butt-la good pen portrait) are finely told. The love story ends happily. The Munster fisher-folk are described with sympathy and understanding. 
MACKAY, William-(continued).

1031- PRO PATRIA: the Autobiography of a Conspirator. Two Vols. (Remington). 1883.

Tho narrator, Ptolemy Daly, is a weak, conceited youth, given to hysterics and poetry. Full of visions of Robert Emmet, he joins the staff of "The Sumburst," the organ of an insurrectionary movement led by Phil. Gallagher, a fine character, evidently modelled on T. C. Luby. At the critical moment Daly plays the traitor and decamps to England. Isaac Butt and John Rea are introduced, under thinly disguised names. Scene: Dublin and Wicklow. Written in ironical vein: Daly's only "Speech from the Dock" was on a charge of drunk and disorderly.

MACKENZIE, Donald A., b. 1873, a folklorist and archæologist residing in Edinburgh. Author of a series of works on these subjects.

1032— FINN AND HIS WARRIOR BAND; or, Tales of old Alban. Pp. 248. (Blackie). 2s. 6d. 1910.

Stories, arranged in a connected series, of the Fenian cycle, adapted for children from twelve to fourteen or thereabouts. Told in picturesque language, but perfectly simple and direct. For the most part folk-lore, full of magic and wonder, nine-headed giants and fire-breathing dogs. But here and there the antique hero-tale appears, as in the Battle of Gavra and the death of Dermaid. Localities mostly Scotch. The illustrations ( 6 coloured, 34 in black and white) are charming in every way. Picture cover.

1033 WONDER TALES FROM SCOTTISH MYTH AND LEGEND. Demy 8vo. (Blackie). 6s. n. Illustr. by John Duncan, A.S.A. 1917.

Largely based on original research. Besides drawing from such collections as those of the 16th century Dean of Lismore, the Author has gone to the people themselves, and sets down stories heard in the evening ceilidhs in Scotland.

MACKENZIE, R. Shelton. The Author, b. in Co. Limerick, 1809, educated Cork and Fermoy, was a journalist in London, afterwards in New York, and wrote or edited many valuable works, historical and biographical. D. 1880.

1034- BITS OF BLARNEY. (N.Y.: Redfield). [1854]. (N.Y.: Alden). 1884.

"A series of Irish stories and legends collected from the peasantry," familiar to the Author in youth (see Pref.). It is a volume of miscellanies. Includes three stories of Blarney Castle told in serio-comic manner by a schoolmaster; some local legends of Finn McCool, \&c. ; eccentric characters (the bard O'Kelly, Father Prout, Irish dancing masters, Charley Crofts, Buck English); Irish publicists ; sketches of Grattan and O'Connell (the former enthusiastic, the latter not wholly favourableO'C. "the greatest professor of Blarney these latter days have seen or heard"). $\mathrm{He}$ speaks of $\mathrm{O}^{\prime} \mathrm{C}$. from personal knowledge. On the whole thoroughly nationalist in tone.

McKEON, James F., son of T. McKeon, of Anagharah, Co. Armagh. B. Borrisoleigh, 1858. Supervisor of Inland Revenue. Publ. many poems, some of which appeared in volume form.

1035- ORMOND IDYLLS. Pp. 144. (Nutt). 1s. Paper. 1901.

Scene: Co. Kilkenny. Eight little sketches of peasant life, pathetic and sad. In one a glimpse is given with knowledge and sympathy of the work of a country priest.

\section{MOKIM (Joseph).}

1036_ DARCY AND FRIENDS: An Irish Tale. Pp. 313. (F. V. White). 1881. How John Darcy, a young landowner in the West, is inveigled into a secret society by an artful schemer, Gaunt, the villain of the piece. How D. is obliged to take refuge in the $\mathrm{W}$. Indies, leaving his young wife, who dies shortly after. Returning to seek his daughter he falls ill and dies, oursing the secret society. One of the personages is a whiskey-drinking priest who belongs to the society. Written with Orange and anti-Catholic bias. Some good descriptions of Western scenery. 


\section{M'LENNAN, William.}

1037—_ SPANISH JOHN. Pp. 270. (Harper). 6s. Eighteen v. g. Illustr. by F. de Myrbach. 1898.

Adventures of Col. John McDonnell from the Highlands, when a lieutenant in the regiment of Irlandia, in the service of the $\mathbf{K}$. of Spain, operating in Italy (1744-6). At the Scots Callege in Rome, whither he had been sent to be made a priest, he had met a young student, a Mr. O'Rourke. This latter, now a chaplain in the Irish Brigade, saves McD's life on the field of Villetri. Subsequently the two are sent by the Duke of York to Scotland on a mission to Prince Charlie. They find that all is lost. Characters admirably drawn, notably the humorous, warmhearted, heroic Father O'Rourke.

[MACLEOD, - ].

1038- GERALDINE HAMILTON; or, Self-Guidance. 2v. 12mo. (Bentley). 1832.

The heroine, unhappy in her home at "Newtown Hamilton," falls in love with Major Stuart, an officer in a detachment sent to quell disturbances. She discovers he is married, but accompanies him to the Peninsula. After various happenings there and in England she finally marries him. Only the first part deals with Ireland, and that in no very distinctive way. The sufferings of the peasantry are mentioned sympathetically.

"MACLEOD, Fiona"; William Sharp. B. Paisley, 1856. Ed. Glasgow Univ. Spent his boyhood in the West Highlands and Islands and became imbued with love for things Celtic. D. 1905 . Even as late as 1899 it was positively stated that, in spite of conjectures to the contrary, William Sharp and Fiona Macleod were not the same person, and Mrs. Hinkson says in her Twenty-five Years' Reminiscences that she is not yet convinced that they were.

1039_ THE LAUGHTER OF PETERKIN. Pp. 288. (Constable). Four drawings by $\mathrm{S}$. Rollenson. 1897.

"A re-telling of old tales of the Celtic Wonder-World. Contains: "The Laughter of Peterkin'; 'the Four White Swans (Sons of Lir)'; 'the Fate of the Sons of Tuireann'; 'Darthool and the Sons of Usnach." 'Told in language of great beauty and simplicity.

1040_ SPIRITUAL TALES. (EDINB. : Geddes). 1897.

1041 — TRAGIC ROMANCES. (EDINB.: Geddes). 1897.

1042— BARBARIC TALES. (EDrnb.: Geddes). 1897.

1043_ THE DOMINION OF DREAMS. (Constable). 1899.

1044 THE SIN-EATER, and Other Tales. (Constable). 1899.

1045_ THE WASHER OF THE FORD, and Other Tales. (Constable). 1899.

1046_ The collected works written under the above pen-name (between 1894 and 1905). Ed. by his widow, and publ. by Heinemann in seven Vols., 5 s net each, viz.:-I. Pharais; The Mountain Lovers. II. The Sin Eater; The Washer of the Ford. Pp. 450. III. The Dominion of Dreams; Under the Dark Star. Pp. 438. IV. The Divine Adventure; Iona, \&c. V. The Winged Destiny. VI. The Silence of Amor; Where the Forest Murmurs. VII. Poems and Dramas.

Some titles of the stories in these vols.:- "Morag of the Glen," "The Dan-nar. Ron," "The Sin Eater," "The Flight of the Culdees," "The Harping of Cravetheen," "Silk o' the Kine," "Cathal of the Woods," " St. Bride of the Isles," "The Awakening of Angus Ogue," "Three Marvels of Iona," \&c. 


\section{"MACLEOD, Fiona"; William Sharp-(continued).}

These books of Fiona Macleod's are, for the most part, shadowy, elusive, dreampoems in prose, wrought into a form of beauty from fragments of old Gaelic tales heard in the Western isles (where the Author lived for years) from fishermen and crofters. They are full of the magic of words subtly woven, of vague mystery, and of nature-wind and sea and sky. He strives to infuse into his stories the sadder and more mystic aspects of the Gaelic spirit, as he conceives it. "I have not striven to depict the blither Irish Celt." But many of his stories are simply Irish legends, e.g., The Harping of Cravetheen. The Author thus describes his work: "In certain sections are tales of the old Gaelic and Celtic Scandinavian life and mythology; in others there is a blending of paganism and Christianity; in others again are tales of the dreaming imagination having their base in old mythology, or in a kindred mythopæic source. ... Many of these tales are of the grey wandering wave of the West, and through each goes the wind of the Gaelic spirit which turns to the dim enchantment of dreams." On the other hand some of these stories deal with life in modern Gaelic Scotland, e.g., The Mountain Lovers, which, however poetically told, is after all a tale of seduction. The Winged Destiny, amid much matter of a different nature, contains several tales of Gaelic inspiration.

\section{MACLEOD and THOMSON.}

1047- SONGS AND TALES OF ST. COLUMBA AND HIS AGE. By Fiona MacLeod and J. Arthur Thomson. Third edition. Large paper 4to. (EDINB.: Patrick Geddes). 6d. nett.

M'MAHON, Ella. Dau. of late Rev. J. H. MacMahon, Chaplain to the LordLieutenant. Ed. home. Has written much for various magazines and periodicals, and particularly on historical and archæological subjects. Has publ. about 17 novels. Now resides in Chelsea.-(WHo's Who). Au. of The Divine Folly, 1913; A Rich Man's Table, 1916, etc.

\section{8- FANCY O'BRIEN. (Chapman \& Hall). 6s. 1909.}

A tragedy of city life centring in the betrayal and desertion of Bridgie Doyle by Fancy O'Brien. Full of human interest, careful and skilful study of character and motive. Catholic in sympathy. "In its minor details the book is true to life, photographic in its realism." The story is of high dramatic and literary excellence. In the account of the Easter Monday excursion to Bray "the story of Bridgie's undoing is told with a rare combination of poetry, force, and restraint." - (N.I.R., Aug., 1909).

\section{9_ THE JOB. Pp. 383. (Nisbet). 6s. 1914.}

Sir Thady, a Cromwellian-Irish baronet, grows interested in his Irish surroundings on his estate of Ballymaclashin. He ceases to haunt the Bath Club, Piccadilly, and takes to starting carpet factories (The $J o b)$. Many of the incidents are furnished by the difficulties that beset the task owing to the amateurish innocence of the baronet and the stupidity of his local helpers. And besides there are the love affairs of Sir Thady and the English Miss Devereux. The point of view is AngloIrish, the "mere" Irish being regarded de haut en bas as rather impossible, thriftless, poor people, in short, as a problem to be dealt with philanthropically. The style is easy and pleasant.

MacmanUS, Miss L. Holds a distinct place among Irish authors of to-day as being one of the very few writers of Irish historical fiction who write from a thoroughly national standpoint. Her books are straightforward, stirring tales, enthusiastically Irish, free from itedious disquisitions, but based on considerable historical research. She is a worker in the ranks of the Gaelic League, and in her Co. Mayo (Kiltimagh) home does much for the cause of Irish Iroland. She is interested in folklore, and some of the tales she has collected have recently been publ. in the FolkLore Journal. Some of her stories in the 
MacMANUS, Miss L.-(continued).

Dublin weeklies deal in the weird and the mysterious. The following have been publ. by the Educational Co. of Ireland as penny pamphlets:-In the High King's Camp, A Battle Champion, Felim the Harper, The Prince of Breffny's Son, How Enda went to the Iceland, The Leathern Cloaks. Sho has publ. two serials in SINN FEIN : The Professor in Erin and One Generation Passeth. The former, an imaginative glimpse into the Ireland of the future, has just been issued in volume form.

1050_ THE SILK OF THE KINE. Pp. 282. (Fisher Unwin). 3s. 6d. (N.Y.:

Scene: chiefly Connaught and south-west Ulster during the Parliamentary Wars. The heroine is a daughter of the Maguire of Fermanagh. Her capture by the Roundhe'ads, her rescue from the mall-huntens by a Parliamentarian officer, her condemnation to slavery in St. Kitt's, and her escape, are told in vivid and thrilling style. It is a story for young readers especially:

\section{1— LALLY OF THE BRIGADE. (Duffy). 2s. 1s. (Boston : Page). 0.25.} 1899.

Adventures, during the War of the Spanish Succession, of a Colonel of the Brigade, who, after many thrilling experiences, distinguishes himself at Cremona, and marries a girl whom he had met during the war under romantic circumstances. The tale is lively and interesting, and makes one realise somewhat of the intrigues and dangers of war. . . . Young readers may derive a great deal of amusement and instruc. tion from the book.-(N.I.R.). Lally is a young captain in the regiment of Dillon. "James III." Louis XIV., Prince Eugene, Marshal Villeroy, and General O'Miahony all appear in the story.

1052_ NESSA. Pp. 147. (Sealy, Bryers). 2s. (N.Y.: Benziger). 0.60. n.d, 1904.

A tale of the Cromwellian Plantation, characterized by a simple unpretentious style and considerable power of description, both of character and scenery.-(Press Notices). The little book was highly praised by the ACADEMY and by the IRISH Times. It is, of course, strongly national in sentiment. Scene: an old castle near Lough Conn, Co. Mayo.

1053_- IN SARSFIELD'S DAYS. Pp. 306. (Gill). Illustr. 1907.

"A Passage from the Memoirs of Brigadier Niall MacGuinness of Iveagh, sometime captain in Sarsfield's Horse." Scene: Limerick during Siege. Includes account of Sarsfield's Ride and of the repulse of William's assault. The plot hinges on the disappearance of Balldearg O'Donnell's cross, which Iveagh is suspected of having stolen. The central figure is perhaps the wayward and imperious Ethna Ni Briain. The story moves rapidly, unencumbered by descriptions or digressions. The scenes are vivid and dramatic. The Author's play, "O'Donnell's Cross," is founded on this novel. Publ. in U.S.A. (N.Y.: Buckles), 1.50, under title The Wager.

1054 NUALA. Pp. 322. (Browne \& Nolan). 3s. 6d. Four Illustr. by Oswald Cunningham. 1908.

Tells how the only child, aged fifteen, of the head of the O'Donnells, then in the service of the Austrian Government, is entrusted by her father just before his death with the mission of obtaining the Cathach, or battle-book of the O'Donnells, from the monks at Louvain. On the way she passes through exciting adventures, being captured by some of Napoleon's soldiers. Gen. Hoche figures in the story. Juvenile. 
MacmanUS, Seumas. B. Mountcharles, Co. Donegal, 1870. Son of a peasant farmer. Was for some years a National School teacher, but subsequently turned entirely to journalism. Has written for most of the Irish papers and magazines and for many English and American periodicals. Is well known in the States, where he frequently goes on lecturing tours.

\section{5 - SHUILERS FROM HEATHY HILLS. Pp. 102. \\ (Mountcharles : G. Kirke). 1893.}

The Author's earliest poems and three prose sketches:- "Micky Maguire" (the last of the hedge schoolmasters), "How you bathe at Bundoran," and "A Trip with Phil M'Goldrick."

1056- THE LEADIN' ROAD TO DONEGAL. Pp. 246. (Digby, Long). 38. 6d. (N.Y.: Pratt). 2.00. [1896]. Second ed., 1908; others since.

Twelve short stories of the Donegal peasantry, full of very genuine, if somewhat broad, humour and drollery. They are not meant as pictures of peasant life. The dialect is exaggerated for humorous purposes, and at times the fun goes perilously near " Stage-Irishism." But they are never coarse or vulgar.

1057_ 'TWAS IN DHROLL DONEGAL. [1896, Downey]. (Gill). 1s. Third ed., 1897.

Eight tales dealing with the humorous side of the home-life of Donegal peasants. A few, however, are folk-tales of the Jack the Giant-killer type. Told with verve and piquancy and with unflagging humour, but the skill in story-telling is naturally not as developed in this as in the Author's later work, employing humorous padding to aid the intrinsic humour of the incidents.

\section{8- THE BEND OF THE ROAD. (Gill, Duffy). 2s., 3.s. (N.Y.: Pratt). 1.75. [1897].}

This is a sequel to A Lad of the O'Friels, ${ }^{*}$ but consists of detached sketches, and is not told in the first person. Most of the sketches are liumorous, notably "Father Dan and Fiddlers Four"; but there is pathos, too, as in "The Widow's Mary," a scene at a wake before an eviction. The introduction is an admirable summing up of the peculiarities, emotions, and vicissitudes of life in an out-of-theway Donegal countryside.

Seven stories admirably told, and full of the richest and most rollicking humour. In the first only, viz., "When Barney's Thrunk Comes Home," is there a touch of the pathetic. It would be hard to beat "Shan Martin's Ghost," and "Why Tómas Dubh Walked," and "How Paddy M'Garrity did not get to be Gauger." "One St. Patrick's Day " gives the humorous side of Orange and Green rivalry.

1060 THROUGH THE TURF SMOKE. Pp. 174. 12mo. (Fisher Unwin). 2s. (N.Y.: Doubleday. Tononto: Morang). 2.00. [1899]. 1901.

Simple tales of the Donegal peasantry. There is both pathos and humour-the former deep, and at times poignant; the latter always rich and often farcical. The Author writes with all the vividness of one who has lived all he writes about. $\mathrm{He}$ has full command of every device of the story-teller, yet never allows his personality to show except, as it should, through the medium of the actors. Mostly in dialect. Contains "The Bewitched Fiddle," "Patrick's Proxy," "When Myles Maguire Melted," "The Boyne Waters," etc.

* Yet seems to have been publ. before it. I give the dates as they are given (doubtless by the Author) in the Literary Year Book. 
MacMANUS, Seumas-(continued).

1061_- IN CHIMNEY CORNERS. Pp. 281. (N.Y. : Harper). Illustr. by Pamela Colman Smith. 1899.

"Subtle, merry tales of Irish Folk-lore."-(Pref.). The stories are very similar in kind to the same Author's Donegal Fairy Tales. There is the same quaint, humorous, peasant language, the same extravagances and impossibilities. The illustrations are very numerous. They are very brightly coloured, but for the most part extremely bizarre.

1062-THE BEWITCHED FIDDLE, and Other Irish Tales. Pp. ix. +240 . (N.Y. : Doubleday and McClure). 1900.

Ten short stories, humorous for the most part, but one, "The Oadger Boy's Last Journey," moving and pathetic. They are an exact reproduction in dialect and phraseology of stories actually heard by the Author at Donegal firesides, and the fidelity of the reproduction is perfect.

\section{DONEGAL FAIRY STORIES. Pp. 255. (Isbister). 1902. (N.Y.: Mcllure).}

Dedication in Irish and English. Thirty-four full-page pen and ink drawings, signed "Verbeek." These latter are quaint and amusingly grotesque. The stories are folk-tales, told just as the peasantry tell them, without brogue, but with all the repetitions, humorous extravagances and naïveté of the folk-tale. They are just the thing for children, and are quite free from coarseness and vulgarity.

\section{THE RED POOCHER. Pp. 130. (N.Y.: Funk \& Wagnalls). 75c.} Frontisp. 1903.

Four stories in which the R.P., a mysterious personage with the brazen audacity of Arsène Lupin, is the central figure. Told in dialect by a gamekeeper. Much quiet humour in the stories and in the manner of their telling. Scene: Donegal.

1065- A LAD OF THE O'FRIELS. Pp. 318. (Gill; Duffy). 2s., 2s. 6d., 3s. (N.Y.: McClure). 1.50. [1903]. Third ed., 1906.

In this book one actually seems to have been living among the childlike and quaint yet deep-natured, true, and altogether lovable little circle of Knocknagar, and to have shared its joys and sorrows. Every character described stands out altogether distinct, old Toal a'Gallagher the sententious; his wife, Susie of the sharp tongue; their son, Taal the "Vagabone," with his wild pranks; the grandiloquent "Masther," and all the rest. Through it all runs the simple love story of Dinny O'Friel and Nuala Gildea, companions from childhood. The book is full of deep, but quiet and restrained, feeling. The description of the pilgrimage to Lough Derg has much beauty.

1066- DOCTOR KILGANNON. (Gill). 1s. (Wrapper). Well illustr. 1907.

A string of loosely-connected after-dinner stories chiefly about comic duelling and electioneering. Told with pleasant drollery.

1067- YOURSELF AND THE NEIGHBOURS. Pp. 304. (N.Y.: Devin Adair Co.). Five Illustr. by T. Fogarty. 1914.

A picture by one who has lived it of the life of the Donegal peasant-not their outward life merely, but their most intimate thoughts and beliefs, hopes and joys, their whole outlook on things. The Author is discerning and sympathetic in a high degree. Yourself and Herself gives a Donegal man's life story from "the barefoot time " through love and marriage to "evening's quiet end." Some of the remaining stories show the Author's humour at its best-the Homeric struggles of the "priest's boy" with the Now Curate and the 'Tartar of a postmistress, the "come home Ylankee," and so on. 


\section{M'NALLY, Mrs.*}

1068- ECCENTRICITY. Three Vols. (over 1,000 pp.). (Dubl.: C'umming).

An endless series of love affairs between charming ladies and wealthy gentlemen, all of the upper classes, very proper, very stilted, and dull. The eccentricity is on the part of an old soldier who is a misanthrope and a hermit, but resolves to return to normal life and renew acquaintance with his danghter. $\mathrm{He}$ descends upon the friend's family in which he has left her, carries off another by mistake, \&c. The plot never really moves on.

\section{M'NALLY, Louisa.}

1069 - THE PIRATE'S FORT. Pp. 210. (Hodges \& Smith). 1854.

The fort is Dunalong, on Inisherkin, in Baltimore Bay, a stronghold of the O'Driscolls towards close of 16 th cent. English ship captured. O'D.'s natural son, a ferocious pirate, falls in love with captain's daughter. She is true to her English officer. The beautiful daughter of O'D. saves her from his fury. Vengeance of the English: destruction of the fort: double wedding of the two fair maids to two English officers. A prominent rôle is assigned to a money-grabbing, idle, besotted Franciscan friar.

\section{MACNAMARA, Brinsley.}

1070 THE VALLEY OF THE SQUINTING WINDOWS. Pp. 212 . (Maunsel). 5s. n. 1918.

\section{MACNAMARA, Lewis.}

1071- BLIND LARRY: Irish Idylls. (Jarrold). 3s. 6d. 1897.

"Artless records of life among the very poor in West of Ireland, the fruit of kindly observation, and, obviously, essays in the Thrums style. Larry is a poor blind fiddler, whose one joy in life is his son, and he turns out a reproach to his father. "Katty's Wedding" is a very Irish bit of farce, and "Mulligan's Revenge" expresses the vindictive passions of the Celt, an episode of jealousy and crime, alleviated at the close by repentance and reconciliation."-(Baker).

MACNAMARA, Rachael Swete. B. in Enmis, Co. Clare, but resided until five years ago in Cork, her father being manager of the Munster and Leinster Bank there. Ed. in Cork. Has travelled much abroad. Now resides in London. Publ. some nine novels. In most of these, notably in The Fringe of the Desert and A Marriage has been Arranged, there are Irish characters, but only the following deals expressly with Ireland. A novel which she hopes to publish next spring has Irish scenes. Au. of many poems, some of which have appeared in volume form.

1072 - SPINNERS IN SILENCE. Pp. 317. (Blackwood). 6s. 1911.

Fingal and Lutie are lovers somewhere in the wilds of Ireland. Enter's an Interloper (a danseuse of doubtful repultation), who falls genuinely in love with $\mathrm{F}$., and tries to win him. She fails, and exit. The atmosphere is very ideal and the language, especially the conversations, somewhat high-flown. Author writes well, and is clearly sympathetic to Ireland. The housekeeper cousin of " county family" status, with her genteel notions, is well sketched.

* So the name is given on the title-page, and it seems improbable that this Author is the same as the Author of the following item, first because there is a difference of thirty-four years between the dates, and secondly becanse the two books are wholly unlike. But the B. Museum Catal. assigns both to the same person. 
M'NULTY, Edward. B. 1856, Randalstown, Co. Antrim. Ed. in the Incorporated Society's School, Aungier St., Dublin, where he was a schoolmate and intimate of G. B. Shaw. Contributes to various periodicals-Irish Society, The Occult REview, \&c., and has written a play, "The Lord Mayor," for the Abbey Theatre. Satirizes Irish failings, but is proud of being an Irishman himself. Resides in Ranelagh, Dublin.

1073- MISTHER O'RYAN. Pp. 271. (Arnold). 3s. 6d. 1894.

A priest, squat, red-faced, whiskey-loving, unspeakably vulgar, and a ruffian to whom he is disgracefully related, organise a branch of the "Lague," and boycott a farmer who will not join. The latter's daughter dies tragically in consequence. The typical "pesint" is introduced as cringing, priest-ridden, and wholly degraded. Impossible brogue throughout.

\section{4 - SON OF A PEASANT. Pp. 342. (Arnold). 1897.}

A great advance on Misther O'Ryan, q.v. A tragi-comedy of life among lower middle class people in a small provincial town. The "son of a peasant" is Clarence Maguire, an obscure young schoolmaster, who in the end comes in for great wealth and all but wins the daughter of Sir Herbert O'Hara, an impoverished gentleman. A sub-plot is furnished by the love affairs of Constable Kerrigan and his determined efforts after promotion. The plot affords the Author scope for many genuinely humorous scenes, especially those in the Flanagan family, which are admirably done, and for the clever portrayal of some of the meaner aspects of human nature-class pride, servility, the worship of the moneyed man, time serving, \&c. The plot largely turns on ian absurd superstition about changelings. This leads to the hideous tragedy of the close. The book is marred by a travesty of the brogue. Otherwise it is not anti-national.

1075-MAUREEN. Pp. 343. (Atrnold). 6s. 1904.

Of the same type as Misther O'Ryan. One of the priests introduced trades with a miraculous statue on the superstition of the people; the other is a sleek, smooth fop, thoroughly and heartlessly vicious. There is little else besides this in the book.

1076 - MRS. MUILIGAN'S MILLIONS. (Hurst \& Blackett). 6s. 1908.

A broad farce, with Irish people (of the worst stage-Irish type) as actors, and a small, vulgar Irish town for scene. Mrs. Mulligan is a very low species of tramp. She is supposed suddenly to come in for a fortune, and her relations tumble over one another in efforts to gain her favour-until the bubble bursts. There is much caricature of Irish traits and mamners. Local journa:ism is specially ridiculed.(News cuttings).

MacSORLEY, Catherine Mary. Author of Harold's Mother, The Old House, Nora, \&c.

1077- THE ROAD THROUGH THE BOG. Pp. 128. (S.P.C.K.). 1s. 9d. n. One illustr. in colour. 1918.

A little domestic story of a girl, condemned to bo companion to a wayward and irritable old lady in Dublin, but set free in an unlooked-for manner to marry the man of her choice and settle in his country home of Lisgarva. Unaffectedly told, with real feeling and unobtrusive lessons of kindness and unselfishness. No trace of sectarian and political bias. Mrs. Moriarty is the only really Irish personage.

M'SPARRAN, Archibald. (1795-1850?) was' a school-master in Derry, who emigrated to America in 1830, where he published Tales and Stories of the Alleghenys and The Hermit of the Rocky Mountains.

1078 - THE LEGEND OF M'DONNELL AND THE NORMAN DE BORGOS. Pp. 213, close print. 16mo. (Gill). 1s. [BeLfast, 1829]. Still in print.

A tale of the struggles between O'Neills, O'Donnells, O'Cahans, M'Quillans, $M^{`}$ Donnells, and other Ulster septs. Scene: northern portions of Antrim, Derry, 
M'SPARRAN, Archibald-(continued).

and Donegal. The work of a half-educated man. A rambling story marked by frequent lapses from literary good taste and numerous grammatical mistakes. The peasantry talk in broad modern brogue, full of " arrah," " musha," "tare-an-ouns," \&c. Shows a considerable though undigested knowledge of Irish history and topography. The book had considerable vogue both here and in U.S.A.

MacSWEENEY, Rev. Patrick M., M.A. One of the most erudite of Irish priests. Was Chancellor's Gold Medallist in the Royal University. Was afterwards Professor of Mod. Lit. in Holy Cross College, Clonliffe. Is at present editor of the Irish Ecclesiastical Record.

1079- THE MARTIAL CAREER OF CONGHAL CLAIRINGHNEACH. Pp. Ixvii. +225. (Nutt, for Irish T'exts Society). 1904.

Ed. for the first time with all the apparatus of scholarship-critical study of the Tale or Saga, literary study of the text, grammatical study, notes, glossary, and index. The story belongs to the pre-Cuchulainn stage of the Red Branch Cycle. Conghal is supposed to have reigned from 177 to 162 B.C.

MacWALTER, J. G., F.R.S.L., \&c. Wrote also The Irish Reformation Movement, 1852 ; Modern Mystery, 1854, \&c.

1080_ TALES OF IRELAND AND THE IRISH. Pp. 224. (Farquhar Shaw). 1854.

The object of these three stories is to point out the wickedness and the evil influence, especially in Ireland, of the Catholic Church. In "Betty Bryan's Fortune," Thady becomes a Protestant, and all goes well with him; the sign of the Cross is called a charm; and there is a description of Beltaine superstitions. In "The Terry Alt," a girl is seized just after marriage and immured in a convent for life: the conspirator's are a monk, a priest, and "Blackboys."

See Note following No. 980.

MACHRAY, Robert. B. 1857. Formerly Prof. of Ecclesiastical History in St. John's University College, Manitoba. War editor, DAILY MAIL, 1904-05. Between 1898 and 1914 has publ. a dozen novels, besides other works.

1081- GRACE O'MALLEY, Princess and Pirate. Pp. viii+338. (Cassell). 6s. 1898.

Purporting to be "Told by Ruari Macdonald, Redshank and Rebel, The same set forth in the Tongue of the English." Scene: various points on the west coast from Achill to Limerick. To a dual love story-of Grace (=Grania Waile) and Richard Burke, Ruari (the hero) and Eva, Grace's foster-sister-are added many stirring descriptions of sea-fights and escapes, sieges and hostings. Historical personages, such as Sir Nicholas Malbie, the Earl of Desmond, and Stephen Lynch of Galway, are introduced. The moral tone is entirely good. The point of view is Grace O'Malley's.

MADDEN, Mabel S. B. in Cork, dau. of the then Dean of Cork. Nearly related to the well-known writers, Daniel Owen Madden and Denny Lane. Sister of the Rev. Owen Madden, Rector of Castle Townshend, near Skibbereen, where she frequently stays. Hias done much journalistic work, first in Ireland, afterwards in London, where she resides, and on the continent. Au. of two other children's books, Sir Guyon the Interloper (Irish in tone and setting), and Sir Guyon in Snowland.

\section{2 - THE FITZGERALD FAMILY. (R.T.S.). 2s. Three ill. in colour by} Victor Prout. 1910.

The family is left very poor on death of father, a C. of I. clergyman. Rich and vulgar relations adopt Barry and Moya, the former of whom becomes an unbearable bounder, the latter a heartless flirt. The rest of the family remains very poor, very: good, and rather dull. There is an occasional mention of Irish peasants and the Irish language. Apart from this, the persons, their doings, and the atmosphere are wholly un-Irish. The story has a moral purpose that is good and not too obtrusive. 
MAGENNIS, Peter. A retired National School teacher. B. near Derrygonnelly, Co. Fermanagh, in 1817; the son of a farmer. D. 1910, aged 93, at his birth-place.

1083- THE RIBBON INFORMER: a Tale of Lough Eme. Pp. 158. (London). 1874.

An unskilfully constructed, rambling narrative, interspersed with indifferent verse. The Author says in his Preface: "This novel is founded on fact, almost every incident in it actually occurred, and many of them within the recollection of the writer. It contains local traditions and legendary lore. It treats of highway robbery, illicit distilling, rural manners, party feeling, and a rather disorganized state of society."

1084 TULLY CASTLE: a Tale of 1641. Pp. 266. (Enniskillen: Trimble). 1877.

A very crude, rambling tale, bringing in a few incidents of the Confederate War and several historic characters, but mainly taken up with private love affairs, abductions, \&c. No character study and no real portrayal of the times. Occasional vulgarity. Scene: chiefly the shores of Lough Erne.

\section{MAGINN, J. D.}

1085 - FITZGERALD, THE FENIAN. Two Vols. Pp. 576. (Chapman \& Hall). 1889.

Deals with Fenian and Land League movements. The Author is unacquainted with the history and organization of Fenianism. The land agitation he represents as forced upon an unwilling peasantry by a kind of murder-club in America. Scene: mainly Co. Sligo. Parnell and Biggar are brought in under assumed names, and are broadly caricatured. The portrayal of Butt is truer to reality and less marred by bias. The Author is uninformed and, on the whole, uncomprehending: hence some absurd statements about things Irish, some objectionable (but evidently unintentionally so) references to the Catholic Church, and a quite impossible Irish brogue. But he is on the whole not unfriendly to Ireland.

MAGINN, William. B. Cork, 1793. Ed. T.C.D. Began early to write for the magazines (BLACKwoon's, \&c.), chiefly parodies and other jeux d'esprit. Went to London, 1823, where, in 1830, he established Frazer's Magazine, which, with Carlyle, Thackeray, Maclise, Prout as contributors, for some years was at the head of English periodical literature. $\mathrm{He}$ fell more and more into habits of drunkenness, and engaged in disreputable journalism. Writing to the end, he died in 1842. Thackeray drew a portrait of him as Captain Shandon in Pendennis. Many memoirs of him have been written. His "Bob Burke's duel with Ensign Brady" is said to be the raciest Irish story ever written.

1086_ MISCELLANIES: Prose and Verse. (IondoN). [First collection, 1840]. Selections ed. by "R. W. Montagu." 1885. (N.Y.: Scribner). 9.60.

Contains "Bob Burke's Duel," “The Story without a Tail," and other Irish stories, published in magazines between 1823 and 1842. These stories are told mostly in a vein of broad comedy. Their characters are roisterers and swaggerers. Maginn was a man of brilliant gifts. The fantastic humour and wild gaiety of his stories give them an original flavour. Maginn was a high Tory and an Orangeman. - (Krans). Dr. Mackenzie edited, in 1857, The Miscellanies of William Maginn (5 vols.), published in America. Contents:-Vols. I. and II. "The O'Doherty Papers." III. "The Shakespeare Papers." IV. "Homeric Ballads." V. "The Fraserian Papers," with a life of the Author.

MAHER, Mary.

1087- HER FATHER'S TRUST: a Catholic Story. Pp. 170. (Burns \& Oates). (N.Y. : Benziger). 0.75. 1901.

A story of the life of the Catholic upper middle classes of Dublin, its trials, failures, heroisms. The lovable Eileen makes an attractive Catholic heroine, and Mrs. O'Hara is well portrayed.-(Press Notice.) 
MAHONY, Martin Francis; " Matthew Stradling." B., Co. Cork, 1831. D. 1885. Was a nephew of "Father Prout." Also wrote C'hcap John's Auction.

1088- THE IRISH BAR SINISTER. Pp. 136. LoNdoN. 1872.

"New ed. in four chapters." The original was publ. by Gill, Dublin, 1871. Really a pamphlet showing up the place-hunting whiggery that prevailed in the Irish Bar at that time, and giving a picture of Irish politics after the Fenian insurrection, and at the outset of the Home Rule movement.

1089 THE MISADVENTURES OF MR. CATLYNE, Q.C. An Autobiography. Two Vols. (T'insley). 1873.

Elaborates the idea of the above-mentioned work. Depicts, under assumed names, well-known Irish lawyers of the day. Intrigues of the candidate for a small Irish borough, and his difficulty in placating all parties well described. This originally appeared in Fraser's Magazine. There is little plot, and no romantic interest.

1090 JERPOINT. An ungarnished Story of the Time. Three Vols. (Chapman \& Hall). 1875.

A satirical study of parvenus, snobs, and various curious types, very cleverly characterised. The story is chiefly concerned with the Courtneys, risen from the publichouse to county-family importance. P. $49 \mathrm{sq}$. gives an excellent picture of a meet, with a study of the personages present. Full of close observation and excellent descriptions. Among the best portraits are those of the Hanlon family, always shabby and out-at-elbows, yet ever struggling with fortune. We are not told the situation of "the Cathedral City of Jerpoint on the Sea."

MALONE, Molly. A Dublin lady, married to a Mr. Riordan, living in Carlow. 1091- THE GOLDEN LAD. 16mo. (C.T.S. of Ireland: Iona Series). 1 .

A study of Dublin slum-children, told with humour, insight, and sympathy, by one who thoroughly knows their ways. The dialect is faithfully rendered.

\section{MANNERS, T. Hartley.}

1092— PEG O' MY HEART. Pp. 320. (Hodder \& Stoughiton). 1913.

"Novelized" from a popular play, which in Aug., 1918, had 10,238 performances to its credit. Peg is diaughter of an Irish agitator of the eighties who goes to America in the troubled times. On the death of Peg's mother her father returns to Ireland, and lives there for many years till bright prospects call him back to America. But the main part of the action is taken up with Peg's visit of a month to her English relations in Scarborough. The Author rather overdraws the contrast between English and Irish types. There is much clever dialogue. Ends with passing of second reading of Home Rule Bill, and the glorification of the one-time agitator. The play has been publ. in book-form, 1918.

MANNIX, Mrs. Mary E., née Walsh. B. N.Y. 1846. Ed. Convent of Notre Dame, Reading, Ohio. Has written much for Catholic periodicals, notably the Avs Maria and the Catholic World. She makes a speciality of children's stories.

1093 MICHAEL O'DONNELL; or, The Fortunes of a Little Emigrant. (Boston: Flynn). 0.60. [1900]. In print, 1910.

Michael, an honest, industrious youngster, not too good to use his fists when attacked by other boys, comes to the U.S., and steps into an excellent situation after three months of walking across the Continent. By a series of innocent misunderstandings, combined with hostile malice, he is made to appear guilty of theft; but the truth is soon manifest. . . Told with much animation and liveliness." (American Eccles, Rev.) Juvenile.

1094- PILGRIM FROM IRELAND. From the German of the Rev. Maurus Carnot, O.S.B. q.v. (Boston: Flynn). 0.36. In print, 1910. 
MAPOTHER, Mary J. Of an old Catholic county family residing at Kilteevan, Co. Roscommon

1093 - THE DONALDS. Pp. 455. (Gill). 1883.

Alfred Donald, his character vitiated by self-indulgence, falls lower and lower in the moral scale till a terrible crime committed in a moment of frenzy brings him to his senses and his complete regeneration begins. But his career ends tragically. Helen Donald's is an odious character to which such fall and such regeneration would be alike impossible. These characters are well delineated. No less so are the minor characters-good-natured, procrastinating Denis Neil, his open-hearted unsuspicious, out-spoken son Thady, and especially Henry Johnson, busybody, scandal monger, mischief-maker, but withal highly respectable and circumspeot. There is a good deal of genuine pathos, and some tendency to be didactic. The story is long and complicated. There is little that is specifically Irish about the persons of the story, and the scene is not indicated.

\section{MARSH, Mrs.}

1096— THE NEVILLES OF GARRETSTOWN. Three Vols. (Saunders \& Otley). 1860.

The main plot is a somewhat slight story of a lost heir returning to claim his inheritance, which had been usurped by an intruder. But the chief interest lies in the numerous side incidents and digressions which are designed to portray various phases of the life of the times. Opens and closes at Clonmel, but the scene shifts to Dublin, Bantry, Paris, and other places. Introduces Jacobite conspiracies, street rioting, hedge-schools, city entertainments, political discussions, the working of the Penal laws, and historical personages, such as Primate Stone, Thurot, Prince Charles Edward, Archbishop Dillon, and many others. Is more or less on the side of the English colony, but is not unfair to any party. Has little or no character study, and not much human interest, but abounds in incident.

\section{MARSHALL (Thomas H.).}

1097- THE IRISH NECROMANCER; or, Deer Park. 3 Vols.

MARTIN, Mary Letitla, "Mrs. Martin-Bell" (pen-name for following novel). 1815-1850, generally called Mrs. Bell Martin, and known also as the "Princess of Connemara," was d. of T. B. Martin of Ballinahinch Castle, Co. Galway. Her father died in 1847, leaving the estates heavily encumbered. The property of 200,000 acres came into the Encumbered Estates Court, and as a result sho was left landless and practically pemniless. She emigrated to France and there supported herself by writing. During the great fiamine the Martins, and especially our Author, worked strenuously for the poor.

1097A-JULIA HOWARD. 3 Vols. (Bentley). [1850]. 2nd ed. 2 vols. 1850.

Period c. 1740. The Author draws upon her own experiences. The hero, Alister O'Connor, through no fault of his own, loses his estates and becomes a soldier of fortune. Col. Herbert, a fine type of a member of the Irish Parliament, tolerant to Catholics and broadminded, purchases the estates of the fallen O'Connors. His niece and heiress Julia Howard is the friend and protector of the peasants. Another fine type is the good priest Father Eustace, whose devotion and that of the tenantry to the old family is well depicted. Ends tragically with the rescue of Julia by Alister from abduction by his apostate brother, and the death of all three. The workings of the Penal Laws are well shown-their fostering of domestic baseness, of dissension in fiamilies, and of the draining of Ireland's best blood for foreign service.

\section{MARTIN (Ewan).}

1098 - DAUNTLESS. A Story of a Lost and Forgotten Cause. Pp. viii. +365. (Pearson). n.d.

Love story of Harry Dauntless, a representative of a Norman Irish family from the Vale of Shanganagh (Co. Dublin), and his fortumes, first in the Royalist army of Ornond, then in service with the Confederate Catholics. Benburb fully described. Owen Roe O'Neill (of whom there is an ample and careful portrait), Ormond, Ever MacMahon, Daniel O'Neill, and Sir Hiardress Waller figure in the tale. Also "Captain Cuttard," a character of the Dugald Dalgetty type. The Author's. sympathies are thoroughly Irish, yet not unfair to the opposing side. 


\section{MARTIN, Miss H. L.}

1099-CANVASSING. (Duffy). Still in print. (N.Y.: Kenedy). [1832].

Published as one of the "O'Hara Tales." See Banims. An elaborate tale of matchmaking and marriage among the upper classes, written with a moral purpose. Incidentally there is a good picture of an election contest in the first quarter of the nineteenth ceritary.

MARTIN, James, 1783-1860, a prolific writer, chiefly of verse. Publ some twenty little vols. Lived near Oldcastle, Co. Meath. Much of his verse was translated from the Irish.

1100_ JOHN AND MARY. A modern Irish tale. (T'RIM). 1855.

\section{MARTIN (R. J.). "Ballyhooly."}

1101- BITS OF BLARNEY. Pp. 225. (Sends). 1899.

A vol. of short staries, sketches, and verse, almost all dealing with Irish life and almost all humorous. The humour is of the boisterous, rough-and-tumble kind, with plenty of brogue.

MARTINEAU, Harriet (1802-1876), a distinguished writer, Author of a long series of works on economics, sociology, religion, travel, etc., etc. In her day she was a well-known literary celebrity. She was a Unitarian, but was not without sympathy for Catholicism. Among her numerous works was her series of "Letters from Ireland," reprinted from' the DAILy News in 1852. She published her Autabiography in 1855.

1102-IRELAND, a Tale. 16mo. Pp. 136. (London: Charles Fox). 1832.

Intended as one of a series illustrating economic conditions. The plot of the tale (concerning a family of the West coast in extreme poverty) is simple, but some of the scenes are highly effective. "No pains have been spared," says the Author in a preface, "to ascertuin the correctness of the data on which my story is constructed." Shows throughout keen observation, independent thouglit, and reasonable sympathy. "She (the Author) speaks as a well-wisher to Ireland and an indignant witness of her wrongs." (Pref.) She sets forth the reforms which she believes to be needed. The little book well deserves to be reprinted.

\section{MASON, Miss.}

1103- KATE GEARY; or, Irish Life in London. (Iondon: Dolman). 1853.

"A Tale of 1849." "The specific object of this work is to exemplify the various ways in which the poor are placed at in disadvantage, and the misery and, almost of necessity, the crimo that ensue from their present crowded condition." "Miss M. describes the life of one who might be called a Sister of Charity living in the world . . . She tells us she has witnessed the incidents of her tale, which are descrihed with vivacity..... The Author has entangled her heroine in a love affair, which, in itself, is very frigid and tedious."-(D.R.).

MASON, A. E. W. B. 1865. Ed. Dulwich Coll. \& Oxford. A well-known novelist, Author of The Philanderers, Parson Kelly, The Broken Road, Running Water, The F'our Corners of the World (1917), etc.

1104 CLEMENTINA. (Methuen). 2s. Eight illustr. by Bernard Partridge. [1901]. Second ed., 1903. (Nelson). New ed., 7d. 1911.

The story of the romantic escape in 1720 of the Princess Clementina Sobieski from Austria, and how she was conducted to Rome to be married to the Pretender by the Chevalier Charles Wogan, member of an Anglo-Trish family of Clongcwes Wood, in the County of Kildare. Some glimpses of the Irish Brigade. $A$ lively narrative. Mr. Baker calls it "a partioularly close imitation of Dumas." 
MASON, A. E. W.-(continued).

1105- THE FOUR FEATHERS. Pp. 338. (Smith Elder). 6s. (Nelson). 7d. [1902]. 1912.

Scene varies between London, Devonshire, the Soudan, and Donegal (Ramelton and Glenalla) the scenery of which latter is finely described. The theme is original and striking. The hero, an English soldier, is all his life haunted by the fear of showing "the white feather" at a critical moment. He resigns his commission rather than risk in a campaign his reputation for courage. This action brings on him the dreaded imputation of cowardice. How he redeems his honour is finely told. A delicate soul-study. The heroic self-sacrifice of Jack Durance still further raises the moral worth of the book.

\section{MASON JONES, see JONES.}

MATHEW, Frank. A grand-nephew of Father Mathew, the Apostle of Temperance. B. 1865 ; ed. Beaumont, King's College School, and London Univ. The writer of the Pref. to the New Ed. of the Cabinet of Irish Literature says: "A good many people of excellent judgment look upon Mr. Mathew as the Irish novelist we have been so long awaiting. . . He does not write morely from the point of view of a sympathetic outsider. He has the true Celtic temperament, with the advantage of education, inherited and otherwise, over the peasants of genius who have so long represented the Irish spirit." Wrote also Father Mathew, his Life and I'imes, One Queen Triumphant, The Royal Sisters, \&c. Resides in London.

1106- AT THE RISING OF THE MOON. Pp. 240. (McClure). 3s. 6d Twenty-seven good Illustr. (N.Y.: $M^{\prime}$ Clure). 1.50. [1893]. 1895.

Twenty tales (memories of the old days, says the Author), picturing many phases of peasant life on the West coast; incidents of the moonlighting days, faction fights, the joke of the potheen-makers, the attachment of priests and people, the hardships of the poor, the days of sorrow, the love of home and country. Told with sympathy in simple but literary style. Dialogue clever and full of bright snatches of Celtic humour.

\section{7- THE WOOD OF THE BRAMBLES (Jane). 6s. 1896.}

Gives a grotesque picture, intended for vivid realism, of the rebellion. The rebels are comic savages, their leaders (the priests included) little better than buffoons. It is a burlesque '98. It is well, however, to add the following estimate from the prefatory essay to the new edition of The Cabinet of Irish Literature: "A born critic here and there will find out that Mr. Frank Mathew's Wood of the Brambles is as full of wit, wisdom, observation, and knowledge as genius can make it; but to the ordinary reader it is deliberately and offensively topsy-turvy, and there's an end of it."

\section{8- THE SPANISH WINE. Pp. 180. (Lane). 3s. 6d. 1898.}

A tale of Dunluce Castle, Co. Antrim, in the days when the MacDonnells from Scotland were Lords of Antrim, and Perrott was Elizabeth's deputy. The story is told in form of reminiscence, the actual movement of the plot occupying only a few hours. Little attempt at description of scenes or times. The Author's sympathies are with the MacDonnells, who were on the English side at the time. The book has been greatly admired, especially for the vividness of its historical atmosphere and its poetic and romantic glamour.

\section{9 - I.OVE OF COMRADES. (Lane). 3. 6d. 1900.}

"Ultra romantic. The sprightly daughter of a Wicklow squire, bosom friend of Lord Strafford (then Lord Lieutenant of Ireland), goes on a perilous journey disguised as a gallant, with a message of life or death to Strafford at Dublin."-(Baker, 2). 
MATURIN, Charles Robert. 1782-1824. " Denis Jasper Murphy." Born in Dublin, and educated at Trinity College. Was a clergyman of the Church of Ireland, and all his life the sworn enemy of Catholicism and of Presbyterianism, both of which, especially the latter, he treats unsparingly in some of his books. Besides his novels he wrote tragedies, such as "Bertram," and blood-curdling melodramas, such as "Fredolplio." In his way of life he was somewhat of an oddity-the madness of genius, his admirers said-and this is reflected in his works. "His romances attracted Scott and Byron, and many critics have given them great though qualified praise. Bombastic extravagance of language, tangled plots, and impossible incidents characterize them all. A remarkable eloquence in descriptions of turbulent passion is his strong point." Besides the novels mentioned below, he wrote Melmoth, the Wanderer, generally considered his masterpiece, and "The Albigenses, his last and best (1824), which was pronounced by BLACKwood to be 'four volumes of vigour, extravagance, absurdity, and splendour" "(compiled from Krans and Read). It should be noted that this writer sometimes violates good morals by indecency. Mr. N. Idman, of Lotsgotan, Helsingfors, Finland, is at present engaged on a study of M. which he intends to publish. The 1892 ed. of Melmoth contains an introductory memoir of M., a bibliography, and a criticism of each of his works. 1110_ THE WILD IRISH BOY. Three Vols. 12mo. (London). [1808]. 1814, 1839.

Republ. in "The Romancists' and Novelists' Library," two vols. (Clements), 1839. The original ed. was anon.-by the Author of "Montorio" [i.e., "Dennis Jasper Murphy" ]. Intended as an exposition of the unhappy condition of Ireland and as a picture of the life and manners of the time. The former is soon lost sight of, but the latter is well carried out. The hero is a strong Nationalist who works wholly for Ireland's cause. Apart from this graver purpose, interest is sustained by a succession of exciting incidents and by good character drawing. There is little plot, a great deal of sentiment, and a great many disreputable intrigues, without, however, objectionable details. The scene varies between Dublin and the W. of Ireland-life in the family of a Protestant landowner and in that of a Catholic feudal chief. Period, $c$. 1806-8. The society depicted is that of the aristocratic classes. Author's standpoint full of sympathy and even admiration for Ireland. Strongly Protestant (Ch. of I.) and anti-"Roman."

\section{1 - LE JEUNE IRLANDAIS. 4 rols. (PaRIS). 1828.}

Traduction par Madame la Comtesse de Molé.

\section{2- THE MILESIAN CHIEF. 4 vols. 12mo. (LoNDon). 1812.}

"Was generally well received by the critics. Even Talfourd, who had been rather hard on his first novel (The Fatal Revenge), said of this: 'There is a bleak and misty grandeur about it which, in spite of all its glaring defects, sustains for it an abiding place in the soul." "-(C. A. Read). Deals with the "prehistoric" Milesian invasion. Gustave Planche in his critique on M. says of this book, "C'est un livre où étincellent ça et lì des pages magnifiques."

1113 _ CONNAL OU LES MILESIENS. Traduit de l'anglais par Madame la Comtesse [de Molé]. 4 tom. (Paris). 1828.

1114 WOMEN; or, Pour et Contre. 3 vols. [1818].

Young de Courcy rescues Eva, who had been carried off to be made a Catholic of by a fanatical grandmother, and he falls in love. This brings him into Calvinistic Methodist circles in Dublin. These the Author describes minutely and with satire. The Methodist gloom and coldness drive the hero to the company of a brilliant actress (really Zaira, Eva's mother). $\mathrm{He}$ is long torn between the two, but finally goes to Paris with Zaira. There he deserts her for another. There is a fine description of Z.'s despair. Eva dies of decline, and de Courcy, repentant, soon follows. "A moral and interesting tale." "The full praise both of invention and execution must be allowed to Mr. M.'s sketch of Eva." As regards Methodism, Mr. M. "has used the scalpel, not, we think unfairly but with professional rigour and dexterity."-(From a review by Sir Walter Scott in the Eorns. REv., xxx., 234). 
MATURIN, Charles Robert-(continued).

1115-EVA; ou, Amour et Religion. Traduit de l'anglais sur la $2 e$ éd. par M. 4 tom. (PARIS). 1818.

MATURIN, Edward, son of preceding. B. 1812, in Dublin. Went to U.S.A., where he taught classics first in South Carolina College and afterwards in N.Y.' D. at N.Y. 1881.

1116 THE IRISH CHIEFTAIN; or, The Isles of Life and Death. Pp. 316, v. close print. 16mo. (GlasGow: Griffin). 1848.

A wild story, in which historical names (O'Ruarc of Breffny, Dermod MacMurrough, Strongbow, Eva, Devorgilla) are given to the personages, but which has no foundation in history. The incidents are supposed to take place some short time after the Norman invasion, but the book bristles with anachronisms. It is a series of thrilling adventures, fighting, revenge, murders, hairbreadth escapes, and so forth. Highly melodramatic, sentimental, and extravagant.

1117- BIANCA: a Tale of Erin and Italy. Two Vols. 660 pp. (N.Y.: Harper). 1852.

An outlandish sort of story, full of murders, perhaps a dozen, if not more. Nearly all the characters have some terrible secret connected with their past; hardly any of them are legitimate children. A duel between two brothers, and banshees, and mysterious ladies with dark prophesyings, etc., and all the fee-faw-fum of the times when all this was popular.

MAXWELL, W. Hamilton. 1792-1850. He was a clergyman of the Church of Ireland, with a parish at Ballagh, in the wilds of Connaught, but was largely relieved of pastoral duties by the absence of a flock. He divided his leisure between field sports of all kinds and the writing of books. Wild Sports of the West, Stories of Waterloo, and The Bivouac were the most successful of these; they are still much read. He tells a story capitally, with verve and spirit, and his situations are as exciting as those of any modern novelist. Maxwell was the first writer of military novels : he is the forerunner and even the inspirer of Lever. Mr. Baker describes his Stories of Waterloo as "A furrago of Irish stories, sensational, with a dash of Hibernian character and local colouring." This book is still to be had (Routledge, 2s.), and a new ed. of his Wild Sports appeared in Sept., 1915, publ. by The Talbot Press, Dublin (Every IrIshyan's LIBRARY), and ed. by Lord Dunraven. William Maginn says of Maxwell"He is of soldier-romance-mongers the first. : . Among rollicking describers of fights, campaigns, sieges, carousings, rioting, love-makings . . . he decidedly bears off the bell." "He flings off his tales as if they were so many tumblers of punch, hot and strong, pleasant and heart-cheering, hastily mixed and as hastily disposed of." "In his sketches of the gentleman class of I. in their hours of relaxation and in their own wild, untameable, and somewhat ferocious jollity, or violence, being of them in blood and bone, he and his people before him for many a long day-is quite at home-not only with his own Wild Sportsman of the West, but with all that horsewhip-handling, trigger. pulling, lady-killing, claret-drinking, steeplechasing, hot-headed, puzzle-pated, tumultuous race of gentlemen," and he goes on to describe them more amply.

\section{8- O'HARA. Two Vols. (Andrews). [1825].}

A Protestant landowner casts in his lot with the United Irishmen. The Government attaints him of treason; he is tried by a jury of drunken bigots, and hanged as a traitor. His son, the hero of the tale, then throws himself heart and soul into the rebellion. The interest centres in the accounts of the fighting in the North. The hero is a leader at the battle of Antrim. Some light is thrown on the nature of the friction between the Catholic and the Protestant commanders, which constantly threatens the disruption of the rebel forces.-(Krans). Publ. anon. 
MAXWELL, W. Hamilton-(continued).

1119 - THE DARK LADY OF DOONA. [1836]. Also (Smith Elder) 1837.

Pp. 306. (Belfast) 1846. (Lond.) 1854. (Warne). 6d. 1891.

"A weak historical novel, in Scott's manner, which attempts a picture of sixteenth-century life."-(Krans). The heroine is Grace O'Malley. The story" opens in 1601, but there is a retrospective portion going back to tell the early lifo of the heroine. A tale of love and wild vengeance. In the story figure the heir of the Geraldines (who marries Grace's granddaughter), Hugh O'Neill, and Sir Richard Bingham. Grace joins the latter against O'Neill. Well written on the whole.

1120 LA DAME NOIRE DE DOONA. Roman historique traduit par Pâquis. 2 tom. (PARIS). 1834 (!).

1121- ADVENTURES OF CAPT. BLAKE; or, My Life. (Routledge). 6d. [Bentley, 1835]. 1838. Third ed., 1882.

Really two practically independent stories, that of Major Blake and that of his son, the Captain. The former is far the more interesting, giving a good account of Gen. Humbert's invasion and of the manners of the peasantry at the time (especially their open-hearted hospitality and kindliness), and some nice descriptions of Connaught scenery. But for an absurd scene of confession in a courthouse no religious bias is displayed. The remaining two volumes are a rambling series of miscellaneous adventures in Portugal, Paris, and London, consisting largely of amorous episodes not edifying, to say the least, and told in a facetious and somewhat vulgar strain.

1122-THE ADVENTURES OF HECTOR O'HALLORAN AND HIS MAN, MARK ANTONY O'TOOLE. (Warne). 6d. Paper. (N.Y.: Pratt). 0.30. [1842]. n.d. (recently reprinted).

The hero is the son of a landlord and ex-soldier living in the South of Ireland. Beginning with an attack on the castle by local malcontents, Hector and his man pass through a series of adventures (some of which are described with considerable "go "), first in Dublin, then in London, and finally in the Peninsular War under Wellington. Most of the incidents take place amid the lowest society, and some of them are distinctly coarse. There is no character-drawing and little or no attempt to picture the life of the period. The military experiences in Spain form, perhaps, the best part of the book. There is no sympathy for Ireland, and there are some gibes at Catholicism.

\section{3 - THE ADVENTURES OF CAPT. O'SULLIVAN. Three Vols. (Colburn).} [1848]. 1855.

"Or adventures civil, military, and matrimonial of a gentleman on half-pay." Soine of these take place near "Ballysallagh," in Commaught, where the hero is stationed, his duties being mainly to keep down the Ribbonmen and to hunt for illicit stills. Attitude towards the former somewhat bloodthirsty. The two chief houses belong to the priest and the tithe-proctor, the task of the latter being described as the grinding of money "out of the wretched serfs." Little plot, long and tedious conversations.

1124 - ERIN GO BRAGH; or, Irish Life Pictures. Two Vols. Pp. $358+368$. (Bentley). Portrait. 1859.

A posthumous collection of short stories originally contributed to BENTLEY's Miscellany and other magazines. Written in the light, rollicking, high-spirited vein characteristic of Maxwell. Many of them are recollections of actual experience. Prefaced by biographical sketch of the Author (6 pp.) by Dr. Maginn.

Titles:-An incursion into Connemara, Last scenes of the condemned, Robert Emmet and A. Aylmer or Dublin in 1803 (a vivid sketch of the rebellion), Terence O'Shaughnessy's first attempt to get married (indelicate), Richard Rafferty or the Irish fortune hunter, and several others. 


\section{MAXWELL, W. Hamilton-(continued).}

1125_LUCK IS EVERYTHING; or, The Adventures of Brian O'Linn. Pp. 440. (Routledge). (N.Y.: Pratt). 3.00. 1860.

An infant, child of a dying mother who liad been abducted, is landed on Innisturk. He is adopted by the head man there, grows up, goes to England, and after many exciting adventures, love episodes, and hair-breadth escapes, finds out his own origin and succeeds to ancestral estates. Originally appeared as serial (with illustrations on steel by John Leech) under the title of Brian O'Linn in BentLex's Miscellany.

MAYNE (Ethel Colburn). Author of The Fourth Ship, Gold Lace, Things that No One Tells, \&c.

1126- ONE OF OUR GRANDMOTHERS. Pp. 280. (Chapman \& Hall). 1916.

An artistic, emotional girl surrounded by unsympathetic natures and fettered by her elders' early Victorian ideas of woman's place in the world. Her first love ends in disappointment and heart-burning. Finally she takes refuge from her hateful environment in a loveless marriage. The scene is Killarney about fifty years ago. The manners of the upper middle class of those days are well depicted. There is little about the state of Ireland as a whole. Religion and politics are not introduced.

MAYNE, Thomas Ekenhead. Son of a well-known bookseller of Belfast. Was fast earning for himself a considerable literary reputation, but died at 32, 1899.

1127_— THE HEART O' THE PEAT: Irish Fireside and Wayside Sketches. Pp. 214. (Belfast: W. Erskine Mayne). 1s. Paper. 1899.

"These are all Irish stories, written on the spot, witl a faithfulness that can be felt in every line. There is no attempt at meretricious workmanship, no maudlin sentimentality, no mock heroics. They are simple tales, simply told; but occasionally the restraint, which is everywhere discernible, is relaxed for a moment, and the fire of the poet glows in half a dozen lines, as a landscape or a sea-piece is enthusiastically drawn, or some incident touches the gentle human heart of the writer."-(James $\mathrm{H}$. Cousins, in Srnn FerN).

"MEADE, L. T."; Elizabeth Thomasina Toulmin Smith. Dau. of Rev. R. T. Meade, of Nohoval, Co. Cork. B. at Bandon. Lived in England from 1874 till her death in 1915. Mudie's catalogue enumerates 185 of her novels, many of which were stories for school girls. Of these novels several, no doubt, besides those here mentioned, relate to Ireland.

1128- THE O'DONNELLS OF INCHFAWN. (Hatchards). 6s. 1887.

1129 - THE WILD IRISH GIRL. Pp. 444. (Chambers). 6s. 8 coloured Illustr. by the well-known Punch artist, Lewis Baumer. 1910.

Warm-hearted, impulsive Patricia has been allowed to run wild at her own sweet will in Ireland. She is brought to London, finds the conventional restraints of society too narrow for her, and as a consequence gets into many amusing and harmless scrapes, and out of them agrain.-(Press Notices).

\section{DESBOROUGH'S WIFE. Pp. 319. (Digby Long). 6s. One lllustr.} 1911.

Scene: near Tralee, in Kerry. Patrick D. contracts a runaway marriage with a beautiful peasant girl. He falls helavily in debt, finds that his mother, on whom he had relied, is even more heavily involved, and that the only way out is a marriage with a rich heiress. Patrick brasely yields, and the poor wife consents to "disappear," but in a strange way, connected with a certain "silent room" in the D. mansion, whose secret we shall not divulge, things right themselves at last. Peter Maloney, Patrick's faithful foster-brother, is curiously similar to Griffin's Danny Mann. The moral tone is high. 
"MEADE, L. T."-(continued).

1131- PEGGY FROM KERRY. Pp. 330. (Chambers). 6s. Pretty cover and

8 coloured Illustr. by Miss A. Anderson. 1912.

Peggy is the daughter of a poor Irish peasant and of an officer. She is now an orphan, but has been adopted by an English friend of her father's and sent to an English boarding school. The story is made up of plots and petty jealousies amongst the schoolgirls. Peggy, though much ridiculed for her dreadful brogue, triumphs over her special enemy and the latter's followers and ends by being popular and happy.

1132- KITTY O'DONOVAN, Pp. 330. (Chambers). 5s. 6 good coloured Illustr. by J. Finnemore. 1912.

Doings in a select English boarding school, where the pretty heroine from Kerry comes scatheless through the spiteful plots of her jealous rivals, and is crowned Queen of the May. There is a pretty description of Kerry scenery, but most of the action takes place outside of Ireland.

\section{3- THE PASSION OF KATHLEEN DUVEEN. Pp. 284 . (Stanley Paul).} 6s. 1913.

"A tale of the novelette class about a young Irishman forced into crime and faithlessness to his young wife by his family's need of money."-[TIMES LIT. SUPPL.] Another Colleen Bawn story. Brilliant young officer marries penniless girl. Financial straits. Murder; and Nemesis.

1134-AT THE BACK OF THE WORLD. (Hurst \& Blackett). 6s. n.d.

Scene : "Arranmore," on the sea coast of Cork. Sheila O'Connor is long sundered from her lover by the suspicion, shared by herself, that he is the murderer of her father, the Squire. Whether they are ever united again we leave the reader to discover. There are many scenes that show us the life of the peasantry, in particular their religious customs. The book seems free from bias, and the brogue is not exaggerated.

[MEANY, Mary L.].

1135- CONFESSORS OF CONNAUGHT; or, The Tenants of a Lord Bishop. Pp. viii. +319. (PHrladelphis : Cunningham). [1864]. n.d. (still in print).

Hardly a story: rather a relation of real incidents in which the names are thinly disguised. Turns chiefly on the proselytising efforts of Lord Plunkett, Protestant Archb. of Tuam, resulting in the Partry evictions. Archb. MacHale, Father Patrick Lavelle, Mgr. Dupanloup, and J. F. Maguire play parts in the tale. Written with strong Catholic bias, but among the chief characters are a Protestant minister and his wife, who are represented as estimable in every way. Style lively and at times humorous. Dialogue good and natural. The Author is a great admirer of William Smith O'Brien. She has also publ. Grace Morton; or, The Inheritance. A Catholic Tale.

MEANY, Stephen Joseph. B. nr. Ennis, Co. Clare, .1825. A noted journalist, first in his native Clare, then in Dublin. In 1848 he was imprisoned for some months. Then he went to Liverpool, where he founded the first English Catholic paper outside London-The Lancashire Free Press. Went to U.S.A., 1860. Returned to England, and was arrested on a charge of Fenianism, 1867, and sentenced to 15 years. D. N.Y., 1888. His "Life" has been written by John Augustus O'Shea.

1136- THE TERRY ALT: a Tale of 1831. Three Vols. 1841.

The "Terry Alts" was a name adopted by the secret agrarian agitators in Munster, previously known as "Whiteboys." Not in British Museum Library. 


\section{[MEIKLE, James.]}

1137- KILLINCHY; or, The Days of Livingston. Pp. 156. 12mo. (Belfast : McComb). 1839.

Description of Presbyterfan life in Ulster immediately after the Scottish Plantation, with biographical details concerning Rev. John Livingston, a Scot from Kilsyth, who was minister at Killinchy, Co. Down, from 1630-5. Story element slight. The Author was a schoolmaster in the district.

MELVILLE, Theodore. Author of The White Knight, The Benevolent Monk, \&c.

\section{8 - THE IRISH CHIEFTAIN AND HIS FAMILY. 4 Vols. Pp. 910. \\ (Londow: Lane, Newman). 1809.}

The chieftain is The O'Donoghue of Killarney, dispossessed for loyalty to the Stuarts. His family, that of Lord Roskerrin, a Williamite, rewarded with an estate, and an exiled Venetian are the dramatis personae. Scene: chiefly Killarney. Period, only vaguely indicated, 18th century. Connad O'D. the hero, falls in love with the daughter of the hated Lord $\mathbf{R}$. There are kidnappings and highly sensational adventures of all kinds, told in a romantic manner, among others how Conrad helps to reinstate the exiled Venetian grandee. Author's sympathies thoroughly on the Irish side, but does not seem unfair to the English. Grood description of Killarney.

\section{MEREDITH, Mrs.}

1139 THE LACEMAKERS. Pp. 375. (LoND. : Jackson, Walford, \& Hodder). 1865.

The writer begins with a history of the lace industry from 1847 to date. To illustrate the economic and social influence of the industry three tales are then given, viz., 1. "Ellen Harrington"; 2. "The Redeemed Estate"; 3. "Mary Desmond." In 1 . the heroine raises herself from poverty to affluence and a successful marriage. Some details of the famine years. In 2. the daughters of a reduced family finally win back the ancestral home. No. 3 relates to W. Cork in 1850. It is similar to 1., but the heroine's experiences lare more trying and even tragic. The tales are didactic but well told, with fidelity to real life, and not without humour. Some anti-Catholic bias and some favour to "Souperism" are shown. Append. with statistics of the industry.

MEREDITH, George. B. Portsmouth, 1828. He had, as he used to boast, both Welsh (from his father) and Irish blood (from his mother) in his veins. Ed. chiefly in Germany. The writer of his life in the Encyclopedia BRITIANICA says of him, "In Meredith went the writer who had raised the creative art. of the novel, as a vehicle of character and constructive philosophy, to its highest point. . . . The estimate of his genius formed by 'an honourable minority,' who would place him in the highest rank of all, by Shakespeare, has yet to be confirmed by the wider suffrage of posterity." He died in 1909.

\section{0 - CELT AND SAXON. Pp. 300. (Constable). 6s. 1910.}

Left unfinished, like Dickens's Edwin Drood. The plot has hardly begun to work out. The chief interest lies in the punpose which was-the Author tells usto contrast English, as typified in John Bull, to the description of whose characteristics a whole chapter is devoted, with Celtic characier and ideals. This purpose is manifest throughout the book. There is a set of Irish and a set of English characters, and within these two sets are types differing widely from one another. One of the most pronounced types of Irishman is married to a lady of peculiarly English characteristics, and the resulting ménage affords the Author scope for much dry humour A romantic episode is just beginning to develop. The highlywrought Meredithian style is as distinctive as in his former books, and there are stray glimpses of the Meredithian philosophy. 
“MERRY, Andrew "; Mrs. Mildred H. G. Darby, née Gordon-Dill. B. 1869, in Sussex, dau. of a North of Irelander, a cousin of Sir Samuel Dill, and of an English mother. Ed. at home. Married in 1889 J. C. Darby, Esq., D.L. Her writings are noted for their impartial standpoint as regards Irish questions, and for their virile style. Never in the criticisms of her literary work has it been suggested that the pen-name hid a woman.

1141 -THE GREEN COUNTRY. Pp. viii.+378. (Grant, Richards). 1902.

Little studies, humorous or pathetic, of the Irish people of today. Both the landlord class and the peasantry, Catholics as well as Protestants, figure in the tale. The Author makes (see Pref.) her characters responsible for the views they express. She applies herself with insight and sympathy and without bias to a careful presentation of various aspects of the national character, its shadows no less than its lights. But there is no preaching. The story entitled "The Love of God or Men "is full of true religious feeling.

\section{PADDY RISKY; or, Irish Realities of To-day. Pp. $367 . \quad$ (Grant,} Richards). 1903.

Seven stories dealing with aspects of Irish life from the landlord and Unionist point of view, yet tone not anti-Irish, nor unjust to any class. The spirit is that of Davis' "Celt and Saxon," quoted at outset:-

"What matter that at different times

Your fathers won this sod?

In fortune and in name we're bound

By stronger links than steel," \&c.

One story shows the hardship of compulsory sale of grass lands. Another deals (delicately) with seduction in peasant life. Most of the characters in the stories are perasants of the Midlands. Charming descriptions of Irish scenery.

1143 THE HUNGER: Being Realities of the Famine Years in Ireland, 18451848. Pp. 436. (Melrose). 6s. 1910.

This is, in the form of fiction, a narrative of happenings in one district, with a plot and personal dnama and talk proper to the novel, and all of these show the gifts of a practised and able novelist; but " every incident," the writer assures us, "is fact, not fiction." His matter is mainly derived from oral statements, helped and verified from books, records, and trustworthy private sources; and in an introauction Mr. Merry deals with the causes and characteristics of the famine, the horrors of which were such that even many of the incidents here selected had to be modified in their details to become publishable.-(Times Lit. Suppl.).

MEYER, Kuno. B. Hamburg, 1858. Ed. Hamburg and Leipzig. Lecturer in Teutonic Languages at Univ. Coll., Liverpool, 1884; Professor, 1895. Founded the Zeitschrift fur Celtische Philologie, 1895, and along with Whitley Stokes, the Archiv. Fur Celtische Lexicographie, 1898; founded the School of Irish Learning in Dublin, 1903; Prof. of Celtic in Univ. of Berlin since 1911. Has publ. a long series of most valuable works on Celtic-Irish subjects.

1144 - CATH FINTRAGA; or, the Battle of Ventry. Pp. xxiv.+116. 4to. (OxFond : Clarendon Press). 1885.

Anecdota Oxoniensia Series. Ed. for the first time with transl. from Rawlinson iMS. The great battle in which Finn was slain in the slaughter of his Fians, a veritable Homeric combat.

1145- THE IRISH ODYSSEY [Merugud Uilix Maicc Leirtis]. Pp. xii.+36. $(N u t t) .1886$.

A very curious Irish version of the story of. Ulysses is here edited for the first time from an ancient MS. written at Kilcormac (Frankford, King's Co.) in the year 1300. Introd., English transl., notes and glossary. The text is compiled from the Kilcormac MS. collated with another version preserved in the Book of Ballymote. 


\section{MEYER, Kuno-(continued).}

1146 THE VISION OF MACCONGLINNE: a Twelfth Century Irish WonderTale. $(N u t t)$. 7s. 6d. net. 1892.

Transl. by K. Meyer, literary introd. by W. Woolner. "A primitive tale combining two elements-satire of the Abbot and Monks of Cork, and the vision of the Lake of Milk, which reveals to the gleeman MacConglinne how King Cathal may be delivered from the demon of gluttony that has been the bane of his land. Full of extravagance and comic fancy."-( Faker, 2).

\section{7- HIBERNICA MINORA. Pp. xvi.+104. 4to. (OxFond: Clarendon
Press). 1894.}

This is a fragment from a treatise in old Irish on the Psalter. But it contains several sagas and tales with translation, e.g., the story of MacDatho's boar and the excuse of Gulide's daughter and another.

1148 _ THE VOYAGE OF BRAN, SON OF FEBAL, TO THE LAND OF THE LIVING. An old Irish saga, now first edited, with translation. Notes and Glossary by Kuno Meyer. With an Essay upon the Irish Vision of the Happy Otherworld, and the Celtic Doctrine of Rebirth by $\Lambda$ lfred Nutt. [Grimm Library, Vols. 4 and 6].

Vol I. "The Happy Otherworld." Pp. xviii.+331. 1895.

Vol. II. "The Celtic Doctrine of Rebirth." Pp. xii. +352. 1897. (Nutt). 10s. 6d. each.

\section{9- LIADAIN AND CUIRITHIR. ( $\left.{ }^{\top} u t t\right) . \quad 1 s .6 d .1902$.}

An Irish love-story of the ninth century, partly in prose, partly in verse. Old Irish text and English translation. Introduction by Editor. Interesting chiefly to the student of Old Irish and the foll-lorist. A poetic version of this story has been given to the public recently (1917) by Moireen Fox, under the same title. Published by Blackwell, Oxford.

\section{0 - THE DEATH TALES OF THE ULSTER HEROES. -Pp. viii.+52.} (Hodges Figgis). 1s. 6d. 1906.

Royal Irish Aademy, Todd Lecture Series xiv. Introd. gives MS. sources. Stories of the deaths of Conchobar, Lóegaire, Búadach, Celtchar, Fergus MacRóich and Cet macMagach. Irish text with trans. opposite. The first is the story so finely told in verse by T. D. Sullivan of how the brain-ball started from Conor MacNessa's head when he was told about the Crucifixion of Christ.

\section{1— FIANAIGECHT. Pp. xxxii+114. Demy 8vo. (Hodges Figgis). 2s. 6d. 1910.}

R.I.A. Todd Lecture Series xiv. A collection of hitherto inedited Irish poems and prose tales relating to Finn and his Fiana, with English transl. "It is the object of this volume to draw attention to the existence of the oldest accounts of Finn and to the gradual growth of the cycle connected with him." (Introd.) $\mathrm{He}$ proceeds to give "a list of all accessible tales, poems, and references bearing upon our cycle known to me." These are given century by century from the 8th to the 14th. Of the tales No. 2 is the quarrel between Finn and Oisin, No. 6 is The Chase of Sid na mBan Finn. All the apparatus of scholarship.

MEYER and STOKES (q.v.).

\section{2 - IRISCHE TEXTE.}

A series of volumes issued at intervals between 1884 and 1909, and publ. at Leipzig, containing texts in the Irish language (chiefly Old-Irish). In many cases English translations are given, in other cases German. Thus the vol. for 1900 gives the whole text of the Acallamh na Senorach and gives (pp. 225-271) an Engl. trans. of those parts of it which were omitted from the version in Silva Gadelica (q.v.). The table of contents gives, in English, an analysis of the whole story or tract, which relates to Finn, Ossian, and Cailte. 
MILligaN, Alice L. B. in Omagh. Dau. of Seton F. Milligan, Esq., of Belfast. Was ed. at Methodist Coll., Belfast, and King's Coll., Iondon She has writtell much for Nationalist periodicals (UnIted Irecand, The United Irisiman, Sinn Fein, etc.) and founded an excellent periodical, The Shan Van Vocht, which ran in Belfast for several years. She has written several plays and published a volume of poetry, Hero Lays.

1153-A ROYAL DEMOCRAT. Pp. 288. (Gill). c. 1892.

A fanciful forecast of Irish political history, 1892-1948, embodied in the story of Arthur Cormac Christian Frederick, Prince of Wales, born 1918. The rebellion of 1895 had been crushed and the national leaders, Davitt, Dillon, Parnell, O'Brien, etc., killed in action or executed. Prince Cormac on a tour round the world is shipwrecked on the Donegal coast. He keeps his identity secret, engages in political life, enters a secret society in order to turn it from agrarian murder to mere cattle driving, is arrested and sentenced to death for murder. He is saved by his cousin Frederika, who had become Queen, but his identity is never disclosed. There is a pleasant love interest and the story is well told, but, of course, wildly improbable. Scene Donegal and Dublin.

MILLIGAN, Alice and W. H.

1154 SONS OF THE SEA KINGS. Pp. 404. (Gill). 6s. T'en illustr. by J. Carey. 1914.

Based on the Scandinavian sagas-the Burnt Njal, Snorri Sturleson's Saga of Olaf, Tryggvesons, the Heimskringla, \&c. Iceland is the centre of these sagas, but Ireland looms in the background, for the hero, Kiartain, comes of framous IrishDanish stock. The Authors have vividly realised and vividly pictured these far times (end of 10th century). The tone and "atmosphere" of the sagas have been preserved with great fidelity, and the tale, told in language of much dignity and beauty, is of high dramatic force and interest.

[MILLIGEN, John Gideon]. B. Westminster, 1782. Son of a Dutch merchant. Served as Surgeon in Peninsular War under Wellington, 1809-1814. Wrote many plays, a history of duelling, and other works. D. 1862 . (Boase).

1155- ADVENTURES OF AN IRISH GENTLEMAN. Three Vols. (Colburn \& Bentley). 1830.

A very unpleasant book. Only the opening and closing scenes are in Ireland (neighbourhood of Bantry Bay, Skibbereen, and Tralee), the interval being filled by adventures in Portugal (where the Inquisition is held up to obloquy), and in Paris (where Freemasonry is praised and convents vilified). These adventures are, for the most part, more or less scandalous "love" affairs. At the outset there is a good deal about Irish disaffection and lawlessness. The Author seizes every occasion to drag in the confessional, the Pope, \&c., and to inveigh against them.

\section{MONAHAN (Henry J.).}

1156- O'ROUARK; or, Chronicles of the Ballyquin Fiamily. (1)uffy). 1852.

Subt.:--"Detailing what they did and what they did not; the wise maxims that they didn't put in practice and the good resolutions which they left to be performed by their descendants: and laying the whole of their private transactions fully before the public." The story begins in the year of the Famine and closes at the Special Commission of Clonmel, 1849. "To those who delight in a hearty laugh," says a reviewer in Duffy's Fireside Magazine, "we would point out the description of Ballyquin, the Charity Ball, Miss Uphemia M'Guire's examination as a witness in the Petty Sessions Court, etc."

MONTGOMERY, J. W. The Author was a native of Virginia, Co. Cavan. He was a zealous antiquary, and wrote on antiquarian subjects. Published, besides the above, two volumes of verse and one of prose slietches. D. Bangor, Co. Down, 1911.

1157- MERVYN GRAY; or, Life in the R.I.C. Ferguson). 1s. c. 1875.

(EDinburaf: Cameron de 
MOORE, F. Frankfort. B. in Limerick, 1855, but brought up and ed. in Belfast. Began to write at 16 . For sixteen years worked on staff of BELFAST NEWS. LET'TER. See his Journalist's Note Book, 1894. All this time he was turning out at least one book a year. In 1893 he scored a great success with his $I$ Forbid the Banns. Since then his output has been very large. He resides at Lewes.

1158- DAIREEN. (Smith Elder). 2 vols. [1893]. New ed. (Collins). 1910. (Hutchinson). n.d.

Opens with stock picture of tumbled-down Irish castle in which dwells The O'Dermot Macnamara, a grotesque specimen of the stock broken-down Irish gentry. Daireen Gerald lives in a neighbouring castle and Standish Macnamara is in love with her. The plot brings these personages to Cape Town. The passengers on the voyage out furnish the remainder of the dramatis personae. The story becomes of the which-will-she-marry order. The issue is left undecided, after the tragic failure of Daireen's first love affair.

\section{9_ THE JESSAMY BRIDE. (Hutchinson). 6s. (N.Y.: Fenno). 50c. 1897.}

The story of the last years and death of Goldsmith, told with all the Author's well-known verve. Full of dialogue, witty and lively, yet not merely flashy, in which Johnson, Burke, Garrick, and other wits and worthies of the day take part. The central theme is Goldsmith's attachment to the beautiful Mary Horneck, called the Jessamy Bride. There is much true pathos in the story, and not a word that could offend susceptibilities.

\section{0-CASTLE OMERAGH. (Constable). 2s. 6a. (N.Y.: Appleton). 1.50.} 1903.

Scene: the West of Ireland (Co. Clare) during Cromwell's invasion. The central figures are the Fawcetts, a Protestant planter family, whose sympathies have become Irish. The eldest son is an officer in the army of O'Neill. The second, the hero, is literary and unwarlike, and inclined to Quakerism. A Jesuit friend of the family figures prominently in the story, and is presented in a very favourable light. The Drogheda massacre and Cromwell's repulse at Clonmel are included.

\section{1- THE ORIGINAL WOMAN. Pp. 343. (Hutchinson). 1904.}

Thesis: whatever culture may have done for the modern woman, she reverts to the instincts of the original woman in the crisis of a life-decision. Scene : first, country house in Galway. The heroine is a typical modern girl of the best kind. The hero, who is also the villain, is a singularly attractive personality, the complicated workings of whose mind the Author delights to analyse. Iater the scene changes to Martinique. Here an element of the supernatural and uncanny enters the story. The style is witty, the character-drawing clever.

\section{2— CAPTAIN LATYMER. (Cassell). 6s. Also 6d. ed. 1908.}

A sequel to Castle Omeragh. The eldest Fawcett is condemned by Cromwell to the West Indies, but escapes along with the daughter of Hugh O'Neill, nephew of Owen Roe. There are exciting adventures. The book, as does C'astle Omeragh, gives a faithful picture of the times.

\section{3- THE ULSTERMAN: a Story of To-day. Pp. 323. (Hutchinson). 6s.} 1914.

A very candid, plainspoken, and judicious picture of life in North-East Ulster. Pictures what the Trmes LIT. SuPPL. calls "the unsympathetic materialism, the drab ugliness of a life which finds its chief recreation in religious strife, and much of its consolation in strong drink." But dwells upon the sterling good qualities that go to counterbalance these others. Opens in a mid-Antrim town on the eve of "the 12th." Story of a bigoted Ulster mill-owner whose sons eventually marry into Catholic families of a lower class. Not political. 
MOORE, F. Frankfort-(continued).

1164 - THE LADY OF THE REEF. Pp. 348. (Hutchinson). 6s. 1915.

A young English artist in Paris suddenly inherits a property in North Co. Down, and arrives to find himself in a puzzling environment. Cleverly sketched characters are introduced-MacGowan, the pushful attorney, the excellent parson Gilliland, and the dipsomaniac captain. Then there is a wreck, a rescue, and enter the "Lady of the Reef." The sequel tells whether she accepts the artist or not.-(I.B.L. and T. Lit. Suppl.).

\section{5- A FRIEND INDEED. Pp. 336. (Hutchinson). 6s. n.d. (1916).}

Two friends in love with the same girl. Harold Escott sacrifices his love and sets himself to secure Tom Melling's happiness by saving him from the consequences of his folly. Then on his supposed death-bed Harold confesses himself the author of a theft really committed by Melling. H. recovers, goes to Ireland to escape prosecution, and subsequently to Australia. There he learns of M.'s falseness, and in the end is united to his first love. The scenes and persons are English except for eight chapters in which the author gives his views of the Irish question in the eighties and brings into strong relief the iniquities of the Land League.

MOORE, George. A distinguished poet, novelist, dramatist, and art critic. Was born in Ireland, 1857, of a Catholic family of Co. Mayo, many of whose members were distinguished nationalists. He has produced some twenty books. Much of Mr. Moore's education has been acquired in France, with the result that, as Dr. William Barry says, "he is excessively, provokingly un-English." At the same time he has little but scorn for things Irish. He has, as he tells us in Confessions of a Young Man, abandoned the Catholic Church He may be said to be at war with all prevailing types of religion and current codes of morality. His books bear abundant evidence of the fact. Many of them treat of most unsavoury topics, and that with naturalistic freedom and absence of reserve. They were consequently excluded from lending libraries such as Mudie's and Smith's. Many critics rank Mr. Moore very high as a psychologist and as a critic. An interesting article on him will be found in G. K. Chesterton's Heretics. His non-Irish stories include Evelyn Innes, Sister 'I'heresa, Esther 'Waters, A Mummer's Wife, Celibates, Vain Fortune, A Mere Accident, \&c. Within the last two or three years he has published at intervals three vols. of reminiscences entitled Ave, Salve, Vale, in which no privacies are respected and which in other respects resemble his novels.

1166_ A DRAMA IN MUSLIN. Pp. 329. (Vizetelly). [1886]. 8th ed. (Walter S(ott). 1918.

Period : just before and just after the Phœnix Park murders. Some attention is given to Land League tyranny before, and coercion after. The interest centres in a party of girls educated at a convent school at St. Leonard's, and their subsequent adventures in Irish society looking for husbands, and all eventually going to the bad, with two exceptions. Of these latter, one is a mad missionary and a Protestant, who becomes a Catholic and a nun, the other is a free-thinker and an authoress, a combiration which the Author considers natural. For the Irish peasant the Author has cnly disgust. The picture of a Mass in an Irish chapel (pp. 70-72) would be offensive and painful to a Catholic. Re-issued as Muslin, 1915.

1167- - THE UNTILLED FIELD. (Unwin). 6s. (Phrladelphia : Lippincott). 1.50. [1903]. New ed. (Heinemann). 1914.

A series of unconnected sketches of Irish country life, most of which deal with relations between priests and people-evil effects of religion on the latter, banishing joy, producing superstition, killing art. In some of the stories priests are depicted favourably. In the first the subject of the nude in artists' models is treated with complete frankness. Another contains warnings against emigration. Some of the sketches are exquisite; most of them, religious bias apart, true to life. Has been transl. into Irish under title An $t-U r$ Gort by P. O'Sullivan. 
MOORE, George-(continued).

1168- THE LAKE. Pp. 340. (Heinemann). 6s. 1905. (N.Y.: Appleton).

"A vague and inchoate novel with some passionate and delightful descriptuons of Nature. 'The theme, very indecisively worked out, is that of a young priest's rebellion against celibacy stimulated by the attractions of a girl whom he drove from the parish because she had gone wrong."-(Baker). Scene: Connaught and Kilronan Abbey. The story seems meant to uphold the purely Hedonistic view of life. Described in Ernest A. Boyd's Ireland's Literary Renaissance, 1916, as the literary revival's "first and only novel of distinction." He bestows upon it almost unqualified praise. It is free from sensual suggestiveness.

\section{9_ A STORY TELLER'S HOLIDAY. (' $T$. Werner Laurie). £2 $2 s$. net. 1918.}

"Irish folk-lore which has escaped the attention of the professional collector." It is issued for private circulation by "The Society for Irish Folklore" to subscribers only, and in a limited edition. After $60 \mathrm{pp}$. of discursive comment on art, love, women, priests, and land in the Author's characteristic vein we are introduced at Westport to Alec Trusseby, a fern-gatherer who has had sunstroke in America and is a noted shanachie-he is supposed to have heard his stories from his grandfather. These might be classed in second-hand i catalogues as "facetiae." Mr. Moore then proceeds to tell stories to Alec, only slightly less suggestive than his own. The book is, to say the least, improper and, in places, even blasphemous.

\section{MOORE, Sidney 0.}

1170 THE FAMILY OF GLENCARRA : a Tale of the Irish Rebellion. Pp. 154. (Bath). Six illustr. of little value. n.d. (1858).

Ninety-eight (Humbert's Invasion) seen from the standpoint of the "Irish Society" (a proselytising organisation). The book is intended to set forth "the ignorance and degradation peculiar to the Romish districts of Ireland," and tells how Aileen who was engaged to one of the rebels (a murderer) is converted, and endeavours to convert others, with varying success. The book is full of calumnies against, and grotesque misrepresentations of, the Catholic Church. It closes with an appeal to the "Daughters of England" for funds for the Irish Society.

MORAN, D. P. Editor since its inception of the Leader (Dublin). A Waterford man, ed. Castleknock College.

1171- TOM O'KELLY. Pp. 232. (Duffy). 3s. 6d. 1905.

An ugly picture of lower middle class life in a small Irish provincial town. It depicts the vulgarity and shoneenism of this class, its drunkenness, its efforts to imitate the well-to-do Protestant better classes, \&c., \&c. Unsparing ridicule is showered upon Nationalist politics and politicians. The unpleasantness of the picture is somewhat relieved by the doings of Tom O'Kelly and the juvenile Ballytowners. Very slight plot.

[MORAN, Edward,] brother of the preceding, but about 25 years his senior. Practised as a solicitor in Waterford, where he mitde one of a literary circle that included Richard Dowling, Thomas Sexton and Edmund Downey. Went to America and practised as lawyer in Brooklyn. D. in U.S.A.

1172- EDWARD O'DONNFIL : a Story of Ireland of Our Day. Pp. 300. (N.Y.: Green). 1884.

Scene somewhere near Fethard, Co. Tipperary, during Land League agitation. The Author's sympathies are against the L.L. and for the physical force party, often called dynamiters at the time. The book is full of the agrarian question, viewed with bitterly anti-landlord bias. Eviction scenes, boycott.ng, midnight conspiracy. Satirical portrait of the pious Catholic attorney who battens on the miseries of the poor; also of various landlord types. In the case of "Father Tim" the portrait shows all the weak spots, but without bitterness or disrespect. See ch. 18, Fr. 
[MORAN, Edward]-(continued).

Tim's sermon against the dynamiters. Good picture of a disperrsary doctor's life and difficulties. Well written, but rather a pamphlet than a story. In a contribution to I.B.L. for Sept., 1915, Mr. Edmund Downey unhesitatingly assigns the book to the late Edward Moran, but the edition I examined bears on the title page what purports to be a facsimile of the signature of the well-known Fenian leader O'Donovan Rossa (1831-1915).

MORAN, J. J. "Mr. Moran has done much good work as a publisher of Irish books in Aberdeen. In his humorous sketches of Irish life he has ever striven to eschew the 'Stage-Irishman' type of vulgar comicality. He writes much for various papers. Besides the books noted here, he has published $A$ Deformed Idol, \&c." Resides at present, I understand, at Durban, Natal.

1173 — THE DUNFERRY RISIN'. (Digby, Long). 1894.

A study of the Fenian movement. The Evening Sun of London devoted a twocolumn review to the book, written by an old participator in the Fenian movement (we understand that the writer was the late J. F. X. O'Brien, M.P.), in which the story was described as one of the most vivid pictures of the Irish Republican Brotherhood and their movement that had yet been written.

\section{4 - IRISH STEW. (Digby, Long). 1894.}

A collection of humorous stories. "Jack Arnold's Tour," the longest story, may be taken as typical. It relates the comical adventures of an English visitor at Bundoran. The stories are remarkable for their spirited and racy dialogue.

1175- STORIES OF THE IRISH REBELLION. (AberdeEN: Moran). 1s. $6 d$.

Short stories, noteworthy for vividness and dramatic power (for example, the story of Leonie Guiscard and Teeling). Humour and pathos alternate. Neither is overdone.-(Publ.).

\section{6- TWO LITTLE GIRLS IN GREEN. (ABERdeEN : Moran). 6s. 1898.}

Land League story-extreme popular point of view; gives vivid idea of feelings of people during hottest years of the agitation. Introduces amiable Englishman who sees justice done for his tenants. Clear and pleasant style.-(IrISH Monthiry).

\section{7- IRISH DROLLERIES. (Drane). 3s. 6d. 1909.}

Ten comic stories such as "Pat Mulligan's Love-making," a bashful young man " proposing" by proxy; "Miss Mullen's Mistake," story of an elderly spinster who answers a matrimonial advertisement with amusing results. Others are: "Torsney's Ghost," "O'Hagan's Golden Weddin'," "Tim Mannion the Hero,"

"The Wake at Mrs. Doyle's," and so on.-(Press Notice).

MORGAN, Lady. She was the daughter of a poor Dublin actor, named Owenson, and was born in 1777 . Her self-reliance, gaiety, and accomplishments won her a prominent place in the litenary and social life of Dublin. She married Sir T. C. Morgan, physician to the Lord Lieutenant. She protests energetically in her books against the religious and political grievances of Ireland. "Her books are a sign of the growth of a broader spirit of Irish nationality and reflect the growing interest in Irish history and antiquities."-(Krans). She is said to have published more than 70 volumes. Her satires of the higher social life of Dublin are spirited and readable even to-day, but their tone is often sharp and bad-tempered. She caught well the outward drolleries of the lower classes: postillions, innkeepers, Dublin porters, \&c.; but she seldom looks beneath the surface. It has been well said that her novels are thoroughly Irish in matter, in character, in their dry humour, and cutting sarcasm; no less than in their vehemence and impetuosity of feeling." Twenty-two of her works are mentioned by Allibone. She died in 1859 
MORGAN, Lady-(continued).

1178 - ST. CLAIR; or, the Heiress of Desmond. [1803]. 1807, 1812.

"St. Clair, in sentiment and situation a weak imitation of Werter, introduces an Irish antiquary, who discourses upon local legends and traditions, ancient Irish MSS., and Celtic history, poetry, and music."-(Krans). Aims at upsetting the notion of the possibility of platonic love between the sexes without any approach to real attachment. Into the description of places and scenes the Authoress worked much of her Connaught experience.

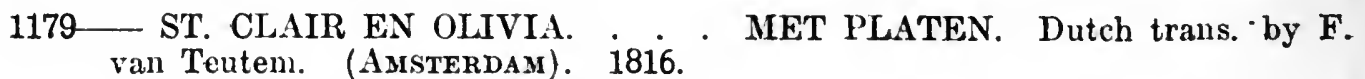
1180- THE WILD IRISH GIRL. [1806]. (N.Y.: Haverty). 1.50. (Routledge). n.d. $6 d$.

A love story of almost gushing sentiment. The scene is the banony of Tirerragh, in Sligo (where the book was actually written). Here the "Prince" of Inismore, though fallen on evil days, still keeps up all the old customs of the chieftains, his ancestors. He wears the old dress, uses the old salutations, has his harper and his shanachie, \&c. His daughter, Glorvina, is the almost ethereal heroine. The personages of the book frequently converse about ancient Irish history, legend, music, ornaments, weapons, and costumes, There is much acute political discussion and argument in the book. It is fervently on the side of Irish nationality. "Father John" is a fine character modelled on the then Dean of Sligo. It contains many other portraits drawn from real life. Its success at the time was enormous. In two years it passed through seven editions.-(Fitzpatrick, Krans, \&c.).

1181- O'DONNEL. P'p. 288. (Downey). 2s. 6d. [1814]. 1895.

The central figure of this tale is a scion of the O'Donnells of Tyrconnell, proud, courteous, travelled, who has fought in the armies of Austria and of France, and finally that of England. $\mathrm{He}$ is a type of the old Catholic nobility, and his story is made to illustrate the working of the Penal laws. Nearly all the personages of the story are people of fashion, mostly titled. There is much elaborate characterstudy, and not a little social satire. The native Irish of the lower orders appear in the person of $M^{\prime}$ Rory alone, a humorous, faithful old retainer, whose conversation is full of bulls. Iady Singleton, the meddling, showy, flippantly talkative woman of fashion, and Mr. Dexter, the obsequious, a West Briton of those days, are well drawn. The main purpose of the book, says the Author, was to exhibit Catholic disabilities. There lare interesting descriptions of scenery along the Antrim coast and in Donegal. As fiction it is slow reading, yet Sir Walter Scott speaks highly of it.

\section{2- FLORENCE MACARTHY. (N.Y.: Sadlier). 1.50. 1816.}

Combines, as so many of Lady Morgan's books do, political satire with a romantic love tiale. A kidnapped heir asserts his claim to a peerage and estates and unwittingly woos the romantic Florence, to whom he had been betrothed in his youth. Mr. Fitzpatrick calls the book " an exceedingly interesting and erudite novel," and tells us how, before attempting it, she had "saturated her memory with a large lamount of reading which bore upon the subject of it." The character of Counsellor Con Crawley constitutes a bitter attack on Lady Morgan's unscrupulous enemy, John Wilson Croker. The half-mad schoolmaster, Terence Oge O'Leary, is a curious type.

1183_ THE O'BRIENS AND O'FIAHERTYS. Three eds. in one year. [1827]. (N.Y.: Haverty).

May be said to liave for its object Catholic Emancipation, yet the author was no admirer of O'Connell, and in this book keen strokes of satire are aimed at the Jesuits, and even at the Pope. Mr. Fitzpatrick says that "though professedly a fiction it is really a work of some historical importance, and may be safely consulted in many of the details by statistic or historic writers." He tells us also 
MORGAN, Lady-(continued).

that it " contains a few coarse expressions; and, in common with its predecessors, exhibits a somewhat inconsistent love for republicanism and aristocracy." The novel is the story of a young patriot who, expelled from Trinity College along with Robert Emmet and others, becomes a volunteer and a United Irishman, and is admitted to the counsels of Tone, Napper Tandy, Rowan, and the rest. After '98 (which is not described in detail) he goes to France, where he rises to be a General, and marries the heroine. The book depicts with vividness and fidelity the manners of the time (hence the occasional coarseness). There are lively descriptions of Castle society in the days of the Duke of Rutland. Lord Walter Fitzgerald was the original of "Lord Walter Fitzwalter."

1184 LES O'BRIEN ET LES O'FLAHERTY OU L'IRLANDE EN 1793 is the title of a French translation of the preceding by J. Cohen. Three Vols. (Paris: C. Gosselin). 1828.

1185 DRAMATIC SCENES FROM REAL LIFE. Two Vols. (Saunders d Otley). [1833].

Contains a piece entitled "Mount Sackville." "It possesses a great deal of her peculiar power, has much truth, and much good feeling, alloyed with some angry prejudice. There are some scenes inimitable for their racy humour, and the characters of Gallagher, the Orange agent, his ally the housekeeper, and Father Phil, are worthy the hand that sketched M'Rory and the Crawley family . . . . The Whiteboy scenes, though forcibly drawn, are perhaps too melodramatic. Shows much bitterness against the repealers."-(DuBL. REv.).

MORLEY (Mabel). "Author of When We Two Parted, Snowdrop, and other tales."

\section{6- BOYCOTTED. Pp. 267. (Remington). 5s. 1889.}

Capt. Boyd, a small landowner in the West, is boycotted. Capt. St. Helier and a company of dragoons are sent down to protect him and his wife and sister-in-law. With the latter the Captain falls in love. These four are of the stock characters ii novels. But the writer draws two striking and life-like portraits-Blake the dispensary doctor, and "Johnnie the Post." A minor incident is the undoing of poor Bridget by the sergeant. Written from the landlord standpoint, but the case against absenteeism is vehemently set forth by Blake and the bias is not excessive. The moral tone is good, and the efforts of the priest to protect his flock are well brought out. The dialect rings true.

MORRIS, E. O'Connor. B. near Dublin, 1861, dau. of late Judge O'Connor Morris, of Gortnamona, Tullamore, the distinguished author of many historical and political works. Was a keen student of Irish affairs and a staunch Unionist in politics. Besides her three novels she wrote stories for the CHuRch of IRELAND Magazine, The Fireside, and the Church Monthly. D. at Gortnamona, 1917.

1187— KILLEEN : a Study of Girlhood. Pp. 348. (Elliot Stock). 1895.

Scene: “Killeen Castle," Queen's County. The plot turns on misunderstandings that keep lovers apart. The characters are of the Anglo-Irish and English upper classes. The book is religious and moral in tone, the standpoint Protestant. Peasant character sympathetically treated.

\section{8- Clare NUGeNT. Pp. 324. (Digby, Long). 1902.}

A rather sentimental tale of an Irish girl who goes to work in England, in order to retrieve the fallen fortunes of the family. This a particularly successful marriage enables her to do, and all ends most ideally. An ordinary plot, somewhat long drawn out. One or two charming descriptions of Irish scenery. 
MORRIS, E. O'Connor-(continued).

1189 _ FINOLA. Pp. 304. (Digby, Long). 6s. 1910.

Scene: chiefly Dublin at the present day. Murrough O'Brien is to get a great inheritance on condition of marrying Finola de Burgh. He gives his consent. Then he is ordered off to S. Africa. On his return he falls in love with a certain Kathleen Burke, and is resolved to lose his inheritance for her sake. The situation has been planned by the romantic Lady Mary Eustace. Her plans nearly turn out in an unforeseen way. The interest then settles on the identity of Kathleen Burke. Several of the characters are well sketched. Notably Eleanor Butler, a sharp and amusing spinster.

MORRIS, W. O'Connor. B. 1824 at Kilkenny. Son of B. Morris, Rector of Rincurran, near Kinsale. Ed. in England. Became a County Court Judge. He devoted himself largely to politics; was a Liberal-Unionist, strongly opposed to Home Rule, and especially to the land agitation. Was himself a good landlord, and an estimable man. D. 1904. See his reminiscences, Memories and Thoughts of a Life.

1190_ MEMOIRS OF GERALD O'CONNOR. Pp. 311. (Digby, Long). 1903.

Reminiscences (told in the first person) of one Gerald O'Connor, an ancestor of the Author. "Compiled partly from old documents and papers in my possession, partly from reminiscences handed down from father to son during five generations, and partly from my own researches."-(Pref.). But the Author has freely filled in gaps in the authentic records and supplied colouring, though there is practically no dialogue. O'Connor served in the Williamite Wars, 1689-91, emigrated to France with Sarsfield, and joined the staff of Marshal Villars. Was in all the great battles of the War of the Spanish Succession. The Author describes effects on Ireland of conquest and confiscation from point of view of $O^{\prime}$ Connor, but admits in Preface that he himself looks at modern Ireland from the landlord's standpoint.

MULHOLLAND, Clara. Is a sister of Lady Gilbert. Was born in Belfast, but left it at an early age, and was educated at convents in England and Belgium. The style of her stories is simple and bright, their tone thoroughly wholesome. Even when there is nothing directly about religion, they breathe an atmosphere of Catholicism. All of them can safely and with profit be given to the young. Many of them are specially meant for young readers. Among her non-Irish stories are 'The Miser of Kingscourt and $A$ Striking Contrast.

\section{1- LITTLE SNOWDROP AND OTHER STORIES. Pp. 192. (Wash- bourne). 2s. 6d. Illustr. 1889.}

The scene of the principal story, a great favourite with children, is laid in Killiney; near Dublin. It tells of a child kidnapped by gypsies.

1192_ THE LITTLE BOGTROTTERS. Pp. 188. (Belfast : Ward; Battimone, U.S.A.: John Murphy). Illustr. n.d.

The child heroine actually loves her prospective step-mother, and is delighted at the approaching marriage. During the honeymoon Elsie visits her cousins the Sullivans in Ireland-a pleasant household of harum-scarum boys and girls, with whom Elsie has many adventures. "Father John" is a fine type of Irish priest.

1193 - DIMPLING'S SUCCESS. Pp. 150. (N.Y.: Benziger). n.d.

Reminds one of Little Lord Fauntleroy, but Dimpling O'Connor not only wins her stern old grandfather's heart, but wins him to the Catholic Church. There are plenty of adventures and a good deal of piety, not of the goody-goody description.

1194 - Kathleen MAVOURNeEN. Pp. 143. (Baltimore : Murphy). 1890.

A cruel Donegal landlord fearing that his son is becoming attached to Kathleen Burke, daughter of a poor tenant of one of his farms, evicts Mrs. Burke. This blow kills her. Kathleen goes as a governess to London, and there the lovers meet again. But the hero has seen the error of his father's ways, and goes into Parliament. In the end he and his father too become Catholics, and all ends well. For young people." 
MULHOLLAND, Clara-(continued).

1195_ LINDA'S MISFORTUNES, AND LITTLE BRIAN'S TRIP TO DUBLIN. (Gill). (N.Y.: Benziger). 0.70 net. [c. 1892]. Still in print.

Two stories, the first and longer not being concerned with Ireland. The second is a delightful little children's story.

1196- IN A ROUNDABOUT WAY. Pp. 224. (Washbourne). 2s. 6d. 1908.

Main theme: a plot to defraud an orphan girl of inherited property, which in a strange manner fails, and all is well again. Scene: first, London, then Donegal, of the scenery of which the Author gives vivid descriptions. The life of the peasants and their relations with their priests are depicted with sympathy and feeling.

1197- TERENCE O'NEILL'S HEIRESS. Pp. 358. (Browne d Nolan). 33.6d. Illustr. by C. A. Mills. (N.Y.: Benziger). 1.35. 1909.

A pleasant story of a young girl left an unprovided orphan, who is cared for by generous relatives, whom in their hour of need slie strives to repay. Suspected of $a$ theft, she is vindicated only after much sorrow and heart-burning. The heroine is a noble and beautiful character. Refined and sensitive, loving music and art, she is obliged to take service as a governess in an English family. There she meets the great trial of her life, but also the final crown of her happiness.

1198- SWEET DOREEN. (Washbourne). 3s. 6d. 1915.

Poverty and misery in Ballygorst have reached a climax. At the suggestion of the Agent, Father Ryan goes to Dublin to get the Landlord to do something. The latter is respectful, but will do nothing. Just as Father Ryan is going the Landlord's daughter and her American friend Laura come in. They will go to Ballygorst, and Papa is persuaded to be of the party. The story tells how they came, met. "Sweet Doreen" and her brothers and sister, and met with many" adventures, pleasant and unpleasant, in the effort to do good.

MULHOLLAND, Rosa; Lady Gilbert. Born in Belfast, about 1855 . She spent some years in a remote mountainous part of the West of Ireland. Of the rest. of her life most has been passed in Ireland, where she still lives. In her early literary life she received much help and encouragement from Dickens, who highly valued her work. She has written much poetry of high literary quality and "marked by a thought and diction peculiar to herself."-(IRISH LIT.). Her novels are intensely Catholic, though without anti-Protestant feeling, and intensely national. But their most striking quality is a literary style of singular purity and grace, and a quiet beauty very different from the flash and rattle of much recent writing. She has publ. several vols. of verse. Among her nonIrish novels may be mentioned The Late Miss Hollingford, The Squire's Granddaughter, The Haunted Organist. Lady Gilbert has also written many children's stories full of originality and playful fancy.

1199_- DUNMARA. By “ Ruth Murray.” Three Vols. (Smith, Elder). 1864.

Wrecked on the coast Ellen, of mysierious antecedents, is taken into the family of Mr. Aungier, of Dunmara Castle, in the West. Strange household-the halfwitted Miss Rowena, the dark, vindictive Miss Elswitha, with unpleasant family history in the background. A will is discovered making Ellen heiress of Dunmara, but revealing to her that she is the daughter of a man formerly slain by Mr. Aungier, who had asked her in marriage. This long keeps the two apart, but they are married in the end. Little Irish colour. Written in somewhat strained style and at times over-emotional.

1200 - HESTER'S HISTORY. 2 vols. (Chapman \& Hall). 1869.

Pastoral life in the Glens of Antrim at the time of the Union, the main theme being a love story. Humour and tragedy alternate. Incidents of the rebellion of '98, including an attack on a castle in the Glens by the English soldiery. Some historical characters are introduced. During part of the action the scene shifts to London. The story was written at the request of Charles Dickens for ALL THE YeAR Round, and he thought highly of it. 


\section{MULHOLLAND, Rosa; Lady Gilbert-(continued).}

1201— EIDERGOWAN; and Other Tales (three). (Marcus Ward). Illustr. 1874.

"Eldergowan" is a very careful and clever study of a girl's varying moods. "It is an excellent example of artistic work and perfect in its way." "Mrs. Archie" is a comedy in which the chief actors are the antiquated family of the MacArthurs, dwelling in the glens of Antrim. The third story, "Little Peg O'Shaughnessy," is written in a lively style, with plenty of interest of a healthy "real" kind.-(I.M.).

1202- - FOUR LITTLE MISCHIEFS. Pp. 187. (Blackie). 2s. 6d. 1882.

Four children sent to a farmhouse to recover strength after the mumps have all kinds of humorous adventures. They pass the time in making up ingenious plays. The tragedy of a little circus girl's fall from a rope calls forth deeper feelings.

1203 THE WILD BIRDS OF KILLEEVY. Pp. 311. (Burns \& Oates). (N.Y.: Benziger). 1.10. [1883].

An exquisite little tale, not of the realistic sort, but sweet and ideal. Kevin and Fanchea are little peasant playmates together in Killeevy. Kevin is dull at his books, but full of the love of nature. Fanchea is a fairy with a bird-like voice. One day she is stolen by gypsies, then by strange fortune gets into the upper stratum of society. Kevin goes out into the world to look for her. He gets education and becomes a poet. After long years they meet again and all is well. Killeevy is an Irish-speaking district where the people treasure religiously their Irish MSS. Here and there there are pen-pictures of much beauty. It is not of course a mere children's book. It has been well said of the book : "It is our own world after all, seen through the crystal of pure language, artistic sense, and joyous perception of natural beauty."

1204 THE WALKING TREES; and Other Tales. Pp. 256. (Gill). 1885.

Contains "The Girl from under the Lake," an Irish fairy tale, occupying about one-third of the book. It is charmingly told.

1205- MARCELLA GRACE: an Irish Novel. (Kegan, Paul). 6s. 1886.

A story with an elaborate plot, full of dramatic incident. Incidentally the evils of landlordism and Fenianism are dwelt upon, the former in the picture drawn of the hovels, the starved land, and the meek misery of the people-and here the Author is at her best. The minor characters are clearly and sympathetically drawn, evidently from life. There is much sadness and even tragedy in the story. The Phœnix Park murders are touched upon.

1206_ A FAIR EMIGRANT. Pp. 370. (Kegan, Paul). 2s., \&c. [1889]. New ed., 1896, \&c.

Period: about the 'seventies. Scene: at first in America (farming life), then in Ireland, north coast of Antrim. A love story. The heroine, one of those whom all must love, is an only daughter, whose mission in life is to clear her dead father's reputation. Full of romantic incident. There is a picture of the landlord class of the time, and there are many good things about the vexed economic and social questions of the day. The book has the Author's usual grace of diction, sincerity of thought, and fine descriptions of scenery. It was very highly praised in Irish, English, and Scotch literary journals.

1207- THE GIRLS OF BANSHEE CASTLE. Pp. 384. (Blackie). 3s. 6d. Illustr. by John Bacon. n.d. [1894]. New ed., 1902.

Three girls, brought up in poverty by a governess in London, migrate to Galway to occupy the castle, pending the discovery of the missing heir. The latter turns up, but is not what he was thought to be, and there are complications." The girls hear a great deal of folk-lore and legend from the servants and from the peasantry. 
MULHOLLAND, Rosa; Lady Gilbert-(continued).

1208- GIANNETTA. Pp. 352. (Blackie). 8 full-page illustr. by Lockart Boglo [1889]. New editions since.

A story for girls. Giannettd, a little ltaluan child, is claimed by an Irish gentleman as his lost daughter. She comes to Ireland, where she witnesses a heartrending eviction scene, grows interested in the peasantry, and starts cottage industries to help them. Eventually it turns out that she is not the true heiress and she becomes an artist. The character of the little heroine, an affectionate and earnest-minded child, is made very winning and very real. Besides the main plot of the story there are several mysteries of identity or supposed death which heighten the interest. The eviction scene was suggested by the well-known Glenbeigh evictions in the eighties.

1209- NANNO. Pp. 287. (Grant Richards). 3s. 6d. 1899.

A rural love story. Scene: Dublin and Youghal and Ardmore. The heroine is a girl born in the workhouse, who is saved from its dangerous and degrading atmosphere, and raised, by true affection and by living among good country people, to high moral feeling and purpose and to the heights of self-sacrifice. The most realistic and the strongest of Lady Gilbert's works. Esteemed by the literary critics and by herself to be the best of her novels. It is based on facts, and it occasioned the reform of certain abuses in workhouses.

\section{0- ONORA. Pp. 354. (Grant Richards). 1900.}

A story of country life in Waterford in the days of the Land League. Eviction scenes. Life in Land League huts on the Ponsonby Estate. Has a strong emotional interest, with much study of the family affections and of the interplay of character. Many touches of humour. Highly praised in English literary reviews. Incidentally there are glimpses of Mount Melleray and of the scenery on the Blackwater. The sterling goodness of obscure people is rendered with womanly sympathy. Interwoven with the main story is that of Norah's little lame poet brother Deelan, a pathetic episode. Also folk-tales and ballads.

\section{1 - CYNTHIA'S BONNET SHOP. (Blackie). 5s. Eight illustr. by G.}

Demain Hammond, R.I. 1900.

"Cynthia, daughter of an impoverished Connaught family, wants to support a delicate mother. She and her star-struck sister go to London, where Cynthia opens a bonnet shop. How they find new interests in life is told with mingled humour and pathos."-(Publ. $)$.

1212- TERRY; or, She Ought to Have Been a Boy. Pp. $112 . \quad$ (Blackie). Thirteen good illustr. by E. A. Cabitt. 1902.

Scene: West of Ireland. A story for children, about a girl and boy of an adventurous turn, relating their doings while living with their grandmother and their nurse, their parents being away in Africa.

1213 - THE TRAGEDY OF CHRIS: The Story of a Dublin Flower-Girl. (Sands). [1903]. Second ed., 2s. 6d. 1914.

Sheelia, the little workhouse girl, is boarded out with Mary Ellen Brady, and lives a happy life with her in her cottage in the fold of the hills. But Mary Ellen dies, and Sheelia, to escape dependence on the worthless cousins of her dead "Mammy," runs away to Dublin. Here she is friendless and penniless till she becomes a flower-girl under the tutorship of Chris. Tragedy comes when Chris disappears (she had been decoyed away to London and made a "white slave"), and Sheelia makes it her life-work to find her again. She does so, but in the saddest circumstances. The pitful story is told with perfect delicacy. Scene: Dublin, various other parts of Ireland, and London.

1214 THE STORY OF ELLEN. Pp. 434. (Burns \& Oates). 5s. 1907.

This is a reprint of an earlier story entitled Dunmara (Smith, Elder), q.v. 


\section{MULHOLLAND, Rosa; Lady Gilbert-(continucd).}

\section{5- OUR SISTER MAISIE. Pp. 383. (Blackie). 6s. Illustr. by G. Demain Hammond, R.I. 1907.}

Maisie, aged eighteen, comes from Rome to take charge of a whole family of step-brothers and sisters. She owns an island off the West coast. The family goes there. The children, after many vicissitudes, turn out clever, develop special aptitudes, and put these to use in helping the poor islanders in various ways. There is a pretty love-story towards the close.

1216- COUSIN SARA. Pp. 399. (Blackie). 6s. Eight fine illustr. by Frances Ewan. 1908.

An ideal love-story woven into a strong plot. There is tragedy and humour with touches of heroism. High ideals are set forth. The scene varies between the North of Ireland, Italy, and London. The central idea of the story is this: Sara's father, a retired soldier, has a talent for the invention of machinery. One of his inventions is stolen, and then patented by one whom he had trusted. Then Sara shows her true worth.

1217- A GIRL'S IDEAL. Pp. 399. (Blackie). Bound in solid gift-book style; cover attractive though not in perfect taste; many illustr. 1908.

Tells how an Irish-American girl comes to Ireland to spend a huge fortune to the greatest advantage of her country. Adversity reveals her to herself and brings to her true happiness. There is also a love interest. Incidentally there is a description of the Dublin Horse Show; a number of folk-lore tales are told by Duncie, and there are good descriptions of Connaught scenery.

\section{8- THE RETURN OF MARY O'MURROUGH. Pp. $282 . \quad$ (Sands).}

2s.

(N.Y.: Benziger). 0.75. [1908]. Cheap ed., 1915.

Illustrated by twelve exceptionally good photos of Irish scenery and types. Scene: near Killarney. The girl comes back from the States to find her lover in jail, into which he had been thrown owing to the perjury and treachery of some of the police. We shall not reveal the sequel. The story is told with a simplicity and restraint which render the pathos all the more telling. It is faithful to reality, deeply Catholic, and wholly on the side of the peasantry, af whose situation under iniquitous laws a picture is drawn which can only be described as exasperating.

\section{9- THE WICKED WOODS. Pp. 373. (Burns \& Oates). [1897]. New ed 1909.}

The hero is a scion of a family in which a curse, uttered against one of its founders by poor peasants whom he had dispossessed, had worked ruin for many generations. He is wholly unlike his ancestors, yet he, too, in a strange and tragic manner, falls under the influence of the curse-for a time. The story tells how he escapes from the terrible trial. Incidentally the best qualities of the peasantry are beautifully shown forth, especially the charity of the poor to one another.

\section{0 _ THE O'SHAUGHNESSY GIRLS. Pp. 383. (Blackie). 6s. Eight} pleasant half-tone ill. by G. Demain Hammond. (N.Y.: Benziger). 1.50. 1910.

Scene: partly in London, partly by the Blackwater, in Munster, where live Lady Sibyl O'Shaughnessy and her two unmarried daughters. Of these latter, Lavender lives at home, takes an interest in things Gaelic, and has fireside ceilidhes. The other, Bell, runs away and goes on the stage. The search for Bell and the discovery of the identity of a mysterious boy on the $\mathrm{O}^{\prime} \mathrm{S}$. farm constitute the main incidents of a delightful story. There is a love interest. The moral of the whole (not too obtrusive) is "Do the work that's nearest, though it's dull at times." 


\section{IULHOLLAND, Rosa; Lady Gilbert-(conimin:c?).}

1221- FATHER TIM. Pp. 314 (large print). (Sands). 2s. 6d. net. One coloured illustr. (Benziger). 0.90. 1910. Still in print.

Father T. is a zealous curate, first in a Dublin mountain parish, afterwards in a parish among the Dublin slums. The interest centres in his influence and work imong upper and lower classes alike. The story tells, too, of the varying fortunes of other people that come into his life. Harrowing pictures are drawn of the Dublin slums. Written with the Author's habitual literary charm. The plot is slight, but the incidents follow one another rapidly and the interest does not flag.

1222_ OUR OWN STORY AND OTHER TALES. Pp. 250. (C.T.S.).

Nine short stories chiefly about Ireland and Irish people. Written with simplicity and unaffected charm. The title-story (the longest) tells of the faith and trials of two young lovers, parted in a strange fashion, and of their happiness in the end. As usual the Author tells of the hard lot of the poor with understanding and sympathy.

1223 FAIR NOREEN; The Story of a Girl of Character. Pp. 392 (Blackie). 6s. 8 illustr. by G. Demain Hammond. 1912. (N. Y.: Benziger). 1.50.

Scene: a village on the W. Coast. Noreen, a little girl of ten, claims to be the daughter-supposed dead-of Lord Finbarr, who had gone on a Polar expedition and had not since been heard of. She is brought up by relatives along with Brian, an ambitious boy with a taste for engineering. After many vicissitudes her father returns and all ends happily. The charm is in the telling.

1224 - TWIN SISTERS. Pp. 392. (Blackie). 6s. 1912.

Pippa and Sue Hurley, left poorly off, return from Spain to relatives in Ireland. Pippa, dissatisfied with the life provided for her, strikes out for herself. Sue, though of a different type, shows herself a girl of no less character than Pippa. The Irish environment is, as usual, skilfully sketched.-(Publ.).

1225 OLD SCHOOL FRIENDS; A Tale of Modern Life. Pp. 382. (Blackie). 6s. 1913.

A character study of two girls and the story of their careers. Brigit is Irish, and when Jessica falls on evil days owing to sudden deafness, Brigit invites her to the home of the Aylmers in Ireland. Jess is everlastingly in difficulties from which Brigit extricates her. Things turn out very happily for both in the end.- $(P u b l$.$) .$

1226- NORAH OF WATERFORD. Pp. 251. (Sands). 3s. 6d. 1915.

A republication of Onora. q.v.

1227- NARCISSA'S RING; the story of a strange quest. Pp. 376 . (Blackie). 6s. 1916.

The quest of a certain mysterious perfume connected with a mysterious ring brings the chief personages of the story from Ballyhuckamore to Egypt first and then to Moscow, where dwells the hero, Ivan Derinvar, son of an Irish emigrant. These personages are the whimsical Countess of Tanderagee and her ward Narcissa. Another curious (and amusing) personage is a sort of poet Diogenes who lives in Surrey. Many beautiful descriptions of travel scenes, especially in Egypt.

1228- O'LOGHLIN OF CLARE. Pp. 259. (Sands). 3s. 6d. 1916.

Scene: Co. Clare, c. 1746. A story illustrating in almost its every detail the Ireland of the time and in particular the working of the Penal Laws. Morrogh O'Loghlin is a Catholic gentleman of the old type living almost surreptitiously in his Clare home with his daughter Brona, his Frenchified sister, and his chaplain. Brona, brought to Dublin by kind Mrs. Delany, wife of the then Dean of St. Werburgh's, meets a Mr. Hugh Ingoldesby, a Clare landowner of English origin. Difference of religion bars the way to their union. Morrogh's worthless son turns Protestant to gain the family estates but Ingoldesby intervenes and later, becoming a Catholic, marries Brona. The story is told with much literary charm. 
MURPHY, Mr. (?Arthur Murphy, 1727-1805, the playwright. Au. of The Grecian Daughter, and All in the Wrong, \&c.).

1229 ISABELLA: or, The Memoirs of a Coquette. (Dublin: James Hoey). 1761 .

Just the reminiscences of an elderly lady who had been an inveterate, though harmless, flirt and had turned over a new leaf in her old age.

MURPhY, Con. T. B. Cork, 1841. Went to U.S.A., 1847. Gained a considerable reputation as an actor and wrote several very popular plays, such as:"Killarney," "Fairies' Well," "Ivy Leaf," "Gamekeeper," \&c. Also a volume of verse. Lived for the most part in Saint Louis but died at Lake Bluff, near Chicago, 1907. His writings are Irish in sympathy and in spirit.

1230_ THE MILLER OF GLANMIRE. Pp. 227. (ChICago: Baker). 4 poor illustr. 1895.

Scene: near Cork some 20 years ago. A moral story of a crude though unobjectionable kind, devoid of literary skill, defective in construction and in style.

MURPHY, James. B. Glynn, Co. Carlow, 1839. Ed. locally. He entered the teaching profession, and was for some years the Principal of the Public Schools at Bray, Co. Wicklow, being appointed in 1860 . He was successively Town Clerk of Bray and Prof. of Mathematics in Cath. Univ. and in Blackrock Coll. $\mathrm{He}$ resides in Kingstown. He has written more than 25 novels, 11 of which have been published. Others he hopes to publish in the near future.

1231- THE HAUNTED CHURCH. Pp. 367. (LoNd. : Spencer Blackett). 4 eds. [1889.]

The story of a treasure buried by buccaneers in an old graveyard near Dublin, telling how the chief characters of the tale, after many exciting adventures in Peru at the time of the revolution there, eventually find the treasure and also the heir to the earldom of Glenholme.

1232- THE SHAN VAN VOCHT: a Tale of '98. Pp. 347. (Gill). 2s. $6 d$. n.d. [1883]. Several since.

A melodramatic story, full of hairbreadth escapes, related with a good deal of dash, and at times of power. Tells of Tone's negotiations in Paris leading to the various attempted French invasions of Ireland, with a detailed and vivid account of that in which Admiral Bompart was defeated in Lough Swilly and Tone himself captured, also details of the latter's trial and execution.

1234 THE FORGE OF CLOHOGUE. Pp. 332. (Sealy, Bryers, and Gill). [1885]. 5th ed., 1912.

The story opens on Christmas Eve, 1797, and ends with the battle of Ross, including very stirring descriptions of the battle there and at Oulart. As is usual with this Author, the plot is somewhat loose, there are improbabilities, and the love interest is of a stereotyped kind; yet the reader is carried along by the quick succession of exciting incident. Of course the standpoint is national. A good idea is given of the state of the country at the time.

1235- THE HOUSE IN THE RATH. Pp. 291. (Sealy, Bryers). 2s. [1886]. Fifth ed., 1909.

Has the usual qualities of this Author's stories: plenty of exciting and dramatic incident, and stirring descriptions-among the latter the battle of Camperdown. Deals with Wolfe Tone's efforts to obtain aid from France for the United Irishmen and with the plans of the latter at home. Lord Edward Fitzgerald and Oliver Bond appear. There are pictures, too, of the atrocities of the yeomanry. Interwoven with these events there is a romance of private life centring in the cleverly-drawn character of Teague, the Fiddler, and Kate Hatchman. As usual, the Author makes much use of "the long arm of coincidence." 


\section{MURPHY, James-(continued).}

1236- CONVICT No. 25; or, The Clearances of Westmeath. A Story of the Whitefeet. Pp. 324. (Duffy). 3s. 6d. [1886]. Fifth ed., 1913.

Depicts landlordism in its worst days and at its worst-about forty or fifty years ago. A complicated and somewhat melodramatic plot in which probability is a good deal strained. A slight love story runs through the book.

1237- THE FORTUNES OF MAURICE O'DONNELL. Pp. 418. (DUbLN:

Falconer). [1887]. Other editions since.

The hero, implicated, though without his fault, in an affray between smugglers and revenue officers off the west coast of Ireland, is forced to fly the country. $\mathrm{He}$ has many exciting adventures in the American Civil War. Meanwhile his betrothed in Ireland has been abducted and shut up in a lonely tower near the Killaries, Connemara. She escapes, the hero returns, hidden treasure is discovered, and all ends happily. The deus ex machinc plays a prominent part, and the coincidences are surprising, but the reader is carried along without pause from adventure to adventure.

1238- HUGH ROACH, THE RIBBONMAN. (Duffy). 1s. [c. 1887]. Fourth ed., 1909.

One of the most popular of the Author's stories. The leading incidents are founded on occurrences of the time. Full of thrilling and dramatic situations and historical pictures.-(FreemaN).

1239- LUKE TALBOT. Pp. 278. (Sealy, Bryers). 1s. [1890]. Sixth ed. in preparation.

A sensational story, filled, without any interval of dulness, with exciting adventures-sea battles, wrecks, hairbreadth escapes, fighting under Wellington in Spain, \&c., \&c. The main theme is a murder conmitted by a wicked land agent in Ireland-Malcolm $\mathrm{M}^{\prime} \mathrm{Nab}$ - and of which Luke is suspected on strong circumstantial evidence. All through the book, until just the end, $\mathrm{M}$ 'Nab is on top, but right finally triumphs. There is no attempt at character drawing and very little probability.

1240_- THE FLIGHT FROM THE CLIFFS. Pp. 266. (Duffy). 1911.

Author's avowed intention-to present Irish and Catholic view of the Confederation War. With the political and military events of the time is mingled the romance of Walter Butler (the hero), who is on the Confederate side, and the daughter of Inchiquin. Owen Roe and Father Luke Wadding are prominent in the tale. Careful description of Benburb. Scene laid in many parts of Ireland (Dublin, Wicklow, Cork, Donegal, \&c.), and in Spain and Rome. Full of exciting adventures, battles, sieges, \&c. Illustr. very numerous. They are crude, but serve to enliven the narrative.

1241- LAYS AND LEGENDS OF IRELAND. 4to. Pp. 104. (Duffy). 1912.

Twelve in prose and five in verse. Includes two of Author's best short stories"Maureen's Sorrow" and "At Noon by the Ravine," as well as several of his best-known ballads. Also "The Tower of Doon" (Williamite Wars), "The Midnight Train," "On the Dublin Mountains," etc.

\section{2_ THE INSIDE PASSENGER. (Duffy). 1913.}

The mail coach from Limerick is overtaken by a snowstorm near the old castle of Bullock, near Dalkey, and held up by a snowdrift. Passengers have to get out and shelter in the castle. To while away the time they tell stories, each more weird and wonderful than the preceding, and all referring indirectly to the Inside Passenger. Towards morning the I.P., the coachman, and the six brass-bound boxes are found to have disappeared. The story tells what befell on the head of this and how the mystery was finally solved. 
MURPHY, Nicholas P. D. 1914. Ed. Clongawes Wood College. Was a member of the English Bar. Wrote also Trainsplanted.

1243- A CORNER IN BALLYBEG. Pp. 256. (Long). 6s. 1902.

A collection of short, humorous sketches of life in a midland village in Ireland at the present day. The dialect is well done. The book is not written in a spirit of caricature.

MURRAY, John Fisher. B. Belfast, 1811, son of Sir James Murray, an eminent doctor; ed. T.C.D. $\Lambda$ distinguished satirist and poet. Wrote much for BLACKwood's, the Dublin University Magazine, the Nation, the UNITED IRISHMAN. D. 1865, in Dublin.

1244- THE VICEROY. 3 vols. Pp. 913. (Murray). 2nd ed. 1841.

Written mainly to satirise Dublin Castle, its government, and the ascendancy aristocracy. Incidentally it shows up the average Englishman's ignorance of things Irish. It also reveals the Author as a lover of Ireland after his own fashion. Strong Protestant bias. Except in the case of a visit to O'Connell at Derrynane, which is well described, everything Catholic appears coarse and vulgar. Fr. Corrigan is a "stage-Irish" priest. Moves somewhat heavily as a story, but is full of clever pictures of the times. A satirical tone is adopted throughout. First appeared in BlackWood's Magazine.

NAUGHTON (William) of Gortnadieve.

1245_ THE PRIEST'S BOY. A Story of Irish Rural Life. Pp. 36. (Dublin: The Sackville Press). n.d.

The first 12 pages are in doggerel verse. The rest consists of the report of a trial with two speeches to the jury and examination of witnesses. Gortnadieve is near Creggs, Co. Galway. It is a pamphlet aimed at a priest who was accused by the local U.I.L. of taking land on the Pollock estate which was then the subject of agrarian agitation.

\section{NEVILLE (Elizabeth O'Reilly).}

1246- - FATHER TOM OF CONNEMARA. Pp. 394. (Chicago and N.Y.: Rand McNally). 1.50. 8 illustr. from photos. 1902.

Fifteen short stories in most of which figures Father Tom, an Irish Catholic priest. They depict the lives of the peasants with knowledge and sympathy. There is a vividly-drawn background of Galway scenery. Humour, pathos and sentiment alternate, and they ring true. The standpoint is thoroughly Irish and Catholic, though the writer is not always accurate in speaking of Catholic practices and ceremonies. The dialect is well handled. The photos illustrate Irish scenery.

NEVILLE, Ralph. Wrote also The Squire's Heir, 1881.

1247- LIOYD PENNANT: a Tale of the West. Two Vols. (Chapman dIH (all). 1864.

First ran as a serial in Duffy's Hibernian Magazine, 1863. Weell-written and exciting melodrama, with a good plot, but very quiet and plain in style. The hero, who bears an assumed name, and is really heir of an old Anglo-Irish family, joins the British navy. He is unjustly accused of disloyalty and intimacy with Lord Edward Fitzgerald. But all ends well, including his love affair with Kate Blake, daughter of a family that plays a principal part in the story. The Humbert invasion is touched upon, especially the Castlebar "Races." There is a good deal about the ways of gombeen men and middlemen in the West. Sympathies national.

\section{NEWCOMEN, George.}

1248- A LEFT-HANDED SWORDSMAN : a Romance of the Eighteenth Century. Pp. 239. (Smithers). 6s. 1900.

The life and doings of Cicely Grattan and of her adopted son, Victor La Roche, a noble and generous youth, brave and skilled in sword-play-examples respectively of womanly virtue and manly character. The interest centres chiefly in Cicely's wrecked love affairs and in Victor's successful ones. Abundance of incident sustains the interest throughout, and the book gives a fairly good picture of society in the Dublin of the day, with not a little reference to its loose morals. 
NEWTON, W. Douglas. Born in England, but of Irish and Scotch extraction. Not attached to any political party, but in sympathy a Liberal and a Home Ruler. A Catholic in religion.

1249- THE NORTH AFIRE: A licture of what may be. Pp. 200. (Methuen). 2s. 1914.

Comyns Loudon, an English officer in garrison at Armagh, is engaged to April Gavin, daughter of a typical Ulster Protestant, at the moment of keenest tension on the Home Rule question in the summer of 1914. Marnus Moore, Master of an Orange Lodge, is killed by a policeman, in search for arms. The mab hang the policeman on a lamp post, and come into conflict with the military. All Ulster is in an uproar-the North is afire. April Gavin becomes a nurse for the Ulster force; her brother Stackpoole, formerly Ioudon's fellow officer in the British Army, is one of the Ulster leaders. Loudon shoots him dead at the capture of a munition store. Just then peace is proclaimed, and April arrives, looking for her brother. Here the story ends. While badly out in his reproduction of the Ulster accent, and deficient in topographical knowledge, the Author has interpreted the spirit animating the several sections of combatants pretty fairly. The descriptions of street-fighting are very well done.

NOBLE, Mrs. Nicholas; [Madge Irwin].

1250 - THE DIAMOND MOUNTAIN; or, Flowers of Fairyland. (DUNDALK: The Dundalgan Press). 1.. Illustr. by A. Domnelly. 1908. Cover in white and gold.

1251- DRUIDEAN THE MYSTIC, and Other Irish Stories. P'p. 93. Sq. $12 \mathrm{mo}$. (DUNDALK: IV. T'cmpest). 1s. 6d. 1913.

Three little stories, only the last of which has a definite plot, and a poem. They deal with peasant life. They are told in a dialect which is not very sure of itself nor very true to reality. The nine little illustrations by J. E. Corr and the excellent printing and general get-up make the book very dainty.

\section{NOBLE, E.}

1252- AN IRISH DECADE. I'p. 110. (Digby, Long). n.d. (1891).

Three stories:-1. "The O'Donol (sic) Rent," 1879-80; 2. "Rosie," 1885; 3. " By Kerry Moonlight," 1889. How a thriftless young farmer went in for anti-rent agitation and brought ruin on himself and his young wife. 2. Story of a resisted eviction ending in tragedy. 3. The "moonlighter" phase of the land war. All three stories are written to show the wickedness and the uncalled for nature of the land agitation. They are nicely written, and constitute a clever piece of special pleading. In 2, the miest is represented as "heartily sympathetic with the Cause, but utterly unsympathetic with gratuitous demonstrations of mass violence."

NOLAN, Alice.

1253- THE BYRNES OF GIENGOULAH. Pp. 362. (Battimore: O'Shea). n.d. (c. 1876).

"The incidents related in this tale really occurred, though not in the consecutive order in which they are placed". . . viz. : "the trial and execution, in Feb.. 1846, at Mullingar, af Bryan Seery for the murder of Sir Francis Hopkins." "The characters introduced are all real." (T'ref.) A sad and touching story of the heartless treatment of the Irish peasantry by certain of the landlords, picturing the deep religious faith of the former and their patient resignation in their sufferings. The plot, which is vigorously worked out, centres in the above-mentioned trial and execution. 
O'BRIEN, " Attie," i.e., Frances Marcella O'Brien. B. 1840, near Ennis, Co. Clare. D. 1883. Many of her writings, which are of high literary value, are to be found in the volumes of the IrISh Monthly. See sketch of her life in that periodical, 1887, p. 406. See also Glimpses of a Hidden Life: Memories of Attie O'Brien, gathered by Mrs. Morgan John O'Connell, 1886.

1254- THE CARRADASSAN FAMILY. 12mo. (N.Y. : Sallier). 1897.

Ran serially in the IrIsh Monthly. Vol. XVI. (1888). C. is the Fitzgerald estate on the Shamnon, where dwe!l Col. F. his family and Charlie McCarthy, an orphan protégé of his. Charlie is in love with letty, the eldest daughter, but the English Capt. Calvert and family misfortunes come between. But after many vicissitudes Charlie comes back from America to save the family estates and to marry Letty. Well written, especially in places. There is in the back-ground a religious lesson of trust in God's providence, but it is not obtruded on the reader.

O'BRIEN, Charlotte GRACE. B. 1845. A dau. of William Smith O'Brien, the Young Ireland leader who in 1848 was condemned to death for high treason, a sentence afterwards commuted to transportation. Lived nearly all her life in Co. Limerick. Worked strenuously on behalf of Irish emigrants. Took active part in Nationalist politics and in the Gaelic League. Became a Catholic towards the end of her life. D. 1905. See Charlotte Grace O'Brien, Selections from her Irritings and Correspondence, with a memoir by Stephen Gwynn [her nephew]. (II a unsel). 1909.

1255_ DOMINICK'S TRIALS : an Irish Story. Pp. 120. (Gall \& Inglis). n.d. (1870).

A little tract in story form, telling how Dominick was converted by his Bible, lost his job as farmer's scarecrow, converted his sister Judy, and was sent with her to a Protestiant or"phanage in England, after which "they never lost an opportunity of turning any poor benighted Roman Catholic to the light of God's truth."

1256- LIGHT AND SHADE. Two Vols. Pp. 287, 256. (Kegan, Paul). 1878.

A tale of the Fenian rising by the daughter of William Smith O'Brien. A double love story runs through the book. The descriptions of the scenery of the Shannon and neighbouring districts are derived from lifelong observations. Tone pure and healthy, dialect perfect. Of this story Stephen Gwynn says : "Violent, even melodramatic, in incident, it lacks the power of characterisation, but it has many passages of beauty. . . . She worked largely upon material gathered from the lips of men who had been actors in the Fenian rising."

O'BRIEN, Dillon. B. 1817, at Kilmore, Co. Roscommon. Ed. at St. Stanislaus Coll., Tullabeg. Went to U.S.A. and, after many years as Government teacher at the Indian mission of La Pointe, settled in St. Paul, Minn., where he rose to a foremost place as a leading Catholic. Wrote a good deal of verse and several novels of Irish-American life. D. 1882. His serial Dead Broke, in the IRISH Monthly of 1882 , is a good example of his pleasant, gay manner of telling a story.

1257- THE DALYS OF DALYSTOWN. Pp. 518. (U.S.A.: St. PAUL). 1866.

How old Mr. Daly, head of a proud old Catholic " county" family, falling into financial difficulties, dies amid the wreck of his fortunes. How the son goes out to Michigan, then-the eighteen fifties-a virgin forest, and refounds the family. How, after twenty years, he returns and buys back the family estate. The favourable picture of the old type of landed gentry is of much interest.

1258- FRANK BLAKE. Pp. 270. (St. Paul: The Pioneer Press). 1876.

Scene: "Renville," a fishing village near Oranmore, on Galway Bay, about beginning of 19 th century. Story apparently founded on fact. Young Lt. Frank Blake, R.N., charged with murder of Hon. Robert Eyre, is saved by Willie Joyce, whom Blake had previously rescued from the clutches of the law. This is finely 


\section{O'BRIEN, Dillon-(continued).}

worked out, and interwoven with it are two pretty love stories ending happily. As background there is a vivid and convincing picture of Co. Galway Society. We meet Dillons, Lynches, Frenches, Bodkins, Concannons, etc., at the seaside or, after a day's hunting, spending the evening at Kilbury's Hotel in Eyre Sq. All the features of the life of those times are introduced. A pathetic episode is the death of Father John St. Leger, S.J., a victim of his devotion during an epidemic of typhus.

O'BRIEN, FltzJames. One of the most distinguished of Irish-American writers. B. Limerick, 1838. Ed. T.C.D. Went to U.S.A. in 1852. Fought in Civil War and was killed in a skirmish in 1862. He is a master of the weird and eerie, after the manner of Lefanu $(q . v$.$) and Poe. His prose works are little if at all$ concerned with Ireland.

\section{9 - THE POEMS AND STORIES OF FITZJAMES O'BRIEN. Pp.}

lxii.+485. (Boston : Osgood). 1881.

Coll. and ed., with sketch of Author, by W. Winter.

1260 THE DIAMOND LENS, and other Stories. (Downey). 1887.

Sketch of Author prefixed. Contains no Irish stories.

O'BRIEN, Hon. Georgina. Eldest dau. of the late Lord O'Brien of Kilfenora, Lord Chief Justice of Ireland.

1261- THE HEART OF THE PEASANT, and Other Stories. Pp. 277 . (Sisley). 6s. 1908.

Twelve stories of various types. Some have a slight meaning behind the mere tale. Four or five do not concern Ireland, and several others do not touch peasant life. The tone is on the whole sympathetic towards the external aspects of Catholicism. The stories do not deal in politics or in problems. They are chiefly little aspects of life and feeling. The last and longest is a very modern story of the love affair of Rev. Mark Dibbs and a certain Lady Glynn.

1262-A TWENTIETH CENTURY HERO. Pp. 308. (Maunsel). 6s. 1913.

The scene and most of the characters of this story are English. Some Irish interest, however, is afforded by Mr. and Mrs. Flanagan, the latter bright, thrifty, busy, the former of the happy-go-lucky type, content to let his wife do the bread. winning.

\section{O'BRIEN, Morrough.}

1263 THE LEAGUE OF THE RING and TORN APART. (Ireland's Own Library). 6d. n.d. (1914).

Exciting stories of mysteries unravelled by the great Irish detective, Dermod O'Donovan. Villainy is defeated and couples are happily married. Quite healthy in tone, but very sensational. The scene is Belfast and neighbourhood.

O'BRIEN, Mgr. Richard Baptist; “Father Baptist." B. at Carrick-on-Suir, 1809. D. 1885. A distinguished priest, who was Dean of Limerick. Was well-known in religious and philanthropic works. He wrote poems for the NATION under the pen-name of "Baptist."

1264-AILEY MOORE. Pp. 311. (Duffy). 3s. [1856]. Fifth ed. n.d. (N.Y.: Benziger). 0.60. Still in print.

Period: the years before and after '48. Plot pleasant, but main interest abundance of side incidents, character studies and details of Irish life, introduced chiefly to picture the evils of misgovernment prevailing at the time. The style is agreeable, though there are rather lengthy moralizings. It was advertised by Dolman as "showing how Eviction, Murder, and such like pastimes are managed and Justice administered in Ireland." 


\section{O'BRIEN, Mgr. Richard Baptist-(continued).}

1265- JACK HAZLITT, A.M: Pp. 380. (Duffy). Third ed n.d. Still in print. (N.Y.: Benziger). 0.60. [1875].

The Preface tells us that Jack Hazlitt, whose fortunes are followed in this book, was a real person known to the Author, and that many of the adventures recorded are true. Scene: first, banks of Shannon (King's County or Westmeath), then America. Story of sensational kind, but with many moral lessons, often verging on homilies, directed chiefly against free thought and undenominational education.

1266- THE D'ALTONS OF CRAG. Pp. 283. (Duffy). 2s. 1882 . (N.Y.: Benziger). 0.60. [1882]. Still in print.

A tale laid in a time of helplessness and hopelessness, in which the Author gives " many illustrations of the beautiful and devoted love that has ever bound together the people and the priests of Ireland."-(Pref.). The Author tells us that every one of the main incidents is based on fact, and that many of the characters are portraits of real persons. The story is told with great vigour, and is full of diversified incident of no humdrum or commonplace character.-(IRISH MonthLY).

O'BRIEN, Seumas, a Corkman living in the United States. Author of "Duty" and other plays, and a sculptor of much originality.

1267- THE WHALE AND THE GRASSHOPPER and other fables. (BusToN). 1.38 net. 1916.

Twenty whimsical and fantastic stories. They are told in the course of talks between two old friends in the Co. Cork, Padua Dan and Micus Pat. The Author puts a good deal of homely and commonsense philosophy into their mouths. Indeed they talk rather above their roles. Such titles as:- "The White Horse of Banba," "The Mayor of Loughlaurna," "The King of Goulnasparra," "The Linnet with the Crown of Gold," and so on.

O'BRIEN, William. B. Mallow, Co. Cork, 1852. Ed. Cloyne diocesan seminary and Queen's Coll., Cork. Early engaged in journalism. He long edited UNITED IRELAND, to which he contributed much prose and verse. Is one of the best known and most remarkable of modern Irish politicians. Has been prosecuted nine times for political offences, and spent more than two years in prison, where When We were Boys was written. Has been Member of Parliament, except for short intervals, since 1883.

1268- WHEN WE WERE BOYS. Pp. 550. (Longmans). 6s. [1890]. Frequently republished. Cheap ed. (Maunsel), 1s. 6d. n. 1918.

One of the most remarkable of Irish novels. A tale of Ireland in Fenian times. Scene: Glengariff, Co. Cork. A very brilliant book, sparkling with epigram and metaphor. Full of criticism, argument, thought and dream about Ireland. The story itself is strong in romantic and human interest. The characterization is full of life and reality, yet many of the characters are types. In the course of the tale many aspects of Irish life, among all classes, pass in review. There are many touches of satire. Over all the characters and scenes the Author's exuberant imagination has cast a glare as of the footlights, making them stand out in vivid colours and clear outlines. Yet there is little or no distortion or misrepresentation. The Author's sympathies are strongly nationalist and Catholic, yet national failings are not blinked, and some of the portraits of priests are distinctly satirical. The central interest, perhaps, is the romantic excitement, enthusiasm, and exaltation of an impending rising.

1269_ A QUEEN OF MEN. Pp. 321. (Unwin). [1898]. Third ed., 1899. There is a cheap ed. in paper cover.

Scene: Galway City, Clare Island, and the opposite coast, just before the great War of the Earls. A very highly-coloured romance, full of flashy and dramatic censation, told with an exuberance of language that sometimes exceeds, but at times 
O'BRIEN, William-(continued).

is very effeetive. Some of the descriptive pieces are quite above the common and attain remarkable vividness. The book was written in the midst of the scenes described. An effective device to secure colour is the frequent interjection of Gaelic phrases phonetically spelt. The heroine of the tale is the famous Grania Ni Mháille, who appears not only as dauntless sea-queen of the O'Malleys, but above all in her womanly character. Fitzwilliam, Bingham, and Perrott also appear, the last as a hero. Though many of the incidents are quite fictitious and few happened exactly as narrated, yet some of those which might seem most incredible to anyone unacquainted with the State Papers could be paralleled by real happenings. Some of the incidents narrated are: the Composition of Connanght, the disgrace of Perrott, the wrecking of the Armada on the Commaught coast, Gránia's visit to Elizabeth. With Gránia's love story is entwined another, that of Cahal O'Malley and Nuala O’Donnell.

O'BRIEN, Mrs. W. Wife of preceding; rée Sophie, dau. of Herman Raffalovich, of Paris. She is a convert to Catholicism, and a thoroughly naturalised Irishwoman for many years past. She has written also a book of reminiscences. Under C'roagh Patrick. I have also seen mentioned as by her a book entitled Amidst Mayo Bogs.

1270_ ROSETTE: a Tale of Dublin and Paris. Pp. 266. (Burns \& Oates). 1907.

Diary of Rosette, only child of a Parisian bourgeois family. Deals chiefly with the life of this family in Paris, and afterwards in Dublin. There is no sensationalism. Rosette's religious development is thoughtfully worked out, and there is good character-drawing (e.g., Rosette's artistically inclined mother and the old servant, Mélanie). The point of view is, of course, distinctly feminine. The style is pretty and graceful.

" O'BYRNe, Dermot," i.e., Arnold Bax.

1271- THE SISTERS AND GREEN MAGIC. Pp. 76. (Daniel: The Orpheus Series). 2s. 6d. [1912].

Two short stories. In the first the sisters Sorcha and Noreen, beautiful peasant girls, both love Bartley. The latter marries Sorcha but he is soon after drowned, and Noreen transfers her love to the widow and her unborn babe. She dreams a horrible dream of seagulls. The newborn child proves to have a seagull's webbed foot instead of one hand. The sequel is tragic. In the second the heroine's mystic fascination for the sea finally results in her drowning herself. In the treatment of these themes the Author shows much power of psychological analysis and also of description of nature, especially the sea. But he attributes to the peasants a selfconscious clairvoyant faculty worthy of spiritists. Scene: Western Donegal.

Seven stories reprinted from The Irish Review and Orpievs (an Art periodical). They belong to the literary movement associated with the Abbey Theatre. They have the weird imaginativeness and the flavour of the occult and uncanny of Yeats's prose stories, together with the vivid word-painting of "Fiona McLeod." The Author delights in the portrayal of primitive and savage passions on the one hand, and on the other in the suggestion of the wild landscapes, rock-strewn and mistshrouded, of Western Donegal (e.g., Glencolumbcille, in "Ancient Dominions"). These stories of pure fancy are strangely interwoven with settings of extreme realism -drunken tinkers, peasants, \&c. Only here and there have we remarks like the following (p. 123):- "But those who are intimate with the soul of the Gaelic peasant know that the God of the Christian is only one amongst a Pantheon of hidden dominations lovely and terrible, though the priest at the altar may thunder anathemas from a fettered intelligence," \&c. The reviewer in the Times LIT SUPPL. pointed out the real defect of these stories-they are wanting in heart. 
" O'BYRNE, Dermot," i.e., Arnold Bax-(continued).

1273_- WRACK, and Other Stories. Pp. 195. (The Talbot Press). 3s. 6d. net. Dec., 1918.

Seven stories, viz. :-1. "Wrack," 2. "Before Dawn," 3. "From the Fury of the O'Flahertys," 4. "A Coward's Saga," 5. "The Invisible City of Coolanoole," 6. "The King's Messenger," 7. "The Vision of St. Molaise." No. 1 is the story of an old mad woman; 2 is an episode of gun-running; 3 is a story of savage blood feuds in Iar Connacht; 4 a story of the Desmond wars; 5 and 6 are laid in some vaguely remote period of Irish history, the former shadowing forth some dim allegory, the latter a primitive belief that a man might be slain in order to convey a message to the dead; 7 gives a glimpse of very early Christian times. In all, the plot and narrative are of secondary interest. The main aim seems to be the conveying of various impressions of fantastic horror or elemental passion or savage squalor. All are, like Children of the Hills, unhuman, works of pure fantasy, untouched by feeling. They show intimate knowledge of the idiom of Gaelic.

\section{O'BYRNE, M. L., "Emelobie de Celtis." A Dublin lady. Died some years ago}

1274 - THE PALE AND THE SEPTS. Two Vols. (Gill). [1876].

The design is to illustrate, in all its cruelty, treachery, greed, and unscrupulousness, the steady advance of the English settlement. Yet by no means all the English are painted as villains. We are shown the forces of government at work at home in the Castle. Careful portraits of Archbishop Loftus and the old Earl of Kildare. Descriptions of battle of Glenmalure, Hungerford's massacre at Baltinglass, the capture and recapture of Glenchree, \&c., \&c. Fine description of scenery, e.g., Gougane Barra. The religious persecutions are vividly portrayed. Highly praised by the Atreneur. The original sub-title was "Or, The Baron of Belgard and the Chiefs of Glenmalure. A Romance of the 16th Century, by Emelobie de Celtis."

\section{5- LEIXLIP CASTLE. Pp. 649. (Gill). [1883]. Others since.}

Period: years $1690 s q q$. Deals with battle of Boyne, flight of James II., sieges of Limerick and Athlone, the battle of Aughrim-all fully and vividly described. Standpoint: strongly national and Catholic. Gives pleasant insight into the private lives of some Catholic families at the time and their difficulties with Protestant neighbours. Narrative somewhat tedious and slow-moving.

1276_ ILL-WON PEERAGES; or, An Unhallowed Union. Pp. 716. (Gill). 1884.

At the outset of this book we are introduced in a series of pictures to the homes of representative people of various parties, and long, imaginary political conversations between the prominent men of the time are given. Then there is a full account of the rebellion from the battle of Kilcullen to Vinegar Hill. I'ractically every noteworthy personage of the time is described in private and in public life. The romantic interest is entirely subservient to the historical, yet there is plenty of adventure. The bias is ultra-nationalist. The style, and especially the descriptions, were highly praised by a reviewer in the TABLET.

\section{7- ART MACMURROUGH O'KAVANAGH. Pp. 706. (Gill). [1885].}

A full account of the life and exploits of Art MacMurrough, with many adventures of fictitious characters, and much description of the manners and life of the times within and without the Pale. In the conversations the Author attempts to reproduce the spoken English of the time, with a lamentable result. They are full of yclept, eftsoons, by my halidom, marry, \&c., so as to be unintelligible at times. The speech of the Irish characters is nearly as full of Gaelic expressions. "Many of the events narrated in this story are supplied from tradition," says the Author. But she has been at much pains to utilize undoubtedly authentic sources. The style, on the whole, is pleasant. 
O'BYRNE, M. L., "Emelobie de Celtis"'-(continued).

1278- THE COURT OF RATH CROGHAN. Pp. 465. (Gill). 2s. 6d. 188\%.

The story of the Norman Invasion of Ireland, together with the series of events that led to it, and the consequences that followed, the central idea being that it was the treachery and disumion of her own princes that wrought the ruin of Ireland. All the chief men connected with the events narrated play prominent parts in the story. St. Laurence O'Toole is finely drawn. The last Ard Righ, Roderick, is slown weak and unfit to rule in perilous times. Strongbow is a leading character; his death is vividly described. Art MacMurrough is, of course, the villain. The style is some. what high-flown and often loaded with antiquated phrases and latinized expressions. Yet the story, apart from its historical value, which is considerable, has a strong. interest of its own.

1279 LORD ROCHE'S DAUGHTERS OF FERMOY. Pp. 344. (Sealy, Bryers). (N.Y.: Pratt). 1.50. 1892.

In the course of this romance the whole history of the Wars of the Confederation of Kilkenny and of the Cromwellian Invasion is related. The story is described by the Author as " a very encyclopædia of tragedies." The Author is strongly on the side of Owen Roe O'Neill as against the Confederate Catholics of the Pale, and, of course, the Puritans. A fine series of adventures and of historical pictures, but spoiled by frequent lapses from literary good taste.

O'BYRNE, Rev. Mark, C.C., Wexford. B. New Ross, 1874; ed. Maynooth. Has always been prominently identified with the Graelic League in Wexford, and has done much propagandist writing. Has contributed stories and sketches to various periodicals, but chiefly to the Catholic Bulletin. We may look forward to the appearance before long of another such collection as the following.

1280_ THUNDHER AN' TURF. Pp. 127. (Gill). 1s. (N.Y.: Kenedy).

Illustr. [1916]. New ed. 1917.

Ten animated stories of present-day country life in the S. of Co. Wexford, showing intimate knowledge of.the people and thorough sympatly with them. Incidentally the "Irish Ireland" and the Volunteer movements, as well as the older Land League agitation are sympathetically dealt with. The same persons keep turning up in successive stories, Father Martin and his housekeeper Ellen, Mary Doyle the postmistress, Mogue Power the "strong farmer" and others. Humour, good and pleasant, predominates, but occasionally one of the clouds that are apt to darken Irish life casts a passing shadow. The tales, though unambitious, are effectively told. Illustrations are rather crude.

O'BYRNE, W. Lorcan. B. in Dublin, 1845. Son of Christopher O'Byrne, of Ballinacor, Co. Wioklow. Delighted from earliest youth in Irish lore of all kinds. Held a position in the Education Office during the greater part of his life. D. 1913. His books, though popular in style, were the result of much patient research.

1281- A LAND OF HEROES. Pp. 224. (Blaclie). 2.. 6d. Well illustr. by J. H. Bacon. (N.Y. : Scribners). 1.25. 1899.

"Intended to reach the level of children." Very interesting Introduction. The book is a series of Irish hero tales from various cycles, including the best-known (Sons of Tuirean, Lir, Usnach, \&c.), and the Romance of the early kings very much as in Miss Hull's Pagan Ireland. The book contains a larger number of tales than any other except the most expensive. The bare story is told without any attempt to work up the materials into poetic or dramatic form.

1282- KINGS AND VIKINGS. Pp. 240. (Blackie). 2s. 6d. Six illustr. by Paul Hardy. n.d. (1900). (N.Y.: Scribners). 1.25.

Drawn from published translations of Gaelic MSS., e.g., Standish H. O'Grady's Silva Gadelica; Dr. Todd's edition of the Wars of the Gael and Gall; Dr. O'Donovan's Battle of Magh Rath, \&c. Contents: stories of early Christian times, 


\section{O'BYRNE, W. Lorcan-(continued).}

chiefly from the lives of St. Patrick, St. Brigid, St. Columbkille, and St. Brendan; the trial of the Bards; the battles of Dunbolg, Moira, \&c.; stories of the Danish invasions, and in particular of Brian Borumha. Full of good information, but not strong in narrative interest.

\section{CHILDREN OF KINGS. Pp. 240. (Blackie). 2s. 6d. Illustr. by Paul} Hardy. 1904.

"The aim of this book is to present tales from Three Cycles of Romance, viz., the Cuchulain, the Ossianic, and the Arthurian, interwoven after the manner of a Celtic design" (Introduction). The chief characters of the three cycles appear in various stories (there are thirty-one in all). A truly wonderful knowledge of the period embraced by these tales is displayed in the book, but the glamour of romance and the magic of words are wanting.

1284 THE KNIGHT OF THE CAVE; or, The Quest of the Pallium. Pp. 248. (Blackie). 2s. 6d. Six illustr. by Paul Hardy. 1906.

A thin thread of narrative comnecting much interesting and valuable information about historical events and about the life of the people at the period. The hero passes from England, then laid waste by the wars of Stephen's reign, to Ireland, where we are shown in great detail the civil and ecclesiastical life of the day. Thence he accompanies St. Malachi to Clairvaux on a visit to St. Bernard. Then he visits Italy-Tivoli, Horace's Sabine Farm, and Rome, whose antiquities he describes at length. Finally he returns to Ireland, whose state is again dwelt upon. The narrative is relieved by exciting adventures and by stories told incidentally. The Author's erudition is extensive and accurate. The title refers to St. Patrick's Purgatory, Longh Derg.

1285- THE FALCON KING. Pp. 240. (Blackie). 2s. 6d. Six illustr. by Paul Hardy. Picture cover. 1907.

"A series of historical episodes (beginning in Wales, 1146), vignettes of contemporary life, and stories from Celtic and Icelandic sagas and Norman French chansons de geste, illustrating events, manners, and religion . . . . Shows Henry II. and his barons engaged in the conquest of Ireland, and gives a good account of Dermot MacMurrough, and also of life in Dublin."-(Baker, 2).

[O'CONNELL, Mrs. K. E.], of Leenane, Co. Galway ; "Aroon." 1286- NOREEN DHAS. Pp. 62. (S'ealy, Bryers). 1s. 1902.

A pretty love-story of Connemara (the Killaries). The Author is for the language movement, and strongly opposed to the bargain marriages of the West.

1287- WHITE HEATHER. Pp. 62. (Sealy, Bryers). 1s. 1903.

Three tales of Connemara. The first is a graceful little fairy story, the third a story of faithful love.

\section{O'CONNOR, BARRY.}

1288- TURF-FIRE STORIES, and Fairy Tales of Ireland. Pp. $405 . \quad$ (N.Y.: Kenedy). 0.63. Illustr. with woodcuts. 1890.

"The greater number of the following sketches are original; the others have been transcribed, and in most cases materially altered, from the musty pages of some 'Quaint and curious volumes of forgotten lore.'" (Pref.) Most of the stories are comic. The persons and incidents are mostly drawn from peasant life. Most of them are capitally told. A few are somewhat joumalistic and hurriedly written. There is no caricaturing nor " Stage Irishism." Some are legends of places, others typical fairy or folk tales. There are a large number of woodcuts, which, however, have no connection with the letter-press. 
[O'CONNOR, Joseph K.], “ Heblon." B. 1878, at Ashford, Co. Limerick. Ed. S. Heart College, Limerick, and Clongowes Wood College. A Barrister residing ir Dublin. Wrote also a drama entitled "Blight," which was produced in the Abbey Theatre, Dec., 1917.

1289 STUDIES IN BLUE. (Fallon). 2s. Illustr. by C. A. Mills. [Sealy, Bryers, 1900]. 1905.

Sketches, true to life, and cleverly told, of the most disreputable side of Dublin slum-life, as seen, chiefly, in the Police Courts. Amusing, but at times verging on vulgarity.

O'CURRY, Eugene, 1796-1862. One of the greatest of Irish scholars. A native of Carrigaholt, Co. Clare, and a native speaker of Irish. In 1834 was employed on the topographical survey, which was discontinued in 1837. Worked on Irish MSS. in Royal Irish Academy, T.C.D., etc. In 1849 and 1855 he examined the Irish MSS. in the British Museum. Was the first professor of Irish history and archæology in the Catholic University of Ireland, 1855. $\mathrm{He}$ published his lectures, Manners \& Customs of the Ancient Irish and The MS. Materials of Irish History, and edited a very large number of important Irish works.

1290- THE BATTLE OF MAGH LEANA; together with the Courtship of Monera. Pp. xxiv. +190. Demy 8vo. (Dublin: Printed for the Celtic Society). 1855.

Ed. for Celtic Society, with transl. from the Yellow Book of Lecan, and introduction setting forth the historical basis of the tales. The second tale relates the expedition of Eoghan Mor into Spain to wed Monera, the daughter of the King of Spain.

\section{1- THE SICK-BED OF CUCHULAINN AND THE ONLY JEALOUSY OF EIMER. Pp. 59. (Dublin : Fowler). 1858.}

Irish text and transl. reprinted from Atlantis for July, 1858.

O'DONNELL, John Francis, "Caviare," etc. D. 1874 at the age of 35. Publ. Memories of the Irish Franciscans, a volume of verse; sometime editor of THE LAMP. A well-known literary man in his day. I am informed that he published novels entitled Evictions and Evicted and Sadlier the Banker, but have not been able to trace them further. Wrote for many Irish magazines.

1292_ THE EMERALD WREATH. (Duffy). 3s. 6d. Frontisp. in colour and numerous engravings by Bros. Dalziel. 1865.

"A fireside treasury of Legends, Stories, etc." (Subt.). Contains two poems and the following stories :- "Sybil Grey's Secret," "Benevolent Freak of an Old Gentleman," "The Double Shadow," "Tom Hickey and the Good People," "Mike Driscoll and the Fairies." The two last are humorous Irish stories, told in the dialect of Adare and Castleconnell, where the scenes are laid.

\section{O'DONNELL, LUCY.}

1293-S'T. PATRICK'S CATHEDRAL. Pp. 86. (Dublin : Curry). 1855.

The fortunes of the house of Desmond in the 16th century, and chiefly those of Lord James Fitzgerald (son of the great Earl) who became a Protestant, and was therefore rejected by his people and retired to England. The story opens with i Protestant service in St. Patrick's Cathedral in 1581. It contains interesting allusions to Glendalough, Dublin, and Adare. Author's viewpoint Protestant.

\section{“ O'DONOVAN, Gerald."}

1294_ FATHER RALPH. Pp. 494. (Macmillan). 6. Six impressions within a few months. 1914.

An anti-clerical and modernist novel by an author with inside knowledge of the Catholic Church in Ireland. It is the story of a young priest from his birth until 
" O'DONOVAN, Gerald "-(continued).

we take leave of him (défroqué) on board a ship leaving Ireland. In the course of the narrative there is presented a general view of Irish life, as seen from the standpoint of such writers as M. J. F. M'Carthy, W. P. O'Ryan, and " Pat," but clerical life is depicted with far more minute knowledge than by any of these. Sensational features, such as the amours of priests, nuns, \&c., are avoided, though much innuendo is indulged in. All the estimable characters in the book are ropresented as either Modernists, or else voteens and people who avoid thinking on serious problems. The Bishop, Father Molloy, and Ralph's mother, as depicted by the Author, are revolting in the extreme. Except in rare instances all the outward details of Irish life are true to reality, but seen with jaundiced eyes. It may fairly be said that there is scarcely a page of this book that does not appeal in one form or another to non-Catholic prejudice.

1295- WAITING. Pp. 387. (Macmillan). 6s. 1914.

Maurice Blake is a young National Schoolmaster, an ideal teacher, an enthusiast for Irish Ireland and for industrial revival. He falls foul of Father Mahon, the P.P., who is made as odious as possible. Maurice cannot get a dispensation to marry Alice Barton, a Protestant, and is compelled to marry her in a registry office. Maurice is selected as candidate by his constituency but, through the agency of Fr. Mahon, is set aside in favour of a worthless drunkard, and a mission is preached by "Seraphists." Ch. XXIII., describing this mission, is most offensive and vulgar. Minor characters are Driscoll, the former Master; Breslin, editor and free-thinker; Fr. Malone, a lovable character; Dr. Hannigan with his "diffident, humble manner" covering the pride of Lucifer" ; Fr. Cafferley, fond of tea parties in publicans' back parlours, \&c. The CHURCH Times says of the book, "It is much more angry and malevolent than its predecessor," and the TIMEs IIT. SUPPL., in an article obviously written by a non-Gatholic, "It is bitter and, if true, a deadly attack on the priesthood, and an almost rancorous indictment of the practice and influence of the Roman Catholic Church in Ireland."

O'DONOVAN, John, 1806-1861. One of the greatest of Irish scholars. Did great work in company with O'Curry on the Irish Ordnance Survey. Ed. many of the publications of the Irish Archaeological Society. 1'ubl. an Irish Grammar in 1845. His great work was his ed. of the Annals of the Four Masters, 1848-51.

1296- THE BANQUET OF DUN NA nGEDH AND THE BATTLE OF MAGH RATH. Pp. xxiii.+358. 4to. (DuBLIN : for the Irish Archaeological Soc.). 1842.

An ancient historical tale here first publ. with transl from a MS. in T.C.D. Library, for the Irish Archaeological Soc. The battle is said to have been fought in 637 A.D. and was one of the most famous ever fought in Ireland. The story of it is here interspersed with fables.

1297— THE BOYISH EXPLOITS OF FINN MAC CUMHAILL. (DUBLIN: printed for the Ossianic Society). 1859.

P.p. 281-310 of a vol. of Fenian Poems ed. by John O'Daly, who gives a general introduction about the Fianna.

\section{O'DONOVAN, Michael.}

1298- MR. MULDOON. Pp. 328. (Greening). $6 s$.

Scene: Dublin and suburbs. A book for an idle hour, recounting the whimsical adventures of the hero and his experiments with professions of all kinds. Humour broad, but not vulgar.

O'DUFFY, Richard J.

1299 THE FATE OF THE CHILDREN OF LIR. (Society for the Preservation of the Irish Language). [1883]. New ed., 1897, etc.

Irish text and transl. founded upon O'Curry's version. 
O'DUFFY, Richard J.-(continued).

1300 - THE FATE OF THE CHILDREN OF TUIREANN. Pp. 270. (Society for the Preservation of the Irish Language). 1888.

Ed. with transl. from a MS. of William Casey, 1820. One of the famous three sorraws of story-telling.

1301- THE FATE OF THE CHILDREN OF UISNEACH. Pp. xii. +150. Demy 8vo. (Society for the Preservation of the Irish Language). 1898.

Ed. with transl. from a MS. of Andrew MacCurtin, 1740.

O'FlAnAgan, James Roderick, B.L., M.R.I.A. Was b. at Fermoy in 1814. Practised successfully at the bar for many years. Wrote some important works on Irish biography and topography, such as 'The Blackwater in Munster; T'he History of Dundalk (with John Dalton); Lives of the Lord Chancellors of Ireland; The Munster Circuit; 'The Irish Bar. Founded the FenMor Journal. Publ. his autobiography, An Octogenariun Literary Life, Cork, 1896.

1302- GENTLE BLOOD; or, The Secret Marriage. A Tale of High Life. (Gill). 1861.

Founded on the Yelverton marriage case, a cause célibre of the fifties. The characters and scenes are thinly disguised-Whiteside, Serj. Sullivan, Killowen, Avondale, etc. The unpleasant theme is carefully handled. Several pages are devoted to well-known anecdotes of Barry Yelverton, first Lord Avondale. There is a good deal about the Crimean War and, as usual with this Author, there are excellent sporting scenes such as the descriptions of coursing in the Galtees. The dialect is well reproduced.

1303 - THE LIFE AND ADVENTURES OF BRYAN O'REGAN : An Irish Sporting Tale. Pp. viii.+260. (Dublin: Warren). Boards. n.d. (1866).

The autobiography of a young squireen at the opening of the 19th century. The hero hunts with the Duhallows (here the country round Fermoy and Mallow is described), wins a steeplechase, courses on the Curragh, staghunts in Leitrim. He becomes defendant in a breach of promise case tried before Chief Justice Joker (Norbury), the counsel in the aase being Sergeant Silver (Goold), and Daniel Derrynane (O'Connell). He is called to the bar and then happily married, but goes through many further vicissitudes of fortune. A pleasant, healthy story modelled on Lever's earlier manner. Appeared originally in Dublin Saturdar Magazine, Vol. 1.

1304- CAPTAIN O'SHAUGHNESSY'S SPORTING CAREER.
biography. 2 rols. pp. 283+275. (Chapman i Hall). 1873.

All Auto-

The Capt., after a childhood spent at "Ballyhooly Castle," his ancestral home near the Blackwater in Munster, joins the arny. Is stationed first in Ireland, then in India. Returns to be aide-de-camp to the Lord Lieutenant. Scene: Ireland and India, with incidental descriptions of France, Belgium, and Switzerland. The interest is two-fold:- first to uphold the renown of the south for field-sports which are lavishly described, second, description of manners from about 1850 till the end of Lord Carlisle's Viceroyalty, 1864, with descriptions of some historical events such as the investiture of the Prince of Wales in 1868 as Knight of St. Patrick. The plot is slight.

[O'FlANAGAN, T.]; "Samoth." A native of Castlefin, Co. Donegal. He wrote also Strubane and Lifford, The Consequences of a Refusal, \&c.

1305- NED M'COOL AND HIS FOSTER BROTHER. Pp. 281. (DeRRY: printed at Offices of Derry Journal). 1871.

Sub-t., "An Irish tale founded on facts." 
O'FlANAGAN, Theophilus, "formerly Saholar of T.C.D. land now Secretary to the Gaelic Society."

1306 - DEIRDRI, or, The Lamentable Fate of the Sons of Usnach. Pp. 178. (Dublin : printed by John Barlow). 1808.

Literal trans. with notes, etc., to which is annexed the old historic account of the facts on which the story is founded. The text is also given. It is printed as part of Vol. I. of the Transactions of the Gaelic Soc. of Dublin.

OGLE, Thomas Acres. Was a militia captain and resided at Logan Shade, Carm, Co. Wexford. Publ. two vols of poetry, 1865.

\section{7- THE IRISH MILITIA OFFICER. Pp. 314. 12mo. (Dublin: no name} of publ.). 1873.

"The tale embraces the services of the old Wexford Regiment from 1810 to its disbandment in 1816, and is a true picture of the rollicking and free life of that halfdisciplined soldiery." (l'mef.). Full of staries, good, bad, and indifferent, told with considerable spirit. One chapter goes back to '98, and gives some interesting personal reminiscences. There are a good many love affairs. The Author is a firm loyalist, and something of an Orangeman, but displays little bias. The scene is laid in various parts of Ireland.

O'GRADY, Standish. B. 1846, at Castletown Berehaven, on Bantry Bay, Co. Cork, of which his father was rector. Fd. at home and in Tipperary, and at T.C.D. Was called to the Bar, but his main occupations have been literary. Besides the works here mentioned he has written much on literary, political, and economic subjects, and is one of the most distinguished of living Irish writers. A collected ed. of his works in 7 vols. has for some time been announced by the T'albot Press. His most recent publication is a tiny booklet (Talbot Press, 1917) The Departure of Dermot, i.e., of Dermot MacMurrough on his mission to Henry II. It reads like a chapter from a longer historical novel.

\section{8- HISTORY OF IRELAND. The Heroic Period. Two Vols. Pp.} xxii.+267+348. (Sam pson, Low). 1878.

Described by the Author (Pref.) as "the reduction to its artistic elements of the whole of that heroic history taken together, viewing it always in the light shed by modern archæologians, frequently using the actual language of the bards, and as much as possible their style and general character of expression."

"Through the loose chaotic mass . . . . I have endeavoured to trace the mental and physical personality of the heroes and heroines, and to discover the true order of events." The chapter headings read like those of a novel-" Only a Name," "Perfidy," "In Vain," "Swift Succour." Vol. I. deals with the Fianna, Cuchulain, the Cattle-raid of Culailgne. Vol. II. is entirely taken up (all but the first $88 \mathrm{pp}$.) with the Cuchulain cycle. The above work is carefully to be distinguished from the Author's History of Ireland, Critical and Philosophical. Vol. I. (all publ.) pp. 458 (Sampson, Low), 1881. In the Pref. to this latter he says, "The books already published by me on this subject are portions of a work in which I propose to tell the History of Ireland through the medium of tales, epic or romantic."

N.B.-This is not a work of fiction. But it seems well to mention it here for it is really an elaborate re-telling of the ancient Irish hero-myths and romances.

1309 — RED HUGH'S CAPTIVITY. 1889.

An early ed of The Flight of the Eagle, q.v.

1310_ FINN AND HIS COMPANIONS. Pp. 182. Size, $4 \times 6 \frac{1}{2}$. (Unwin, Children's Library). Illustr by J. B. Yeats. 1892.

Delightful tales of the heroic age of the Fianna told in poetic but very simple language. Will appeal not to children only but to all. Part IV., "The Coming of Finn," is particularly fine. "Most of these tales are, I think, quite new."(Preface). 
O'GRADY, Standish-(continued).

\section{1- THE BOG OF STARS. Pp. 179. (Fisher Unwin, New Irish Library). 2s. 1893.}

Stories and pictures, nine in number, of Ireland in the days of Elizabeth " not so much founded on fact as in fact true."-(Pref.). (1) How a drummer-boy saved Clan Ranal from destruction by the Deputy; (2) A Sketch of Philip O'Sullivan, historian, soldier, and poet; (3) The destruction of the O'Falveys by Mac an Earla of the Clan M'Carthy ; (4) The vengeance of the O'Hagans on Phelim O'Neill; (5) A sketch of Sir Richard Bingham, the infamous but mighty Captain of Connaught; (6) How the English surprised by treachery Rory Og O'More and his people; (7) The story of Brian of the Ramparts O'Rourke; (8) Don Juan del Aquila, the heroic defender of Kinsale; (9) Detailed and vivid description of the battle of the Curlew Mountains from the Irish point of view. These have all the great qualities of the Flight of the Eagle, and indicate the same views of history-the selfishness and frequent savagery of some of the Irish chieftains, their hatred of one another, their constant readiness to submit to the Queen's grace when it suited-all this is brought out. Yet the Author is on the side of Ireland: he dwells on what is heroic in our history, he paints the Elizabethan deputies and their subordinates in dark colours.

1312- THE COMING OF CUCHULAINN. Pp. 160. (Methuen). Six good illustrations by D. Murray Smith. 1894. New editions since.

'The story of the hero's boyhood told in epic language, full of antique colour and simile, and rising at times to wild grandeur. The great shadows of ancient $\mathrm{De}$. Danaan gods are never far from the mortal heroes who figure in the saga.

1313_THE GATES OF THE NORTH. New ed. Pp. 151. (Sealy, Bryers). 3s. $6 d .1908$.

A sequel to the preceding, telling the heroic tale of how Cuchulainn held the fords cf Ulster alone against the hosts of Maeve. It is even fuller than is the first book of the myth and lore of the primitive Gael. There is a very interesting introduction by the Author.

The Talbot Press announces a new ed., with an Introd. by $\mathbb{E}$., of the above two books, together with a third, The Triumphs and Passing of Cuculain, the whole under the title of The Cuculain Cycle.

1314_LOST ON DHU CORRIG. Pp. 284. (Cassell). Nine good illustr. 1894.

Strange adventures among the caves and cliffs of the west coast, with a touch of the uncanny, and some interesting and curious things about seals. For boys.

1315_ THE CHAIN OF GOLD. Pp. 304. (Fisher Unwin). Sixteen good illustr. Nice cover. 1895.

A story of adventure on the wild west coast of Ireland. Curious and original plot, with an element of the supernatural. A book for boys.

1316- UIRICK THE READY. (Sealy, Bryers). 3s. 6d. [1896]. New ed.

Period : last years of Elizabeth's reign. Scene : the country of O'Sullivan Beare, the south-west corner of Cork. Weaves the battle of Kinsale and the siege of Dunboy into the story of the young O'Sullivan, Ulrick. Full of vividly presented details of the public and private life of the time, and of novel and suggestive presentments of its political and social ideals. These it brings home to the reader as no history could do. Yet the story is not neglected. Standpoint : impartial on the whole.

1317- IN THE WAKE OF KING JAMES. Pp. $242 . \quad$ (Dent). 4s. $6 d$. [1896]. New ed. in Wayfarers' Library, 1917.

$A$ wild and nightmare-like tale. Scene: a lonely castle on the west coast inhabited by a gang of Jacobite desperadoes. Contains no historical incidents. 
O'GRADY, Standish-(continued).

1318- THE FLIGHT OF THE EAGLE. Pp. 298. (Sealy, Bryers). 3s. 6d. [Lawrence \& Bullen, 1897]. New ed., 1908. (N.Y.: Benziger). 1.10.

The historical episode of the kidnapping of Hugh Roe O'Donnell and his escape from Dublin Castle evoked in a narrative of extraordinary dramatic power and vividness. The Author has breathed a spirit into the dry bones of innumerable contemporary documents and State Papers, so that the men of Elizabethan Ireland seem to live and move before us. The effect is greatly strengthened by the vigoar and rush of the style, which reminds one of that of Carlyle in his French Revolution. The Author has peculias and decided views albout Elizabethan Irish politics. "The authorities for the story," he tells us in his Preface, "are the Annals of the Four Masters, the Historia Hibernice of Don Philip O'Sullivan Beare, O'Clery's Life of Hugh Roe, and the Calendar of State Papers, Ireland, from 1587 forward."

1319 STANDISH O'GRADY : Selected Essays and Passages. ('I'albot Press). 3s. n. 1918.

Ed. with introd. by Ernest A. Boyd. Every Irishman's Library.

O'GRADY (Standish Hayes). B. Erinagh House, Castle Connell, Co. Limerick, 1832. A younger son of. Admiral Hayes O'Grady (1787-1864), brother of Viscount Guillamore. Brought up and "fostered" in the Irish-speaking barony of Coonagh, he became thoroughly at home in the language. Ed. Rugby and T.C.D. never losing his love of Irish lore. Became President of Ossianic Society in 1856. Then he spent thirty years in U.S.A. as an engineer. The rest of his life was spent in England, where he died on Oct. 16, 1915. He compiled part (672 demy 8vo. pp.) of a great " Catalogue of Irish Manuscripts in the British Museum." Owing to some disagreement with the Museum anthorities it remained unfinished. Dr. Norman Moore describes it as containing " more learning on Irish literature and history, with better illustrations of the language than are to be found in any other single treatise. A posthumous work of his, an edition of 'The 'Triumphs of Turlough O'Brien by John Rory McGrath is at present passing through the CAMBRIDGE "UNIVERSITy Press. For fuller particulars see Studies for March, 1916, and The IrIsH BOOK Lover for December, 1915, from which the above note has been compiled.

1323 - - THE PURSUIT AFTER DIARMUID O'DUIBHNE AND GRAINNE.

Pp. 324. Demy 8vo. (Dublin : printed for the Ossianic Society by John O’Daly). 1857.

Text and transl. of an ancient Irish saga of the Fenian Cycle. Ed. with introd. and copious footnotes and index. The vol. contains also a story "How Cormac MacAirt got his branch," and a poem, "The Lamentation of Oisin After the Fenians."

\section{1 - THE PURSUIT OF DIARMUID AND GRAINNE. 2 vols. $12 \mathrm{mo.}$} Pp. 297 and 215. (Gill). 1880.

Published for the Society for the Preservation of the Irish Language. " Selected from the publications of the Ossianic Society [1857]" as being " the most solid and useful piece of the class of literature to which it belongs." (Pref. of the Society). Text, Transl. and Notes by Editor. Vocabulary and Append. by the Society. The Editor's introd. (abridged), pp. xxx., has been prefixed to Vol. II. : it deals with the Fenian or Ossianic Cycle. The story tells how Grainne, daughter of King Cormac Mac Art and chosen wife of Fionn, eloped with Fionn's warrior Diarmuid O'Duibhne and how Fionn pursued the pair until the tragic end. Besides its interest as a story this tale oantains much curious information on topography, the natural productions of various localities, and ancient manners and customs. 


\section{O'GRADY (Standish Hayes)-(continued).}

\section{2- SILVA GADELICA. Two Vols. Demy 8vo. (Williams \& Norgate). 1892.}

Vol. I., pp. 416, contains Irish text (Roman letters); Vol II., pp. xxxii.+604, contains Pref., Trans., and Notes. Thirty-one tales and other pieces, all taken from ancient MSS., such as the Book of Leinster, the Leabhar Breac, \&c. Fifteen are from MSS. in the British Museum. Out of the thirty-one, only six or seven had been published before. Ranged under four heads-(I.) Hagiology, or Stories of early Irish saints; (II.) Legend, historical or romantic; (III.) Ossianic lore; (IV.) Fiction, some of which is humorous. The Irish text is presented in a difficult and archaic dialect, much as if, says a critic, Robinson Crusoe and the Anglo-Saxon Chronicle were to be printed in the dialect of Chaucer. The Author in his Preface discusses and describes his sources most minutely. Forty years of study intervened ketween the Author's previous publication Diarmaid and Grainne, for the Ossianic Society (1853) and this. The English of his translation, though sometimes affected, is vigorous, rich, varied, often picturesque, and on the whole thoroughly worthy of the subject. Twenty-eight pages of notes and corrections. Indexes : A, of personal and tribal names; $B$, of place-names.

O'HANLON, Canon John; “Lageniensis.” B. Stradbally, 1821. From 1842-1857 he was in U.S.A., where he was ordained. Publ. 18 important works dealing with Irish history, archæology, and especially hagiography, his great Lives of the Irish Saints, nine vols. of which appeared, being a lasting monument to his research. He died in 1905.

1323 - IRISH FOLK-LORE : Traditions and Superstitions of the Country : with Humorous Tales. (C'ameron d. Ferguson). Pp. viii.+312. 2s. 1870.

A miscellany containing folk-lore proper, studied in popular superstition viewed as remnants of paganism, historical episodes, tales, \&c., gathered from ancient MSS., with a great store of antiquarian and historical information about all periods of our annals and very many parts of Ireland. Much of all this is drawn from rare and not easily accessible sources. Contains chapters on Druidism, Legendary Voyages, Dungal the Recluse. A type of the humorous stories is the capital "Mr. Patrick O'Byrne in the Devil's Glen." The book is intended for the general public rather than for folk-lorists. It is pleasant and chatty in style. 'The source of the stories is not as a rule indicated by the Author.

1324- THE BURIED LADY : a Legend of Kilronan. (DUbLiN). 1877.

1325_ IRISH LOCAL LEGENDS. Pp. 133. (Duffy). 1s. [1896]. Still in print.

A collection of thirty stories picked up by the Author during holidays in various parts of Ireland, and " received mostly from accidental and familiar intercourse with the peasantry." - (Pref.). The place with which the legend is connected is indicated in each case. The legends are of a very miscellaneous nature, local incidents, fairy stories, ghost stories, old hero stories, \&c. A considerable number if counties are represented by one or more stories.

o h-AnnaAchain, Micheal. B. New Ross, Co. Wexford. Ed. Christian Bros.' Schools and Collegiate Academy, Carlow. Wrote a good deal for the Press. Was an ardent worker in the Language Movement. Was executed in May, 1916, as a result of the Rising in Dublin in Easter Week of that year.

\section{6- A SWORDSMAN OF THE BRIGADE. Pp. 231. (Sands). 3s. 6d. 1914.}

A fine stirring adventure story of the doings of one of the "Wild Geese" in Sheldon's division of the Irish Brigade in the service of France. Scene : Flanders, Bavaria, Italy, and Dublin. c. 1703. Told in a breezy way and thoroughly. Irish in spirit. 


\section{O h-ANNRACHAIN, Micheal-(continued).}

\section{7— WHEN THE NORMAN CAME. Pp. 170. (Maunsel). 1919.}

A straightforward historical romance of the Invasion 1169 sqq., with plenty of adventure, showing competent knowledge of the period, but not over-weighted with erudition.

\section{O'HARE, Hardress.}

1328-CONQUERED AT LAST: from Records of Dhu Hall and its Inmates. A Novel. Three Vols. 1874.

O'HIGGINS, Brian; "Brian na Banban." B. Kilskyre (Cill Scire), Co. Meath, 1882 ; ed. there. Came to Dublin about twelve years ago and threw himself into the work of the Gaelic League, for which he became a travelling teacher (múinteoir taistil) in Cavan and Meath. Has publ. two books in Irish. Has for years past been a frequent contributor to the Catholic and Irish press at home and in America and Australia. His songs are popular at Irish-Ireland concerts all over the country.

\section{9 - BY A HEARTH IN EIRINN. (G'ill). 1s. 1908.}

The gay and humorous side of the language movement seen from a League point of view-the Seonín, the Feis, the Gaelic Christmas hearth. One sketch gives a glimpse of the early years of John Boyle O'Reilly.

1330 GLIMPSES OF GLEN-NA-MONA. Pp. 115. (Duffy). 6d. Paper. [1908]. New ed. (Whelan). 1s. 6d. 1918.

Sketches of peasant life in a remote glen (place not indicated). Almost wholly taken up with the sadness and the miseries of emigration. Simple, pathetic, and religious.

\section{1- FUN O' THE FORGE. (Dublin: Whelan). [1915]. New and greatly} enlarged ed. at $2 s .1918$.

A collection of humorous stories. Contents:-1. The blacksmith's charm. 2. How Jimmy settled the sojer. 3. The confiscated bacon. 4. Bow-wow. 5. How Johnnie got his degree. 6 . The best of a bargain. 7. When Denis turned to the tay. 8. A glorious victory. 9. On elections. 10. Ned's trip to Dublin. 11. The lawyer for the defence. 12. The first plum pudding. The connecting link is Ned McGrane the story-telling blacksmith. Broad comedy without vulgarity or any trace of the "stage Irishman." The humour is as much in the telling as in the tale that is told. The quaint idiom is reproduced to the life but the brogue is not phonetically imitated. Several of the stories are adapted from the Irish of an Seavac.

1332- HEARTS OF GOLD, Stories and Sketches. Pp. 121. (Dublin: Whelan). 1s. 6 . $\pi .1918$.

Seventeen little sketches centring, nearly all of them, round Christmas in Ireland. One of them, "The Duckeen," is humorous. The style is full of colour and foeling. Religion is not expressly introduced. The sketches are all very similar in theme.

O'KANE, Rev. W. M. B. 1872, at Millisle, Co. Down. Son of Capt. Francis O'Kane, of Weymouth and Millis!e. Ed. Royal Academical Institution, Belfast, and at Queen's Coll., Belfast; B.A. and LL.B., R.U.I. Was curate in Banbridge and Belfast and is at present incumbent of Ashbourne, Derbyshire. Author of The King's Lucl: and Guppy Guyson.

1333 - WITH POISON AND SWORD. Pp. 402. (Mills \& Boon). 6s. 1910.

Love story and adventures, in 1561 or thereabouts, of Cormac O'Hagan, follower and friend of Shane O'Neill, his escape from the Tower, his rescue of Marjorie Drayton, his share in the battle of Armagh where Shane defeats the Deputy, his going with Shane to visit Elizabeth, and many sensational adventures in consequence. He finally gives up Ireland altogether, settles in England, and he and his descendants ever after are good Englishmen. One of the chief characters is the ever resourceful Dickie Toogood. 
O'KEARNEY, Nicholas.

1334 THE BATTLE OF GABHRA. (Printed for the Ossianic Society by John O'Daly). 1853.

Ed. for the first time for the Ossianic Society with introd. and transl. Legendary account of the great battle of Gabhra fought in the year 283 A.D., in which the Fianna were finally defeated by Cairbre, King of Leinster.

1335 - THE STORY OF CONN-EDA; or, The Golden Apples of Loch Erne, from the Irish. Pp. 17. (London: J. R. Smith). 1855.

Reprinted from the Proceedings of the "Cambrian Archæological Association."

1336 - THE FESTIVITIES AT THE HOUSE OF CONAN OF CEANN-SLEIBHE.

Pp. 216. (Printed for the Ossianic Soc. by John O'Daly). 1855.

Ossianic Soc. Translations II. Ed. with introd. and transl. from an ancient MS.

O'KEEFFE, Christopher $\boldsymbol{M}$. Was sentenced about 1866 to penal servitude for Fenianism, was released about 1877, went to U.S.A., and died in Brooklyn about 1889. Wrote also a Life of O'Connell in two vols.

1337— THE KNIGHTS OF THE PALE; or, Ireland 400 years ago. Pp. 263. (GLasGow: Cameron \& Ferguson). 1870.

"The object of the following story is to give, as livingly as the writer's powers admit, the impression which a prolonged study of Irish antiquarian authorities ... has produced on the author's mind, . . . to realize to the minds of the 19th century the aspects of warlike Ireland in the 15th." A rambling tale loosely connected iby the love story of Maude Barnewall and the O'Farrell of Annaly moves slowly through long descriptions and a wealth of archæological lore, e.g., ch. ix., the initiation of a knight, ch. xxi., a tournament, ch. xxxi., the burning of an old bard at the stake, the home life and manners of the O'Byrnes of Glenmalure, etc. The scene is Dublin and its neighbourhood, including the Castle of Drimna; the period is the reign of Henry VII. Introduces a strange half-mythical being, the Dollaher. The style is turgid and sprinkled with Irish words. The story abounds in improbabilities and in coarse and violent, though not immoral, scenes.

O'KEEFFE, J. G. ed.

1338- THE ADVENTURES OF SUIBHNE GEILT. Pp. xxxviii.+197. (Lond. : David Nutt for Irish Texts Soc.). 1913.

Trans., with Introd., Notes, and Glossary, of a middle-Irish romance in prose with long poems interspersed. It was composed between the 13 th and 15 th centuries. Suibhne, a chief of Dalaradia, goes mad in consequence of the curse of St. Ronan and wanders about Ireland, meeting with many adventures and suffering many things. The supernatural is freely introduced-hags, goblins, etc., and the incidents are strange and fantastic. Some of the poetry is very beautiful.

O'KELLY, Seumas. B. about 1881 at Loughrea, Co. Galway. Ed. there at St. Brendan's Seminary. After leaving school began career as journalist by writing for and editing provincial papers in Skibbereen and in Naas. Soon he contributed largely to Dublin weeklies and monthlies. Later he settled in Dublin, where he joined in the new literary movement centring in the Abbey Theatre. Has written a number of successful plays. Died Nov., 1918. For some time before his death he had been editing Nationality.

1339 - BY THE STREAM OF KIIMEEN. (Sealy, Bryers). 6d. Paper. c. 1910.

Ten short sketches of the little tragedies and comedies of the lives of the humbler classes. They are simple, true, and sincere. The scene is Clare or Galway.

1340 THE LADY OF DEERPARK. Pp. 308. (Methuen). 5s. N. 1917.

Mary, heiress of Deerpark, an estate in Connacht, is the last of the Heffernans, a proud, hard-drinking, profligate race, who have successively squandered the 


\section{O'KELLY, Seumas-(continued).}

property, till now it is all but a fiction and Heffernan grandeur is no more. Suddenly comes unlooked-for affluence and with it new life and hope to Mary Heffernan. She bestows her love on petty, mean-spirited, selfish Paul Jennings. It is rejected and she subsequently marries Kish Massy, horse trainer, a coarse and vulgar brute. The end is unrelieved tragedy. The central figure is Mary with her high-born, oldworld refinement and dignity. The writing is uneven, scenes of genuine pathos and reality alternating with melodrama. The descriptions of the Hunt Club annual concert and of Ballyrea Fair are two pletures of real Connacht life.

\section{1- WAYSIDERS. Pp. 203. (The Talbot Press). 2s. 6d. Frontisp. by} Michael Willmore. 1917.

Ten stories and impressionist sketches of Western Connacht. They are distinguished by a style that is above the common, by a sense of material things-western landscapes, sounds, etc.-conveyed with exceptional vividness. Occasionally they strike one as overwrought, notably the study of the agonies and death of the white goat. But for the most part they are studies from life seen with the eye of an artist. They are varied-the quietly humorous yarns of the Shoemaker, the delightful fairy tale of the Grey Lake, the Rector, that little glimpse of Irish Protestantism seen from outside, the sadness of the pauper's grave, the weirdness of the Sick Call, the tragedy of the Building. There are no politics and but little dialect.

O'KENNEDY, Father Richard. B. 1850 near Shanid Castle, Co. Limerick. Ed. at Maynooth. Has been for a long time P.P. of Fedamore, near Bruff, Co. Limerick. For nearly 50 years past has been contributing tales and sketches on Irish peasant subjects to various periodicals--the Monitor, the CATHOLIC WorLD (U.S.A.), the IrIsh Monthly, the Ave Maria (U.S.A.). Hitherto his only publications in volume form have been books on devotional subjects. "He knows his people intimately and knows how to interest us in the simple pains and pleasures of the poor. . . His style is charming. He has an eye for the simplicities of life."-(IRISH Lit., which gives a specimen of his work).

O'LEARY, C. Wnote also The Last Rosary (Boston), 1869.

1342_ THE IRISH WIDOW'S SON ; or', The Pikemen af '98. (Boston). 1869.

O'Leary, Canon Peter, P.P., An $\tau$-A亡ar peatar. B. Liscarrigan, Co. Cork. Ed. at St. Colman's Coll., Fermoy, and Maynooth. P.P. of Castlelyons, Co. Cork, Vice-President of the Gaelic League. Generally held to be the greatest living master of Irish prose. Author of a long series of some 24 books in Irish, including translations and adaptations, as well as original works. Among these are 11ani, eisire, Oricriu, an Cleasure, An Craos-Oeaman, several plays and a volume of sermons. He has recently published his autobiography, 1839-1912, under the title, mo sséal férn.

1343_ SHIANA. Pp. 291.

(Irish Bool: Co. and Browne and Nolan).

$6 s$.

Portrait of Author. 1916.

A version in idiomatic and readable English (retaining, however, much of the peculiar flavour of the Irish original) of the Author's Sédona, which first appeared 11 years ago. The story is a kind of fairy tale or rather a "morality play" (like Faust) in narrative form and with an Irish setting. The moral interest is predominant throughout. Shiana, a country shoe-maker, gets into the power of the Devil, who is to come for him after 13 years, but by renunciation and good works and with supernatural help from heavenly visitants Shiana gets the upper hand and the "Black Man" is worsted in the end. The tale purports to be told at the fireside by a little girl to four younger companions and there are interludes of lively dialogue. There is much quiet humour throughout. The account of the fair in Ch. IV. and of the fairy music in Ch. XXVII. are noteworthy pieces of description. 
O'MAHONY, Nora Tynan. A sister of Katharine Tynan, q.v. Dau. of the late Andrew C. Tynan, of Whitehall, Clondalkin, Co. Dublin. Married John O'Mahony (d. 1904), a brilliant Irish barrister. She has written much for Irish and American periodicals and has just published a vol. of poems which has been highly praised. Her work is simple, gentle, with many touches of beauty. The atmosphere is always Irish and Catholic.

1344-UNA'S ENTERPRISE. Pp. 241. (Gill). Neat binding. 1907.

Struggles of a young girl of good social position to maintain her widowed mother and little brother and sister. She eventually does this by means of poultry farming, of which much is said. There is little distinctively Irish in the story. The style is graceful and pleasing.

\section{5_ MRS. DESMOND'S FOSTER CHILD. Pp. 120. (Browne \& Nolan).}

1s. 6d. Frontisp. 1912.

A slight story for children about a little girl left behind by Anglo-Indian parents in charge of an Irish farmer's wife. The latter for some motive exchanges babies but, when there is question of taking the supposed Anglo-Indian child back to India, she breaks down and confesses. The incidents are trifling for the most part and the Author assiduously "writes down" to her juvenile readers. The " atmosphere" is not distinctively Irish.

\section{O'MEARA, Graves.}

1346- OWEN DONOVAN, Fenian. (Sealy, Bryers). 6d. Paper. 1909.

Adventures of a Fenian in England, and of his lady-love, a prima donna at Covent Garden. Plenty of sensation, of a crude and improbable type. A "time-slayer,". as the Author calls it.

O'MEARA, Kathleen; "Grace Ramsay." B. Dublin, 1839. Dau. of Dennis O'Meara, of Tipperary, and granddaughter of Barry $\mathrm{O}^{\prime} \mathrm{M}$., Napoleon's surgeon. She went with her parents to Paris at an early age, and it is doubtful whether she afterwards visited her native land. D. N. B. enumerates fifteen of her works, six of which were novels. D. 1888.

1347- THE BATTLE OF CONNEMARA. (Washbourne). 1878.

A story of priests and people in Connaught in the days of the Soupers by an Author distinguished in other fields of literature. The scene is laid partly in Paris. Noteworthy characters are Mr. Ringwood, an English convert clergyman, and Father Fallon, an Irish country priest. The plot turns mainly on the conversion of an English lady who had married an Irishman and settled in Connaught. Controversy is avoided.

O'MULLANE, M. J., M.A. B. 1889 in Sligo. Gained an honours diploma in education in the National University. Is Principal of the National Examining Institute of Ireland, Professor of Mod. Languages in Christian Schools, Westland Row, and of Irish in Spiddal Summer Irish College, Galway. He has contributed serials on Irish historical subjects to Oun Boys. He has done much to spread among the people knowledge of and interest in the heroic period of early Gaelic Ireland by means of his excellent penny C.T.S.I. pamphlets, soon, we hope, to be given a more permanent form.

1348- IRISH HERO TALES :-

Craobh Ruadh; or, the Red Branch Knights. Two parts. 1910.

This is partly a serious study of the subject, partly a retelling of the old sagas.

I'he 'I'uatha de Danaan; or, the Children of Dana. Two parts.

Linlis with the Past. Containing "Lug-na-Gall" (a legend of 1642), "Green are the Distant Hills," "The Origin of Lough Gill," "Melcha," "The Wooing of Eithne."

The Coming of the Children of Miledh.

Finn Macloole. 
O'MUllane, M. J., M.A.-(continued).

Biroge of the Mountain, and Other Tales, viz. :- "The Recovery of the Táin Bo Cuailgne," "The First Water-Mill in Ireland," "The Wooing of Moriath," -all tales of early Ireland.

T'he Return of the Red Hand. A story of Dunamase, fortress of the O'Moores in the year 1200.

The Wooing of Etain. 1916.

These nine pamphlets are very well but not pretentiously written. They are written with good knowledge of the period referred to, but are not overloaded with archæology. In footnotes the pronunciation of the Gaelic names is given phonetically. The first eight of these booklets, together with Fr. Skelly's Cuchulainn of Muirthemne (q.v.) form an excellent introduction to Ireland's Heroic Period and to our saga literature.

O'NEILL, John. Born in Waterford, 1777. Lived the last years of his chequered life in poverty in London. Published several volumes of verse, chiefly on 'lemperance subjects, and a drama entitled Alva. D. c. 1860.

1349 HANDRAHAN, the Irish Fairy Man; and Legends of Carrick[-on-Suir]. Edited by Mrs. S. C. Hall and publ. 1854. (London : Tweedie). Pp. 187.

A very good and original story. Handrahan is a kind of herb-doctor skilled in potions and in charms against the fairies.

1350_ MARY OF AVONMORE; or, The Foundling of the Beach. Three Vols.

"O'NEILL, Moira," Mrs. Skrine, née Nesta Higginson. Author of the well-known Songs of the Glens of Antrim. Her home was long in Cushendun, Co. Antrim. She has also published An Easter Vacation, 1893. A frequent contributor to Blackwood's MaGazine

1351_ THE ELF ERRANT. Pp. 109. (A. H. Bullen). Seven illustr. by W. E. F. Britten. [1895]. New ed. 1902. Republished, Christmas, 1909, by Sidgwick \& Jackison, 38. 6d.

An excursion into Fairyland. A fanciful tale, told in exquisite and simple language, with elves and fairies for characters. All through there is a subtle comparison, which only the grown and thoughtful children will notice, between English and Irish character. This latter by no means interferes with the interest of the bork for children, but makes it well worth reading by the grown-ups.

O'REILLY (Gertrude M.), b. in Ireland of a family much identified with the national cause. Her mother was a McDonnell of the Glens of Antrim, a daughter of Col. Alexander McDonnell, of Cushendal, a convert to the Catholic faith. Ed. by Sacred Heart Nuns, Mt. Anville and Roehampton. Went through a distinguisned University course. Won special prize at Oireachtas for studies in ancient Irish MSS. In 1905 her health broke down. She settled for a time in the Claddagh, Galway, but in 1907 went to U.S.A. She has since written much for the Press, and lectured on Irish subjects. She resides in Chicago.

1352_- JUST STORIES. Pp. 233. (N.Y. : Devin-Adair Co.). 1.00. 1915.

Agnes Repplier says of the book: "These Irish stories are as good as good can be; gay, sad, amusing, pathetic, human. I like the stories themselves; I like the way they are told. They don't. suggest 'plot,' but bits of real life." In the Pref. the Author says : "Thoughts go back to the long restful days beside Galway Bay, to the still evenings in the Cork hills. . . . These little stories are the fruit of these moments of retrospection." There is much dialect, well reproduced.

"O'ReIlly, Private Myles," see halPine. 
ORPEN, Mrs.

1353-CORRAGEEN IN '98. (Methuen). 6s. (N.Y. : New Amsterdam Book Co.). Pp. 325. 1.50. 1898.

"Written with sympathy for the loyalists. A realistic description of the more horrible features."-(Baker).

O'RYAN, Julia and Edmund, sister and brother. The latter was a doctor in Youghal, where he died in 1903, aged 78 . He wrote for the TABLET, Nation, LAMP, etc. His sister was his partner in literary work, contributing verse and stories to the Irish Monthly, Catholic World (N.Y.), Chambers' Journal, etc. She died in 1887.

1354-IN KE GARLAND. Pp. 219. (Richardson). 1873.

'Time : after Famine of 1846, when the Encumbered Estates Court was in full swing. Cleverly written, and showing intimate knowledge of Munster ways of speech and thought among the farming and lower classes. Good taste and strong faith in the people and in the people's faith are everywhere discernible. The writers eschew all moralising and also all description of scenery.-(IRIsh MonthLy).

O'RYAN, W. P.; “ Kevin Kennedy." B. near Templemore, Co. Tipperary, 1867. Lived for several years in London, where he took an active share in the activities of the Southwark Irish Literary Club and the Irish Literary Society : he has written a history of their beginnings. Was editor of The Peasant, and of its successors, The Irish Peasant and The Irish Nation. In these he mingled anti-clericalism with much excellent writing strongly national in tone. 'The Plough and the C'ross is largely autobiographical. Publ. 1912, The Pope's Green Island.

1355- The PLOUGH AND The CROSS. Pp. 378. (The Irish Nation). $1 s$. 1910.

A story, how much of which is fact we do not learn, woven round certain real events of recent date, and in particular the stopping of a paper of which the Author was editor. Many of the characters may be recognised as portraits of real personages, among others the Author himself, Mr. T. P. O'Connor, Geo. Moore, Mr. James McCann, Mr. Edward Martyn, and Mr. Sweetman. The book is largely taken up with convensations in which the Author gives expression to his peculiar views on many subjects. Many of these belong to the class of ideas known collectively to Catholics as Modernism. Throughout the book there is constant criticism of the Irish clergy, much of this criticism being put into the mouths of "progressive" priests. The personages and the series of events dealt with are highly idealised. Distinctly well written, but somewhat "exalté" in style. Scene : Dublin and the Boyne Valley.

See RYAN, W. P.

\section{O'SHAUGHNESSY, TOM.}

1356_ TERENCE O'DOWD; or, Romanism To-day. Pp. 350. (Philadelphia : Presbyterian Board of Publication). n.d.

"An Irish story founded on facts." Scene near Mt. Nephin and the Deel, Co. Mayo. A long diatribe against the Catholic Church, representing it in the most odious light, in order, says the Introd., to warn Protestants that it is the same monstrously wicked system as ever. Ignorance, squalor, rudeness, and brutality are the terms constantly used to describe the Irish peasantry. The tone is often facetious and sarcastic. The peasants, including "Father McNavigan," speak an extraordinary jargon. Appendices give extracts from Kirwan's letter to Bishop Hughes. 
O'SHEA, James.

1357- FELIX O'FLANAGAN, an Irish-American. Pp. 206. (CoRK: Flynn). 1902.

The story of an Irish peasant lad, first in Ireland as clerk in a shop and commercial traveller in a small way, then in America as labourer, soldier, and business man. Good picture of farming and provincial town life in Ireland of the day. Point of view Catholic and strongly nationalist. The book is almost a sermon against drink and emigration. Style and handling of plot somewhat immature.

O'SHEA, John Augustus; "The Irish Bohemian." 1840-1905. B. Nenagh. Ed. Catholic Univ. Went to London, 1859. Was war correspondent and writer on THE STANDARD for twenty-five years. Was a man of extraordinary versatilityjournalist, writer on continental politics, lecturer, dramatist, Irish politician. He was a member of the Southwark Irish Literary Ciub, 1885, sqq. Mr. W. P. Ryan speaks of him as drawing upon his own experiences of "merry and dashing life" in Tipperary for his stories- "Conal O'Rafferty" and others. See his Leaves from the Iife of a Special Correspondent and Random Recollections.

1358- MILITARY MOSAICS: a Set of Tales, \&c. Pp. viii.+303. (Allen). 1888.

\section{O'SHEA (J. J.), Mrs. O'Shea Dillon.}

\section{9 — DARK ROSALEEN. 3 vols. (Tinsley). 1884.}

The Author was a sister of the preceding. The story introduces Father John Kenyon of '48 fame and James Stephens, the Fenian leader. Fenianism under the name of the Brotherhood of the Mystic Star is depicted, not unfavourably: the Master of it, James Hinson, is invested with some of the characteristics of Parnell. There is plenty of exciting incident. The whole book is inspired by an intense patriotism.

[O'SUllivan, Rev. P. P.], “An Irish Clergyman." B. 1874 in Ballina, where his parents, both natives of Berehaven, Co. Cork, were temporarily residing. Ed. at private school near Berehaven and at T.C.D., where he graduated as Senior Moderator and Gold Medalist in Mental and Moral Science. Was a native speaker of Irish, in which language he has preached. Has contributed Irish prose and verse to various periodicals and has translated George Moore's Untilled Field (q.v.) into Irish. Was a firm believer in the ideals of the Gaelic League. Was a professor in the Methodist Coll., Belfast. Was a clergyman of the C. of I. D. 1918.

1360 DOCTOR BLAIR; or, Irish Protestants under Home Rule. Pp. 204, close print. (Belfast: Carswell). 1s. 6d. 1912.

A speculative forecast of the fate that might befall the principal religious denominations in Ireland if they continue to stand in the way of the march of Irish ideals. An exhortation to the Churches to be Irish.

1361- THE DOWNEALL OF GRABBUM. Pp. 148. (Belfast: Carswell). 6d. Illustr. 1913.

A political skit on the then situation in Ulster. Grabbum=the English Garrison in Ireland; Drudge, his devoted dupe=Orangeism. Farmer John Bull sends Grabbum over to Pat to help him, and is amazed at the result. The moral is the beneficial effects (including an Anglo-American alliance) of Home Rule. Irish public men-F. J. Bigger, Sir Roger Casement, Douglas Hyde, \&c., are introduced under thin disguises. The tone is, of course, light and facetious.

"O'SULLIVAN, Seumas," James Starkey, one of the best known of our contemporary Irish poets. B. Dublin, 1880 ; resides in Rathmines. Has written much for the United Irishman, Irish Homestead, Sinn Fein, Dana, Shanachie.

1362- MUD AND PURPLE. Pp. 96. Demy 8vo. (The Talbot Press). 3s. 6d. n. Frontisp. from an original drawing by E. F. Solomons. 1917.

"Pages from the diary of a Dublin man." Highly subjective episodes, impressions, and musings suggested by Dublin places-the Botanic Gardens, Merrion square, a canal, an old Georgian House, Stephen's Green. One hardly knows whether they are moods of the Author or moods of the city set forth in a prose that is reposeful and delicately wrought. 


\section{O'SUllivan, Richard.}

1363_ STORIES FOR THE FIRESIDE. Pp. 238. (Dublin: A. M. Sullivan). n.d.

Three stories:-1. The Privateer's Revenge, 2. Full Retribution, 3. The Smuggler. In 1 the scene is Hook Head, Co. Wicklow. Tells how Edward Devereux becomes an American privateer and returns to take vengeance on Sir Hubert L'Estrange for the latter's barbarity to E.'s mother in '98. After many exciting episodes Edward takes vengeance in a very Christian manner on the now changed Sir H. No. 2 has a finely worked out plot with much mystery and dramatic incident. It takes place near Bantry and deals incidentally with smuggling, which is the main theme of No. 3. This has the same scene and has plenty of rescues, fights, escapes, etc. All are good healthy stories, Catholic in tone.

OUTRAM, Mary Frances. Author of In the Van of the Vikings.

1364 BRANAN THE PICT. Pp. 356. (R.T.S.). 2s. 6d. Coloured frontisp. 1913.

"An exceedingly well-written tale of the times of St. Columba, based on the ' life' by Adamnan. The hero and his associates are fictitious, but the setting of the story is worked out with remarkable care."-(C.B.N.).

PAGE, Gertrude, Mrs. Dobbin, is English, but is connected with Ireland through her husband, an Armagh man. Author of a long series of very popular novels, Love in the Wilderness, 't'he Edge of Beyond, Follow After, The Rhodesian, etc., etc. She resides in Salisbury, Rhodesia.

1365- PADDY THE NEXT BEST THING. Pp. 288. (Hurst \& Blackett). 2s. 29th ed. 1918.

Scene: Omeath at the foot of the Mourne Mountains, an important element in the heroine's character being the love of this beautiful country. Paddy, the irrepressible tomboy, grows into an admirable woman. She and her mother and sister, left badly off by her father the Colonel, are obliged to go to live in London, much to their disgust. But the right young men turn up and after many vicissitudes all ends well.

PARKER, Winifred M., ed.

1365A-GAELIC FAIRY TALES. (GLASgow: MacLaren). 1s. 6d. Illustr. in colour.

Gaelic text and English trans, on opposite pages. Three tales reprinted from other printed sources.

" PARLEY, Peter," see GOODRICH.

[PARNELL, WILLIAM, M.P.]. Wrote also An Historical Apology for the Irish Catholics (1807). He was knight of the shire for Wicklow and brother of Lord Congleton. He died 1821. (See Moore's Memoirs, vii. 109). Charles Stewart Parnell came of the same family.

1366- MAURICE AND BERGHETTA; or, the Priest of Rahery. Pp. xxiv. +213. (Boston and London). [1819]. Second ed., 1825.

"Dedicated to the Catholic priesthood of Ireland." "The character of Maurice is drawn from a person who not many years ago was a ploughman. The Author's abject is not to write a novel but to place his observations on the manners of the Irish peasantry in a less formal shape than that of a regular dissertation." -(Introd.) Related by Father O'Brien. The love of Maurice O'Neal for Berghetta Tual, their marriage and subsequent fortunes, misfortunes, and romantic adventures, till they rise to be grandees of Spain. The coincidences are rather far-fetched and improbable and the characters not very real. Many moral lessons are inculcated. 
[PATRICK, Mrs. F. C.].

1367- THE IRISH HEIRESS. (LONDON). 18-.

PAUL, Major Norris.

1368- MOONLIGHT BY THE SHANNON SHORE. Pp. 312. (Jarrold). [1888].

An anti-Land League novel, describing the terrorism of that organisation and the sufferings it entailed. The plot is the love-story of John Seebright, an Englishman, for Irish Eveline Wellwood, who is persecuted by the League. Devoid of humour and almost of romance. The dialect is well handled, and the writer clearly knew well his Limerick and Clare. But the tone of the book is on the whole bitter and somewhat narrow-minded.

\section{9 _ EVELINE WELLWOOD. (Jarrold). 1892.}

This is another ed. of Moonlight by the Shannon Shore.

PEARSE (Mary P.), sister of P. H. Pearse (q.v.)

1370_ THE MURPHYS OF BALLYSTACK. Pp. 251. (Gill). 3s. 6d. $n$. 1 illustr. 1917.

Two interwoven stories, that of the Murphys and that of Barney O'Hagan. The latter seems the real hero and is clearly intended as a type of a true Irish Catholic. But his character, like that of others in the book, is scarcely consistent. The Murphys present a strange combination of qualities. Old Murphy keeps a small shop run on absurd lines. His daughter's were "finished at a college on the continent." One soll writes poetry, another goes to Munster to "study nature." The book is a series of loosely connected episodes, comical for the most part. It is meant to be as Irish and Catholic as possible.

PEARSE (P. H.), piorais mac piarais. B. 1880 in Dublin of English parents but identified himself wholly with Ireland from his early years. Became a fluent speaker and writer of Ir 1 sh, in which language all the best of his literary work, both prose and poetry, has been done. He edited various Gaelic periodicals, lectured and wrote much on Irish Ireland topics, and created a secondary school, St. Enda's, with a distinctively Irish Ireland atmosphere. He' was executed on May 3rd, 1916, as a result of the Rising in Easter Week of that year. He was essentially a poet, a visionary, a man who lived wholly for ideals. He was at the same time a man of most lovable personality.

1371 - THE MOTHER, and other Tales. Done into English by Rev. T. A. Fitzgerald, O.F.M., with foreword by Helena Concannon, M.A. Pp. 88. (Dundalk: Dundalgan Press). 2s. 6d. Photos of the Author, his Mother, Fr. Fitzgerald, and Mrs. Concannon. 1916.

Five little stories of Connacht peasant life seen, one might say, from within, and with intensely sympathetic insight. Told with great simplicity and sincerity, yet with a special and very delicate literary fragrance. They are a revelation, yet a purely objective one (for the Author does not intrude hiniself nor lecture) of the Gaelic mind. The translation is perfectly done, and Mrs. Concanuon's foreword enhances the value of the book.

\section{2- COLLECTED WORKS. Vol. I. (Maunsel). 7s. 6d. 1.1917.}

This volume contains: 1. Plays. 2. Poems. 3. Stories, with an introduction by Rev. P. Browne, Maynooth. The greater part of the contents is translated from the Irish. The stories are: the Mother, the Dearg-daol, the Roads, Brigid of the Songs, the Thief, the Keening Woman, Iosagan, the Priest, Barbara, Eoineen of the Birds. These had been published in Irish in two little volumes, viz., An matain and Tosasan asus ssetrita elle. The translation here given is by Joseph Campbell. It succeeds in preserving much of the Irish idiom without doing great violence to the English. The last four of these tales are not in the book published by Tempest, as noted above. "The Author depicts his child types in particular with knowledge and loving insightParaic reading "Mass" from a school book with his mother's red petticoat for vestment, the boy stealing the doll for his ailing sister, the little owner of the doll Barbara, Eoghanin with his birds. 


\section{PECK, Mrs. $F$.}

\section{3 — THE LIFE AND ACTS OF THE RENOWNED AND CHIVALROUS} EDMUND OF ERIN, commonly called Emun ac Knuck or Ned of the Hills, \&c. Two Vols. Pp. 345, 300. (Dublin: Tegg). Other eds., 1841. Ten good illustr. by B. Clayton. [1818, 3 vols.].

Sub-title : "An Irish Historical Romance of the Seventh Century founded on facts and blended with a brief and pithy epitome of the origin, antiquity, and history of Ireland." An extraordinary and rather eccentric production, written in a strain of exaggerated enthusiasm for Ireland. The facts are supposed to be taken mainly "from some very ancient documents found amongst the papers of the late Dr. Andrews, Provost of T.C.D., whose grandniece the Author was." To the novel she appends " a Circular Letter," relating her matrimonial differences with her husband, Capt. P. She also wrote 'Tales for the British people.

\section{PELHAM, Gordon.}

1374_ SHEILA DONOVAN, a Priest's Love-Story. Pp. 295. (Iynwood). 1911.

"Stephen Glynn loves Sheila D., and there is never the smallest reason why he should not marry her. Both are represented as sweet and good, and he is a clergyman. After their sin Stephen's whole mind is set on religious atonement: he joins a religious order, leaving Sheila to struggle on alone with her child. He breaks his vows, and all is apparently to end happily when, acting under a misapprehension, he drowns himself."-(T. Lit. SUPPL.).

PENDER, Mrs. M. T., née O'Doherty. B. Co. Antrim. Ed. at home, at Ballyrobin National School and Convent of Mercy, Crumlin Road, Belfast. Has contributed much prose and verse to various Irish periodicals.

1375- THE GREEN COCKADE. P.p. 380, close print. (Downey). [1898]. New ed. (Sealy, Bryers). 3s. 6d. n.d.

A love story, the scene of which is laid in Ulster during the rebellion. Full of romantic adventures. Historical characters introduced: Lord Edward, Putnam M'Cabe, and especially Henry Joy M'Cracken. Battle of Antrim described, but remainder of incidents almost entirely fictitious. No attempt at impartiality. The Government side is painted in the darkest colours.

\section{6_ THE LAST OF THE IRISH CHIEFS.*}

A sensational romance of the time of Sir Cahir O'Doherty's rising and the governorship of Paulett in Derry. c. 1608.

PENROSE, Mrs. H. H., née Lewis. B. Kinsale. Ed. at Rochelle School, Cork. Took honours in T.C.D. in German and English Literature. In addition to her novels she has written innumerable stories for the magazines, e.g., Temples $\mathrm{BAR}_{\mathrm{AR}}$ and the Windsor. Resides in Surrey. Besides the novels mentioned below As Dust in the Balance and An Unequal Yolie are partly concerned with Ireland.

\section{7- DEN1S TRENCH. Pp. 432. (Alston Rivers). 6s. 1911.}

Denis and his sister on their mother's death are left in doubt about the character and identity of their father, whom they had seen only in their infancy, and who, as a matter of fact, had left his wife in order to become a Roman Catholic priest. 'This priest acts as a kind of providence to his two children, and reveals himself only on his death bed. The Authoress seems quite unacquainted with Catholic practice, but does not depict it in a hostile spirit. The scene is partly in Ireland, but the only trace of Irish interest is an occasional reference to a mysterious quality in the Celtic blood of the hero and heroine, and the character of the poor girl Stella Delaney, whom Denis marries.

* I have not been able to ascertain whether this novel was ever reprinted in rolume form from the periodical in which it appeared as a serial. 
PENROSE, Mrs. H. H., née Lewis-(continued). 1378- A FAERY LAND FOLORN. Pp. 312. (Alston Rivers). - 6s. 1912.

Life among better-class Protestant folk in a little seaside town in the $S$. of Ireland. The main interest is furnished by the sad love story of Evelyn Eyre. Mr. Eyre, gentle and bookloving, and Capt. Donovan, given to drink, and a tyrant in his family, are neighbours and close friends till a misunderstanding brings estrangement and leads to a tragedy, resulting in the separation-for ever, as it proves- of Evelyn and her lover Terence Donovan. The story is wholesome and human and free from religious or other bias. Aunt Kitty, a lovable old maid, provides an element of humour.

1379_ BURNT FLAX. Pp. 319. (Mills \& Boon). 6s. 1914.

The Land League agitation from landlord standpoint. Excellent but over-firm landlord, hired agitator, attempt on landlord's life. The rent-payers are brutally murdered by leaguers, who are represented as drunken and credulous. There is some good character-drawing : Timsy O'Halloran, the half-witted boy, is original : Father O'Riordan is represented as a good sensible priest. The brogue is travestied.

[FERCIVAL, Mrs. Margarst]. Author of Rosa, the Worl Girl.

1380 - THE IRISH DOVE; or, Faults on both Sides. Pp. 306. (Dublin: Robertson). 1849.

Helen Wilson, whose mother was Irish, inherits an estate in Kerry. After years of residence in India and then in England, she comes to live in Ireland, grows to love the people, and spends what is left of her failing life in teaching the natives the New Testament in Irish. The interest of the book lies in its picture of, and apology for, the attempt made (chiefly by "The Irish Society") in the first half of the 19th century to convert the Irish to Protestantism through the medium of the Irish language. The witness it gives to the bitterly anti-Irish feeling prevailing in England at the time is interesting. The peasantry is represonted as debased and priest-ridden, but their condition is ascribed in part to English hostility and to absenteeism.

\section{PETREL, Fulmar.}

1381- GRANIA WAILE. Pp. 285, large print. (Unwin). Frontispiece and map. 1895.

A fanciful story written around the early life and after-career of the O'Malley Sea-queen. Her robbing, when only a young girl, of the eagle's nest, her desperate sea-fights, and her many other adventures make pleasant reading. The atmosphere of the period is well brought out. But few of the incidents narrated are historical facts.

PICKERING, Edgar. Author of After Sedgmoor, The Dogs of War, An Old-T'ime Yarn, King for a Summer, etc.

1382_ TRUE TO THE WATCHWORD. Pp. 299. (Warne). 3s. 6d. Eight illustr. 1902.

A spirited account of the siege of Derry from the point of view of the besieged. Full of hairbreadth escapes and of desperate encounters with the Irishry, who are spoken of throughout as ferocious savages. Apart from this last point there is no noteworthy falsification of history. For boys.

PIM, Herbert Moore, "A. Newman." Educated as a Quaker, became a Catholic and a Nationalist, and until recently edited THE IRISHMAN, an organ of advanced rationalism. In the spring of 1918 he wrote a letter to the Press declaring that he had reverted to Unionism. He has published several volumes of verse, and has contributed much to periodicals on a great variety of subjects.

1383- UNKNOWN IMMORTALS IN THE NORTHERN CITY OF SUCCESS. Pp. 96. Demy 8vo. (T'he 'T'albot Press). 3s. 6d. n. Decorations by John McBurney. 1917

Nine fantastic studies, some of them in narrative form, of queer types to be met with in Belfast-the rent man, the fish man, the willick woman, the rag and bone man, a madman, etc. "Monsieur among the Mushrooms" (30 pp.) is a study of a lunatic. 
POLLARD, Eliza F. Au. of a very large number of historical stories. D. some years, ago.

1384-THE KING'S SIGNET. Pp. 288. (Blackie, and U.S.A., Scribner). [1899]. New ed. 1908.

France in the days of Madame de Maintenon, and Ireland during Williamite wars. B. of the Boyne described. Juvenile.

POLSON, Thomas R. J. An Englishman, and originally a private soldier who owned and edited the Fermanagh MaIl for about forty years. D. 1908 at age of 85.

\section{5 — THE FORTUNE TELLER'S INTRIGUE. Three Vols. (Dublin:} McGlashan). 1847.

"Or, Life in Ireland before the Union, a tale of agrarian outrage." An unasually objectionable and absurd libel on the priests and people of Ireland. The latter are represented as slavishly submissive to the former, who are spoken of as "walking divinities." The priests attend their dupes at their execution for agrarian crimes, telling them that they are martyrs for the faith. The scene is Co. Clare.

PORTER, Anna Maria. Born 1780, in Durham. Died 1832. Was daughter of a surgeon of the 6th Inniskilling Dragoons, of Ulster extraction, and a sister of Jane Porter, author of The Scottish Chiefs, \&c. She published more than nineteen books.

1386- HONOR O'HARA. Three Vols. (Longmans). [1826]. American ed., Harper, 1827. Two Vols.

The scene is laid in the N. of England, and the book has no relation to Ireland except that the heroine is supposed to be of Irish origin.

1387- THE LAKE OF KILlaRnEY. Pp. 350. (London : 'T'egg). New ed., 1839.

Described by the Author as " a harmless romance, which, without aiming to inculcate any great moral lesson, still endeavours to draw amiable portraits of virtue." - (Pref.). An old-fashioned novel in the early Victorian sentimental manner. The plot is laid chiefly in Killarney (of which there is some description) and Dublin, at the time of the earlier Napoleonic wars, when Dublin had its parliament and was the centre of fashion. The plot is intricate, but turns chiefly on the mischances and misunderstandings that keep apart the hero, Felix Charlemont, and the heroine, Rose de Blacquiere. This latter name was the title of later editions of this book, e.g. (London : C. H. Clare), 1856.

POWER, Marguerite A. 1815-1867. A niece of the Countess of Blessington; wrote also Evelyn Forrester, 1856, and The Foresters, 1857, and much poetry.

1388- NELLY CAREW. Two Vols. (Saunders \& Otley). Engraved frontisp. 1859.

The heroine, daughter of an Irish landlord, is driven by the scheming of a crafty French stepmother (once her governess) into marriage with an Irish roué, and leads a life of bitter humiliation. But her honour is stainless through it all, and there is a happy ending. Characters (e.g., Larry McSwiggan) are for the most part capitally drawn. The moral is good. The brogue is well done.

POWER, Victor O'Donovan. B. Rosbercon, Co. Kilkenny. His mother, who was of the O'Donorans of West Cork, was a poet of considerable merit; his father, Michael Power, was a distinguished Nationalist. Ed. at St. Patrick's College, Carlow. Began writing for the Press at the age of 16 , since when he has done an enormous amount of literary work for such periodicals as The LAMP, THE Irish Emerald, The Irish Fireside, The Shampock, The Weekly Freeman, 
POWER, Victor O'Donovan-(continued).

The Catholic Times, Donohoe's Magazine (U.S.A.), Ireland's Own, Cork Examiner, Catholic Fireside, etc., etc. Among his serials may be mentioned "The Fermanaghs of Castle Connor," "The O'Connors of Lisnamona," "The Unseen Witness," "The Hawk and the Dove," "The Castle Mona Mystery," " Kildoona," "The Hated Bond." His "Some Experiences of Kitty the Hare" (which has long been running in IrELAND's OwN), is about to be pub. lished in volume form. His stories deal chiefly with West Cork (Carbery) peasant life, and are drawn very frequently from his own experiences. He has also written many successful Irish plays, which are performed by his own company.

1389_ BONNIE DUNRAVEN : a Story of Kilcarrick. Two Vols. (589 pp.). (Remington). 1881.

A very sympathetic and pleasant love story of modern life in Co. Cork. The characters are thoroughly natural and human, and, moreover, thoroughly Irish. Conversations good. But perhaps the "chief merit of the story is its faithful reproduction of South of Ireland " atmospihere," especially by word-pictures of Southern scenes-the coasts, the Blackwater, Mount Melleray. Was highly praised by The Athenfeum, The Academy, and by the Catholic Press.-(I.M.).

1390 - THE HEIR OF LiSCARRAGH. (Leamington : Art \& Book C'o.). 1892.

First appeared as serial in the Catholic Times. A romantic and tragic story of love and mystery. Contains many descriptions of scenery in Co. Cork, where the scene is laid.

1391— TRACKED. (Ineland's Own Library). 6d. Paper Covers. 1914.

A wholesome and pleasant story of unrequited love and of jealousy. Scene : Innishowen (Co. Donegal). A well-worked out plot, with good descriptions of scenery. Peasants depicted with sympathy and understanding.

\section{PRESTON, Dorothea.}

1392_ PADDY, the story of a little Irish boy. Pp. 64. (Sealy. Bryers). 1 s. Twenty coloured illustrs. 1907.

Paddy's dreams and adventures in Celtic Fairyland.

PREVost, Antoine Francois; called Prevost d'Exiles, 1697-1763. A French abbé, and a very voluminous author, having published upwards of 200 vols. There is a selection of his works in 39 vols. in the Library of T.C.D. 'His chief title to fame is the romance Manon Lescaut.

1393_ LE DOYEN DE KELLERINE. Histoire morale composée sur les mémoires d'une illustre famille d'Irlande; et ornée de tout ce qui peut rendre une lecture utile et agréable. (LA Haye : P. Poppy). 1744.

A trans. of this under title The Dean of Coleraine. A Moral History founded on the Memoirs of an Illustrious Family in Ireland, was printed in London (Vol. I.) and Dubl. (Vols. II. and III.) in 1742; another ed. 1780. The work was originally publ. in Paris, 1735, and there were further editions in 1750, 1821 (six vols.), \&c. The present is a well written, though very long, story, showing how the teller of the tale, the Dean or P.P. of Coleraine, in Antrim, watched with more than a father's anxious care over the fortunes of his two half-brothers and sister. Their several characters appear admirably in the telling, especially that of the poor good Dean, unworldly, unselfish, deeply affectionate, but over anxious and almost over conscientious. His efforts to keep his wayward charges in the straight path amid the allurements of Paris are very well told. There is nothing in the least objectionable. There is an air of reality about the whole, though the style is old-fashioned. Towards the close the Dean acts as a Jacobite agent in Ireland. 
PREVOST (J. J.). Was one of the collaborator's in the 4th series of the REvUE Brittanique, Paris, 18z6-1840. 1394 - LE COMTE DE DROMORE OU LA TERREUR IRLANDAISE.

\section{PURCELL (MrS.).}

1395_ THE ORIENTALIST; or, Electioneering in Ireland, 2 vols.

Griffin. LoNDON : Buldwin, Cradoek \& Joy). 1820.

Scene, Co. Antrim (Muckamore Abbey and Loch Larne are mentioned). How the absentee Lord Clanroy comes to Ireland to secure a parliamentary seat for his son. His opponent is a gentleman of Indian extraction (the orientalist) who afterwards turns out to be the long-lost Lord Dalkeith. Electioneering scenes described with some verve. Otherwise the story is somewhat stilted and tedious. Shows little knowledge of Ireland.

PURDON, K. F. B. in Enfield, Co. Meath, and has always resided there. Ed. at home, in England, and at Alexandra College, Dublin. Has written much for Irish and English periodicais, ther first encouragement coming from the IRISH Homestead. She also owes much to helpfulness of Richard Whiteing, the wellknown writer.

1396 CANDLE AND CRIB. Pp. 42. 12mo. (Maunsel). 1s. Christmas, 1914.

Quietly but tastefully bound. Four good illustr. in colour by Beatrice Elvery. An exquisite little Christmas idyll, telling of the strange way Art Moloney brought his new wife home to Ardenoo for Christmas.

1397- THE FOLK OF FURRY FARM. Pp. 315. (Nisbet). 6s. 1914.

A story of life at Ardenoo, somewhere in the midlands, depicting in the most intimate way the conversation, manners, humours, kindliness of the people. Told as if by one of themselves, with the strange phraseology, the unexpected turns, the often poetic figurativeness of the best shanachies. Miss Purdon writes as one with close and accurate knowledge of the home-life, at least in its outward aspects, of the small farmer class to which the chief characters belong. The matrimonial affairs of Michael Heffernan and his sharp-tongued sister Julia are humorously told, and the Author is almost a specialist in tramps. Pref. by "Geo. Birmingham," giving a sketch of the Irish Literary movement.

1398 DINNY OF THE DOORSTEP. Pp. 253. (The 'Talbot Press). 6s. net. 1918.

Pages from the lives of two Dublin slum children, written with sympathetic understanding of the outlook of the poor and much knowledge of child nature. The children are not unduly idealised, and the conditions in which they live are faithfully and vividly presented, but without railing and bitterness. The queer types of the slums are drawn to the life. Every turn of the Dublin idiom high and low is reproduced with exact fidelity.

QUigleY, Rev. Hugh; "A Missionary Priest." 1818-1883. B. in Co. Clare, studied in Rome, and was there ordained for the American Mission. Was Rector of the University of St. Mary, Chicago, but resigned, and laboured among the Chippewa Indians and among miners in California. Died in Troy, N.Y.

1399_ THE CROSS AND SHAMROCK. Pp. 240. (Duffy). 2s. (N.Y.: Benziger). 0.60. Still in print. โ1853」.

Religious and moral instruction conveyed in the form of a story of the trials and sufferings (amounting at times to martyrdom) of a family of orphan children at the hands of various types of proselytisers. A harsh and satirical tone is adopted in speaking of American Protestantism. Incidentally there are sidelights on several , phases of American life, notably rail-road construction. Full sub-t. :- "Or, how to defend the faith, an Irish-American Catholic tale of real life descriptive of the temptations, trials, sufferings, and triumphs of the children of St. Patrick in the great republic of Washington." 


\section{QUigley, Rev. Hugh, "A Missionary Priest"-(continued).}

\section{0 - THE PROPHET OF THE RUINED ABBEY; or, A Glance of the Future of Ireland. Pp. 247. (Duffy). 1863.}

" A narrative founded on the ancient 'Prophecies of Culmkill' and on other predictions and popular traditions among the Irish."-(Title p.). To keep alive these traditions is the Author's first aim, his second " to keep alive and kindle in the bosoms of the Irish Catholic people of this republic genuine sentiments both of patriotism and religion." - (Pref ). Fr. Senan O'Donnell, under sentence of death in town of Cloughmore, Co. Waterford, at the hands of the British Government,is rescued by his brother. In the first part of the book there is abundance of stirring incident, thrilling escapes, \&c., but the latte: part becomes more wildly improbable and unreal as it proceeds. Fr. Senan is wrecked off coast of Clare, and lives for years in a cave in cliffs of Moher with a little boy, rescued from the eagles. Time : about 1750-1798. Bitterly anti-English sentiment throughout. Only by an incident in the last few pages are the title and sub-titles justified.

1401 - PROFIT AND LOSS; or, the Life of a Genteel Irish-American. Pp. 458. (N.Y. : T'. O'Kane). 1873.

Purpose : to teach Catholic piety and to guard youth from danger. The genteel Irish-American is Michael Mulrooney, who was driven out of Ireland by the tyranny of the landlord class. The first twenty-five pp. tell us of his troubles in Ireland.

QUINLAN, May. B. 1872 in Melbourne, Australia, daughter of Judge Quinlan, a native of Co. Tipperary. Ed. in her native city at the Convent of the Faithful Companions. Gained social experience in the London slums, the following volumes being the outcome. Of late years has written only occasionally for periodicals.

1402- IN THE DEVIL'S ALLEY. Pp. 262. (Art and Book C'o.). 3s. 6d. Illustr. very cleverly and humorously by the Author. 1907.

Sketches of the lowest life in the East End of London, chiefly among the poorest Irish. Told with sympathy, close observation, and quiet humour. There is pathos too, but the Author never strains it nor forces the note. Sunt lachrimae rerum.

1403_- MY BROTHER'S KEEPER. Pp. 157. (C.'T'S.) 1906.

Sketches similar to the preceding.

“ RATHKYLE, M. A.," Miss Marianne Younge, of Upper Oldtown, Rathdowney. Died 1917. A good deal of her writing, both serials and short stories, was publ. in Ireland, a short-lived Irish American periodical. There is matter for several volumes and it is hoped that they may be publ. after the war. According to very good literary judges they thoroughly deserve publication. See I.B.L. vol. x. p. 6 for an appreciative article.

1404_ FAREWEIL TO GARRYMORE. Pp. 127. (Scaly, Bryers). 1s. net. 1912.

A simple little tale of life in an Irish village, showing knowledge of the countryfolk and of their ways of thought and speech; also a thorough understanding of children. Padraic Colum thought this book extraordinarily close to Irish peasant life and that the talk was more Irish than any dialogue he had read.

READ, Charles Anderson. 1841-1878. Born near Sligo. Was for some years a merchant in Rathfriland, Co. Down. Went to London, 1863. Was an industrious and able writer, and a man full of enthusiastic admiration for Ireland, its people, and its literature. Produced numerous sketches, poems, short tales, and nine novels, the most notable of the latter being Love's Service; but better known are his Aileen Aroon and Savourneen Dheelish, of which the LoNDon REvIEw said : "We are presented with a view of agrarian crime in its most revolting aspect, and there is no false glamour thrown around any of the characters. Many of the incidents are highly dramatic, while the dialogue is bright and forcible." The above notice is taken from an article by Mr. Charles Gibbon in the Cabinet of Irish Literature, edited by Mr. Read himself. 
READ, Charies Anderson-(contintisd).

1405- SAVOURNEEN DHEELISH; or, One True Heart. 16mo. (London : Henderson). 1s. [1869]. 1874, 7th ed.

First appeared in The WeEkLY Budget. A melodramatic but finely told story. The principal incident is the historic tragedy utilised by Carleton in his "Wild Goose Lodge." Especially thrilling is the scene where Kate Costelloe gives the evidence which she knows will bring her brother and her lover to the gallows. Barney Fegan, a jovial pedlar, plays a conspicuous part. The usual devices of evictions, murders, Whiteboys, traitors, trials, secret caves, etc. Scenery well described: brogue well done. The fair at Keady is a noteworthy piece of description. Scene: the district round Dundalk.

1406 AILEEN AROON; or, The Pride of Clonmore. (London: Henderson). 1s. [1870]. Sixth ed. n.d.

First appeared in The WeekLy BUdget. Garratt O'Neill is falsely accused of murder. His sweetheart Aileen on her way to Downpatrick to defend him is abducted by his enemy. Suspected of infidelity, she is driven from her home, but is befriended by Father Nugent, an unfrocked priest, and his Fenian band, who lurk in the Mourne Mountains. After many thrilling episodes and hairbreadth escapes the lovers are united at last. Sensational but well-told, and containing some good descriptions.

\section{READE, Amos.}

1407- NORAH MORIARTY; or, Revelations of Irish Life. (Blackwood). Two Vols. 1886.

"A romance bound up with the story of the Land League, its rise . . . . in 1880, its development, and the outrages and bitter sufferings endured by the victins." (Baker).

READE, Mrs. R. H. Author of Milly Davidson, Dora, Silver Mill, \&c. 1408_ PUCK'S HALL. Pp. 254. (Belfast : Charles W. Olley). 1889.

Scene: Newcastle, Co. Down. A pleasant story, told in a straightforward way, with good characterisation.

REED, Talbot Baines (1852-1893). Was a son of Sir Chas. Reed, M.P., F.S.A., Deputy Governor of the Irish Society, and nephew of John Anderson, the Belfast bibliographer. 'He had a great love for Ireland and her people, and always delighted in visiting her shores. Publ. some 12 or 13 stories for boys, such as The Fifth Form at St. Dominick's and The Cock House at Fellsgarth.

1409- SIR LUDAR. Pp. 343. (R.'T.S.). Seven illustr. by Alfred Pearse. [1889]. Cheap reprints (Leisure Houn Office). 6d., 1910, and Boys' Own PAPER) 1913.

Adventures of an English 'prentice boy in company with Sir Ludar, who is a son of Sorley Boy MacDonnell of Dunluce Castle, Co. Antrim. There is a constant succession of exciting incidents. The retaking of Dunluce from the English is the most noteworthy. The heroes are on board the Armada during its fight with the English. The tone is not anti-Irish, but occasionally unfair to Catholics. It is a book for boys.

1410_ KILGORMAN. Pp. 420. (Nelson). Six illustr. (good). 1906.

Scene : mainly in Donegal. Relates adventures of Donegal fisherboy, first at home, then in Paris during Reign of Terror, then at battle of Camperdown, then in Dublin, where he frequents meetings of United Irishmen and meets Lord Edward. Standpoint: not anti-Irish, but hostile to aims of United Irishmen. Full of exciting adventure. Juv. 
REID, Forrest. B. in Belfast and ed. there at the Royal Academical Institution, and at Christ's College, Cambridge. Began his literary career in 1904 with The Kingdom of 'T'wilight, published in Fisher Unwin's First Nover Library. Wrote also T'he Garden God (1905), 'T'he Spring Song, T'he G'entle Lover (1913), and a critical study of W. B. Yeats. Resides in Belfast.

1411- THE BRACKNELS : a Family Chronicle. Pp. 304. (Arnold). 6s. 1911.

This unpleasant and, we hope, abnormal family is that of a self-made Belfast merchant. The book is a study in temperaments; Mr. Bracknell himself, a harsh man, with little humanness, without affection, except a certain regard for an illegitimate child of past days; the daughter Amy, in love with Rusk, the tutor, and ready to go to any lengths to win him; the wilful, selfish, elder son; above all, Denis, the youngest, morbid, dreamy, the victim of delusions, engaging in strange pagan worship, yet with amiable traits. There is not a trace of religion in the chronicle of this family.

\section{2_ FOLlOWING DARKNESS. Pp. 320. (Arnold). 6s. 1912.}

A soul study in form of autabiography. The hero is a son of a Co. Down schoolmaster. $\mathrm{He}$ is brought up amid uncongenial people and in uncongenial circumstances, first amid the Mourne Mountains, then in sordid Cromac St., Belfast. His soul sickens with the dreariness of the education, and especially of the religion that is imposed on him, and the father, a hard, unresponsive man, is perversely blind to the genius (an artistic and somewhat moody temperament) and aspirations of the young man-with consequences almost fatal. He is thrown back on himself. Hence intense introspection and then an outlet sought in occult sciences. There is a love story, too, but it is of minor importance. The book is but a fragment, and has no real conclusion. The style is exceptionally good.

\section{3_ AT THE DOOR OF THE GATE. Pp. 332. (Arnold). 6s. 1915.}

A study of the unfolding of a young man's mind, an abnormal, perhaps a morbid, mind, condemned to dwell amid the uncongenial narrowness and vulgarities of lower middle class life in a Belfast suburb. The work of a consummate craftsman, with an unfailing grasp on reality. There is much restrained humour and irony in the narration of the petty doings of this petty world, e.g., the 12th of July excursion, the Swedenborgian meeting, the Jackson family. But the close is all gloom, tragedy on tragedy. We leave the hero setting forth alone towards some bourne of vague mysticism. Richard is shown in his relations with three women-his mother, who loves his brother ibest, Rose, his pretty empty-headed wife, and Grace towards whom he is drawn by every attraction of sympathy, and who is ready for his sake to disregard the bonds of marriage. Politics and religion are not discussed.

1414- A GARDEN BY THE SEA. Stories and Sketches. Pp. 152. (The Talbot Press). 3s. 6d. net. 1918.

Twelve short pieces, fow of which are Irish in subject and few of which are narratives. Also two poems. "An Ulster Farm" is a squalid tragedy of peasant life. The scene of "A Boy and his Dog" is laid in Dublin and that of "The Reconciliation" in Co. Dorwn, but there is no local colour. In the rest the scene is not indicated. The sketches vary much in character but all reach a high level of literary style.

REID, Lizzie C. A Belfast lady whose short stories appear frequently in THE People's Friend and other periodicals.

\section{5- (c. 1905).}

A lady doctor's adventures in an Ulster town. Some good character studies. Interwoven with a narrative of mystery and plotting there is a pleasant love story. Under the same cover is "Two Merry Eyes of Brown" (pp. 85), the story of a foundling. Scene: Ireland, but no definite place indicated. 
[REYNOLDS (Dr James)], of Booterstown, Co. Dublin. "Brother James." He contributed several serials to Dufry's Fireside Magazine under the signatures "E. L. A. Berwick" and "A Well-known Novelist."

1416 - THE ADVENTURES OF MOSES FINEGAN, AN IRISH PERVERT: A True Story. 16mo. Pp. 158. (Duffy). n.d. (c. 1871). Still in print.

The hero, a carpenter by trade, but an idler and a drunkard, seeing that "convarts were high in the market," and desiring without labour to have money for drink, becomes a Bible Reader in a small town in the West, along with a similar convert, by name Gilhooly. They provoke a quarrel, and are somewhat roughly handled by the people. They are befriended by a local magistrate, who takes them into his house. But Mogue, though a married man, goes off to America with his benefactor's daughter, whom he has duped by feigned piety. There he makes away with her, and is-his own son being a witness-sentenced to death for murder. The story contains some crudities and improbabilities.

\section{7— THE JUVENILE LIBRARY. 16mo. (Duffy). n.d.}

Twelve stories bound into a volume, but not continuously paged. They are stories with a moral, of the type of Canon Schmid's, but perhaps less spun out and less obviously didactic. The language is very simple, and there is usually an abundance of incident of the kind that children like. Most of the tales have an Irish setting as regards names and places, but in other respects are not peculiarly Irish. Titles-Busy Peter, White Lies, The Two Boys, The Little Drummer (Indian Mutiny), Fidelity Rewarded, The Little Adventurer, Cathleen, etc.

\section{8— TALES AND STORIES FOR THE AMUSFMENT AND INSTRUCTION} OF YOUTH. Sq. 16mo. (Duffy). 4s. 12 illustr. by Geo. Measom. 1858.

Contains-Rody O'Leary, O'Hara Blake, Clare Costelloe, Gerald O'Reilly, Catherine Hall, Eva O'Beirne, the Two Friends, Miles O'Donnell, Little Mary, the Cousins, The Bequest, The Rose and The Lily. These little tales are of the same character as the preceding. Some of the subtitles indicate this, e.g., the triumph of principle, the reward of industry, the test of friendship, and so on.

RHYS, Grace. "Mrs. Rhys (née Little) was born at Knockadoo, Boyle, Co. Roscommon, 1865. She is youngest daughter of J. Bennett Little, and married, in 1891, Ernest Rhys, the poet . . . Her novels deal with Irish life, which she knows well, and are written with sympathetic insight, tenderness, and tragic power."-(IRISH Lit.). She resides in London.

1419 - MARY DOMINIC. Pp. 296. (Dent). 1898.

The main theme is the seduction of a young peasant girl by the son of the landlord, and the Nemesis that overtook the seducer after many years. The story is told with exceptional power and pathos. There is no prurient description, unless one half-page might be objected to on this score. The peasants are natural and life-like, but there is something strangely repellent in the pictures of the upper classes. There are incidents bringing out the darker aspects of the land-war. There is no anti-religious bias.

\section{0_ THE WOOING OF SHEILA. (Methuen). 6s. [1901]. Second ed.,}

1908. (N.Y.: Holt). 1.50.

A gentleman, from unnatural motives, deliberately brings up his son as a common labourer. The boy falls in love with and marries a peasant girl, whom he had saved from the pursuit of a rascally young squire. On her marriage morning she learns that her husband has killed her unworthy lover. She at once leaves her husband, but a priest induces her to return, and the crime is hushed up in a rather improbable manner. As in the Author's other books, there is a subtle charm of style, delicate analysis of character, and fair knowledge of peasant life.

\section{1— THE PRINCE OF LISNOVER. (Methuen). 1904.}

Ireland in the early 'sixties. Has same qualities as Mary Dominic. Devotion of the people to the old and dispossessed "lord of the soil "is touchingly brought out. A pretty girl-and-boy love story runs through the whole. 
RHYS, Grace-(continued).

1422- THE CHARMING OF ESTERCEI. Pp. 318. (Dent). 6s. 1913.

A love story of Ireland in the days of $O^{\prime} N$ Neill and Essex. The main interest lies in the story of how Estercel is brought to love his cousin Sabia, and in the adventures of the former, an $\mathrm{O}^{\prime} \mathrm{Neill}$ and the envoy of the great Hugh, in Dublin and in Ulster. But the historical background is well painted and the historical personages carefully studied. The hero's wonderful horse, Tamburlaine, is a strange and original "character" in the piece, and there is a splendid description of kow he carried his master from Dublin home to the North. The Author writes with sympathy for Ireland. The charm of the style is enhanced by her sympathy with wild nature and delicate perception of its sights and sounds.

RHYS, Rt. Hon. Sir John, M.A., D.Litt. B. Cardiganshire, 1840. Ed. Bangor and Oxford. Also at the Sorbonne College de France, Heidelberg, Leipsic, and Göttingen. Prof. of Celtic at Oxford since 1877. Member of innumerable learned societies and royal commissions. He has read many valuable papers on Celtic subjects before the R.I.A. Publ. a long series of works on Celtic subjects, e.g., Celtic Heathendom, 1886. D. 1915.

1423 CELTIC FOLK-LORE, Welsh and Manx. Two Vols. Pp. xlvi.+718. (Oxford : C'larendon Press). 10s. 1901.

Stories gathered partly by letter, partly viva voce, classified and critically dis. cussed. The group of ideas, he concludes, connected with the fairies is drawn partly from history and fact, partly from the world of imagination and myth, the former part representing vague traditions of earlier races. Many subsidiary questions are raised, e.g., magic, the origin of druidism, certain aspects of the Arthurian legends, \&c. Ch. x. deals with Difficulties of the Folklorist; Ch. xi. with Folk-lore Philosophy; Ch. xii. with Race in Folk-lore and Myth. Throughout constant references are made to and frequent parallels drawn with Irish folk-lore, e.g., the Cuchulaim cycle.

RIChARDSON (Samuel). B. in Clonmel; ed. Clongowes Wood College, 1858-63. Was a barrister.

1424 - NOEL D'AUVERGNE. Pp. 496. (Washbourne). 1869.

A highly moral and religious (Catholic) novel, the scene of which is laid chiefly in Dublin, in the sixties, with changes to Killarney, London and America (Civil War). Noel (a Dublin law student of French origin) becomes engaged to his friend Harold Leyne's sister, Madelaine. The villain of the piece, the Hon. O'Malley Oranmore, comes between them. She accepts him, but when she is reduced to poverty he throws her over and enters upon a career of crime. She dies, her prayers reclaim him from degradation, and he expiates the past. Years afterwards Noel meets Madelaine's younger sister Mary (a beautiful portrait) and they are united. Besides these there are minor threads of narrative. Descriptions of Dalkey, Killarney, and Queenstown. The style is literary but highly sentimental, and the book is full of moralisings.

RICKARD, Mrs. Victor. Au. of The Light Above the Crossroads, Dregs, The Frantic Boast, etc.

1425_ THE FIRE OF GREEN BOUGHS. Pp. 311. (Duckworth). 6s. n. 1918.

The central figure is Sylvia Tracy, who is depicted as a kind of conscientious rebel against all laws, customs, and conventions. She carries her theories into action with strange consequences, and the Author shows us a kind of perverse reasonableness in all her vagaries. The book contains descriptions of Ireland " in its present disturbed state" and of London during an air raid. The title is suggested by the holocaust of the world's youth on the battlefields of France (T. Lir. SuPPL.). Sylvia's uncle, Sir Jasper Roydon, gives her an old estate in Kerry, twelve miles from Tralee, She harbours a dying German officer and gets into trouble. From this she is rescued by Willie Kent, a Nationalist M.P., whom she afterwards marries. Dialect of Mrs. Casey very well done. 
RIDDELL, Mrs. née Charlotte E. Cowan. B. Carrickfergus, 1832. Publ. her first book 1858, since when she has written nearly 40 novels. All of these are remarkably clever, and some have been very popular. They deal chiefly with social and domestic life among the Protestant upper and middle classes. The scene is laid in London, Hertfordshire, Lincolnshire, Scotland, \&c. Few deal with Ireland. We may mention George Geith of Fen Court (1864), City and Suburb (1861), A Life's Assize (1870), Above Suspicion (1875), Too Much Alone, Susan Drummond, Race for Wealth, Head of the Firm. Her books are noteworthy for the intimate knowledge of the proceedings of law and the business world of London which they display. D. 1906.

1426- MAXWELL DREWITT. (Arnold). [1865]. New illustr. ed., 1869.

A rather lengthy but well-told tale of adventures in Connemara, including an old-fashioned election (time, 1854) and a well-described trial for robbery on the Drogheda and Dundalk Railway. The plot is well constructed and the characters, mainly of the landlord class, sympathetically depicted. The peasantry are faithfully, if somewhat humorously, delineated. Dr. Sheen, the dispensary doctor and his patients are well portrayed,

\section{7- A STRUGGLE FOR FAME. 1883. Several eds.}

Partly autobiographical Describes a young girl and her father sailing from Belfast with her MS. to win her way in London. Her experiences of publishers and love affairs.

\section{8- BERNA BOYLE. Pp. 443. (Macmillan). 6s. [1884]. 1900, \&c.}

A love story of the Co. Down about fifty years ago. Deals mainly with the trials of a young lady, who suffers much from suitors with disagreeable relatives. The characters are mainly drawn from a rather uninspiring and unsympathetic type of Ulster folk. Perhaps the most striking feature is the character of Berna's mother, a vulgar, pushful, foolish woman. There is humour not a little in the situations and characters. The story suffers from its great length.

1429_ THE NUN'S CURSE. (Ward \& Downey). [1887]. 1890.

Considered by a competent critic to be her best Irish novel. Scene : Co. Donegal, near Dunfanaghy, c. 1850. The working out of an inherited curse. Terence Conway tries to take it off by being a model landlord. $\mathrm{He}$ has an intrigue with a peasant girl and is forced by his fiancée to marry the girl. The latter pines and dies. Her son is kidnapped and afterwards returns as priest of the parish. Terence marries again, a father, and prosperous, still feels the curse. The Author knows the Ulster peasant, and so the descriptions and the dialogue are well done, with a well-painted background of Donegal scenery.

1430 THE BANSHEE'S WARNING, and Other Tales. (LoNdoN : Macqueen). 6d. Paper. 1903.

Six stories, four having some concern with Ireland. The first tells how the Banshee goes to London to warn the scapegrace son of an Irish family, who is a clever surgeon, yet always plunged in debt. It is a study of a strange personality. "A Vagrant Digestion" humorously relates the journeyings of the hypochondriacal Vicar of Rathdundrum in search of health. "Mr. Mabbot's Fright" and "So Near, or the Pity of It" both illustrate the honesty and the proper pride of the Irish. The latter is pathetic. The former is humorous, is full of life and movement, and contains fine descriptions of the coast-drive from Belfast to Larne in the old days, and of an exciting run-away.

RIDDALL, Waiter. The second son of the late Dean Riddall of Belfast; died in 1913, at the age of forty.

1431— HUSBAND AND LOVER. Pp. 304. (Swift). 6s. 1913.

The love affairs of a London journalist who comes to Ireland, marries Doris, and makes love to Laura.-(T. LiT. SuPPL.). 


\section{RILEY, James.}

\section{2_CHRISTY OF RATHGLIN. Pp. 343. (Boston : C. M. Cark Publishing} Co.). 10 well-drawn illustr. 1907.

Adventures of Christopher Reardon of Rathglin, Co. Longford, Ireland, near Ballymahon, from his fifth year, at the time of Smith O'Brien's rising (1848). Stirring adventures (not a few of them highly improbable) right through. $C$. is kidnapped and kept in a lonely tower, then sold to a sweep, Larry the Gaff. Chance brings him back to his own home. He settles down and works the farm, but things go against them, and they are evicted (a fine scene). He is arrested for murder, but escapes to an American ship. Endless adventures in Civil War, Larry being on the opposite side but a friend. Fortune brings him back in the end to Rathglin. Pleasant breezy style carries one along. Thoroughly Irish point of view.

"RITA," Mrs. Desmond Humphreys. B. near Inverness, Scotland. Ed. in Australia. Wife of W. E. Humphreys of Ballintemple, Co. Cork. Resides at Bournemouth. A very successful and popular novelist, author of nearly 60 novels on a great variety of themes, e.g., love stories like Darby and Joan. Faustine : stories of Australian life, such as Sheba: novels castigating the sins of the smart set-Souls, Vanity, The Jesters, etc. Calvary, a tragedy of sects and Grim Justice, a study of the nonconformist conscience, indicated a new departure. Then there are her usually sympathetic studies of Irish life, including, besides those noted below, An Old Rogue's Tragedy (1900), The Sinner, Kitty the Rag (Hutchinson, 1896), Petticoat Toose, and Half a Truth. T'he Masqueraders describes the wanderings and social experiences of two Jrish singers. And her latest work, 'T'he liubbish Heap ('tutnams, 1918), contains little Irish Mara, a waif, and Katty Quirke.

1433_ PEG THE RAKE. 3 vols. (Hutchinson). [1894]. 1896.

Contains sympathetic pictures of Ireland and the Irish, and an equally sympathetic and winning presentation of the woman who is no longer in her first youth, who is not faultless, and whose love story is not a happy one. (Press Notices). The sales of this book have reached a quarter of a million.

1434_ THE SIN OF JASPER STANDISH. Pp. 342. (Constable). [1901]. (Long). 7d. 1916.

Scene : one of the midland counties. The story is founded on the Newtownstewart, Co. Tyrone, tragedy, where a scoundrelly inspector of police murders the local bank-manager, then himself conducts the investigation, but is unmasked and brought to justice by the English heroine and her housekeper. A morbid and sensational type of book, with not a few traces of religious and national bias. The English characters are belauded, the Irish for the most part represented as fools. There is much "stage-Irish" dialogue.

\section{5_ A GREY LIFE. P.p. 347.' (Stanley Paul). 6s. - 1913.}

Scene: a boarding house in Bath kept by three reduced ladies, with whom Rosaleen 0'Hara passes (in the later 1870's) the three or four years covered by the story. The central figure is the Chevalier Theophrastus O'Shaughnessy, a charming, scholarly man, with sad stories of this past to tell.

ROBINSON, Frances Mabel, “W. S. Gregg." Author of Disenchantment, Irish History for English Readers. (4th ed. 1890), and many novels.

1436_ MR. BUTLER'S WARD. Pp. 376. (Vizetelly). 1885.

Story of Deirdre, daughter of a bailiff who has been murdered as the result of a cruel eviction. Mr. Butler, the bailiff's employer, adopts her, and sends her to a French convent (Bon Secours), and then appoints her as governess to his daughters. She is twice married, the second time (unaware) to the son of her father's murderer. On discovering this she goes into a melancholy madness and does not know her husband. Told with a good deal of tragic power. Written as by an ardent Catholic. Scene: mainly the W. of Ireland. 
ROBINSON, Frances Mabel, "W. S. Gregg"-(continued).

1437- THE PLAN OF CAMPAIGN : a story of the fortune of war. Two Vols. (Vizetelly). 1888.

Scene: Dublin, except for a chapter at Dromore and a visit to London. Deals with the famous agrarian "Plan of Campaign" in the eighties, viewed with nationalist sympathies. Religion is not discussed. A number of men and women of the educated classes meet to talk politics. They go to see evictions, and vivid but heartrending pictures of these are drawn. A bad landlord is killed by a gentleman named Considine. The latter's friend, Talbot, helps him to escape, but his daughter Stella dies of grief. Considine, who is an unbeliever, shoots himself. The story is a good one and skilfully worked out.

ROBINSON, Lennox. B. 1886 at Douglas, Co. Cork. Ed. Bandon Grammar School. Was Manager of Abbey Theatre from 1910 to 1914. Has publ. several successful plays, e.g., The Cross Roads and The Clancy Name. Hopes to publ. soon, through the Talbot Press, Seven Short Stories. Publ. The Lost Leader, a play in three acts (Dublin: Kiersey), Autumn, 1918. Resides Cahirmoyle, Ardagh, Co. Limerick.

1438- A YOUNG MAN FROM THE SOUTH. Pp. 213. (Maunsel). 3s. 6d. 1917.

Willie Powell, brought up in a Protestant and Unionist environment, comes up to Dublin. He drifts into Nationalist circles, and then, one evening, "Kathleen ni Houlihan," played at the Abbey Theatre, converts him wholly to nationalism. Before long he is the life and soul of the extreme party. But an incident occurs which seems to send all his ideals once more into the melting pot: he disappears, and his place knows him no more. The Author allows the various persons, who, in turn, tell Willie's story, to see it through their own temperament and tell it in their own way. He keeps studiously in the background. The book is a carefully drawn picture (not a discussion) of certain phases of Irish life to-day. It was finished in December, 1915; but Easter, 1916, was already in the air, and the personages that move around Willie Powell are typical of the men and women concerned in thase eventful days. Some are almost portraits.

1439 _ DARK DAYS. Pp. 33. Sq. 12mo. (Talbot Press). 1s. Paper. 1918.

Four very short stories, viz., "An Irishwoman," Aug., 1915 (war from a purely Irish standpoint); "A Sinn Feiner," May, 1916; "A Crazy Man," May, 1916; "In Silence and Tears," Aug., 1916. The dates are significant. A view of Easter Week, 1916, from a curiously detached standpoint, with leanings, however, towards complete Irish nationalism.

ROCHE, Hon. Alexis C. B., third son of 1st Baron Fermoy. B. 1853. Resided near Kanturk, Co. Cork. D. 1915.

1440_ JOURNEYS WITH JERRY THE JARVEY. (Smith Elder). 6s. 1915.

Yarns told by a country car driver in the South of Ireland to his passenger. Their merit is that they read almost exactly as if they were literally what they purport to be, and there seems to be no reason to doubt the statement in the Preface that they are written down from memory. Told in humorous brogue that is very pronounced yet is not travestied. They are mostly stories about the local county families, some of them bordering on scandal and some not a little coarse. The humour is genuine enough.

ROCHE, Regina Maria. 1765-1845. A once celebrated novelist. For many years before her death she lived in retirement at Waterford. Wrote also The Vicar of Lansdowne (1793), Maid of the Hamlet, 'The Monastery of St. Columba, \&c., \&c.

1441_ THE CHILDREN OF THE ABBEY. Four Vols. 12mo. [1798]. (Mason). Twelfth ed., 1835; others 1863, 1867.

A sentimental story of a very old-fashioned type. The personages are chiefly earis and marquises, the heroines have names like Amanda, Malvina, \&c. Though in 
ROCHE, Regina Maria-(continued).

this novel Irish places (Enniskillen, Dublin, Bray) are mentioned, the book does not seem to picture any reality of Irish life. This is still on Mudie's list. It was republ. in U.S. $\Lambda$. at Hartford, Exeter, Philadelphia, and N.Y.

\section{2— THE MUNSTER COTTAGE BOY. Four Vols. Pp. 1195. (London: Newman). 1820.}

A little girl, Fidelia, grows up without knowing who her parents are. Bad people try to exploit her: a servant named Connolly tries to save her, but she falls from one misfortune into another, till finally she meets her father, and finds herself an heiress. Interminable conversations and intricacies of episode. A multitude of characters, who are for the most part English in Ireland. No humour, nor style.

1443- THE BRIDAL OF DUNAMORE. Pp. 888. (London: Newman). 1823.

A character study of Rosalind Glenmorlie, beautiful but haughty and ambitious, and of the misery she caused to many and finally to herself. It is tragedy almost all through. The scene is "Dunamore," on the E. coast of Ireland. The character of the heroine is overdrawn and cxaggerated, like most of the Author's dramatis personce.

1444 THE TRADITION OF THE CASTLE; or, Scenes in the Emerald Isle. Four Vols. Pp. 1414. 1824.

A very long story, with a multitude of characters. The aim seems to be to plead that Irishmen should resido in their own country and work for its welfare. Scenery of Howth, Artoir-na-Greine, a place near Dublin, and Killarney. Dialect good. No discussion of religious matters, but a good deal of politics. The story opens during last session of Irish Parliament, and, in a discussion between husband and wife, the Author's nationalist sentiments appear. Donoghue O'Brien, the hero, is long kept apart from his Eveleen Erin, but they are united in the end.

\section{5- THE CASTLE CHAPEL. Three Vols. Pp. 963. (London: Newman).}

A story of a family of O'Neills of St. Doulagh's Castle, somewhere in Ulster, early nineteenth century. Eugene falls in love with Rose Cormack, his sister's companion, and they make vows of marriage in the chapel by moonlight. Eugene, who dabbles in phrenology and seems somewhat of a fool, goes away. On his return he is told that Rose has been killed in an accident. In reality she thas been taken away by her father, a Mr. Mordaunt, former owner of the castle, who has poisoned his wife. Rose becomes an heiress, dies abroad, and leaves her fortune to the O'Neills, and an apology for her duplicity. A queer, outlandish sort of story.

\section{ROCHFORT, Edith.}

1446- THE LLOYDS OF BALLYMORE. Two Vols. (Chapman \& Hall). 1890.

A domestic story, told with simplicity and feeling. The Lloyds belong to the Protestant landlord class, as do most of the personages in the tale. Period : 1881 : the Land League days. Scene: the Midlands and afterwards Dublin. The first part of the plot turns on the agrarian murder of Mr. Lloyd, the trial, and execution of the murderer; the second on Tom Lloyd's being suspected of a bank-robbery when the Lloyds are living in very straitened circumstances. All through runs a delicately told and very sympathetic love story. The land question is viewed from the landlord standpoint, but discussed without excessive bitterness. Conversations natural and peasant dialect good.

\section{RODENBERG, Julias, alias Levy.}

1447- DIE HARFE VON IRLAND: Märchen und dichtung in Irland. Pp. 299. 16mo. (LEIPZIG: Grunow). 1861.

Contains:-I. Thirteen Irish melodies, with music. II. Tales. III. Poems and songs transl. into German verse. At the end are useful notes, and at $p .283$ a list of sources. These are chiefly the Dublrn and London Magazine for 1825-7. Two are given as " mündlich" (gathered orally). Titles such as:-The land in the sea, the wizard of Crunnaan, two stories of the Leprechaun, the landi of the ever young (Tir na n-óg), the fairy handkerchief of the Phuka, the fair Nora, \&c. 
ROGERS, R. D.

1448- THE ADVENTURES OF ST. KEVIN, and Other Irish Tales. (S'wan Sonnenschein). Pp. 266. [1897]. 1907.

A dozen humorous sketches, well told, giving the old legends in a modern comic setting, much in the vein of Edmund Downey's Through Green Glasses. The brogue is faithfully rendered.

" ROHMER (Sax)," John S. Ward. Author of The Yellow Claw, Dr. l'u Manchu, The Sins of Séverac Bablon, 'T'he Romance of Sorcery, etc.

1449_ THE EXPLOITS OF CAPTAIN O'HAGAN. Pp. $231 . \quad$ (Jarrold). 3s. $6 d$. 8 clever illustr. by Cyrus Cuneo. n.d. [1916].

The exploits of Capt. the Hon. Bernard O'Hagan, V.C., D.S.O., take place in modern London, but the hero of them is not of the modern world except by the accident of time. $\mathrm{He}$ is a kind of compound of Don Quixote, the Admirable Crichton, Athos, the Scarlet Pimpernel, and Thackeray's Barry Lyndon, a compound, that is, of pride of lineage, antique chivalry, reckless and brazen audacity. With his air of distinction, rich but unusual dress, and perfect self-assurance he penetrates into the most exclusive circles. He devotes his leisure hours to rescuing distressed damsels or defeating rogues in the manner of a knight errant. Told in an almost obtrusively vivacious manner. Not for children but free from objectionable incident.

ROLLESTON, T. W. B. 1857, at Shinrone, King's Co. His father was County Court Judge for Tipperary. Ed. St. Columba's, Rathfarnham, and T.C.D. Lived some years on the Continent, but has since lived alternately in London and in Dublin. Has written much verse. Also several literary, philosophical, and biographical works. Was the first secretary of the Irish Literary Society, London.

1450_ MYTHS AND LEGENDS OF THE CELTIC RACE. Pp. ix +457. (Harrap). 7s. 6d. Sixty-four full-page illustr. by Stephen Reid-excellent. (N.Y. : Crowell). 2.50. 1911.

A very handsome volume, beautifully printed and bound. Contents :-1. The Celts in ancient history. 2. The religion of the Celts. 3. The Irish invasion myths. 4. The early Milesian kings. 5. Tales of the Ultonian cycle. 6. Tales of the Ossianic cycle. 7. The voyage of Maeldun. 8. Myths and Tales of the Cymry. Elaborate Glossary and Index. From about p. 106 onwards the legends, sagas, \&c., are not simply discussed but told as stories. The résumé of early Celtic history, with the customs, art, religion, and influence of the race, is very valuable, but the main interest lies in his complete survey of the cycles of Irish myth and legend. The editor claims that he has " avoided any adaptation of the material for the popular taste." Some very unfortunate (to say the least) remarks about religion (see pp. 47 and 66) might well have been omitted.

1451 — THE HIGH DEEDS OF FINN, and Other Bardic Romances of Ancient Ireland. Pp. Iv.+214. (Harrap). 5s. Sixteen illustr. by Stephen Reid. (N.Y. : Crowell). 1.50. 1910.

Introduction long, but very interesting, by the well-known man of letters (author of nearly thirty volumes), Rev. Stopford Brooke. Deals with the relationship and contrasts between the various cycles of Irish bardic literature and their several characteristics-and this in a style full of literary charm. The stories told by $\mathrm{Mr}$. Rolleston (than whom few more competent could be found for the work) are :ctellings in a style graceful and poetic, but simple and direct, of ancient Gaelic romances, some already told in English elsewhere, others now first appearing in an English dress. They are drawn from all three cycles above mentioned. Source for each mentioned at end of book. Some of these tales are already well known, such as Oisin in the Land of Youth, and the Children of Lir. The style, it may be added, has not the fire and the dramatic force of Standish O'Grady, but it has good qualities of its own. 


\section{ROONEY, Miss Teresa J.; “Eblana.” A Dublin lady. B. 1840. D. in 1911 .} Wrote also Erin Quintiana. (N.Y. : Benziger). 0.80 . 1889, \&c.

Period : reigns of T'uathal and Diarmaid O Cearbhail. Scene : chiefly the district around Tara. Aims to present a detailed picture of the daily life and civilisation of Ireland at the time. Chief events: the murder of Tuathal, the judgment of Diarmaid against Columbkille, followed by the battle of Cooldrevne, and finally the Cursing and Abandonment of Tara. The story is slight and moves slowly; there is no love interest. The historical events are not all, perhaps, very certain, but the Author has brought very great industry and erudition (from the best sources) to the portrayal of the life of the time. The edition (of 1889) was revised and corrected by Canon U. J. Bourke, M.R.I.A., and is admirably produced.

\section{3_ EILY O'HARTIGAN, an Irish-American Tale. (Sealy, Bryers). 2s. 1889.}

Time of the Volunteers. Chief incidents in the tale : Battle of Bunker's Hill, and Irish Declaration of Independence in 1782. A disagreeable person of the name of Buck Fox (the name under which the story originally appeared) takes up quite too large a space in this book; and he and his friends, with their soi-disant English accents, are most decided bores. The point of view is strongly national.-(I.M.).

\section{4 - THE STR1KE. (Sealy, Bryers). 6d. 1909.}

"A stirring tale of Dublin in the eighteenth century, when Ireland stood well ahead in industrial activity, and the Dublin Liberties were the hub of Irish Industrialism."

\section{RORISON, E. S.}

\section{5__ A TASTE OF QUALITY. Pp. 319. (Long). 6s. 1904.}

Family life among Protestant upper middle class folk in a country district-very pleasant and refined society. A kindly, human story, eminently true to life, without bias of any kind. One becomes quite familiar with the cleverly-drawn charactersthe kindly, cultured Archdeacon and his sister; patient, crippled Larry, with his cheery slang; devoted Auntie Nell, bringing comfort and brightness where she goes; the Austrian countess; and the twins.

ROWE, John G. B. Liverpool, 1874, of Irish parents. Ed. at various schools in or near Liverpool, ending with St. Francis Xavier's (S.J.), where he did a very brilliant course. He went in for journalism, writing innumerable serials, short stories and articles for the Press. Many of these were Irish in subject, e.g., "At his Foe's Mercy, a tale of '48"; "The Mill of Knockraheen, a tale of '98"; "By Irish Bayonets, or how O'Mahony saved Cremona." Also stories dealing with deeds of Irish regiments in the present war, many Irish plays, and an English Catholic historical novel, The Pilgrims of Grace.

\section{6- WITH STRONGBOW AT WEXFORD. \\ A Tale of the Norman Invasion. Pp. 232. (Educational Co. of Ireland). 8d. Cloth boards, picture cover, 1 illustr. 1916.}

Foreword by Patrick O'Daly. Period c. 1171. Love story of Turlough, heir of Mac Gillapatrick, Prince of Ossory and Ethnea O'Cosgry, daughter of a chieftain of the Hy-Kinsella, with a carefully drawn historical background. The wealth of historical and topographical detail does not hamper nor obscure the narrative. Roderick O'Connor, Dermot McMurrough, Strongbow, Maurice de Prendergast, figure in the story but its heroes are the Mac Gillapatricks in their struggle against the invaders. The book needs a map of twelfth-century Ireland. 


\section{ROWLANDS (Effie Adelaide), now Madame Albanesi.}

\section{7- AN IRISH LOVER. (Hodder \& Stoughton). 6d. 1914.}

The Author is a very prolific writer of popular novels. Between 1911 and 1915 she published about 90, e.g., "Love's Fire," "Love's Harvest," "Love's Mark," "Love's Shadows," "Love's Young Dream," etc., etc.

ROY (Gordon). Author of For Better for Worse (1892), Her Cousin Adair.

1458- FOR HER SAKE. A taie of life in Ireland. Pp. 395. (Nelson). attractive illustr. in colour in new ed. [1889]. New ed. 1906.

Capt. Stanford brings his Scotch bride Leslie to Ireland to live in a dilapidated mansion near the squalid village of Timoleague (not the actual place of that name). She is depressed by the place, and neglected by her husband, but comes to love the poor people around. A cruel eviction is followed by a plot and a murder. Stanford is suspected. but Leslie is able to prove his innocence, and all ends in reconciliation. Without religious or political bias.

\section{RUSSELL, Maud Mary.}

1459_ SPRIGS OF SHAMROCK; or, Irish Sketches and Legends. Pp. 135. (Browne \& Nolan). 6d. net. Wrapper. A few photos. n.d. (1900).

“ In memory of the Queen's visit to Ireland in May, 1900." Pp. 1-62 are taken up with short accounts of tours-the Shannon, the Giant's Causeway, Lough Rynn, Kilkee, Waterford, etc. Pp. 67-135 various legends-" "The Legend of Lough Neagh," "Innisfail," "The Curse upon Carkry," "Maev, the Shannon Queen," "The Bride of Inniscalthra." Nicely told.

\section{RUFFIN, Mrs. M. E. HENRY-, see HENRY-RUFFIN.}

RUSSELL, T. O'Neill; “ Reginald Tierney." B. near Moate, Co. Westmeath, 1828. Son of Joseph Russell, a Quaker. Was devoted from about 1858 till the end of his life to the revival of the Irish language. During the Fenian movement he was an object of suspicion. He emigrated, and spent thirty years in U.S.A. Returning in 1895, he threw himself heart and soul into the Gaelic Revival. D. 1908.

1460 TRUE HEART'S TRIALS. (Gill). 1s. and 1s. 6d. Still in print, 1910. A rather rambling tale of the troubles of a pair of lovers. Scene: first, the Lake district of Cavan and Westmeath, where we have a glimpse of squireen life. Afterwards the backwoods north of Albany, U.S.A. Both light and shade of American colonist life depicted. There are many laughable episodes in the book.

1461_ DICK MASSEY. Pp. 300. (Gill). 1s. [1860]. New ed., poor print, 1908.

Famine in 1814 and following years, as background for a story full of incident, humour, and pathos, with faithful pictures of many sides of Irish life-the emigrant ship, a wedding, relations of good and bad landlords wilh tenants. Altogether on the side of the peasant. Original title :-The Struggles of Dick Massey; or, the battles of a boy, by " Reginald Tierney."

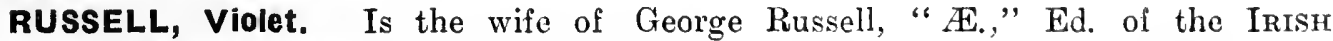
HOMESTEAD and a well-known poet.

1462- HEROES OF THE DAWN. Pp. 251. (Maunsel). 5s. Sixteen black and white drawings and four coloured illustr. by Beatrice Elvery. n.d. [1913].

Stories of the Fionn cycle, drawn from Standish O'Grady's Silva Gadelica and from the Transactions of the Ossianic Society, and retold with a pleasant simplicity and directness, for children. "I would have you see in them," says the dedication, " a record of some qualities which the heroes of ancient times held to be of far greater worth than anything else-an absolute truthfulness and courtesy in thought and speech and action; a nobility and chiva!ry of mind, \&c. ..." But the Author leaves the reader to draw his own moral and does not force it on him. The illustrations are charming, and the whole book is produced with great artistic taste. 
RYAN, W. P., see also O'RYAN, W. P.

1463 — THE HEART OF TIPPERARY. Pp. 256. (Ward \& Downey). 1893.

A romance of the Land League, but not too much taken up with politics. Nationalist. Introd. by William O'Brien, ex-M.P.

1464 STARLIGHT THROUGH THE ROOF. Pp. 240. (Downey). 1895. Under pseudonym "Kevin Kennedy."

Scene: an inland village of Munster (presumably in Co. Tipperary). A tale of peasant life-Utopian reforms realized by a returned emigrant, opposed by land agents and a landlord's priest; partial conversion of the latter to the people's side; arrest of reformer on false charge of murder; breaking open of prison, and rescue, \&c. An early and crude effort in fiction. Pleasant, emotional style. Very strong Nationalist bias.

SADLIER, Anna T. Dau. of Mrs. James Sadlier. B. 1854 at Montreal. Her work includes over 40 volumes, together with very numerous contributions to Catholic periodical literature. Among her books are:-Names that Live, Women of Catholicity, 'T'he Pilkington Heir, Arabella, Phileas F'ox. Resides in Ottawa. 1465- WAYWARD WINIFRED. (Benziger). 1.25. 1905.

Appeared originally in Ave Maria, 1902. Gold seeking in Co. Wicklow is one of the sources of interest in the story.

SADLIER, Mrs. James, née Madden. Born at Cootehill, 1820. D. 1903. In 1844 she went to Canada, where the rest of her life was spent. Between 1847 and 1874 she wrote frequently for the principal Catholic papers in America. In 1895 she received the Laetare Medal. "Each of her works of fiction had a special object in view, bearing on the moral and religious well-being of her fellow Irish Catholics." She says: "It is needless to say that all my writings are dedicated to the one grand object: the illustration of our holy Faith by means of tales or stories." Her sympathies are strongly nationalist. Besides the books here noticed, she also published The Red Hand of Ulster, and a large number of religious works. Flynn of Boston publishes a uniform ed. of her works at 0.60 each vol. Many of them were originally published by the firm of her husband, James Sadlier.

1466- THE FATE OF FATHER SHEEHY. Pp. 178+appendix 76. (Duffy).

1s. 6d. Still in print. [c. 1845]. (N.Y.: Benziger). 0.60 .

The story (true, though told in form of fiction) of how the heroic patriot-priest was judicially murdered at Clonmel in 1766 by the ascendancy faction, backed by the Government. Appendix by Dr. R. R. Madden, giving full details of the trial, depositions of witnesses, \&c.

1467- WILLY BURKE. Pp. 224. (Duffy). 1s. 6d. [c. 1850]. In print, 1909.

Story of two Irish emigrant boys left orphans in the States, and their struggles with temptations against their Faith. One is a model boy; the other goes off the track, but is brought back again. A moral and religious story, full of Catholic faith and feeling. It might, however, be not unreasonably considered somewhat "goody-goody."

1468_ NEW LIGHTS; or, Life in Galway. Pp. 443. (N.Y.: Sadlier). [1853].

Peasant life in Famine times. Written with a strong sympathy for the sufferings of the people, and with admiration for their virtues. There is a good deal about the proselytism or "souperism" that was rife at the time. The evils of landlordism, resulting in evictions, \&c., are depicted. There is no love interest.

1469- THE BLAKES AND FLANAGANS. Pp. 391. (N.Y.: Kenedy). 0.60 net; and (Duffy) 2s. 6d. [1855]. 1878 (Sadlier). 1909.

Life among lower middle class Irish in New York, showing in a somewhat satirical way, evil effects of public school education. The moral purpose, though fairly evident, does not detract from the naturalness of the story. The conversation is particularly lifelike. 


\section{SADLIER, Mrs. James, née Madden-(continued).}

1470 - THE CONFEDERATE CHIEFTAINS. Pp. 384. Demy 8vo. (Gill). 4s. Many editions. [1859]. Still in print. (N.Y. : Benziger). 0.60 net.

A romance of a popular kind, without great literary pretensions, giving a good picture of the events of the time, written from a Catholic standpoint, and sympathising with the Old Irish party led by O'Neill, who is the hero of the tale. All the chief men of the various parties figure in the narrative. Full expression is given to the Author's sympathies and dislikes, yet without, we believe, historic unfairness.

1471— BESSY CONWAY; or, The Irish Girl in America. Pp. 316. (N.Y.: Kenedy). 0.60 net. Print rather poor. n.d. [1861]. Still in print.

Theme of story: influence of religion on character. Object (as stated in Pref.) : to point out to Irish girls in America (especially servants) "the true and neverfailing path to success in this life, and happiness in the next." Bessy, daughter of Tipperary farmer, leaves for America. She finds when on board that Henry Herbert, son of her father's landlord, a Protestant, is, without encouragement from her, following her through love. The story tells how a change came over the wild young man, how he became a Catholic, and married Bessy; how the two of them made their fortunes in N. Y., and how Bessy came home just in time to stop the eviction of her father in the Famine year. Readable, with touches both of humour and of pathos. Highly moral and religious in tone.

1472— THE RED HAND OF ULSTER; or, the Fortunes of Hugh O'Neill. (LoNDON and DubLin). c. 1862.

Mentioned in most lists of this Author's works, but not in British Museum Library.

\section{3- THE HERMIT OF THE ROCK. Pp. 320. (Gill). 2s. 6d. n.d.}

[1863]. In print.

Story of Irish society in the 'sixties. The "hermit," who tends the graves and monuments on the Rock of Cashel, is a sort of Irish " Old Mortality," and is a storehouse of legend and tradition. The story is by no means a tame one : there is a murder mystery, and sensation, though the latter does not degenerate into melodrama.

1474 THE DAUGHTER OF TYRCONNELL : a Tale of the Reign of James I. Pp. 160. (Duffy). 1s. (N.Y.: Kenedy). 0.60 net. [1863]. Still in print.

Sufferings of Mary O'Donnell, daughter of the exiled Earl of Tyrconnell, at the hands of James I., who adopted her and wished her to marry a Protestant. She dresses as a man and escapes to the Continent, where she enters a convent. Founded on a tradition recorded in MacGeoghegan's History of Ireland. James is painted in very dark colours; Mary is almost too good for real life.

1475_ SIMON KERRIGAN; or, The Confessions of an Apostate. Pp. 252. (Boston and Montreal: D. \& J. Sadlier. Also Duffy). 1864.

The life-story of an Irish farmer's son, who emigrates to America, and there loses his faith. He marries the daughter of a Protestant deacon, and thinks he has found happiness. But misfortunes of all kinds come upon him. Finally he reverts to Catholicism, and returns to die in his native Glendalough. The story purports to be a MS. found in his house after his death. The moral purpose and the religious bias of the book are prominent throughout. The story is melodramatic and somewhat unreal.

1476_ CON O'REGAN ; or, Emigrant Life. Pp. $405 . \quad$ (N.Y.: Kenedy). 0.60 [1864]. 1909.

A powerful anti-emigration novel, depicting the hardships of Irish emigrants in the New England states in the 'forties. Thoroughly Catholic and sympathetic to the Irish, but does not conceal their faults. 
SADLIER, Mrs. James, née Madden-(continued).

1477- THE OLD HIOUSE BY THE BOYNE. Pp. 319. (Gill). 2s. 6d. [1865] ; also (LondoN) 1888. New ed., 1904. (N.Y. : Benziger). 0.60.

Scene : Drogheda. Many descriptions of old historic spots, and much legendary lore. There is a love interest also, but the book is hardly up to the Author's usual standard. At the outset of the book Drogheda is well described.

1478- THE HEIRESS OF KILORGAN. Pp. vi.+420. (N.Y. : Kenedy). 0.60. [1867]. New ed. 1909.

"A slight and very simple thread of fiction connects thronghout the series of historical sketches constituting these "Evenings with the old Geraldines.' "(Pref.). The plan is similar to that of Hibernian Nights Entertainments (Ferguson), $q . v$. At Kilorgan, near the Maigue, in Co. Limerick, dwell a poor family of descendants of the Geraldines. They are visited by an Englishman, who has (without their knowledge) bought the old place in the courts. Every night of his stay a story is told, the intervals being filled in by somewhat insipid love episnases, long poems (by Mrs. Hemans, Longfellow, Gerald Griffin, \&c.), and songs. The stories are a series of episodes from Geraldine history from Gerald FitzWalter in Wales to the Sugan Earl, c. 1598, together with a few miscellaneous romantic stories. They are simply and interestingly told. Some are hardly for children. An Appendix gives some Geraldine documents.

\section{9- MacC.ARTHY MOR. Pp. 277. (N.Y.: Kenedy). [1868]. At present} in print. n.d.

Life and character of Florence MacCarthy Mór based on his Life and Letiers by Daniel M'Carthy. M'Carthy is said by the Author (Pref.) almost to merit the name of the Munster Machiavelli. The book presents a striking picture of the struggles of the great families of the day to preserve faith and property amid the petty persecutions of the government and the intrigues of rivals. Chief events introduced : battles of Pass of Plumes, Curlew Mountains, and Bealanathabuidhe. Elizabeth, Cecil, Burleigh, the Northern Earls, the "Sugán" Earl, Sir Henry Power, \&c., appear incidentally. The scene varies between the Killarney district, West Carbery, the Council Chamber of Elizabeth, and the Tower. The episode of the marriage of the daughter of MacCarthy Mór to Florence MacCarthy Reagh forms the theme of Miss Gaughan's The Plucling of the Lily, q.v.

\section{0_- MAUREEN DHU. Pp. 391. (N.Y. : Sadlier). . [1869].}

A tale of the Claddagh, the famous fishing village beside Galway city. Its manner's and ways are described in detail and with fidelity. Tells how the beautiful daughter of the chief fisherman is wooed and won from all competitors by a wealthy. young merchant of the city. The plot is well sustained and interesting, though somewhat complicated and hampered by digressions.

\section{SANBORN, Alvan Francis.}

1481 - MEG McINTYRE'S RAFFLE, and Other Stories. Two Vols. (Boston : Small \& Maynard). 1.25 each. 1896.

"Studies of the poorest classes in a great city, the pathos often ghastly in its intensity. The title-story is an Irish idyll."'-(Baker, 2).

SAVAGE, Marmion W. 1805-1872. B. Dublin. Ed. T.C.D. He was a government official in Dublin for some years, and at that time wrote for DUBL. UNIV. Magazine. In 1856 he went to London, and there edited several periodicals. $\mathrm{He}$ was a witty and clever novelist, very popular in his day. Wrote also Bachelor of the Albany, My Uncle the Curate, Reuben Medlicott, A Woman of Business. 1482- THE FALCON FAMILY. (Chapman \& Hall). [1845]. (Ward, Lock).

"The best known and choicest of the Author's numerous stories. It is intended as: a satire on the leaders of the Young Ireland Party; and some of the satire is 


\section{SAVAGE, Marmion W.-(continued).}

very keen and amusing, but as political pictures his sketches are no better than caricatures."--(Read). John Mitchel, reviewing it (ThE Natron, 13th December, 1845), calls it " another of those pamphlet novels that infest the literary world ... though too obviously the production of an Irishman, is as obviously intended and calculated for the English market. . . . We have had some opportunities of acquaintance with the men the writer attempts to satirize, and do unfeignedly declare that we have never met (them). . . . In short, this book is a very paltry and ill-conditioned performance."

1483 _ See in Addenda under Savage.

SAVILE, Mrs. Helen. Author of The llings of the Morning, and A Poor Buffer. 1484_ LOVE THE PLAYER. (Sonnenschein). 6s. 1899.

"A tragic plot, with sketches of Irish life, and unpleasant specimens of humanity in the rector and rector's wife in the Protestant community of Tuleen. Old Mickey Hogan, the sexton, is depicted with humour."-(Baker, 2).

SAVILE, $H$.

1485- MICKY MOUNEY, M.P. Pp. 250. (Bristol : Arrowsmith). Illustr.

by Nancy Ruxton. 1902.

Career of the hero from bog-trotter to M.P. As a background, a vulgar and absurd caricature of Irish life. Humour throughout of a very broad kind. Characters speak in an impossible brogue.

\section{SCHLICHTRULL, Aline Von.}

1486 DER AGITATOR VON IRLAND. Pp. 1043. (BerLIN : Otto Janke). 1859.

O'Connell is the hero, but there are a multitude of characters, chiefly of the ruling classes. Politics are much discussed, the Author's sympathies being pretty clearly on the Catholic and Nationalist side. Scene partly in Ireland, partly in England, where the reader listens to speeches in the House of Lords.

SCHOFIELD, Lily, Mrs. S. R. Schofield. Author of many books for children. 1487- ELIZABETH, BETSY, AND BESS. (Duckworth). 6s. 1912.

"The purport of the Author is to reveal the varied charm and grace of a delightful Irish girl's character between the ages of thirteen and eighteen or so. A vital, significant portrait."-(T. LrTT. SUPPL.) Scene: partly at "Castlemorne," partly in a big English school near Liverpool.

ScOTT, Florence, and HODGE, Alma.

1488- THE ROUND TOWER. Pp. 229. (Nelson). 1s. 6d. Yretty picture cover. 1906.

A very slight story centring in the landing of the French at Killala in 1798. Adventures of two small English boys. An interesting but one-sided glimpse of some of the episodes of the time. For boys.

SENIOR, Dorothy. Author of Caprice, The Gay King, The King who Never Died. (1910), etc.

1489_ THE CLUTCH OF CIRCUMSTANCES; or, The Gates of Dawn. Pp. 333. (Black). (N.Y.: 'T'he Macmillan Co.). Frontisp. 1908.

An Arthurian romance, with Finola, daughter of Cormac, King of Leinster, as heroine. She is married to a brutal husband, but in the end is united to her true love. Not, however, without passing through a long series of adventures, rescues by knights errant, escapes, \&c. Has all the usual elements of the romantic chanson de geste-tourneys, rose-gardens, adventures in the green-wood. Told in highly romantic manner, but with the romance is blended a curious element of the modern problem novel. 


\section{SEYMOUR, St. John D.}

1490 - IRISH WITCHCRAFT AND DEMONOLOGY. Pp. 256. (Hodge\& \& Figgis). 5s. net. 1914.

A very competent piece of work from a scientific point of view. From the point of view of fiction it is full of weird and uncanny stories, gleaned from all sorts of sources.

\section{SEYMOUR, St. John D., B.D., and HARRY L. NELIGAN, D.I., R.I.C.}

1491— TRUE IRISH GHOST STORIES. (Hodges \& Figgis). 3s. 6d. 1914.

Author says in Pref.: "For myself I cannot guarantee the genuineness of a single incident in this book-how could I, as none of them are my own personal experience. This at least I can vouch for, that the majority of the stories were sent to me as first or second-hand experiences by ladies and gentlemen whose statement on an ordinary matter of fact would be accepted without question." The names of some contributors are mentioned. The stories are classified partly according to locality, partly according to the type of ghost in question. A final chapter gives a kind of Apologia for the book. Index of place names. The telling is perhaps a little monotonous and dull.

SHAND, Alexander Innes. 1832-1907. A Scotchman who interested himself in the Irish land question and wrote Letters from the West of Ireland, 1884. Other novels of his were Against Time and Shooting the Rapids.

1492- KILCARRA. Three Vols. (Blackwood). 1891.

The influence of a good and sweet-natured woman on selfish men, with the Land League agitation in Co. Galway for a background. The peasantry are depicted as wild and lawless and mere tools of the Land League, but as capable of much good. The shooting of landlords is sheer barbarism, no attempt being made by the Author to set forth its causes. The plot is furnished by the efforts of the hero, Capt. Martin Neville, to trace the murderer of a previous owner of the Kilcarra estate, and also by the story of his love for his cousin Ida, or rather hers for him. There is much about the relations between landlord and tenant.

SHARP, WIIliam, see " FIONA MACLEOD."

\section{SHAW (JOhn).}

1493- THE DIAMOND MERCHANT. Pp. 177. (Belfast : Aiken). 18. 1898. Six short stories. The title story deals with Belfast in the twenties and contains interesting details of old streets and lanes that have long since disappeared. The other stories are: "Ramore Hill" (a tale of Portrush), "Wanted a Tenor," "Only a Poor Actor," "Jack Temple's Detective Experience," "The Widow's Mite."

SHEEHAN, M. F.

1494_ NEATH SUNNY SKIES: Stories of the Co. Waterford. Pp. 123. (Waterford News). $6 d$. 1912.

A series of simple tales well told and true to life.

SHEEHAN, Canon Patrick A., D.D. B. 1852. Educated at St. Colman's, Fermoy, and Maynooth. Spent two years (1875-77) on English mission in Devonshire. Parish Priest of Doneraile from 1895 till his death in 1913. His books deal chiefly with Catholic clerical life in Ireland-a subject which he was the first to deal with from within. He brought to bear on the features and problems of Irish life a deeply thoughtful and cultured mind. $\mathrm{He}$ did not indulge in thoughtless panegyric of Irish virtues, but touched firmly, though sympathetically, upon our national shortcomings and failings. His ideals are of the loftiest, yet never of an unsubstantial and airy kind. His style is influenced too much perhaps in his earlier books by his very wide reading in many 


\section{SHEEHAN, Canon Patrick A., D.D.-(continued).}

literatures, but particularly in Greek, German, Italian, and English. Besides the novels mentioned here, he has published two books of studies and reflections, viz., Under the Cedars and the Stars, and Parerga; also a book of poems, Cithara Mea, a selection of Early Essays and Lectures and The Intellectuals: an experiment in Irish club life. As well as several works of piety. His life, written by Herman J. Heuser, D.D., has recently (1918) been published.

\section{5-GEOFFREY AUISTIN, STUDENT. (Gill). 3s. 6d. [1895]. Fifth ed.,} 1908.

Story of life in a secondary school near Dublin, nominally controlled by the clergy, but in reality left to the care of a grinder of more than doubtful character. A nost uncatholic worldliness prevails at Mayfield, and the standards of conduct and of religion are very low. Geoffrey's faith is weakened and well-nigh ruined. The curtain falls upon him as he goes out to face the world, and we are left to conjecture his fate. Has been translated into French under title Geoffroy.

1496- THE TRIUMPH OF FALURE. Pp. 383. (Burns \& Oates). [1899].

A sequel to the preceding. It is a close and sympathetic soul-study. Geoffrey loses all his worldly hopes and falls low indeed. He suffers the shipwreck of his faith. But in this valley of humiliation he learns strength to rise and conceives far different hopes, and we leave him on the heights of atonement and of regeneration. The book is philosophic in tone, and is enriched with many elevating thoughts from German, Frenoh, and English moralists. It is said to have been the Author's favourite. It has been translated into many languages, e.g., French, under title Le succès dans l'échec (1906), and German as Der Erfolg des Misserfolgs (Press of the Missionaries of Steyl), M. 6.

1497- MY NEW CURATE. Pp. 480. (Art and Book C'o.). 6s. 18th ed. 18 rather poor illustr. [1899]. New ed. (Longmans), 2s. 6d. 1914. (Boston : Marlier). 1.50.

Into a sleepy, backward, out-of-the-way parish comes a splendid young priest, cultured, energetic, zealous, up-to-date. He succeeds in many reforms, but the moral of the whole would seem to be, "Nothing on earth can cure the inertia of Ireland," or rather, perhaps, "You cannot undo in a day the operations of 300 years." 'The old parish priest tells the story. There is in the book intimate sympathy with, and love of, the people, their humours, and foibles, and virtues. There is plenty of very humorous incident and of delightful moralizings, like those in the Author's Under the C'edars and the Stars. It is full of undidactic lessons for both priests and people. The religious life of the people is, of course, much dwelt on, and a good deal of light is thrown on the private life of the priests. Transl. into French (Mon nouveau vicaire), Dutch (Mijn nieuwe kapelaan, by $\mathbf{M}$. van Beek, 1904), German (Mein neuer Kaplan, Bachem, M. 6.), Italian, Spanish (Mi nuevo coadjutor, Herder), Hungarian, Slovene, Ruthenian, Flemish.

\section{8- LUKE DELMEGE Pp. 580. (Longmans). 6s. [1901]. New ed., 1915. 4s. $6 d$.}

The life-story of a priest. The main theme of this great novel is the setting forth of the spiritual ideals of the race and of the heights and moral beauty and heroism to which these ideals can lead. A strong contrast is drawn between the ideals which the hero sees at work around him during his stay in England, and those which he finds at work at home. Many phases and incidents of Irish life are shown-the home-life of the priest, the eviction, the funeral, scenes in Dublin churches, the beauty of Irish landscape. One of the best, if not the best, of Irish novels. Yet as a "problem" novel it is strangely inconclusive. Luke seems to die with his life-questions unanswered. Trans. into French. Tuke Delmege, âmes celtiques et âmes saxonnes; German, Lulias Delmege, trans. Ant. Lohr. (Habber'), M. 6, 1906, sixth ed.; and Hungarian. Canon Sheehan used to say of this book that its central idea was the doctrine of vicarious atonement. 


\section{SHEEHAN, Canon Patrick A., D.D.-(continued).}

1499_ GLENANAAR. Pp. 321. (Longmans). 6s. [1905]. New ed., 1915. 2s. $6 d$.

"Tainted blood, inherited shame, is a terrible thing amongst a people who attach supreme importance to these things." This is, perhaps, the central theme of the story. The narrative opens in 1829, with the famous Doneraile Conspiracy trial in Cork, when O'Connell, summoned in hot haste from Derrynane, was just in time to save the lives of the innocent prisoners. The story traces to the third generation the strange fortunes of the descendants of one of the informers in this trial: There are glimpses of the famine of ' 48 and of the spirit of the men of '67. The story of Nodlag is a touching and beautiful one, and the episode of the returned American is very well done. Trans. into German, Das Christtagskind (STEYL : Mission Press), M. 2.50. First appeared in The Dolphin, 1904-5 (U.S.A.).

1500_ LOST ANGEL OF A RUINED PARADISE. Pp. vi.+168. (Longmans). [1904]. New ed., 1915. 4s.

Three schoolgirls on leaving college take part in a tableau vivant as Parcae or Fates. They announce in make-believe the fates of their companions. A mysterious voice from the audience announces their own. The story tells how their fates worked out. The first part of the drama takes place in Dublin, but after a time the scene shifts to London. Transl. into French as Ange égaré d'un paradis ruiné.

1501- THE SPOILED PRIEST, and Other Stories. Pp. 213. (Gill and Burns d. Oates). 5s. Nine illustr. by M. Healy. 1905.

Eight stories. The title-story gives a glimpse of the workings of an ecclesiastical seminary, and also of the Irish peasants' attitude towards a student who has been refused ordination. "Remanded" is the story, founded on fact, of a hero-priest of Cork. "The Monks of Trabolgan" is a curious, fanciful story of Ireland at some future period. The remaining tales, "Rita, the Street Singer," "A Thorough Gentleman," and "Frank Forest's Mince-Pie," \&c., do not deal with Ireland. Has been transl. into German and Dutch.

1502-LISHEEN; or, the Test of the Spirits. Pp. 454 . (Longmans). 68. [1907]. New ed., 1914. 2s. 6el.

The conception is that of Tolstoi's Resurrection, with the scene transferred to Kerry. It is the story of how a young man of the Irish landlord class determines to put to the test of practice his ideals of altruism. To this end he abandons the society of his equals and lives the life of a labourer. $\mathrm{He}$ finds how full of pain and heartburning and disappointment is the way of the reformer. There are many reflections on the national character, and its defects are not whittled down. The book has two main themes-the greed and callousness of Irish landlords, and the inability of the Englishman to understand Irish character.

1503_ THE BLINDNESS OF DR. GRAY; or, The Final Law. (Longmans). 6s. [1909]. New ed., 1914. 4s. 6d.

The interest of this novel centres partly in its pictures of clerical life, partly in a charming love story of an uncommon type. The central figure is drawn with care and thoroughness. He is a strict disciplinarian, a rigid moralist, who worships the law with Jansenistic narrowness and hardness. But as the story goes on we discover beneath this hard surface unsuspected depths of human kindness. He himself finds out before the end that it is love, not law, that rules the world. The story contains many beautiful and touching scenes, and some fine description, notably in the South African portion of the book. There is some incidental criticism of various features of Irish life-popular politics, religious divisions, the Gaelic League, the change in the mentality of the people, and there is in it food for thought about some of our besetting faults. Considered by many to be the Author's most finished and most powerful work. Transl. into German, Von Dr. Grays Blindheit, with introductory sketch (EINSIEDELN : Benziger). M. 6. 1911. 


\section{SHEEHAN, Canon Patrick A., D.D.-(continued).}

1504 MIRIAM LUCAS. Pp. 470. (Longmans). 6s. [1912]. New ed., 1914. 4s. $6 d$.

Miriam is the daughter of wealthy Protestant parents in Glendarragh, in the W. of Ireland. Her mother, on beconing a Catholic, is driven by domestic persecution into evil ways, and subsequently disappeans. Society ostracizes Miriam, who, in revolt against it, goes to Dublin, where, in alliance with a young visionary Trinity student, she flings herself into the Socialist movement. Her efforts end in a disastrous strike. For a time she stays off crime and tragedy, but it comes at last. Book III. brings her to New York in search of her mother, whom she discovers sunk to the lowest moral depths. The story hinges partly, too, on the lifting of the curse of Glendarragh by Miriam and the hero, who makes her happy in the end. There are not a few fine dramatic situations, but the plot does not hang together. The book is meant to deal with Irish social and religious problems, and to picture certain phases of Irish life. The life pictured is chiefly that of the Protestant upper classes, of whom a severe and satirical portrait is drawn. There are just a few glimpses of peasant life. The Author raises more problems than he solves, and the prevailing impression left upon the reader is one of gloom. Has been transl. into German.

\section{5-THE GRAVES OF KILMORNA. Pp. 373. (Longmans). 6s. 1915.}

An attempt to set forth the spirit of the Fenian movement of 1867 , and even to contrast it with subsequent movements, to the great disadvantage of the latter; for the Author thought that the fire of Nationality has burned very low since ' 67 . The heroes are James Halpin (apparently intended for Peter O'Neill Crowley, who fell in '67) and Miles Cogan, Fenians and unselfish patriots. There is some good character drawing, but the interest of plot and incident is slight, the chief interest being the vein of very ideal philosophy which runs through the book. The Author is gloomy and pessimistic about modern Ireland.

SHERLOCK, John. B. in Dublin, 1870. Ed. Christian Bros., N. Richmond St. B.A. of Royal University. Became a reporter for the Dublin daily l'ress. In this way has visited every part of Ireland. Since 1909 Hansard official reporter in Ho. of Commons. Has written about 60 short stories and two novels in serial form. viz., "In the Days of the Land League" and "The Missing Man" (Weekry Freenian). He embodies in his fiction his recollections of persons and places in Ireland and the things he has seen and lived.

1506- THE MAD LORD OF DRUMKEEL. Pp. 199. (Sealy, Rryers). 3R. 6d. 1909.

"An unexciting chronicle of the solitary Lord Barnabweel, his quaint experiments with his Irish property and tenantry, and the story of his son who left him, married in a Dublin lodging-house, and became a famous musician."-(Itr. Suppr.).

SHORTER, Dora Sigerson, dau. of Dr. Geo. Sigerson, the well-knowll Irishman of letters. Married C. K. Shorter, a distinguished English literary man, editor of the Sphere, and has since lived in England. A gifted poetess. Publ., besides many volumes of verse, Do Little and Do Well : a fairy tale, The Country House Party, etc. Her poetry is full of the love of Ireland. Died 1918.

1507- THE FATHER CONFESSOR. Stories of death and danger. Pp. 381. (Ward Lock). 1900.

Seventeen stories, glnomy with a gloom unrelieved by any ray, painful and morbid. Several of them introduce the preternatural in woird forns. No. 9. "The Strange Voice," has an Irish peasant setting. No. 4 and No. 10 have a vague Irish background. No. 14. "The Lion Tamer," a particularly painful story, has an Irish hero and an Irish heroine, the final scene being laid in Ireland. 
SIDGWICK, Ethel. B. in 1877 at Rugby. Ed. Oxford. Has published 9 novels in the last ten years, 5 of which have been spent in France, Paris being her permanent place of residence. Has spent little time in this country, but has Irish blood on the maternal side, and has strong sympathies with Ireland, her people, artistic productions, sorrows and hopes. Her novels show special interest in the subject of national characteristics.

1508- HERSELF. Pp. 375. (Sidgwick \& Jaclison). 68. 3rd impr. 1912.

Though the scene of this story is (except for an incident in Donegal) not laid in Ireland, the three central figures around which it turns (Brian Clench, Harriet his daughter, and Pat Clench his nephew) are Irish, and the book might almost be called a study in Irish temperament, or rather in that peculiar type of it, the Clench family temperament. Round these three revolve a number of personages, English for the most part, of various degrees of pleasantness or unpleasantness, but on the whole very commonplace folk. The Clench spirit is unconventional, unpractical, fond of all beautiful things, impulsive, generous. The incidents of the story bring out these traits. There is a love interest, but with an unusual denouement. The style is vif and crisp, with much clever dialogue that never flags.

1509- HATCHWAYS. Pp. 325. (Sidgwick d Jackson). 6s. 1916.

Young du Frettay, a French airman, comes on a visit to Hatchways, an aristocratic country house in England. He meets the Irish Duke of Wickford and Lord Iveagh Suir, and Lise, an Irish girl, among a number of other personages. Slight incidents and the conversations bring out very naturally and admirakly the characters of the various dramatis persone, and the Irish characters so revealed are pleasant on the whole. Du Frettay's views of English society are interesting. There is sentiment, but not over much.

1510- JAMESIE. Pp. 255. (Sidguicli d Jaclison). 5s. n. 1918.

A sequel to Hatchways. Told in 250 letters (one to a page), several of the writers (there are over 30) being Irish (Protestant upper class) e.g., Duke and Duchess of Wickford, Irish landed proprietors, and their boy (aged 7); Marquis of Kells : Lord Iveagh Suir who manages their Irish estate; Stephen Crawford who has mismanaged it and made enemies of the people: Jamesie (aged 7), son of Lord and Lady Iveagh Suir, etc. Most of the characters are involved in the war. Iveagh is shot at in Ireland by tenantry. The writer's object seems to be to make the writers reveal their Irish characters in their letters.

SIGERSON-SHORTER, Dora, sce SHORTER.

SIGERSON, Hester. Was the wife of Dr. Geo. Sigerson, the well-known Irish writer.

1511 _ A RUINED RACE; or, the Last Macmanus of Drumroosk. (Ward \& Downey). 68. 1890.

A very gloomy view of Ireland. The Author displays intimate knowledge of Irish scenes, idioms, and characteristics. Period : middle of nineteenth century. Pictures with painful fidelity and much power the misfortunes of a once happy and prosperous couple belonging to the well-to-do peasant class. Misery seems to dog their steps from one end of the book to the other. The girl dies in the workhouse, the man takes to drink and is killed in an accident. Seems to aim at picturing the difficulties and sufferings of the peasantry, especially under the old land system.

SIME, William. B. Wick, Caithness, 1851. D. Calcutta, 1895. Author of several other works of fiction-King C'apital, To and Fro, Boulderstone.

1512 THE RED ROUTE; or, Saving a Nation. Three Vols. (Sonnenschein). 1884.

Scene : West and South of Ireland, beginning with Galway, where the hero, Finn O'Brien, goes to college and suffers much both from collegians and peasantry. Finn becomes a Fenian, but falls in love with an English widow who had become 
SIME, William-(continued).

a Catholic to escape the pursuit of bishops and parsons of her own Church. The heroine is a Claddagh girl, whose love for an English captain, Jeffrey, is crossed by the fact that she is a Fenian. One of the love affairs ends happily, the other tragically. The Author is not anti-Irish, but knows little about Ireland. He drags in priests "smelling strongly of whiskey" and nuns who have broken their vows.

\section{SIMPSON, John Hawkins.}

1513_ POEMS OF OISIN, Bard of Erin. Pp. 280. (M'Glashan d Gill). 1857.

Translated into English prose from Irish by the Author with help of native speakers. Contents : Oisin, Bard of Erin (introductory by the Author); Deardra; Conloch son of Cuthullin (sic); The Fenii of Frin and Fionn MacCumhal; Dialogue between Oisin and St. Patrick (pp. 61-184); Mayo Mythology (various Fenian Tales); The Battle of Ventry.

SKEFFINGTON (Francis Sheehy). B. Bailieboro', Co. Cavan, 1878. Ed. at home and at University College, R.U.I., Dublin, where he took out his M.A. degree with honours, winning also various distinctions such as the Chancellor's Gold Medal, which he gained by an essay on Grattan. At first he was a keen supporter of the Irish Parliamentary Party and helped to found the Young Ireland Branch of the United Irish League. Later he lost faith in the Party and in the good-will of the British Democracy. He threw himself dis-interestedly into many movements, such as Women's Suffrage, Labour Reform, and International Peace, suffering much for his convictions. He wrote incessantly on these and other such subjects. During the Rising of Easter Week, 1916, he was arrested and shot by order of a military officer, though he had taken no part in the movement. His novel was written some years before the date of publication.

1514 IN DARK AND EVII, DAYS, Pp. 237. (Duffy). Portrait and biographical notice by H.S.S. 1916.

The fortunes of a Wexford family, the Kyans, in 1798. The story, which is vividiy and forcefully told with abundance of incident, calls up before us not only the events of those tragic days but the feelings animating the Wexford insurgentstheir habitually peaceful and law-abiding disposition goaded to fury by the atrocities of the soldiery; the recital of the latter would be incredible to one unacquainted with the history of the period. The excesses of the insurgents are not glossed over. In the course of the story Esmond Kyan stabs his betrothed to save her from outrage. In one chapter we are given an inside glimpse of the Castle and its methods. Reynolds the informer, Lord Camden the Viceroy, Sir Ralph Abercromby (a very favourable portrait), and other historical personages are introduced.

SKELLY, Rev. A. M., O.P.

1515- CUChULAIN OF MUIRTHEMNE. Pp. $48 . \quad$ (C.T.S.I.). 1d. 1908.

A paper read before the Catholic Literary Society, Tralee. The Cuchulain epic briefly but admirably related. Passages of verse from Ferguson and De Vere are skilfully interwoven. Excellent notes at the end explain difficulties and references.

SMART, Hawley. 1833-1893. A well-known sporting novelist.

1516 _ THE MASTER OF RATHKELLY. (F. V. White). [1888]. Fifth ed. 1890. Re-issued (Chatto d Windus). 1897, 1898. (Ward Lock), 1909.

A stirring story of love and sport in "Co. Blarney" in "the eighties." Mr. Eyre, one of the " ould stock," gets into difficulties with his tenants, who stop the "Harkhallow" hounds and boycott him. Written from the English and landlord standpoint. The dialect is wonderfully good, and the "horsey" scenes well done. 


\section{SMITH, Agnes; Mrs. Lewis.}

1517- THE BRIDES OF ARDMORE : A Story of Irish Life. Pp. 393. (Elliott, Stock). Frontisp.-view of Ardmore. 1880.

Ardmore, Co. Waterford, in twelfth century. A few descriptions of scenery, but little local colour, and almost no historical mise-en-scine. The chief object of the story appears to be to picture forth a "primitive" Irish Church, unconnected with Rome, and resembling the modern Church of Ireland in many of its features. The priests are all married. Indeed their matrimonial affairs and the cruel interruption of these by decrees from Rome provide the greater part of the incidents. The tone is not bitter towards Catholicism, but innocently patronising and didactic.

\section{[SMITH, John].}

1518_- IRISH DIAMONDS. Pp. 183. 16mo. (Chapman \& Hall). 1847. (Gibbings). Five Illustr. by "Phiz." 1890.

Chapters :- On the Road, Young Ireland, Irish Wit, Irish Life, Irish Traits, The Latter End. Humorous Irish anecdotes, rather above the average "pigs, poteen, and praties" type, frankly meant to amuse, but showing not a little knowledge of and sympathy with Irish traits. When the book was written the Author was "one of the editors of the Liverpool Mercury."

SMITHSON, Annie M. P. B. Sandymount; ed. partly in Liverpool. Became a Catholic, 1907, since when she has followed the nursing profession, chiefly as a district nurse. Has contributed short stories to Tre Cross, but this is her first novel.

1519 HER IRISH HERITAge. Pp. 269. (Dublun : T'le 'T'albot Press). 5s. 1917.

Dedicated "To the memory of the men who died Easter, 1916." A novel of middle class Dublin life in Irish Ireland circles during the two years preceding the Rebellion, the scene changing to Clare during the Rebellion itself. It tells how Claire Castlemaine, daughter of an Irish Catholic mother and of an English agnostic father, who brings her up without religion, comes into her inheritance of faith and Nationality. These latter are the two dominant notes of the story. Its tone is deeply religious and strongly national, but free from bigotry and political animus. The characters of the Blake family are skilfully and sympathetically drawn. A subordinate, yet important part of the tale is the story of Mary Carmichael, with its pictures of slum work and of "St. Columba's" [St. Iawrence's] Home for district nurses. There is humour as well as sentiment and pathos in the book.

SMYTH, Patrick G. B. Ballina, Co. Mayo, 1857. Was in early years a National School teacher. Besides his novels, he wrote verse for several Irish periodicals between 1876-1885. Emigrated to America, 1889. For some time he was engaged on a Chicago paper.

1520_ THE WILD ROSE OF LOUGH GILI. Pp. 3C6. (Gill). 2s. 6d. [1883]. Fifth ed., 1904. (Benziger). 0.85.

Though nominally not the heroes, Owen Roe O'Neill and Miles the Slasher are the chief figures in this fine novel of the Wars of the Confederation. A love-story is interwoven with the historical events. The view-point is thoroughly national. The style abounds in imagery and fine descriptive passages. The novel is one of the most popular ever issued in Ireland. The story ends shortly after the fall of Galway in 1652. The scene is laid partly in Co. Sligo, where (near Jough Gill) one of the most thrilling episodes, founded on a still living tradition, takes place.

1521_ KING AND VIKING; or, The Ravens of Lochlan. Pp. 200. (Sealy, Bryers). 18. n.d. (1889).

Tireragh (Co. Sligo) in 888, the date assigned by the Four Masters to a great battle fought between the men of Connaught and the Danes. The wars between Danes and Irish furnish the chief interest of the book, but there is also the story of the feud between Ceallach the tanist of $\mathrm{Hy}$ Fiachrach and Dungallach, a rival. Much information, drawn from reliable sources, is given regarding the Irish clans, their customs and their territories. 
SOMERVILLE and Ross. Miss Edith Enone Somerville, dau. of the late Col. Somerville of Drishane, Skibbereen, Co. Cork, and Miss Violet Florence Martin ("Martin Ross"), of Ross, Co. Galway, have for many years collaborated in a wonderful literary partnership, the story of which is related in Irish Memories (Longmans), 1918, published after Miss Martin's death, which took place at Cork in December, 1915. They were both granddaughters of Chief Justice Charles Kendal Bushe, a great opponent of the Union. But their views, on the whole, are those of the majority of the class to which they belong. Occasionally this appears unmistakably from episodes in their books which a Nationaiist might well consider libellous. But usual' politics are kept out. It has been very truly said of their writings, "They are the only humorists who never relax. Their whole attitude to life is humorous, and so splendid is their sense of duty to their readers that their almost every sentence is humorous." Their knowledge of the people and their ways (an outside knowledge perhaps) is wonderful, and the people's speech is cleverly reproduced. But the "natives" are seen only in their relations with their "betters," and therefore it is chiefly the class of servants and dependants that is depicted in these books.

1522- AN IRISH COUSIN. Pp. iv.+306. (Longmans). 3s. 6d. [1889]. New ed., quite re-written, 1903. Ten illustr. by E. W. Somerville.

Modern country-house life in Co. Cork. A serious study of the slow awakening of a young man to the realisation that there are things in life more real to him than horses and dogs. His love for a clever cousin returned from Canada has a tragic ending. The characters of the tale are drawn from Protestant county society. Clever description of Durrus, the ramshackle home of the Sarsfields. Miss JacksonCroly's "At Home" and the run with the Moycullen hounds are said to be worthy of Lever.

1523- NABOTH'S VINEYARD. Pp. 280. (Spencer Blacliett). 1891.

An early novel of these Authors but unworthy of their later reputation. It presents a loathsome, sordid picture of Ireland. The Irish are treacherous, drunken, dishonest, and their religion has no good influence on their morals. Scene: a small town on a "fiord" between Cork and Kerry. The chief personages are the repulsive O'Donovan, publican and president of the local Land League, and his still more odious wife. The plot is made up of their schemes against O'Grady, with whom Mrs. O'D. is vainly in love, and the Leonards, whose daughter is loved by O'G. O'Grady, the one decent character, has " the contempt for his fellow countrymen which the Irishman generally imports from America." There is vivid, but sordid, realism in the descriptions.

1524_ THE REAL CHARLOTTE. (Longmans). 3s. 6d. [1894]. Three Vols. (Ward \& Downey).

A dark tale of a world "weary, stale, flat, and unprofitable." An unscrupulous woman works the ruin of a sweet-natured, ill-trained girl. Scene: Irish country neighbourhood. Characters, land agents, farmers, great ladies, drawn with impartial and relentless truth. Pronounced by many critics to be worthy of Balzac.

1525 THE SILVER FOX.

Pp. 195.

(Longmans).

3.. $6 d$.

[1898]. (Lawrence and Bullen).

The chief interest in this story lies in some sporting scenes in the West of Ireland. The peasantry are seen from an uncomprehending standpoint, and the chief figures are people of fashion, of no particular nationality. "Broadly speaking, the novel may be said to exhibit in a dramatic form the extraordinary hold which superstition still possesses on the minds of the Irish peasantry."-(s pectutor).

1526- SOME EXPERIENCES OF AN IRISH R.M. Pp. iv. +310. Thirty-second thousand. (Longmans). 3r. 6d. Thirty-one illustr. (pen and ink sketches) by E. E. Somerville. [1899]. (Nelson). 9d. 1916.

Racy, humorous sketches of hunting and other episodes in the south and west. The Author's most successful work. Originally appeared in THE Banminton Magazine. 


\section{SOMERVILLE and ROSS-(continued).}

1527- FURTHER EXPERIENCES OF AN IRISH R.M. Pp. $315 . \quad$ (Longmans).

3s. 6d. [1908]. (Nelson). 9d. 1917.

1528- ALL ON THE IRISH SHORE. Pp. iv.+274. Eighteenth thousand. (Longmans). 3s. 6d. Ten illustr. by O. E. Somerville [1903]. (Nelson). 9d. 1917.

Sketches of fox-hunting, horse-dealing, racing, trials for assault between neighbours, petty lboycotting, rural larking, full of sprightly and rollicking humour. Chief characters, the petty country gentry. The peasantry are drawn in caricature, usually friendly, and are shown in relations to their social superiors, not in their own life and reality. If these sketches were taken seriously, the peasantry would appear as drunken, quarrelsome, lying, dirty, unconsciously comical-with scarcely a single redeeming trait. The scene is south-western Cork.

All on the Irish Shore has been described (IrIsh Montulu) as " a blend of Lover and Lever (in his coarser rollicking days) refined by some of the literary flavour of Jane Barlow, but with none of the insight and sympathy of Irish Idylls. The same may be said of the Experiences of an Irish R.M., which, moreover, contains here and there passages needlessly offensive to national feeling." Titles of some chapters:- Fanny Fitz's Gamble, A Grand Filly, High Tea at McKeown's, A Nineteenth Century Miracle, \&c.

1529 - SOME IRISH YESTERDAYS. Eleventh thousand. (Longmans). 38. 6d. Fifty-one illustr. by E. E. Somerville. 1908. (Nelson). 9d. 1917.

Admirable illustrations of Connemara scenery, clever sketches of "natives" (usually of the lowest type). Light magazine sketches written in clever, racy style. Subjects: Holidays in Aran and Connemara and Carbery, picnics, country house anecdotes, superficial studies of peasants in Connemara and Cork. "In Sickness and in Health" pays a tribute to the strength of the marriage bond in Ireland.

\section{0- DAN RUSSELL, THE FOX. Pp. 340. (Methuen). 6s. 1911.}

Miss Rowan comes over to Ireland and takes "Lake View," in the midst of a hunting district in S. Munster. She falls in love-for the time-with John Michael, handsome, and the most valiant of huntsmen, but a child of nature whose whole mind is absorbed in hounds and horses. Hence complications. The Author's usual pictures of hunting scenes and happy-go-lucky country gentry. Mrs. Delanty, the sharp and devious widow, is a curious portrait. Dan Russell is scarcely more than a minor character in the piece. It is a story about which we cannot speak favourably.

N.B.-In 1916 Messrs. Longmians issued cheap uniform editions at 3s. $6 d$. of Some Irish Yesterdays, Some Experiences, etc., Further Experiences, etc., All on the Irish Shore, An Irish Cousin, The Real Clarlotte, The Silver Fox.

1531_ IN MR. KNOX'S COUNTRY. Pp. 312. (Longmans). 5s. n. 8 full-p. illustr. by E. E. Somerville. 1915.

A series of eleven humorous episodes told in the first person by "Major Sinclair Yeates," the Irish R.M. Old Mrs. Knox and Flurry and Dr. Jerome Hickey are in the stories as well as a host of minor characters, all amusing. Fully equal in humour to the earlier books.

SquiRE, Charles. D. some years ago.

1532- THE BOY HERO OF ERIN. Pp. 240. (Blackie). 2s. 6d. Handsome cover. Four good illustr. by A. A. Dixon. 1907.

The Cuchulainn Saga told in simple and clear, but somewhat unemotional and matter-of-fact, style. Sources : Miss Hiull's Cuchulaina Saga and Miss Winifred Faraday's Cattle Raid of Cuailgne $(q, v$.) The Author holds Cuchulainn to be a hero "not less brave and far more chivalrous than any Greek or Trojan" (Pref.), and thinks that the ancient Gael "invented the noble system of conduct which we call courtesy." 
SQUIRE, Charles-(continued).

1533- CELTIC MYTH AND LEGEND, Poetry and Romance. Pp. 450. (Gresham Publishing Co.). Four plates in colour by J. H. F. Bacon; fourteen in monochrome by the same and others, and a few photos. n.d.

A kind of digest of the chief published translations of ancient Irish and Welsh saga and romance, preceded by four short essays on the interest of Celtic mythology, and the sources of our knowledge of it, the origin of the Britons and their religion (44 pp. in all). Pp. 47-248 are a summary of Gaelic myth, \&c., and pp. 250-395 of British ditto. Then there is an essay on survivals of Celtic paganisms, and an Append. giving brief bibliogr. Index. The myths and romances are not related as a tale is told; they are merely placed on record, almost stripped of their poetry, along with all the extravagances and absurdities that disfigure them, chiefly through modern corruptions. Of little or no interest for young people.

N.B.-The editions seem to be as follows :-Mythology of the British Isles. Introduction to Celtic Myth, Legend, Poetry, and Romance. Pp. 456 (Blackie). 128. $6 d$. 1905.

The Mythology of the British Isles : Celtic Myth and Legend in Poetry and Romance. (Blackie). 7s.6d. New ed. illustr.

Mythology of Ancient Britain and Ireland. Pp. 86. (Constable). 18. 1906.

STACE, Henry. Author of A Case for Compromise, Kicks \& Ha'pence.

1534 - THE ADVENTURES OF COUNT O'CONNOR in the Dominions of the Great Mogul. Pp. 343. (Alston Rivers). 1s. [1907]. 1909.

A string of impossible situations and thrilling escapes, purporting to be the adventures of an Irish soldier of fortune in India about 1670, related by himself. The Count frequently discourses of the honour of an Irish gentleman, but never acts up to it. His character is that of a thorough rascal. The book contains many disreputable adventures in harems.

\section{STACPOOLE KENNY, MrS. See KENNY.}

STACPOOLE, H. de Vere. Son of Rev. William Church Stacpoole, D.D., of Kingstown, Co. Dublin. Ed. Malvern College, and St. Mary's Hospital, London. Is a qualified medical man, but does not practise. Has travelled much. Resides near Chelmsford. Has publ. about twenty-two novels.-(WHo's Who). Some of these have been very successful, e.g., The Blue Lagoon.

1535_ PATSY. Pp. 362. (Fisher Unwin). 6s. 1908.

A gay and humorous story of a house-party in a country mansion somewhere in "Mid-Meath." Full of amusing characters, cleverly sketched, e.g., the Englishman, Mr. Fanshawe, and the naughty and natural children. Above all there is Patsy, the page-boy, an odd mixture of soft-hearted simplicity and preternatural cuteness. $\mathrm{He}$ is the deus ex machina of the piece, causes all sorts of entanglements, and unravels them again in the strangest way. There is just a little study of national characteristics, but no politics nor problems.

1536 - GARRYOWEN : The Romance of a Racehorse. Pp. 352. (F'isher Unwin). 6s. 1910.

"A rattling good story... Moriarty the trainer is a gem-Mickey Free redivivus, as full of tricks as a bag of weasels. The Author knows his Irish peasantry inside and out, and the only blot on an exceptionl book is a needlessdisquisition on the rights and wrongs of "cattle-driving." "-(I.B.L.).

1537- FATHER O'FLYNN. Pp. 245. (Hutchinson). 1s. 1914.

The idea of the book, which is dedicated to Sir E. Carson and Mr. Redmond, is (see Pref.) to show the Catholic priest as the chief factor in present-day Irish life. The priest in question is represented in a favourable and friendly spirit, though perhaps hardly " at his best," as the Author suggests. The chief interest is perhaps a love affair, conducted chiefly on horseback, which is told in a lively and spirited way. 
STALLARD, Mrs. Arthur, née C. L. Adams. B. 1870 at Kingstown. Ed. Alexandra Coll., Dublin. Has publ. also Castles of Ireland, and The House as Home. Resides in London.

1538_- THE FORD. Pp. 307. (Nash). 5s. n. 1917.

A vigorous and direct criticism of certain aspects of Irish life, from a distinctly hostile standpoint. English and non-Catholic. A coarse, hard-drinking squireen and a drunkard priest seem offered as types. Irish snobbery is satirised. English personages are introduced by way of contrast with the natives, and are made to score oft these latter. "Mrs. S. has a very poor opinion of the Irish, and in The Ford she expresses her disapproval with considerable freedom. Her real opinion of them, however, must be much worse than she avows. . . . " (TIMres Litrerarx Supplement). There is nothing morally objectionable. The Author shows much appreciation of natural beauty, especially in gardens, and a gift for expressing this appreciation.

STAVERT, A. A. B., an Oblate of Fort Augustus Monastery, Scotland, residing in Edinburgh, where he directs a school. B. in Edinburgh, 1864, ed. in Edinburgh, at Aachen in Germany, and at Durham University (M.A.). His father was a farmer residing near Westport, Co. Mayo.

\section{9- THE BOYS OF BALTIMORE. Pp. 212. (Burns \& Oates). 2s. 6d.}

A splendid boy's story. Rich in the vein of adventure, of sport and fight by land, of war by sea, of captivity and slavery. With this there is a solid, but not too obtrusive, lesson of the value of faith and piety in a boy's life. The piety of the young heroes has nothing mawkish about it. The tone is Catholic. The brogue is very badly imitated.-(N.I.R.). Scene changes from Cork to Africa, and thence to London. Strafiord, Wentworth, Laud, and Charles I. appear in the story.

STEPHENS, James. B. Dublin, 1884. Worked for some years in a solicitor's office, but has definitely taken to literature. His first published volume was Insurrections, since which two other volumes of verse have appeared, and a fourth is about to appear. Resided in Paris for some years, but is now living in Dublin, where he holds the position of Registrar at the National Gallery of Ireland. His writings have met with an enthusiastic reception from the critics. See Supra. No. 570.

1540 THE CHARWOMAN'S DAUGHTER. Pp. 228 . (Macmillan). 38. 6d. 1912. Publ. in U.S.A. under title Mary, Mary.

A study of the soul of a simple girl of the people and its development amid the surroundings of a Dublin tenement house and of the Dublin streets-her girlhood, her dreams for the future, her love aftairs. The incidents are quite subordinate to the psychological interest. The atmosphere of reality is carefully reproduced if somewhat idealised. There is nothing morbid nor sensational in the book. This, the Author's first published novel, and many think his best, first appeared in THE IRISH REVIEW.

1541- THE CROCK OF GOLD. Pp. 312. (Mramillan). Many reprints. 1912.

Described accurately enough by THE Trmes as, "this delicious, fantastical, amorphous, inspired medley of topsy-turveydom." A fantasy in which human beings with Irish names, Irish gods and fairies, and the god Pan are mingled to bewilderment. And the whole is leavened with what may or may not be the Author's philosophy. "Love is unclean and holy" . . " Virtue is the performance of pleasant actions." "Philosophy would lead to the great sin of sterility." These sentences are isolated from the context, but they seem to indicate the general trend-the philosophy of Pan. However, there is much besides this in the torrent of wayward thought and fancy that is here let loose. The pictures of nature are finely and delicately touched, and there is humour of a strange kind not easy to define. 
STEPHENS, James-(continued).

1542_ HERE ARE LADIES. Pp. 349. (Macmillan). 58. 1913.

Fragments of the Author's peculiar philosophy of life conveyed in odds and ends of stories and sketches. Some are pure fancy, some are very closely observed bits of real life; some are humorous, with a kind of sardonic humour; some whimsical, some border on pathos. Many deal with various phases of married life. Little poems are sandwiched between the tales. The book is full of aphorisms, indeed the style is a riot of curious metaphor, flights of fancy, unexpected turns of phrase. The last piece (pp. 277-348) consists of a series of disquisitions by an old gentleman in the style of the Autocrat of the Brealfast Table. An Irish flarour is noticeable at frequent intervals. The idiom (not the brogue) of Anglo-Irish conversation is well reproduced.

1543_- THE DEMI-GODS. Pp. 280. (Macmillan). 5s. 1914.

The travels through Ireland of Patsy McCann, tinker and general rascal, and his daughter Mary, in company with three angels, become tinkers for the nonce. Patsy is a very human and a very real tinker, an ugly specimen of a disreputable class. The wanderings of this strange company form a thin thread on which is strung a medley of strange fancies, wayward comments, scraps of very excellent description, and glimpses of low life in its most sordid aspects (e.g., the drab Eileen Cooley, who appears at intervals). There is an effort to picture not only the outward doings, experiences, and sensations of the tramps, but also their outlook, such as it is, upon life, their makings of a philosophy, and the morality of the roads.

STEUART, John A. Author (born 1861) of A Millionaire's Daughter, Self Exiled. In the Day of Battle, The Minister of State, Wine on the Lees, The Eternal Quest, A Son of Gad, The liebel Wooing, \&c., \&c. Was born in Perthshire; lived in Ireland, America, and England. Edited Publisher's Circular, 1896. 1900.

1544___ KILGROOM. Pp. 228. (Low). 6s. and 2s. 6d. [1890]. 1900.

The interest of the story turns on incidents of the Land War in a southern county. The Author takes the popular side, and paints the evils of landlordism in the darkest colours. Most of the characters are humble folk, including an amusing Scotchman, Sandy M'Tear. The story tells how a thirst for vengeance, engendered by oppression, takes possession of the young peasant, Ned Blake, almost stifling his love for his betrothed and ruining his life.

STEVENSON, John. Is a member of the printing and publishing firm of McCaw, Stevenson \& Orr, of Belfast. He made his first hit with Pat McCarty, Farmer of Antrim : His lhymes with a Setting (1903), in part reprinted from THE PeN, a magazine run by the employes of his company.

1545_- A BOY IN THE COUNTRY. Pp. 312. (Arnold). 5s. Illustr. by W. Arthur Fry. 1913.

A lad sent for his health to the care of an aunt in Co. Antrim tells his experiences and observations, his thoughts and dreams, and he tells them charmingly. Stories and anecdotes of the lives of the folk among whom he lives, told with insight and sympathy.

STEW ART, Agnes M. Wrote a great number of stories between 1846 and 1887. All are highly moral in aim and tone, a series of them having for titles the various moral virtues.

1546- GRACE O'HALLORAN. (Gill. N.Y. : Benziger). 0.60 net. [1857]. 1884, \&c.

Sub-title : "Ireland and Its Peasantry." “ Another of A. Stewart's pious little stories. . . The reader will fail to discover much originality or force; but in these days it is no small praise to say there is nothing to condemn."-(D.R.). 
STEWART, Agnes M.-(continued).

1547- FLORENCE O'NEILL; or, The Siege of Limerick. 1871.

Appeared under title Florence $O$ 'Neill, The Rose of Saint Germain, in a little Catholic periodical, Rose and Shamrock, edited by Miss Stewart, 1862.

1548 - THE LIMERICK VETERAN ; or, The Foster Sisters. Pp. $253 . \quad$ (U.S.A., Baltimore: Kelly, Piet \& Co.). 1873.

A Catholic story of the Jacobite invasions of Scotland, 1715 and 1745 . It is not concerned with Ireland except in the person of the Limerick veteran, Denis O'Sullivan; " the faithful servant of the brave Sarsfield, who on his master's death transferred his allegiance to that master's bosom friend and brother in arms, St. John." Now sold by Benziger Bros., N.Y., at 60 cents.

\section{STEWART, Miss E. M.}

1549 ALL FOR PRINCE CHARLIE; or, The Irish Cavalier. Pp. 270.

$(D u f f y)$. 1s. Very cheap paper and print. n.d.

The '45 from a strongly Catholic and Jacobite standpoint. The story opens in an old castle in Bantry Bay, where the hero and heroine meet before the former goes off to fight for Prince Charlie. Various adventures during the raid on England and the retreat, and a complicated plot turning on the close resemblance between the hero and a twin lbrother, supposed dead, but who plays the traitor and the spy. All is well in the end. Some glimpses of penal laws at work. A little comic relief is afforded by the talk of Paddy O'Rafferty. Dialect poor.

STEWART, ReV. J.

1550-THE KILLARNEY POOR SCHOLAR. Pp. $164.16 \mathrm{mo.}$ (LoNDoN). [1845]. Third ed., 1846. New ed., 1866.

Sub-t. :- "Comprising the most remarkable features of the enchanting scener'y of, the Irish lakes, interspersed with sketches of real character." In Pref. Author claims thorough knowledge of places and people described. His object is to impress a high moral tone upon the mind. "A moral is deduced from every incident : a moral established by every dialogue." This aim is fully carried out in the little story, which is merely a peg whereon to hang a moral, and is very sentimental.

STOKER, Bram. 1847-1912. B. in Dublin. Ed. T.C.D., where he had a distinguished career. Entered Civil Service and was called to the Bar, but subsequently for twenty-seven years secretary to Sir Henry Irving. Wrote also Dracula, Miss Betty, The Mystery of the Sea, Snowbound, \&c., \&c.

1551— THE SNAKE'S PASS. Pp. 372. (Collier). 1s. New ed. [1891]. (N.Y.: Harper). 0.40. 1909.

A tale written around the strange phenomenon of a moving bog. Scene: the Mayo coast, which is finely described. Hidden treasure, prophetic dreams, attempted murder, and much love and sentiment are bound up with the story. The sentiment is pure and even lofty. There is no bigotry nor bias, and no vulgar stage-Irishism. Andy Sullivan, the carman, is drawn with much humour and kindliness, but we cannot consider "Father Pether" a true type of Irish priest.

STOKES, Whitley, 1804-1878. B. in Dublin, son of an eminent doctor and himself an eminent doctor; one of the greatest of Irish archæologists. Was President of the R.I. Academy 1874-8. Edited most learnedly many Irish texts and wrote also many valuable works on medicine.

1552— THE DESTRUCTION OF DA DERGA'S HOSTEL.

(PARIS : Bouillon). 1902.

"Conary becomes king on condition that he abide by certain bonds (geasa) imposed on him by his fairy kinsfolk. Having transgressed these conditions, he comes to his death in a great affray with outlaws, who attack the hostel. Portents and marvels are characteristic of the story from beginning to end."-(Baker, 2). 
"STRADLING, Matthew." See MAHONY, Martin F.

STRAHAN, Samuel A. K., M.D., a Belfast man.

1553_ THE RESIDENT MAGISTRATE. (LoNDon : Alexander \& Shepherd). 1s. 1888.

A tale of the "Jubilee Coercion days." The leading character is founded on Captain Plunket of "Don't hesitate to shoot" fame. With the doings of this personage (which look like clippings from the STAR newspaper of those days) is mingled the story of a persecuted heroine suffering from an uncommon form of mania (in which the Author was a specialist). Another of his stories, Dead yet S peaketh (Arrowsmith), was founded on the sudden death in his chambers in the Temple of an Irish fellow-student of the Author.

STRAIN, E. H. A Scottish lady resident in Ayrshire who has also published several other works of fiction, e.g., A Prophet's Reward, Elmslie's Drag Net.

1554_ A MAN'S FOES. Pp. 467. (Ward, Lock). 6s. Illustd. by A. Forestier. (N.Y. : New Amsterdam Book Co.). 0.50. [1895]. 1899, 1910, etc.

A strongly conceived and vigorously written historical tale of the siege of Derry. Point of view aggressively English and Protestant. The personages in the story often express bitterly anti-Catholic sentiments, but only such as may reasonably be supposed to have been freely expressed at the period.

STRATTON-PORTER (Gene). This Author is fond of introducing Irish characters into her novels. Thus the hero of Freckles is a waif of Irish parentage who gets a job in a Canadian lumber property. Lord and Lady O'More come over to Ireland in quest of a lost nephew and Freckles turns out to be the missing one. The Irish characters are dealt with very sympathetically. These novels are very ideal and sentimental though dealing with rough and low life. Freckles (Murray), 18., has been many times reprinted between 1905 and the present year. It is dedicated " to all good Irishmen." The hero of Michael O'Halloran is a waif of unknown parents, a variation on Freckles.

SUTHERLAND (Alexander). Author of Summer Rambles in the W. Highlands, 1825.

1555_ ST. KATHLEEN, or The Rock of Dunismoyle. 4 vols. (Lond.: $A . K$. Newman). 1820.

A complicated plot in the course of which the virtue of the heroine, Edith Nugent, triumphs over every kind of misfortune. Most of the incidents occur in Ireland (place not clearly indicated) but for part of the time the scene changes to Scotland. Many exciting incidents, much pathos and sentiment. A strong love interest ending in the happy marriage of Edith to Alan Lennox. The period is 1798 but the historical background is of slight importance. St. Kathleen is the family name of the Earl of Innisboyne.

1555A — REDMOND THE REBEL; or, They Met at Waterloo. 3 vols. 1819.

" SWAN, Annie S."; Mrs. Burnett Smith. B. Mountskip, Goresbridge, N.B. Ed. Edinburgh. Has written a great many novels. Resides in England or at Kinghorn, Scotland.-(Wro's Wro). Titles of over 60 other novels will be found in Mudie's list.

1556- A SON OF ERIN. Pp. 344. (Hutchinson). 6s. Six illustr. 1899 and 1907. New ed., 6d.

Scene : first Edinburgh, then chiefly Co. Wicklow. Period : just before retirement of Butt and rise of Parnell, who is one of the personages of the tale. The interest turns on the discovery of the identity of a child abandoned in Edinburgh when an infant. No love interest. 
SWEETMAN, Walter. B. 1830 at Clohamon, Ferns, where he died 1905. Was fourth son of Michael Sweetman, of Longtown, Co. Kildare, and came of an old family of Dublin merchants. Ed. at Stonyhurst College (Jesuits) and London University, where he graduated. Was called to the bar but preferred the life of a country gentleman. Married the eldest sister of Gen. Sir W. Butler. Publ. vols. of verse in 1871 and 1875. Wrote much on religious and philosophical subjects. Took some share in the "liberal" movement of the day but remained himself a staunch Catholic.

1557- THROUGH THE NIGHT: a tale of the times. To which is added ONIVARD, or a Summer Sketch. 2 vols. (Longmans). 1869.

The first-named story fills the first vol., Onward fills the second. The motto of the book is "Je compte vivre en pénitent Catholique et en Libéral impénitent." (Lacordaire) and the P'ref. (11 pp.) is an appreciation of Lamennais with suggestions towards an application of his philosophy to modern conditions of life. Marcus Brown comes home from the continent to a neglected estate. $\mathrm{He}$ is full of continental liberal and democratic notions and proceeds to propagate and to apply them. Incidentally the Author brings out the evils of absenteeism, the need for proper housing and for old age pensions. An episode in the Fenian movement is described. It curiously resembles recent happenings. The narrative is somewhat clogged by theological and philosophicai discussions. Onward deals with the life of an English family in Switzerland. A strongly Catholic tone prevails throughout.

1558 (1896).

A book of an unusual type giving the "history of some ten days of rather unusual Irish life." (Pref.). The personages, though they discuss Irish politics, have but a slender hold on Irish life. Alfred and Ethel Archbold are English settlers, Mr. Smith is an English visitor. So is Father Barnwell, the Jesuit, of whom a favourable portrait is drawn. Jules de Gernon is French. The rest are of "county family" class. Even the hero, scion of an Irish clan, has been educated in England and holds a strange mixture of politics. Nearly all are Catholics. They are pleasant, cultured people who discuss the current problems of the day, political, moral, and especially religious. These last the Author has thought out to good purpose. The plot reveals the gradual winning back of Roland to Catholicism and leaves him at last betrothed to Ethel. The scene is an Irish country seat with pretty lake and river scenery.

SYKES, Jessica S. C. Author of Algernon C'asterton and Mark Alston.

1559_ THE M'DONNELLS. Pp. 299. (Heinemann). 6s. 1905.

Aims at presenting picture of early Victorian manners and morals as seen in the life of this (rather unattractive) family, of Irish origin, but living in England, and in their surroundings. It was a period lacking in ideals and unstirred by new ideas, artistic, literary, or other. The Author paints it stupid, gross, and material, and seems to sum it up as "humbug" (from a review in the ATHENaum).

Lord Charles Beresford, in a letter to the writer (see Pref.), acknowledges the book as "a true picture of English and Irish life in the upper circles of society five and forty years ago," and that "it explains the idiocrasies (sic) of the Irish people, both Nationalist and Orange, and gives a clear explanation of the real causes of the unceasing discontent and strife existing in our sister isle." "I have tried to give a description of the condition... to which English females of position were reduced by a wave of Evangelical cant and exaggerated morality. ..."-(Pref.).

"SYNAN, A." see ClERY, A. E.

TAUNTON, M.

1560 _ THE LAST OF THE CATHOLIC O'MALLEYS. (Washbourne. N.Y. : Kenedy).

Scene : Western Mayo, about 1798, but no historical events are introduced. An unpretentious little story, telling how Grace is married at fifteen against her will 
TAUNTON, M.-(continued).

to a disreputable young man. He grows fond of her, and dies penitent three years after. Their child is stolen by a too fond nurse. The child grows up and joins the navy. Years after, Grace, who has married a naval officer, gets her sailor son back.

TAYLOR, Mary Imlay. Au. of An Imperial Lover, The Reaping, A Yankee Volunteer, etc.

1561- MY LADY CLANCARTY. Pp. 298. (Gay d Bird). Illus. by A. B. Stephens, 1905.

" Being the true story of the Earl of Clancarty and Lady Elizabeth Spencer." Donough McCarthy, a Jacobite nobleman, married in childhood to wealthy heiress of English Whig family, does not meet his bride again till many years later, and then in strange circumstances. Scene: England in days of William III., with glimpses of Ireland in the background. Appears to be founded on 'Tom Taylor's play, Clancarty.

TEMPLETON, Herminie. An American lady married (in Ireland) to Judge Kavanagh of Chicago.

1562_ DARBY O'GILL AND THE GOOD PEOPLE. Pp. 294 (N.Y.: Doubleday \& Page). 1.50. 2nd ed. [1903. N.Y. : McClure, Phillips]. New ed., 1915. Chrcago : The Reilly \& Britton Co.

Adventures of a Tipperary man, Darby O'Gill, among the fairies of Slieve-na-mon, supposed to be related to the Author in dialect (well reproduced) by a Tipperary car-driver. Scene : Tipperary and Clare. Darby is the central figure in a series of tales. In one Darby gets taken prisoner by the fairies and is kept for six months. Then he frees himself by a ruse but wins the good-will of the fairies by doing them a good turn. A great deal of amusing fairy-lore is introduced. There is no caricature of things Irish.

N.B.-The new (1915) ed. bears on the title-p. the name Herminie Templeton Kavanagh. It has a frontisp. by John R. Neill. The contents are as follow :Darby O'Gill and the Good People, Darby O'G. and the Leprechaun, The Conversion of Father Cassidy, How the Fairies came to Ireland, The Adventures of King Brian Connors (in 3 chapters), The Banshee's Comb ( 4 chapters). All as in earlier editions.

TENCH, Mary F. A. An Irish lady, now living in London, who spent her childhood and youth at the family place on the Wexford coast. After leaving Wexford she lived 16 years in Ceylon. But she has ever retained a deep affection for Ireland and things Irish. Her second novel A Prince from the Great Never Never (Hurst \& Blackett, 1899) opens in Ireland with the same realistic touches as are in her first. Then the scene is transferred to Australia.

1563 - WHERE THE SURF BREAKS. (Hurst \& Blackett). 1897.

A first novel. A thread of narrative strings together a series of sketches and tales of Wexford (Barony of Forth) peasants and servants, some humorous, others deeply pathetic.

1564 AGAINST THE PIKES. Pp. 357. (Russell). n.d. (1903).

How the sins of the fathers are visited upon the children to the third and fourth generation. Phil O'Brien, returning to Ireland after long years of sin and suffering in Australia, finds his first love unchanged in heart-only to see her taken from him by death. He foregoes for her sake revenge on the man who had wrecked his life, and dies to save his enemy. Though the characters are Irish, there is little about Irish life (nothing about pikes). The whole book is very sad, and the pathos at the close is painful, " navrant." 
THACKERAY, William Makepeace. The great novelist paid only one visit to Ireland (1842), the immediate outcome of which was his Irish Sketch Book (1843). The tone of this book gave great offence to Irishmen generally. Sir Samuel Ferguson severed his connection with the Dublin UnIversity MagaZINE because Lever, then editor, accepted Thackeray's dedication. He could speak of the Young Irelanders only in terms of ridicule-witness his ballad "The Battle of Limerick" - though he was a personal friend of Gavan Duffy. He derived some of the incidents of Barry Lyndon from the chap-book, Life of Freney, which he read one night in Galway. Many of the characters in his greater novels are Irish, e.g., "The O'Mulligan," said to be founded on W. J. O'Connell; "Capt. Shandon," whose original was Dr. Maginn; "Capt. Costigan " and his famous daughter, "the Fotheringay," said to be suggested by the dramatic triumph of Miss O'Neill, afterwards Lady Becher. "Ye hate us, Mr. Thackeray, ye hate the Irish," said to him Anthony Trollope's old Irish coachman. "Hate you? God help me, when all I ever loved on earth was Irish!" and his eyes filled with tears.-('Trollope). His wife was Irish.

\section{5 — THE MEMOIRS OF BARRY LYNDON, ESQ. [1844]. Many editions in all styles.}

The autobiography of a blackguard and a cad, a compound of every vicemeanness, mendacity, licentiousness, heartless selfishness. Add to these swagger, vulgarity, and a fire-eating audacity, which, however, is always on the safe side, and you have the portrait of the hero as painted by himself. All the characters are vicious or contemptible or both, the English and other foreigners no better than the Irish. Lyndon (real name Redmond Barry) belongs to an ancient and decayed family, once aristocratic. The story tells how he fights a duel at home in Ballybarry, falls in with swindlers in Dublin, deserts from the army, serves under Frederick the Great in the Seven Years' War, becomes a professional but aristocratic gamester, marries (after a desperate struggle) the rich Lady Lyndon, blazes through a brief season in Dublin (1771), worries his wife into her grave, and finally runs through all his wealth. There is some humour in places, but it is grim and sardonic, and does not relieve the picture. Moral (see footnote near the close)- "Do not as many rogues succeed in life as honest men? More fools than men of talent ?" Founded in part on the strange marriage of Andrew Bowes and the Countess of Strathmore at end of eighteenth century.

THÉBAUD, Augustus, S.J., fourth president of St. John's Coll., Fordham University and first Jesuit president. B. Brittany, France, 1807. D. at Fordham, 1890. Went to America 1839. President of Fordham 1846-63. Subsequently resided at St. Francis Xavier's Coll. N.Y. City. Publ., among other works, T'he Irish Race in the Past and Present. (N.Y.: Sadlier). 1880.

\section{6-LOUISA KIRKBRIDE : A Tale of New York. Pp. 528. (N.Y. : Kenedy). 0.90. Illustr. 1878.}

A novel with a purpose, which "aims at the reformation of abuses" (Pref.), and in particular the greed for gold and the "want of proper strictness in domestic education." In the Pref. the Author forestalls the charge that his book is a "glorification of Irish Catholics in America." It certainly is a vindication of them. The heroine (who becomes a Catholic in the end) is the only admirable character in the book who is not Irish. All the Irish characters but one are good. The plot turns on the fortunes of two families, the O'Byrnes, fresh come from Enniscorthy, and the Kirkbrides, Mr. Kirkbride being of North of Ireland origin. Other Irish names that occur being Doyle, Ahern, Dolan, O'Donnell, Dillon, O'Sullivan, McElheran (described as a full-blooded Irishman). Period : just after Civil War. The incidents bring out, among other things, the prevalent dislike of the Irish, the latter's good qualities, religious and social, the iniquities of the Stock Exchange. Plenty of incident. 
THOMAS, Edward. Has also publ. Norse Stories and many other works on a variety of subjects. He resides in Hampshire.

1567- CELTIC STORIES. Pp. 128. (OxFond : The Clarendon Press). 1911.

"The Boyhood of Cuhoolin" "Father and Son," "The Battle of the Companions" (C. and Ferdia), "The Death of C.," "Deirdre and Naisi," "The Palace of the Quicken Trees," "The Land of Youth." The rest (pp.82-end) are Welsh tales. Told very plainly and briefly, yet not dully. The diction is quite modern and prosaic. The grotesquer folk-lore elements are not excluded.

THOMPSON, E. Skeffington. Was a granddaughter of John Foster, last Speaker of the Irish House of Commons. She was an ardent Nationalist. About 1889 she and her sister Mrs. Rae founded the Southwark Junior Irish Literary Society.

1568_- MOY O'BRIEN. Pp. 300. (Gill). 3s. 6d. [1887]. New ed., 1914.

Deals with the politics of the day, but not to the neglect of the story. which shows considerable literary power, though containing but little incident. Strongly patriotic in tone. There is no religious bias. Treats of social and political life in Ireland thirty or forty years ago. Ends with many happy marriages. First appeared in U.S.A. in HARPER's.

THOMSON, Miss C. Linkiater. Author of many works, chiefly educational.

1569- THE CELTIC WONDER WORLD. Pp. 155. (Horace Marshall). 1902.

No. 2 of the Romance Readers. Irish, Welsh, and Breton stories edited for children. Very pretty and imaginative illustr. by E. Connor. The tales are taken from good sources-Whitley Stokes, Standish O'Grady, Crofton Croker, "Atlantis," Q'Curry, the Mabinogion, \&c. Contains "Deirdre," "Ossian in the Land of Youth," Cuchulainn stories, \&c., told in simple but not childish language.

THURNEYSEN, Rudolf, of Swiss origin, for many years Prof. of Romance languages at Freiburg in Breisgau. Since 1912 Prof. of comparative philology at Bonn. $\mathrm{He}$ visited Ireland several times for the purpose of learning the language.

1570_ SAGEN AUS DEM AITEN IRLAND. Pp. 152. Demy 8vo. (Berlin : Wiegandt \& Grieben). 1901.

Short introd., then very briefly (in German, of course) the chief Irish sagasthe Courtships of Etain and of Fraoch, Mesgedra, Bricriu, episodes from the Cuchulainn cycle, the birth of Conachar, the Vision of MacConglinne, \&c.

THURSTON, E. Temple. His novels are for the most part a series of studies or rather pamphlets on the action and influence of the Catholic Church on human nature. His conclusions are usually hostile to that Church. His writings give constant evidence of misconception of Catholic doctrine. Incidentally Irish types and scenes are introduced, and the writer is fond of comments on Irish life and character. Moreover, his first four books aim at "brutal" realism, or naturalism. His recent book, The City of Beautiful Nonsense, is a reaction to. Idealism. Besides his Irish novels, noticed below, he has written Sally Bishop, The Evolution of Katherine, The Realist and Other Tales (more or less antiChristian in tendency), Mirage, David \& Jonathan, 1918, and some half a dozen others.

1571- THE APPLE OF EDEN. Pp. 323. (Chapman \& Hall). 1905.

An argument against the celibacy of the clergy, conveyed in the story of a young priest-his childhood, inexperience, life at Maynooth, first experiences in confessional. Here he meets the woman whom he had loved. He tells her that, but for the fact that she is married, he would break all ties for her sake. There is much study of Irish life (in Waterford), but the Author has nothing good to say about anything Irish, country doctors and priests being especially attacked. 
THURSTON, E. Temple-(continued).

1572— TRAFFIC. Pp. 452. (Duckworth). 1906.

Scene: Waterford and London. Has been well described by the ATHEN aum as a pamphlet in guise of a story, the thesis being that the refusal of the right of divorce in the Catholic Church may lead in practice to results disastrous to morality. This is conveyed in the story of a girl who leaves an unworthy Irish husband, and goes tc London, where, being obliged to refuse an offer of marriage from an honourable Protestant, she takes to the streets. Contains strange misconceptions of Catholic doctrine and morality.

\section{3- THE GARDEN OF RESURRECTION. Pp. 307. (Chapman \& Hall). 6s. [1911]. 1912.}

Sub-t.: "Being the love story of an ugly man"-viz., Bellairs, a confirmed bachelor, who tells his own story. Overhears in restaurant conversation of a young man, from which he learns that the latter is about to marry a young West Indian girl named Clarissa, but cares only for her money. Bellairs is struck with pity for her, and determines to tell Clarissa of the worthlessness of Harry. He goes to the W. of Ireland, where Harry had left her in charge of two maiden aunts. She will not believe him, and goes to London with Harry. He betrays and deserts her : she comes back forlorn to Bellairs, and they are married. The writer has a keen feeling for nature, and there is much description. The character study is careful and the style is full of pleasant whimsicalities. The "Cruikshank" and "Bellwattle" of The Patchwork Papers reappear here.

1574_ THIRTEEN. Pp. 279. (Chapman \& Hall). 1912.

Short stories reproduced from magazines. Three of the thirteen are little bits of Irish-Wexford-life:- "The Little Sisters of Mercy," "An Idyll of Science," and "Holy Ann." The rest deal with London. There is sentimentality and mannerism, but the literary craftsmanship is very good.

1575_ THE PASSIONATE CRIME: A Tale of Faerie. Pp. 311. (Chapman \& Hall). 6s. 1915.

Anthony Sorrel, a poet of promise, a visionary, settles in a poor hut in a mountainous part of Tipperary. He tries "to rise above emotions and bring out the God that is in him." The neighbours think him queer. Anna Quartermaine, a rich, educated, Catholic lady, also considered queer, crosses his path. Mutual affection springs up: the lady is found murdered on the mountain side; the poet is hanged. The Author sets ont to solve the mystery of how "one who would not steal a linnet out of its nest or break a bubble if he took hold of it" could have been guilty of the revolting deed. His psychological theories are peculiar-his views of life and women like those of Tolstoy as revealed in the Diaries lately published. $\mathrm{He}$ finds something like Fetishism in the wilds of Tipperary. The people thought Sorrel and the other principal characters queer. Queer is the epithet, I fancy, they would also apply to the book. The Author, as usual, shows misunderstanding of Catholic doctrine.

\section{6- ENCHANTMENT. Pp. 316. (Fisher Unwin). 6s. 1917.}

Charles Desmond, a Waterford squire, a tippler and a spendthrift, vows his daughter to a convent. Afterwards he bargains with a priest to reform his life if the priest will release him from his vow. But twelve years later the girl declares her vocation. On news that she has been rescued on her way to the convent, he sets out in search of her, and meets his death. With this story, a sordid one in. detail, is interwoven another scarcely less so of another Waterford family. To "the Prince," a member of this family, falls the role of destroying Margaret Desmond's vocation. His character is as disreputable as that of her father. The Author's gift of style throws a glamour over all. 
THURSTON, Katherine Cecil. B. Cork in 1875. Dau. of Paul Madden, a friend of Parnell, and at one time nationalist mayor of Cork. She began to write only In 1903, and married E. Temple Thurston, q.v. She lived a considerable time at Ardmore, Co. Waterford. Died at Cork, 1911. In this short period appeared six or seven novels. Of John Chilcote, M.P., her greatest success, it is estimated that 200,000 copies were sold in America alone.

1577- THE GAMBLER. (Hutchinson). 6s., and 6d. n.d. (1906). (N.Y.: Harper). 1.50. New ed., 7d. 1917.

A psychological study of an Irish woman's character. Treats of Protestant upper middle class society, but questions of creed do not enter into the book. The scene for about the first third of the book is laid in Ireland, in an out-of-the-way country district. Then it shifts to Venice, and afterwards to London. In both places the heroine moves in a smart set, whose empty life and petty follies are well drawn. There is a problem of pathetic interest centring in two ill-assorted marriages. The part about Irish life, showing the foolish pride of some of the Irish gentry, is skilfully and sympathetically done.

1578- THE FLY ON THE WHEEL. Pp. 327. (Blackwood). 6s. (N.Y.: Dodd \& Mead). 1.50. 1908.

Middle class Catholic society in Waterford, pictured, without satire, in its exterior aspects by one quite familiar with them. The heroine is an impulsive, self-willed girl in revolt against conventionality. With her Stephen Carey, a middle-aged man, conventionally married, falls in love and is loved in return. The theme on the whole is treated with restraint, yet there are passionate scenes. The complication is ended by the intervention of a priest, whose character is very sympathetically drawn. The end of all is the suicide of the girl. The manner of the Author's own death gives this a poignant interest.

THYNNE, Robert. B. Dublin 1827, son of Rev. William S. Thynne, an eminent T.C.D. man and an author. Ed. T.C.D. $W$ as in Australia 1852-62. On his return wrote for the reviews, the Edinburgh, Fraser's, All the Year Round. Was a Liberal-Unionist and afterwards a Unionist in politics. D. 1907.

1579__ RAVENSDALE. Three Vols. (Tinsley). 1873.

An attempt to represent the men and motives of the Emmet insurrection. Point of view Unionist. Free from caricature, vulgarity, patois, and conventional local colour. IScene at first in England, but mainly Dublin and Co. Wicklow. Deals with fortunes of a family named Fetherstone-loyalists, with one exception, Leslie, who is a friend of Emmet. Michael Dwyer, Emmet, Lord Kilwarden, \&c., figure in the tale. Love, hatred, murder, incidents of 1803, Emmet's trial, escape of Leslie and his ultimate restoration keep up the interest to the end, when the real murderer confesses.

1580_ TOM DELANY. Three Vols. (Tinsley). [1873]. 1876.

Begins with sale, in Encumbered Estates Court,of Mrs. Delany's property in the West. The family then emigrate to Melbourne, where the rest of the story takes place. Most of the characters, however, are Irish, from Sergeant Doolan to Mr. Brabazon. There are various love-affairs, ending some brightly, others sadly; and there are pictures of life in the gold-diggings. Eventually the estate is restored, and the family comes back to Ireland.

1581— FOR THIS CAUSE. Three Vols. (Sampson Low). 1877.

Ross and John Canberry are co-trustees of the will of the eccentric Lord Killery. Ross misappropriates the property to meet his liabilities. Then his daughter is unhappily married and separated and her marriage portion has been lost. Then, like a deus ex machina, enter John with his Australian money and together they save the situation. Scene mostly Dublin. Old debtor's prison described. 
THYNNE, Robert-(continued).

1582 - THE TURN OF THE TIDE; an Irish story of the day. Pp. 430. (Roxburgh Press). 1896.

Another anti-Land League novel. Excellent landlord trying to carry on in spite of undeserved boycott. Plenty of intimidation and murder and fights with the police. Firebrand C.C. ; moderate P.P. whose efforts finally prevail. Love story subordinate to main interest. Good dialogue and characterization.

\section{3- STORY OF A CAMPAIGN ESTATE. Pp. 429. (Long). 6s. Several} editions. [1899].

A tale of the Land League and the Plan of Campaign, written from the landlord's point of view. The estate is placed near the Curragh of Kildare. The chief characters are nearly all drawn from the Protestant middle and upper classes. There is also a fanatical Land League priest, and a peace-making one, of whom a favourable portrait is drawn. "More cruel," says the hero, "more selfish, more destructive than our fathers' loins is the little finger of this unwritten law of the land-this juggernaut before which the people bow, and are crushed." The question is ably argued out in many places in the book. The Author seems to identify the Land League with the worst secret societies, such as the Invincibles. The tone is not violent; there is no caricaturing, and no brogue.

1584- IRISH HOLIDAYS. Pp. 317. (Long). 6s. [1898]. 1906, \&c.

Story of an Englishman who goes down to spend his holidays with the Rev. John Good, Curate of Coolgreany, somewhere in the Bog of Allen, six miles from Birr and six from Banagher. Chiefly concerned, apart from a few sporting incidents, with aspects of agrarian agitation. Traditional English Conservative standpoint, accentuated by jgnorance of Irish history and present conditions, and by ludicrous misconceptions. Fanciful descriptions of moonlighting, in which the peasantry appear as a mixture of fools and ruffians. But little humour, and that unconscious. No objectionable matter from religious or moral standpoint.

1585_BOFFIN'S FIND. Pp. 324. (Long). 6s. 1899 and 1906.

An exciting tale of Australian life in the fifties. One of the characters is a stageIrishman of the earlier Lever type, who in one chapter relates his experiences with the Ribbonmen.

1586- JOHN TOWNLEY. Pp. 346. (Drane). 1901.

A political novel, "the last of a trilogy of Irish disaffection."-(Pref.). J. T. is an Anglican clergyman who becomes a Catholic and, later, a priest. He comes to Ireland, where he finds the priests immersed in politics and using the confessional for political purposes. $\mathrm{He}$ is involved in circumstances of a tragic kind, and to escape from a disagreeable situation he goes to $\mathrm{S}$. Africa, where he reverts to Protestantism. Dwells much on boycotting, moonlighting and murder. Describes the Phœnix Park murdens, the subsequent trial, and the murder of the informer. The interest is exclusively political.

\section{TIGHE (Francis O'Sullivan).}

1587- THE PORTION OF A CHAMPION. Pp. 368. (N.Y.: Ch. Scribner's Sons). 1.35. 1917.

A tale of ancient pagan Eire, time of King Dathi, c. A.D. 405. A good boy's story that rattles along from adventure to adventure in lively modern style. How Conal gradually gains recognition as a champion, figures at the great fair of Tailtenn, defends his father's dun, goes off with King Dathi on his raid into Gaul and Italy, fights the Huns and the Romans, meets St. Patrick in Gaul and delivers to him the famous message from the people of the Wood of Fociuth, and at last returns to win the fair Etain. Without any archæological disquisitions the Author contrives to give a vivid picture of the times in accordance with what is known of them from the ancient sagas. Mesgedra, Dathi, Ferdiad, Laeghaire. 
TORRENS, Robert. B. in Ireland 1780. Was in Royal Marines until 1834, when he retired. Was M.P. for various English constituencies at intervals from 18261834. Was employed on Government business in connection with Australia. Lake Torrens was named after him. Wrote a series of works chiefly on economics and wrote another novel entitled Celebia Choosing a Husband (1809). Came of a Protestant family, though title of novel seems to suggest conversion to Catholicism.

1588- THE VICTIM OF INTOLERANCE : or, the Hermit of Killarney. 3 vols. (Gale, Curtis \& Fenner). 1814.

" A Catholic tale" (title p.). The hermit who lived in ruins of Muckross Abbey dies. Papers found recording his story. They tell how the Penal laws closed every avenue of advancement and crossed him in love till in disgust he retired from the world. Narrative interest quite subordinate to politico-religious purpose of the book. Beauties of Killarney described at outset.

TOTTENHAM, G. L. Author of Harry Egerton, Harcourt, and The Peasant Proprietor of Norway, a study on the Irish Question, 1889.

1589 TERENCE McGOWAN, the Irish Tenant. Two Vols. (Smith, Elder). 1870.

Depicts, from the landlord's point of view, the land struggle in the sixties. This view-point is, in general, that "poor backward, barbarous, benighted Ireland" owed whatever good it possessed to the landlord class: the influence of the priest was evil: and Ireland's troubles due mainly to the lawlessness and unreasonableness of the people and the weakness of the government. But the writer is not without knowledge of the people, and his pictures of life are probably true enough in the main. The story is well told, and the love story of Terence and Kathleen O'Hara and their sad fate is feelingly related. The book brings out well the evil results of the rule of a thoroughly unsympathetic landlord in the person of the English Mr. Majoribanks. An idea is given of how elections were conducted at the time.

TOWNSHEND, Dorothea; Mrs. R. B. Townshend. Author of The Great Earl of Cork, Lost Leader (S.P.C.K.), A Lion, a Mouse, and a Motor Car (1914), otc. Resides. in Oxford.

1590 - THE CHILDREN OF NUGENTSTOWN and their Dealings with the Sidhe.* Pp. 176. (Nutt). 3s. 6d. Eight good iliustr. by Ruth Cobb. 1911.

The young Nugents, two boys and a girl, go to visit their Aunt in her tumbledown old family place near Cork. The children get into touch with the fairies, and as a result family papers are recovered and fortune smiles once more on the Nugents.

\section{“ TraVers, Coragh." See CraWford, Mary S.}

TRENCH, W. Stewart. 1808-1872. Was land agent in Ireland to the Marquess of Lansdowne, the Marquess of Bath, and Lord Digby. Owing to his admirable character he came to be respected by the people. His opinion of Irish character was very high. His views will be found set forth more fully in his Realities of Irish Life.

1591— IERNE. (Longmans). Two Vols. 1871.

"A study of agrarian crime... in which the Author used material collected for a history of Ireland, which he refrained from publishing owing to the feeling occasioned by the controvensy over the Irish Land Bill. He endeavours . . . to show the causes of the obstinate resistance by the Irish to measures undertaken for their benefit, and to show the method of cure."-(Baker).

TROLLOPE, Anthony. 1815-1882. Lived in Ireland, 1841-1859, at Banagher and at Clonmel. Finished in Ireland his first two novels, The MacDermotts (1844), and The Kellys and O'Kellys (1848), both failures with the public. He claims to have known the people, and was sympathetic but anti-nationalist. It would

*i.e., Fairies. 


\section{TROLLOPE, Anthony-(continued).}

be out of place here to dwell on the place in English literature of the Author of Barchester Towers and The Warden and Orley Farm, and the rest. An admirable contemporary article on his novels will be found in DuBLIN Review, 1872, Vol. 71, p. 393. The following deserves quotation: "This Englishman, keenly observant, painstaking, absolutely sincere and unprejudiced, with a lynx-like clearness of vision, and a power of literal reproduction of which his clerical and domestic novels, remarkably as they exhibit it, do not furnish such striking examples, writes a story as true to the saddest and heaviest truths of Irish life, as racy of the soil, as rich with the peculiar humour, the moral features, the social oddities, the subtle individuality of the far west of Ireland as George Eliot's novels are true to the truths of English life."

1592— THE MacDERMOTTS OF BALLYGLORAN. (Lane). 1s. [1844]. 1909.

Scene: Co. Leitrim. Chief characters: the members of a broken-down Catholic county family. Miss MacDermott is engaged to a Sub-Inspector of police. This latter, because of certain difficulties that stand in the way of their marriage, attempts to elope with her. Her brother comes on the scene, and there is an affray, in which the Sub-Inspector is killed. Young MacDermott is tried and publicly hanged. This is the mere outline. More interesting is the background of Irish rural life, seen in its comic and quaint aspect, by an observant and not wholly unsympathetic Englishman. The portrait of the grand old Father John M'Grath is most life-like and engaging, but the pictures of low life in the village and among the illicit stills is vulgar in tone and the humour somewhat coarse. The book is spoken of by a competent critic, Sir G. O. Trevelyan, as in some respects the Author's best. 'The Author himself considers this his best plot. It has been spoken of as "one of the most melancholy books ever written."

1593 - THE KELLYS AND THE O'KELLYS. (Chapman \& Hall). [1848]. New ed., 1907. (Lane). $1 s$.

Scene: Dunmore, Co. Galway, at the time of O'Connell's trial, 1844. Mainly a love story of the upper classes. Some clever portraits, e.g., Martin Kelly, the Widow Kelly, and the hero, Frank O'Kelly, Lord Ballindine. Picture of hardriding, hard-drinking, landlord class. A much more cheerful story than the preceding. It is fresh and genuinely humorous, and the human interest is very strong. The seventh London ed. appeared in 1867.

1594_CASTLE RICHMOND. Pp. 474. (Harper, Ward, Lock). 2s. [1860]. Fifth London ed., 1867. Still in print.

Scene: Co. Cork during the Famine years, 1847, and following, with which it deals fully. Tale of two old Irish families. The plot is commonplace enough but redeemed by great skill in the treatment, by admirable delineation of character, and by the drawing of the background. Absolutely cool and free from partisanship, he yet draws such a picture of those dreadful times as, in days to come, it will be difficult to accept as free from exaggeration. It is a graphic and terrible picture. The noble character of Owen Fitzgerald is finely drawn. There are touches of pleasant humour and of satire.

1595-_ PHINEAS FINN, the Irish Member. (Bell). 1866.

1596- PHINEAS REDUX. (Bell). 1874.

A study of political personalities. The scene is London, and the story is little, if at all, concerned with Ireland.

1597- THE LAND LEAGUERS. Three Vols. (Chatto \& Windus). 1883.

Story of an English Protestant family who buy a property and settle in Galway. The book was never finished, and has, perhaps, little interest as a novel. But the life and incidents of the period are well rendered, notably the trials of people who are boycotted. Much sympathy with the people is displayed by the Author, and, 


\section{TROLLOPE, Anthony-(continued).}

on the whole, fair views of the faults and misunderstandings on both sides are expressed. The plot turns on the enmity of a peasant towards his landlord, whom he tries to injure in every way. The landlord's little son is the only witness against the peasant. The child is murdered for telling what he knows. There is some harsh criticism of Catholic priests. N.B.-The book was written in Ireland.

TROTTER, John Bernard. 1775-1818. Of a Co. Down family, and brother of E. S. Ruthven, M.P. for Dublin. Ed. T.C.D.; B.A., 1795 . Barrister, and private secretary to Charles James Fox. Was a Protestant of Liberal views. Died in great poverty in Cork. His Walks in Ireland is his best known work, though he wrote many other works, literary and political. He did much for Irish music. Founded the Harp Society in Dublin in 1809, and organised an O'Carolan Commemoration.

\section{8_ STORIES FOR CALUMNIATORS. Two Vols. (DUblin : Fitzpatrick). 1809.}

"Interspersed with remarks on the disadvantages, misfortunes, and habits of the Irish." Dedicated to Lord Holland. A remarkable book in many ways. Through the medium of three stories, largely based on fact, the Author sets forth instances. of the sad aftermath of the rebellion, illustrating the tragic consequences that may ensue if those in authority listen to the voice of slander and condemn on suspicion. The stories are told to a Mr. Fitzmaurice by persons related to the victims, and Mr. F.'s own romance is interwoven with the tale. Incidentally the Author gives his own views on Irish politics, views full of the most kindly tolerance and of true patriotic feeling without ráiméis. He seems not a Catholic, but is most friendly towards Catholics. He is strongly in favour of the Irish language, of land reform, and of the higher education of women-astonishing views considering the period.

TURK, S. A. Authoress of prize stories: "The Ghost of Elton Towers" and "Lord Eldon's Mistake"; also "Kathleen's Victory; or, A Mixed Marriage "; "A Child of Mary," and "The Two Vocations." (Title-page).

1599_- THE SECRET OF CARRICKFEARNEAGH CASTLE. An Irish Romance. Pp. 201. (Washbourne). 2s. [1906]. 1915.

Witches, banshees, and poison potions, murders, " doomed chambers," and plots, all somewhere near the banks of the Shannon and in our own times. The chief personages are all titled. A few of the peasantry appear, speaking a dialect which, though not so intended, is a travesty of Irish peasant speech. The style is immature and the story as a whole is unreal and in the highest degree improbable. It is not in any sense a picture of Irish life, but the Author's intentions are excellent, and there is no hostility to Ireland.

1600 - NEMESIS; or, The Two Pathways. (N.Y. : Benziger). 1908.

A vol. of short stories, some of them Irish, all deeply religious in tone. Commended by Card. Logue. (The Ave Maria).

TYNAN, Katharine; Mrs. H. A. Hinkson. B. in Dublin, 1861, ed. Dominican Convent, Drogheda. Lived for many years in England, but now resides in Co. Mayo. Her stories aim at the purely romantic. As they are not concerned with the seamy side of life, their atmosphere is almost entirely happy and ideal. They are never morbid nor depressing. They do not preach, and are not of the goody-goody type. The style is pleasant and chatty, with plenty of colour, often full of the poet's vivid sense impressions. The tone is Catholic, the sentiment Irish. Mrs. Hinkson is a very prolific writer. Besides the novels mentioned, and several volumes of poems, she has written several novels which are not concerned with Ireland, e.g., A Red Red Rose, The Luck of the Fairfaxes, Dick Pentreath, For Maisie, Mary Gray, \&c. In choice of subject she has made a speciality of broken-down gentlefolk, and often introduces Quakers into her stories. Within the last two years she has publ. two vols. of reminiscences, Lord Edward a study in romance, many novels, and some volumes of poems. 


\section{TYNAN, Katharine-(continued).}

1601__ A CLUSTER OF NUTS. Pp. 242. (Lawrence \& Bullen). 1894.

Seventeen short sketches written for English periodicals. Subject : daily life of the peasantry-the village " characters," a spoilt priest, the migrating harvesters, and a pathetic picture of a poor old village priest. Charming descriptions of scenery, not too long drawn out. Much tender and unaffected pathos.

1602— AN ISLE IN THE WATER. Pp. 221. (Black). 1895.

Fifteen short pieces collected out of various English periodicals. The scene of about half of them is an unnamed island off the West coast. The scene of another is Achill. The title does not cover the rest. Sketches chiefly of peasant life, in which narrative (sometimes told in dialogue) predominates. The stories are very varied. There are pathetic sketches of young girls: "Mauryeen," "Katie," "How Mary came Home"; tales of the supernatural, such as "The Death Spancel "; "A Rich Woman," a racy story of legacy hunting; while heroic self-sacrifice is depicted in "The Man who was hanged" and "A Solitary." The last two pieces in the book are not stories: they are musings or subjective impressions.

1603- THE WAY OF A MAID. Pp. 300. (Lawrence \& Bullen). 1895.

Domestic and social life in Coolevara, a typical Irish country town, chiefly among Catholic middle class folk. It is a simple and pleasant story of love and marriage with a happy ending.

\section{4- A LAND OF MIST AND MOUNTAIN. Pp. 195. (Catholic 'Truth} Society). 1895.

Short sketches of Irish life written with the Author's accustomed tenderness and simple pathos. Noteworthy are the tales that contain Jimmy, the Wicklow peasant lad, who loves all animals; the prodigal who returns after twenty years, and the exiles Giuseppe and Beppo, in their queer little Dublin shop. Real persons-Rose Kavanagh, Ellen O'Leary, and others-are introduced in a fictitious setting.

The Land I Jove Best is another series of eight tales issued by the same publishers about 1898. 200 pages. 1605- THE DEAR IRISH GIRL. (Smith, Elder). 6s. (ChICAGo: McClurg).

Motherless, and an only child, Biddy O'Connor brings herself up in a big, lonely Dublin house. Dr. O'Connor lives amid his memories and his books. Biddy is a winsome girl, and keeps the reader's heart from the time we first meet her with the homeless dogs of Dublin as her favourite companions to the day when she weds the master of Coolbawn. The chief charm of the book lies in the picture of life amid the splendid scenery of Connaught. The book has a pleasant atmosphere of bright simplicity and quick mirthfulness. The Spectator calls it "fresh, unconventional, and poetic." Mc(lurg). 1.50. 1899.

Three delightful girls of a class which the Author delights to picture-impoverished gentry and their love affairs. The minor characters, servants, village people, \&c., are very humorous and true to life. In this story the course of true love is by no means smooth, but all is well at the last. The scene varies between "Carrickmoyle" and London.

1607- LED BY A DREAM, and Other Stories. Pp. 190. $7 \times 3 \frac{1}{2}$. (C.T.S., 69 Southwark Bridge road, London, S.E.) 1s. $6 \dot{d} .1899$.

The address on the title-page is that of the Catholic Truth Society, through which the Author had already published two volumes, which are uniform with the above in format, price, and character of contents. Seven little Irish stories, not religious in subject, though the "atmosphere" is Catholic. They display all the Author's qualities-lightness and deftness, clever plot weaving, good dialect, touches of pathos not over-wrought. The third, "An Irish Peasant Woman," is a piece of close observation and a study from life. 
TYNAN, Katharine-(continued).

1608_ A GIRL OF GALWAY. (Blackie). 5s. Handsome gift-book binding. 1900.

She stays with her grandfather, a miserly old recluse living in the wilds of Connemara, seeing nobody but his agent, an unscrupulous fellow, in whom he has perfect confidence. A love affair is soon introduced. It secms hopeless at first, but turns out all right owing to a strange unlooked for event. Pleasant and faithful picture of Connemara life.

1609_ THREE FAIR MAIDS. Pp. 381. (Blackie). 6s. [1900]. (N.Y.: Scribner). 1.50. Twelve illustr. by G. Demain Hammond. 1909.

The three daughters of Sir Jasper Burke are of the reduced county family class, about which the Author loves to write. The expedient of receiving paying guesty results in matrimony for the three girls. With this simple plot there are all the things that go to make Katharine Tynan's works delightful reading : insight into character, impressions of Irish life, lovable personalities of many types.

\section{0_ A DAUGHTER OF THE FIELDS. (Smith, Elder). 6s. (ChICAGo :} McClurg). 1900.

" Another gracious Irish girl. Well educated, and brought up to a refined and easy life, she applies herself to the drudgery of farm work rather than desert her toiling mother; but the novelist finds her a husband and a more fortunate lot." (Baker).

1611 _ A UNION OF HEARTS. Pp. 296. (Nisbet). 2s. 6d. and 1s. 6d. n.d. [1900].

A typical example of Mrs. Hinkson's stories. The main plot is a simple, idyllic love-story. The hero, much idealised, is an Englishman who tries to do good to his Irish tenants in his own way, and hence incurs their hatred for a time. The heroine is an heiress come of a good old stock. Several of the characters are cleverly sketched; old Miss Lucy Considine and her antiquarian brother in particular. Scenes of peasant life act as interludes to the main action, which lies in county family society. All the chief persons are Protestants, but the religious element is quite eliminated from the book.

1612_-THAT SWEET ENEMY. (Constable). 6s. (PhIladelphia : Lippin. cott). 1.50. 1901.

" A sentimental story of two Irish girls, children of a decayed house; their love affairs, the hindrance to their happiness, and the matrimonial dénouement."-(Baker).

1613-A KING'S WOMAN. Pp. 155. (Hurst \& Blackett). 6d. [1902]. 1905.

Told by Penelope Fayle, a young Quaker gentlewoman, a loyalist or King's woman, but sympathetic to the Irish. Scene: a Leinster country house in 1798 . No descriptions of the fighting, but glimpses of the cruelty of Ancient Britons, yeomanry, \&c., and of the dark passions of the time. Racy, picturesque style, with exciting incidents and dramatic situations.

1614-THE HANDSOME QUAKER. Pp. 252. (A. H. Bullen). 1902.

Eighteen exquisite little stories and sketches dealing, nearly all, with the lives of the poorest peasantry. They have all the Author's best qualities.

1615- LOVE OF SISTERS. Pp. 344. (Smith, Elder). 6s. [1902]. Third ed.,

The scene varies between the West of Ireland and Dublin. A love-story, in which the central figures are Phillippa Fetherstonhaugh and her sister, Colombe: a contrast in character, but each lovable in her own way. The plot turns on the unselfish devotion of the former, who, believing that her lover has transferred his affections to her sister, heroically stands aside. We shall not reveal the dénouement. The minor characters are capital, all evidently closely copied from life. 


\section{TYNAN, Katharine-(continued).}

There are the elderly spinsters, Miss Finola and Miss Peggy, and quite a number of charming old ladies, the country priest and the sisters' bustling, philanthropic mother, always in a whirl of correspondence about her charities, and others equally interesting.

1616- A DAUGHTER OF KINGS. (Nash). 6s. (N.Y.: Benziger). 1.25. 1903.

The daughter of a broken-down aristocratic county family is obliged to take service as chaperon in an English family. Careful study of girl's lovable character. Contrast between the pride and poverty of Witches' Castle, Co. Donegal, and opulence of English home.

1617- THE HONOURABLE MOLLY. Pp. 312. (Smith, Elder). Second impression, 1903. 1s. n. 1917.

The Honourable Molly is of mixed Anglo-Irish aristocratic (her father was a Creggs de la Poer) and Scoto-Irish middle class origin (her mother's people were O'Neills and Sinclairs). She has two suitors, one is from her mother's people, the other is the heir to Castle Creggs and the title. Both are eminently worthy of her hand. She finally chooses one, after having accepted the other. Has all the sweetness and femininity of Katharine Tynan's work. Is frankly romantic but not mawkish. There is no approach to a villain. There is some quiet and good-natured satire of old-fashioned aristocratic class-notions. The portraits of the two old maiden aunts are very clever.

\section{8- JULTA. Pp. 322. (Smith, Elder). 6s. Second impression, 1904.}

How a baseless slander nearly ruined the life of Julia, the Cinderella of her family, how she was nearly lost to her lover, and by what strange turns of fortune she was restored. The chief characters belong to two branches of a Kerry family, whose history is that of many another in Ireland. Julia's mother is a splendid type of the old-fashioned Irish matron. There is touching pathos in the picture of the Grace family (minor personages of the tale) - mother's absolute devotedness to a pair of thankless and worthless daughters. The old parish priest, too, is well drawn.

\section{9 - THE ADVENTURES OF ALICIA. (White). 6s. 1906.}

"A characteristically winning story of a poor young Irish girl, who had to serve English employers, but, in spite of all temptations, remained true to her Irish lover." -(Press Notice).

\section{0_ THE STORY OF BAWN. Pp. 312. (Smith, Elder). 6s. (Chicago: Mc(lurg). 1.50. 1906.}

One of the Author's prettiest stories. Family of high standing falls into the meshes of the money-lender. The daughter consents to marry him-but the plot need not be revealed. The scene appears to be Co. Kerry in the early 'sixties, but there seem to be some anachronisms.

\section{1- HER LADYSHIP. Pp. 305. (Smith, Elder). 6s. (Chicago : McClurg).}

1.25. Second impression, 1907.

Lady Anne Chute is mistress of a vast estate in Co. Kerry. From the moment of her succession to the property she resolves to act the part of Providence in her people's lives. She set about improving their condition, founding industries, \&c., and with full success This is the background to a love-story. Old Miss Chenevix, once a "lady," but now living almost on the verge of starvation in an obscure quarter in Dublin, is a pathetic figure. Pathetic also is the devotion of her old servant to the fallen fortunes of the family. Then there is the picture, drawn with exquisite sympathy, of the poor girl dying of consumption, and of how her religion exalted and brightened her last days. The descriptions or rather impressions of nature which brighten the story are peculiarly vivid. 


\section{TYNAN, Katharine-(continued).}

1622_ THE HOUSE OF THE CRICKETS. (Smith, Elder). 1908.

A story of Irish peasant farmer life. The heroine lives, with her brothers and sisters, a life of abject slavery, ruled by a tyrannical and puritanical father. In this wretched home she and her brother, Richard, develop noble qualities of character and mind. The members of the family are life-like portraits, and the picture of Irish life is drawn with care and skill.

1623— MEN AND MAIDS. Pp. 294. (Sealy, Bryers). 3s. 6d. Illustr. by Dorothea Preston. 1908.

A collection of short stories, chiefly thoroughly romantic love-stories. "A Big Lie" is, however, of a different character, and the Author has hardly ever written a more delightful story.

\section{PEGGY THE DAUGHTER. Pp. 335. (Cassell). 1909.}

A romance of Ireland in early Victorian days. A young spendthrift nobleman, a widower, runs away with Priscilla, a Quakeress, and also an heiress. The description of the pursuit is exciting and dramatic. The penalty of his deed is a long imprisonment, from which he issues a sadder and wiser man. Priscilla's care of his little daughter, Peggy, in the meantime is a pathetic story. The plot suggested by the attempted abduction by $\operatorname{Sir} \mathrm{H}$. B. Hayes of the Quakeress, Miss Pike, of Cork.

1625- COUSINS AND OTHERS. Pp. 319. (Laurie). 1909.

Eleven stories. The title story, the longest (there are nine chapters) tells how a shabby branch of an old Irish family finally won recognition by means of a marriage with the supposed heir and by the finding of certain old fanily papers. Contains some goodnatured satire on the snobbishness of Irish county society. One of the remaining stories is Irish in subject. All show the Author's best qualities -freshness, charm, and cheerful optimism.

1626- THE HANDSOME BRANDONS. (Blackie). 3s. 6d. New ed. Illustr. by G. Demain Hammond. feud.

How a marriage between scions of two ancient Irish houses heals a long-standing

1627- THE HOUSE OF THE SECRET. Pp. 314. (James Clarke). 6s. 1910.

The story of Maeve Standish's self-sacrifice in the sorrow-shadowed home of her father's old friend, Miss Henrietta O'Neill, of her ultimate good fortune, and finally of her happy marriage. The setting is entirely Irish.-(Press Notices).

1628- HEART O' GOLD; or, The Little Princess. Pp. 344. (Partridge). 3s. 6d.

Story of how Cushla MacSweeney and her sister, left as orphans, are carried off from their tumbled-down Irish home and brought up at Tunbridge Wells. How Cushla returns at twenty-one full of dreams for the improvement of Ireland, and is aided in her plans by a young man whom she afterwards marries. Full of the Author's interesting character-studies.

1629- THE STORY OF CECILIA. Pp. 304. (Smith, Elder). 6s. (N.Y.: Benziger). 1.00. 1911.

Scene: Kerry and Dublin. Two stories, of mother and daughter, Ciss and Cecilia, interwoven. Ciss's fiancé is reported killed. She loses her reason and persuades herself that a Dr. Grace, who is of peasant extraction, is her lover come back. To save her from the asylum Lord Dromore, her cousin and guardian, has to consent unwillingly to the marriage. The absent lover returns, but she does not meet him for twenty years. Meanwhile Ciss's mésalliance is causing trouble in the course of Cecilia's love for Lord Kilrush. But all ends happily. The characters are mainly drawn from the denationalised Irish upper classes. The story is told with much charm. 
TYNAN, Katharine-(continued).

1630 — PRINCESS KATHARINE. Pp. 320. (Ward). 6s. 1912.

A girl educated much above her mother's condition in life and mixing in upper class society.

\section{1- ROSE OF THE GARDEN. Pp. 312. (Constable). 1912.}

The story of Lady Sarah Lennox (1745-1826) in the form of fiction. A good many Irish members of the beau monde appear in the tale. It is not for young readers. See The Life and Letters of Lady Sarah Lennox, edited by the Countess of Ilchester and Lord Stavordale. Two vols. (Murray).

\section{2- A SHAMEFUL INHERITANCE. Pp. 324. (Cassell). 6s. 1914.}

"Katharine Tynan, in her gentle way, puts before us the growing up of the boy Pat in ignorance of the disgrace (a jewel robbery) of his mother and the suicide of his father, and the effect upon him of the disclosure. A lovable and spiritual Father Peter plays a leading part in it all."-(T. Litr. Suppl.). Pat finds his mother in time to comfort her deathbed, and in the end marries an old friend. Somewhat vague, and not free from inconsistencies.

\section{3- COUNTRYMEN ALL. Pp. 238. (Maunsel). 2s. 1915.}

A volume of stories and sketches, very varied in its contents, from well-told but rather unconvincing little melodramas, like "The Fox Hunter" and "John a" Dreams" to very vivid glimpses of life, choses vues et vécues. These show various sides of Irish life and character; an umpleasant side in "The Ruling Passion" (a woman discussing her own funeral with her daughter), as well as the pleasant and lovable aspects. "The Mother" and "The Mother of Jesus" are little studies of exquisite tenderness. Several of the sketches are humorous, for instance the weird episode, "Per istam sanctam unctionem," related by a priest. The scene of several seems to be the neighbourhood of Dublin.

\section{4- THE HOUSE OF THE FOXES. Pp. 307. (Smith, Elder). 6s. 1915.}

The Turloughmores are overshadowed by a curse made long ago by an old woman wounded to death by the hounds of a former Lord $\mathrm{T}$. when hunting. According to the curse, every head of the house must die a violent death, in forewarning of which foxes will be seen in twos and threes about the house for some time before. The actual Lord $T$. is expected home from his yachting cruise, his wife ever in dread of the doom. He is wrecked and apparently lost, but Meg Hildebrand, who is staying at the castle, discovers the almost dying lord in mysterious circumstances. $\mathrm{He}$ dies in his bed, his heir is married into a lucky house, and the curse is said to be lifted. Founded on a legend (still current) of a well-known Irish family. Many threads of various interest are woven into the tale.

1635 - MEN, NOT ANGELS, and Other Tales told to Girls. (Burns \& Oates). 3s. 6d. Many full-p. illustr. 1915.

Dainty stories, healthy and pleasant in tone, not weakly sentimental, definitely Catholic in character. Laid in various countries-England, France, Switzerland, as well as Ireland. Sympathetic studies of priests.

1636-JOHN-A-DREAMS. (Smith, Elder). 1916.

The central figure is the youngest son of Sir Anthony McGrady. Gentle, sensitive, shrinking from action and publicity, he stays at home in Clare to write his poems and to be the comfort and stay of his mother. Into his life comes Octavia, daughter of Denis Sweeney of Sweeney's N.Y. of peasant stock but accepted by N.Y. "society." She is a sunny gleam amid the sad and sentimental atmosphere of the McGrady family. The love story of Octavia and John is worked out with complications and cross purposes, with other love stories as sub-plots. There is the Author's habitual background of "soft" Irish ways, and her pleasant, confidential, gossipy manner. 
TYNAN, Katharine-(continued).

1637- MISS MARY. Pp. 309. (Murray). 5s. n. 1917.

Scene: Castle Morrogh in the West, seat of Sir Hugo de Burgh. Maurice Roche, stable boy, but of good old stock, devoted slave of Mary the daughter of the house, is taken up and educated by the Vicomte de Luynes, a friend of the family. Mary is engaged to Christopher Damer who during the courtship endeavours to seduce a peasant girl, Bawn. The engagement is broken off and Mary in the end marries the faithful Maurice. Lady de Burgh and the Vicomte are types of saintly people who make sainthood amiable. The former, an Englishwoman, sympathises with Ireland in a way incomprehensible to her Irish Unionist husband. The atmosphere is as usual most pleasant and the Author brings out what is best in Irish life.

\section{8- KIT. Pp. 352. (Smith, Elder). 6s. n. 1917.}

Kit, a western peasant girl, is driven from her village by the cruelty of the neighbours, due to the tragic death of her mistress's daughter (whose story is told with pathos and tenderness) in trying to save Kit's life. She is befriended and educated by people of the upper class in England, but remains true to her early love, and returns to marry Donal, who has come back rich from America. Some of the minor characters, notably the old Paxish Eriest, Father O'Hart, and Mr. Dempsey, the schoolmaster, are carefully and faithfully drawn.

UPTON, W. C. Carpenter working at Ardagh, who afterwards went to America.

1639—UNCLE PAT'S CABIN. Pp. vi.+284. (Gill). 1882.

"Or life among the agricultural labourers of Ireland." "All the facts relative to the agricultural labourer in these pages can be vouched for." - (Pref.). Describes vividly the long struggle of a labourer against adversity, the evils arising out of the competition for the land. A graphic picture of the conditions of the poor. Scene: Co. Limerick in the years from 1847 to 1880 or so. The chapters relating to a Parliamentary contest are less valuable than the rest of the book. Lecky, in his History of Ireland in the Eighteenth Century (Vol. 3, ch. 8, pp. 413-14 in a footnote), speaks of the book as "one of the truest and most vivid pictures of the present condition of the Irish labourer."

VAIZEY, Mrs. G. de Horne. B. Liverpool about 1858 and ed. there. She never resided in Ireland but visits to very old family friends in King's Co. suggested Pixie. For the last seven years of her life she lived in Hampstead and there died in 1917. Was of a most amiable character and accomplished in many ways. Her Pixie and Peggy have become girl classics. Fresh editions in England and America have continued to appear year after year. Their success is due to her wonderful sympathy with young people and her interest in all their concerns. Pixie O'Shaughnessy was followed by More about Pixie and The Love Affairs of Pixie.

1640_- PIXIE O'SHAUGHNESSY. Pp. 316. (R.T.S.). 2s. 6d. 7 illustr. [1903].

Scene: first, a fashionable English girls' school, afterwards a half-ruined castle in the West of Ireland. The book is taken up with the amusing scrapes and other adventures of a wild little Irish girl, and with the love affairs of her sisters. Gives a good, if somewhat overdrawn, picture of Irish character, especially of traditional Irish hospitality.

1641- MORE ABOUT PIXIE. (R.T.S.). [1913]. 6d. 1918.

1642_ THE FORTUNES OF THE FARRELLS. Pp. 190. (Leisure Hour LIBRARY Office). $6 d .1911$.

VANCE, Louis J., an American writer, b. Washington, 1879. Author of T'he Private War (1906), The Brass Bowl, The Black Bag, The Day of Days (1913), etc., etc. 
VANCE, Louis J.-(continued).

1643- TERENCE O'ROURKE, Gentleman Adventurer. Pp. 393 . (E. Grant Richards). 1905.

Thrilling adventures of a penniless soldier, who goes about Don Quixotewise rescuing distressed damsels--each more beautiful than the last-fighting duels, and so forth. A good story of its class, and free from anything objectionable.

VEREKER, Hon. C. S., M.A., F.G.S. Was commandant of the Limerick City Artillery Militia, and son of Lord Gort.

1644_ OLD TIMES IN IRELAND. Three Vols. (Chapman \& Hall). 1873.

Chiefly heavy light-comedy, with conventional characters and an air of unreality about the whole. The humour, the dialect, the characteristics of the various personages, all are highly exaggerated. A Lord Lieutenant, a Duke, the absurd Mr. and Mrs. O'Rafferty, the still more absurd love-sick schoolmaster, ruffianly Terry Alts, figure, among many others, in the tale.

VERNE, Jules, the great French writer for boys. D. 1906.

1645_ FOUNDLING MICK (P'tit Bonhomme). Pp. 303. (Sampson, Low). Seventy-six good illustr. 1895.

The very varied and often exciting adventures of a poor waif. Rescued from a travelling showman at Westport, Co. Mayo, he is sent to a poor school in Galway, resembling the workhouse in Oliver Twist. Further adventures bring him to Limerick, and then to Tralee, and afterwards to many other parts of Ireland. The book is written in thorough sympathy with Ireland, and in particular with the sufferings of the poor under iniquitous Land Laws, though at times with a little exaggeration. There is a vivid description of an eviction. Other aspects of Irish life are touched on, and with considerable knowledge. Dublin, Belfast, Killarney, Bray, are some of the places described. The spirit is Catholic : witness the kindly words on page 8 about Irish priests.

WAILLY, Léon de. A popular French writer and Republican politician. Author of a life of Angelica Kauffmann.

1646_ STELLA ET VANESSA. See No. 528, supra.

1647— ROMANS IRLANDAIS. (PARIS). 1861.

A French transl. of three tales from Carleton's Traits and Stories, viz., Denis c'Shaughnessy, T'he 'Three Tashs, and Wild Goose Lodge.

\section{WALLAS (Walter).} 1648- THE BAGOTS. A novel of nationality. Pp. viii.+352. (Hutchinson).

Mainly the story during some years (the early nineties to the Easter Rising, 1916) of three members of an Anglo-Irish Unionist family, viz., Phue Bagot, subagent on an estate which is "one of the worst centres of outrage in the West," and his two nephews, George and Philip. The two latter, reacting against environment, and feeling isolated from the national life, go to England. Here they find themselves roreigners. They are with Ireland in her national aspirations, especially during the Uarson campaign against Home Rule. They are heartily with the Allies in their fight for small nationalities-that Ireland is a small nationality is a constant refrain of the Author's. Philip, the parson, on the point of becoming a Catholic, is killed in the Easter week rising-shot by the rebels. Many national, moral and religious problems are broached, but the answers are not very clear. The Author is sympathetic towards Irish national aspirations.

WALSH, Louis J., Solicitor, Ballycastle, Co. Antrim. B. Maghera, Co. Derry, 1880. Well-known as a strenuous politician. Contested South Derry in the Sinn Fein interest in the elections of 1918. Is a brother of Mrs. Concannon (q.v.). 


\section{WALSH, Louis J.-(continued).}

1649 - THE YARNS OF A COUNTRY ATTORNEY. (Gill). 38. 6d. Clever and appropriate illustr. 1917.

The humorous side of legal proceedings, as seen by a solicitor in North-East Olster-the yarn of old Andy the incorrigible litigant, of the pair of swindlers who took in all the attorneys, of auctioneers and electioneers, who for their own ends worked upon the prejudices of each section of the people in turn. Of how the local A.O.H. lent its band to the local Orange lodge to celebrate the Twelfth, and soon the humour is the main thing throughout, but incidentally we get a very good notion of the peculiar atmosphere, political, religious, and social of N.E. Ulster. The satire is always good-natured. There is no vulgarity, but the society is distinctly low. The story "The Last Will" stands quite above the rest. It is a pathetic little tale of self-sacrifice.

1650_ THE NEXT TIME, a Story of Forty-eight. Pp. 242. (Gill). Frontisp. (Baliingarry). 1919.

Art O'Donnell grows up in the early days of Emancipation. His father is a loyalist out of self-interest. $\mathrm{He}$ is educated at Clongowes, and then goes to Dublin to study law. He falls in with the Young Ireland Party, and soon joins the movement. His brief career closes at Ballingarry, which is fully described. A romance runs through the book but history rather predominates. O'Connell, Davis, Duffy, Meagher, Mitchel, and O'Brien appear in the story. Famine scenes well described. Dialect carefully rendered.

WALSHE, Miss E. H.

1651— THE FOSTER BROTHERS OF DOON. Pp. 394. (R.T.S.). Illustr. n.d. (c. 1865).

The foster-brothers are Myles Furlong, a Co. Wexford blacksmith on the rebel side in the rising of '98, and Capt. Butler, a loyalist. Their respective adventures amid the historic events of the time are very well told. The Captain's election as M.P. for Doon is well described. Putnam McCabe, Hamilton Rowan, Tone, Curran, and Jackson appear in the tale. Dialect good. Leans to loyalist side. "Written from a decidedly Protestant standpoint."-(Nield).

1652_ THE GOLDEN HILLS. (R.T.S.). 1865.

The Famine.

1653 THE MANUSCRIPT MAN ; or, the Bible in Ireland. Pp. 226. (R.T.S.). 1869

In the biographical note prefixed to this story we are told that the Author was all her life interested and actively engaged in evangelical work. She was born in Limerick, 1835, died 1868. The story tells how a family of Protestant landowners succeeded in distributing among their Catholic tenantry copies of the Bible in Irish, and thereby converted a number of them to Protestantism. The converts afterwards emigrate and settle in America. Scene : apparently West Connaught. Throughout "Romanism" and "Romish" practices are contrasted with Protestantism, greatly tc the disadvantage of the former. The book is well and interestingly written.

WARD, Mrs.

1654 WAVES ON THE OCEAN OF LIFE : a Dalriadian Tale. Pp. 322. (Simpkin). 1869.

Domestic life, with glimpses of religious and political strife in Ulster at close of eighteenth century truthfully delineated. Scene: Lough Erne and Antrim, the scenery of Dunluce and the Causeway described, and some real incidents introduced. Symnathetic towards the people, and does not disparage the '98 insurgents. 


\section{WATERS, Thomas.}

1655_ THE RIBBONMAN; or, The Secret Tribunal. Pp. 306. (Glasgow : C'ameron \& Ferguson). n.d.

The story consists of a series of terrible plots by Ribbonmen against the life of a good landlord, Mr. Bolivor. These are frustrated by a faithful groom, Murphy, and his sweetheart, one of the maids, and by a policeman named Loftus, who is in love with another servant in the house. Mr. B. is shot, but recovers, and the priest (favourably represented) saves the mother and sister of Murphy from the Ribbonmen. The crimes of the Ribbonmen are much enlarged upon, with many moralisings by the Author, but there is no hint of the evils out of which Ribbonism arose. The Author is Protestant, but not bigoted. The publishers explain that they were induced to publish this story by the evident honesty and earnestness of the Author and by his appeal to their sense of fairness. The Author vouches for most of the facts related.

WATSON, Helen H., Mrs. Herbert A. Watson. Has never resided in Ireland but was ed. at Clifton, where many of her best school friends were Irish. Has since retained an attachment for Ireland and things Irish.

1656_ PEGGY, D.O. : the Story of the Seven O'Rourkes. Pp. 312. (Cassell). 3s. 6d. Four coloured plates from drawings by Gertrude Steele. 1910.

The story told by a little lame girl of fourteen of a proud Irish family reduced to a cheap flat, and living in discomfort and anxiety without losing their cheerfulness of heart. There is both humour and pathos. We are introduced to some pleasant and lovable children. Peggy, S.G. is a sequel to this.

\section{WEBSTER (F. A. M.).}

1657- THE HOUND OF CULANN. Pp. 287 (closely printed). (McBride, Nast). 5s. n. Binding somewhat cheap and fragile. 1918.

A well-meaning attempt to tell for English children the story of Cuchulainn, by the Author of Britain in Arms, Britain's 'Territorials, and The Evolution of the Olympic Games. It does not show familiarity with Irish life, and there is much of the professional prizefighter in the Author's Cuchulainn. The style alternates between that of a translation of Homer and that of commonplace modern journalism. Nevertheless almost the whole Cuchulainn epic is here related, including the cattle raid of Cuailgne, the Fate of the Sons of Usna, etc. There are no chapter headings throughout.

WENTZ, Walter Yeeling Evans, Docteur ès Lettres, France; A.M., Stanford College, California; Member of Jesus College, Oxford; an American, and a pupil of Sir John Rhys, $q . v$.

1658_ THE FAIRY-FAITH IN CELTIC COUNTRIES : Its Psychical Origin and Nature. (RENNES : Imprimerie Oberthur). 1909.

An investigation and discussion of " that special form of belief in a subjective realm inhabited by subjective beings which has existed from prehistoric times until now in Ireland, Scotland, Man, Wales, Cornwall, and Brittany." The Author, a believer in the existence of fairies, went himself through many parts of the countries above mentioned and spoke with and studied the peasantry. Divisions of work : I. The Living Fairy Faith Psychically Considered. II. The Recorded Fairy Faith Psychically Considered. III. The Cult of Gods, Spirits, Fairies, and the Dead. IV. The Fairy Faith Reconstructed.

\section{WERNER, A.}

\section{9_ O'DRISCOLL'S WEIRD. Pp. 316. (C'assell). 5s. 1892.}

A volume of sketches, only the first of which is Irish in subject. O'D. is an enthusiastically patriotic Irishman who joins the dynamiters in America. $\mathrm{He}$ is sent to England on a mission, but his humaner feelings get the upper hand, and he returns to New York to face manfully his doom. 
[WEST, Jane]. 1758-1852. B. in London; the wife of a farmer in Northamptonshire. Author of $A$ Gossip's Story.

16EG_ THE HISTORY OF NED EVANS: A Tale of the Times. Two Vols. (Dublin). [1796]. 1805.

Title-p. :- “ Interspersed with moral and critical remarks; anecdotes and characters of many persons well known in the polite world; and incidental strictures on the present state of Ireland." The hero is supposed to be the son of a Welsh parsor. The story opens in 1779, and is the love story of the Lady Cecilia, daughter of Lord Ravensdale, and the hero, who turns out in the end to be the true Lord Ravensdale. The story is full of incident. Ch. xxii. brings the hero to Ireland. $\mathrm{He}$ has some adventures in Dublin, which is partly described; then goes down to Ravensdale, which is seventy-six miles from Dublin. He goes to the American war, and has many adventures with Indians, narrow escapes, \&c.; but finally returns to wed Cecilia. The story is highly moral and sentimental, with a religious tone. The characters are mainly of the Anglo-Irish gentry-Lord Rivers, Lord Squanderfield, \&c. The then state of Ireland is but slightly dwelt on.

[WESTRUP, Margaret]; Mrs. W. Sydney Stacey. Author of Elizabeth's Children, Tide Marks, Roger Ingram, and some half-dozen other novels.

1661_ THE YOUNG O'BRIENS. Pp. 347. (Lane). 6s. 1906.

Doings of a family of Irish children left with an aunt in London during their father's absence in India. With all their fun and pranks the children pine in London and long for the meadows and the woods of their home in Kilbrannan.

WEYMAN, Stanley, a very well-known novelist. Author of A Gentleman of France, The House of the Wolf, etc., etc.

1662- THE WILD GEESE. (Hodder \& Stoughton). 6s. [1908]. (N.Y. : Doubleday). 1.50. New thin paper ed., pp. 384, 2s. 1911. (Nelson). 1s. 1917.

Story of an abortive rising in Kerry in the reign of George I., with exciting situations and a love interest. Style clear and vigorous. Irish characters nearly all vacillating, treacherous and fanatical. Generally considered as giving an unreal idea of the times.

WHISTLER, Rev. Charies Watts. B. 1856. Author of a series of admirable stories for boys.

1663_- A SEA QUEEN'S SAIIING. (Nelson). 3s. 6d. 1907.

The Vikings about A.D. 935, time of Hakon the Good. Adventures of a Scottish Norseman, a West Saxon lady and an Irish prince with the Vikings. Scenes : the Northern and Irish coasts. Juvenile.

1664 - A PRINCE ERRANT. (Nelson). 2s. 6d. 1908.

S.W. Wales, Cornwall, and Ireland about A.D. 792. ! Saxon, Briton, Norseman, and Dane. Juvenile.

\section{WHITE, Captain L. Esmonde.}

1665- IRISH COAST TALES OF LOVE AND ADVENTURE. Pp. 307. (Smith, Elder). 1865.

Contains two tales-(1) "The Black Channel of Cloughnagawn; (2) "The Lovers of Ballyvookan." Dr. Small goes to the west as a dispensary doctor, and meets the various types of character. The pursuit of a slave ship is well described, as are the men who man the western hookers, and know every turn of the dangerous Black Channel. The second deals with the wreck of H.M.S. Wasp and the love story of Norah Flynn. Both are exciting stories. The brogue is fairly good. 
[WHITTY, Michael James]. (1795-1873). B. Wexford, 1795, he came to London in 1821. In 1823 he was appointed editor of the London and Dublrn Magazine, in which he published his work on Robert Emmet. From 1829 till his death he lived and worked in Liverpool. His Liverpool DaIly Post, 1855, was the first penny daily paper.-(D.N.B.). His son, E. M. Whitty (1827-1860), was a brilliant journalist, and wrote a novel : Friends in Bohemia, and Parliamentary Portraits.

1666 TALES OF IRISH LIFE. Two Vols. 12mo. (London : Robins). Six illustr. by Cruikshank. 1824.

" Illustrative of the manners, customs, and condition of the people." Contents :" Limping Mogue," "The Rebel," "The Absentee," "The Robber," "The Witcin of Scollough's Gap," "The Informer," “The Poor Man's Daughter," "Pooc Mary," "North and South, or Prejudice Removed" (showing, see especially pp. '29 sq., V. II., the Author's freedom from bigotry), "The Priest's Niece," "The Last Chieftain of Erin," "Turn-coat Watt" (Proselytism), "Protestant Bill," \&c. Intended " to disabuse the public mind and communicate information on a subject confessedly of importance." Excellent stories by a journalist very well known in his day. These volumes have been translated into German and publ.

WHYTE-MELVILLE, Major G. J. (1821-1878).Had Irish connections and wrote many novels. Killed in hunting-field-a death he had often described.

1667- SATANELLA : A story of Punchestown. Pp. 307. (Chapman and Hall). 1873. 2s. other eds.

A racy story of sportsmen and soldiers. Opens in Ireland. Then scene shifts to Liondon. The talk of grooms and trainers fairly well done. The fate of the heroine and the famous black mare, both called "Satanella," is tragic.

\section{WIGHTMAN, James A.}

1668_ THE MAGIC HORSEHAIR. Cap. 4to. ('I'he Talbot Press). 38. 6d. net. 7 full-p. illustr. by the Author. 1918.

Seven pleasant little episodes from the life of Paddy Dolan, a little National schoolboy. Each time he is saved from a scrape by the magic horsehair given him by his friend the Leprechaun. There is a good deal of peasant dialect.

WILDE, Lady; "Speranza." Well known as a poet of the NATIon, one of the most passionately patriotic of them all. B. in Wexford, 1824. D. in London, 1896. Wrote also Ancient Cures, Charms, and Superstitions of Ireland, Drift. wood from Scandinavia, The American Irish, \&c.

1669 ANCIENT LEGENDS, MYSTIC CHARMS \& SUPERSTITIONS OF IRELAND, with Sketches of the Irish Past. Pp. 350. (Ward \& Downey). 6s. [1888]. (Chatto \& Windus). 3s. 6d. 1902. Still reprinted.

A collection of fairy stories, legends, descriptions of superstitious practices, medical cures and charms, robber stories, notes on holy wells, \&c., taken down from the peasantry, some in Gaelic, some in English. The legends, \&c., are preceded by a learned essay on the origin and history of legend, and the book concludes with chapters on Irish art and ethnology and a lecture by Sir W. Wilde on the ancient races of Ireland. Contains a vast amount of matter useful to the folklorist, to the general reader, and even to the historian. The stories are rather pathetic and tender than humorous.

WILliamS, Charles. B. Coleraine, 1838. D. London, 1904. The celebrated war correspondent of the DAILY CHRONICLE and STANDARD; first editor of Evening News, and founder of the Press Club. Wrote a Life of Sir Evelyn Wood.

1670- JOHN THADDEUS MACKAY. Pp. 327. (Burleigh). (1889). 6s.

In this clever novel the Author draws upon his recollections of early days in Ulster. The hero, " a stickit minister," goes out to India in company with a "Howley" father, so named after a famous Archbishop of Canterbury, and both 
WILliamS, Charles-(continued).

learn charity and brotherly love and see the narrowness of their own views through mixing with the natives. Many real personages are introduced under thinly disguised cogmomens, thus "Rev. Thomas Trifle" is the late Rev. Thomas Toye, of Belfast.

\section{WILLIAMS, Mary Gertrude.}

1670A- ALIAS KITTY CASEY. Pp. 178. (N.Y. : Kenedy). 1911.

A lively American story of the present day. Katherine Carew, a stenographer, who thinks she is going blind, takes the place of Kitty Casey, a new Irish servant, in a summer hotel, in the hope that the country air may benefit her failing eyesight. Her adventures make up the story. Irish dialect well reproduced.

WILLS, William Gorman. B. Kilkenny, 1828. D. London, 1891. Poet, Painter, Dramatist, and Novelist. Ed. T.C.D. Son of Rev. James Wills, also a prolific writer. Wills is better known as a dramatist, having written no fewer than thirty-three plays. amongst the finest of them being Charles I., Olivia, and Faust. Amongst his other novels are Life's Foreshadowings, which first appeared as a serial in IRISH Metropolitan Magazine, 1857-8; The Wife's Evidence, founded on an Irish tragedy, where a man named McLaughlin was hanged for a murder committed by his mother; The Three Witches, Notice to Quit, David Chantry, besides a long poem, Melchior.

1671— OLD TIMES. Pp. 395. Demy 8vo. (Lond. : Saunders \& Otley). With 8 full-page illustr. by the Author. 1857.

A complicated and somewhat tedious plot, but masterly characterization and many scenes and situations of great power and pathos for which the writer has largely drawn upon his experiences during many years of his profession as a portrait-painter. (See Preface). Among the personages are the quietly dignified David Cordell, whose goodness is rather felt than seen, and who, without undercurrent of selfish motive, is at the service of all. Then there is the Rev. Mr. Leeson, a vain and shallow worldling, with an outward mask of impeccable decorum. And there is kindly simple-hearted Aunty who toils and slaves to ward off sorrow and hardship from others. It is in the side episodes and scenes and in the depicting of character that lies the real value and interest of the book-the career of Mr. Francis Cordell, the sturdy friendship of Tom Simpson, the naif simplicity of Marguerite, and so forth. Scene: Dublin and Kingstown.

1672— THE LOVE THAT KULLS. Three Vols. (Tinsley). 1867.

"It [the above novel] drew striking pictures of the relations between landlord and tenant in Ireland, the Irish Famine, and the Rebellion of 1848: and it showed a warm glow of sympathy with the Irish peasantry, which no one would have suspected in a man apparently so wholly out of touch with politics." [From "Life of W. G. Wills" by Freeman Wills. London, 1898].

WILMOT-BUXTON, E. M., F.R. Hist. S., author of a large number of educational works on history.

1673 BRITAIN LONG AGO: Stories from Old English and Celtic Sources. (Harrap : Told through the Ages series).

1674- OLD CELTIC TALES. Pp. 128, large clear type. (Harrap). 6d. 1910.

One of Harrap's "All-Time Tales," a series of supplementary readers for young children. The first tale is "The Children of Lir," told in three-and-a-half pages. The rest are from the Mabinogion and other Welsh sources. Six or seven moderately good full page ill. (one col.). Neat cover. Remarkably cheap. 
WINGFIELD, Hon. Lewis Strange. B. 1842. Son of 6th Lord Powerscourt. Ed. Eton and Bonn. Lived a very strange life, trying as experiments various rôlesactor, nigger minstrel, attendant in a mad-house, traveller in Algeria and China, painter, \&c., \&c. Wrote many novels and books of travel. D. 1891.

1675_ MY LORDS UF STROGUE. Three Vols. (Bentley). 1879.

"A Chronicle of Ireland from the Convention to the Union." History and romance curiously intermingled, e.g., Robert Emmet's Insurrection is purposely ante-dated by two years and a half. "The prominence given to such unpleasant personages as Mrs. Gillin makes the book unsuitable at least for the lending libraries of convents."-(I.M.). The Author is fair-minded and not anti-national.

woods, Margaret L. B. Rugby, 1856. Dau. of late Dr. Bradley, Dean of Westminster. Ed. at home and at Leamington. Lives in London. Author of about a dozen volumes-novels, poems, and plays.

\section{6- ESTHER VANHOMRIGH. Pp. 347. (Murray). 1891.}

A clever and interesting psychological study of the relations between Swift and the two Esthers, Johnson and Vanhomrigh, the latter being the chief centre of interest. Scene partly in Ireland, partly in England. The political events and questions of the time are scarcely touched upon, but the atmosphere, language, and costume of the time have evidently been carefully studied, and are vividly reproduced. Swift's relations to these two women are represented in a convincing and sympathetic manner. There is nothing objectionable in the tone of the book.

1677- THE KING'S REVOKE. Pp. 334. (Smith, Elder). 6s. (N.Y.: Dutton). 1.50. Second impression. 1905.

The strange adventures of Patrick Dillon, an officer in the Spanish army, in the course of his attempt to set free Ferdinand VII. of Spain, imprisoned in France by Napoleon I. Its pictures of Catholic life in spain are not always flattering, though doubtless not intentionally offensive.

[WRIGHT, E. H.]

1678- ANDRÉ BESNARD. (CoRK). 1889.

A tale of Old Cork, giving good descriptions of its people, buildings, \&c. Period: that preceding the times of the Volunteers. A tale of courtship and adventure. One of the chief characters is Paul Jones, the celebrated American admiral. Published under pen-name "G. O'C."

WRIGHT, John, A.M. One time Rector of Killeevan, Co. Monaghan.

1679 THE LAST OF THE CORBES; or, The MacMahon's Country. Pp. 342. (Macrone). 1835.

Described on title-p. as " a legend connected with Irish history in 1641." A plain tale, devoid lof /description, excitement, and historical "atmosphere;"; chiefly concerned with a family named Willoughby. The writer is anti-Puritan but not pro-Irish. He mentions the deed of the traitor O'Connolly with approval, and dwells much on the excesses of the insurgents. Heber Macmahon (afterwards Bishop of Clogher), Sir Phelim O'Neill, and Roger Moore are introduced into the story.

WRIGHT, R. H. A Belfast man who served with the Rimmington Guides in the South African War and afterwards emigrated to New Zealand. He was wounded in the present war. Besides the following, he has written The Scout in War, I'he Outer Darkness, and many short stories and articles.

1680_ A PLAIN MAN'S TALE. Pp. 192. (Belfast : McCaw, Stevenson \& Orr). 1904.

Adventures of a young Yorkshireman who, about the '98 period, sails for Ireland and lands at Island Magee, in Antrim. Exciting episodes-love-making, smuggling, \&c. Much dialect. Not concerned with the rising. For boys. 
WRIGHT, R. H.-(continued).

1681— THE SURPRISING ADVENTURES OF MY FRIEND PATRICK DEMPSEY. Pp. 90. (Sealy, Bryers). 6d. Paper cover. n.d. [1910].

Seven yarns told by the hero himself. They depend for their humour on extravagance and intentional absurdity of the "Stage Irishman" type. Not intended as a picture of Irish life but merely as broad comedy. Conventional brogue of the "Biddy me darlint, says Oi" type. Sometimes border on vulgarity.

WYNDHAM, Eleanor. Author of The Lily and the Devil, 1908.

1681A- THE WINE IN THE CUP. Pp. 380. (Werner Laurie). 6s. 1909.

Scene laid in Rathlin Island, but the book cannot be said to depict the life of the place with fidelity to real conditions.

\section{WYNNE, Florence.}

1682_- THE KING'S COMING. Pp. 489. (Skeffington). 6s. 1904.

The king is "Edward VII. of England and I. of Ireland" (sic). Nearly half the book is composed of minute descriptions of his reception in various parts of Ireland. The rest is chiefly made up of long discussions (mostly by the hero and heroine) on religion, divorce, loyalty, Irish history, the position of the Church of Ireland, and landlords. The Author seems to be strongly "loyal," a High-Church member of the C. of I., an ardent Home-Ruler, and a Gaelic enthusiast. But no bias is displayed against any class or creed, though the Author does not seem partial to the landlord class, unpleasant specimens of whom are introduced. Written with obvious sincerity and earnestness.

"WYNNE, May"; Miss N. W. Knowles. Writes much for magazines, and has published over thirty books. Has much sympathy with Ireland and the Irish. Resides in Kent.

\section{3- LET ERIN REMEMBER. Pp. 312. (Greening). 6s. 1908.}

A sensational romance of the Norman invasion of Ireland, very similar in kind to the Author's For Church and Chieftain, q.v. The Irish are depicted as a wild, passionate people, torn by murderous feuds, led by selfish, unscrupulous chieftains. The Normans, who appear in the story, Strongbow in particular, are represented as gentle and courteous knights.

1684 FOR CHURCH AND CHIEFTAIN. Pp. 314. (Mills \& Boon). 6s. 1909.

A romance of the thrilling and popular type. Full of wonderful coincidences and the still more wonderful escapes of the heroes from the clutches of their enemies. The story is little concerned with historical events and persons. The Earl of Desmond, Archbishop O'Hurley, Dowdall, and Zouch are introduced occasionally. The tone is healthy, the standpoint Irish and Catholic.

1685- FOR CHARLES THE ROVER. Pp. 324. (Greening). 6\&. (N.Y.: Fenno). 1.50. Third ed., 1909.

Scene : Cork city, and the neighbourhood of Kenmare. Adventures of Hugh Graham, a Scotchman, in recruiting for the Irish Brigade in company with Morty Oge O'Sullivan, a gay, reckless, debonnair type of. Irish chieftain. On the other side are the brainless Whig fop, Sir Henry Morton, and O'Callaghan, a spy in King George's pay. The unfortunate love-story of O'Callaghan's beautiful sister and the happier love of the sister of Morty are interwoven with the narrative. The Author's sympathies are Irish and Jacobite.

WYNNE, George Robert, D.D. Archdeacon of Aghadoe, Rector of St. Michael's, Limerick, and Canon of St. Patrick's, Dublin. Author of a number of religious works : The Light of the City, Spiritual Life in its Advancing Stages, \&c. 


\section{WYNNE, George Robert, D.D.-(continued).}

1686_ NOT PEACE BUT A SWORD. Pp. 190. (R.T.S.). n.d. (1897).

Relates how Miss Sybil Marchant a young English lady, succeeded in converting to Protestantism some members of a poor family of Joyces in Connemara. Is concerned chiefly with trials of the new converts, at the hands of friends and the clergy. Tone not bitter towards Catholicism, which, however, is regarded from the Low Church, strongly Protestant, standpoint. The story is pleasantly told.

1687- BALLINVALLEY; or, A Hundred Years Ago. Pp. 244. (S.P.C.K.). 2s. 6d. Two illustr. by J. Nash. 1898.

Scene : Wicklow, whose scenery is well described. Rebellion seen from Protestant and loyalist standpoint. Rebels appear as recklessly brave savages. Battles of New Ross and Hacketstown described. Characters well brought out. Some aspects of the life of the times described, notably stage-coach travelling and illicit distilling. Brogue not well reproduced. Based, says the Pref., chiefly on Lecky, but also on Maxwell, Musgrave, and Hay. There is a good deal about gold-mining in Co. Wicklow.

YEATS, William Butler. B. 1865, at Sandymount, Co. Dublin. Son of J. B. Yeats, R.H.A., a distinguished Irish artist. Ed. Godolphin School, Hammersmith, and Erasmus Smith School, Dublin. Went to London in 1888, and there, in 1889, publ. his first volume of verse. Since then many others have appeared, and he is now known as one of the foremost poets of the day, perhaps the only Irish poet whose name is familiar to students of European literature outside of Ireland, and it is true to say with Mrs. Hinkson in her Reminiscences, "All the world that cares about literature knows of his work to-day." $\mathrm{He}$ was for a number of years actively interested in spiritism and magic, and there is more of this than of genuine folk-lore in his writings. What there is of folklore in them seems to have been gleaned during visits to his mother's people in Sligo. His prose is that of a poet, full of changing colour and strange rhythm and vague suggestion.

(W. $S \cot t)$. 3s. $6 d$. and 1s. [1888]; often republ.

Introd. and notes by Ed. The Tales, sixty-four in number, are selected from previously published collections (Croker, Lover, Kennedy, Wilde, \&c.), including several examples of poetry about the fairies. They are classed under these heads :-The Trooping Fairies, The Solitary Fairies, Ghosts, Witches, Tir na-n-óg, Saints and Priests," The Devil, Giants, \&c. Each class is introduced by some general remarks. There is nothing objectionable, but it is hardly a book for children. The weird and grotesque element largely predominates.

1689 _ IRISH FAIRY AND FOLK-TALES. Twelve full page illustr. by James Torrance. (W. $S \cot t)$. 3s. 6d.

1690 JOHN SHERMAN, and DHOYA. Pp. 195. (Fisher Unwin). 1891.

John Sherman is not wild and fantastic like The Secret Rose, \&c., but a pleasant narrative dealing with life in Ballah (Sligo), the scene at times shifting to London. The descriptions both of scenery and character are full of quaint little touches of very subtle observation. The style is remarkable for a dainty simplicity, lit up now and then by a striking thought or a brilliant aphorism. Dhoya (last $25 \mathrm{pp}$.) is a wild Celtic phantasy.-(I.M.). Published under the pen-name of " Ganconagh."

1691 IRISH FAIRY TALES. Ed. with Introd. by. Pp.236. 16mo. (Fisher Unwin). 2s. 6d. Illustr. by J. B. Yeats. Third impress. 1892.

A dainty little volume, very popular with children. None of the stories included in it are to be found in the same Author's Irish Fairy and Folk-tales.-( W. Scott).

1692_ THE SECRET ROSE : Irish folk-lore. Illustr. by J. B. Yeats. Pp. 265. (Maunsel). 3s. 1898. (N.Y.: Dodd \& Mead). 2.00. 
YEATS, William Butler-(continued).

Wild, formless tales, altogether from the land of dreams, told with the Author's accustomed magic of word and expression, but to the ordinary reader well-nigh meaningless. In one of these tales some monks solemnly crucify a wandering gleeman because he had dared complain of the filthy food and lodging which they had given him. This tale may fairly be taken as typical of much that is in the book.

1693 THE CELTIC TWILIGHT. Pp. 235. (A. H. Bullen). 3s. [1893]. New ed., enlarged, 1902. (N.Y. : Macmillan). 1.50.

Disconnected fragments of dim beliefs in a supernatural world of fairies, ghosts, and devils, still surviving among the peasantry. Told in a style often beautiful, but vague and elusive, by a latter-day "pagan," who would fain share these beliefs himself. The talk of half-crazy peasants, the Author tells us, is set down as he heard it. To the ordinary reader the book cannot but seem full of puerilities. The peasants of whom the Author speaks are chiefly those of North-Eastern Sligo.

1694 STORIES OF RED HANRAHAN : The Secret Rose : Rosa Alchemica. Pp. 228. (Bullen). 68. net. 1913.

The first ed., 1897, had the general title The Secret Rose, q.v. In the present volume the revised ed., which appeared in Mr. Yeats's collected works, 1908, has been followed. In 1914 this book was published in U.S.A. (N.Y. : The Macmillan Co.) under the same title, but, as the Author tells us, rewritten in the "Kiltartan" dialect.

YOUNG, Ella. B. 1867, at Fenagh, Co. Antrim. Is a graduate of the Royal, now the National, University. Is chiefly interested in the old tales of the Irish MS. collections and in folk-lore gathered directly from the people. Has published a volume of poems and many articles and tales in the MANCHESTER Guardian, The Irish Review, Irish Year Book, \&c., and in American and New Zealand periodicals. Her writings are full of the influence of the Celtic Revival, in which movement she numbers many friends.

\section{5- THE COMING OF LUGH. (Maunsel). 6d. net. 1909.}

"A Celtic Wonder-tale Retold" for the young. A dainty little volume in which is prettily told the story of Lugh Lamh Fada's sojourn in Tir-na-nOg and his return to Erin with the Sword of Light to drive out the Fomorians. The illustrations by Madame Gonne-MacBride are very well done.-(Press Notice).

1696_ CELTIC WONDER TALES. Pp. 202. (Maunsel). 3s. 6d. Illustr. by Maud Gonne. 1910.

Tales of the ancient days of De Danaan gods and heroes-of Angus and Midyir and Lugh and the Gobhaun Saor. Told in rhythmic and musical language and with much beauty of expression, but most of the tales are altered quite out of their antique and primitive form by a strong flavour of modern mysticism and symbolism of the school of Yeats and AE. "Conary Mor," the finest (we think) of the tales, is perhaps freest from this. The first two or three are most influenced by it. Tales like "A Good Action," "The Sheepskin," strike a different and, as it seems to us, a discordant note, viz., broadly comical episodes, in which the actors are gods. Includes The Children of Lir" and the Children of Turann (under title "The Eric Fine of Lugh"'), and the Coming of Lugh. Original and artistic Celtic cover design, head-pieces, and tail-pieces. Four coloured illustr. The first two are mystic and symbolic. Most Catholics would consider them very much out of place here. The book is beautifully produced.

YOUNG, Filson (Alexander Beli Filson Young). B. Ballyeaston, Co. Antrim, in 1876. Son of Rev. W. Young, of Portaferry. Has had a very varied career as a musician, war correspondent, journalist, lieut. in the Royal Volunteer Naval Reserve. Au. of a great variety of works-music, verse, travel, biography, fiction, etc., including Ireland at the Cross Roads, 1903. 
YOUNG, Filson-(continued).

1697- WHEN THE TIDE TURNS. Pp. 346. (Grant Richards). Frontisp. in colour. 1908.

Rupert Savage, a young Irish Protestant of good family, falls in love with Lady Fastnet, wife of a Catholic peer. She is a good woman, and gives him no encouragement. He leaves Ireland and falls in with Bohemian society in London. He forms a liaison with a Mrs. Graeme. Owing to a foolish but not immoral action he falls under a shadow, is ostracised, and finally takes refuge in Spain along with Mrs. Graeme and a disreputable poet, Midwood. In the early chapters and in the last the scene is laid near a Co. Down (Strangford Lough) village, and some landscapes are well and feelingly drawn.

\section{ADDENDA.}

\section{WITH SOME ANNOUNCEMENTS.}

These additions have been rendered necessary by the length of time which, owing to various causes, the book has taken to pass through the press.

BOYS' STORIES. - In the eighties of last century Edwin J. Brett, Publisher, London, brought out many sixpenny reprints of stories for boys which had appeared in such publications as "The Boys of England," "Young Men of Great Britain." Such were Fred Frolic, Wildfoot the Wanderer of Wicklow, Pat O'Connor's School Days or The Boys of the Shannon. The Irish characters in these are of the traditional type expected by the English public. There is no wilful misrepresentation of Ireland but much ignorance of Irish conditions.

Another similar book was Roderick of Kildare, which ran as a serial in one of the Red Lion House (James Henderson \& Co.) publications, and was afterwards republished in $3 d$. pocket novel form by the same firm about 1880 .

an pilloin.

1698 - THE WISDOM OF THE WORLD. A book of wonder tales. Pp. xxxix. 12mo. (Dublis : The Candle Press). 1s. 1919.

Six full page illustr. in black and white by Caitia ni Chormaic. Contents :-1. The Second Grail. 2. The Crane. 3. Christopher. 4. The Last Mass at Teampall na-Sceilg. 5. The Swan Children. 6. At the Inn. Brief tales with an allegorical significance, written in the spirit of ancient Gaelic christianity, and deeply religious. Told in language of antique flavour. They appeared originally in THE Cross, edited by the Passionist Fathers.

BIGGER, Francis Joseph, a solicitor practising in Belfast. One of the greatest

Irish Ireland forces in Ulster. His activities in the cause are innumerable, taking especially the form of keeping alive or reviving tradition, local and national. He edits the ULSTER JourNal of ARCH

1699_ FOUR SHOTS FROM DOWN. (BELFAST : Sweeney). 1s. Illustr. 1919.

Fireside stories into which the Author manages to weave traditions of Co. Down places (Dundonald, Newtownards, Downpatrick, Loughinisland) and Co. Down families (Montgomery, Colville, Bradshaw, Cleland, Stewart). The narratives are sometimes humorous, sometimes pathetic. One cannot but smile at the tale of Bradshaw's "Beetle" and all it gave rise to, and the pathetic story of Thomas Russell will linger for ever around the "Buck's Head" inn at Loughinisland.(I.B.L.)

BLACAM, Aodh de. B. London, son of W. G. Blackham, M.P.S., of Newry. Formerly a Presbyterian, now a Catholic. Since 1909 connected with Irish Ireland journalism, contributing tales and essays (mostly on Gaelic literature) to SinN FEIN, the LEader, the IrIsh Rosary, IrIsh MoNTHLY, etc. Literary critic to SUNDAY INDEPENDENT since 1915. Has just launched a new monthly, the Irish Commonwealtr. Au. of Dornán Dán (lyrics in Irish), Stór i gCeili (a story in Irish that appeared serially in Young IRELAND), Towards THE REPUBLIC (an uncompromising statement of the full Sinn Féin faith).

1700 THE SHIP THAT SAILED TOO SOON, and other tales. (Maunsel.) Forthcoming, Spring 1919. 


\section{BLACAM, Aodh de-(continued).}

"Romantic and humorous stories of Irish-speaking Ireland, past and present. Red Hugh O'Donnell is the central figure of the title story. "Tales of my own people " describe Irish London."

1701 - THE DRUID'S CAVE : a romance of two Ages. Forthcoming 1919.

"Irish youths and an English tripper pass up the River of Time into primitive Ireland and take part in the war between the Gaels and the Fomorians."

BoINVILLE, Mrs. Chastel de. This Author's husband is a Canon of the Church of Ireland and is incumbent of the town of Tipperary.

1702- O'REILLY OF THE GLEN. (Hutchinson.) 6s. 9d. n. 1918.

A story of the Rising of 1916 written from an entirely outside point of view by one who would show sympathy to the "dear Irish" but has no understanding of their national aspirations. O'Reilly, the Sinn Fein leader, is upright and gallant but visionary and emotional. He has been led astray into Sinn Feinism by O'Donnell, a thorough anti-English scoundrel. The story tells how Rosamund Rynd is almost won from her respectable English soldier lover by the romantic glamour of the O'Reilly. The latter is killed in the Rising. There is some descrip. tion of the Glen of Aherlow, Co. Tipperary.-(Press Notices.)

CRICHTON, Frances Ellzabeth, died Nov., 1918. Was a daughter of the Rt. Hon

Thomas Sinclair, D.L. of Belfast. Her husband is the head of the Liverpool

firm of W. Sinclair \& Co. Her The Precepts of Andy Saul is an amusing skit

on Ulster character.

\section{FLOWER, Elliott.}

1703- POLICEMAN FLYNN. (N.Y.: Century Co.) 1902

"Flynn, a big, brave, rather slow man, illiterate, but with occasional vivid flashes of cleverness, is shown in his encounters with crime, with boyish mischief, with his wife's attempts to improve hin, with corrupt politics, etc. ; and if he be not always happily triumphant, he is always triumphantly funny, and his brogue is good. . . ."-(The Dolphin.)

\section{GREGORY, Lady.}

1704 - VISIONS AND BELIEFS IN THE WEST OF IRELAND. With two

Essays and Notes by W. B. Yeats. Two volumes, $12^{\circ}$ (Putnams). Approxi-

mate price, 3.50. Forthcoming, Autumn, 1919.

"To those who have felt the haunting charm that inheres in the Celtic conscions. ness of an imminent supernaturalism, this collection of Irish fancy, belief, and folklore, gathered from the lips of the people with patient and reverent care, will have particular value. It has interest as an exceptionally thorough and representative study of psychic sensitiveness in Ireland, and the slightness of the barrier between worlds seen and unseen." - (Publ.t

HOGAN, J. F., author of The Irish in Australia.

1705- AN AUSTRALIAN CHRISTMAS COLLECTION. (Downey.) n.d.

Contains four Irish Australian tales:-Ella Gray, Little Loney, Flora's Quest, and The Stone Hut.

LEADBEATER, Mary (1758-1826), a Quakeress who resided in Ballitore, Co. Kildare, at the end of the 18th century. She was a friend of Edmund Burke and the daughter of his old schoolmaster, Shackleton. She wrote The Annals of Ballitore, which includes a vivid and impartial account of what she had seen of '98. A miscellaneous collection of writings was published in 1862-The Leadbeater Papers, 2 vols., containing much information about the rebellion.

1706 COTTAGE DIALOGUES OF THE IRISH PEASANTRY. 1st Series 1811 , 2nd 1813.

Cast in narrative form. Written with a didactic purpose, viz., to contrast the careless, idle type of peasant with the thrifty, industrious housewife.

LESLIE, Shane. B. 1885, eldest son of Sir John Leslie of Glaslough. Ed. Eton and Cambridge. Became a convert to Catholicism while working among the Irish poor. Twice contested Derry City as a Nationalist. Interested in Celtic Revival. Author of a series of some dozen books about Ireland. Publ. 


\section{LESLIE, Shano-(continued).}

reminiscences-The End of a Chapter. Ed. Dublin Review, since 1916.

Frequently visits U.S.A. (Сатн. Who's Who.)

1707- THE STORY OF ST. PATRICK'S PURGATORY. (ST. LoUIs : Herder). 2s. 6d. n. 1918.

Consists of an Introd. and eight tales, some purely fictitious, for which the history of Lough Derg and its pilgrimage is taken as a basis. They give "a glimpse of a very legendary past" (Pref.), and the Author has cast them in an altogether romantic form.

MCCALL, P. J. Died March, 1919.

\section{MacNAMARA, Brinsley.}

1708- IN CLAY AND BRONZE. (Kiersey). 6s. n. Forthcoming.

"Develops a very intense and powerful study of a young Irishman sprung from the clay, and driven by what appears a relentless destiny to achieve a position amongst the Immortals in the Ireland of his time." (Publ.)

\section{O'LEANNIN, $M$.}

1709- 'GAINST SATAN'S FANGS. Or, The Adventures of Ciaran Ryan. Pp. 155. (Whelan). 2s. n. 1918.

Ciaran runs away from St. Declan's, is kidnapped by buccaneers, escapes, and takes service with Maronia (Somewhere in S. America) against Ironto, a freemason state. Thrilling adventures in submarines and aeroplanes. Period c. 1940, Ireland being then a prosperous Republic. A book for boys.

\section{O'TIGEARNAIGH, MIcheal and Colm O'Loohlainn ed.}

1710 THE VOYAGING OF BRENDAN. Pp. 100, f'cap. 4to. (The Candle Press). Antique leather 17s. 6d., boards 10s. 6d. Decorated in black and white by William MacBride. (Forthcoming.)

This famous medieval wonder-tale is here presented in an English transl. from the Latin by the editors.

\section{RICGKARD, Mrs. VIctor.}

1711_- THE HOUSE OF COURAGE. (Duckworth). 7s. not. March, 1919.

In reviewing this book a writer in Everyman says, "Once again Mrs. Rickard uses her own country as a background to the story she has to tell; and in writing of the south-west of Ireland her talent for description and her quiet humour have full scope. In so far as they deal with Ireland, Mrs. Rickard's novels are a very notable contribution to the Irish literary movement. She writes of the fastdeclining generation of landlords and their homes with an intimate knowledge and a sure touch; and she is almost the only writer who has understood and described that very human and self-sufficient race of men and women. . . . . It is the best book that Mrs. Rickard has yet written."

\section{SAVAGE, Marmion W.}

1712— MY UNCLE THE CURATE. (Chapman \& Hall). [Anon. 1849]. 5th ed. 1867.

"Scene, chiefly coast of Donegal. Time, 1831. The curate, Hercules, Woodward, a genial giant of rough exterior but with heart of gold, plays a heroic part in storms, shipwrecks, highway robbery of a tithe proctor (for which his nephew is wrongfully accused) and the abduction of a niece. A clean, healthy story, scenery well described and dialect well rendered. Exhibits a shrewd knowledge of the peasantry, though often rather satirical. Condemns alike Orangeism and Repeal, and inculcates toleration. The rector's essay on "The Island of HiggeldyPiggeldy " reminds one of Swift. Many interesting and well-drawn characters from all sections of society introduced, providing an excellent picture of the pcriod."

\section{SAYRE, Theodore Burt.}

1713 TOM MOORE. (N.Y. : Stokes). 1902.

"A novel made by interlarding a few descriptive passages with the scenes of a play, composed of impossible Irish, atrocious puns, and indifferent English, the whole intended to show Moore's early struggles in London, his courtship, etc. ... He is said to have been Poet Laureate!" (THE DolphIN).

STEPHENS, James, has a new work ready for publication. Competent critics have pronounced it superior to any of his work hitherto published. 


\section{APPENDIX A.}

\section{SOME USEFUL WORKS OF REFERENCE.}

\section{IRISH LITERATURE. Ten Vols. 4126 pp., exclusive of introductory essays,}

which average over $20 \mathrm{pp}$.

Originally published by John D. Morris \& Co. Afterwards taken over by the De Bower Elliot Co., Chicago, and brought out in 1904.

Edited by Justin M'Carthy, M.P., with the help of an advisory committee, including Stephen Gwynn, ex-M.P., Lady Gregory, Standish O'Grady, D. J. O'Donoghue, Douglas Hyde, LL.D., J. E. Redmond, M.P., G. W. Russell (" Æ..'), J. J. Roche, LL.D., of the Boston Pilot, Prof. W. P. Trent, of Columbia University, Prof. F. N. Robinson, of Harvard, H. S. Pancoast, and W. P. Ryan; with Charles Welsh as Managing Director.

Scope and Object : To give a comprehensive, if rapid, view of the whole development of Irish literature from its earliest days. In the words of the Editor, it is " an illustrated catalog of Ireland's literary contributions to mankind's intellectual store."

The Choice of Extracts is determined by two canons : literary value and human interest. The Library gives examples of " all that is best, brightest, most attractive, readable, and amusing," in the writings of Irish authors. There is no dry-asdust. The extracts comprise mythology, legend, folk-lore, poems, songs, street ballads, essays, oratory, history, science, memoirs, fiction, travel, drama, wit, and humour. The vast majority are chosen as being specially expressive of Irish nationality. Choice is made both from the Gaelic and the Anglo-Irish literatures, but the ancient Gaelic literature is given solely in translation. A volume (the tenth) is given to modern Gaelic literature, the Irish text and English translation being given on opposite pages. This volume also contains brief biographies of ancient Gaelic authors. The extracts are never short and scrappy, but nearly always complete in themselves.

Other Special Features: Three hundred and fifty Irish authors are represented by extracts. Of these one hundred and twenty are contemporaries, the great modern intellectual revival being thus very fully represented.

The extracts are given under the names of the authors, and these names are arranged alphabetically, beginning in Vol. I. with Mrs. Alexander, and ending with W. B. Yeats in Vol IX.

To the extracts from each author there is prefixed a biographical notice, including in many cases, a literary appreciation by a competent authority, and a fairly full bibliography.

Each volume contains an article by a distinguished writer on some special department of Irish literature. Thus the Editor-in-Chief gives a general survey of the whole subject. W. B. Yeats writes on Irish Poetry, Dougias Hyde on Early Irish Literature, Dr. Sigerson on Ireland's Influence on European Literature, Maurice Francis Egan on Irish Novels, Charles Welsh on Fairy and Folk Tales, J. F. Taylor, K.C., on Irish Oratory, Stephen Gwynn on the Irish Theatre, \&c.

Index of authors, books quoted from, titles and subjects dealt with-exceptionally full and valuable (over $80 \mathrm{pp}$.).

Publisher's Work: 1. Illustrations, over 100 (several in colour), consisting of facsimiles of ancient MSS., and of ancient prints and street ballads, portraits of Irish authors, views of places, objects, scenery, and incidents of Irish interest.

2. Letterpress-large and ciear type.

3. Binding-cloth, and half-morocco.

4. Price has varied a good deal since first publication. A new and much

cheaper edition has recently been issued.

$311+324+346+369$ (GreshameratuRE. Four Vols. Super royal 8vo. Pp. in black and white by J. H. BaCon, C. M. Sireldon, W. Ratney, \&c., and portraits. 1903.

Editors : Originally planned by C. A. Read, who collected matter for the first three volumes of the original edition. Completed and edited by T. P. O'Connor. M.P. New edition brought out by Mrs. Katharine Tynan Hinkson. 


\section{THE CABINET OF IRISH LITERATURE-(continued).}

New edition: The original edition (1879) was published by Blackie. The new edition contains about the same quantity of matter, but large portions of the original edition have been omitted to make room for new matter, which occupies. the whole of the fourth volume and a large part of the third. A new Introduction (pp. xi.-xxxiv.) has been prefixed. It is a general survey of Irish literature.

Scope, arrangement, \&c.: The authors are arranged chronologically. There is first a sketch (full and carefully done) of each author's life and works; then follow extracts, as a rule very short, from his works. The principle of selection is to give such extracts as would best illustrate the author's style, to avoid anything hackneyed, and "anything that would offend the taste of any class or creed."

In the original edition there was, perhaps inevitably, little of Irish Ireland, still less of Gaelic Ireland. That has been to a certain extent remedied in the new edition. But the old edition had the advantage of containing a mass of information about little known writers and of extracts from curious and rare books.

3. BAKER, Ernest A., M.A., D.Lit., F.L.A.

A GUIDE TO THE BEST FICTION IN ENGLISH. Sq. 4to. Pp. 813.

(Routledige). 21s. [1902, Sonnenschein]. New ed., enlarged and thoroughly revised. 1913.

This new edition is a superb work, deserving the title of an Encyclopedia of English Fiction. It gives information in descriptive notes of between 7,000 and 8,000 works of fiction, including particulars of publishers (both in England and in U.S.A.), prices and dates of publication. It comprises every description of novel, translations of important continental and even non-European fiction, and of early stories and sagas from the Norse and from Celtic languages. The Guide is selective-not everything in the novel line is included-but it is most comprehensive. The arrangement is first by nationalities (English, American, Celtic, pp. 517-521, French, \&c.). Each of these divisions is sub-divided according to the century in which the book was published, and the entries under the various centuries are arranged alphabetically, according to names of authors. The Index, which runs to 170 pp., gives full references to Authors, Titles, and Subjects. Every specific subject illustrated in the works is indexed with extraordinary accuracy and completeness.

4. - A GUIDE TO HISTORICAL FICTION. Pp. xii. +566. 1914.

A new ed. of the Author's History in Fiction; a companion to the preceding and uniform with it in size, publisher, and price. As in the case of the former work, full bibliographical particulars and descriptive notes are given. The main arrangement is according to countries. Under each country it is chronological. The Index (140 pp.) gives information as full as in the preceding work. The standard of selection is " the extent to which a story illustrates any given period of history." -(Pref.). Ireland is not dealt with separately, the history of the British Isles being taken as a whole.

5 - HISTORY IN FICTION. Two Vols. 16mo. Pp. 228+253. (Routledge). 2s. 6d. each. n.d. (1906).

"A kind of dictionary of historical romance from the earliest sagas to the latest historical novel."-(Pref.). Aims to include "every good work of prose fiction dealing with past times."-(Pref.). Full bibliographical particulars (date, price, publisher) are given about each book. In most cases a short descriptive note is added. The entries average seven on a page. The titles are arranged first in order of countries. Thus in Vol. I., pp. $1-128$ deal with English History; pp. 129-154, with Scotch; pp. 155-167, with Irish, and so oll. Vol. II., pp. 1-56, U.S.A.; pp. 61-117, France; pp. 118.131, Germany, and so on. The books dealing with the history of each particular country are arranged in order of date. A copious Author Title, and Subject Index is appended to each volume. We retain the note on this book as, though now in a sense out of date, it is still in print, and its price makes it more generally available than is the new edition.

\section{NIELD, Jonathan.}

A GUIDE TO THE BEST HISTORICAL NOVELS AND TALES. Pott 4to. Pp. xviii.+522. (Elkin Mathews). 8s. nett. [1902, pp. viii.+124].

Fourth ed., rev. and enlarged. 1911.

Introd. pp. 16 defends historical fiction. The work is in two parts-the main body as it appeared in the third ed., and a supplement nearly as large. Each is 
NIELD, Jonathan-(continued).

separately indexed. Each part is arranged in chronological order. The titles of the books, the author and publisher, the subject are arranged in three vertical columns. Prices are not given. On pp. $119 s q$. there is a supplementary list of noteworthy semi-historical novels. On p. 129 a list of fifty representative historical novels. The Author appends suggested courses of juvenile reading and a valuablo Bibliogr. The Indexes are (1) Author and title, (2) Title only. The former give the dates of publication of the books. The number of novels noted is about 3,000 . Ireland is, of course, not dealt with separately, as the histories of the various countries are mingled in one chronological list.

7. BUCKLEY, J. A., M.A., and W. T. WILLIAMS, B.A.

A GUIDE TO BRITISH HISTORICAL FICTION. Pp. 182. (Harrap). 2s. $6 d$. 1912.

Intended for teachers of Secondary and Elementary schools. Chronological order with author and title-indexes. Neatly arranged for ready reference. Full note on each novel. A good many Irish novels are included.

\section{KRANS, Horatio Sheafe.}

IRISH LIFE IN IRISH FICTION. Pp. 338. (N.Y.: Macmillan Co.)

6s. 6d. net. 1903.

The Author is a Professor of Columbia University.

Scope of work: A survey and criticism of the leading Irish novelists of the first half of the nineteenth century in so far as they give us a picture of the national life and character.

Contents: Chap. i. A general survey of Irish society during the period treated by the novelists, viz., 1782-1850, based on O'Neill Daunt's Eighty-five Years of Irish History, Justin M'Carthy's Outline, J. E. Walshe's Ireland Sixty Years Ago, Harrington's Reminiscences, \&c. Chap. ii. The novelists of the Gentry. Chap. iii. The novelists of the Peasantry. Chap. iv. Types met with in the novels and typical incidents taken from them. Chap. v. Literary estimate. Then there is a "Jist of the more important stories and novels of Irish life by Irish writers whose literary activity began before 1850." Throughout copious quotations are made.

Treatment: Wholly free from bias. Marked by broad-minded, judicial spirit, thorough interest in and sympathy with the subject, wide knowledge, and a remark. able gift of literary characterisation. On the whole a work which I can scarcely praise too highly.

\section{BOYD, Ernest A.}

-.- TRELAND'S LITERARY RENAISSANCK. Domy 8vo. Pp. 415.

(Maunsel). (N.Y. : John Lane Co.). 1916.

A careful critical survey of recent Anglo-Irish literature from the early writings of Standish O'Grady to 1916. Chapter xv. (tho last) deals with Fiction and Narrative Prose. Bibliography pp. 400-415.

\section{MALYE, Jean.}

LA LITTERATURE IRLANDAISE CONTEMPORAINE. (PARIS). 1913. 11. BIBLIOGRAPHY OF IRISH PHILOLOGY AND OF PRINTED IRISH LITERATURE. Pp. xii.+307. Demy. 8vo. Published officially by the National Library of Ireland. (Dublin). 1913.

A scholarly and scientific bibliography of books and articles about the Irish language and about its literature, and of books and articles printed in Irishtales, sagas, poetry, religious writings, history, etc., etc. Elaborate Index.

12. The following books may be mentioned as possibly useful to reviewers, teachers, and others :-

WHITCOMB, Selden L.

THE STUDY OF A NOVEL. (Heath). 1906.

It is "the result of practical experience in teaching the novel, and its aim is primarily pedagogical." - (Pref.). Contents :-External Structure, Consecutive Structure, Plot, The Settings, The Dramatis Personx, Characterisation, Subject Matter, Style, Influence, Rhetoric, Asthetics, Analysis.

13. THE IRISH BOOK-LOVER. Published by Salmond \& Co. Monthly. 2s. $6 d$. per annum, post free.

This excellent little periodical, edited by Dr. J. S. Crone, Kensal Lodge, Kensal Green, London, N.W., is entirely devoted to Irish books and their authors, and is the only publication of the kind. Beginning in August, 1909, and appearing 


\section{THE IRISH BOOK-LOVER-(continued).}

monthly since then, its nine volumes are a most valuable storehouse of Irish booklore of all kinds. As regards fiction, it reviews most of the Irish novels that appear, has many articles on Irish novelists past and present, and supplies a quarterly classified bibliography of current Irish literature, in which there is a section for fiction. The obligations of the present work towards it are very great.

\section{APPENDIX B. PUBLISHERS AND SERIES.}

1 The Principal Irish Publishers :-

Dublin : Messrs. Browne \& Nolan, Nassau Street.
" James Dufry \& Co., Westmoreland Street.
", The Educational Co. of Ireland, Talbot Street.
" The Talbot Press, Talbot Street.
" M. H. Girl \& Co., O'Connell Street.
" Hodges \& FigGis, Grafton Street.
", Maunsel \& Co., Ltd., 50 Lower Baggot Street.
, Sealy, Bryers \& Walker, Crow Street.
", Alex. Thom \& Co., Crow Street.
"WhelaN \& Co., 17 Ormond Quay.
", The Candle Press, 44 Dawson Street.
" Fallon \& Co., 13 Dame Court.
" Thomas KIERSEY, Palmerston Gardens.

\section{McCaw, Stevenson \& OrR.}

Belfast : Ershine Mayne.

CORK : GUY \& Co.

Dundalk : The Dundealgan Press (W. Tempest).

Note.- None of these publishers, with the exception of Messrs. Maunsel, has a London house. The London address of Messrs. Maunsel is 40 Museum Street, W.C.

2. IRISH NATIONAL TALES AND ROMANCES. Nineteen Vols. (Colburn). 1833.

By Lady Morgan (O'Briens and O'Flahertys), J. Banim ('T'he Anglo-Irish), E. E. Crowe (Yesterday in Ireland), Thomas Colley Grattan ('T'ales of Travel), \&c. This series is occasionally to be met with on sale at second hand.

3. DOWNEY \& CO.'S IRISH NOVELISTS' LIBRARY. EDMUND DOWNEY,

General Editor. Biographical sketch prefixed to each volume, and portrait of Author. Price, 2s. 6d., cloth.

$$
\text { Included :- }
$$

O'Donnel. By Lady Morgan. Biography by Mrs. Cashel Hoey.

ORMONd. By Maria Edgeworth. Biography by Mrs. Cashel Hoey.

Fardorougha the Mrser. By W. Carleton. Biography by D. J. O'Donoghue.

The Epicurean. By Thomas Moore. Biography by E. Downey.

Rony O'More. By Samuel Lover. Biography by Mrs. Cashel Hoey.

The Collegians. By Gerald Griffin. Biography by E. Downey.

The O'Donoghue. By Charles Lever. Biography by E. Downey.

Torlogh O'Brien. By J. Sheridan Lefanu. Biography by E. Downey.

Downey \& Co. issued, 1902, paper-covered, well printed, on good paper, a Sixpenny Library of Novels, many of which were by Irish Authors, such as Lever, Banim, Lady Morgan, Lover, and Carleton. Irish novels were included in several other series published by this firm.

4. CHEAP POPULAR Fiction. Published by Cameron \& Ferguson, of Glasgow.

The publications of this firm were taken over by Messrs. Washbourne, who

keep in print such of them as were of any value.

The Green AND the ReD; or, Historical Tales and Legends of Ireland. Picture boards, $1 s$.

Gerald and Augusta; or, the Irish Aristocracy: A Novel. $1 s$.

The Mis'tletoe and the Shamrock : a National Tale. 18.

Billy Bluff aNd the Squire : a Picture of Ulster in 1796. $6 d$.

The IrIsh GIRL; or, the True Love and the False. $6 d$.

The Knights of the Pale; or Ireland 400 Years Ago. 256 pp. 6d. 


\section{SEALY, BRYERS \& WALKER'S SIXPENNY LIBRARY OF FICTION.}

Owen Donovan, Fenian. By Graves O'Mara. A Tale of the '67 Rising.

Captain Harry. By J. H. Lepper. A Tale of the Royalist Wars.

A Sower of the Wind. By Cahir Healy. A Tale of the Land League.

Olaf the Dane. By John Denvir. A Story of Donegal.

The Gaels of Moondrarrig. By Rev. J. Dollard. A Tale of the Famous Kilkenny Hurlers.

Frank Maxwell. By J. H. Lepper. A Royalist Tale of 1641.

Paul Farquhar's Legacy. By J. G. Rowe. A Thrilling Tale of Mining Life in South Africa.

Only a Lass. By Ruby M. Duggan. A Tale of Girl School Life.

The Strike. By T. J. Rooney. A Tale of the Dublin Liberties.

Bully Hayes, Blackbirder. By J. G. Rowe. An Adventure Tale of the South Seas.

The Enchanted Portal. By Mary Lowry. A Tale of the Giant's Causeway.

Stormy Harr. By M. L. Thompson. A Thrilling tale of Adventure.

Told in the Twilight. By Robert Cromie. A Romance of the Norwegian Fjords.

By the Stream of Kilmeen. By Seamas O'Kelly. Exquisite Sketches of Irish Life.

The Machinations of Cissy. By Mrs. Pierre Patiison. A Tale of a Sister's Jealousy.

When Strong Wills Clash. By Annie Collins. A Tale of Love and Pride.

The Humours of a Blue Devil in the Isle of Saints. By Alan Warrener. A Tale of the Love Escapades of a certain Captain.

The Honour of the Desboroughs. By Rita Richmond. Concerns the Love Affairs of Honor Desborough, and a fight for an Estate.

The Luck of the Kavanaghs. By C. J. Hamilton. Relates the extraordinary Adventures of an Emigrant Irish Boy.

The Doctor's Locum-Tenens. By Lizzie C. Read.

Lady Greville's ERror. By Mrs. Watt.

Sweet Nellie O'Flaherty. By T. A. Brewster.

\section{6. "IRELAND'S OWN" LIBRARY.}

This excellent popular periodical, the circulation of which in England and abroad as well as in Ireland is very considerable, is bringing out cheap reprints of stories and other features that have appeared in its pages. The following is a list of the Library to date :-

Red Rapparee. By Desmond Lough.

Barney the Boyo. By L. A. Finn.

The Black Wing. By Desmond Lough.

Tracked. By V. O'D. Power.

IRELAND's OwN SONG BooK.

The League of the Ring and Torn Apart. By Morrough O’Brien.

Each price 6d. Address :- "The People" Printing and Publishing Works, Wexford; or, Lower Ormond Quay, Dublin.

7. DUfFY'S POPUlaR LITERATURE. Messrs. DUfFy publish and keep in print very cheap editions of the standard Irish novelists.

(1) The following by Carleton: The Black Baronet, The Evil Eye, Valentine M'Clutchey, Willy Reilly, Art Maguire, Paddy-go-Easy, The Poor Scholar, Traits and Stories (1s.); The Red Well, Rody the Rover, Redmond Count O'Hanlon. (2) All Griffin's works, at 2s. each. (3) All Kickham's novels. (4) Banim's Boyne Water and The Croppy, at 2s. 6d. each. (5) Many stories by Lever, Mgr. O'Brien, Mrs. Sadlier, \&c., noticed in the body of this work.

Besides these, Messrs. Duffy issue seven or eight series of popular fiction. The volumes of these series are neatly, in many cases tastefully, bound, and very cheap. Many, however, are old-fashioned in turn-out, and printed from old founts. The majority of the stories are moral and religious in tendency, but by no means all. The literary standard in some is not very high, but in many it is good. Of "Prize Library," Series I. (42 titles), Mrs. Sadlier's Daughter of Tyrconnell is an example; of II. (20 titles), the same author's Willy Burke; of III. (24 titles), Curtis's Rory of the Hills, and Anon. The Robber C'hieftain. Series IV. has 16 titles, 28. $6 d$. each; V., 15 titles, at 3s.; VI., 9 titles at $3 s$. $6 d$. There is also a "Popular 
DUFFY'S POPULAR LITERATURE-(continued).

Library " at $6 d$., "for the instruction of youth," and a "Juvenile Library," with 24 stories, at $1 d$. each.

\section{MESSRS, M. H. GILL \& SONS.}

This firm (originally McGlashan, then McGlashan \& Gill) has behind it a long history of publication, most of the books issued by it being Irish in subject. At present the catalogue of its publications contains various popular series or "libraries" at more or less uniform prices. None of these consist exclusively of fiction. The "Green Cloth Library" is one of them.

\section{THE CATHOLIC TRUTH SOCIETY OF IRELAND (C.T.S.I.).*}

The main object of this Society is religious and moral propaganda, but it aims also at fostering among the people an interest in their country-its history, antiquities, ruins, scenery, \&c. Cheap popular fiction is one of the chief vehicles of this propaganda, and it has published in the twenty years of its existence-it was founded in 1899-upwards of a hundred penny booklets, besides the shilling series mentioned below. Nearly all these stories are Irish in subject. Most of them are distinctively Catholic in tone, and a number of them aim directly or indirectly at religious instruction. But there are a fairly considerable number which simply tell tales of ancient Ireland in pagan as well as in Christian times. The importance of the work of this Society may be gathered from the fact that since its start it has distributed over seven million copies of its publications. All that can be done here is to give a list of the stories published by the C.T.S.I., indicating the nature of the contents of some of them.

T. B. Cronin.-THE Colleen From the Moor.

The Boy from Over the Hill. These are two stories of Kerry life, deservedly popular.

Mary Maher.-The Irish Emigrant's Orphan.

Lady Gilbert (Rosa Mulholland).-A Mother of Emigrants.

Nano Tobin.-Nancy Dillon's Choice and From Texas to Inchrue.

A. Cunningham. Passage Trckets. Four emigration stories.

E. F. Kelly. Kevin O'Connor. Religious persecutions in 17th cent. at horne and in convict settlements.

Alicia Golding.-ELLen RYan. Land Troubles.

Patricia Dillon.- In the Wake of The ARmada. Home life of native Irish chiefs and their intercourse with continent, end of 16th century.

Mary T. McKenna.-Maureen Doherty : the Story of a Trinket.

Anna M. Martin.-Mahon's Leap. S. Sligo in '98.

Alice Dease.-ON the Broad RoAd. A Story of the White Slave Traffic.

K. M. Gaughan.-SheelaH : the Story of a Mixed Marriage.

Myles V. Ronan, C.C.-Woman's Influence : a Dublin Hospital Romance.

The House of Jullanstown : or, a Flight for the Faith. Days of the Volunteers. Historically true.

"Marbhan."-An American Wake \& Other Sketches.

For Hearthstones Pure \& Other Sketches. Tales of the Night Shelter.

M. Sullivan.-The Deserter and Other Stories. Very nicely told.

MacDonagh (Mary L.), née Burroughs Parker.-ThreE TIPPERARY Boys. One of whom, a minister's son, is converted and marries Delia.

Lady Gilbert.- AvourneEN. A waif cast up by the sea on the island of Inishglas, and his life among the islanders.

The Ghost in the Rath.

- Mrs. Blake's Next of Kin.

Delia Gleeson.-Where the Turf Fires Burn.

Others by Lucy M. Curd, Nora F. Degidon, S. A. Turk, \&c., and a series of thirteen stories entitled The Emerald Library.

For M. J. O'Mullane's stories, see in the body of the book under his name.

\section{TEMPERANCE STORIES.}

A Batch of Sacrifices. By Rev. Frederick C. Kolbe, D.D.

ThE STRIKe; or, The Drunkard's Fate.

The Broken Heart and The Miser's Death.

Donal's Extravagance. By Rev. David McKee, C.C.

* O'Connell Street, Dublin. 


\section{TEMPERANCE STORIES-(continued).}

Reaping THE WhirLwind. By Molly Malone.

Helena's Son. By Nora F. Degidon.

The Chmo of his Heart. By Mary T. McKenna.

Mike Hanlon's Mother-in-Law. By K. Gaughan.

More Temperance Stories. By Alice Dease.

THE IONA SERIES. A new venture of the Irish Catholic Truth Society. Consists of $16 \mathrm{mo}$. volumes, prettily bound in cloth, with frontispiece. Price $1 s$.

The Coming of the King. A Jacobite Romance. By Arthur Synan.

Hiawatha's Black Robe. Father Marquette, S.J. By E. Leahy.

PegGy the Millionaire. By Mary Costello.

Earl or Chieftain? The Romance of Hugh O'Neill. By Patricia Dillon.

Isle of Columbcille. A Pilgrimage and a Sketch. By Shane Leslie.

The Golden Lad. A Story of Child Life. By Molly Malone.

A Life's Ambition. Ven. Philippine Duchesne. By M. T. Kelly.

The Making of Jim O'Neill. A Story of Seminary Life. By M. J. F.

Nicholas Cardinal Wiseman. By Rev. Joseph E. Canavan, S.J.

The Sorrow of Lycadoon. By Mrs. Thomas Concannon, M.A.

The Emperor Marcus Aurelius. A Study in Ideals. By John C. Joy, S.J.

A Group of Nation Burlders-O'Donovan, O'Curry, Petrie. By Rev. P. M. MacSWeeney, M.A.

\section{THE CATHOLIC TRUTH SOCIETY.}

Address, 69 Southwark Bridge Rd., London, S.E. This is the original Society, founded in 1884, on the model of which the Irish, Scottish, and Australian bodies were founded. It has on its lists a few Irish stories. Lady Gilbert has written a certain number for it, e.g., Penal Days, Nellie. Her sister Clara Mulholland has published through it a little shilling volume: Some Stories (also in penny parts); Katharine Tynan another shilling volume: The Land I love best; Alice Dease : Some Irish Stories, 6d. (and in penny parts); and "M. E. Francis" has also some stories.

\section{MESSENGER OFFICE.}

The Office of the little periodical The Irish Messenger of the S. Heart, Gt. Denmark St., Dublin, publishes penny booklets of a kind similar to those of the Catholic Truth Societies. Here are some of the titles:-

Joe Calimnan. (In its 20th thousand).

No. 18 BLanK St. (85th thousand).

The Tram of the Traitor. (35th thousand). A story of Cromwell's Sack of Wexford.

Kathleen's Pilgrimage. By M. P. (30th thousand). A tale of Lough Derg.

Temperance Stories. By M. A. C. (20th thousand).

A True Boy and Other Stories. By Rev. Martin B. Corbett, S.J.. (20th thousand). 3rd ed. 1917.

Rogers of Seaforth's. By the same. New ed. (15th thousand). 1913.

The fiction in the IrIsh Messenger itself and in the Madonna is almost always of an Irish complexion. The circulation of the former of these is over 170,000 a month.

12. EVERY IRISHMAN'S LIBRARY.

An enterprise of the TAlbot Press, 89 Talbot Street, Dublin. The aim is to bring out in a cheap $(3 s .6 d$.$) but worthy form both well-known$ works by Irishmen about Ireland and new works. The Editors-in-chief are Mr. Alfred Perceval Graves, Prof. William Magennis, and Dr. Douglas Hyde. It hopes to include every department of Irish literature-poetry, fiction, oratory, sport and travel, history, wit and humour, essays and belles lettres, politics, biography, art, music and the drama. Each book is in the hands of a competent editor, so that none of the books in the series are mere reprints. The volumes have been designed, printed, and bound (cloth, Celtic design in green and gold) in Ireland. The publication has been greatly interfered with by the war.

$$
\text { Now Ready :- }
$$

The Colleginas. By Gerald Griffin. Introd. by Padraic Colum.

Tromas Davis. Selections from his Prose and Poetry. Edited by T. W. Rolleston, M.A.

Wild Sports of the West. By W. H. Maxwell. Edited by the Earl of Dunraven. 
EVERY IRISHMAN'S LIBRARY-(continued).

LEGENDS OF SaINTS AND Sinners. From the Irish. Edited by Douglas Hyde, LL.D. Humours of IrIsh Life. Edited by Charles L. Graves, M.A. (Oxon.).

IrIsh Orators and Oratory. Edited by Professor T. M. Kettle, National University of Ireland.

The Book of Irish Poetry. Edited by Alfred Perceval Graves, M.A.

Standish O'Grady. Selected essays and passages, ed. with an introd. by Ernest A. Boyd.

Poems of Sir S. Ferguson, ed. with an introd. by A. P. Graves.

The Recollections of Jonah Barrington, ed. with introd. by Geo. Birmingham. Carleton's Stories of Irish Life. Introd. by Darrell Figgis.

Maria Edgeworth Selections. Ed. by Malcolm Cotter Seton.

13. MAUNSEL \& Co., Ltd.

Has in course of publication two series of novels and stories by Irish writers, viz. :-

(1). A series of $1 s$. , bound in red cloth, crown 8 vo. size, with excellent paper and printing. It includes the following books:-

The Northern Iron. By George A. Birmingham.

Ballygullion. By Lynn, Doyle.

The Glade in the Forest. By Stephen Gwynn.

The Prisoner of his Word. By Louie Bennett.

Cambia Carty. By William Buckley.

(2). A series of $2 s$. , crown 8vo., cloth; equal in get-up to the average 6.s. novel. The following is a list of the books hitherto published in this series :-

Mrs. Martin's Man. By St. John G. Ervine.

The Blind Side of the Heart. By F. E. Crichtoll.

Countrymen All. By Katharine Tynan.

The One Outside. By Mary Fitzpatrick.

N.B.-1919 war conditions have temporarily modified these prices.

14. AMERICAN PUBLISHERS OF IRISH BOOKS.

A great many American publishers bring out books on Irish subjects : few specialise in this line. On the whole little new fiction of an Irish complexion is published in the States On the other hand a.large number of Irish tales and novels which have been allowed to go out of print in this country are still reprinted and sold on the "other side." Many such books will be found in the catalogues of such firms as Benziger Bros., of New York; P. J. Kenedy, of the same city; Flynn, of Boston; John Murphy Co., of Baltimore; McVey, of Philadelphia, \&c. J. S. Pratt, of 161 6th Ave., nr. 12th St., N.Y., publishes a catalogue containing Irish items exclusively. Flynn and Co., of Boston, has a catalogue of Catholic works which contains many Irish items.

\section{APPENDIX C. \\ CLASSIFIED LISTS OF IRISH FICTION. \\ I.-IRISH HISTORICAL FICTION.}

The following is a select list : it does not aim at including all the historical novels mentioned in the body of this work. But many novels that, as literature, are of very little value have been included in order to cover periods not otherwise dealt with in fiction.

Various periods : Legends of the Wars in Ireland. R. D. Joyce.

Stories from IrIsh History. Mrs. Stephen Gwynn

Tales from Irish History. Alice Birkhead.

N.B.-These latter two are not fiction.

405 sq. The Portion of a Champion. F. O'S. Tighe.

St. Patrick, a National Tale. Anon.

432 sqq. Dalaradia. William Collins.

c. 500-1016 KINGS AND VIKINGS. Lorcan O'BYRNE.

500-507 The Last Monarch of Tara. T. J. Rooney.

c. 550-597. Branan the Pict. Mary Frances Outram.

c. 560-615. Columbanus the Celt. Walter T. Leahy. 


\section{IRISH HISTORICAL FICTION-(continued).}

c. 584-592. The Druidess. Mrs. Florence Gay.

c. 650 The Life and Acts of Edmond of Erin. Mrs. F. Peck.

The Invasion. Gerald Griffin.

888. KING AND VIKING. P. G. Smyth.

935. A Sea Queen's Sailing. C. W. Whistler.

c. 1130-1151. The KNIGHT of the Cave. W. Lorcan O'Byrne.

1152-1172. Dearforgil, the Princess of Brefrny. C.B. Gibson.

\section{The Invasion and After.}

1167-1198. The Court of Rath Croghan. Miss M. L. O'Byrne.

1171 sq. With Strongbow at Wexford. J. G. Rowe.

When the Norman Came. M. O'Hanraghan.

Let Erin Remember. May Wynne.

1333. The Return of Claneboy. Sir Samuel Ferguson.

1373-1399. UNDER ONE Sceptre. Emily S. Holt.

1375-1417. art MacMorrougri O'Kavanagh. M. L. O'Byrne.

c. 1397. The Capture of Killeshin. Sir Samuel Ferguson.

c. 1410. Corby MacGillmone. Sir Samuel Ferguson.

The Knights of the Pale. C. M. O'Keeffe.

\section{The Geraldines.}

The Heiress of Kilorgan. Mrs. J. Sadlier.

\section{silken Thomas.}

1533-7. Thomas Fitzgerald the LoRd of OfFaly.

1532-1537. The Weird of "The Silken Thomas." R. Manifold-Craig.

1534-5. The Siege of Maynooth.

1534-5. The Rebellion of Silken Thomas. Sir Samuel Ferguson.

\section{Seaghan 0 'Neill.}

1559-1567. A Prince of Tyrone. Charlotte Fennell and J. P. O'Callaghan. With Poison and Sword. W. M. O'Kane.

\section{The Desmond Wars.}

c. 1560. The Pale and the Septs. M. L. O'Byrne.

1565. RALPH WYNWARD. H. Elrington.

c. 1577. For Church and Chimftain. May Wynne.

1577-1582. Maelcho. Emily Lawless.

1580-2. Geraldine of Desmond. Miss Crumpe.

\section{Grania Ni Mhallie (Grace O'Malley).}

c. 1585-1590. A QueEn of Men. William O'Brien, M.P.

c. 1579 sq. Grace O'Maliey, Princess and Pirate. Robert Machray.

c. 1585. Grania Watle. Fulmar Petrel.

c. 1585. The Dark Lady of Doona. W. H. Maxwell.

\section{Elizabothan Persecutions.}

The Spaewife. Rev. John Boyce, D.D.

1584. The Sorrow of Lycadón. Mrs. T. Concannon.

\section{Elizabethan Ireland.}

1585-1590. Sir Ludar. Talbot Baines Reed.

Hibernian Nights Entertainments. Sir Samuel Ferguson.

The Bog of Stars. Standish O'Grady.

1580-1600. The Spanish WrNe. Frank Mathew.

1580 sqq. The Pale and the Septs. M. L. O'Byrne.

\section{The War of the Earls.}

1542-1603. Le Comte de Tyrone. C. Guenot.

1587. Flight of the Eagle. Standish O'Grady.

Earl or Chieftain. Patricia Dillon.

1601-1602. UlRICK THE READY. Standish O'Grady.

The Adventurer.

The Red Hand of Ulster. Mrs. Sadlier. 


\section{THE WAR OF THE EARLS-(continued).}

c. 1597. 1599-1603.

1599.

1608.

1603.

1609.

1633.

1640 .

1641-1646. 1641-1652. $1641 s q q$. $1641-1652$. 1642-1652. 1644.

c. 1645 . 1645.

1647-1654.

1649.

1649.

1649.

1649.

c. 1649 .

1652-1660.

1654.

1654.

1654.

-

1660 sq. 1680.

1685-1691. 1689.

1689-1690.

1689.

1689.

1690.

1690.

1689-91.

1689-1691.

1689-1690. 1689-1691.
1671-1748.

The Charming of Estercel. Grace Rhys.

MacCarthy Mor. Mrs. James Sadlier.

Last Eart of Desmond. C. B. Gibson.

The Broken Sword of Ulster. Richard Cuninghame.

Sir GuY D'Esterre. Selina Bunbury.

With Essex in Ireland. Emily Lawless.

Ireland under James 1. and Charles I.

The Last of the Irish Chiefs. Mrs. M. T. Pender.

The Daughter of Tyrconnell. Mrs. James Sadlier.

Hugh Talbot. W. J. O'Neill Daunt.

Kathleen Clare [Strafford]. Dora McChesney.

Frank Maxwell. J. H. Lepper.

Love of Comrades [Strafford]. Frank Mathew.

The Confederation and the Parliamentary Wars.

Clongibbon. James French.

The Confederate Chieftains. Mrs. James Sadlier.

Dauntless. By Ewan Martin.

The Wild Rose of Lough Gill. P. G. Smyth.

The Chances of War. Rev. T. A. Finlay, S.J.

Captain Harry. J. H. Lepper.

Silik and Steel. H. A. Hinkson.

Friends Though Divided. G. A. Henty.

Lord Roche's Daughters of Fermoy. M. L. O'Byrne.

The Flight rrom the Ciffrs. James Murphy.

When Cromwell Came to Drogheda. Randal M'Donnell.

In the King's Service. F. S. Brereton.

Castle Omeragh. F. Frankfort Moore.

John Marmaduke. Samuel Harden Church.

The Silk of the Kine. Miss L. MacManus.

\section{Roundhead Rule.}

The King of Claddagh. T. Fitzpatrick.

Captain Latymer. T. Frankfort Moore.

Ethone. Mrs. Field.

Nessa. L. MacManus.

The Restoration.

Old Rowley. By M. M'D. Bodkin.

\section{The Williamite Wars.}

Memoirs of Gerald O'Connor. W. O'Connor Morris.

The Fight of Faith. Mrs. S. C. Hall.

The Boyne Water. J. Banim.

True to the Watchword. E. Pickering.

A Man's Foes. E. H. Strain.

The Knights of the White Rose. George Griffith.

William and James. Anon.

DERRY. Charlotte Elizabeth.

In Sarsfield's Days. Miss L. MacManus.

Leixlip Castle. M. L. O'Byrne.

The Fortunes of Colonel Torlogh O'Brien. J. Sheridan Le Fanu.

My Sword for Patrick Sarsfield. Randal M'Donnell.

For Three Kingdoms. By H. C. Crosfield.

The Crimson Sign. S. R. Keightley.

Orange and Green. G. A. Henty.

Baldearg O'Donnell. Hon. Albert S. Canning.

The House of Lisronan. Miriam Alexander.

Love is LIFE. By Mrs. L. Stacpoole Kenny.

The King's Kiss. By Mrs. L. Stacpoole Kenny.

1689-1770. The Irish Chinftains. Charles Ffrench Blake-Forster.

SARstreld. By D. P. Conyngham. 


\section{The Elghteenth Century-Penal Laws, eto.}

c. 1696. The Denounced. John Banim.

1696. ReDMond O'Hanlon. William Carleton.

1690-1726. LutTrell's Doom. D. F. Hannigan.

c. 1698. The Coming of the King. Arthur Synan.

c. 1705-1710. The Cock and Anchor. J. Sheridan Le Fanu

c. 1712. Esther VANHOMrigh. Margaret L. Woods.

1715. A TORY IN ARMs. J. H. Lepper.

Crohoore of the Billhook. Banim.

Castle Rackrent. Edgeworth.

The Absentee. Edgeworth.

1769. ORMOND. Edgeworth.

1769. The Hearts of Steel. James M'Henry, M.D.

1770. ANDRE BESNARD.

1770. In the Days of Goldsmtr. M. M'D. Bodkin.

c. 1771. The Jessamx Bride. F. Frankfort Moore.

$1750-1798$

1760 .

1766 .

The Two Chiefs of Dunboy. J. A. Froude.

Sarsfield. Dr. John Gamble.

The Fate of Father Sheehy. Mrs. James Sadlier.

\section{The Irish Brigade.}

c. 1702. Mountcashel's Brignde. Brigadier-Gen. C. G. Halpine.

c. 1702. Lally of the Brigade. Miss L. MacManus.

1703-1710. In the Irish Brigade. G. A. Henty.

1710. Thady Halloran of the Irish Brigade. J. W. Breslin.

1719. Clementina. A. E. W. Mason.

Spanish John. William McLennan.

c. 1745. Treasure Trove. Samuel Lover.

Desmond O'Connor. By G. H. Jessop.

Grattan's Parliament and the Union.

c. 1785. The King's Deputy. H. A. Hinkson.

1780-1797. THE Lost LAND. Julia M. Crottie.

1782-1803. My Lords of Strogue. Lewis Wingfield.

1793-1798. The O'Briens and O'Flahertys. Lady Morgan

1797-1801.

c. 1800 .

1790-1800. IlL-won Peerages. M. L. O'Byrne.

The Knight of Gwynne. Charles Lever.

Rose Parnell. D. P. Conyngham.

\section{Ninety-eight in the North.}

The Insurgent Chief. James McHenry.

O'Hara. W. H. Maxwell.

The Northern Iron. George A. Birmingham.

The Green Cockade. Mrs. M. T. Pender.

Strong as Death. Mrs. Charles M. Clarke.

The Northerns of '98. Eyre Evans Crowe.

A Prisoner of His Word. Louie Bennett.

Ninety-Eight and Sixty Years After. "Andrew James."

Betsy Gray. W. G. Lyttle.

The Pikemen. S. R. Keightley.

Ninety-elght in Wexford.

In Dark and Evir Days. F. Sheehy-Skeffington.

The Forge of Clohoge. James Murphy.

The Croppy. Michael Banim.

Croppres Lie Down. William Buckley.

Agnes ArNold. William Bernard MacCabe.

NiNetY-Erght. " Patrick C. Faly" (John Hill.

Maureen Moore. Rupert Alexander.

Kathleen Mavourneen. Randal M'Donnell.

The Irish Wroow's Son. C. O'Leary.

Corrageen in '98. Mrs. Orpen.

Rose Parnell. D. P. Conyngham.

Olive Lacy. Anna Argyle. 
NINETY-EIGHT IN WEXFORD-(continued).

The Wood of the Brambles. Frank Mathew.

UP FOR THE Green. H. A. Hinkson.

The O'Mahony, Chief of the Comeraghs. D. P. Conyngham.

1798-1805. Michael Dwyer, the Insurgent Captain. Dr. Campion.

\section{Humbert in the West.}

1798. The Round Tower. Florence Scott and Alma Hodge.

1793-1809 Maurice Tiernay. Charles Lever.

Connaught : A Tale of 1798 . M. Archdeacon.

1798. Le Briseur de Fers. Georges D'Esparbes.

The Race of Castlebar. Emily Lawless and Shan F. Bullock.

The United Irishmen, Etc.

Stories of the Irish Rebellion. By J. J. Moran.

True to the Core. C. J. Hamilton.

The Patriot Brothers. Charles Graham Halpine.

1798. The Shan VAN Vocht. James Murphy.

c. 1796. Lord Edward Fitzgerald. M. M'Donnell Bodkin.

$1792-1798$

1796.

1796-1797.

1797.

Kilgorman. Talbot Baines Reed.

The Rebels. M. M'Donnell Bodkin.

The House in the Rath. James Murphy.

The O'Donoghue. Charles Lever.

Charlton. Dr. John Gamble.

\section{Emmet.}

1803. Robert Emmet. Stephen Gwynn.

True Man and Traitor. M. M'D. Bodkin.

1803. Ravensdale. Robert Thynne.

1797-1803. The Island of SorRow. George Gilbert.

\section{The Nineteenth Century.}

1817. The Black Prophet. William Carleton.

1829. Glenanaar. Canon P. A. Sheehan.

183\%. Hugr RoACh the Ribbonman. James Murphy.

c. 1830. The Manor of Glenmore. Peter Burrowes Kelly.

1831. The Terry Alt. Stephen Joseph Meany.

IrIsh Life in Court and Castle. (Isaac Butt).

1843. The Kellys and the O'Kellys. Anthony Trollope.

\section{The Famine and Young Ireland.}

The Hunger. Andrew Merry.

1845-1848 Castle Daly. Miss Keary.

1846-1847 Castle Richmond. Anthony Trollope.

1848. Mononia. Justin M'Carthy.

1848. LiLy Lass. Justin Huntly M'Carthy.

1848. The Falcon Family. Marmion Savage.

1848. Maurice Rhynhart. J. T. Listado

1848. The Next Time. By Louis J. Walsh.

\section{Fenianism.}

1865-6. The Three Fenian Brothers. John Hamilton.

The Graves at Kilmorna. Canon P. A. Sheehan.

1866. Carroll O'Donoghue. Christine Faber.

1865-1883 FitzGerald the Fentan. J. D .Maginn.

1865.

1866.

1867.

1867.

1870.

When We Were Boys. William O'Brien, ex-M.P.

Ridgeway. "Scian Dubh."

The Dunferry Risin'. J. J. Moran.

Light and Shade. Charlotte Grace O'Brien.

\section{Home Rule, \&e.}

c. 1870.

The Bad Times.

G. A. Birmingham.

1875-1891. Her Majesty's ReBels. S. R. Lysaght.
Note.-For a critical account of some of the best Irish historical novels together

A Son of Erin. Annie S. Swan. with some remarks on the lacunae that remain to be filled, the Author ventures to refer the reader to two articles published respectively in the Sept., 1915, and March, 1916, issues of STudIEs. 


\section{II.-GAELIC EPIC AND ROMANTIC LITERATURE.}

I have thought it well to set apart from the mass of Anglo-Irish fictional literature and to put together in a list that portion of our national fiction which draws its inspiration from ancient Gaelic sources. To do this with any sort of completeness, it would be necessary, of course, to deal with the whole body of fiction that has been written in the Irish language. Reasons have been given in the Preface stating why this task was not undertaken. A further reason presented itself some years ago, viz., the appearance of the magnificent work published in 1913 by the National Library-Bibliography of Irish Philology and of Printed Irish Literature (price 5s.). In this scholarly work the literature of Gaelic epic, saga, and romance is scientifically classified and described with the greatest bibliographical accuracy. For me to attempt that task over again would be little better than an impertinence. It might even be thought, and not unnaturally, that the present list is wholly superfluous. Yet perhaps it may not be without its utility, owing to the fact that in the work just referred to descriptive notes are not provided. This list, then is practically an excerpt from that work, with the addition of some notes that may be useful. The notes will be found in the body of the book.

O'Grady, Standish Hayes. Silva Gadelica.

- - The Pursuit after Diarifuid and Grania.

Faraday, Winifred, M.A. The Cattle Raid of Cuallnge.

Meyer, Kuno. The Voyage of Bran, Son of Ferbal, to the Land of the Living.

-_- The Battle of Ventry.

- The IrIsh OdysSeY.

- Hibernica Minora.

- The Death Tales of the Ulster Heroes.

— Liadain and CUIRITHir.

- The Vision of Macconglinne.

- Fianaigecht. Irische Texte.

Joyce, P. W. Old Celtic Romances.

Gregory, Lady. Cuchulain of Muirthemne. Gods and Fighting Men.

Skelly, Rev. A. M., O.P. Cuchulain of Muirthemne.

O'Mullane, M. FinN MACCoole: His Life and Times, and other pamphlets published by the C.T.S. of Ireland. See under name O'Mullane.

Hull, Eleanor. The Cuchullin Saga in Irish Literature.

- Cuchulain the Hound of Ulster.

Rolleston, T. W. THE High DeEds of Fins, and other Bardic Romances of Ancient Ireland.

Myths and Legends of the Celtic Race.

Russell, Violet. Heroes of the Dawn (Stories of Finn and the Fianna).

O'Grady, Standish. Finn and his Companions.

The Coming of Cuchulainn.

The Gates of the North.

The History of Ireland. Heroic Period.

Leahy, A. H. The Courtship of Ferb.

Ancient Heroic Romances of Ireland.

Squire, Charles. The Boy Hero of EriN.

Celtic Myth and Legend.

O'Byrne, W. Lorcan. Children of Kings.

a Land of Heroes.

MacLeod, Fiona. The Laughter of Peterkin, etc.

Carbery, Ethna. IN The Celtic Past.

Hopper, Nora; Mrs. W. H. Chesson. Ballads in Prose.

Dease, Alice. Old-time Stories of Erin.

Buxton, E. M. Wilmot. Old Celtic Tales Retold.

M'Call, P. J. Fenian Nights Entertainments.

Young, Ella. The Coming of Lugh.

Celtic Wonder Tales.

Simpson, John Irawkins. Poems of Orsin, Bard of Erin.

Carmichael, Alexander. Deirdre and the LAy of the Children of Ursne. 
GAELIC EPIC AND ROMANTIC LITERATURE-(continued).

Thomas, Edward. Celtic Stories.

Chisholm, Louey. Celtic Tales.

Furlong, Alice. Tales of Fairy Folks, Queens and Heroes.

Campbell, J. F. The Celtic Dragon Mxth.

Henderson, George. The Feast of Bricriv.

MacSweeney, P. M. Martial Career of Conghal Clajringhneach.

Hyde, Douglas. Adventures of the lad of the Ferule.

- Adventures of the Chuldren of the King of Norway.

Macalister, R. A. S. Two Irish Arthurian Romances.

Stokes, Whitley. The Destruction of Da Derga's Hosted.

Bugge, A. Cathreim Cellachain Carsil.

Thurneysen, Rudolf. Sagen Aus Dem Alten IrLand.

Dottin, Georges. Contes et Legendes d'IrLande.

D'Arbois de Jubainville. Cours de LttTerature Celtique.

- Tatn Bo Cualnge.

Dunn, Joseph. The Ancient Irish Epic, Tain Bo Cualnge.

OFlanagan, Theophilus. DeIRdRr.

Brunton, F. C. The Enchanted Lochan.

Cameron, Rev. Alex. Reliquiae Celticae.

Comyn, David. The Youthrul Exploits of FinN.

Flood, J. M. Ireland, Its MYths AND Legends.

Hennessy, Wm. Mesca Ulad.

Hogan, Fr. E. Battle of Rosnaree.

O'Curry, Eugene. The Battle of Moylena.

- The Sick Bed of CUChulainN.

U'Donovan John. The Banquet of DUN-Na-NGedh.

- The Boyish Exploits of Finn.

C'Duffy, Richard. The Fate of the Children of Lir.

- The Fate of the Children of TuireanN.

- The Fate of the Children of Usnach.

O'Kearney, Nicholas. The Festivities at the House of Conan

The Battle of Gabhra.

Webster, F. A. M. The Hound of Culann.

Many of our heroic legends and ancient sagas have been retold in English verso.

Though fiction in verse does not come within the scope of the present Guide, yet it may be of interest to mention here a few of these poetic renderings of ancient Gaelic tales. Sir Samuel Ferguson's Congal, Conary, Lays of the Red Branch, and Lays of the Western Gael; Aubrey de Vere's Foray of Queen Maeve; Robert Dwyer Joyce's Blanid and Deirdre; John Todhunter's Three Irish Bardic Tales; Douglas Hyde's Three Sorrows of Story-telling; Herbert Trench's The Quest; Katharine Tynan's "Diarmuid and Grainne" in her Shamrocks; Mrs. Hutton's stately blank verse translation of The Táin; and Dr. Geo. Sigerson's The Saga of King Lir; also The Red Branch Crests, a trilogy by Charles L. Moore; The Death of Oscar by Alice Sargant; Liadain and Cuirithir, by Moireen Fox. Hector MacLean has collected in the Highlands and presented in English verse Ultonian Hero Ballads, which, as the title implies, are of Irish origin. For notes and bibliographical particulars of the above see $A$ Guide to Books on Ireland, Part I. (Hodges \& Figgis), 1912.

For an introduction to Gaelic Literature the reader may be referred to :Douglas Hyde. Story of Early Gaelic Litmature.

Miss Hull. Pagan Ireland.

- TEXT-Book OF IRISH Literature.

Matthew Arnold. Introduction to the Study of Celtic Literature.

It may be useful to subjoin here a list of publications (periodicals and others) which contain, generally along with other matter, ancient Gaelic Tales in English. I can give here only a bare list, but it will serve to give an idea of what has already been accomplished in this field.

(a) Publications of the following Societies :-

The Gaelic Society. 1808. One volume.

The Ossianic Society. Six big volumes concerned exclusively with the Fenian Cycle. 1854-1861. 
GAELIC EPIC AND ROMANTIC LITERATURE-(continued).

The Irish Archæological Society and the Celtic Society, afterwards united as the Irish Archrological and Celtic Society. Twenty-seven volumes.

The Royal Historical Archæological Association. Nine volumes.

The Irish Texts Society. 20 volumes; five or six more in preparation.

The Gaelic League. Oireachtas publications, etc., etc.

The Society for the Preservation of the Irish Language.

The Celtic Society. 1847-55. Six volumes.

The Iberno Celtic Society. 1820. One volume.

The Royal Irish Academy. Transactions. 1786-1907.

(b) Periodicals :Proceedings, 1836-1918, in progress.

AtLantrs.

The Gaelic Journal.

ERIV. Organ of the School of Irish Learning; in progress.

The Celtic Review of Edinburgh. Nine volumes; in progress.

La Revor Celtique. Collected in thirty-eight volumes; in progress.

Zeitschrift fur Celtische Philologie. Collected in eight or nine volumes; in progress.

The Celtic Magazine. Thirteen volumes. 1876-88.

The Gael (N.Y.).

GaDELICA. Three or four volumes.

Guth Na MBLIadhna (Highland Gaelic and English); in progress.

(c) Various :-

Kuno Meyer's Anecdota Oxoniensia.

Irische Texte of Windisch and Whitley Stokes. Five volumes, 3793 pp., exclusive of introductory matter.

O'Curry : Manuscript Materials of Ancient Irish History. Manners and Customs of the Ancient Irish (Appendices).

De Jubainville: L'Epopée Celtique en Irlande.

Windisch's great edition of the Táin, pp xcii.+1120. Leipzig. 1905.

III.-LEGENDS AND FOLK-TALES.

Croker, Thomas Crofton. FaIry Legends and Traditions of the South of Ireland.

KrLLARNEY LEGENDS.

LEGENDS OF THE LAKES.

Wilde, Lady; "Speranza." ANCIent Legends of Ireland.

Kennedy, Patrick. Legendary Fictions of the Irish Celts.

The Fireside Stories of Ireland.

Fictions of OUR Forefathers.

The Bardic Stories of Ireland.

LEgends of MOUNT LEINSTER.

O'Hanlon, Canon John; "Lageniensis." Irrsh Folk-Lone; Traditions and Superstitions of the Country, with Humorous Tales. IRISH LOCAL LEGENDS.

Blake-Forster, Charles Ffrench. A Collection of the Oldest and Most Popelar Legends of the Peasantry of Clare and Galway.

Joyce, Robert Dwyer. Legends of the Wars in Ireland.

- Fireside Stories of Ireland.

Bardan, Patrick. The Dead-Watchers.

Curtin, Jeremiah. MYths aNd Folk-Lore of Ireland.

Hero Tales of Ireland.

Tales of the FaIries aNd of the Ghost World.

Hyde, Douglas. Beside the Frre. Gaelic Folk-stories.

An Sgealaidie Gaedhealac.

Legends of SaINTS and Sinners.

Larminie, William. WeSt IRISh Folk-tales and Romances.

Yeats, W. B. The Cfittc Twilight. The Secret Rose : Irish Folk-lore.

Fairy and Folk Tales of the Irish Peasantry.

Gregory, Lady. A Book of Saints and Wonders. 


\section{GAELIC EPIC AND ROMANTIC LITERATURE-(continued).}

Deeney, Daniel. Peasant Lore from Gaelic Ireland.

Dunbar, Aldis. The Sons o' CoRMaC; an' Tales of other Men's Sons.

M'Anally, D. R., Jr. IRISH WONDERS.

Kenedy, P. J. (publ.) Irish Fireside Stories, Tales and Legends.

- Legends and Fairy Tales of Ireland.

C'Connor, Barry. Turf Fire Stories and Fairy Tales of Ireland.

Lover and Croker. LEgends and TALES OF IRELAND.

Anon.; C. J. T., ed. Folk-LORE and Legends (Ireland).

O'Neill, John. Handerahan, The Irish Fairy Man.

Brueyre, Loys. Contes Populaires de la Grande Bretagne.

Rhys, Prof. John. Celtic Folk-lore, Welsh and Manx.

O'Donnell, John F. The Emerald Wreath.

Russell, Maud Mary. Sprigs of Shamrock.

Wentz, Walter Yeeling Evans. The Fairy-faith in Celdic Countries :

Hunt B. FolK-Tales From BREFrNi.

Andrews, Elizabeth. UlSTER FolK-LORE.

Crawford, M. G. Legends of the Caringford Lough District.

Doyle, J. J. Cathair Conroi, \&c.

Henderson, Geo. Survivals in Belief Among the Celts.

Hardy, P. Dixon. Legends, Tales, and Stories of Ireland.

Drohojowska, Countess. Recits DU Foyer.

Keegan, John. Legends and Poems.

Rodenberg, Julius. Die Harfe von IrLand.

Seymour, St. John D. IrISh Witcharaft and Demonology

- True Irish Ghost Stories.

It may be of interest to mention, as specimens, some of the chief collections of Scottish Gaelic folk-lore, for it is, at bottom, identical with that of Gaelic Ireland. Campbell, J. F., of Islay. Popular Tales of the West Highlands.

MacDougal, Rev. J. Folk Tales and Fairy Lore in Gaelic and English.

Waifs and Strays of Celtic Tradition. A Series initiated and directed by Lord Archibald Campbell. It comprises four volumes :-

Vol. I.-Craignish Tales. Ed. by Rev. J. MacDougall.

Vol. II.-Folk and Hero Tales. Ed. by Rev. D. MacInnes.

Vol. III.--Folk and Hero Tales. Ed. by Rev. J. MacDougall.

Vol. IV.-The Fians. Ed. by John Gregorson Campbell of Tiree.

Ferguson, R. M. The Ochil Fairy Tales.

McKay, J. G. The Wizard's Gillie.

- The Six Little Bannocks.

Mackenzie, D. A. FinN AND his Warrior Band.

Wonder Tales from Scottish MYth and Legend.

Parker, Winifred M. Gaelic Fairy Tales.

\section{IV.-FAIRY TALES FOR CHILDREN.}

Graves, Alfred Perceval. The IRISh FAIRY Book.

Bayne, Marie. FaIry Stories From Erin's Isle.

Hannon, John. The Kings and the Cats. Munster Fairy Tales.

Grierson, Elizabeth. The Children's Book of Celtic Stories.

MacManus, Seumas. Donegal FaIry Stories.

- IN Chimney Corners.

Leamy, Edmund. The Fairy Minstrel of Glenmalure.

Ireish Fairy Tales.

Yeats, W. B. IrIsir Fairy Tales.

IrIsh FaIry Tales. Illustr. by Geoffrey Strahan (Gibbings).

Downey, Edmund; “F. M. Allen." The Little Green MaN.

Furlong, Alice. Tales of Fairy Folks, Queens and Heroes.

O'Neill, Moira. The Elf Errant.

Irwin, Madge. The Diamond Mountain; or, Flowers of Fairyland.

Preston, Dorothea. PADDY.

Thompson, C. L. The Celtic Wonder World.

Jacob, Joseph. Certic Fairy Tales.

More Celtic Fairy Tales.

Wightman, James A. The Magic Horsehair. 


\section{V.-CATHOLIC CLERICAL LIFE.}

Banim, Michael. Father Connetr.

Banim, John. The Nowlans.

Neville, E. O'Reilly. Father Tom of Connemara.

Carleton, William. The Poor Scholar, and Other Tales.

- Denis O'Shaughnessy Going to Maynooth. Father Butler.

McCarthy, M. J. F. Gallowglass.

Moore, George. The Lake.

McNulty, Edward. Misther O'Ryan. MAUREEN.

Hinkson, H. A. Father Alphonsus.

Buchanan, Robert. Father ANTHONY.

Fremdling, A. Father Clancy.

Sheehan, Canon P. A. My New Curate.

- Luke Delmege.

The Spoiled Priest, and Other Stories.

- The Blindness of Dr. Gray; or, The Final Law.

Most of Canon Sheehan's books deal directly or indirectly with the priestly life.

Guinan, Rev. J. Scenes and Sketches in an Irish Parish; or Priests and People in Doon.

The Soggarth Aroon.

The Island Parish.

And, in fact, practically all his books.

Hickey, Rev. P. InNISFAIL.

Thurston, E. Temple. The Apple of Eden.

O'Donovan, Gerald. Waiting.

- Father RaLph.

Anon. The Protestant Rector.

- The Roman Catholic Priest.

The Irish Priest.

Father John ; or, Cromwell in Ireland.

Priests and People.

Fuller, J. Franklin. Culmshire Folk ("Father O'Flynn").

Jay, Harriett. The Dark Colleen.

—-The Priest's Blessing.

Archdeacon Matthew. Shawn na Soggarth.

Stacpoole, H. de Vere. Father O'Fuxnn.

Brittaine, Rev. Geo. Irishmen and IrIShwomen.

Byrne, Frank. An Irish Stew.

It would be easy to extend this list, as many novelists introduce Irish priests, at least incidentally.

\section{VI.-HUMOROUS BOOKS.}

The word "humour" is used here in a wide sense to cover wit and comicality or broad comedy, as well as humour in the strict sense of the word. The present list is not a selection of the best samples of Irish humour. It merely brings together a number of books which are entirely or mainly of a humorous character. Humour of a greatly superior order is often to be found here and there in books of a predominantly serious purpose-in My New Curate, for instance, or in Knocknagow.

O'Donoghue, D. J. The Humour of Ireland.

MacDonagh, Michael. Irish Life and Character.

Harvey, W. Irish Life AND Humodr.

Kennedy, Patrick. The Book of Modern Irish Anecdotes.

Lever, Charles. A DAY's RIDE. *

* The rollicking novels of Lever's earlier manner might all be included here. 
HUMOROUS BOOKS-(continued).

Lever, Charles. The Dodd Family Abroad.

Lover, Samuel. HANDY ANDY.

FURTher Stories of Ireland..

MacManus, Seumas. The Leadin Road to Donegal.

- The Humours of Donegal.

- 'Twas in Dhroll Donegal.

- Doctor Kilgannon.

Downey, Edmund. Through Green Glasses.

GreEN as Grass.

From the Green Bag.

And most of his other books; see pp. 91-2.

Bodkin, M. M'D. Pat o' Nine Tales.

- Poteen Punch.

Patsy the Omadhaun.

"Heblon." Studies in Blue.

Dunne, F. P. The Dooley Books.

Archer, Patrick. The Humours of Shanwalla

Doyle, Lynn. Ballygullion.

Mr. WILDRIDGe OF THE BANK.

McIlroy, Archibald. The Humour of Druid's Island.

Moran, J. J. IRISH Stew.

- IrIsh Drollertes.

Birmingham, G. A. Spanish Gold.

- The Major's 'Niece.

- The Lighter Side of Irish Life.

And those of his books that are mentioned on pp. 33-4.

Crane, Stephen, and Barr, Robert. THE O'RuDDY.

O'Donovan, Michael. Mr. Muldoon.

Wright, R. H. The Surprising Adventures of my Friend Patrick Dempsey.

Gill, M. H. \& Co., Publ. Irish Pleasantry and Fun.

Lyttle, W. G.; "Robin." Robin's Readings.

Maginn, Wm. Mrsceltantes.

Harkin, Hugh. The Quarterci.IFT.

Blenkinsop, A. Paddiana.

Conyers, Dorothea. Most of her sporting novels are humorous.

Rogers, R. D. The Adventures of St. Kevin.

Roche, Hon. Alexis. Journeyings With Jerry the Jarvey.

Langridge, Rosamund. Imperial Richenda.

Jebb, Horsley. Sport on Irish Bogs.

The Irish Bubble and Squeak.

Croker, T. Crofton. Adventures of Barney Mahoney.

Cronin, Will. A Hamper of Humour.

Egan, M. F. The Wiles of Sexton Maginnis.

Fitzgerald, Rev. T. A. Five volumes of stories.

Graves, Chas. Ed. Humours of Irish Life.

Healy, Cahir. The Escapades of Condy Corrigan.

Lefanu, J. Sheridan. A Chronicle of Golden Friars.

MacManus, Seumas. The Red Poocher.

C'Byrne, Rev. Mark. Thunder and Turf.

There are some humorous stories in Lefanu's "Purcell Papers" that make us regret that he did not give us more in the same vein. Carleton's "Stories" are a miscellany containing episodes of the wildest fun amid much that is gloomy, and scenes of pleasant and kindly humour interspersed with traits of savagery and of fanaticism.

\section{VII.-FICTION FOR BOYS.}

In the issues of Studies for December, 1918 and June, 1919, will be found a series of lists of Irish Fiction suitable for boys of from about twelve to fifteen. 


\section{APPENDIX D.}

\section{IRISH FICTION IN PERIODICALS.}

A great mass of Irish fiction good, bad, and indifferent lies buried in the back numbers of Irish periodicals. To attempt to set down here a complete catalogue of all this fiction would be to swell unduly this already bulky volume, and indeed it would be beyond the power of its author. Yet a guide to Irish fiction would be unwarrantably incomplete without some indication of stories and novels which do not deserve oblivion merely for not having attained the dignity of book form. Many of our best writers sent their work to these periodicals, and by no means all of that work has been collected and republished. And even in the case of minor writers, some of their stories in long-forgotten magazines possess, apart from their literary worth, no small interest as pictures of bygone days by those for whom they bad but just gone by. I have therefore endeavoured in this edition to present a much fuller list of Irish periodicals past and present, and to give a fuller indication of their contents. Only such periodicals here find mention as have some claim to be literary and of general interest. Periodicals such as THE IRISH Cyclist or The IRISH BUILDER, school magazines or archæological journals, find no place in the list.

I have made the order of the list alphabetical rather than chronological, because the former is the order in which periodicals are stored in the National Library.

\section{I.-DEFUNCT PERIODICALS.}

THE ALL IRELAND REVIEW. (Dublin). 6 vols. folio. Weekly. 1900-1906.

Ed. by Standish O'Grady. Contains some excellent Irish fiction; e.g., In the Gates of the North, The Lost Land $(q \cdot v \cdot)$ in Vol. I., Nessa $(q \cdot v \cdot)$ in Vol. III., Foughilotra $(q . v$.$) in Vol. V., etc. Some of the volumes contain no fiction.$

ANTHOLOGIA HIBERNICA ; or, monthly collection of science, belles lettres, and

general history, Irish history, antiquities, topography, etc. (Dublin : Mercier).

4 vols. 1793-4. Each vol. has about 500 pp. demy 8vo.

The contents are of a superior kind, e.g., the first No. has an essay on the Irish language and one on the ancient names of Ireland, an account of Peter Lombard, Catholic Primate of Armagh, and many other articles of great interest, largely Irish in subject. No fiction.

ANCIENT IRELAND, a weekly [afterwards monthly] magazine. Ed. by Philip

F. Barron. Printed in Dublin. 1835.

Ran to four numbers, 176 pages double columns of close print, demy 8 vo. The first number outlines a splendid programme for a campaign to revive the Irish language and the study of Irish history. It gives a list of 26 works which the editor had in preparation for that purpose. As this was to have been a purely literary magazine, it would doubtless have contained fiction, but its early demise

prevented that.
ATLANTIS : a register of literature and science of the Catholic University of Ireland. Ran from 1858 to 1870.

Contains besides a great mass of valuable matter by J. H. Newman, D. F. McCarthy, etc., etc., several Irish texts, ed. by O'Curry, with transl. Among others :-

\section{The Sick Bed of Cuchulainn.}

The Exile of the Children of Usnagh (from the Yellow Book of Lecan).

The Fate of the Children of Lir.

The Fate of the Children of Tuireann.

THE BELFAST MONTHLY MAGAZINE. 13 vols. 8vo. 1808-1814.

A non-political and non-controversial miscellany, serious in purpose, tolerant in its views, and Irish ("Whatever relates to our country should have the first place") without being Nationalist. Regular reviews of books, original poetry, articles of a serious kind, little fiction, except a few stories like " Rosa, a moral tale," "The Ten Days of Happiness" (an eastern tale), etc. It was ed. by Dr. William Drennan. BOLSTER'S QUARTERLY MAGAZINE. (CoRK : Bolster). 12 numbers in 3 large volumes. 1826-31. 


\section{DEFUNCT PERIODICALS-(continued).}

A substantial magazine, with nearly $100 \mathrm{pp}$. in each number. Its aim, as the first number tells us, is to call forth native Irish literary talent, with a view to the eventual founding of an Irish academy. Contains some fiction of Irish interest, e.g., A Wake in the Irish Highlands; Tiarna na clanna MacDiarmuidh, an Irish legend; C'Driscoll, an Irish tale; May Eve, an Irish legend; The Song of the Little Bird, a legend of the S. of Ireland by T. Crofton Croker; Sir Walter Raleigh, a story of the South; The Geraldine, a tale of the South; Mielane's Rock, an Irish legend; C'Connor of Carrigafoyle; The Legend of Carrig na Ceat; Passages in the Life of Dennis Delany; The Cross of Coole, etc., etc.

\section{THE CATHOLIC CHILDREN'S MAGAZINE. (DubliN). 3 vols. fortnightly.} 1878-81.

THE CATHOLIC GUARDIAN; or, The Christian Family Library. (DUBLIN : Duffy). 1d. weekly. 1852-3. One vol. of $700 \mathrm{pp}$. small 4 to.

Contains politics, controversy, and miscellaneous literature. Strongly religious and national. Among the serials are :-The Pervert; Darby Malony's Destiny; Zoe's Sacrifice (not Irish); Over Indulgence of the O'Keefes of Tirvoe. There are also a number of short stories. No names of authors are given.

THE CATHOLIC PENNY MAGAZINE. (Dublin : Coldwell). Weekly. One vol. 8 vo. 1834-5. Contents mainly religious or controversial. No fiction.

THE CELT : a weekly periodical of Irish national literature. (DubLIN). 1857-8. Ed. by a Committee of the Celtic Union, with Dr. Cane of Kilkenny as chief ed.

Had a curious series of articles on Ireland's temptations, failings and vices. Sketches of S. of Ireland by Aymer Clington. Sketches by J. T. Campion. C. M. O'Keeffe's "Knights of the Pale" ran as a serial.

CELTIA : a Pan-Celtic Monthly Magazine. (Dublin). Ran from 1901 to 1908, forming 8 thin 4to vols.

Has scarcely any Gaelic fiction, consisting, as it does, chiefly of propagandist literature and news of the Celtic world. But here and there there is a folk tale given in the original, with English translation, e.g., King Oghy has Horse's Ears, in the April No., 1903.

THE CELTIC MAGAZINE. 1876 to 1888. Collected in 13 vols. (INverness : Mackenzie).

"Devoted to the literature, history, antiquities, folk-lore, traditions and the social and material interests of the Celt at home and abroad." Ed. at first by Alexander Mackenzie and Alexander MacGregor, and later by Alexander MacBain. Full of Gaelic fiction in English, e.g., a series of Hero-Tales of the Gael.

CHAMNEY'S ILLUSTRATED JOURNAL, a monthly magazine, price twopence.

(DubLIN : Chamney). 1868. Contains original stories, poetry, biography, travel, etc., etc.

THE CHRISTIAN EXAMINER AND CHURCH OF IRELAND MAGAZINE. $1825-1869$.

Almost purely religious and controversial in character and contents, but a small proportion being devoted to general literature. No fiction.

THE CITIZEN, a monthly journal of politics, literature, and art.

Doyle, afterwards Machen). 2 vols. of 500 pp. demy 8vo., 1839-40

Contains a good deal of Irish fiction, e.g., in vol. I. "Charley Molony" (a serial),

"The Cousins," a story of life in Dublin. In vol. II. " Aileen O'Dwyer," "Records of the Heart" by Carleton. Very national in tone.

THE COLLEGE MAGAZINE. (Dublin : McGee). 1 vol. 1858.

"Conducted by members of the University of Dublin." Contains nine chapters of an unfinished Irish serial "The Living Secret" by "C. P. M."

THE CORK MAGAZINE. (CoRK : Bradford). Nov., 1847-Dec., 1848.14 numbers.

Contributions by Fitzjames O'Brien, Denny Lane, M. J. Barry, de Jean Fraser, Justin McCarthy, etc., etc. The Last Lord of Beara (1572-1610), an historical novel, ran as a serial. Other stories contained in it are Judith Donoghue (a tale of the S uth of Ireland); Jerry Horgan's Match at Billiards; A Legend of Glendoe; St. Mary's of the Isle, a story of Cork in the 16th century (a serial); My First Trip to Trinity; A Story of the Blackwater (serial); My Aunt O'Dea's Dinner Party; The Heiress of Ballypooreen (serial), by J. R. O'Flanagan. 
DEFUNCT PERIODICALS-(continued).

THE CYCLOPEDIAN MAGAZINE AND DUBLIN MONTHLY REGISTER. $2 \frac{1}{2}$ vols. 1807-9. Articles on very varied topics, reviews, verse, etc. No fiction. DANA, an Irish magazine of independent thought. (DubLIN : Hodges, Figgis). 1904.5

Articles on religion, politics, literature, etc., by writers connected with the literary revival. An occasional story, e.g., King Diarmuid by W. Buckley, and Michael, a Meditator, by Jane Barlow.

DROZ'S LITERARY JOURNAL. 5 vols. 1774-8.

Little fiction, and that not Irish. The earliest of original Irish periodicals.

DUBLIN AND LONDON MAGAZINE. (LoNDON : J. Robins). 1825-7. Ed. M. $\mathrm{J}$. Whitty $(q . v$.$) . Thoroughly nationalist and Catholic in tone.$

The ed. contributes many excellent stories under various pen-names, e.g., Z.Z., Rory O'Rourke, Geoffrey $K-n$, O'Sullivan Bear. Contains several series, such as Superstitions of the Irish Peasantry, Tales of Irish Life, Traditionary Tales of the Irish Peasantry. Other writers were Thomas Furlong, Joseph O'Leary of Cork, Denis Shine Lawlor. Mr. D. J. O'Donoghue considered this " far and away the best Irish periodical of its time," and thinks Whitty's stories well worthy of republication. See article by D. J. O'D. in I.B.L., Vol. 8, p. 53.

THE DUBLIN EXAMINER OR MONTHLY JOURNAL. 1816. 2 vols.

Described in 1833 as " a stupid collection of reviews and poetry." It avoided politics.

THE DUBLIN JOURNAL of temperance, science, and literature. (DUBLIN). Weekly. Two vols. of over $400 \mathrm{pp}$. very close print, demy 8vo. 1842-3.

Contains a good deal of Irish fiction, mostly anonymous, e.g., p. 5 A Tale of the Boyne, p. 25 and subsequent numbers, a series, "The Romance of Irish History," “The Emigrant's Return," “The Buckaugh's Legend," by Ed. Walsh, and others by the same author; "Early Courtship" by Lodey McLoddan. In fact almost all the fiction is thoroughly Irish in subject.

THE DUBLIN LITERARY GAZETTE, or weekly chronicle of criticism, belleslettres, and fine arts. Ran from Jan. to June, 1830, 26 Nos. in all. 412 pp. 4to., closely printed.

The 1st No. contains a sketch by Mrs. S. C. Hall, "Kate Connor." No. 4 has Confessions of a Reformed Ribbonman. Lever was a contributor. Long reviews of Griffin, Banim, and Carleton. Continued as the National Magazine (monthly). Dublin, 1830-31 (q.v.).

T'HE DUBLIN LITERARY JOURNAL and Select Family Visitor for the dissemination of useful knowledge. 1843-1846. 34 Nos. No fiction.

THE DUBLIN MAGAZINE; or general repertory of philosophy, belleslettres, etc. (Dublin). Jan.-Dec., 1820. Two vols. of 500 pp. 8vo. Ed. by E. W. M. Rice and W. G. Cole.

Serious articles on science, literature, music, biography, etc. No fiction.

THE DUBLIN MAGAZINE and Irish Monthly Register. (Dublin : Moore). July, 1798 , to Dec., 1800.

Five vols of $400 \mathrm{pp}$. each. The news, foreign and domestic, is given in the fullest way, and discussed. State trials, such as that of the Bros. Sheares are given in full. Though the prospectus promised "novels and tales" there is practically no fiction.

THE DUBLIN MAGAZINE; or, the Gentleman's new miscellany. (DubLN). 1733 , one vol. $1762-5$, six or seven vols.

Articles on current affairs, verse, reviews of literature, essays. No fiction.

THE DUBLIN MAGAZINE, or monthly memorialist; a work sacred to the preservation of fugitive genius, national events, and important discoveries. One vol. 8 vo. pp. 760 . 1812-3

Articles on a great variety of serious subjects. No fiction.

THE DUBLIN MONTHLY MAGAZINE. A literary and theological miscellany. (Dubun : Tyrrell \& Tims; afterwards Samuel J. Machen). 1830, afterwards revived in 1842-3.

Contains several Irish serials, without authors' names, e.g., Gerald Kirby, a tale of '98; Macklin or the Son's sacrifice; The Clandestine Marriage; Lord Connor of Innisfallen, a tale of 1641 (in the 1830 vol.). Some of Carleton's Traits and Stories first appeared here. Other stories :-The Glen of Derrygoulah, The Intermarriage, 


\section{DEFUNCT PERIODICALS-(continued).}

The Duellists. It also contains a good deal of Irish music, and some monographs or. Irish artists.

T'HE DUBLIN MUSEUM, or entertaining pocket companion. (DUBLIN : Charles).

1 vol. $12 \mathrm{mo}$. pp. 597. 1807

Contains a good many anecdotes about celebrated personages, a few tales, and a serial, "Rebecca." None of these are lrish in subject.

THE DUBLIN PENNY JOURNAL. The $1832-3$ vols. were printed and published

by J. S. Folds. Those of $1834-6$ by Philip Dixon Hardy (q.v.).

Contains many of Carleton's stories. Many Irish stories by McC., S.W., J.H.K., E.W., etc. Reminiscences of a Rockite (4 numbers). Romances of Irish History (3 numbers). Some of these stories were afterwards reprinted under title Picnics from the Dublin Penny Journal, a note on which will be tound in the body of this work.

A new series ran from 19'j2-1905. No serials, but many Irish stories. Most of these are unsigned, especially in the earlier issues. Among the names given we may mention K. F. Purdon, Ethel Goddard, John K. Cotton, Ed Walsh, D. B. Fitzgerald, John K. Cotton, Ed. Walsh, D. B. Fitzgerald, Anne O'Hagan.

THE DUBLIN SATURDAY MAGAZINE. (DUblin : John Mullany). 1865. sq.

Contents :-Antiquities, Topography, Biography, Miscellaneous Essays.

Contains also a good deal of Irish fiction, e.g., Tales of Country Quarters, The Heiress of Ballypooreen, by Major Fogarty; Above their Fortunes; Jerpoint Aibey, a tale of the time of Henry VIII.; Herbert Lyndon; McCormack's Grudge by Robert Curtis, and others by the same writer; Life and Adventures of Bryan U'Regan; The Groundless Accusation, or the Sufferings of Bernard O'Loughlin, a successful candidate for the priesthood, a tale of the North of Ireland by Peregrinus, revised and edited by his brother, Rev. Bernard Tracy. Recollections of Country Life from the Diary of a Visitor (stories) by D. G. D. Much of the fiction is anonymous.

THE DUBLIN UNIVERSITY MAGAZINE. 1833-1877. (Vol 89).

The bound volumes of this review form an immense collection of literature, nearly all by Irish authors and containing much that is of Irish interest. Throughout the greater part of its career it contained all that was best in Anglo-Irish literature, apart from Catholic and from nationalist literature. Its first volume contains Lover's "Barney O'Reirdon the Navigator." Vol II. contains "The Dead Boxer," by Carleton. Subsequent volumes contained other pieces by the same writers. Sir S. Ferguson's Hibernian Nights first appeared there. Lever contributed almost from the first, and many of his novels first ran there as serials. Isaac Butt was editor for a time, and contributed to it his Chapters of College Romance. Later volumes contained serials like "The Nevilles of Garristowr" by Miss Marsh, "Haunted Lives" by Lefanu. Vol. 41 contains an article "Our Past, our 'resent, and our Future," giving much information about the magazine.

In 1877 it became The University Magazine, and ceased to be distinctively Irish. THE DUBLIN UNIVERSITY REVIEW. (Dublin : Cornish). Monthly. $6 d$. 1885 and 1886.3 vols. Pp. 164, 400, 1054 8vo.

Contributed to by the best writers of the time. Contains one Irish story, How Thomas Connolly met the Banshee, by J. Todhunter. A considerable proportion of its contents is thoroughly national in spirit.

DUFFY'S FIRESIDE MAGAZINE; a monthly miscellany. Four 4to vols. 1851-4.

Contains Adventures of an Irish Giant by Gerald Griffin (posthumous); The Poor Scholar-his legends and tales by W. Bernard McCabe; The Fate and Fortunes of Castle de Burgo by "E. L. A. Berwick" (Dr. Reynolds, the Ed.); The Irish Privateers, a tale of the Penal Laws by John O'Connell-all substantial serials. Among the short storie's were Ellen O'Leary; The Luck Money; The Smuggler's Daughter (Dunlicky); Mathew McQuake; The Emigrants, a tale of the Williamite wars; The White Hen (Irish fairy tale), and very many others. Ed. by Dr. Reynolds, "Bro. James" (q.v.).

DUFFY'S HIBERNIAN MAGAZINE. Ed. by Martin Haverty. (DubliN : James Duffy). First Series, July, 1860, to Dec., 1861; Second Series, 1862-4.

Five vols. "A monthly sixpennny journal of legends, tales, and stories, Irish antiquities, biography, science, and art. Principal contributors:-Lady Wilde, Julia Kavanagh, Fr. C. P. Meehan, John O'Donovan, Carleton, J. F. O'Donnell (Caviare), J. D. McCarthy, etc." This the title page tells us, but in the course of 
DEFUNCT PERIODICALS-(continued).

the periodical no names of authors are given. Contains many of Carleton's stories, such as The Man with the Black Eye; The Rapparee; The Double Prophecy. Also serials such as Raymond de Burgh, Romance of the Exodus, and Winifred's Fortune, a Story of the Days of Queen Anne. There are many stories by Robert Dwyer Joyce (e.g., The Building of Mourne, The Mournful Squire, Earl Gerald and his Bride). Other titles are Tom Dunn's Corner; Oona Moriarty by Martin Haverty (the Editor); The Mysterious Wooer; The Old House on the Esplanade by Frances Crosby; The Lovers of Moville by Erionnach. There is much less Irish fiction in the second series than in the first. It contains Lloyd Pennant $(q \cdot v$.$) .$

DUFFY'S IRISH CATHOLIC MAGAZINE. Monthly. One large 4to. vol. 1877-8.

Contains much interesting Irish matter, but little fiction except a serial, King Simnel and the Palesmen, which, however, seems to have been dropped after the thirteenth chapter. Twenty-two numbers in all appeared. Other stories were :A Tale of the Penal Times; A Legend of Ballylebane Castle; Reminiscences of the Irish Mission (a series by Dr. Geo. Crolly of Maynooth); The Last Baron of Cluan.

THE EMERALD : a monthly magazine of literature, politics, and general information. (LIVerpool : Fitzsimons). 1864.

A little magazine of 32 pp. 8vo., thoroughly nationalist in tone. Contains an unfinished serial Out on the Hills : A Tale of ' 98 by Henry de Monton, and a short tale by Joseph P. Malone, illustrative of the Irish dialect of the English language. Also verse and articles. (I.B.L.).

ERIN'S HOPE : The Irish Church Mission Juvenile Magazine. 14 vols. Monthly. 1853-66.

THE GAEL, a monthly bilingual magazine devoted to the promotion of the literature, historv, language, art, music, industries, etc., of Ireland. (NEw York : The Gael Publishing Co.). Reached its 23rd and last vol. in 1904.

Has contributions from all the best Irish writers of the time. It contains a good proportion of Anglo-Irish fiction. Spirit strongly national.

N.B.-A weekly journal of the same name issued four numbers in Dublin in 1861. THE HARP : an Irish Catholic monthly magazine. (Cork : Roche). 1 vol. Pp. 375. demy 8vo. March to Oct., 1859.

Articles on Irish history and archæology, reviews, national ballads, Catholic news. thoroughly national in sentiment. Contributors:-M. J. M'Cann (ed.), J. R. O'Flanagan, "Feardana." R. D. Joyce. The latter contributed some "Stories and Legends of Ireland." The only other Irish fiction is Nan Haley, a serial by Ullin.

HIBERNIA. A monthly popular review. 1st series. 1882 ; 2nd series, 1883. F'cap. Of the second series only two numbers appeared.

Contains articles on a great variety of subjects, but no fiction.

ILLUSTRATED DUBLIN JOURNAL. A weekly miscellany of amusement and popular information. (Dublin : Duffy). 1861-2. One vol. of 588 closely printed 4to. pages.

Essays, topographical sketches, verse, anecdotes and a large proportion of fiction. e g., The Miller of Mohill by Carleton: Suil Dhuv the Coiner by Griffin. The Black Doctor (a serial story of Dublin); A Night at Sea; Stories by R. D. Joyce (q.v.) and many others.

THE IRISH EMERALD, a popular penny weekly. Reached its 20 th annual vol. in 1912, when it amalgamated with the IRISH SHAMrock (q.v.).

The fiction is usually of a highly sensational type, and very nationalist. There are some excellent serials.

THE IRISH LITERARY GAZETTE, a weekly journal of national literature, criticism, fiction, industry, science and art. (Dublin : Chamney). 1857-61. Vol. I. 348 pp. large 4to., close print. Vol II. 332 pp. Subsequent vols. were reduced in format, No. of pages, and price, and appeared monthly.

There are a good many stories and some serials. Among the latter are "The Consequences," a tale of the Bodkins of Ballycastle; "The Heiress of Glenloe." both by the author of "Eveleen," "The Queen's Dwarf," etc. ; "The Guerilla" by Elliott Hope. Then there is "The Whitethorn Tree", by R. D. Joyce.

THE IRISH MAGAZINE, and Monthly Asylum for Neglected Biograñhy.

(Dublis). 1807-1815, 


\section{DEFUNCT PERIODICALS-(continued).}

This is the famous Watty Cox's Magazine, a militant national and Catholic periodical, at a time when nationalists and Catholics were tame and temporising. Contains scarcely any fiction, but in the number for Jan., 1814, there is a story Cormac and Muirne, by "Fearflaitha O'Gniomh," and in the next number the "Life and Adventures of Daniel Dunn."

IRISH METROPOLITAN MAGAZINE. (DUBLIN : Milliken). 3 vols. 1857-8.

Contains an Irish serial story, "Life's Foreshadowings," by William Wills (q.v.). Also "Chronicles of an Old Race," a fine hero-tale of the Red-Branch in 13 chapters, very well written. "Mrs. Stevenson's Will "; " Fitzmaurice of Danganmore"; and "The Irish Brigadesman, a tale of the War of the Succession," are other short Irish serials.

THE IRISH MONTHLY MAGAZINE of Politics and Literature. (DuBLIN).

May, 1832, to Sept., 1834. 3 vols. Pp. 850, 545, 507.

The 1st No. contains "Biographical account of the Dublin magazine periodicals who have lived and died since the Union." The magazine is fearlessly national and O'Connellite. Goes in for Belles Lettres as well as politics, e.g., The Children of Usnach, a dramatic poem. It contains some stories, such as "The Ghoulagh," Vol. I., p. 803; " Rody Heffernan," p. 437; "The Murderer's Fetch," Vol. II.; "The Irish Aeronaut"; "The Suicide's Grave"; "The Burkers of Dunluce"; "The Dream of Gold"; "The Sun Stroke" (G. Gerald Griffin); "The Barnabys," and a good many more. No names of authors. See THE IRISH UNION MAGAZINE.

THE IRISH PACKET of fact, fun, and fiction, a popular penny weekly, Ran from 1903 to 1909 . Ed. by M. M'D. Bodkin.

Fiction by Jane Barlow, the Editor, Justin McCarthy, Katharine Tynan, William Buckley, J. D. Guinan, M. E. Francis, William Boyle, N. P. Murphy, and most of the best Irish writers of the day. Seems to have somewhat declined in literary value towards the end.

THE IRISH PENNY JOURNAL. (DUBLIN : Gunn \& Cameron). 1840-1. Weekly. 4to. 52 numbers in all.

Besides some excellent topography by O'Donovan, among others, it is full of good stories and sketches (no serials) by Mrs. S. C. Hall, Carleton, John Keegan, "Martin Doyle," M.G.R., "J. G. MacTeague," Naisi, and many anonymous writers, e.g. A series on Irish superstitions, by Carleton; a series of sketches, The Irish in England by Mrs. S. C. Hall. By Carleton-The Irish Fiddler, Buckramback, The Irish Matchmaker, Bob Pentland, The Irish Midwife, and many others. Orohoo, the fairy man by $\mathbf{A}$. Bodach an Chota-lachtna, Peggy the Pishogue by $\mathbf{A}$. McC. St. Bridget's Shawl by T.E., Author of Darby Doyle, etc. The Drunkards by R.M. The America letter by A. McC. Paddy Corbett's First Smuggling Trip by E.W., etc., etc.

THE IRISH PENNY MAGAZINE. (DubLIN). 1833. Vol I. pp. 416. 4to.

Vol. II., Nos. 1 and 2 are dated 1834. No. 3 (paged continuously with 1 and 2) did not appear till 1842 ! Contents : Topography, Biography, Belles Lettres. There are many anonymous short stories. Lover contributed Illustrations of National Proverbs. Other series are Queer Stories by a Queer Fellow, and Fairy Legends of the North of Ireland. Lever was also a contributor.

THE IRISH QUARTERLY REVIEW. (DUBLIN : Kelly). 9 vols. small 4to., each of about $750 \mathrm{pp}$. $1851-60$.

Long articles of solid and permanent value, largely on Irish subjects. No fiction. THE IRISH REVIEW, a monthly magazine of Irish literature, art, and science. (Dublin). 4 vols. 1911-14.

The chief organ of the modern Irish literary renaissance. Writers :-Padraic Colum, James Stephens, P. H. Pearse, Thomas MacDonagh, G. W. Russell (ÆE), Daniel Corkery, Seosamh MacCathmhaoil, Lord Dunsany, Dermot O'Byrne, 'Joseph Plunkett, in fact nearly all the principal writers of the revival. There are some Irish stories of high literary value.

IRISH UNION MAGAZINE. (DUbLiN : Keene). A substantial monthly. Four half-yearly vols. of about $450 \mathrm{pp}$. each. 1845-7.

With Vol. II. the title was changed to the IRISH Monthly Magazine. Unionist in politics. Contains some Irish stories, e.g., Mary Mansfield (a serial), Kathleen's Leap, and one or two others. 
DEFUNCT PERIODICALS-(continued).

KENNEDY'S BRITISH AND IRISH CATHOLIC MAGAZINE. (DUBLIN : James Duffy). 1836. 8vo. monthly.

The contents are mainly religious and controversial, with miscellaneous literary articles, and some verse. But there is practically nothing in the shape of fiction.

I'HE KERRY MAGAZINE. A monthly journal of Antiquities, Polite Literature, Criticism, Poetry. (Tralee. Proprietor F. C. Panormo). 12 Nos. 3 vols. 1854.6. Contains a serial, The Moores, but little fiction besides.

THE LYCEUM, a monthly educational and literary magazine and review. (DUBLIN). 6 vols. 4to. Sept., 1887, to Sept., 1893.

Articles on current topics, and on a great variety of serious subjects. Catholic. No fiction.

THE MILESIAN MAGAZINE, or Irish monthly gleaner, ed. by John Brenan. (Dublin). 1812-20.

Full of politics and of controversy of a violent and abusive kind. No fiction. THE MONITOR. (Dublin : Dollard). 1875-9.

The first series (4 vols.), entitled The Illustrated Monitor, was almost exclusively religious (Catholic), but in the 3rd vol. The False Witness, or The Martyr of Armagh by A.M.S. (A. M. Stewart?) ran as a serial. The second series (3 vols.) contains more fiction, e.g., "The Moores of Moore's Court" by D. F. Hannigan, "Julia Marron, a tale of Irish peasant life," by "Celt."

THE MONTHLY MISCELLANY or Irish Review and Register. 1 vol. 8vo. Apr. to July, 1796.

Correspondence, articles on general subjects, verse, reviews. Some stories, e.g., Cuthberga (a serial), but none of them Irish.

THE MONTHLY MUSEUM or Dublin literary repertory of arts, science, litera ture, and miscellaneous information. (DusLiN : Kempston). 2 vols. Oct. 1813, to Dec., 1814.

An ambitious periodical treating de omni scibili. No fiction.

THE MONTHLY PANTHEON or general repertory of politics, arts, science, literature, and miscellaneous information. (Dublis : Gilbert \& Hodges). 3 vols. 1808-9.

Articles on a great variety of subjects-none were excluded from its purviewbut no fiction.

'] HE NATIONAL MAGAZINE. (Dublin : Wakeman). 1830-1. 2 vols. Pp. 755-480.

A continuation of the Dublin LITERARY GazeTte $(q . v$.$) . In the introductory$ article the editors say, "We are Tories and churchmen : we propose to make politics a frequent subject of discussion in our pages." Ed. by Ch. Lover. Contributed to by Petrie, Carleton, etc. Contains a good deal of fiction. E.g., in No. 1. "Eveleen O'Connor; a tale," "The Force of Habit; a true Irish story," " Alley Sheridan" (Carleton), "The Donagh" (ditto), etc. Vol. II. has some 15 stories by various authors. Continued as

The National Magazine and Dublin Literary Gazette. Ed. by Philip Dixon Hardy. (Dublin). 1630-1.

THE NATIONAL REVIEW of politics, literature, art, and social progress. 1 vol. June to Nov., 1868. Folio double columns, close print.

Strongly national in tone. No fiction.

THE NEW IREIAND REVIEW. (Dublis) Montlily. 1894-1911. 34 vols.

Ed. throughout by the Rev. T. A. Finlay, S.J. Articles and reviews on a great variety of topics, Irish for the most part. Fiction not a regular feature but occasional short stories, e.g., a series of Irish folk-tales in Irish and English by Conor Maguire (Vol. 26-7), Father Dick's Hyacinths by N. T. O'Mahony, and The Second Sorrow of Fergus (Vol. 28). The Ford of the Dead by William Barry (Vol. 1), The Story of Luainmaisi (Vol. 4). Many of the vols. contain no fiction.

THE NEW IRISH MAGAZINE and monthly national advocate. (DURLIN : Connolly). 1 vol. Pp. 280. 8vo. 1822-3.

A political periodical of nationalist and Catholic views.

THE NEW MAGAZINE. (DUBLIN). 1799-1800.

Described by a reviewer of 1832 as " dull, without erudition, and trifling, without the power to amuse."

THE NEW REVIEW, philosophical and literary. (Dublin : Hodges \& Smith). vols. demy 8vo. Pp. 630, 605. 1863. 


\section{DEFUNCT PERIODICALS-(continued).}

Serious articles on politics (Conservative point of view), literary criticism, and current topics. No fiction.

THE NEWRY MAGAZINE, or literary and political register. (NEwRY : Wilkinson). 4 vols. 8vo. 1815-8. Ed. by James Stewart of Armagh.

Appeared every second month. Articles on a great variety of serious subjects, but no fiction.

PADDY KELLY'S BUDGET; or, a pennyworth of fun. (Dublin : Bourke). 5 or 6 vols. 1832-5.

A weekly collection of verse, jokes, puzzles and stories. The latter are for the most part very short, and the majority are comic. Samples of the latter are "Paul Dogherty's Recollections of his Younger Days" (broad farce), Comic Irish Sketches (ditto), Irish Family Sketches (a series), The Conclave (a serial), The Mether, a legend of Croagh Patrick. Nearly all the stories are full of very "stage-Irish" brogue. There are 415 pp. 4to. in Vol. I.

PAT. (Dublin : Swan). Weekly. 1881-3. A comic periodical closely resembling $\mathrm{Zoz}(q \cdot v$.$) .$

An occasional very short comic story.

SAMHAIN, an occasional review, ed. for the Irish Literary Theatre by W. B. Yeats. (Dublin : Sealy Bryers). 1901-4.

Criticism and plays in English and Irish. No fiction.

THE SHANACHIE, an Irish miscellany illustrated. (DUbLIN : Maunsel). 1906-7. By the chief writers of the literary revival.

Contains some stories, e.g., The Miraculous Revenge, a Dublin story by G. Bernard Shaw; Fundamental Sociology, a story by G. A. Birmingham; The Child of Our Hope by the same. Owny on the Turf by K. F. Purdon; A Prayer to St. Anthony by John Guninan; Marcus of Clooney by Padraic Colum, and several others.

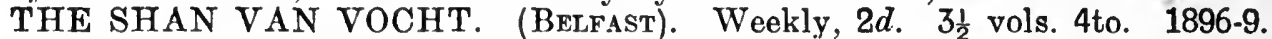

Run by Miss Alice L. Milligan (q.v.) and "Ethna Carbery" (q.v.). Contains a good deal of fiction, e.g., the series "In the North Countrie," "At the Bocht of the Ballagh," "From the Celtic Past," and " Out of the Mountain Mists." Besides these there were short stories by T. E. Mayne (q.v.), Walter Lecky ("With the Irish Fairies"). The tone and spirit was that of advanced nationalists and Gaelic Leaguers.

TINSLEY'S MAGAZINE.

This was by no means an Irish magazine, but it is worthy of mention here inas. much as, during the editorship of Edmund Downey, from 1880 to 1884, it contained much work by Irish writers such as John Augustus O'Shea, Tighe Hopkins, James C'Donoghue, Richard Dowling, Fitzgerald, Molloy, John Hill, W. B. Guinee, Robert Wogan McDonnell, and the Fditor himself. These contributions included some fiction, Irish in subject, notably the Editor's stories and Running for Life by James O'Donoghue, but no Irish serials. For full account see I.B.L., vol. 8, pp. $73 \& 97$.

THE ULSTER MONTHLY MAGAZINE. 2 vols. large 8vo. Pp. 776, 142. 1830-1.

Commenced by C. H. Teeling and continued for two years. Articles on politics, current events and general topics and verse. Some stories; few of Irish interest. But there is The Castle of Strankally and The Bride of O'Cahan and one or two others.

THE ULSTER REGISTER. (BELFAST). 5 vols. 1816-8.

A political and literary magazine, ed. by John Lawless. Liberal and tolerant in its views. Mainly current affairs, but some articles on general topics. No fiction. THE UNIVERSAL MAGAZINE and Review or Repository of Literature. (Dublin : Byrne). 9 vols. 8vo. 1789-93.

Contains a few tales, but not any of Irish interest.

THE UNIVERSITY REVIEW AND QUARTERLY MAGAZINE.

Grant \& Bolton, and Wakeman). Jan. to April, 1833. Pp. 174.

Consists for the most part of extended reviews. Contains two Irish stories :Neal Malone by Carleton and Brian Reft Brian.

WALKER'S HIBERNIAN MAGAZINE, or Compendium of Entertaining Knowledge. (DuBLIN : Walker). 1771-1811. Bound in 50 volumes.

N.B.-The first page of part two bears the title :-Universal Magazine and Review or Repository of Literature. Contents : Politics, Current Affairs, Biography, Book Reviews, Essays, Verse, Also some stories. These latter are not Irish in subject, 
DEFUNCT PERIODICALS-(continued).

YOUNG IRELAND. Illust. 16 pp. 4to. 1d. weekly. 1875-1890.

Bound a vol. to a year. In 1875 began a new series. It was run first from $\mathrm{THE}$ Nation office, afterward from the oftice of the IRISH Catholic. Vol. I. contains serial stories by Nugent Robinson, 'I'homas Sherlock, Capt. Mayne Reid ("'The Irish Night Mail " and several other stories), Koger Starbuck. Vol. II. has stories by T. M. Healy, John George Mclarthy. And throughout the sixteen thick quarto volumes a fine supply of tiction, mostly national in tone, but suited to boys, is kept up. Other writers for it were P'atrick O'Conor MacLaughlin, Attie O'Bórien, M. Mackey, Major Alfred Rochfort, William Boyle, Richard Dowling, Miss O'N. Daunt, V. O'D. Power, James Murphy, William Collins, P. G. Smyth, Annie Keary (Castle Daly), C. J. Kickham, Jủstin McCarthy, etc., etc.

The paper at present runuing under the title Young lakeand (weekly, 2d.) bears no resemblance to the above. it is a political paper (Sim Féin) and contains no fiction. It is clearly intended, not for boys, but tor young men.

ZOZIMUS. Weekly. 1870-z. An excellent Irish humorous paper on the lines of PUNCH. Contains a good many short stories.

ZOZ, a comic weekly. 1876-8. Very clever illustrations, jokes, verse, humorous paragraphs. No fiction.

\section{II.-CURRENT PERIODICALS.}

In the case of periodicals which are still running I have not attempted so full a treatment as in the case of those which have ceased to appear, the chiet reason being that it is easy to purchase the current number, and one can thell apply the adage ex uno disce omnes. I have thought well to adopt the same alphabetical arrnagement. THE CATHOLIC BULLE'IN. (LUBLIN : crill). Monthly, $3 d$. Is now in its eighth yearly volume.

Does not contain a great proportion of fiction, and does not go in for serials. Father Fitzgerald's volumes of stories $(q \cdot v$.$) have been reprinted from its pages.$

THE CEL'IC REVIEW. Quarterly. 1904 to date-Current.

Carries on the work of the Celtic MAG. (q.v. supra), but on a grander scale, and with riper and more European scholarship.

THE UUBLIN REVIEW. (LoNDON : burns \& Oates). Quarterly, 6s.

Not properly speaking a literary periodical, though it has articles on literary subjects. Its earlier series were lrish 11 character, but it has for a good while back ceased to be distinctively Irish. No fiction.

ERIU : The journal of the School of Irish Learning. Founded 1904. 8 vols.

Contains some texts of Gaelic tales and romances, in many cases with translations, e.g., 'The First Battle of Moytura (1915), MacDá Cherda and Cummaine Foda (1911), The Wanderings of the Empress and the rearing of her Two Sons, a romantic tale (1911) and many others.

IRELAND'S OWN, a journal of fiction, literature, and general information. (DUbLin : "IRELAND's Own" Office, 40 Lower Ormond Quay). 2d. weekly. 34 pp. large 4to.). Is now in its 33rd vol., making over 840 numbers

It is on the style of the IRISH P'ACKET $(q . v$.$) . Has publ. a very large amount of$ popular fiction, largely of an Irish complexion. See Library of Reprints referred to supra, Append. B, No. 6.

THE IRISH COMMONWEALTH. Founded March, 1919. A monthly review of social affairs, politics and literature. Monthly. 1s. (Kiersey). Ed. by

Aodh de Blácam.

THE IRISH MONTHLY. (DUBLIN : Gill). $6 d$. Now in its forty-sixth volume, and 546th number. From its beginning until 1912 it was ed. by Father Matthew Russell, S.J.

Its volumes contain work by nearly all the best writers of Irish fiction in the last fifty years. Lady Gilbert, M. E. Francis, and Katharine Tynan were frqeuent contributors. Of late years the amount of fiction is less. There were only about half a dozen stories during 1918.

THE IRISH MESSENGER of the Sacred Heart. (DuBLIN : "The Messenger" Office, Great Denmark St.). 1d. monthly. 16mo. Now in its 32nd vol.

Contains a great many stories, some of them serials, nearly all Irish in subject.

THE IRISH ROSARY. (Dublin : St. Saviour's Priory, Dominick St.) Monthly. 4d. Began 1897; now in its 23rd vol. 


\section{CURRENT PERIODICALS-(continued).}

Contains a great amount of excellent Irish fiction. It has long been the only Irish illustrated magazine in the proper sense of the word. It is directed by the Dominican Fathers.

IRISH SOCIETY and Social Review. Now in its 32nd year and 1620th number. Weekly. Price at present $1 \frac{1}{2} d$.

Consists chiefly of fashionable intelligence, accounts of social functions, the fashions, cookery and household matters, etc. Published serials, e.g., A Plucky Irish Girl by C. J. Hamilton. Also occasional stories.

OUR BOYS. (DUBLIN). $2 d$. An illustrated monthly directed by the Christian Brothers, on the lines of the B.O.P. and CHums, but thoroughly Irish in sentiment and outlook.

The stories are by no means goody-goody. They are as thrilling as a boy could desire. It is now in its fifth volume.

THE SHAMROCK, a national weekly journal of Irish history, literature, science, arts, etc. (DuBLIN). 1867.

Contains much fiction. Serials :- "The Outlawed Chief," "Pardoned Yet Guiltless" by Denis Holland, "Tried in the Crucible" by John Augustus O'Shea. Is chiefly remarkable for the Mick McQuaid series $(q . v$.$) , which ran from the first$ number to the last. "Donal Dun O'Byrne" by D. Holland, "Myles Urson," a tale of the Irish Revolution of 1848, by T. C. Irwin," Marion" by John K. Casey. Other serials by Holland, Casey, Lynam. It subsequently degenerated in literary quality.

N.B.-In 1912 it amalgamated with the IRISH EMERALD. See previous list. In the current series (its 52nd year) of the SHAMROCK there is a good deal of fiction, e.g., a serial, An Emissary of France by Shaun MacManus.

STUDIES. (DUBLiN : T'he Educational Co. of Ireland). 2s. 6d. "An Irish Quarterly Reviow of Letters, Philosophy, and Science."

Now in its eighth vol. Has not as yet publ. any fiction.

The first issue contains some fiction.

Besides the above there are several minor periodicals that, without making a special feature of fiction, occasionally publish stories. Such are the religious magazines:-Madonna, The Cross, The Annals of St. Antony, St. Joseph's SHEAF, etc. Also the sporting and society weekly, IRISH LIFE.

Much fiction was, before the war, to be found in the weekly numbers of the daily papers, such as the Independent, Freeman's Journal, Irish Times, Belfast News. LETTER, etc., and in the provincial papers, of which there are some one hundred and sixty (1917), about half as many as appear in Scotland.

The Gaelic periodicals: Fânne an lae, an loćrann, an Stoc, an Crann, an Oranar, an Ceaćcalre (the Gaelic Messenger) do not, properly speaking, fall within the scope of this book, as they do not publish any fiction in English. 


\section{N D E X}

OF

\section{TITLES AND SUBJECTS}

1. The body of the work constitutes an index to Authors.

2. This is, in the main, an index of Titles. Of the subjects of the novels only the more important have been indexed. Subjects dealt with in the classified lists in Appendix C are, for the most part, not again referred to here.

3. Books are referred to by their numbers and not by the pages on which the title occurs.

\section{A}

Abbey of Innismoyle, The ... ... 281 Above and Below $\quad . .6 \quad \ldots . \quad \ldots .632$ Absentee, The ... ... ... ... 543 Absenteeism … 75, 111, 126, 543, 544 Across an Irish Bog ... ... ... 705 Adventurer, The $\quad \ldots .6 . . . . .6$ I Adventures of Alicia, The $\ldots . \quad \ldots 1619$ Adventures of Barney Mahoney, The 425 Adventures of a Bashful Irishman ... 470 Adventures of Captain Blake, The... 1121 Adventures of Captain O'Sullivan, Tne ... 1123 Adventures of the Children of the King of Norway ...

Adventures of Count O'Connor, The 1534 Adventures of Felix and Rosarito, The ...

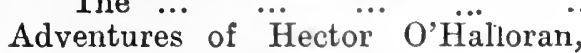
The

$$
\text { .......... }
$$

Adventures of an Irish gentleman ... 1155 Adentures of an Irish Girl at Home and Abroad

Adventures of Maeve... ... ... 707\%

Adventures of Mick Callighin, M. $\dddot{P} .125$ Adventures of Moses Finegan ... 1416 Adventures of St. Kevin and other Irish Tales, The $\ldots \quad \ldots \quad \ldots 1449$ Adventures of Suibhne Geilt $\quad \ldots 1338$ Against the Pikes $\quad . . \quad \ldots \quad \ldots 1564$ Agitator von Irland, Der ... ... 1486 Agnes Arnold ... $\ldots . \quad \ldots \quad \ldots 985$ Agrarian Agitation ... $.5,33,40,55,67$, $84,89,98,101,142,151,162,180,191$, $195,229,235,251,324,329,406,444$, $454,675,677,688,818,858,870,973$, $983,996,1135,1136,1252,1264,1368$, $1385,1446,1492,1544,1583,1584$, 1589, 1591, 1597.

(See also under Land League.)

Aileen Alannah $\quad \ldots . \quad \ldots \quad \ldots 640$ Aileen Aroon $\quad \ldots \quad \ldots \quad \ldots \quad \ldots 1406$ Ailey Moore $\quad \ldots \quad \ldots \quad \ldots \quad \ldots \quad \ldots 1264$ Albion and Ierue Alias Kitty Casey Alice
Aliens, The

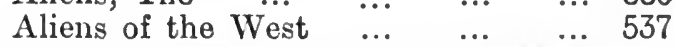

Alley Sneridan, or the Runaway Marriage, and other Stories

All for Prince Charlie

All on the Irish Shore $\quad . . \quad \ldots 1528$

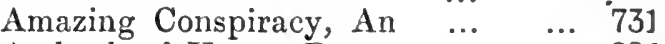

Ambush of Young Days $\ldots . \quad \ldots 884$

America, Irish in ... $79,88,101,275$, $288,297,349,373,439,494,496,525$, $535552,704,731,795,798,871,878$, $929,930,1092,1093,1206.1218,1259$, $1260,1265,1357,1460,1469,1471$, 1476, 1566, 1660, 1703.

Amusing Irish Tales $\quad \ldots \quad \ldots 339$

Anchor Watch Yarns ... $\quad . .6 . \quad \ldots .506$

Ancient Heroic Romances of Ireland 877

Ancient Irish Epic Tale, The Tain, An $\quad . . . .6 \quad \ldots . \quad \ldots . \quad \ldots 533$

Ancient Legends of Ireland ... $\quad \ldots 1669$

André Besnard $\quad \ldots \quad \ldots \quad \ldots 1678$

Anglo-Irish of the Nineteenth

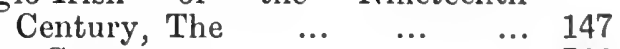

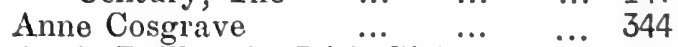

Annie Reilly, the Irish Girl $\quad \ldots .44$

Another Creel of Irish Stories _.. 175

Antrim $\quad \ldots$ 48, 146, 197, 413, 4344, 446, $462,577,587,667,794,797,966,1019$, $1021,1025,1078,1108,1181,1200$, $1201,1206,1375,1393,1409,1545$, $1654,1680$.

Apple of Eden, The $\quad \ldots \quad \ldots \quad \ldots 1571$

$\begin{array}{llllll}\text { Ardnaree } & \ldots & \ldots & \ldots & \ldots & 1008\end{array}$

$\begin{array}{llllll}\text { Armagh } & \ldots & \ldots & \ldots & \ldots & 1008 \\ & \ldots & \ldots & \ldots & 842, & 1333\end{array}$

Arran Islands ... 150, 477, 891, 938, 1529

Arrival of Anthony, The ... ... 385

Arthurian Romances, Two Irisin $\quad \ldots 981$

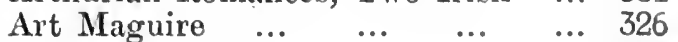

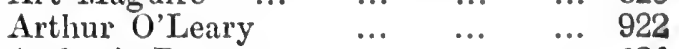

Arthur's Rest $\quad$... $\quad$.. $\quad \ldots 6624$

Art MacMurrough O'Kavanagh ... 1277

At the Back of the World ... ... 1134

Athlone $\quad \ldots \quad \ldots \quad \ldots \quad 63,192$

At the Door of the Gate ... ... 1413

At the Rising of the Moon ... $\quad . .1106$

$\Lambda$ tilla and his Conquerors $\quad \ldots .6353$

Attorney, Tne ... $\quad \ldots \quad \ldots . \quad \ldots \quad 137$ 
Auld Meeting' Hoose Green ... ... 1021 Aunt Jane and Uncle James ... ... 378 Australia ... 34, 202, 303, 591, 747, 772, $851,1165,1580,1705$.

Australian Christmas Collection, An 1705 Autobiography of a Child ... ... 972 Awkward Squads, The $\quad \ldots \quad \ldots 267$

\section{B}

Bad Times, The

Bagots, The $\quad . . \quad \ldots . \quad \ldots \quad \ldots 1648$

Baldearg O'Domnell ... $\quad \ldots . \quad \ldots \quad 312$

Ballads in Prose $\quad \ldots . \quad \ldots . \quad \ldots \quad 773$

$\begin{array}{llllll}\text { Ballinvalley } & \ldots & \ldots & \ldots & \ldots & 1687\end{array}$

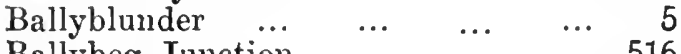

Ballybeg Junction $\quad \ldots . \quad \ldots . \quad \ldots \quad 516$

$\begin{array}{llllll}\text { Ballygowna } & \ldots & \ldots & \ldots & \ldots & 657\end{array}$

$\begin{array}{llllll}\text { Ballygullion } & \ldots & \ldots & \ldots & \ldots & 523\end{array}$

$\begin{array}{lllll}\text { Ballymuckbeg } & \ldots & \ldots & \ldots & 701\end{array}$

$\begin{array}{llllll}\text { Ballyronan } & \ldots & \ldots & \ldots & \ldots & 122\end{array}$

Banker's Love Story, A $\quad . . \quad \ldots 1024$

Banks of the Boro, The ... ... 846

Banquet of Dun na $\mathrm{n}$ Gedth and the Battle of Magh Rath ... ...

Banshee's Warning and otner Tales, The

Barbara

Barbaric Tales ... ... ...

Bardic Stories of Ireland, The

Barney the Boyo

Barrington

Barry Lyndon, Memoirs of ...

Barrys, The

Barrys of Beigh

Battle of Connemara, The ...

Battle of Gabra, The ... ...

Battle of Magn Léana, The ...

Battle of Rosnaree, The

Beckoning of the Wand, The

Before the Dawn in Erin ...

Beggar on Horseback, A

Begorra!

Belfast, 234, 56̈, 719, 798, $1024, \cdots 1411$, $1623,1645$.

Belfast Boy, The

Bell Barry

Bend of the Road, The

Benedict Kavanagh ...

Berna Boyle

Beside the Fire ".

Bessie Conway ...

Betsy Gray

Bewitched Fiddle and other Irish Tales, The ... ... ...

Beyond the Boundary

Beyond the Pale

Biance

Bird of Passage, A

Bits of Blarney

Bits of Blarney

Bit o' Writing, The ...
1290

1430

139

... 1042

.. 849

... 590

... 935

... 1565

... 270

... 685

... 1347

... 1334

... 1290

... 471

... 489

.. 834

7

,

234

.. 869

... 1058

... 196

... 1428

... 791

... 1471

.. 978

... 1062

… 7062

... 417

... 1117

... 415

... 1034

... 1101

... 154
... 768 $\begin{array}{llllll}\text { Black Abbey } & \ldots & \ldots & \ldots & \ldots & 433\end{array}$

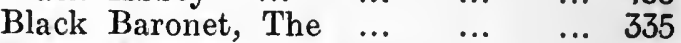

Black Monday Insurrection ... $\quad . .8$

Black Prophet, The $\ldots \quad$... $\quad \ldots \quad 327$

Black Wing, The ... ... ... 955

Blakes and Flanagans, The $\ldots . \quad \ldots 1469$

Blighting of Bartram, The ... 394

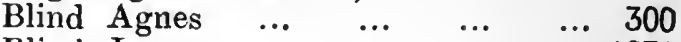

Blind Larry $\quad \ldots \quad \ldots \quad \ldots \quad \ldots \quad \ldots 1071$

Blind Love $\quad . . \quad \ldots \quad \ldots . \quad \ldots \quad 365$

Blind Maureen, and other Stories ... 836

Blindness of Dr. Gray, The ... ... 1503

Blind Side of the Heart, The ... 414

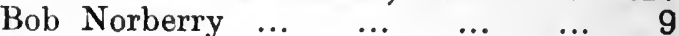

Boffin's Find $\quad \ldots \quad \ldots \quad \ldots \quad \ldots 1585$

Bonnie Dunraven $\quad \ldots \quad \ldots \quad \ldots 1389$

Book of Ballynoggin, The $\ldots . \quad \ldots . \quad 117$

Book of Gilly, The ... ... ... 894

Book of Modern Irish Anecdotes,

The $\ldots \quad \ldots \quad \ldots \quad \ldots . \quad \ldots \quad 850$

Book of Saints and Wonders, A $\ldots .652$

$\begin{array}{llllll}\text { Boycotted } \quad \ldots & \ldots & \ldots & \ldots & 1186\end{array}$

Boycotted Household, A $\ldots . \quad \ldots 996$

Boyne Water, The $\ldots \quad \ldots \quad \ldots .146$

Boy in the Country, A $\quad \ldots \quad \ldots 1545$

Boy in Eirinn, A $\ldots . \quad \ldots \quad \ldots 370$

Boy Hero of Erin, The ... ... 1532

Boy, Some Horses, and a Girl, The... 379

Boys of Baltimore, The ... ... 1539

Boyish Exploits of Finn MacCum$\begin{array}{llllll}\text { haill } \quad \ldots & \ldots & \ldots & \ldots & \ldots & \end{array}$

Boys' Stories (Addenda) Appendix ‘. VII

Bracknells, The ... ... ... 1411

Bramleighs of Bishop's Folly, The ... 941

Branan the Pict ... ... ... 1364

Brandons, The $\ldots \quad \ldots \quad \ldots \quad \ldots \quad \ldots 484$

Brayhard $\quad \ldots \quad \ldots . \quad \ldots \quad \ldots \quad 510$

Bridal of Dunamore, Tne $\ldots . . .1443$

Bridegroom of Barna The $\ldots . \quad \ldots \quad 10$

Brides of Ardmore, The ... ... 1517

Bridget $\quad \ldots \quad \ldots \quad \ldots \quad \ldots 4214$

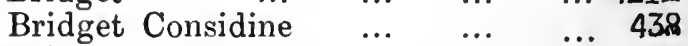

Bridget Sullivan $\quad \ldots, \quad \ldots \quad \ldots, 11$

Brigade, Irish ... 220, $245, \quad 345,593,744$. $815,901,960,1037,1051,1104,1326$ 1405, 1662, 1685.

Briseur de Fers, Le $\quad \ldots \quad \ldots \quad \ldots 487$

Britain Long Ago $\quad \ldots . \quad \ldots . \quad \ldots 1673$

Broken Away $\ldots \quad \ldots \quad$... $\quad \ldots \quad 672$

Broken Sword of Ulster, The $\quad \ldots \quad 66$

Brothers, The $\quad \ldots \quad \ldots \quad \ldots 821$

"Bruce Reynall, M.A.; $\quad \ldots . \quad \ldots .405$

Bunch of Shamrocks, A $\quad \ldots \quad \ldots 215$

Buried Lady, The ... ... ... 1324

Bundle of Rushes, A $\quad \ldots . \quad \ldots 290$

$\begin{array}{llllll}\text { Burnside } & \ldots & \ldots & \ldots & \ldots & 1026\end{array}$

$\begin{array}{llllll}\text { Burnt Flax } \quad \ldots & \ldots & \ldots & \ldots & 1379\end{array}$

Burtons of Dunroe, The ... ... ... 246

By a Hearth in Eirinn... $\quad \ldots . \quad \ldots 1329$

By Beach and Bogland $\quad \ldots . \quad \ldots .168$

By Lone Craig Linnie Burn ... ... 1023

Byrnes of Glengoulah ... $\quad . . \quad \ldots 1253$ 
By t'ne Barrow River, and other

$\begin{array}{crrrrr}\text { Stories } & \ldots & \ldots & \ldots & \ldots & 901 \\ \text { By the Brown } & \text { Bog } & \ldots & \ldots & \ldots & 12\end{array}$

By Shamrock and Heather $\quad \ldots . \quad \ldots . \quad 504$

By the Stream of Kilmeen ... $\quad \ldots 1339$

By Thrasma River $\ldots \quad \ldots \quad \ldots 268$

\section{C}

Cabin Conversations \& Castle. Scenes 279

Cairn of the Badger, The ... $\quad \ldots \quad 177$

Calling of the Weir, The $\ldots . \quad \ldots \quad 880$

Cambia Carty and other Stories ... 265

$\begin{array}{lllll}\text { Candle and Crib... } & \ldots & \ldots & \ldots & 1396\end{array}$

$\begin{array}{llllll}\text { Canvassing } & \ldots & \ldots & \ldots & \ldots & 1099\end{array}$

$\begin{array}{lllll}\text { Captain Harry } & \ldots & \ldots & \ldots & \ldots\end{array}$

Captain Lanagan's Log $\quad \ldots . \quad \ldots .511$

Captain Latymer $\quad \ldots . . . \quad \ldots . .1162$

Captain O'Shaughnessy's Sporting

Capture of $\dddot{\text { Killeshin, }}$ The $\ldots$

Card Drawing $\ldots \quad \ldots \quad \ldots$

$\ldots-\ldots 661$

\begin{tabular}{lllll} 
& & & & 661 \\
\hline
\end{tabular}

$\begin{array}{llllll}\text { Carrigaholt } & \ldots & \ldots & \ldots & \ldots & 285 \\ \end{array}$

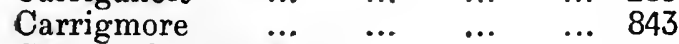

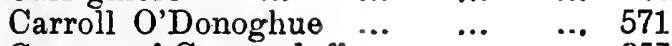

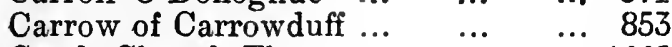

Castle Chapel, The $\quad \ldots \quad \ldots \quad \ldots 1445$

Castle Daly

Castle Omeragh

Castle Rackrent

Castle Richmond

Cathair Conroi ...

Cath Fintraga ...

Catholic Truth Societies Append:x $B$ and

Cathreim Cellachain Caisil ...

Cattle Raid of Cuailgne, The $\ldots .574$

Cavan ... $\ldots . \ldots . . . .267,271,790$

Cavern in the Wicklow Mountains, The

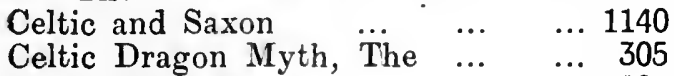

$\begin{array}{lllll}\text { Celtic Fairy Tales } & \ldots & \ldots & \ldots & 801\end{array}$

Celtic Fireside, A

... 608

Celtic Folk-Lore, Welsh and Manx... 1423

Celtic Myth and Legend, Poetry and Romance

1533

$\begin{array}{llllll}\text { Celtic Stories } & \ldots & \ldots & \ldots & \ldots & 1567\end{array}$

$\begin{array}{llllll}\text { Celtic Tales } & \ldots & \ldots & \ldots & \ldots & 355 \\ \end{array}$

Celtic Twilight, The $\quad \ldots . \quad \ldots . \quad \ldots l 693$

Celtic Wonder Tales ..... .61696

Celtic Wonder World, The ...

Chain of Gold, The ... ...

Chances of War, The ...

Changeling, The

Changing Winds

… 16969

... 1315

... 589

Chapters of College Romance $\cdots 229$

Characteristic Sketches of Ireland and The Irish

Charles Mowbray

Charles O'Malley
Charlton ...

Charming of Estercel, The ...

Charwoman's Daughter, The...

Children of the Abbey, The ...

Children of the Dead End ...

Children of Earth

$\begin{array}{llll} & \ldots & & \end{array}$

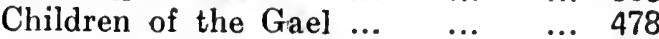

Children of the Hills ... $\quad \ldots . \ldots 1272$

Children of Kings $\quad \ldots \quad \ldots . \quad \ldots \quad 1283$

Children of Light $\quad \ldots \quad \ldots \quad \ldots \quad \ldots 615$

Children of Nugentstown, The $\quad \ldots 1590$

Children of Sorrow ... ... ... 296

Children's Book of Celtic Stories, The 654

Christian Physiologist, The... ... 662

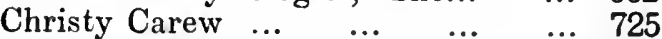

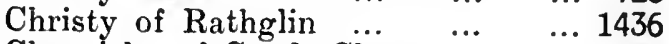

Chronicles of Castle Cloyne ... $\quad \ldots \quad 247$

Chronicle of Golden Friars ... $\quad \ldots .908$

$\begin{array}{llllll}\text { Civil Service } & \ldots & \ldots & \ldots & \ldots & 951\end{array}$

Clare 157, 500, $653, \dddot{664}, 8206,851,889$, $1160,1269,1339,1385,1562$.

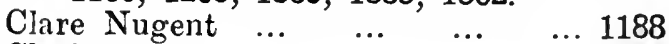

$\begin{array}{llllll}\text { Clashmore } & \ldots & \ldots & \ldots & \ldots & 520\end{array}$

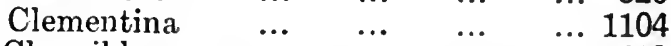

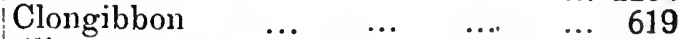

Clongowes Woo $\dddot{d}$ College 841, 1104, 1650

Cluster of Nuts, A $\ldots \ldots \ldots 1601$

Cluster of Shamrocks, A $\ldots . . \ldots 284$

Clutch of Circumstances, The $\quad . .1489$

Cock and Anchor, The $\quad . . \quad \ldots 904$

Collection of the Oldest and Most Popular Legends of the Peasantry of Clare and Galway, A $\quad \ldots 219$

Collected Works (Macleod F.) … 1046

Collected Works (Pearse, P. H.) ... 1372

Collegians, The ... $\quad \ldots \quad \ldots \quad \ldots 660$

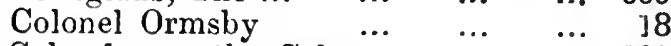

$\begin{array}{lllll}\text { Columbanus the Celt } \ldots & \ldots & \ldots & 898\end{array}$

Coming of Cuchulain, The $\quad \ldots . \quad \ldots .1312$

Comte de Dromore, Le $\quad \ldots \quad \ldots 1394$

Coming of Lugh, The ... $\quad \ldots \quad \ldots 1095$

Coming of the King, The $\ldots . \quad \ldots \quad 360$

$\begin{array}{lllll}\text { Complete Novels } & \ldots & \ldots & \ldots & 917\end{array}$

$\begin{array}{llll}\text { Conan, the Wonderworker } & \ldots & \ldots & 4 \% 9 \\ & & & 4\end{array}$

$\begin{array}{llllll}\text { Con Cregan } & . . & \ldots & \ldots & \ldots & 930\end{array}$

Confederate Chieftains, The ... $\ldots . . . .144^{\prime \prime} 0$

Confessions of Con Cregan ... ... 930

Confessions of Harry Lorrequer ... 918

Confession of a Whitefoot ... $\quad \ldots \quad 455$

Confessions of Honor Delany ... 248

Confessors of Connaught $\quad \ldots \quad \ldots .1135$

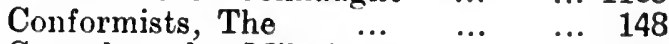

Connal ou les Milesiens $\ldots . . . .11113$

Connaught, a Tale of $\begin{array}{llll}1798 & \ldots & \ldots & 131\end{array}$

$\begin{array}{llllll}\text { Connemara } & \ldots & \ldots & \ldots & \ldots & 445\end{array}$

Connemara, 37, 150, 386, 444, 477, 481, $617,828,892,893,925,1286,1287$, $1426,1529,1608$.

$\begin{array}{llllll}\text { Con O'Kelly } & \ldots & \ldots & \ldots & \ldots & 944\end{array}$

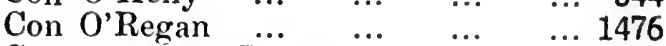

16 Conquered at Last $\ldots . \quad \ldots . \quad \ldots 1328$

17 Considine Luck, The ... $\ldots . . . \ldots 762$

919 Contes et Légendes d'Irlande... . . 498 
Contes Irlandais traduits du Gaëlique Contes Populaires de la Grande $\begin{array}{lllllll}\text { Bretagne } & \ldots & \ldots & \ldots & \ldots & 260\end{array}$ Conversion of Con Cregan, The $\quad \ldots .381$ Convict No. 25 ... $\quad \ldots \quad$... $\quad \ldots 1236$ Corby MacGillimore ... $\ldots . \quad \ldots \quad 679$ Cork, 8, 12, 41, 62, 80, 86, 101, 125, pp. 25, $26,212,222,224,265,273,361,377$, $482,609,618,621,638,663,665,687$, $726,751,788,825,826,888,918,989$, $990,1124,1134,1146,1155,1220,1240$, $1267,1268,1279,1303,1304,1316$, $1352,1389,1499,1522,1528,1540$, $1590,1594,1678,1685$.

Corner in Ballybeg, A...

Corrageen in '98

... $\quad \ldots \quad \ldots 1353$ of the Irish

\section{Peasantry …}

Countrymen All

Country Quarters

Court of Rath Crogan, The ...

Courtship of Ferb, The

Cousin Isabel

Cousins and Others $\quad \cdots \quad$...

Cousin Sara

Crackling of Thorns, The

Craignish Tales

Creel of Irish Stories, A

Crescent Moon, The ...

Crimson Sign, The

Crock of Gold, The

Crohoore of the Billhook

Croppies Lie Down ..

Croppy, The

Cross and Shamrock, The

Cubs, The

Cuchulain of Muirthemme (Gregory) 1515

Cuchulain of Muirthemme (Skelly) ... 1515

Cuchulin Saga in Irish Literature ... 782

Cuchulain, The Hound of Ulster ... 783

Culmshire Folk ... $\quad \ldots \quad$... $\quad$.. 622

Curate of Kilcloon, The $\quad \ldots .6 .680$

Cynthia's Bonnet Shop $\quad \ldots . \quad \ldots 1211$

Daffodil's Love Affairs

Daft Eddie $\quad . . . \quad \ldots$

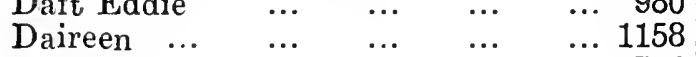

$\begin{array}{llllll}\text { Dalaradia } & \ldots & \ldots & \ldots & \ldots & 366\end{array}$

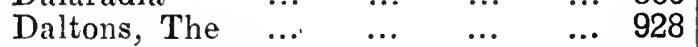

D'Altons of Crag $\quad \ldots \quad \ldots . \ldots 1266$

Dalys of Dalystown, The ... ... 1257

Dan Russell, the Fox ... ... ... 1530

Dan the Dollar ... $\quad \ldots . \quad \ldots . \quad \ldots \quad 275$

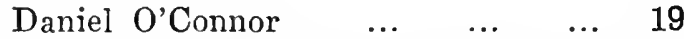

Darby O'Gill and the Good People.. 1562

Darcy and Friends 1036

$\begin{array}{lllll}\text { Dark Cloud, The } & \ldots & \ldots & \ldots & \\ \end{array}$

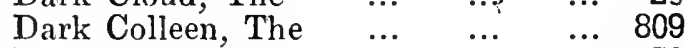

Dark Days $\quad \ldots \quad \ldots . \quad \ldots . \quad \ldots 1439$

Dark Lady of Doona, The $\ldots . .1119$

Dame Noire de Doona, La $\quad \ldots .61120$
Dark Monk of Feola, The ... ... 738

Dark Rosaleen ... $\quad \ldots, \quad \ldots \quad \ldots 1359$

Daughter of Erin, A ... $\quad \ldots . \quad \ldots \quad 592$

Daughter of the Fields, A $\ldots . \quad \ldots 1610$

Daughter of Kings, A ... $\quad \ldots \quad \ldots 1616$

Daughter of Tyrconnell, The... ... 1474

Dauntless $\quad \ldots \quad \ldots \quad \ldots . \quad \ldots 1098$

Davenport Dunn $\quad \ldots . \quad \ldots .6963$

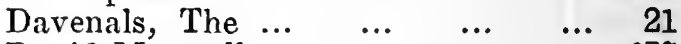

$\begin{array}{lllll}\text { David Maxwell ... } & \ldots & \ldots & \ldots & 439\end{array}$

Days of Fire, The $\quad \ldots . \quad \ldots . \quad \ldots .448$

Day's Ride, A ... $\quad . . . \quad \ldots . \quad \ldots .936$

Dead-Watchers, The $\ldots \quad \ldots . \quad \ldots \quad 159$

Dearforgil, The Princess of Breffny 639

Dear Irish Girl, The ... $\quad . . \quad \ldots 1605$

Death Flag, The ... ... ... 448

Death Tales of Ulster Heroes, The... 1150

Deirdre and the Lay of the Children

$\begin{array}{llllll}\text { of Uisne } & \ldots & \ldots & \ldots & \ldots & 345\end{array}$

$\begin{array}{llllll}\text { Deirdri } & \ldots & \ldots & \ldots & \ldots & \ldots \\ & \ldots & \ldots & \ldots & 1306\end{array}$

Demi-Gods, The $\quad \ldots \quad \ldots . \quad \ldots 1543$

$\begin{array}{llllll}\text { Denis } \quad \ldots & \ldots & \ldots & \ldots & \ldots & 584\end{array}$

Dennis Horgan Gentlemän ... ... 998

Denis O'Shaughnessy Going to May$\begin{array}{llllll}\text { nooth } & \ldots & \ldots & \ldots & \ldots & \end{array}$

Denis O'Shaughnessy Going to Maynooth

$324 \mathrm{~A}$

Denis Trench $\quad \ldots \quad \ldots . \quad \ldots \quad \ldots 1377$

Denounced, The... $\quad \ldots . \quad \ldots . \quad \ldots .149$

Dernier Irlandais, Le ... $\ldots . \quad \ldots \quad 191$

Derry 273, 313, 550, 557, 589, 617, 670, 715, 831, 926, 941, 1007, 1382.

$\begin{array}{llllll}\text { Derry } \quad \ldots & \ldots & \ldots & \ldots & \ldots & 557\end{array}$

Derryreel $\quad \ldots . \quad \ldots . \quad \ldots .607$

Desborough's Wife ... $\quad . . \quad \ldots 1130$

Desmond O'Connor ... $\quad \ldots . \quad \ldots 815$

Desmond Rourke _.. ... ... 729

Destruction of Dá Derga's Hostel,The 1552

Detective Stories $\quad . . \quad \ldots \quad \ldots 1263$

Diamond Lens and other stories, The 1260

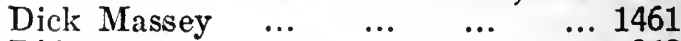

$\begin{array}{llllll}\text { Didy } \quad \ldots & \ldots & \ldots & \ldots & \ldots & 1461 \\ & & \ldots & \ldots & \ldots & 949\end{array}$

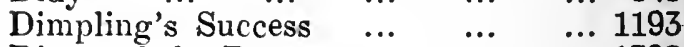

Dinny of the Doorstep... $\quad \ldots \quad \ldots 1398$

Divil-may-Care $\quad . . \quad \ldots \quad \ldots \quad \ldots \quad \ldots 1066$

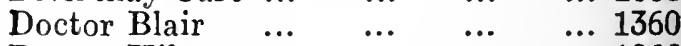

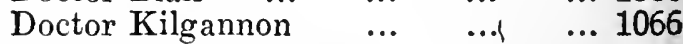

Doctor's Locum Tenens ... ... 1415

Doctor Whitty ... $\quad \ldots \quad$... $\quad \ldots .207$

Dodd Family Abroad, The $\ldots . \quad \ldots .937$

Doings and Dealings ... $\quad \ldots . \quad \ldots .173$

Dominick's Trials $\quad \ldots \quad \ldots \quad \ldots 1255$

Dominion of Dreams, The $\quad . . \quad \ldots 1043$

Donalds, The $\ldots . \quad \ldots \quad \ldots . \quad \ldots 1095$

Donal Dun O'Byrne $\quad \ldots .4 \quad \ldots . \quad \ldots 769$

Donal Kenny ... $\ldots . \quad \ldots \quad \ldots 6679$

Donegal $136,21 \dddot{4}, 217, \dddot{2} 38,257,315,451$, $566,607,635,640,649,681,683,732$, $875,887,938,996,1016,1062,1063$, $1057,1078,1105,1181,1196,1240$, $1305,1391,1410,1616,1712$.

Donegal Fairy Stories ... $\quad \ldots \quad \ldots 1063$

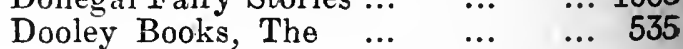


Doreen

Double Trial, The $\quad \begin{array}{lllll} & \ldots & \ldots & \ldots & 968\end{array}$

Dowdenham ...

Down 412, 432, 433, 579, 601, 718, 770, $833,856,976,977,1164,1406,1408$, $1428,1699$.

Downey and Co.

Appendix B.

Downfall of Grabbum, The ... ... 1361

Down West, and other sketches of Irish Life

Doyen de Kellerine, Le

...
1397

Drama in Muslin, $\dot{A} \ldots \ldots . \quad \ldots .1166$

Dramatic Scenes from Real Life ... 1185

Dr. Belton's Daughters ... ... 699

Drink (see Temperance) $61, \ddot{85}, 157,326$, 834, 1031, 1163, 1349, 1378, 1379.

Dromina

Druid's Cave, The $\quad \ldots \quad \ldots . \quad \ldots 1701$

Druidean the Mystic and other Irish Stories

... 1251

Druidess, The ... $\ldots .606065$

Dublin 2, 48, 65, 70, 77, 96, $103,110,116$ $125,134,174,241,295,348,360,370$, $417,419,468,525,554,569,573,596$, $630,641,649,698,721,723,779,800$, $822,823,886,904,909,920,930,940$, 952 A 967, 972, 992, 1091, 1096, 1191, $1198,1213,1217,1221,1231,1240$, $1248,1270,1298,1331,1355,1362$, $1437,1441,1454,1540,1579,1605$, $1615,1627,1660$.

Dublin University, see Trinity College.

Dubliners

823

Dublin Statues “At Home," "The ... 965

Dublin Story, A $\ldots . . . \quad \ldots .570$

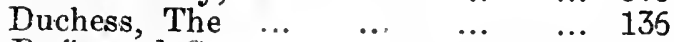

Duffy and Co. $\quad . . \quad$... Appendix B.

Duke of Monmouth, The ... .. 666

Dunferry Risin', The ... ... ... 1173

$\begin{array}{llllll}\text { Dunleary } & \ldots & \ldots & \ldots & \ldots & 521\end{array}$

Dunmara (Mulholland) $\quad \ldots . \quad \ldots 1199$

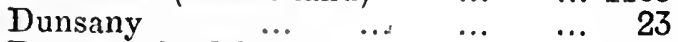

$\begin{array}{lllll}\text { Dust of the World } & \ldots & \ldots & \ldots & 719\end{array}$

\section{E}

Earl of Effingham, The

Earl or Chieftain

Early Gaelic Erin

Eccentricity

Edmond of I Lateragh ...

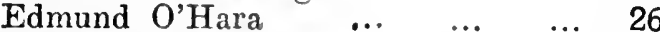

Edward O'Donnell $\ldots . . . . \quad \ldots 1172$

Eight O'Clock and other Stories ... 562

Eily O'Hartigan $\quad \ldots \quad \ldots \quad \ldots 1453$

Eldergowan and other Tales ...

Election, The ... ... ..

Elf Errant, The... …

Fllen

Ellmer Castle $\ldots . . \quad \ldots \quad \ldots$

Emerald Gems ... ...

Emerald Wreath
Emigrants of Ahadarra, The

.. 328

Enchantment $\quad . . \quad \ldots \quad \ldots \quad \ldots 1576$

Enchanted Lochan, The $\quad \ldots . \quad \ldots 261$

Enchanted Portal, The ... ... 966

England, Irish In, 92, 216, 230, 237, 390 , $540,543,549,600,614,706,756,760$, $770,779,798,817,851,856,879,1092$, $1129,1188,1196,1346,1427,1487$, 1596.

English Rose, An $\quad \ldots \quad \ldots . \quad \ldots 967$

$\begin{array}{lllllll}\text { Ennui } & \ldots & \ldots & \ldots & \ldots & \ldots & 544\end{array}$

Erin-go-bragh $\quad \ldots \quad \ldots \quad \ldots \quad \ldots 1124$

Escapades of Condy Corrigan $\quad . .783$

Fssence of Life, The ... $\quad . . \quad \ldots . \quad 116$

Esther Vanhomrigh $\ldots$. $\quad \ldots \quad \ldots 1676$

$\begin{array}{lllllll}\text { Ethne } & \ldots & \ldots & \ldots & \ldots & \ldots & 585\end{array}$

$\begin{array}{llllll}\text { Eva (Daunt) } & \ldots & \ldots & \ldots & \ldots & \ldots \\ \end{array}$

Eva, or Buried City of Bannow ... 711

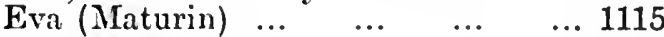

Eva MacDonald $\quad \ldots . \quad \ldots, \ldots 1014$

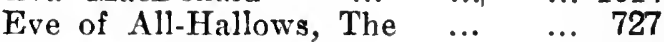

Eveline Wellwood $\ldots$. .. .. 1369

$\begin{array}{llllll}\text { Evelyn Clare } & \ldots & \ldots & \ldots & \ldots & 180\end{array}$

Evenings in the Duffrey $\quad \ldots . \quad \ldots .847$

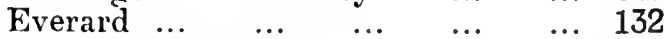

Eve's Paradise ... $\quad \ldots \quad \ldots . \quad \ldots \quad 242$

Fvil Eye, The $\ldots . \quad \ldots . \quad \ldots . \quad \ldots \quad 336$

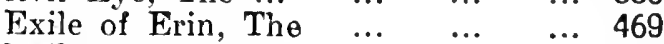

Exiled from Erin $\quad \ldots \quad \ldots \quad \ldots \quad 525$

Exploits of Captain ÖHagan $\ldots 1449$

Experiments of Garrymede Bum,

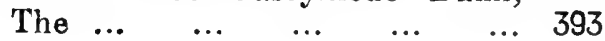

\section{F}

Faery Land Forlorn, A $\quad \ldots \quad \ldots 1378$

Fair Emigrant, A $\quad \ldots \quad \ldots . \quad \ldots 1206$

Fair Maid of Connaught, The $\quad \ldots 780$

Fair Irish Maid, The ... ... ... 993

$\begin{array}{llllll}\text { Fair Noreen } & \ldots & \ldots & \ldots & \ldots & 1223\end{array}$

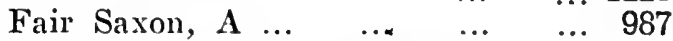

Fairies and Folk of Ireland ... $\quad \ldots \quad 620$

Fairy and Folk Tales of the Irish

Peasantry ... $\ldots . . . . \quad \ldots 1688$

Fairy-Faith in Celtic Countries, The 1658

Fairy Legends and Traditions of the South of Ireland...

424

2 Fairy Minstrel of Glenmalure, Tne ... 900

4 Fairy Stories from Erin's Isle ... 185

... 1201 Famine, the $\ldots 87,287,327,395,584$,

... $255 \quad 763,797,871,875,1143,1461,1468$,

$\ldots 1351 \quad 1594,1650,1652,1672$, and $\Lambda$ ppendix

$\ldots 1487$ C. I.

... 816 Fancy O'Brien $\quad \ldots .40 . \ldots 1048$

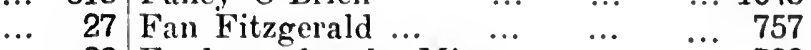

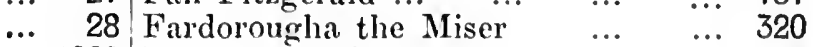

... 1292 Farewell to Garrymore $\quad \ldots . \quad \ldots 1404$ 
Fate of Father Sheehy

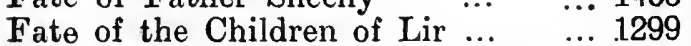

Fate of the Children of Tuireann ... 1300

Fate of the Children of Uisneach ... 1301

Father Alphonsus

Father Anthony

Father Butler

Father Butler and the Lough Derg Pilgrims

Fatiner Clancy

Father Connell

Father John

Father O'Flynn

Father Ralph

Father Tim

Father Tom of Connemara ...

Father Confessor The

Favourite Child, The ...

Fawn of Springvale, etc.

Feast of Bricriu, The ...

Telix O'Flanagan, an ...

Fenians $\ldots 88,101,195,340,347,406$ $571,600,618,623,704,726,766,797$, 868, 942, 968, 986, 987, 1032, 1085. $1088,1173,1205,1256,1268,1346$, 1406, 1505, 1512, 1513, and Appendix C. I.

Fenian Nignts' Entertainments

Fermanagh ... 109, 267, 277, 1050, 1385

Festivities at the House of Conan of Ceann Sleibhe

Fetches, The

Fians, The

Fianaigecht

$$
\begin{array}{ll}
\cdots & \cdots \\
\cdots & \cdots
\end{array}
$$

... 1336

Fight of Faith, The

Financing of Fiona, The

Finn and his Companions ...

Finn and his Warrior Band ...

Finn MacCoole

Finola

Fire of Green Boughs, Tne

Fireside Stories of Ireland, The

Fits and Starts

Fitzgerald the Fenian

Fitzgerald Family, The

Fitz-Hern

Five of Trumps, The ".

Flame and Flood, The

Flaws

Flight from the $\dddot{\mathrm{Cliff}}$, $\dddot{\text { The }}$...

$\cdots+\cdots 143$

... 306

... 1151

... 690

... 391

... 1310

... 1032

$\begin{array}{rr}\ldots & 1032 \\ \ldots & 207\end{array}$

... 1187

... 1425

... 848

... 596

... 1085

... 1082

... 181

... 598A

... 882

... 171

... 1240

Flight of the Eagle $\ldots . \quad \ldots \quad \ldots 1318$

Flitters, Tatters and the Counsellor 723

Florence Macarthy $\ldots$. .. $\quad \ldots 1182$

Florence O'Neill $\quad \ldots \quad \ldots . \quad \ldots .1547$

Flynns of Flyunville, The ... $\quad \ldots 697$

Fly on the Wheel, The $\quad \ldots \quad \ldots 1578$

Folk of Furry Farm, The $\ldots$... 1397

Folk-Lore-Sea Legends and Folk

Tals, Appendix C.

... III

Folk Tales and Fairy Lore $\ldots . \quad \ldots 1010$ A

Folk and Hero Tales (MacDougall) 1010

Folk and Hero Tales (MacInnes) ... 1027

Folk-Lore and Legends
Folk Tales of Breffny ...

... $\quad \ldots \cdot 790$

Following Darkness ... $\quad \ldots \quad \ldots 1412$

For Charles the Rover $\quad$... $\quad \ldots 1685$

For Church and Chieftain ... ... 1684

For Her Sake $\ldots . \quad \ldots \quad \ldots \quad \ldots 1458$

For This Cause $\quad \ldots . \quad \ldots . \quad \ldots 1581$

For Three Kingdoms ... $\ldots . \quad \ldots 440$

Ford, The $\ldots . \ldots . \ldots 1538$

Ford Family in Ireland $\quad \ldots \quad \ldots 33$

Forge of Clohogue, The ..... ... 1234

Fortune, Tne $\ldots \ldots \quad \ldots \quad \ldots, \ldots 643$

Fortunes of Col. Torlogh ÖBrien, The $\quad \ldots \quad \ldots . \quad \ldots \quad \ldots 905$

Fortunes of Glencore, The ... ... 932

Fortunes of Maurice Cronin, The ... 859

Fortunes of Maurice O'Donnell, The 1237

Fortunes of the Farrells, The ... 1642

Fortune-Teller's Intrigue, The ... 1385

Foster Brothers of Doon, The ... 1651

Foster Sisters, Tne _.. $\quad \ldots \quad \ldots 957$

$\begin{array}{llllll}\text { Foughilotra } & \ldots & \ldots & \ldots & \ldots & \ldots \\ & \ldots & \ldots & \ldots\end{array}$

Founding of Fortunes, The ... $\quad \ldots \quad 167$

Foundling Mick $\quad \ldots \quad \ldots \quad \ldots 1645$

Four Feathers, The $\quad \ldots . \quad \ldots \quad \ldots 1105$

Four in Hand ... ... $\quad \ldots . \quad \ldots \quad 598$

Four Little Mischiefs ${ }^{\ldots} \quad \ldots \quad \ldots 120 \%$

Four Shots from Down ... ... 1699

Frank Blake $\quad \ldots \quad \ldots \quad \ldots \quad \ldots 1258$

Frank Maxwell $\quad \ldots . \quad \ldots . \quad \ldots 911$

Frank O'Donnell, (Conyngham) $\ldots .395$

Frank O'Meara $\quad . . \quad \ldots . \quad \ldots \quad 34$

F'rench $\ldots 37,102,178,191,245,260$, $300,459,460,482,487,497,498,527$, $528,1005,1111,1115,1120,1174,1393$, 1488, 1509, 1558, 1647.

Frieze and Fustian ... $\quad \ldots \quad \ldots \quad 612$

Friends though Divided $\quad \ldots . \quad \ldots .742$

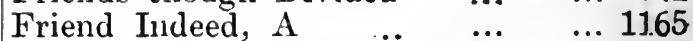

From the East unto the West ... 165

From the Green Bag ... ... ... 509

From the Land of tne Shamrock ... 166

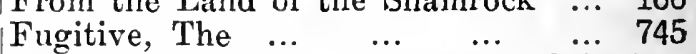

(See Wild Scenes Among the Celts.)

Fun o' the Forge ... ... ... 1331

Further Experiences of an Irish R.M. 1527

Further Stories of Ireland ... ... 962

Gaelic Fairy Tales ...

Gaels of Moondharrig

'Gainst Satan's Fangs

Galloping O'Hogan ...

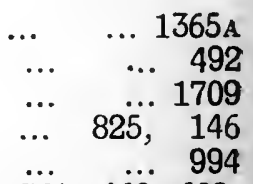

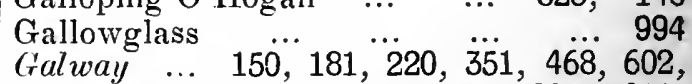
794, 827, 919, 932, 938, 971, 984, 1011, $1207,1269,1468,1480,1492,1512$, 1520, 1593, 1597.

Gambler, The ... .. $\quad \ldots \quad \ldots 1577$

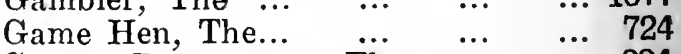

Gap of Barnesmore, The $\ldots . \quad \ldots .294$

32 Garden of Resurrection, The $\quad \ldots 1573$ 
Garden by the Sea, A ...

Garryowen

Gates of the North $\quad \ldots \quad \ldots \quad \ldots 1313$

General John Regan ... $\quad . . . \quad \ldots 208$

Gentle Blood

Gentleman in Debt, The

Gentleman's Wife, A ...

Geoffrey Austin, Student

Gerald and Augusta .

Gerald Barry

Gerald Fitzgerald (Kemble)...

Gerald Ffrench's Friends

Gerald Fitzgerald (Lever)

Geraldine, A

Geraldine Hamilton ... ... ... 1038

German, 22, 82, 143, 226, 452, 526, 680, $876,896,991,1094,1152,1425,1447$, 1486, 1499, 1501, 1570.

Ghost Hunter and his Family, The... 156

Ghost Stories, Irish, 115, 130, 982, 805, 838, 1062, 1491.

Girl of Galway, A

$\begin{array}{llll}\ldots & \ldots & \ldots & 1608\end{array}$

Girls of Banshee Castle. The...

Glade in the Forest, The ...

Glenanaar

Glencoonoge

Glen Farm, The..

Glenmornan

Glen of Silver Birches, The ...

Glenveagh

Glimpses of English History ...

Glimpses of Glen-na Mona ...

Gods and Fighting Men

Golden Bow, The

Golden Guard, The

Golden Hills

Golden Lad, The

Golden Lads and Girls

Golden Morn

Golden Spears

Good Men of Erin

Good Third, A ...

Good Women of Erin ..

Gossamer

Grace O'Donnell

Grace O'Halloran

Grace O'Malley...

Grace Wardwood

Grania

Grania Waile $\cdots$

Graves of Kilmorna, The

Green as Grass .

Green Cockade, The

Green Country, The

Green Tree, A ...

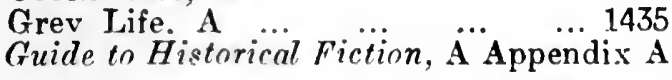

H

Hamper of Humour, A $\begin{array}{llll}\text { Handful of Days, A ... } & \ldots & \ldots & 461 \\ \text { Handrahan, The Irish Fairy } & \text { Man } & \ldots . & 1349\end{array}$

Handrahan, The Irish Fairy Man ... 1349

Handsome Quaker, The $\quad \ldots . \quad \ldots 1614$

Handy Andy ... $\quad . . \quad \ldots . \quad \ldots 959$

Harfe von Erin, Die ... $\quad \ldots \quad \ldots 1447$

$\begin{array}{lllll}\text { Harry Lorrequer } & \ldots & \ldots & \ldots & \end{array}$

$\begin{array}{lllll}\text { Harry O'Brien ... } & \ldots & \ldots & \ldots & 36\end{array}$

$\begin{array}{llllll}\text { Hatchways } & \ldots & \ldots & \ldots & \ldots & 1509\end{array}$

Hate Flame, The $\quad \ldots \quad \ldots . \quad \ldots \quad 182$

Haunted Church, The ... $\quad \ldots . \quad \ldots 1231$

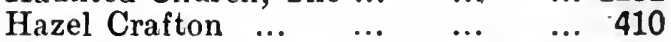

Heart of the Peasant and other Stories, The ... ... ... 1261

Heart of Erin, The $\ldots . \quad \ldots \quad \ldots 218$

Heart o' Gold ... ... ... ... 1628

Heart of a Monk, The... ... ... 115

Heart o' the Peat, The... $\quad \ldots . \quad \ldots 1127$

Heart of Tipperary, The $\quad \ldots \quad \ldots 160$

Hearts of Gold ... $\quad . . \quad \ldots . \quad \ldots 1332$

Hearts of Steel, The ...

Heir and No Heir ...

Heir of Liscarragh, The $\ldots . \quad \ldots 1390$

... 1217 Heiress of Carrigmona, The ... ... 494

... 1207 Heiress of Kilorgan, The $\ldots . \quad \ldots 1478$

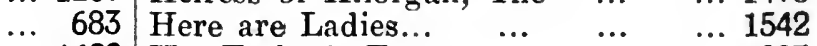

... 1499 Her Father's Trust $\ldots . \quad \ldots . \quad \ldots 1087$

... 873 Her Irish Heritage $\ldots . \quad \ldots . \quad \ldots 1519$

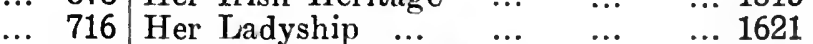

... 1017 Her Majesty's Rebels ...

$\begin{array}{ll}\ldots & 217 \\ & \text { Hermite en Irlande, } \mathrm{L}\end{array}$

... 349 Hermit of Glenconella, The ... ... 1004

... 518 Hermit of the Rock, The ... $\quad . .1473$

... 1330 Heroes of the Dawn ... $\quad . . \quad$... 1462

... 651 Hero Tales of Ireland ... $. . .64 . . .451$

... 435 Hero Tales ... ...Appendix C. II.

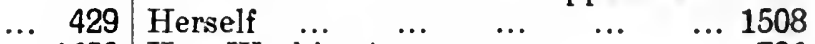

... 1652 Her Week's Amusement $\ldots .786$

... 1091 Hester's History $\ldots . \quad \ldots . \quad \ldots 1200$

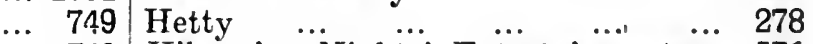

... 760 Hibernian Nights' Entertainments... 576

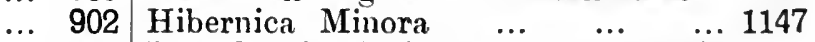

.. 473 High Deeds of Finn and other Bardic

.. 597 Romances of Ancient Irelund,

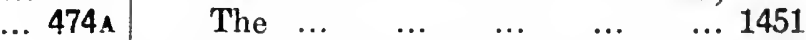

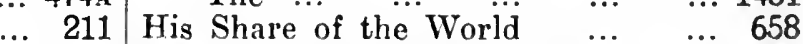

... 984 Histoire Légendaire de l'Irlande ... 178

... 1546 History in Fiction ... Appendix C. I.

... 1081 History of Ireland, Heroic Period ... 1308

... 718 History of Jack Connor, The ... 352

.. 891 History of Ned Evans, The ... ... 1660

... 1381 Hogan, M. P. ... ...

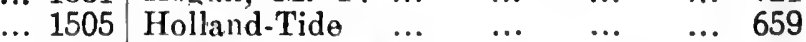

... 512 Homespun Yarns $\quad \ldots . \quad \ldots . \quad \ldots .595$

... 1375 Home Rule ... ... Appendix C. I.

... 1141 Honor O'Hara ... ... ... ... 1386

$\begin{array}{llllll}\ldots . & 999 & \text { Hon. Miss Ferrard, The } & \ldots & \ldots & 722\end{array}$

... 1435 Honor O'More's Three Homes $\quad \ldots .39$

Honourable Molly. The ... ... 1617

Honour of the Desboroughs, The

Hound of Culain

Appendix B.

House by the Churchyard, The ... 906 
House Mission, The

House in the Rath, The

House of Courage, The ... 1235

House of a Thousand Welcomes, The;

$$
\text { See Didy }
$$

House of Itisronar

House of the Crickets, The ...

House of the Foxes, The ...

House of the Secret, The ...

Howard ...

Hugh Bryan

Hugh Roach, the Ribbonman

Hugh Talbot

Humour, Irish

$\cdots$ A $\cdots$

Humour of Druid's Island, The

Humours of Donegal, The ...

Humours of Irish Life

Humours of Shanwalla, The ...

Hunger

Hunger, The

Hunting 376, 377, 379, 381, 382, 383, 384, $385,386,387,389,391,392,393,394$,

417, 468, 1303, 1528, 1638.

Hurrish

Hursh $\cdots, \ldots, \quad \ldots, \quad \ldots$

Hyacinth

.. 889

... 1431

... 194

\section{I}

\section{Ierne}

Ierne O'Neal

\section{Illustrious $\mathrm{O}$....}

Tlistrious O'Hagan The

Ill-Won Peerages

Imelda

Imperial Richenda

In Clay and Bronze

In Chimney Corners ...

In Cupid's Wars

In Mio's Youth.

In Spite of Jemima ...

In Mr. Knox's Country

Innisfail

In One Town

In a Roundabout Way

Inside Passenger, The

In Sarsfield's Days

Irreconcilables

In the Celtic Past

In the Days of Goldsmith

In the Devil's Alley ... ...

In the Irish Brigade ...

In the Kingdom of Kerry

In the King's Service

In the Valleys of South Down

In the Wake of King James

Insurgent Chief, The ... ...

Invasion, The

Invasion of Cromleigh

Inviolable Sanctuary, The ...

Ireland

Ireland: Its Humour and Pathos
Ireland: Its Myt'ns and Legends 606

... 118

... 1622

... 1634

... 629

... 1238

‥ 467

... 1025

... 1059

... 647

... 134

570

143

Ireland, a Tale ...

... 1102

Ireland's Dream

973

Ireland's Own Library... $\quad$ 590, 9055,956 , 1263, 1391, and Appendix B.

Irish Bar Sinister, The ... ... 1088

Irish Bubble and Squeak $\ldots . \quad \ldots \quad 41$

Irish Chieftain, The ... $\ldots . \quad \ldots 1116$

Irish Chieftain and his Family ... 1138

Irish Chieftains, The ... $\ldots \quad \ldots 220$

Irische Texte $\quad \ldots . \quad \ldots . \quad \ldots 1152$

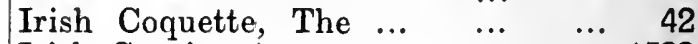

Irish Cousin, An $\quad \ldots \quad \ldots \quad \ldots 1522$

Irish Decade, An $\quad \ldots . \quad \ldots . \quad \ldots 1252$

Irish Detective $\quad \ldots . \quad \ldots \quad \ldots \quad 43$

Irish Diamonds (Smith, John) . ... 1518

Irish Diamonds (Bowles, Emily) ... 235

Irish Dove, The $\quad \ldots \quad \ldots \quad \ldots 1380$

Irish Drolleries $\quad \ldots . \quad \ldots . \quad \ldots 1177$

Irish Excursion, The ... ... ... 367

Irish Fairy Book, The

Irish Fairy Tales (Yeats') $\ldots . \quad \ldots 1691$

Irish Fairy and Folk Tales ... $\quad \ldots 1689$

Irish Fairy Tales (Strahan) $\quad \ldots .44$

Irish Fairy Tales (Leamy) $\ldots . \quad \ldots .899$

Irish Fireside Stories, Tales and $\begin{array}{llllll}\text { Legends } & \ldots & \ldots & \ldots & \ldots & 45\end{array}$

Irish Fireside Tales ... $\quad \ldots . \quad \ldots .826$

$\begin{array}{llllr}\text { Irish Folk-Lore } & \ldots & \ldots & \ldots & 1323 \\ \text { Irish Girl, The ... } & \ldots & \ldots & \ldots & 47\end{array}$

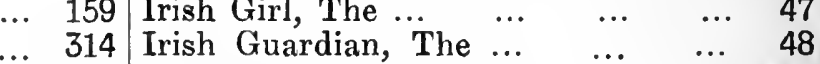

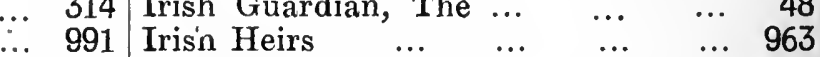

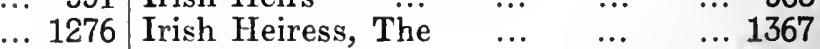

... 1018 Irish Holidays .. $\quad \ldots \quad \ldots \quad \ldots \quad \ldots 1584$

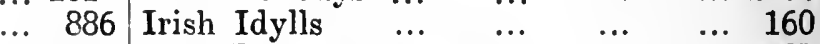

$\ldots 1708$ Irish Life and Character $\ldots . . .1003$

... 1061 Irish Life in Irish Fiction ... Appendix A.

... 637 Irish Life in the Castle and the Courts

.. 176 and the Country ... $\quad$.. $\quad \ldots \quad 293$

$\begin{array}{llllll}\ldots & 354 & \text { Irish Life and Humour } & \ldots & \ldots & 728\end{array}$

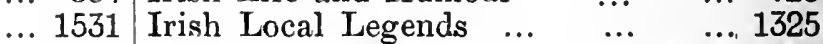

... 747 Irish Lover, An $\quad \ldots \quad \ldots . \quad \ldots \quad 297$

.. 505 Irisn Love Tales $\ldots . \quad \ldots . \quad \ldots .49$

... 1354 Irishman at Home, The $\quad \ldots . \quad \ldots .50$

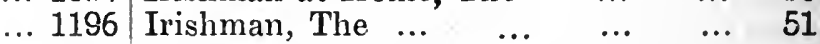

... 1242 Irishman's Luck, An ...

... 1053 Irishmen and Irishwomen $\ldots . \quad \ldots 250$

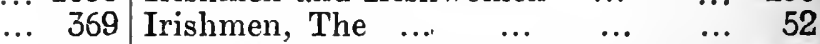

.. 316 Irish Militia Officer, The $\ldots . . \ldots 1307$

... 230 Irish National Tales and Romances

... 1402 Appendix B.

.. 744 Irish Necromancer $\quad \ldots \quad \ldots \quad \ldots 1097$

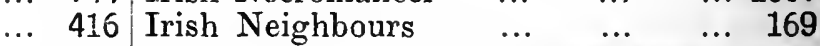

.. 244 Irish Orphan Boy in a Scottish Home,

.. 717 The $\quad \ldots .156$...

.. 1317 Irish Parish : “its $\dddot{\text { Sunshine and }}$

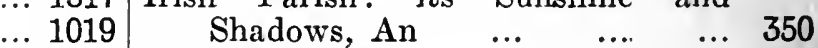

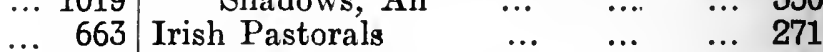

$\begin{array}{lllllll}\ldots & 656 & \text { Irish Pearl, The } & \ldots & \ldots & \ldots & 53\end{array}$

$\begin{array}{llllll}\ldots & 205 & \text { Irish Police Officer, The } & \ldots & \ldots & 453\end{array}$

$\begin{array}{llllll}\ldots & 560 & \text { Irish Pleasantry and Fun } & \ldots & \ldots & 54\end{array}$

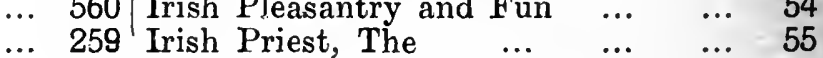


Irish Odyssey

Irish Priests and $\ldots$. . $\quad \ldots 1145$ English Landlords 249 Iriśn Rebels $\ldots . \quad \ldots \quad \ldots \quad \ldots 983$

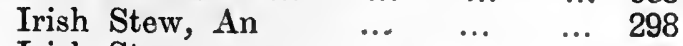
Irish Stew $\quad \ldots \quad \ldots \quad \ldots . \quad \ldots 1174$ Irish Town and Country Tales Irish Utopia, An

Irish Ways

Irish Widow, The

Irish Widow's Son, The

Irish Witchcraft and Demonology

Irishwoman in London

Irish Wonders ... ..

Irrelagh

Irreconcilables $\cdots, \quad \cdots \quad \cdots$

Isabella

Island of Sorrow, The ...

Island Parisin, The

Isle in the Water, An ...

Ismay's Children

J

Jabez Murdock ...

Jack Hazlitt ...

...

Jack Hinton

Jack Westropp ...

Jacquetta

Jamesie

Jane Sinclair

Jennie Gerhart.

Jerpoint

Jess and Co.

Jessamy Bride, The

Jeune Irlandais, Le

Jim Eagan

Joib, The...

Johanna ...

John-a-Dreams ...

John Doe

John Marmaduke

John and Mary ...

John Maxwell's Marriage

John Needham's Double

John Orlebar, Clerk..

Johnny Derrivan's Travels

John Sherman, and Dhoya...

John Thaddeus Mackay ...

John Townley ... ... ...

Joint Venture, Tne ... ...

Journeys with Jerry the Jarvey

Julia

$\begin{array}{llll}\text { Just Stories } & \ldots & \ldots & \ldots \\ \text { Julia Howard } & \ldots & \ldots & \ldots\end{array}$

Juvenile Library, The ...

Juvenile Tales ...

\section{$\mathbf{K}$}

Kate Geary

1103

Kathleen

Kathleen Carmichael's Recollections.

Kathleen Clare ...

... 982

... 396

... 1229

... 641

... 678

... 1602

... 726
Kathleen Mavourneen (M'Donnell, Randal William) ... ... ... 1005 Kathleen Mavourneen (Mulholland). 1194

Kathleen's Motto ... ... ... 59

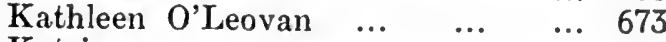

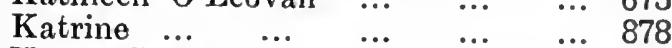

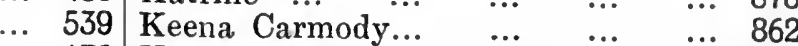

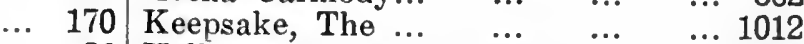

... 56 Kellys and O'Kellys, The $\ldots . \quad \ldots 1593$

... 1342 Kerrigan's Quality $\ldots . \quad \ldots . \quad \ldots .161$

... 1490 Kerry 63, 65, 66, 365, 416, 418, 571, 622,

... $695 \quad 623,644,664,698,955,993,1130,1131$,

... 720

$1132,1380,1425,1502,1621,1629$, 1662 .

Kidnapping of Sally Lunham _.. 364

Kilboylan Bank... ... $\quad$... $\quad \ldots .970$

Kilcarra $\ldots \quad \ldots \quad \ldots \quad \ldots \quad \ldots . \quad \ldots 1492$

Kildare 94, 258, 407, 893, 909, 945, 972,

Ki 1102, 1104, 1274, 1571, 1583.

$\begin{array}{llllll}\text { Kilgorman } & \ldots & \ldots & \ldots & \ldots & 1410\end{array}$

$\begin{array}{llllll}\text { Kilgroom } & \ldots & \ldots & \ldots & \ldots & 1410\end{array}$

Kilkee $\quad \ldots, \quad \ldots, \ldots, \ldots, \ldots 81$

Killenny $63,151,153,155,156,492,555$, 589, 637, 915, 1035.

Killarney $25,65,256,363,369,527,561$, $660,825,1138,1387,1479$.

Killarney Legends $\quad \ldots \quad \ldots . \quad \ldots \quad 423$

Killarney Poor Scholar, The ... ... 1550

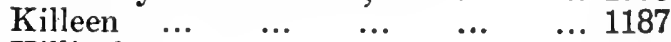

Killinchy $\quad \ldots \quad \ldots \quad \ldots \quad \ldots 1137$

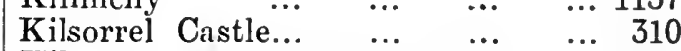

... 1090 Kiltartan Wonder-Book, The $\ldots 653$

.. 187. King of Claddagh, The $\quad \ldots \quad \ldots 602$

... 1159 Kings and the Cats, The $\ldots . \quad \ldots 78$

... 1111 King's Coming ... $\ldots . \quad \ldots . \quad \ldots 1682$

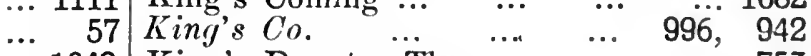

... 1049 King's Deputy, The $\ldots . . \quad \ldots . \quad \ldots 75$

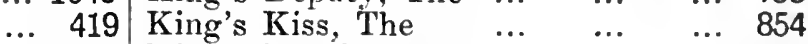

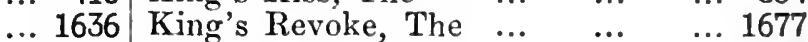

... 142 King's Signet, The ... ...

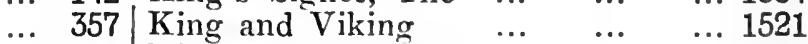

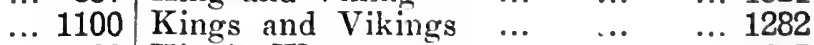

... 682 King's Woman, $A \quad \ldots . \quad \ldots . \quad \ldots 1613$

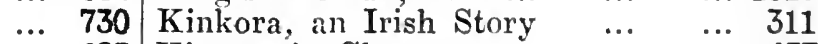

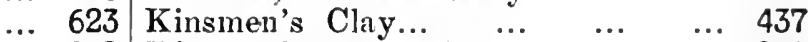

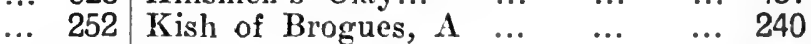

$\begin{array}{lllllll}\ldots 1690 & \text { Kit } & \ldots & \ldots & \ldots & \ldots & \ldots 1638\end{array}$

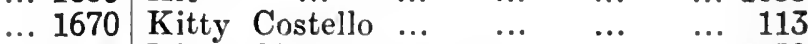

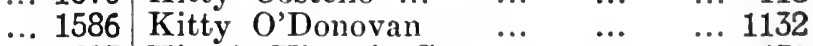

... 603 Kitty's Victoria Cross... $\quad \ldots \quad$... 430

... 1440 Knight of the Cave ... $\quad \ldots . \quad \ldots 1284$

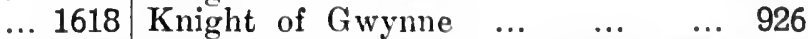

... 1352 Knights of the Pale, or Ireland 400

$\begin{array}{lllllll}\ldots 1097 & \text { years ago } & \ldots & \ldots & \ldots & \ldots & 1337\end{array}$

... 1417 Knights of the White Rose, The ... 670

... 6619 Knockinscreen Days ...

$\begin{array}{llllll}\text { Knocknagow } & \ldots & \ldots & \ldots & \ldots & 865\end{array}$

L

Lacemakers, The

1139

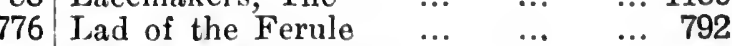

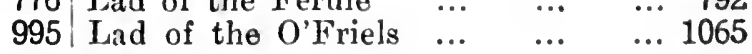


Lady of Deerpark, The

$\begin{array}{llllll}\text { Lady Eleanor } & \ldots & \ldots & \ldots & \ldots & 703 \\ \text { Lady Kildare } & . . & \ldots & \ldots & \ldots & 945\end{array}$

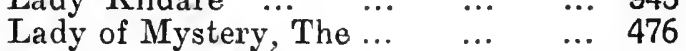

Lady of the Reef $\quad \ldots \quad \ldots \quad \ldots 1164$

Lake, The $\quad . . \quad \ldots . \quad \ldots \quad \ldots 1168$

Lake of Killarney, The $\quad \ldots . \quad \ldots 1387$

$\begin{array}{lllll}\text { Lalage's Lovers... } & \ldots & \ldots & \ldots & 201\end{array}$

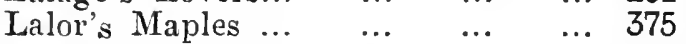

Land of the Kelt $\ldots$... $\quad \ldots \quad \ldots 660$

Land I Love Best, The (Tynan) ... 1604A
Land League 84, 195, 218, 405, 732, 888, $889.909,1085,1165,1166,1176,1210$, 1368, 1379, 1407, 1446, 1583, 1597.

Lind of Bondage

Land Smeller, The

Larry Lynch

Last of the Catholic OMalleys

Last of the Corbes

Last Drop of '68, The ... ...

Last Earl of Desmond, The ...

Last Forward. The ... ...

Last Hurdle, The

Last of the Irish Chiefs

Last King of Ulster. The

Last Monarch of Tara, The ...

Last Recruit of Clare's. The ...

Last Struggles of the Irish Sea Smugglers, The ...

$\begin{array}{lllll} & \end{array}$

... $\quad \ldots 276$

Laughter of Peterkin. The ... $\quad \ldots .1039$

Lays and Legends of Ireland...

Leading Lights All

... 1241

... 351

Leadin' Road to Donegal ... $\ldots 1056$

League of the Ring $\ldots . \ldots . \quad \ldots \quad 1263$

I.eaves from my Note Book $\quad . .6 \quad \ldots 663$

Led by a Dream $\quad \ldots \quad \ldots . \quad \ldots 1607$

Left-handed Swordsman, A $\ldots . \quad \ldots 1248$

Legendary Fictions of the Irish Celts 845

Legendary Stories of the Carlingford Lough District

Légendes irlandaises

Legend of $M^{\prime}$ Donnell and the Norman de Borgos

Legends of Comnaught

Legends and Fairy Tales of Ireland

Legends and Folk Tales..Appendix C.

Legends of the Lakes ...

Legends of Mount Leinster ... $\quad \ldots \quad$... 844

Legends of Saints and Sinners $\ldots 7.795$

Legends and Tales of Ireland $\quad \ldots .964$

Legends and Poems

Tegends and Stories of Ireland $\ldots . .961$

Legends, Tales and Stories of Ireland

Legends of the Wars in Ireland ...

Leigh of Lara...

Jeitrim

Leixlip Castle

Let Erin Remember

Let the Roof Fall In

Liadain and Cuirithir ... $\ldots$
Life and Acts of the Renowed and Chivalrous Edmund of Erin
411

527

1078

130

64

22

964

829

714

825

1000

90,1592

... 1275

... 1683

... 458

... 1149

1373
Life and Adventures of Bryan

O'Regan $\ldots$... $\quad \ldots \quad \ldots 1303$

Life, in the Irish Militia $\quad \ldots \quad$... 65

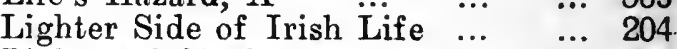

Light and Shade $\quad \ldots \quad \ldots \quad \ldots 1256$

Lights and Shadows of Irish Life... 687

Lily Lass $\quad \ldots . \quad \ldots \quad \ldots . \quad \ldots .990$

Limerick $8,149,220,347,589,657,664$, $743,880,881,905,937,1007,1053$, 1242, 1368, 1639, 1644, 1478.

Linda's Misfortunes \& Little Brian's Trip to Dublin

Lion's VVhelp, The

Lisheen $\begin{array}{llll} & & & \\ & & & \end{array}$

$\begin{array}{lllllll}\text { Lismore } & \ldots & \ldots & \ldots & \ldots & \ldots & 1502 \\ \text { Lismon } & \ldots & \ldots & \ldots & \ldots & 409\end{array}$

$\begin{array}{llllll}\text { Lismoyle } & \ldots & \ldots & \ldots & \ldots & 409 \\ & \ldots & \ldots & \ldots & \ldots & 421\end{array}$

Little Black Devil, The $\quad \ldots \quad$... 549

Little Bogtrotters, The $\quad \ldots \quad \ldots 1192$

Little Green Man, The $\quad \ldots . \quad \ldots \quad 519$

Little Snowdrop $\quad$.. $\quad \ldots \quad$... 1191

Little Irish Girl, A $\quad \ldots \quad \ldots \quad \ldots 787$

I.loyd Pennant ... $\quad \ldots . \quad \ldots . \quad \ldots 1247$

Lloyds of Ballymore ... $\quad . . \quad \ldots 1446$

Lois $\quad \ldots \quad \ldots \quad$.

London, Irish In 35, 147, 212, 21.6, 270 , $543,549,596,706,850,851,856,950$, $984,993,1103,1105,1122,1129,1194$, $1196,1213,1216,1220,1365,1427$, $1437,1500,1539,1540,1572,1573$, $1574,1577,1593,1596,1606,1661$, 1697.

Long Ever Ago ... $\quad \ldots \quad$... ... 781

$\begin{array}{llllll}\text { Longford } \ldots & \ldots & \ldots & \ldots & \ldots & 781 \\ & \ldots & \ldots & \ldots & & \ldots\end{array}$

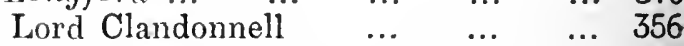

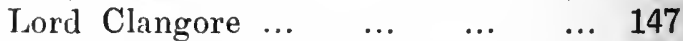

Lord Edward Fitzgerald $\quad \ldots \quad \ldots 227$

Lord Kilgobbin $\quad \ldots \quad \ldots . \quad \ldots \quad 942$

Lord Roche's Dauhgters of Fermoy. 1279

Lost Angel of a Ruined Paradise ... 1500

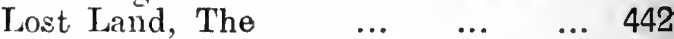

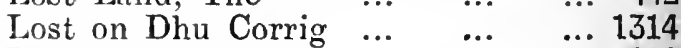

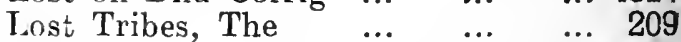

$\begin{array}{llllll}\text { Loughbar } & \ldots & \ldots & \ldots & \ldots & 877\end{array}$

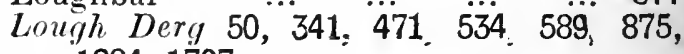
$1284,1707$.

Louisa Kirkbride; a Tale of New

York $\quad \ldots \quad \ldots \quad \ldots, \quad \ldots 1566$

Louth ... 240, 444, $7421405,1426,1477$

Love, the Atonement ... ... ... 303

Love of Comrades ... $\quad \ldots \quad$... 1109

Love Until Death $\quad \ldots \quad \ldots \quad \ldots \quad$... 239

Love that Kills ... $\quad \ldots . \quad \ldots . \quad \ldots 1672$

$\begin{array}{llllll}\text { Love is Life } & \ldots & \ldots & \ldots & \ldots & 1672 \\ \end{array}$

Love, the Player $\quad \ldots \quad \ldots . \quad \ldots 1484$

Love of Sisters ... $\quad \ldots . \quad \ldots . \quad \ldots 1615$

Loyal and Lawless $\ldots . \quad \ldots . \quad \ldots .286$

$\begin{array}{llllll}\text { Lucius Carey } & \ldots & \ldots & \ldots & \ldots & \\ \end{array}$

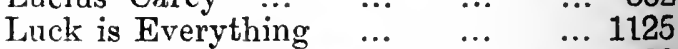

Luck of the Kavanaghs $\quad \ldots \quad \ldots 700$

Luke Delmege ... $\quad \ldots \quad \ldots \quad \ldots \quad \ldots 1498$

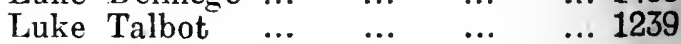

$\begin{array}{lllll} & & & & \\ \text { Luttrell of Arran } & \ldots & \ldots & \ldots & 1239 \\ & & & & \end{array}$ 
Luttrel's Doom

Mack the Miser

MacCarthy Mor

MacDermotts of Ballycloran, The 954

M'Donnells, The

MacMahon, The

MacMahon's Country $\quad \ldots \quad \ldots . \quad \ldots .21679$

Mac's Adventures

Mad Lord of Drumkeel, The...

Maelcho

Magic Horsehair, The ...

Maid of the Manse, A

Maid of Killarney, The

Major's Niece, The

Making of Jim O'Neill, The ...

Manor of Glenmore, The

Man's Foes, A ...

Manuscript Man, The ...

Marcella Grace

Marriage Bonds

Marrying of Bryan

Martin of Cro' Martin

Mary

Mary Dominick

Mary Lee

Mary of Avonmore Martial Career of Conghal Clairingh-
neach

Mary of the Winds

Master John

Master of Rathkelly

Matron of Erin, The

Maud Percy's Secret

Maunsel and Co.

Maureen

Maureen Dhu

Maureen's Fairing

Maureen Moore

Maurice and Berghetta

Maurice Rhynhart

Maurice Tiernay

Maurice Tyrone

Mavourneen

Maxwell Drewitt

Maynooth $\quad \ldots$ 94, 341, 680, 1372, 1571 $1356,1557,1645$.

Mayor of Windgap, The

Meath

218

$218,690,819,1355$

Meave

Meg McIntyre's Raffle

... ... 1079

... 66

... 277

... 1516

... 835
$\ldots .605$

Appendix B.

... 1075

... 163

... 123

.. 1866

.. 950

... 929

... 987

817

.. 1426

571

Memoirs of Barry Lyndon, Esq., The 1565

Memoirs of Gerald O'Connor

Memories of a Month Among tine

$\begin{array}{ccccc}\text { Mere Irish " } & \ldots & \ldots & \ldots & 607\end{array}$

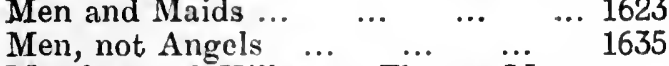

Merchant of Killogue, The; a Munster Tale
Mermaid of Innish-nig, The ... $\quad \ldots \quad 551$

Mermaid of Loch Lene, The $\quad \ldots \quad \ldots \quad 363$

Mervyn Gray $\quad \ldots \quad \ldots \quad \ldots . \quad \ldots \quad 1157$

Mervyn O'Connor and other Tales ... 486

$\begin{array}{llllll}\text { Mesca Ulad } & \ldots & \ldots & \ldots & \ldots & 740\end{array}$

Methodists $\quad \ldots \quad \ldots \quad \ldots \quad \ldots \quad 860,1114$

Michael Cassidy $\quad \ldots \quad \ldots . \quad \ldots \quad 713$

Michael Dwyer, the Insurgent $\begin{array}{llllll}\text { Captain } & \text {.. } & \ldots & \ldots & \text {... } & 309\end{array}$

Michael O'Donnell $\quad \ldots \quad \ldots . \quad \ldots 1093$

$\begin{array}{lllll}\text { Mick McQuaid } & \ldots & \ldots & \ldots & 969\end{array}$

$\begin{array}{llllll}\text { Mick Tracy } & \ldots & \ldots & \ldots & \ldots & \ldots \\ \end{array}$

892 Mickey Finn Idylle $\quad . . \quad \ldots \quad \ldots \quad \ldots 807$

Mickey Finn's New Irish Yarns ... 807A

Mickey Mooney, M.P. ... ... 1485

6 Midlands $\ldots 1142,1397,1434,1446$.

202 Mignty Army, The ... ... . ... 916

Migratory Labourers ... $\quad \ldots \quad 192,1016$

Milesian Chief, The $\quad \ldots \quad \ldots \quad \ldots 1112$

4. Military Mosaics $\quad \ldots . \quad \ldots . \quad \ldots 1358$

3 Miller of Glanmire $\quad \ldots \quad \ldots \quad \ldots \quad \ldots \quad i 230$

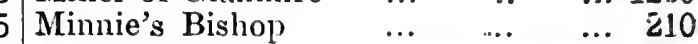

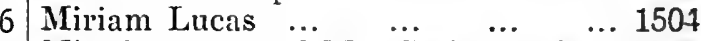

4 Misadventures of Mr. Cathyne, Q.C. 1637

Miscellanies $\quad \ldots \quad \ldots \quad \ldots \quad \ldots \quad \ldots 1086$

$\begin{array}{lllr}\text { Miss Edgeworth's Irish Stories } & \ldots & 547\end{array}$

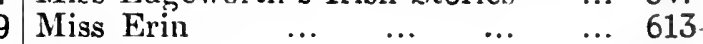

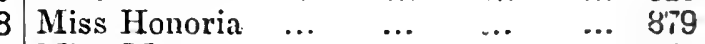

$\begin{array}{llllll}\text { Miss Mary } & \ldots & \ldots & \ldots & \ldots & \mathbf{1} 637\end{array}$

$\begin{array}{llllll}\text { Miss O'Corra } & \ldots & \ldots & \ldots & \ldots & 121 \\ & \ldots & \ldots & \ldots & 121\end{array}$

Misther O'Ryan $\quad \ldots . \quad \ldots . \quad \ldots 1673$

Mistletoe and Shamrock, The $\quad \ldots \quad 58$

$\begin{array}{lllll}\text { Mixed Pack. A } & \ldots & \ldots & \ldots & 389\end{array}$

$\begin{array}{llccc}\text { Modern Daedalus } & \ldots & \ldots & \ldots & 369 \\ & . . & . . & \ldots & 649\end{array}$

$\begin{array}{lllll}\text { Molly Bawn } & \ldots & \ldots & \ldots & 785\end{array}$

$\begin{array}{llllll}\text { Molly Carew } & \ldots & \ldots & \ldots & \ldots & 216\end{array}$

$\begin{array}{llllll}\text { Monaghan } & \ldots & \ldots & \ldots & \ldots & 210 \\ & & \ldots & \ldots & \ldots & 221\end{array}$

Mona the Vestal $\quad \ldots . \quad \ldots . \quad \ldots 495$

Moneylender, The $\quad \ldots \quad \ldots . \quad \ldots \quad 533$

$\begin{array}{llllll}\text { Mononia } & \ldots & \ldots & \ldots & \ldots & 389\end{array}$

Moonlight by the Shammon Snore ... 1368

$\begin{array}{llll}\text { Moores of Glyn, The ... } & \ldots & \ldots & 677\end{array}$

More Celtic Fairy Tales $\quad$... $\quad$... 804

More about Pixie $\quad \ldots \quad \ldots \quad \ldots 1641$

Mother, The $\quad . . \quad \ldots \quad \ldots . \quad \ldots 1371$

Mothers and Sons $\quad \ldots . \quad \ldots . \quad \ldots 253$

Mountcashel's Brigade $\quad$.. $\quad \ldots 693$

$\begin{array}{lllll}\text { Moy O'Brien } & \ldots & \ldots & \ldots & \ldots \\ 1568\end{array}$

Mr. Butler's Ward ... ... .. 14jj

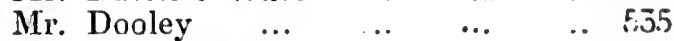

$\begin{array}{lllll}\text { Mr. Dooley Says } & \ldots & \ldots & \ldots & 5.35\end{array}$

$\begin{array}{llllll}\text { Mr. Muldoon } & \ldots & \ldots & \ldots & \ldots & 1298\end{array}$

Mrs. Desmond's Foster Child $\quad \ldots 1345$

Mrs. Martin's Company _.. $\quad \ldots \quad 164$

Mrs. Martin's Man $\quad . . \quad \ldots . \quad \ldots \quad 563$

Mrs. Mulligan's Millions $\quad \ldots . \quad \ldots 1076$

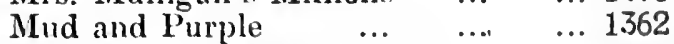

... 1362

... 685

... 400

... 1370

... 811 
My Foster Brother

... $280 \mid$

My Lady Clancarty

My Lady of the Chimney Corner
My Lords of Strogue ... ...

My New Curate

My Own Story ...

My Uncle the Curate

Mystery of Killard, The

My Sword for Patrick Sarsfield

Myths and Folk-Lore of Ireland

Myths and Legends of the Celtic Race 1450

\section{$\mathbf{N}$}

Naboth's Vineyard

1523

Nanno

Narcissa's Ring...

National Feeling

'Neath Sunny Skies

Ned McCool and his Foster Brother.. 1305

$\begin{array}{llllll}\text { Ned Rusheen } & \ldots & \ldots & \ldots & \ldots & 456\end{array}$

$\begin{array}{llllll}\text { Neighbours } & \ldots & \ldots & \ldots & \ldots & 441\end{array}$

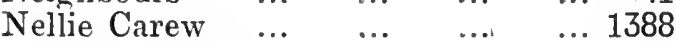

Nellie Netterville $\quad \ldots \quad \ldots . . . .299$

Nelly Nowlan and other Stories ... 691

Nessa

Nevilles of Garretstown

New Lights

Next Time, The; a Story of 'Fortyeight

Night Nurse, The

Nightshade

Nine Days' Wonder, $\begin{array}{llll}\ldots & \ldots & \ldots & 420 \\ & \ldots & \end{array}$

\begin{tabular}{llllll} 
Ninety-eight & $\ldots$ & $\ldots$ & $\ldots$ & $\ldots$ & 573 \\
\hline
\end{tabular}

Ninety-Eight and Sixty Year's After 805

Noel D'Auvergne $\quad \ldots \quad \ldots \quad \ldots 1424$

Nora Brady's Vow $\quad \ldots . \quad \ldots . \quad \ldots 496$

\begin{tabular}{llllll} 
Nora Creina & $\ldots$ & $\ldots$ & $\ldots$ & $\ldots$ & 789 \\
\hline
\end{tabular}

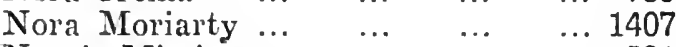

Nora's Mission $\ldots . \quad \ldots \quad \ldots \quad \ldots \quad \ldots 591$

$\begin{array}{lllll}\text { Norah of Waterford } & \ldots & \ldots & \ldots & 1226\end{array}$

Noreen Dhas

North East Corner. The

Northern Irish Tales ...

Northern Iron. The ...

North . South and Over the Sea

North Star, The

Northerners of ' 98 , The

No Sign ... ... ...

Not Peace but a Sword

Nowlans. The ... ...

Nuala

Nugents of Cariconna

Nun's Curse, The

Nurse $M^{\prime}$ V Vourneen

\section{0}

O'Briens and O'Flahertys, Tne

Ochil Fairy Tales

O'Connors of Ballynahinch, The

O'Donel

DDonnells of Glen Cottage, The

9

O'Donnells of Inchfawn, The 1128

O'Donoghue, The $\quad \ldots \quad$...

924

O'Driscoll's Weird $\quad \ldots \quad \ldots . \quad \ldots 1659$

$\begin{array}{lllll}\text { Off the Skelligs } & \ldots & \ldots & \ldots & 796\end{array}$

O'Flynn, The

...

… 992

O'Grady of Trinity

761

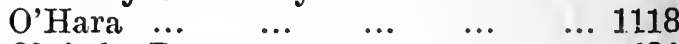

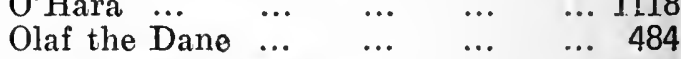

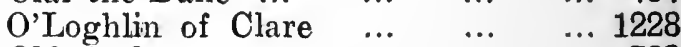

$\begin{array}{llllll}\text { Old Andy } & \ldots & \ldots & \ldots & \ldots & 388\end{array}$

Old Celtic Romances $\ldots \ldots \ldots$...

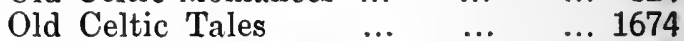

Old Corcoran's Money $\quad \ldots . \quad \ldots .502$

Old Country, The ... ... ... 72

Old House by the Boyne, The $\quad . .1477$

Old Irish Hearths and Homes ... 365

Old Irish Knight, The $\quad$.. $\quad \ldots .485$

Old Knowledge, The ... $\quad \ldots \quad \ldots 681$

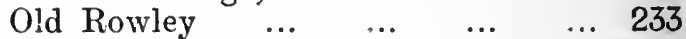

Old School Friends $\quad \ldots \quad \ldots \quad \ldots 1225$

$\begin{array}{llllll}\text { Old 'Times } & \ldots & \ldots & \ldots & \ldots & 1671\end{array}$

Old Times in Ireland ... $\quad \ldots \quad \ldots 1644$

Old-Time Stories of Erin $\quad \ldots \quad \ldots \quad 472$

$\begin{array}{llllll}\text { Old Trinity } & \ldots & \ldots & \ldots & \ldots & 822 \\ & & & \end{array}$

$\begin{array}{llllll}\text { Olive Lacy } & \ldots & \ldots & \ldots & \ldots & 135 \\ & & \ldots & \end{array}$

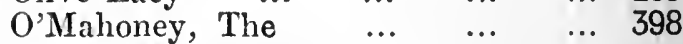

$\begin{array}{lllll}\text { O'Neill McDarragh } & \ldots & \ldots & \ldots & 73\end{array}$

\begin{tabular}{llllll} 
On Tiptoe & $\ldots$ & $\ldots$ & $\ldots$ & $\ldots$ & 74 \\
\hline
\end{tabular}

On an Ulster Farm $\quad \ldots . \quad \ldots \quad \ldots 707$

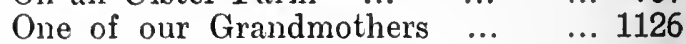

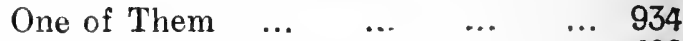

One Outside, The $\quad \ldots \quad \ldots 6 \quad \ldots 600$

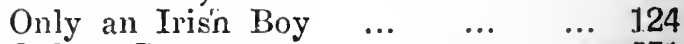

$\begin{array}{llllll}\text { Only a Lass } & \ldots & \ldots & \ldots & \ldots & 531\end{array}$

$\begin{array}{lllllll}\text { Onora } & \ldots & \ldots & \ldots & \ldots & \ldots & 1210\end{array}$

Orange and Green $\quad \ldots \quad \ldots \quad \ldots 743$

$\begin{array}{llllll}\text { Orange Lily } & \ldots & \ldots & \ldots & \ldots & 432\end{array}$

Orangeman, The $\quad \ldots \quad \ldots \quad \ldots \quad 588$

Orangemen $\ldots 206,323,405,432,444$, $523,738,840,856,973,983,1059,1307$, 1361.

... 1286 O'Reilly of the Glen ... ... ... 1702

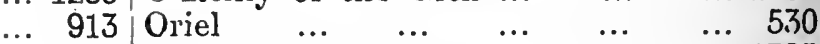

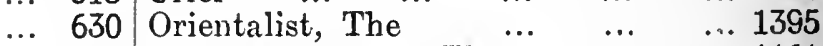

$\ldots 197$ Original Woman, The $\ldots . \quad \ldots 1161$

... 614 Origin of Plum Pudding, The $\ldots 777$

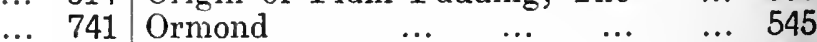

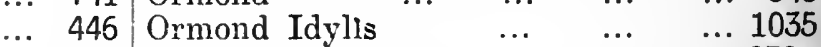

$\ldots 767$ O'Reilly of the Glen $\ldots . \quad \ldots . \quad \ldots 232 \mathrm{~A}$

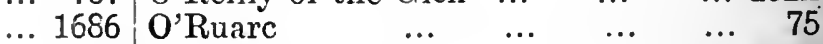

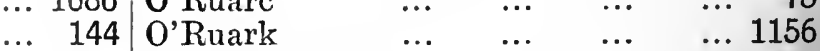

... 1054 O'Ruddy, The $\ldots . \quad \ldots . \quad \ldots . \quad \ldots 408$

... 772 O'Shaughnessy Girls, The $\ldots . \quad \ldots 1220$

... 1429 O'Sullivan, Dernière Insurrection de

$\begin{array}{lllllll}\ldots & 254 & \text { l'Irlande } & \ldots & \ldots & \ldots & \ldots\end{array}$

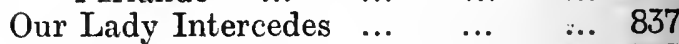

Our Own Country $\quad \ldots \quad \ldots \quad \ldots \quad \ldots 855$

$\begin{array}{lllll}\text { Our Own Story ... } & \ldots & \ldots & \ldots & 1222\end{array}$

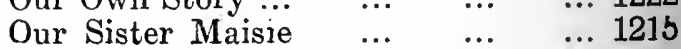

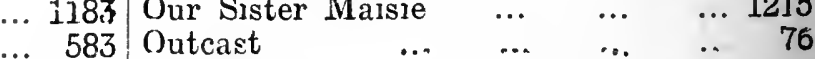

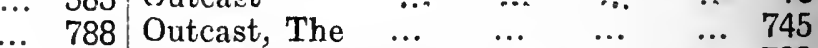

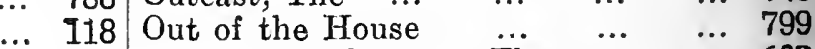

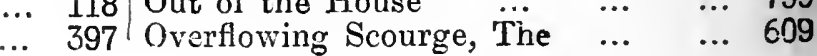




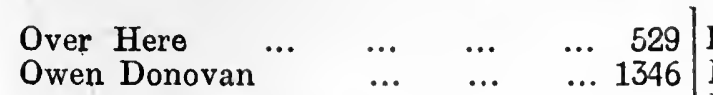
$\mathbf{P}$

Paddiana

Paddy ... $\quad \ldots \quad \ldots \quad 222$

Paddy go Easy and his Wife Nancy.. 322

Paddy the Next Best Thing ... 1365

$\begin{array}{llllll}\text { Paddy Risky } & \ldots & \ldots & \ldots & \ldots & 1142\end{array}$

Paddy's Woman $\quad \ldots . \quad \ldots . \quad \ldots .806$

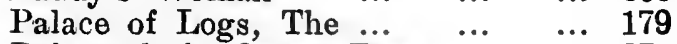

Pale and the Septs, The $\quad . . \quad \ldots 1274$

$\begin{array}{llllll}\text { Parra Sastha } & \ldots & \ldots & \ldots & \ldots & 322\end{array}$

Parish Priest in Ireland, The ... 748

Passion and Pedantry... $\quad \ldots \quad \ldots \quad \ldots 7$

Passionate Hearts, The $\quad . . \quad \ldots \quad 315$

Passion of Kathleen Duveen, The ... 1133

$\begin{array}{lllll}\text { Pastoral Annals... } & \ldots & \ldots & \ldots & 875\end{array}$

$\begin{array}{lllllll}\text { Pat } & \ldots & \ldots & \ldots & \ldots & \ldots & 140\end{array}$

$\begin{array}{lllll}\text { Pat o' Nine Tails } & \ldots & \ldots & \ldots & 226 \\ \end{array}$

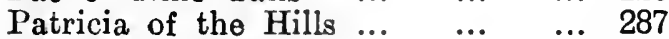

Patriot Brothers, The... $\quad \ldots \quad \ldots 694$

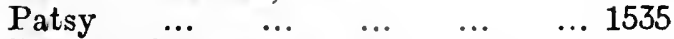

Pearl of Lisnadoon $\quad \ldots . \quad \ldots . \quad \ldots 561$

Peasant Lore from Gaelic Ireland... 481

\begin{tabular}{llllll} 
Peas-Blossom & $\ldots$ & $\ldots$ & $\ldots$ & $\ldots$ & 78 \\
\hline
\end{tabular}

Peep o' Day Boy $\quad \ldots . \quad \ldots . \quad \ldots 263$

Peg the Rake $\ldots . \quad \ldots . \quad \ldots \quad \ldots 1433$

$\begin{array}{lllllll}\text { Peggy } & \ldots & \ldots & \ldots & \ldots & \ldots & 462\end{array}$

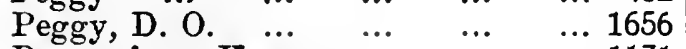

Peggy from Kerry $\quad \ldots . \quad \ldots . \quad \ldots .1131$

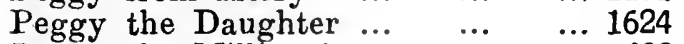

Peggy the Millionaire... $\quad \ldots \quad \ldots \quad 402$

Peg o' My Heart $\quad \ldots . \quad \ldots$.

Penal Laws 220, 334, 446, 493, 827, 844, 852, 984, 1096, 1181, 1549, 1588.

Penitent, The ... $\quad . . \quad \ldots \quad$...

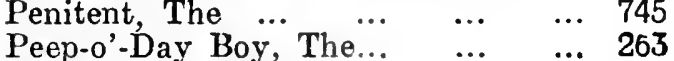

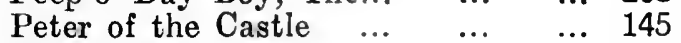

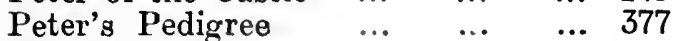

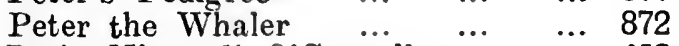

Petite-Niece d' O'Connell $\ldots . \quad \ldots .459$

Philip O'Hara's Adventures ... $\quad \ldots .79$

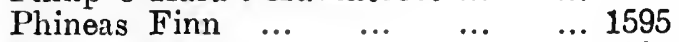

Phineas Redux ... $\quad \ldots . \quad \ldots . .151596$

Picnics from the Dublin Penny $\begin{array}{lllll}\text { Journal } & \ldots & \ldots & \ldots & \ldots\end{array}$

Pig-driving Peelers, The $\ldots$. .. 867

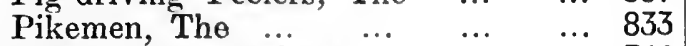

Pilgrim from Ireland ... $\quad \ldots . \quad \ldots \quad 346$

Pilgrim from Ireland ... $\quad \ldots . \quad \ldots \quad 1094$

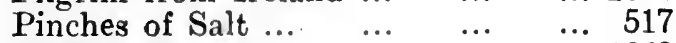

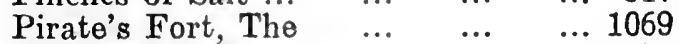

Pirate of Bofine...

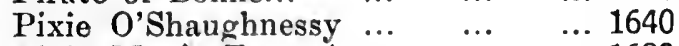

Plain Man's Tale, A ... $\quad \ldots . . \quad \ldots .1680$

Plan of Campaign, The $\quad . . . \quad \ldots \quad 1437$

Plough and the Cross, The ... ... 1355

Plucking of the Lily $\ldots . . .6 . \quad \ldots 634$

Poems and Stories of FitzJames

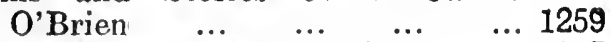

Poems of Oisin, Bard of Erin...
Point of Honour, The ...

Yoliceman Flynn $\quad \ldots \quad \ldots . \quad \ldots 1703$

Poor Paddy's Cabin ... ... $\quad \ldots \quad 81$

Poor Scholar and other Tales, The... 318

Popular Idol, The ... $\ldots{ }^{2} \quad \ldots 1030$

Popular Tales of the West Highlands 304

Popular Tales and Legends of the

$\begin{array}{lllll}\text { Irish Peasantry } & \ldots & \ldots & \ldots & 82\end{array}$

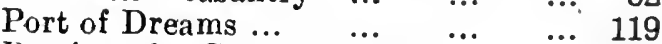

Portion of a Champion, The ... $\quad$... 1587

Poteen Punch ... ... ... ... 225

Poverty and the Baronet's Family... 192

Presbyterian Peasantry 272, 413, 431, 563, 706, 707, 1020, 1021, 1023, 1025, 1361 .

Pretty Rose O'Donoghue ... ... 83

Priests 5, 9, 30, 31, 53, 55, 67, 69, 76,84 , $85,90,110,118,133,134,139,141,142$, $144,155,180,181,182$, 195, 201, 203, $207,215,222,228,249,250,251,253$, $262,281,286,300,313,319,323,325$, $326,372,461,465,467,474,484,489$, $523,539,548,551,579,593,594,598$, $612,615,616,622,623,638,676,677$, $678,679,680,691,713,720,725,734$, $750,753,766,809,810,818,822,836$, $868,873,948,970,971,994,1016$, $1017,1030,1058,1073,1075,1080$, $1097 \mathrm{~A}, 1107,1135,1146,1155,1167$, $1168,1172,1183,1185,1198,1221$, $1240,1244,1245,1246,1274,1280$, $1294,1295,1310,1355,1356,1359$, $1372,1374,1400,1406,1429,1466$, $1497,1498,1501,1517,1537,1558$, $1571,1576,1583,1586,1589,1592$, $1601,1632$.

Priests Irish ... ... Appendix C. V.

Priests Boy, The $\ldots{ }^{2}$... ... 1245

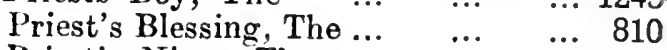

$\begin{array}{lllll}\text { Priest's Niece, The } & \ldots & \ldots & \ldots & 734\end{array}$

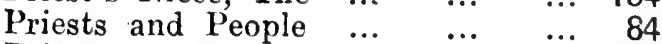

Prince Errant, A $\quad \ldots . \quad \ldots . . .1664$

Prince of Lisnover, The $\quad \ldots .61421$

Prince Patrick ... $\ldots . \quad \ldots . \quad \ldots 6646$

Prince of Tyrone, $A \ldots . \quad \ldots . \quad \ldots .675$

Princess Katharine $\quad \ldots \quad \ldots \quad \ldots 1630$

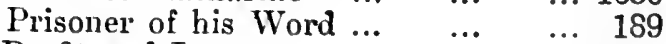

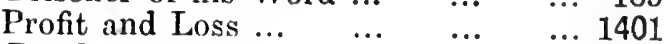

$\begin{array}{llllll}\text { Pro Patria } & \ldots & \ldots & \ldots & \ldots & 1031\end{array}$

Prophet of the Ruined Abbey, The... 1400

Proselytism 22, 26, 27, 30, 33, 38, 46, 53, $56,67,69,76,81,85,96,181,235,248$, $249,251,256,281,319,323,369,479$, 585, $1666,1399$.

$\begin{array}{llll}\text { Protestant Rector, The } & \ldots & \ldots & 85\end{array}$

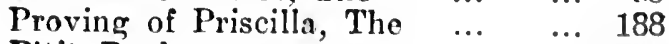

$\begin{array}{lllll}\text { P'tit Bonhomme } & \ldots & \ldots & \ldots & 1645\end{array}$

$\begin{array}{llllll}\text { Puck's Hall } & \ldots & \ldots & \ldots & \ldots & 1408\end{array}$

$\begin{array}{llllll}\text { Punchestown } & \ldots & \ldots & \ldots & \ldots & 1657 \\ \text { Pun }\end{array}$

Purcell Papers, The $\ldots . .6 .4 .6907$

Puritan, The $\ldots \begin{array}{lllll}\ldots & \ldots & \ldots & \ldots & \varepsilon \cdot 6\end{array}$

Pursuit after Diarmuid O'Duibhne and Grainne

1320

... 1513 Pursuit after Diarmuid and Grainne 1321 


\section{Q}

Quaint Irish Bygones

Quarterclift, The

Queen of Connaugint, The

Queen of Men, A ...

Queen's County $\ldots$....

"Quis?"

$\mathbf{R}$

Race of Castlebar

RaIph Wynward

Rambling Rector

Random Stories

Ranelagh, the Lightning Irish Detective

Ratllin Island

Rathlynn

Rat-Pit

Ravensdale

Real Charlotte, The $\ldots{ }^{\ldots} \quad \ldots \quad$... 1524

Real Life in Ireland $\ldots . \quad \ldots . \quad \ldots .554$

Real Pictures of Clerical Life in Ireland

Rebellion of Silken Thomas, The $\ldots . \quad 580$

Rebellen in Irland, Die $\quad . . \quad$... 876

Rebels, The $\quad \ldots \quad \ldots \quad \ldots . \quad \ldots \quad 228$

Recits du Foyer $\quad \ldots \quad \ldots . \quad \ldots \quad 527$

Recollections of an Irish Police Magistrate

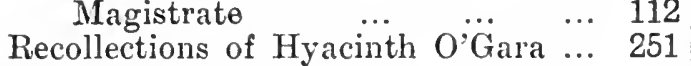

$\begin{array}{llllll}\text { Red Cloud } \quad . . & \ldots & \ldots & \ldots & 292\end{array}$

Red-Haired Man's Wife, Tne $\quad \ldots 340$

Red-Haired Woman, The ... ... 858

Red Hand of Ulster, The (Birmingham)

Red Hand of Ulister, The (Sälier) $\cdots 206$

$\begin{array}{llll}\text { Red Hugh's Captivity } & \text {... } & \text {... } & 1309\end{array}$

Red Leaguers, The $\ldots . \quad \ldots . \quad \ldots \quad 273$

Redmond O'Hanlon $\quad \ldots . . \quad \ldots . \quad \ldots .337$

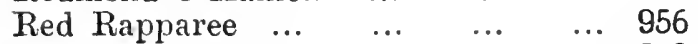

Red Route, The $\quad \ldots \quad \ldots . \quad \ldots 1512$

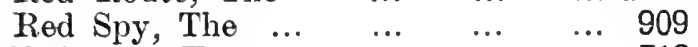

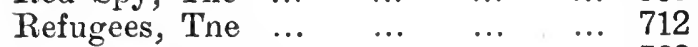

Reliquiae Celticae $\quad \ldots . \quad \ldots . \quad \ldots \quad 302$

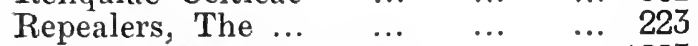

Resident Magistrate, The $\quad \ldots \quad \ldots 1553$

Return of Claneboy, The ... ... 577

Return of Mary O'Murrough, The ... 1218

Return of the O'Mahoney, The ... 618

Revolt of the Young MacCormacks,

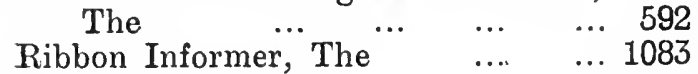

Ribbonman, The $\ldots \quad \ldots \ldots, \ldots 1655$

R.I.C. $\quad$.. 63, 258, 373, 453, 454, 870

$\begin{array}{llllll}\text { Ridgeway } & \ldots & \ldots & \ldots & \ldots & 88\end{array}$

$\begin{array}{llllll}\text { Ring of Day } & \ldots & \ldots & \ldots & \ldots & \ldots \\ \end{array}$

$\begin{array}{lllll}\text { Ring o' Rushes } & \ldots & \ldots & \ldots & 269\end{array}$

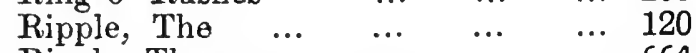

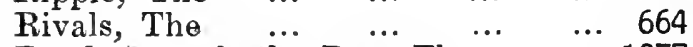

Road tnrough the Bog, The
Robber Chieftain, The

Robert Emmet $\quad$.. $\quad \ldots . \quad \ldots .684$

Robin's Readings $\quad \ldots . \quad \ldots . \quad \ldots 976$

Rockite, The $\quad \ldots \quad \ldots \quad \ldots . \quad \ldots \quad 556$

Rody the Rover $\quad$.. $\quad \ldots \quad$... 324

Roland Cashel $\quad$... $\quad \ldots . \quad \ldots .927$

Roland Kyan ... ... ... ... 1558

Roman Catholic Priest, The... ... 90

Romans Irlandais $\quad \ldots \quad \ldots . \quad \ldots 1647$

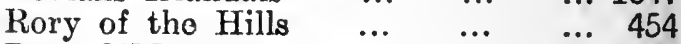

Rory O'Moore $\ldots . \quad \ldots \quad \ldots . \quad \ldots 958$

Rosaleen O'Hara $\quad \ldots \quad \ldots . \quad \ldots .115$

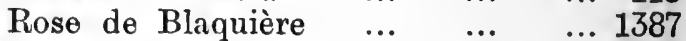

Rose O'Conno: $\quad \ldots \quad \ldots . \quad \ldots \quad 871$

Rose of the Garden $\quad \ldots \quad \ldots . \quad \ldots 1631$

Rose Parnell $\quad \ldots \quad$.. $\quad$... $\quad$.. 399

Rose and Shamrock ... $\quad \ldots .4 \quad \ldots 443$

Rose, Shamrock and Thistle ... $\quad \ldots .863$

$\begin{array}{llllll}\text { Rosette } & \ldots & \ldots & \ldots & \ldots & 1270\end{array}$

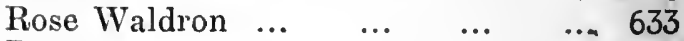

$\begin{array}{llllll}\text { Rosnah } & \ldots & \ldots & \ldots & \ldots & 839\end{array}$

Round about Home $\quad . . \quad \ldots . \quad \ldots \quad \ldots .347$

Round Tower of Babel $\quad \ldots . \quad \ldots .513$

Rowland Cashel $\quad \ldots \quad \ldots . \quad \ldots 927$

Ruined Race, A $\quad$.. $\quad \ldots \quad \ldots 1511$

Rumning Double $\quad \ldots . \quad \ldots . \quad \ldots 779$

Ruth Werdress $\quad \ldots \quad \ldots . \quad \ldots \quad 593$

Royal Democrat, A $\quad \ldots \quad \ldots . \quad \ldots 1153$

s

Sagen aus dem Alten Irland... ... 1570

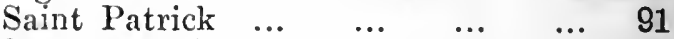

Saints and Sinners $\ldots . \quad \ldots \quad \ldots \quad 466$

$\begin{array}{lllllll}\text { Sally } & \ldots & \ldots & \ldots & \ldots & \ldots & 386\end{array}$

Sandy Married ... $\quad \ldots \quad \ldots . \quad \ldots \quad 387$

Sandy Row Convert, The $\quad . . \quad$... 739

Sarsfield (Conyngham) $\quad$... $\quad \ldots 3960$

Sarsfield (Gamble) $\quad \ldots \quad \ldots . \quad \ldots 6628$

Satanella $\quad \ldots \quad \ldots . \quad \ldots . \quad \ldots 1667$

Savourneen Deelish ... ... ... 1405

Scenes and Sketches in an Irish $\begin{array}{llllll}\text { Parish } & \ldots & \ldots & \ldots & \ldots & 675\end{array}$

$\begin{array}{lllll}\text { Schoolboys Three } & \ldots & \ldots & \ldots & 841\end{array}$

Schoolboy Outlaws, The $\ldots . \quad \ldots \quad 559$

School Life 74, 1028, 1131, 1132, 1116, 1668

Scottish Fairy Book, The ... ... 655

Scotland, Irish In 158, 439, 628, 911, 1015, 1016.

Scratch Pack, The ... ... ... 392

$\begin{array}{llllll}\text { Scullydom } & \ldots & \ldots & \ldots & \ldots & 592 \\ & & \ldots & \ldots & 555\end{array}$

Sea Queen's Sailing, A... $\quad \ldots \quad$... 1663

Sea Stories. See Downey.

Secret of Carrickfearmeagh Castle... 1599

Secret Rose, The $\quad$... $\quad \ldots \quad \ldots 1692$

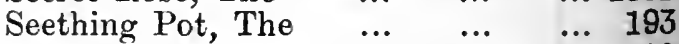

$\begin{array}{lllll}\text { Separatist, The } \ldots & \ldots & \ldots & \ldots & 9 \\ \end{array}$

Sgealuidhe Gaodhalach An (Hyde)... 794

Shadow of the Cross, The ... $\quad \ldots \quad 431$

$\begin{array}{lllll}\text { Shamrock Leaves } & \ldots & \ldots & \ldots & \text { S3 }\end{array}$

Shameful Inheritance, $\dddot{A} \quad \ldots . \quad \ldots 1632$

Shamrock Leaves (Butler) $\ldots . .1 \% 289$

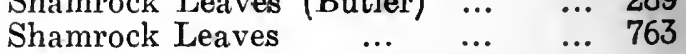


$\begin{array}{llllr}\text { Shandon Bells ... } & \ldots & \ldots & \ldots & 212 \\ \text { Shandy Maguire } & \ldots & \ldots & \ldots & Z 36 \\ \text { Shan Van Vocht, The ... } & \ldots & \ldots & 1232 \\ \text { Shawn na Soggarth } & \ldots & \ldots & \ldots & 1303 \\ \text { Shawn na Soggarth, } & \text { the } & \text { Priest }\end{array}$ $\begin{array}{llllll}\text { Hunter } & \ldots & \ldots & \ldots & \ldots & \\ & \ldots & \end{array}$

Sheila Donovan... $\quad . . \quad \ldots \quad \ldots 1374$

Shemus Dhu $\quad \ldots . \quad \ldots \quad \ldots . \quad \ldots \quad 827$

Shepherd Prior, The ... $\quad \ldots \quad$.. 480

She Walks in Beauty ... ... ... 1606

$\begin{array}{lllllll}\text { Shiana } & \ldots & \ldots & \ldots & \ldots & \ldots & 1343\end{array}$

Shillelagh and Shamrock $\quad \ldots \quad \ldots 229$

Ship that Sailed too Soon, The $\ldots 211$

Ship that Sailed too Soon, The ... 1700

Shuilers from the Heathy Hills ... 1055

Shipwreck, The... ... ... ... 548

Sick Bed of Cuchulainn and the Only Jealousy of Eimer... ... ... 1291

Siege of Bodike, The ... $\quad \ldots \quad \ldots \quad$... 915

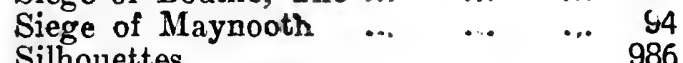

$\begin{array}{llllll}\text { Silhouettes } & \ldots & \ldots & \ldots & \ldots & 986 \\ \text { Silk and Steel } & \ldots & \ldots & \ldots & \ldots & 756\end{array}$

Silk of the Kine... $\quad \ldots \quad \ldots . \quad \ldots 1050$

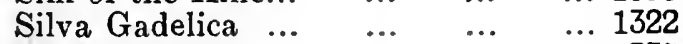

Silver Acre, The... $\quad \ldots . \quad \ldots . \quad \ldots . .338$

Silver Fox, The... $\quad \ldots \quad \ldots \quad \ldots 1525$

Simpkins Plot, The $\quad \ldots \quad \ldots . \quad \ldots \quad 203$

Simon Kerrigan... $\quad \ldots \quad \ldots \quad \ldots \quad \ldots 1475$

Sin of Jasper Standish $\quad \ldots \quad \ldots 1434$

Sin-Eater, The ... $\quad \ldots \quad \ldots \quad \ldots \quad \ldots 1044$

Sir Brooke Fosbrooke ... $\quad \ldots \quad \ldots 940$

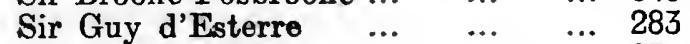

Sir Jasper Carew $\quad \ldots \quad \ldots \quad \ldots \quad \ldots 931$

$\begin{array}{llllll}\text { Sir Ludar... } & \ldots & \ldots & \ldots & \ldots & \ldots \\ & \ldots & \ldots\end{array}$

Sir Phelim's Treasure ... $\ldots . . \ldots 754$

Sir Roger Delany of Meath ...

Six Little Bannocks, The

Sketches of Irish Character.

Slieve Bloom

Sligo

488 4 489, 1520,1690

Smith of the Shamrock Guards ... 96

Smugglers of Strangford Lough, The 979 Smuggling $\quad \ldots .80,308,944,979,1363$

Snake's Pass, The ... ... ... 1551

Soggarth Aroon, The ... $\ldots . . . .676$

Some Experiences of an Irish R.M... 1526

Some Happenings of Glendalyne ... 384

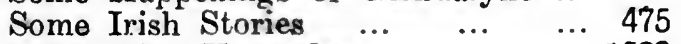

Some Irish Yesterdays $\quad \ldots . \quad \ldots 1529$

Sonǵs and Tales of St. Columba and his Age

$\begin{array}{lllll}\ldots & \ldots & \ldots & \ldots & 1047\end{array}$

Son of Erin, A ... $\quad \ldots \quad \ldots \quad \ldots 1556$

Son of a Peasant $\quad \ldots \quad \ldots . \quad \ldots 1074$

Sons o' Cormac, The ... $\quad \ldots \quad$... 532

Sons of Eire $\quad . . \quad \ldots \quad \ldots \quad \ldots \quad \ldots 1013$

Sons of the Milesians ... $\quad \ldots . \quad \ldots \quad 427$

Sans of the Sea Kings $\quad \ldots \quad \ldots 1154$

Sons of the Sod... $\quad \ldots \quad \ldots \quad \ldots \quad 977$

Sons of Ulster ... $\quad \ldots . \quad \ldots . \quad \ldots .946$

Sorrow of Lycadoon, The $\quad \ldots \quad$... 372

Soundless Tide, The $\ldots$... 412

Soupers 26, 30, 40, 235, 395, 875, 1347,
Sower of the Wind, A ... $\quad \ldots \quad$... 732

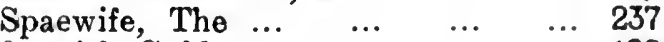

$\begin{array}{llllll}\text { Spanish Gold } & \ldots & \ldots & \ldots & \ldots & 198\end{array}$

Spanish John $\quad \ldots . \quad \ldots . \quad \ldots . \quad \ldots 1037$

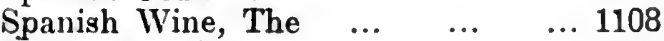

Spinners in Silence $\quad \ldots \quad \ldots \quad \ldots 1072$

Spiritual Tales ... $\quad \ldots . \quad \ldots . \quad \ldots 1040$

Splendid Knight, The ... $\quad \ldots \quad \ldots 759$

Spoiled Priest, The ... $\ldots$.

Sporting Novels 229, 377, 378, 381, 383, $386,417,468,590,747,758,760,778$, $779,812,918,919,924,1028,1516^{2}$, 1528, 1530, 1667.

Sport on Irish Bogs ... $\quad \ldots \quad$. . 812

Sprigs of Shamrock $\ldots{ }^{2} \quad \ldots \quad \ldots 1459$

Sprigs of Shillelagh ... $\quad \ldots \quad \ldots 953$

Squanders of Castle Squander $\quad \ldots \quad 333$

Squireen, The ... $\quad . . \quad \ldots \quad \ldots 272$

Standish O'Grady $\quad \ldots \quad \ldots . \quad \ldots 1319$

Starlight through the Roof ... ... 1464

Stars Beyond, The ... ..., ... 885

Steadfast unto Death ... $\quad$... $\quad \ldots .190$

$\begin{array}{lllll}\text { Stella and Vanessa } & \ldots & \ldots & \ldots & 528\end{array}$

Stories for Calumniators $\quad \ldots . \quad \ldots 1598$

$\begin{array}{llll}\text { Stories from Carleton ... } & \ldots & \ldots & \\ \text { St }\end{array}$

Stories for the Fireside $\ldots . \quad \ldots 1363$

Stories of Irish Life, Past and Present 97

Stories of Red Hanrahan ... ... 1694

Stories of the Irish Peasantry... .. 688

Stories of the Irish Rebellıon... ... 1175

Story of a Campaign Estate ... ... 1583

Story of Bawn, The ... $\ldots . \quad \ldots 1620$

Story of Cecilia, The ... $\quad \ldots . \quad \ldots 1629$

Story of Con-Edda, The $\quad \ldots+13135$

Story of Dan, The $\quad . . \quad \ldots . \quad \ldots 6611$

Story of Ellen, The $\quad \ldots \quad \ldots . \quad \ldots 1214$

Story of Mary Dunne, The ... ... 616

Story of Nellie Dillon, The... ... 98

Story of Parson Annaly, The ... ... 257

Story of St. Patrick's Purgatory, The 1707

Story-Teller's Holiday ... ... ... 1169

St. Clair ... $\quad \ldots \quad \ldots \quad \ldots . \quad \ldots .1178$

St. Clair en Olivia Met Platen ... 1179

St. Kathleen, or the Rock of Dunnismoyle

St. Patrick's Cathedral $\quad \ldots . \quad \ldots 1293$

St. Patrick's Eve $\quad . . \quad \ldots . \quad \ldots 923$

Story of St. Patrick's Purgatory, The 1707

Story-Teller's Holiday, A ... ... 1169

Strangers at Lisconnell $\quad \ldots \quad \ldots 762$

$\begin{array}{lllll}\text { Strayings of Sandy } & \ldots & \ldots & \ldots & 382\end{array}$

Strike, The $\quad \ldots \quad \ldots \quad \ldots . \quad \ldots 1454$

Strong as Death... $\quad \ldots \quad \ldots . \quad \ldots \quad 359$

Struggle for Fame, A ... $\quad \ldots . \quad \ldots 1427$

Studies in Blue ... $\quad \ldots \quad \ldots \quad \ldots \quad \ldots 1289$

Success of Patrick Desmond ... ... 552

Surprising Adventures of my Friend

Patrick Dempsey ... ... ... 1681

Survivals in Belief Among the Celts. 736

Sweet Doreen ... ... $\quad \ldots \quad \ldots 1198$

Sweet Innisfail ... $\ldots . \quad \ldots . \quad \ldots \quad 501$

Swordsman of the Brigade, A... $\quad \ldots 1326$ 


\section{$\mathbf{T}$}

Táín Bo Cualnge Enlèvement du Taureau Divin et des Vaches de Cooley (de Jubainville) ...

Do. Windisch. Append, D.II.

Tales about Great Britain. See Tales about Ireland and the Irish ...

Tales of my Country ... $\quad \ldots \quad \ldots$

Tales of Erin ... … … ...

Tales of Fairy Folks, Queens and Heroes

Tales of the Fairies and of the Ghost

World

Tales of Ireland

Tales of Ireland and the Irish

...

Tales about Ireland and the Irish $\quad . .6 \quad 644$

Tales of Ireland for Irish Children... 186

Tales of Irish Life (Whitty)

Tales of Irisn Life and Character ...

Tales of the Jury Room

Tales and Legends of Ireland

Tales from Maria Edgeworth...

Tales of the Munster Festivals

Tales and Stories for the Aniusement

and the Instruction of Youth ... 1418

Tales of my Neighbourhood ... ... 665

Tales of the Royal Irish Constabulary 258

Tales and Superstitions of the Connaught Peasants

Taste of Quality, A ... ... ... 1455

Temperance $\quad . .61,85,157,326,810$, 1163, 1349.

Temperance Stories, Appendix B.

Terence

Terence McGowan, the Irish Tenant 1589

Terence O'Dowd $\quad . . \quad \ldots \quad \ldots \quad \ldots 1356$

Terence O'Neill's Heiress ... ... 1197

Terence O'Rourke, Gentleman

\section{Adventurer}

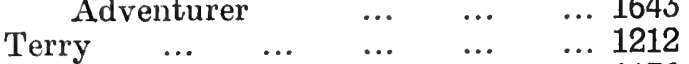

Terry Alt, The $\quad \ldots \quad \ldots . \quad \ldots 1136$

Tnady Halloran of the Irish Brigade 245

That Most Distressful Country _.. 241

That Sweet Enemy $\quad \ldots \quad \ldots \quad \ldots 1612$

Third Experiment, The $\quad \ldots \quad \ldots 883$

$\begin{array}{llllll}\text { Thirteen } & \ldots & \ldots & \ldots & \ldots & 1574\end{array}$

Thomas Fitzgerald, the Lord of Offaley

Thorn Bit, The … $\quad \ldots \quad \ldots$

Those Who Went West

Three Fair Maids

Three Fenian Brothers, The... ... 704

Tnree Girls and a Hermit $\quad \ldots \quad \ldots \quad \ldots 380$

Three Requests, The ... $\quad \ldots . \quad \ldots .838$

Three Wee Ulster Lassies $\quad \ldots . \quad \ldots 648$

Three Whispers, The ... $\quad \ldots . \quad \ldots \quad 403$

Threshold of Quiet, The $\quad \ldots . \quad \ldots .401$

Through Green Glasses $\quad \ldots \quad \ldots \quad 507$

Through the Night $\quad \ldots \quad \ldots \quad \ldots 1557$

Tnrough the Turf Smoke $\quad \ldots \quad \ldots 1060$

'Through Troubled Waters
Thunder an' Turf

Thy Name is Truth $\quad \ldots \quad \ldots \quad \ldots 627$

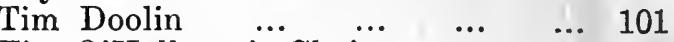

Tim O'Halloran's Choice $\quad \ldots . \quad \ldots .457$

Tinker's Hollow $\quad \ldots \quad \ldots \quad \ldots 413$

T'ipperary $\ldots .395,421,501,730,747$, $865,905,920,1464,1466,1562,1702$.

Tithe-Proctor, The $\ldots \quad \ldots \quad \ldots \quad 329$

$\begin{array}{lllllll}\text { Tivoli } \quad \ldots & \ldots & \ldots & \ldots & \ldots & 888\end{array}$

To-day in Ireland $\ldots{ }^{\circ} \quad \ldots \quad \ldots \quad 444$

Tom Burke of "Ours "; $\quad \ldots . \quad \ldots 921$

Tom Delaney $\quad \ldots \quad \ldots \quad \ldots . \quad \ldots 1580$

Tom Moore $\quad \ldots \quad \ldots \quad \ldots \quad \ldots 1713$

Tom O'Kelly $\quad \ldots \quad \ldots \quad \ldots \quad \ldots \quad \ldots 1171$

$\begin{array}{llllll}\text { Tony Butler } & \ldots & \ldots & \ldots & \ldots & 937\end{array}$

Torn Apart $\quad \ldots \quad \ldots \quad \ldots . \quad \ldots 1263$

Tory in Arms, A $\quad \ldots \quad \ldots . \quad \ldots 912$

Tour de Lough Erne, La $\quad \ldots \quad$... 102

Town of the Cascades, The $\ldots . \quad \ldots \quad 157$

$\begin{array}{lllll}\text { Tracked } & \ldots & \ldots & \ldots & \ldots \\ 1391\end{array}$

Trackless Way, The ... $\quad . . \quad \ldots \quad 568$.

Tradition of the Castle, The ... ... 1444

$\begin{array}{llllll}\text { Traffic } & \ldots & \ldots & \ldots & \ldots & \ldots \\ 1572\end{array}$

Tragedy of Chris, Tne $\ldots$... $\ldots 1213$

Tragic Romances ... ... ... 1041

Traits and Confidences $\quad \ldots \quad \ldots 893$

Traits and Stories of the Irish

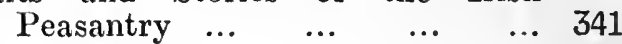

$\begin{array}{lllll}\text { Treasure Trove } & \ldots & \ldots & \ldots & 961 \\ & & \ldots & \ldots & 960\end{array}$

"Trim" and Antrim's Shores ... 587

Trinity College ...75, 232, 548, 569, 749, $761,822,919,942,983,1183,1504$.

Triumph of Failure $\ldots . \quad \ldots \quad \ldots 1496$

$\begin{array}{lllll}\text { Troublesome Trio, A } & \ldots & \ldots & \ldots & \\ \text { True to the Core } & \ldots & \ldots & \ldots & 698\end{array}$

$\begin{array}{lllll}\text { True to the Core } & \ldots & \ldots & \ldots & 698 \\ \text { True Heart's Trials } & \ldots & \ldots & \ldots & 1460\end{array}$

True Heir of Ballymon, The ... $\quad \ldots .1481$

$\begin{array}{llll}\text { True Irish Ghost Stories } & \ldots & \ldots & 1481 \\ \text { True Man and Traitor } & \ldots & \ldots & 232\end{array}$

True Stories of the Past $\quad \ldots . \quad \ldots \quad 784$

True Tales of the Irish Peasantry ... 820

True to the Watchword $\quad \ldots \quad \ldots 1382$

Tully Castle $\quad \ldots \quad \ldots \quad \ldots \quad \ldots 1084$

Turf-Fire Stories and Fairy Tales of $\begin{array}{llllll}\text { Ireland } & \ldots & \ldots & \ldots & \ldots & 1288\end{array}$

Turn of the Tide, Tne $\quad \ldots \quad \ldots 1582$

'Twas in Dhroll Donegal ... ... 1057

Twentieth Century Hero $\quad . . \quad \ldots 1262$

Two Irish Arthurian Romances ... 1262

Two Little Girls in Green ... ... 1176

Twin Sisters ... $\quad . . \quad \ldots . \quad \ldots 1224$

Two Chiefs of Dunboy, The ... ... 621

Two Imposters and Tinker ... ... 383

Two Masters ... ... ... ... 421

Tyrone $\quad \ldots 575,587,766, \dddot{90} 8,987,988$,

1434.

$\mathbf{U}$

Ulick O'Donnell

$\begin{array}{lllr}\cdots & \cdots & \cdots & 770 \\ & & \cdots & 1316\end{array}$

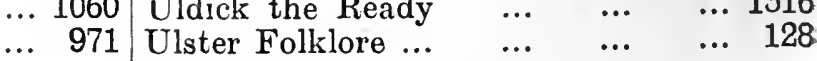


Ulsterman, The ...

... $\quad \ldots \quad \ldots 1153$

Una's Enterprise

Unchronicled Heroes

Uncle Pat's Cabin ...

Unconventional Molly ...

Under One Sceptre

Under Slieve Ban

Under which King ? .

Union of Hearts, A $\ldots$

United Irishman, The ...

United Irishmen 103, $136,197,313,399$, $446,462,1014,1019,1118,1366,1410$, and Appendix C. I.

United States, Irishmen in 79, 101, 525, 603, 798, 807, 878, 927, 930, 949, 1337, $1399,1401,1453,1471,1476,1660$.

Unknown Immortals ... $\quad \ldots \quad \ldots 1383$

Unknown Quantity, An $\quad \ldots . \quad \ldots .764$

Unpardonable Sin, The $\quad \ldots \quad \ldots \quad 499$

Untilled Field, The ... $\quad \ldots \quad \ldots 1167$

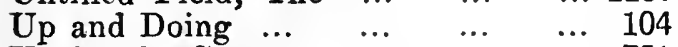

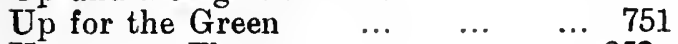

Uprooters, The ... $\quad \ldots \quad \ldots \quad \ldots 952$.

\section{V}

Valentine McClutchy

323

Valley of the Squinting Windows, The 1070

Value of Fosterstown, The ... ... 493

$\begin{array}{lllll}\text { Vertue Rewarded } \quad . . & \ldots & \ldots & 105\end{array}$

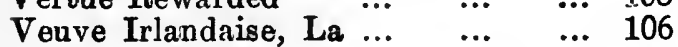

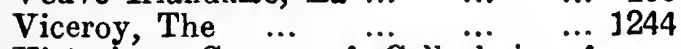

Victorious Career of Cellachain of Cashel, The...

Visions and Beliefs in the West of Ireland

266

Vision of MacConglinne, The $\quad \ldots 1146$

Voyage of the Ark, The ... ... 508

Voyage of Bran, son of Ferbal, to the

Land of the Living, The ... $\quad \ldots \quad 1148$

Voyaging of Brendan, The ... $\quad \ldots 1710$

$\begin{array}{lllll}\text { Vultures of Erin } \quad . . & \ldots & \ldots & 534\end{array}$

\section{w}

Wager, The; see In Sarsfield's Days (MacManus)

... 1053

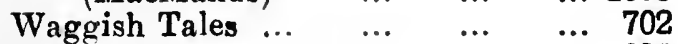

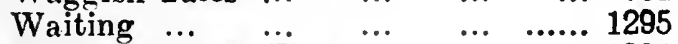

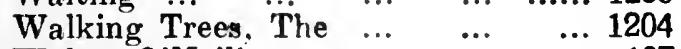

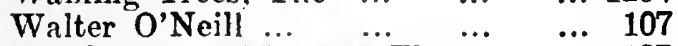

$\begin{array}{llll}\text { Warden of the Marshe } & \text { The ... } & \ldots & 127\end{array}$

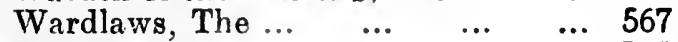

Warp and Weft ... $\quad \ldots . \quad \ldots . \quad \ldots .765$

Washer of the Ford $\ldots .61045$

Waterford 224. 398, 409, 520, 558, 1209, $1210,1226,1349,1389,1494,1571$, 1572, 1576, 1578.

Water Queen. The

Waves of the 0 cen of $\begin{array}{llll} & \cdots & \ldots & 363\end{array}$

Way of a Maid. The ... $\quad \ldots . \quad \ldots 1603$
Way they Loved at Grimpat, The... 565

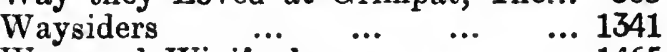

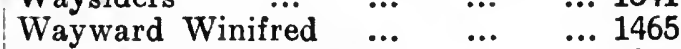

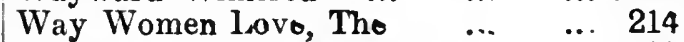

Weans at Rowallan, The $\quad . . \quad \ldots \quad 599$

$\begin{array}{llll}\text { Wearing of the Green, The } & \ldots & \ldots & 868\end{array}$

Weird of "The Silken Thomas," The 407

$\begin{array}{llllll}\text { Weird Tales } & \ldots & \ldots & \ldots & \ldots & 108\end{array}$

Weird Women of the Wraagh _.. 361

West Irish Folk-Tales and Romances 887

West Meath ... ... ... 8, 159, 1460

Wexford 31, 123, 241, 264, 597, 610, 686, $769,845,846,950,958,985,986,1514$, 1574, 1651.

Whale and the Grasshopper, and other Tales, The ... ... ... 1267

When Cromwell Came to Drogheda... 1006

When Lint was in the Bell ... ... 1022

When Love is Kind ... ... ... 752

When we were Boys ... $\quad \ldots . \quad \ldots 1268$

When the Normans Came $\quad \ldots \quad \ldots 1327$

When the Tide Turng ... $\ldots . \quad \ldots 1697$

Where the Atlantic Meets the Land 947

$\begin{array}{lll}\text { Where the Shamrock Grows ... } & \ldots & 814\end{array}$

Where the Surf Breaks _.. ... 1563

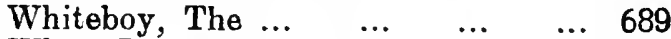

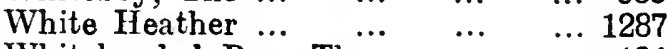

$\begin{array}{llll}\text { Whiteheaded Boy. The } & \ldots & \ldots & 184\end{array}$

Whitethorn Tree, The ... $\quad \ldots .6 \%$.

Wicklow 15, 71, 135, 191, 308, 309, 361, $494,539,694,931,992,1000,1031$, 1109, 1579.

Wild Birds of Killevy, The ... ... 1203

Wild Flowers from the Glens... $\quad \ldots \quad 572$

Wild Geese, The $\quad \ldots \quad \ldots . \quad \ldots 1662$

Wild Irish Boy, The $\ldots . \quad \ldots . \quad \ldots 1110$

Wild Irish Girl, The ("Meade ") ... 1129

Wild Irish Girl, The (Morgan) $\quad \ldots 1180$

Wild Rose of Lough Gill _.. $\quad \ldots 1520$

Wild Scenes among the Celts... $\quad \ldots 745$

Wiles of Sexton Maginnis, The ... 553

$\begin{array}{lllll}\text { William and James } & \ldots & \ldots & \ldots & 109\end{array}$

Willy Burke $\quad \ldots \quad \ldots . \quad \ldots \quad \ldots 1467$

Willy Reilly and his Dear Colleen

$\begin{array}{llllll}\text { Bawn } & \ldots & \ldots & \ldots & \ldots & 334\end{array}$

$\begin{array}{lllll}\text { Wine in the Cup. The } \ldots & \ldots & \ldots & 334 \\ & \ldots & & \ldots & 1681\end{array}$

Wine of Love, The $\ldots \quad \ldots . \quad \ldots 758$

Winter and Summer Stories, and Slides of Fancy's Lantern $\quad \ldots 800$

Wisdom of the World, The ... $\quad \ldots 1698$

With Essex in Ireland ... $\quad \ldots \quad \ldots 890$

With Strongbow at Wexford... $\quad \ldots 1456$

With Poison and Sword ... $\quad \ldots 1333$

Wizard's Gillie. The ... $\quad . . . \quad \ldots .1029$

Wizard's Knot. The $\ldots . \quad \ldots \quad \ldots .183$

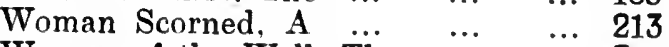

Woman of the Well. The $\ldots . \quad \ldots .774$

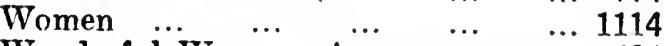

Wonderful Woman. A... $\ldots .6064$

Wonder Tales from Scottish Myth and Legend... $\quad \ldots \quad \ldots \quad \ldots 1033$

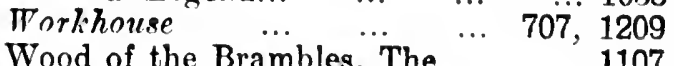


Wooing of Sheila $\quad \ldots \quad \ldots \quad \ldots 1420$ Young O'Briens, The ...

Wrack, and other Stories $\quad \ldots \quad \ldots 1273$ Yourself and the Neighbours... $\quad \ldots 1067$

Youthful Exploits of Fionn ... $\quad \ldots \quad 371$

$\mathbf{Y}$

Zoe: A Portrait ... $\quad \ldots \quad \ldots . \quad \ldots \quad 348$

Yarns of a Country Attorney, The ... 1649

$\mathbf{z}$

Yesterday in Ireland ... ... ... 446

Young Man from the South, A $\quad \ldots 1438$ Zozimus Papers ... 



\title{
PLEASE DO NOT REMOVE CARDS OR SLIPS FROM THIS POCKET
}

\author{
UNIVERSITY OF TORONTO LIBRARY
}




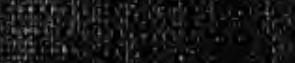

(5)

(1)

a

195.

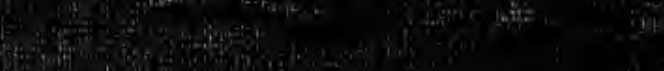

a

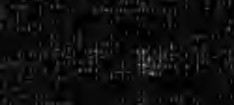

$\left(\frac{10}{301}\right.$

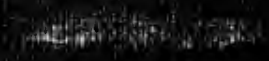

